UNIVERSIDADE DE SÃO PAULO

FACULDADE DE ARQUITETURA E URBANISMO

Julciléa Cristina Zólio

\title{
LUGARES ESQUECIDOS
}

A preservação do patrimônio no interior paulista: investigações sobre as cidades de Dourado e Nova Europa.

São Paulo

2011 


\section{JULCILÉA CRISTINA ZÓLIO}

\section{LUGARES ESQUECIDOS}

A preservação do patrimônio no interior paulista: investigações sobre as cidades de Dourado e Nova Europa.

Dissertação apresentada à Faculdade de Arquitetura e Urbanismo da Universidade de São Paulo para a obtenção do título de Mestre em Arquitetura e Urbanismo.

Área de concentração:

História e Fundamentos da Arquitetura e do Urbanismo.

Orientador:

Prof.a Dr.a Maria Lúcia Bressan Pinheiro

São Paulo

2011 
Autorizo a reprodução e divulgação total ou parcial deste trabalho, por qualquer meio convencional ou eletrônico, para fins de estudo e pesquisa, desde que citada a fonte.

e-mail: zolio@uol.com.br

\section{ZóLıO, Julciléa Cristina}

Título Lugares esquecidos - a preservação do patrimônio no interior paulista: investigações sobre as cidades de Dourado e Nova Europa. - São

Paulo, 2011.

226 p.: il.

Dissertação (Mestrado) Área de concentração: História e Fundamentos da Arquitetura e do Urbanismo - FAUUSP.

Orientadora: Prof.a Dr.a Maria Lúcia Bressan Pinheiro.

1. Preservação do patrimônio cultural; 2. urbanização do interior paulista; 3. cultura cafeeira 
À minha família 
À minha orientadora, Prof. a Dr.a Maria Lúcia Bressan Pinheiro, por sua disponibilidade, paciência e apoio nesta caminhada.

Também sou grata aos membros da banca de qualificação, Prof. Dr. Nilson Ghirardello e Prof. Dr. Vladimir Bartalini, pelas contribuições fundamentais para o desenvolvimento deste trabalho.

Agradeço o apoio financeiro do CNPQ, sem o qual esta pesquisa não seria possível.

Aos meus pais e irmãos pelo infindável apoio, carinho e paciência. Ao Marcelo, pelo companheirismo nos momentos mais turbulentos e também aos amigos Otaviano e Carolina, sempre presentes.

Como este trabalho antes de tudo é uma síntese das muitas histórias que ouço desde a infância, contadas por familiares, amigos e conhecidos, agradeço muito a todos os douradenses que tão gentilmente relembraram e dividiram comigo suas experiências pessoais, algumas vezes com alegria, outras com uma ponta de melancolia e saudade, mas sempre com muita generosidade.

Enfim, agradeço a todos os amigos e colegas da pós-graduação da FAU, que direta ou indiretamente contribuíram para a realização deste trabalho. 


\section{Resumo}

Segundo o Censo do ano 2.000, em torno de 31\% dos municípios do Estado de São Paulo possuem populações entre 10.000 e 50.000 habitantes, tornando-se assim a larga maioria dos municípios de pequeno e médio porte em relação aos $15,5 \%$ de municípios com mais de 50.000 habitantes; ao mesmo tempo, esta maioria é também a menos conhecida em termos de sua criação, evolução enquanto sistema urbano, tornando impraticável um planejamento que vise a sua proteção enquanto patrimônio urbano e arquitetônico e a sua expansão futura de modo ordenado.

A região em estudo é constituída por uma rede de pequenas cidades, que surgem como decorrência de diferentes fatores: a) fixação dos 'torna viagem', provenientes em sua maioria de Minas Gerais; b) a expansão da lavoura cafeeira; c) a chegada da ferrovia; d) ações governamentais, tais como a implantação de núcleos coloniais; e) desmembramento de grandes fazendas.

Apesar das origens diversas, essas cidades fazem parte de um grupo resultante de um ideário urbanístico análogo, e reagiram em maior ou menor grau a eventos como a substituição da cultura cafeeira e a desativação e erradicação da ferrovia em detrimento da opção nacional pelo transporte rodoviário, com o início do processo de redistribuição dos fluxos de transporte das antigas linhas de ferro para as rodovias, reconfigurando as relações de identidade e interdependência dessas localidades.

Entre as cidades pertencentes à zona de estudos que conseguiram um maior desenvolvimento econômico, seus núcleos centrais vem passando por um processo de decadência e deterioração, graças às contradições em seus processos de desenvolvimento, resultando em distorções e na perda da qualidade de seus espaços e conseqüentemente na qualidade de vida. Nas cidades menores, as áreas centrais foram 'preservadas pela pobreza', sendo que na maioria delas, as instituições mais importantes ainda estão ali localizadas, o que não impede que seu patrimônio arquitetônico seja descaracterizado e substituído por falta de legislação específica para suas necessidades e características.

Além da perda do patrimônio arquitetônico, também vem se perdendo os valores e costumes da região, resultando em atitudes equivocadas em relação à realidade física local. Entende-se como necessário um resgate desses valores patrimoniais, principalmente uma maior divulgação da história local aos seus habitantes, a fim de contribuir para a sua ressignificação.

Por acreditarmos que a produção espacial urbana do passado tem vínculos estreitos com o presente, configurando-se como um referencial histórico, e a sua degradação e desvalorização implicam na perda da identidade cultural e da qualidade de vida de toda a região em estudo, o presente trabalho pretende contribuir para a preservação do patrimônio ambiental urbano das cidades de Dourado e Nova Europa, mas de forma flexível e que possa servir de referência para as demais cidades da região.

Palavras chave: Preservação do patrimônio cultural, urbanização do interior paulista, cultura cafeeira. 
According to the 2000 Census, about 31\% of the cities in the state of São Paulo have populations between 10,000 and 50,00 inhabitants, thus pointing that small and medium cities outnumber the $15.5 \%$ of cities with more than 50,000 inhabitants. Yet at the same time, this majority is the least understood in terms of its creation and development as an urban system, which render unfeasible any kind of planning that aims at protecting them as urban and architectural heritage and their future expansion in an organized manner.

The area studied is comprised by a number of small towns which have appeared as result of a variety of factors: a) the settlement of the torna viagem, mostly coming from the state of Minas Gerais; b) the expansion of the coffee culture; c) the advent of railways; d) government actions, such as the implementation of colonial centers; e) the division of large farms.

Despite their different origins, these towns belong to a group that results from an analog urban ideology, and reacted with more or less intensity to happenings such as the replacement of coffee culture and the extinction of railways due to a national option for highways. That was the beginning of a process of redistribution in transport flows from railways to highways, which redesigned the relations of identity and interdependence of such locations.

Among the cities in the studied area that managed to achieve greater economic development, their cores have been experiencing a process of decadence and decay due to the contradictions found in their development history, thus resulting in distortions and a quality loss in physical space and life quality. In small towns, central areas were "protected from poverty" and most of them are still the home for the most important institutions, which nonetheless does not prevent the architectural heritage from being decharacterized and replaced, due to a lack of specific legislation to meet its needs and characteristics.

This loss encompasses not only the architectural heritage but also local customs and values, whose outcome is reflected in erroneous attitudes toward the local physical reality. The revival of these heritage values is deemed as necessary, especially for the promotion of the local history to citizens in order to help them re-understand it.

Because we believe that the past urban space production is strictly bonded to the present as a historical reference and its degradation and impairment represent a loss of cultural identity and quality of life all over the area studied, this paper intends to contribute to the protection of the urban environment heritage of the cities of Dourado and Nova Europa, yet in a flexible manner which can also serve as further reference for other cities in the region 


\section{Sumário}

Introdução.

1. Antecedentes históricos - A ocupação dos Campos

de Araraquara e o desmembramento dos municípios

pertencentes à Zona Douradense.

1.1. A expansão da lavoura cafeeira e a chegada da ferrovia...............................25

1.2. A política de povoamento e a implantação dos núcleos coloniais....................34

1.3. Características gerais de implantação das formações

urbanas da Zona Douradense.

2. Evolução urbana de Dourado

2.1. Pré-inventário da área central de Dourado .91

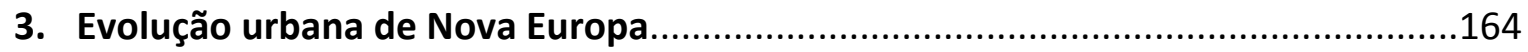

3.1. Pré-inventário da área central de Nova Europa...........................................169

4. Considerações finais

Referencias bibliográficas

Anexos

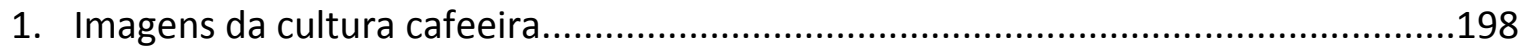

2. Sequencia histórica da divisão politico administrativa do Estado de São Paulo de 1600 a 1997 199

3. Imagens dos núcleos coloniais Jorge Tibiriçá, Campos Salles e Nova Europa............200

4. Levantamento das origens da mão de obra ligada à construção civil na cidade de Dourado no início do século XX.

5. Pré-inventário da Vila Santa Clara 204 


\section{Introdução}

Por volta de 1850 no Estado de São Paulo, especialmente no Oeste Paulista, emergiu uma burguesia agrária local, impulsionada pela cultura do café. Essa cultura demandou ações públicas e privadas que geraram significativas transformações no território paulista, resultando numa urbanização diferenciada, que levou ao surgimento de uma quantidade significativa de novas cidades no estado. As cidades que serão tratadas nesta dissertação estão inseridas nessa dinâmica.

Juntamente com as fazendas de café, as cidades interligadas pelas ferrovias 'escoadoras', consolidam essa integração espacial, gerando um mercado interno e o desenvolvimento de uma estrutura capaz de suprir as necessidades institucionais e materiais, condicionadas pela maior complexidade da estrutura física do estado. A produção do café nessa região implicou no uso de inovações tecnológicas, tais como a extensão da rede ferroviária e o emprego da mão-de-obra imigrante através da fundação de núcleos coloniais.

Segundo COSTA (2003), a questão da urbanização do Estado de São Paulo nesse período estava em planejar o estado territorialmente, sendo a "forma urbana uma consequência, relacionada ao papel dessa cidade na articulação"; a urbanização não está associada apenas ao surgimento e à consolidação dos espaços urbanos, mas também à infraestrutura relacionada aos espaços agrários.

Para esse processo contribuiu todo um conjunto de instituições e técnicas, capazes de respaldar a atividade econômica privada dos cafeicultores paulistas, tais como a Comissão Cartográfica e Geológica do Estado de São Paulo, o Instituto Agronômico de Campinas, a Escola Luiz de Queiroz, o Instituto de Veterinária, a Comissão de Debelação de Pragas, etc..

Os núcleos coloniais atuavam de forma complementar às fazendas de café, funcionando como reservas de mão-de-obra e celeiros alimentares subsidiários do complexo cafeeiro. Neles foram ensaiadas novas perspectivas agropecuárias, como a incubação de novas culturas (algodão e laranja) e a criação de animais alternativos à cultura cafeeira.

Embora São Paulo tenha recebido grandes levas de imigrantes durante a República, o Estado não desenvolveu uma política consciente de assentamentos de colonos em terras 
devolutas, e assim o sistema de colonização por pequena propriedade nunca tomou vulto, tendo se desenvolvido apenas após a I Guerra Mundial, como resultado do parcelamento das grandes propriedades.

As possibilidades de implantação dos núcleos coloniais em São Paulo restringiam-se às terras secundárias à economia cafeeira; os altos custos para viabilizar tais empreendimentos (demarcação e regularização da propriedade dos núcleos, abertura de vias de comunicação para mercados consumidores, auxílios para a construção de casas para imigrantes e demais instalações produtivas, além de subsídios para a implantação das lavouras e criação de animais), dependiam do aparato do Estado. Essas empresas contrariavam os interesses das elites paulistas, pois utilizavam recursos necessários aos outros suportes requeridos pela expansão cafeeira.

Outro aspecto relevante no período de estudo é o papel das ferrovias como estruturadoras do espaço. Algumas dessas ferrovias, como é o caso da Cia. Estrada de Ferro Dourado, foram construídas depois do território desbravado, povoado e do cultivo estendido, a fim de lhe assegurar o frete. A implantação da rede ferroviária paulista é resultado da necessidade de ligação das áreas produtoras de café até os portos. A expansão dessa rede foi a responsável pela integração de parte do território paulista ao desenvolvimento econômico por que passava o país, além de ter incentivado a ocupação territorial, a fixação populacional e o movimento imigratório, tendo promovido a fundação de várias cidades e impulsionado a economia de outras.

Esta dissertação visa buscar os importantes subsídios que as análises particulares e os estudos de caso podem trazer para a compreensão da urbanização no interior do Estado de São Paulo, como a relevância do período cafeeiro na estruturação das bases do urbano nessa região (em especial no período anterior a 1940), do sistema paulista de cidades, bem como as diferentes determinações deste processo nesses espaços regionais.

O objeto geral deste trabalho é a documentação da produção e ocupação de parte do território paulista, aqui chamado 'Zona Douradense', desde as origens de sua formação, até o seu desenvolvimento recente.

Tendo em vista que a zona de estudos é composta por 34 localidades e que seria inviável, dentro do tempo que tivemos para o desenvolvimento desta dissertação, nos determos com igual profundidade sobre cada uma delas, selecionamos 2 localidades que são 
representativas do processo pelo qual passou a região. Essas localidades são: Dourado (localidade que ainda sofre processo de estagnação econômica iniciado com o fim do ciclo cafeeiro e erradicação da ferrovia) e Nova Europa (núcleo colonial, exemplo do planejamento estatal para essa parte do território paulista), que são nossos objetos específicos de estudo.

Essa dissertação foi elaborada a partir do entendimento das seguintes condicionantes: a) condições histórico-espaciais que levaram à implantação dos núcleos iniciais das localidades pertencentes à Zona Douradense; b) a chegada do ciclo cafeeiro, quando muitas são elevadas à categoria de municípios e tem seu desenvolvimento mais significativo; c) implantação da Cia. E. F. Dourado; d) início do processo de estagnação econômica, comum a muitas cidades dessa zona, com a substituição da cultura cafeeira pela algodoeira e posteriormente pela canavieira; e) desativação e erradicação das linhas ferroviárias; f) processo de redistribuição dos fluxos de transporte da ferrovia para a rodovia; g) reconfiguração das relações de identidade e interdependência das localidades, a partir da alteração dos meios de comunicação entre elas.

Também se procurará fazer uma leitura do espaço dessas cidades através das relações entre as pessoas e seu universo físico, entendendo que essas relações mudam com o tempo e que, se se quiser compreender a realidade dessas localidades, a visão não pode ser estática, uma vez que os objetos de estudo definidos, as cidades da rede, estão em constante transformação. Portanto, o que aqui se propõe é o estudo do processo.

Embora com foco nas cidades da Douradense, aqui trabalhamos com uma rede de cidades, por entender que estudos de casos isolados nos dizem muito pouco, mas quando observamos fenômenos que se repetem no tempo e no espaço, podemos identificar relações entre esses fenômenos, tornando possível seu entendimento.

A proposta se justifica pela escassez de estudos sobre a problemática das cidades de pequeno e médio porte, particularmente sobre as cidades pertencentes ao que aqui chamamos de 'Zona Douradense'. É importante ter em conta que, segundo dados do Censo Demográfico de 2.000, dos 645 municípios do Estado de São Paulo, em torno de 200 municípios possuem populações entre 10 mil e 50 mil habitantes e apenas cerca de 100 cidades apresentam populações maiores. Portanto, a grande maioria das cidades do estado 
é de pequeno e médio porte, constituindo um importante campo de atuação dos arquitetos urbanistas.

Ainda segundo dados do Censo de 2.000, esses 200 municípios citados acima tiveram um crescimento $20 \%$ maior do que o crescimento vegetativo da população brasileira na ultima década do século XX, além de apresentarem um taxa de urbanização em geral superior a $75 \%$. Esses dados nos mostram uma mudança no perfil destas cidades, perfil que precisa ser entendido e abordado dentro da atuação dos arquitetos.

A rede de cidades que compõe nosso objeto de estudo, apesar de submetida a determinantes comuns, apresenta trajetórias particulares que marcaram de forma concreta o desenvolvimento de cada uma delas. Quanto às semelhanças, estas cidades tiveram seu desenvolvimento intimamente relacionado com a ferrovia e a agricultura (inicialmente cafeeira, passando pela algodoeira e atualmente a canavieira), além de outras similaridades culturais, arquitetônicas, socioculturais e condições geográficas semelhantes.

O estudo da história da Estrada de Ferro Dourado se faz necessário pelo papel que desempenhou como ponto de ligação e fator de transformação entre as localidades tratadas na pesquisa. É exemplo da importância dessa ferrovia para a região o quanto a erradicação dos seus ramais veio agravar a situação de várias cidades da zona, já abaladas com a crise do café - uma vez que muitas dessas localidades surgiram simultaneamente à expansão ferroviária e mantinham com ela uma identidade de zona e tiveram que reconfigurar toda sua identidade geográfica a partir da substituição da malha ferroviária pela rodoviária, o que dificultou o acesso entre cidades vizinhas, priorizando o acesso aos grandes centros.

Além disso, muitas dessas pequenas cidades sofreram uma enorme redução em sua população a partir da erradicação dos ramais, pois parte considerável dessa população era de funcionários da Cia. E. F. Dourado que perderam seus empregos e tiveram que mudar de cidade com seus familiares em busca de trabalho. Exemplos dessa situação são as cidades de Dourado, que em 1920 chegou a contar com cerca de 18 mil habitantes e, 50 anos depois, em 1970, contava com apenas 5.634 habitantes (atualmente conta com aproximadamente 9.000 habitantes) e Trabijú, que no período da erradicação do ramal sofreu a maior crise de sua história, com a mudança em massa da sua população.

Também justificamos a importância dessa pesquisa tendo em vista que dentre as cidades pertencentes à zona de estudos, nas que conseguiram um maior desenvolvimento 
econômico, seus núcleos centrais vem passando por um processo de decadência e deterioração, graças às contradições em seus processos de desenvolvimento, resultando em distorções e na perda da qualidade de seus espaços e consequentemente na qualidade de vida. Nas cidades menores, as áreas centrais foram 'preservadas pela pobreza', sendo que na maioria delas, as instituições mais importantes ainda estão ali localizadas, o que não impede que seu patrimônio arquitetônico seja descaracterizado e substituído por falta de legislação específica para suas necessidades e características.

Por fim, justifica-se a importância da presente proposta de pesquisa pelo fato de que muito provavelmente a produção espacial urbana do passado tem vínculos estreitos com o presente, configurando-se como um referencial histórico, e a sua degradação e desvalorização implicam na perda da identidade cultural e da qualidade de vida de toda a região em estudo. Além da perda do patrimônio arquitetônico, também vem se perdendo os valores e costumes da região, resultando em atitudes equivocadas em relação à realidade física local. Entende-se como necessário um resgate desses valores patrimoniais, principalmente uma maior divulgação da história local aos seus habitantes, a fim de despertar-Ihes a consciência de fazer parte de uma história.

Contudo, este trabalho pretende contribuir para as discussões sobre a preservação do patrimônio cultural das pequenas cidades do interior paulista e apresenta reflexões a respeito da urbanização desta parte do território e do descompasso entre a arquitetura produzida na região com o que já se construía em centros maiores.

A metodologia de trabalho se fundamentou no trabalho de campo, em revisão bibliográfica e na pesquisa de documentos primários e fontes orais.

A dissertação se organiza em quatro capítulos. No primeiro serão abordadas as questões referentes à ocupação do território da zona douradense e alguns de seus condicionantes como a expansão da lavoura cafeeira, assim como a expansão ferroviária, a politica de povoamento governamental e a implantação de núcleos coloniais. Também procuramos através da observação de mapas de 1938 pertencentes ao acervo do Instituto Geográfico e Cartográfico e da coleção de Aerofotos Obliquas de 1939 pertencentes ao mesmo acervo, assim como de imagens atuais de satélite, sistematizar as características gerais de implantação das formações urbanas, nossos objetos de estudo. 
A partir destas observações foi possível constatar dois tipos de cidade: uma nascida em solo sacro, a partir de patrimônios religiosos e outra nascida em solo laico, a partir dos núcleos coloniais ou de estações ferroviárias.

No segundo capítulo tratamos da cidade de Dourado, apresentando um breve histórico seguido por um pré-inventário arquitetônico e por vistas esquemáticas onde procuraremos observar as características de seu patrimônio construído. Vale aqui destacar a série de dificuldades encontradas para a elaboração deste capítulo, como a ausência de bibliografia específica sobre a cidade, ausência de arquivos organizados, tanto de imagens quanto de documentos históricos. As imagens reproduzidas neste capítulo fazem parte do acervo pessoal de moradores da cidade que gentilmente colaboraram para o desenvolvimento desta dissertação, assim como todos os mapas reproduzidos foram elaborados a partir da observação de imagens de satélite, o que resulta em uma serie de imprecisões, mas que, entretanto não influenciam no resultado das observações.

No terceiro capítulo tratamos da cidade de Nova Europa, também procurando elaborar um breve histórico seguido de um pré-inventário arquitetônico. As mesmas dificuldades relatadas sobre Dourado se apresentaram ainda maiores para Nova Europa, já que a cidade ao longo de sua história 'pertenceu' administrativamente a diferentes cidades e seus documentos históricos estão espalhados em meio a arquivos de Araraquara, Ibitinga e Tabatinga, o que limitou ainda mais o acesso a eles.

Por fim, no quarto e ultimo capitulo trataremos das constatações acerca desta arquitetura cotidiana e anônima, entretanto digna de preservação já que ela, mais que qualquer outra, é quem dá a cara das cidades e mais fielmente nos conta sua história. 
"Todos cantam sua terra Também vou cantar a minha, Nas débeis cordas da lira Hei de fazê-la rainha.

- Hei de dar-lhe a realeza

Neste trono de beleza Em que a mão da natureza Esmerou-se em quanto tinha."

(Casemiro de Abreu) 


\section{0 - Antecedentes históricos - a ocupação dos Campos de Araraquara e o desmembramento dos municípios pertencentes à Zona Douradense:}

As cidades objetos de estudo tratadas nesta dissertação fazem parte da zona ferroviária conhecida como Zona Douradense, que abrange as cidades atendidas no início do século XX pela Estrada de Ferro Dourado. Esta ferrovia se estendia pela região central do Estado de São Paulo, o planalto ocidental paulista, conhecida no século XVIII como Campos ou Sertões de Araraquara.

Segundo Corrêa (1967), a denominação Campos de Araraquara se referia a toda a região ao norte do Rio Piracicaba, tendo inicio na região do Morro de Araraquara, até o lado norte do rio Jacaré Pepira, área ocupada originalmente pelos índios Guaianases.

Já Monbeig (1984) situa os Campos como a área do planalto ocidental paulista delimitada ao sul pelo Rio Grande e ao leste pelas escarpas ou cuestas da Serra Geral, área com clima favorável para a cultura do café (zona de transição entre o clima tropical e o subtropical) e com grande diversidade de espécies vegetais. Ainda nos informa Monbeig (1984) que os Campos apresentam dois tipos de solos, a terra roxa, o solo ideal para o cultivo do café, que aparece nos planaltos de Araraquara, Jaú, Ribeirão Preto e São Manoel e solos areníticos mais pobres, localizados nas bordas das cuestas, formando uma faixa improdutiva em meio aos cafezais.

A ocupação dos Campos teve início nas ultimas décadas do século XVIII, com o estabelecimento de caminhos que levavam às minas de ouro de Goiás e Mato Grosso. Segundo Castro (1916), com objetivo de controlar as remessas de ouro a Portugal e dificultar seu contrabando, em 1721 o então governador da Província de São Paulo, Capitão General Cesar de Menezes dá inicio aos estudos de alternativas de acesso as minas por via terrestre.

Segundo Benincasa (2002), até então se chegava às minas de Mato Grosso através do Rio Tietê e de outros rios navegáveis e se chegava à Goiás de forma ainda mais complicada, por uma rota através dos afluentes da margem esquerda do Rio Grande e da margem direita do Rio Tietê.

O caminho foi finalizado em 1725 e cinco anos depois, em 1730, abandonado por determinação de uma Carta Régia até 1770 , quando foi novamente reestabelecido por 
ordem do Capitão General Luiz Vaz de Toledo Piza, a fim de facilitar a comunicação com a colônia militar de Iguatemi, instalada em Mato Grosso para defender o território contra o avanço espanhol. Com a destruição da colônia militar, este caminho foi mais uma vez abandonado em 1777, para ser reaberto definitivamente dois anos depois, por ordem do então governador da Província de São Paulo, Antonio Manoel de Mello.

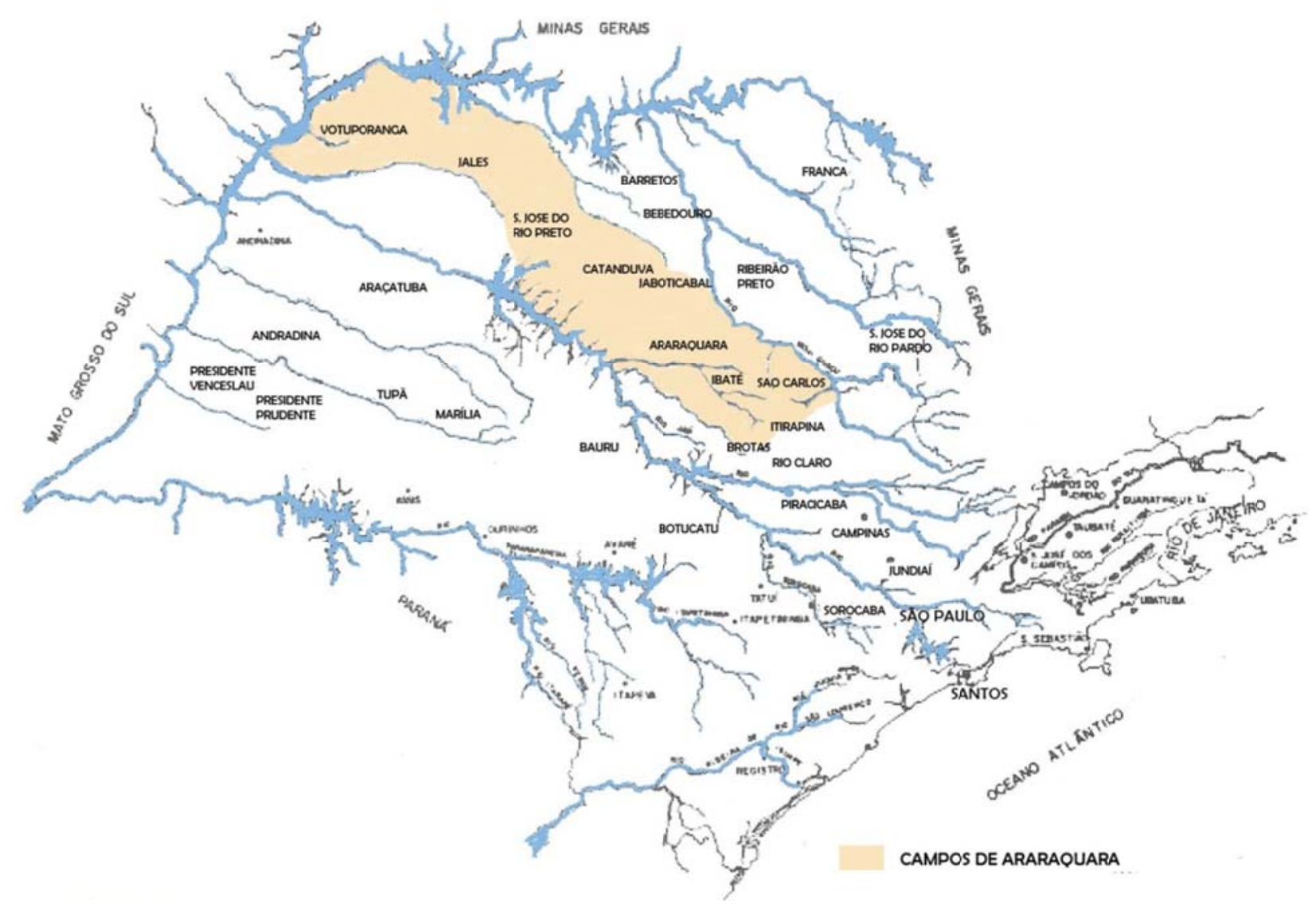

Limites aproximados dos Campos de Araraquara

Mapa esquemático elaborado a partir da apresentação de Maria de Annunciação Madureira no Seminário A Casa do Pinhal em 1999

Segundo Taunay (1981), este caminho ficou conhecido como Picadão de Cuiabá, partia da cidade de São Paulo, passando pelas atuais cidades de Itú, Porto Feliz, Rio Claro, São Carlos, Araraquara, Itápolis, São José do Rio Preto e Paranaíba, até Cuiabá. Lemos, em sua História de Araraquara, relata a importância da ocupação da região para a manutenção do caminho e dos inúmeros boatos sobre os rios e morros auríferos que atraíram muitos aventureiros para a região na segunda metade do século XVIII. 
Seus primeiros sesmeiros migraram das antigas zonas açucareiras que entravam em declínio, especialmente das localidades de Itu, Piracicaba e Porto Feliz a fim de expandir suas lavouras e fornecer gêneros alimentícios para o quadrilátero do açúcar. Posteriormente, já na primeira metade do século XIX, em função do esgotamento das minas de ouro de Minas Gerais e da necessidade de busca de novas pastagens para os rebanhos, os Campos foram ocupados por mineiros vindos em sua maioria, do Vale do Rio das Mortes, em um processo que alguns autores chamam de "frente de expansão".

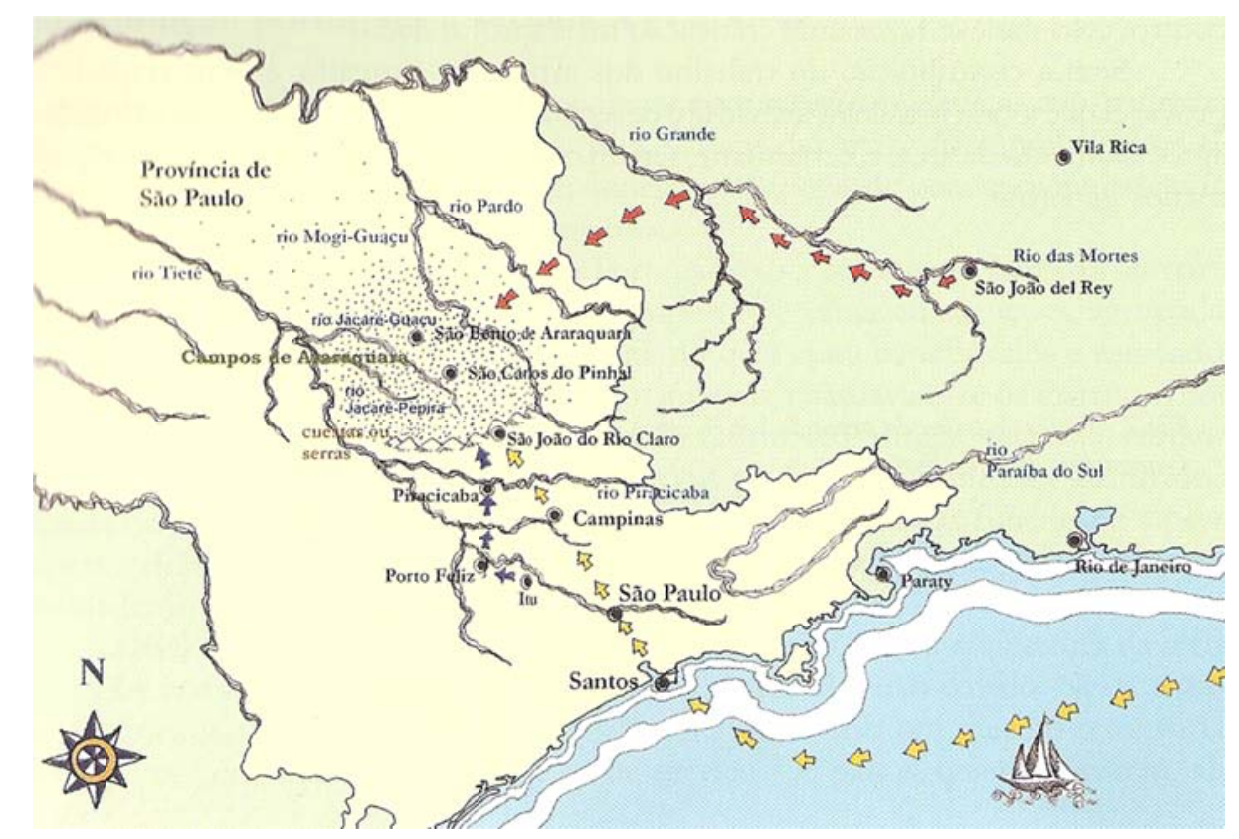

Mapa esquemático das corrente migratórias que povoaram os Campos de Araraquara: as setas vermelhas indicam o fluxo dos mineiros no início do século XIX provenientes do Vale do Rio das Mortes e as setas amarelas indicam o fluxo de imigrantes europeus via porto de Santos a partir da década de 1880 . Fonte: Benincasa $(2003$, p. 83)

Segundo Corrêa (1967), desiludidos com a escassez do metal na região e localizados a grande distancia dos centros produtores, esses primeiros habitantes transplantaram seu modo de vida para o "Sertão Paulista" e foram obrigados a introduzir a criação de gado e desenvolver uma lavoura de subsistência. Por isso, fixaram-se primeiramente nas áreas de campos ou cerrados, mais fáceis de cultivar e propícias à criação de gado. 0 gado era criado solto, exigindo pouca mão de obra e a agricultura era restrita a gêneros de subsistência como mandioca, milho, arroz, feijão e algodão.

As dificuldades econômicas enfrentadas por parte da população mineira e anos depois o alistamento para a Guerra do Paraguai, segundo Monbeig (1984, p.133) incentivaram a emigração: "Crescia a pobreza e contra isso o único remédio era a emigração. Perturbações politicas, a tentativa revolucionaria de 1842, vieram a reforçar a partida dos 
mineiros para a as novas terras. Por fim, durante a Guerra do Paraguai de 1864-1870 preferiu bom numero destes correr o risco da vida no sertão a sujeitar-se ao alistamento militar".

Um terceiro fator importante que influenciou a atração dessa leva de mineiros foi a aprovação da Lei n601 de 18 de setembro de 1850, a chamada Lei de Terras, que embora tenha sido criada para controlar a posse das terras devolutas acabou por intensifica-la. De acordo com Martins (1979), a Lei de Terras foi um instrumento para assegurar a estrutura produtiva escravista mesmo após sua extinção, restringindo o acesso à propriedade da terra e da mesma forma assegurando a oferta de mão de obra para as elites agrarias.

Segundo Ghirardello (2002) o prazo estabelecido para o registro das terras ocupadas antes da aprovação da lei por posse ou concessão governamental e a impossibilidade de ocupação de novas terras devolutas, a não ser por compra direta do Estado, acabaram por incentivar sua ocupação ilegal nesse espaço de tempo. 0 próprio governo, que pela lei deveria demarcar estas terras, reservando as de seu interesse e vendendo as demais, não agiu com a rapidez necessária.

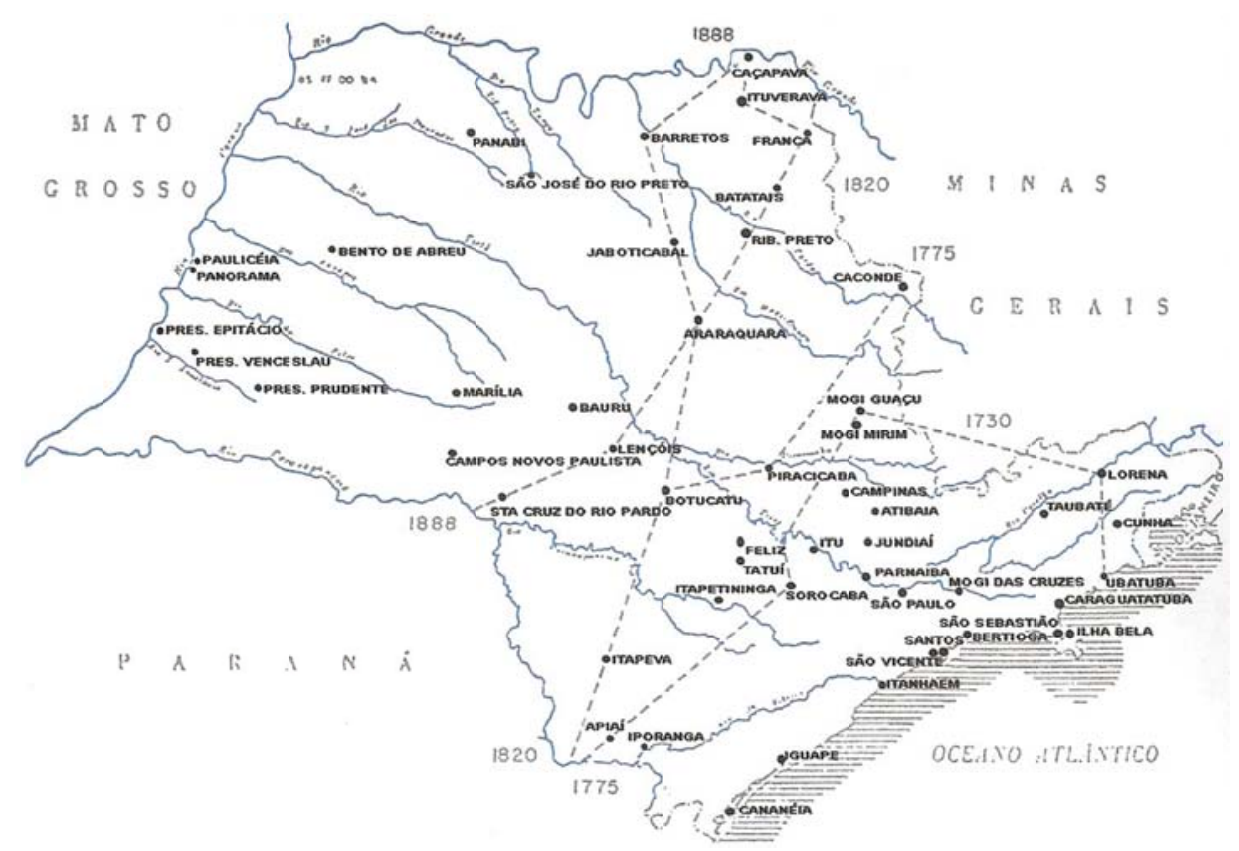

Frente avançada de povoamento no Estado de São Paulo em diferentes épocas. Fonte: Ohtake, 1982.

Em 1817, devido à necessidade da Coroa em se fazer presente naquela região, foi criada a Freguesia de São Bento de Araraquara, o primeiro povoado desta região que se desenvolveu lentamente no inicio do século XIX, até a introdução dla lavoura cafeeira na 
década de 1830, quando passou por um período de grande desenvolvimento socioeconômico, com seu ponto alto na primeira metade do século XX.

Extremamente rentável, a lavoura cafeeira levou à abertura de inúmeras fazendas num curto espaço de tempo e a exigir grande quantidade de mão de obra para seu cultivo, tanto escravos de origem africana quanto trabalhadores livre de origem europeia ${ }^{1}$. De acordo com Ghirardello (2002), os novos ocupantes destas terras terão um perfil diverso do anterior: serão proprietários de terras em outras zonas do estado, detentores de grandes capitais e que formarão de imediato grandes fazendas de café através da compra dos antigos posseiros ou pela apropriação de terras devolutas.

Entretanto, no inicio do século XIX ainda eram poucas as estradas na região, já que a maioria das cidades localizava-se junto à costa ou próximas a cursos d’água. A ligação terrestre entre as diferentes regiões do estado de São Paulo e deste com o restante do país de fato só iria ocorrer com o advento das ferrovias.

A ocupação dessas terras ainda inexploradas no interior do Estado de São Paulo, juntamente com o início da imigração subvencionada, levaram ao surgimento de um número significativo de novas cidades, assim como ao aumento da densidade demográfica, a uma maior interligação territorial e a um aumento da receita estadual. Essas cidades novas, atreladas muitas vezes a fazendas de café e interligadas por ferrovias escoadoras da produção, consolidaram uma inicial rede de cidades que propiciou o surgimento de um mercado interno, produtor e consumidor de bens de consumo. Esse processo exigiu uma estrutura capaz de atender as novas necessidades materiais (sistemas de água e esgotos, serviços, bens industrializados, alimentos, etc.) e institucionais (aparelho administrativo, bancos, escolas, etc.) que acompanhassem seu desenvolvimento.

A chegada da ferrovia terá importante papel de atração para a população urbana, já que viabilizaria a ocupação inicial dos núcleos urbanos, garantindo acesso e propiciando seu desenvolvimento através de do escoamento de sua produção agrícola.

Grande parte das cidades paulistas fundadas em fins do século XIX e nos primeiros anos do século XX terão origem em patrimônios religiosos. Neste período, por suas atribuições, inclusive a formação de povoados, a presença da Igreja Católica significava a

\footnotetext{
${ }^{1}$ Para se ter uma melhor idéia da mão de obra demandada pela cultura cafeeira ver as imagens reproduzidas no Anexo 01, pertencentes ao acervo do Arquivo do Estado de São Paulo.
} 
presença do Estado. Até a República serão constantes as doações de terras para a formação de patrimônios religiosos no estado de São Paulo (Monteiro, 1993, p.248-9).

Sobre o processo de doação de terras rurais para o patrimônio religioso Marx (1991, p.39) nos informa que um fazendeiro ou um grupo deles doava tais terras à Igreja Católica, que passaria a se responsabilizar pelo futuro povoado. Tal patrimônio seria como um dote para a construção da capela, que agregaria população ao seu redor e essa capela estaria sob a proteção religiosa de um santo determinado pelo doador.

De acordo com Ghirardello (2002, p. 155) os nomes dessas futuras cidades sempre viriam precedidos por qualificações sacras, relacionadas ao nome de seus santos padroeiros, pratica que foi aos poucos abandonada por nomes quase sempre ligados a fatores geográficos. Segundo o mesmo autor (p.157-8), o processo de formação dos povoados seguia uma serie de etapas:

" (...) a partir da doação do chão para a Igreja, providenciaria-se por conta da Câmara responsável pelo termo o arruamento do novo Patrimônio. $O$ executor do serviço, o arruador, era indicado pela edilidade e devia, a fim de efetiva-lo, guiar-se por suas posturas. Esse profissional era, regra geral, agrimensor em razão da rara atuação de engenheiros, tanto no pais como um todo, como particularmente no interior de São Paulo até o inicio do século XX." Ghirardello (2002, p. 155)

Neste momento os terrenos urbanos ainda valerão pouco em termos econômicos, mas sua formação e ocupação serão importantes para a valorização e parcelamento das terras rurais e como locais de fornecimento ocasional de mão de obra para as fazendas. Sobre o solo urbano, Queiroz (1996, p.112) afirma que:

"(...) o preço de venda não era alto: o que pretendiam era por meio da criação da vila, da qual seriam fundadores e benfeitores e cuja administração giraria a sua volta, obter facilidades de mão de obra, assim como a valorização de sua própria fazenda, que com o progresso da vila, em breve estaria às portas de um centro populoso e dobraria de preço." Queiroz (1996, p.112)

Alguns autores afirmam que os fazendeiros do café dirigiam o estado de São Paulo, já que muitos deles estavam envolvidos com a politica ou tomavam parte no poder publico ou ainda estavam à frente de instituições bancarias. Segundo Matos (1974), os coronéis do Oeste paulista assumem um caráter "paternal", tornando-se um elemento necessário na conjuntura social e econômica por suas relações com o governo, atuando como elemento de 
ligação entre sua "zona" e os poderes competentes, já que muitas vezes era através de seu intermédio que as povoações conseguiam melhoramentos públicos.

Os povoados que surgiram nesse período tanto por ação dos proprietários rurais quanto, mais tarde, pela chegada da ferrovia, possuem características próprias da implantação de seus traçados, se comparadas a outras que as precederam. Como o traçado das ferrovias era desenhado para escoar a produção, esses povoados surgiam onde havia produção de café. Segundo Costa (2003), nesse momento a questão não era desenhar o urbano, mas planejar o estado territorialmente. A forma urbana seria uma consequência, estaria muito mais relacionada ao papel dessa cidade na articulação territorial.

Segundo Cano (1977), esse processo de urbanização foi possível graças a uma série de fatores: a) produção de café, a atividade principal; b) agricultura produtora de alimentos e matérias primas (tanto a produção de subsistência cultivada no interior da propriedade cafeeira quanto a produção externa a ela, dirigida ao mercado); c) atividade industrial (produção de equipamentos de beneficiamento de café, indústria de sacaria de juta para embalagem e demais setores da indústria manufatureira, em especial, o têxtil); d) implantação e desenvolvimento do sistema ferroviário paulista; e) expansão do sistema bancário e de atividades comerciais de exportação e importação; f) desenvolvimento de atividades geradoras de infraestrutura (portos, armazéns, transportes urbanos e comunicação) e atividades inerentes à própria urbanização (comércio por exemplo); g) atividades dos governos federal e estadual.

Queiroz (1996, p.113) observa que a multiplicação das vilas fez com que se desenvolvesse no estado de São Paulo a pequena propriedade, fenômeno até então raro na historia brasileira.

As cidades que fazem parte da Zona Douradense e que são nosso objeto geral de estudos são: Ribeirão Bonito (localidades Ferraz Salles, Sampaio Vidal e distrito de Guarapiranga), Trabijú, Boa Esperança do Sul (localidades de Java, Pedra Branca e Ponte Alta), Gavião Peixoto (distrito de Nova Paulicéia), Nova Europa (estação Macaia), Tabatinga, Ibitinga (estação Cambaratiba), Borborema, Porto Ferrão, Novo Horizonte, Dourado (Vila Santa Clara e estação Major Novaes), Bocaina (distrito de Pedro Alexandrino e estação Posto Rangel), Taboca, Santa Eulália, Bariri, Morais de Barros, Marambaia, Itapuí (Josué Prado) e Jaú (Pacheco). Entretanto, dessas 34 localidades selecionamos duas que são representativas 
do processo pelo qual passou a região; essas cidades são Dourado (localidade que ainda sofre processo de estagnação econômica iniciado com o fim do ciclo cafeeiro e erradicação da ferrovia) e Nova Europa (núcleo colonial, exemplo do planejamento estatal para essa parte do território paulista), que são nossos objetos específicos de estudo.

Muitas dessas localidades se desenvolveram a partir da base café-ferrovia, apesar da diversidade de fatores que deram origem aos seus núcleos iniciais. São exemplos dessas diversas origens as cidades de Bocaina, que se localizava num ponto de passagem obrigatória para quem vinha da região de Jaú para Araraquara, cujos primeiros moradores foram provenientes de Jaú e Dois Córregos, cidades atingidas entre 1887 e 1889 por surtos de febre amarela; Borborema, que era ponto de passagem para os que seguiam para o Mato Grosso e que teve origem com o quilombo de Fugidos; Dourado, onde no século XIX se fixaram os mineiros 'torna viagem' provenientes de Caldas Novas, Ouro Fino, Pouso Alegre, Alfenas, Campanha, Piuim, Campo Belo e Formiga; Novo Horizonte, inicialmente ocupada por criadores provenientes de Descalvado e Pirassununga em busca de novas terras; Trabijú, que teve origem a partir da construção da Cia. E. F. Dourado, nascendo como vila ferroviária e Nova Paulicéia, que foi originalmente uma das três colônias resultantes do desmembramento do Núcleo Colonial Cambuhy, parte da política de interiorização implementada pela Secretaria da Agricultura.

Entretanto, somente a partir dos anos 1920, quando a malha ferroviária paulista já estava consolidada é que as diferentes regiões do estado passarão a ser reconhecidas pelo nome das ferrovias que as atendiam.

O quadro abaixo mostra a sequencia do desmembramento dos municípios ${ }^{2}$ tratados nesta dissertação. Os quadros em vermelho são municípios da Zona Douradense e os dois que estão destacados em cinza, são nossos objetos de estudos mais específicos. A primeira data entre parêntesis se refere ao ano em que estas localidades foram elevadas à freguesia e a data seguinte se refere ao ano em que se emancipa do município ao qual pertencia, em alguns casos recebendo o status de vila, em outros já como município.

\footnotetext{
${ }^{2}$ Para se ter uma melhor ideia de como se deu o desmembramento politico-administrativo dos municípios do Estado de São Paulo, observar a sequencia de mapas elaborados pela Fundação SEADE reproduzidos no Anexo 02.
} 


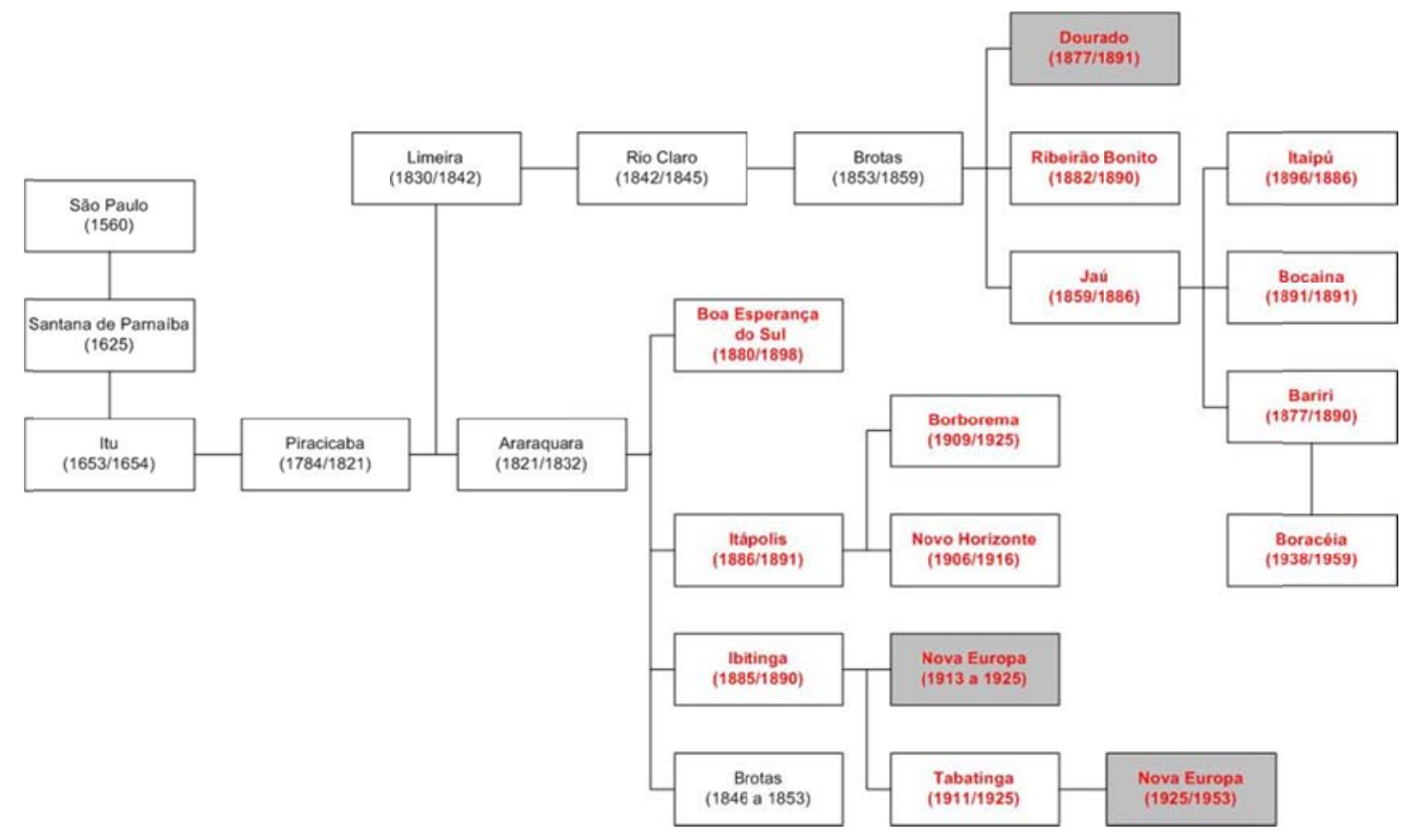

OBS: as datas entre parêntesis à direita correspondem à criação do distrito e as datas localizadas à esquerda à criação do município. FONTE: Quadro do desmembramento territorial-administrativo dos municípios paulistas

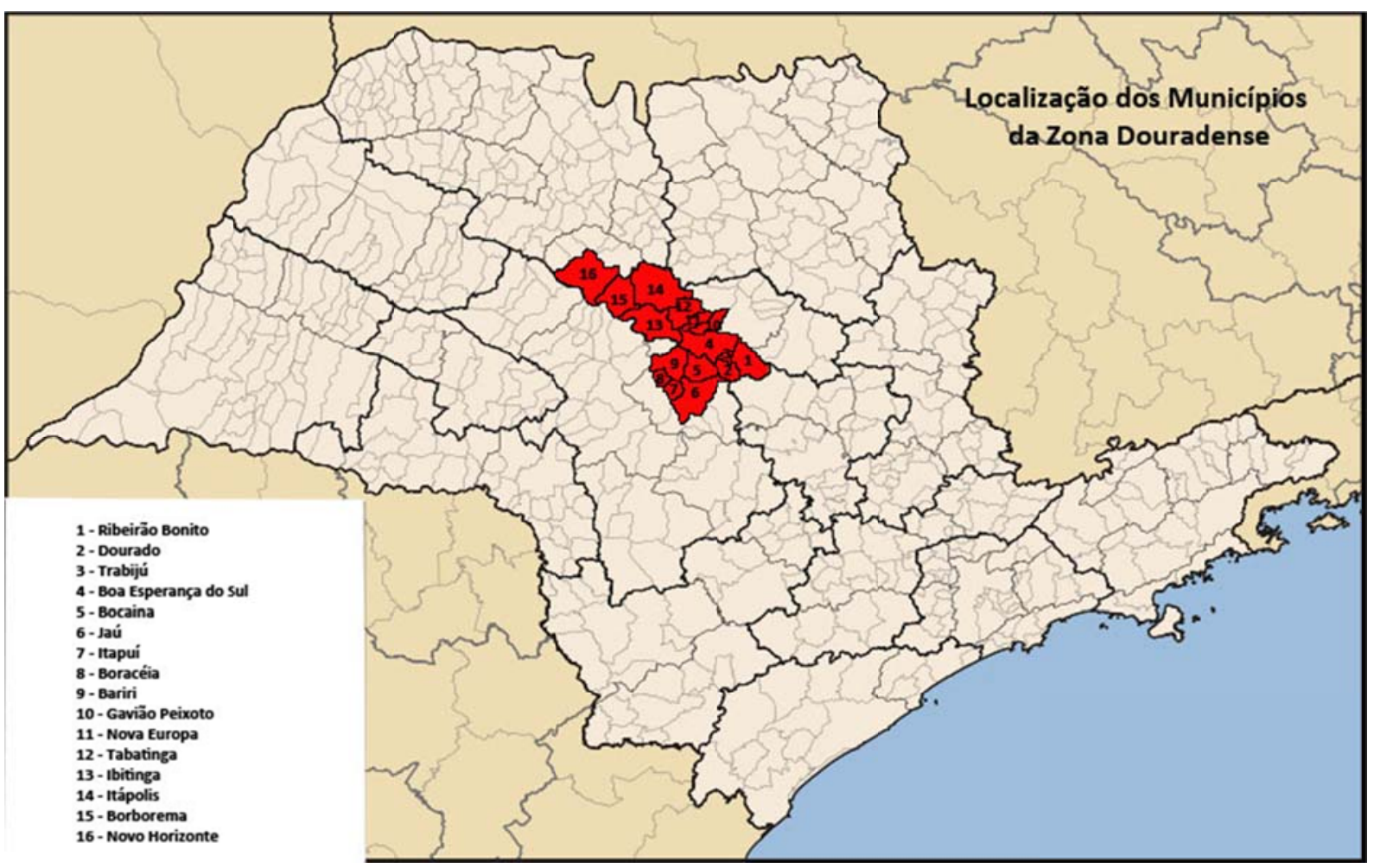

Localização dos municípios pertencentes à Zona Douradense no Estado de São Paulo.

Observar que esta zona ferroviária atendia a municípios de quatro regiões administrativas: Região de: São Carlos (Ribeirão Bonito e Dourado); Região de Araraquara (Trabijú, Boa Esperança do Sul, Gavião Peixoto, Nova Europa, Talbatinga, Ibitinga, Itápolis e Borborema); Região de Jaú (Jaú, Bocaina, Itapuí, Boracéia e Bariri) e Região de Catanduva (Novo Horizonte).

Elaborado a partir de mapa obtido em www.sp.gov.br acessado em janeiro de 2011 


\section{1 - A expansão da lavoura cafeeira e a chegada da ferrovia}

No período entre 1830 e 1870, apesar do café já ter chegado aos Campos de Araraquara, isso aconteceu de forma bastante pontual, já que a estrutura pastoril ainda era a principal fonte de renda e a cana de açúcar ocupava as terras mais férteis.

Segundo Tschudi (1980), não compensava financeiramente plantar café além de Rio Claro, pois a grande distancia até o porto e a precariedade das estradas, inviáveis para o transito de veículos de rodas, encarecia muito e tornava arriscado o transporte da produção em lombo de burro, anulando qualquer tentativa de transformar em comerciais as lavouras da região.

A solução encontrada para baratear os preços do café e garantir a agilidade no seu transporte, tornando-o competitivo no mercado internacional, foi a construção de ferrovias que escoassem a produção até o porto de Santos. Mas segundo Maluf (1995), mesmo com a ferrovia, os preços do transporte não caíram como esperado e os grandes fazendeiros, na tentativa de minimizar ainda mais os custos, articulavam politicamente para conseguir estações próprias ou convenientemente localizadas em suas terras, ou então criavam ramais secundários, vulgarmente chamados de cata-café, que partiam da linha tronco para suas fazendas.

A construção das ferrovias em São Paulo ocorreu após a primeira metade do século XIX, construindo uma verdadeira rede de captação de café em direção ao porto de Santos. Suas linhas se expandiram orientadas pela localização das lavouras e serviram praticamente a todas as regiões do Estado de São Paulo, desempenhando papel fundamental em seu desenvolvimento socioeconômico, deslocando consigo o povoamento e estabelecendo cidades onde se instalavam as estações. Além de transportar a produção agrícola aos mercados internos e externos, transportava os produtos necessários à subsistência dos povoados e à construção e desenvolvimento das cidades.

Das ferrovias de primeira categoria, que funcionavam como os principais corredores, partiam uma série de outras pequenas ferrovias que eram operadas como captadoras de mercadorias, passageiros e animais, constituindo uma rede complexa formada por diferentes ferrovias com diferentes bitolas e extensões. Segundo Nunes (2002), o volume de cargas e passageiros obtidos por esses pequenos ramais era essencial para a 'saúde 
econômica' das linhas tronco, pelo menos até o momento em que não conseguiram mais competir com os automóveis e caminhões.

Além de baratear o transporte da safra e entrega-la sem perdas significativas no porto, a ferrovia possibilitou a implantação de serviço diário de correio, telégrafos e facilitou a importação de produtos, ampliando o comércio com as cidades e também com outros países.

Ainda possibilitou a um único fazendeiro supervisionar várias fazendas ao mesmo tempo. Este novo fazendeiro agora vivia em São Paulo enquanto deixava pessoas de confiança em cada uma de suas fazendas, enquanto controlava seus negócios a partir de seu escritório. As fazendas passaram de locais de moradia a fontes geradoras de recursos que muitas vezes eram aplicados em outros negócios, como bancos, imóveis, casas comissárias, etc.

No final do século XIX, as estradas de ferro em São Paulo pouco haviam avançado em direção ao Oeste, além da região central do Estado. Segundo Milliet (1982), esse quadro começou a mudar a partir de 1870, quando as lavouras do Oeste paulista atingem grande produtividade graças à maior fertilidade de seus solos, da menor idade media dos cafezais, da aplicação de técnicas agrícolas e maquinário de beneficiamento mais eficientes. As novas plantações por outro lado aumentaram as distancias entre a produção e o porto de Santos, atraindo a expansão das linhas férreas nesta direção para que essa produção fosse viável.

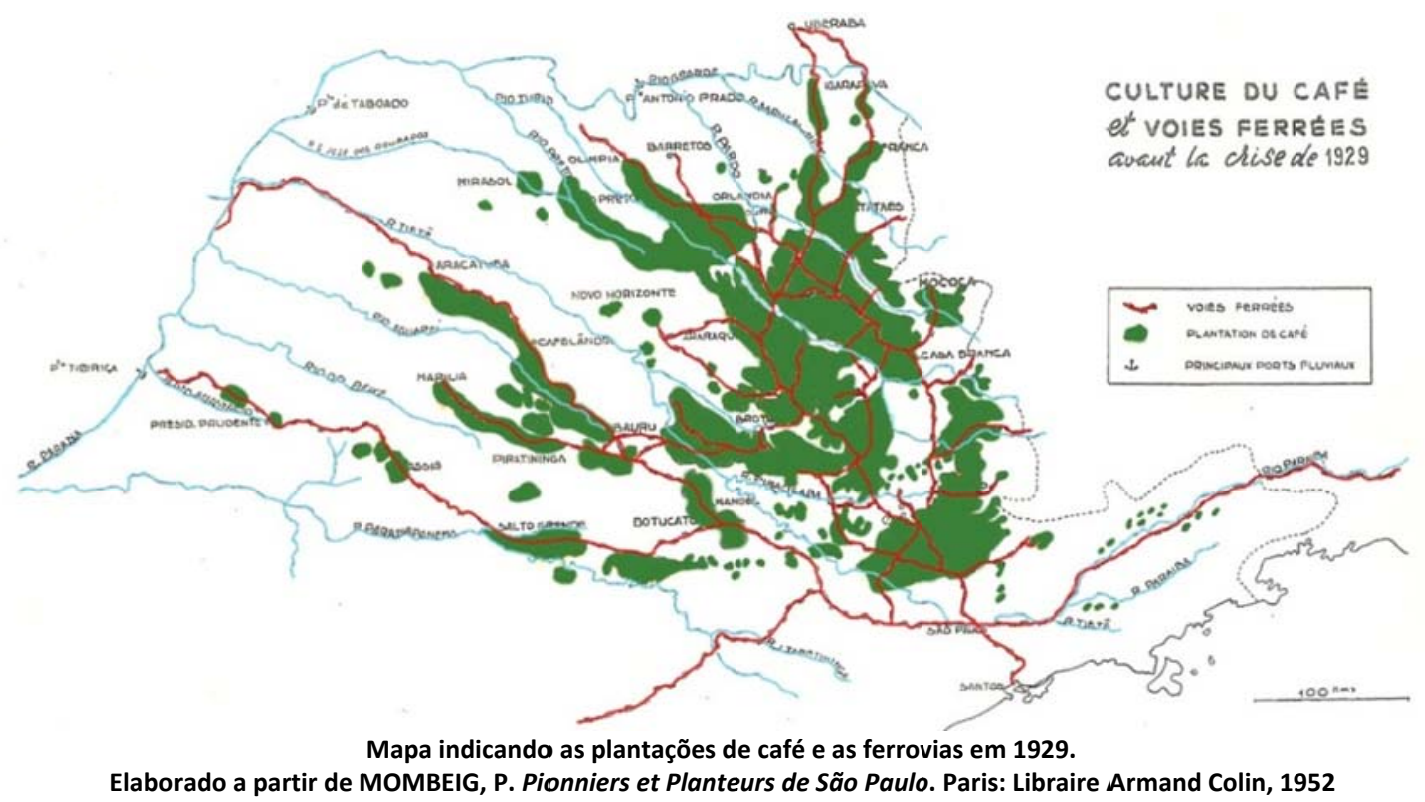




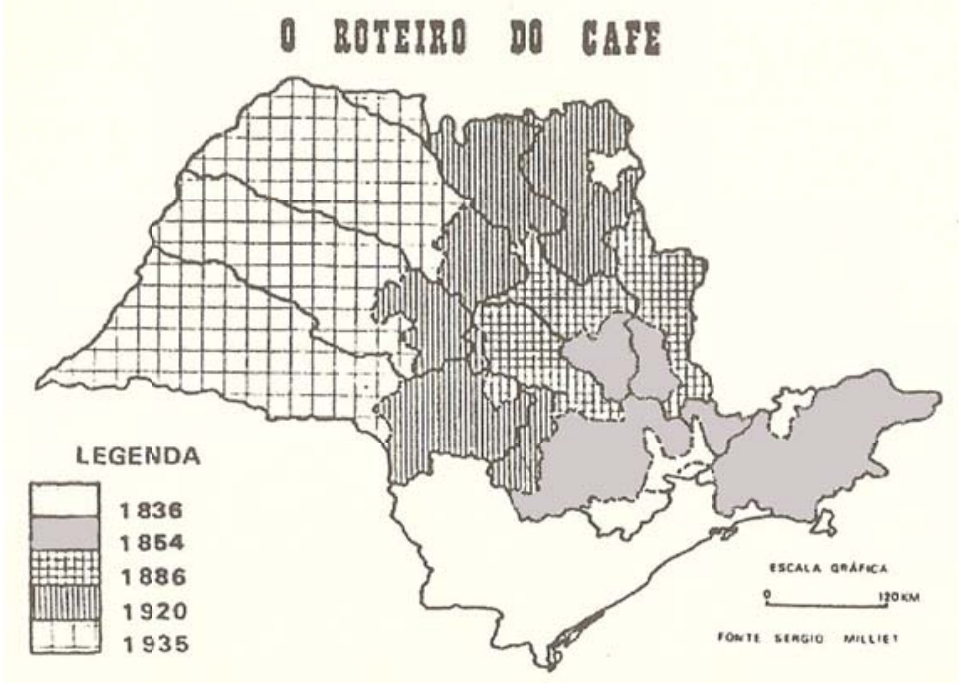

Expansão da cultura cafeeira. Fonte: Matos, 1981

\section{A EvoLugão Ferkovbabia de são pavL [8]}

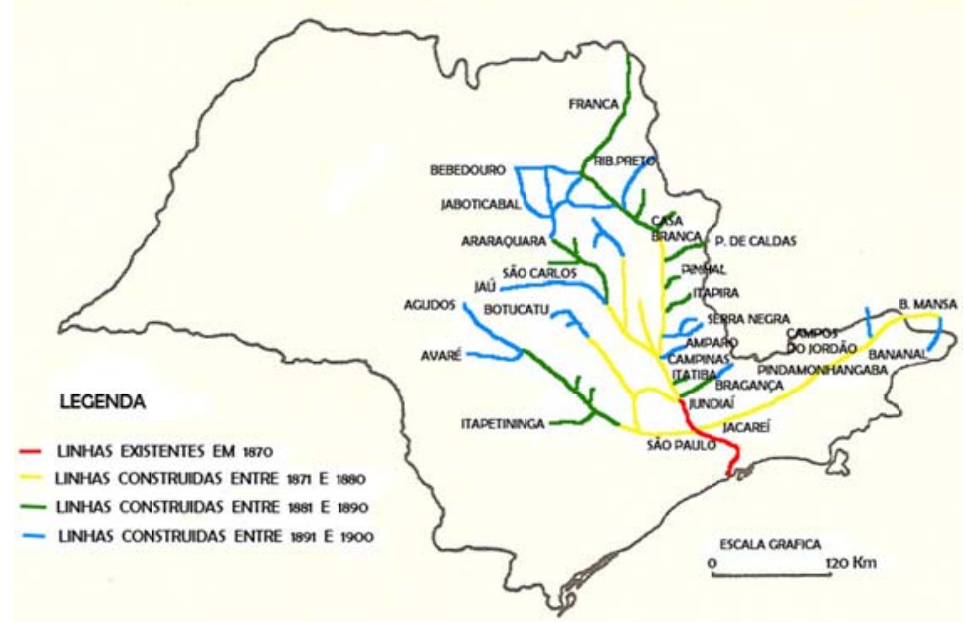

Evolução ferroviária em São Paulo entre 1870 e 1900. Fonte: Matos, 1981.

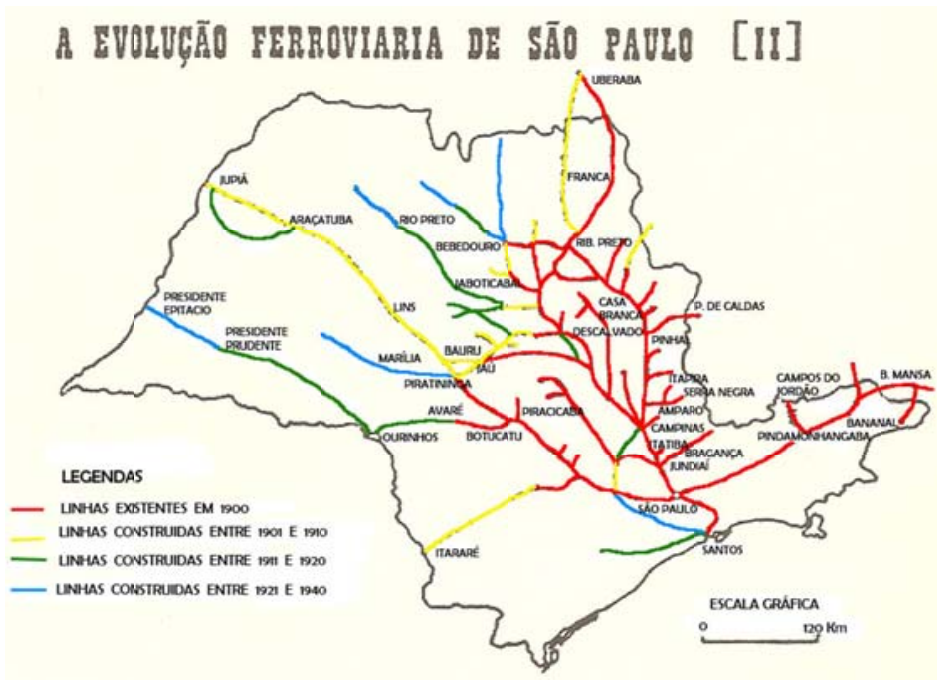

Evolução ferroviária em São Paulo entre 1900 e 1940. Fonte: Matos, 1981. 
Um fator importante para a expansão das linhas férreas foi a promulgação da Lei no 30, de 13 de junho de 1892, que passou a regular a concessão de estradas de ferro no estado de São Paulo, rompendo com o privilégio de zona. Além de outras providências, a referida lei determinava:

"A estrada de ferro gozará de uma zona garantida de cem metros de cada lado, reduzida a cinquenta metros nas gargantas e declives de serras (...) dentro da qual nenhuma outra estrada de ferro poderá receber gêneros ou passageiros, salvo o caso de outras ou mais estradas terem o mesmo ponto inicial e terminal; (...) poderá qualquer outra (ferrovia) atravessar a mesma zona, cruzando a linha, sujeita, porém, ao ônus provenientes do cruzamento". ${ }^{3}$

A Estrada de Ferro do Dourado foi uma ferrovia de terceira categoria, inaugurada em 1900, encampada pela Companhia Paulista em 1949 e desativada em 1969. A expansão de suas linhas deu-se no contexto de expansão da agricultura paulista em direção às novas áreas e também diante da recusa da Companhia Paulista em prosseguir além de Ribeirão Bonito.

Em 1896 Cyro Marcondes de Rezende obteve a licença para a construção e exploração da linha para além de Ribeirão Bonito, fundando a E. F. do Dourado, cujo objetivo inicial foi avançar a linha de Ribeirão Bonito até a Vila de Dourado. Em fevereiro de 1902, uma nova concessão autorizava a expansão da Douradense até Boa Esperança do Sul, seção inaugurada no ano seguinte. ${ }^{4}$

Entre 1903 e 1910 a expansão dos trilhos prosseguiu até os municípios de Boa Esperança do Sul, Trabiju, Bocaina e Bariri, já produtoras de café e também até os recéminaugurados núcleos coloniais de Gavião Peixoto, Nova Paulicéia e Nova Europa e posteriormente para as estações Java e Ponte Alta. Nos anos seguintes com a abertura das estações de Tabatinga (1909) e Ibitinga (1910), a Douradense já se estendia por 122 km. Em 1910, partindo de Trabiju com destino a Jaú, foi criado o ramal de Bariri com aproximadamente $62 \mathrm{~km}$ de extensão, atendendo as localidades de Pedro Alexandrino, Bocaina, Izar, Posto Rangel, Taboca, Santa Eulália e Bariri. ${ }^{5}$

Típico exemplo de ferrovia do café, a Douradense atendia aos municípios de Ribeirão Bonito, Boa Esperança do Sul, Nova Europa, Tabatinga, Ibitinga, Itápolis, Borborema, Novo Horizonte, Bocaina, Bariri e Jaú. A linha-tronco se estendia para Oeste do estado até a cidade

\footnotetext{
3 São Paulo (Estado). Lei no 30, de 13 de junho de 1892.

${ }^{4}$ São Paulo (Estado), Decreto no 1003 de 11 de fevereiro de 1902

${ }^{5}$ CEFD. Relatório do ano de 1907. São Paulo, Duprat \& Cia, 1908, p. 3-5
} 
de Novo Horizonte, tendo à esquerda o Rio Tietê e à direita a E. F. Araraquara, com a qual mantinha contato através da estação de Tabatinga. Essa região composta por pequenas e novas cidades, mas de significativa produção cafeeira, segundo Milliet (1982), chegou a ocupar em 1935 o primeiro lugar na produção de café do Estado de São Paulo.

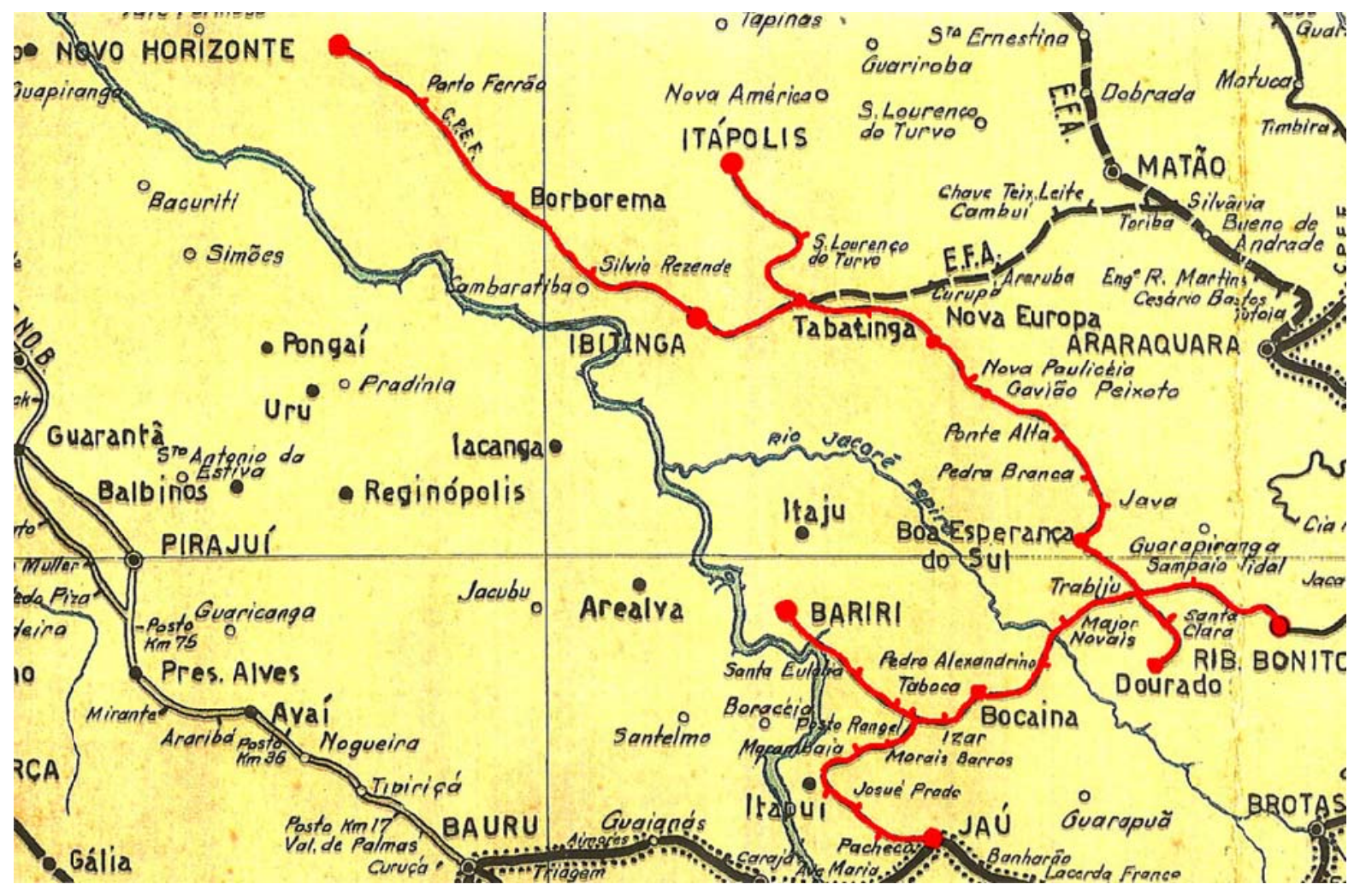

É curioso o fato de esta companhia forma-se e expandir-se no momento em que diversos autores apontam como sendo o da primeira crise da economia cafeeira. Sobre esse período de crise, Abreu (1990) nos informa que se do ponto de vista dos cafeicultores a desvalorização da moeda diminuiu os diversos efeitos da crise, do ponto de vista da ferrovia resultou em uma maior dificuldade na importação de trilhos, vagões e locomotivas, necessários à expansão das linhas.

De forma direta ou indireta, a expansão dos trilhos beneficiava a economia regional e os usuários de uma área geográfica maior do que apenas as cidades onde eram construídas as estações. O estímulo que a ferrovia trazia ao progresso econômico também para estes povoados localizados além da "boca do sertão" também era considerável. Os diversos serviços oferecidos pela ferrovia como o telégrafo, que além de servir à operação da ferrovia 
(circulação de trens, ordens diversas, transmissão de dados, etc.), servia como instrumento de comunicação para a população.

Estas ferrovias menores também desempenharam importante papel na vitalidade econômica de uma serie de pequenas cidades do interior paulista, como a cidade de Dourado, por exemplo, que após a erradicação dos cafezais e da ferrovia, mesmo com a alta da cultura do algodão que se sucedeu ao café, entrou em um processo de involução tanto populacional quanto econômica.

Com a Primeira Guerra Mundial, as ferrovias passam por novo período de crise, não apenas pela própria situação interna, mas, sobretudo pela retração das exportações, o que reduzia significativamente o volume de café transportado pelas ferrovias, comprometendo sua rentabilidade. A redução no transporte do café também foi agravada a partir de 1929 pela politica de desvalorização dos preços do produto, que retinha grande parte das safras nos armazéns reguladores localizados no interior do estado, enviando para o porto de Santos apenas a quantidade imediatamente necessária à exportação. Soma-se a isso o inicio, em 1929, da substituição de algumas lavouras de café por algodão e do surgimento na década de 1930 das relações relativas a encargos sociais, fator também de acréscimo às despesas das ferrovias.

Segundo Saes (1981), a crise foi superada nos anos subsequentes, porém suas sequelas foram irreversíveis. O café continuou como maior fonte de riqueza dos campos de Araraquara até aproximadamente a década de 1930, porem as sucessivas crises por que passou o produto no mercado internacional fizeram com que os fazendeiros aos poucos fossem rompendo com a exclusividade, principalmente a partir de 1929. A decadência iminente da região, fruto da derrocada do café, foi detida devido ao plantio de outros produtos como algodão, a cana de açúcar e laranja.

Em meados da década de 1920, parece ter se iniciado uma mudança significativa na estrutura de transportes no Estado de São Paulo, com um aumento considerável na quantidade de automóveis e caminhões. Até o final da década de 1930, concorrendo ou completando o traçado ferroviário, as estradas de rodagem estavam presentes geograficamente em todas as regiões do Estado, inclusive precedendo a ferrovia em diversas localidades. 
Com a posse do presidente Juscelino Kubitschek, que tinha entre seus lemas "governar é abrir estradas", o transporte rodoviário assim como a instalação de indústrias automobilísticas no Brasil ganharam destaque na cena econômica, fatores que comprometeram ainda mais a rentabilidade das ferrovias.

Segundo Nunes (2002), a crise ferroviária no estado de São Paulo foi resultado da fragilidade das próprias bases em que o sistema foi implantado, especialmente no que se refere à sua dependência para com a produção cafeeira, sendo obrigado a sujeitar-se às oscilações de oferta e demanda do produto, além da disparidade entre o volume de carga transportada das regiões produtoras do interior para São Paulo e de lá para o porto de Santos e o trajeto contrário, já que na volta os vagões geralmente seguiam com sua capacidade ociosa e até mesmo sem carga.

A década de 1960 foi o 'período negro' das ferrovias paulistas. Acumulando déficits operacionais há anos, elas foram aos poucos sendo estatizadas. Em 28 de outubro de 1971 foi promulgada por Laudo Natel, então governador do Estado de São Paulo, a lei que decretava a constituição de uma empresa denominada Ferrovia Paulista S.A. (FEPASA), de economia mista, regida pela legislação usual das Sociedades Anônimas e pelo seu Estatuto e dirigida por um colegiado com mandato de sete anos.

Desta rede de pequenos ramais e sub-ramais férreos pouco restou após a grande operação-desmonte, formalmente instituída com o Decreto-Lei № 2698 de 27 de dezembro de 1955. Este decreto, entre outras providências, determinava a aplicação de recursos em pavimentação, revestimento e construção de rodovias destinadas a substituir ramais ferroviários reconhecidamente deficitários. A lei previa inclusive o aproveitamento do leito ferroviário, que em diversos trechos foi literalmente asfaltado.

A partir de então foram incorporadas à FEPASA a Cia. Paulista de Estradas de Ferro (1868), a Cia. Mogiana de Estradas de Ferro (1872), a Estrada de Ferro Sorocabana (1871), a Estrada de Ferro São Paulo a Minas (1890) e a Estrada de Ferro Araraquara (1895), totalizando $4.500 \mathrm{~km}$ de linhas.

Em 1957, também no governo de Juscelino Kubitschek, foi criada a Rede Ferroviária Federal Sociedade Anônima (R.F.F.S.A.), que incorporou tanto as estradas de ferro já pertencentes e administradas pela União quanto aquelas cujos contratos de arrendamento já houvessem sido encampados ou rescindidos. 
Segundo Nunes (2002), entre março e maio de 1961 foi elaborado o "Plano Quinquenal para Construção e Pavimentação de Rodovias Substitutivas", trabalho sistemático visando relacionar os trechos a serem substituídos por estradas de rodagem que recomendou para erradicação um total de $4.985 \mathrm{Km}$ de linhas. Segundo o mesmo autor, após o golpe militar de 1964 foi criado o Conselho Nacional de Transportes (CNT), que dentre suas atribuições básicas deveria "definir as bases da política geral de transportes do país, rever o Plano Nacional de Transportes e coordenara execução do mesmo, dentre outras".

Para Paulo Roberto Cimo Queiroz "se a rede ferroviária poderia ser retificada ou de qualquer modo melhor adaptada às novas funções que se requeriam dos transportes", o autor reconhece que "o país não dispunha de capitais suficientes para empreender um reordenamento de sua rede ferroviária na escala em que isso se fazia necessário", ressaltando que a política brasileira de transportes havia ficado bastante dependente de capitais externos.

"É interessante notar que não é incomum encontrarem-se ainda entre os brasileiros explicações de cunho francamente conspirativo, segundo as quais o triunfo das rodovias teria sido obtido graças a um verdadeiro complô, envolvendo, numa vasta trama de corrupção, os governos e as grandes empresas petroliferas e automobilísticas (todas estrangeiras) - complô pela qual se teriam deliberadamente deixado as ferrovias à mingua de recursos, os quais em contrapartida, haveriam sido generosamente fornecidos ao setor rodoviário". ${ }^{6}$

A ferrovia entrou em fase de decadência a partir da década de 1950 não só pelo declínio do café, mas principalmente pela politica em favor do transporte rodoviário adotada pelo governo Juscelino Kubitschek e pelos seus sucessores. As ferrovias foram incoerentemente abandonadas pelo poder publico, mesmo sendo um meio de transporte mais barato, eficiente e já instalado e em contrapartida, grandes rodovias foram sendo abertas, a partir de então praticamente seguindo os mesmos traçados daquelas, ao menos no estado de são Paulo.

A erradicação dos ramais veio ainda agravar a situação de várias cidades da zona Douradense, já abaladas com a crise do café. Muitas dessas localidades surgiram praticamente junto com a expansão da ferrovia e com elas mantinham uma identidade de

\footnotetext{
${ }^{6}$ QUEIRÓZ, Paulo Roberto Cimó. Notas sobre a experiência das ferrovias no Brasil: história econômica \& história de empresas, p. 91-111, 1991.
} 
zona, tendo que reconfigurar toda sua "identidade geográfica" a partir da substituição da malha ferroviária pela rodoviária, que dificultou o acesso entre cidades vizinhas.

Além disso, essas pequenas cidades sofreram uma enorme redução em sua população, pois parte considerável dela era constituída de funcionários dessa companhia que perderam seus empregos ou tiveram que mudar de cidade em busca de trabalho. Exemplos dessa situação são as cidades de Dourado, que em 1920 chegou a ter 18 mil habitantes, em 1970 apenas 5.634 habitantes e atualmente pouco mais de 10.000 habitantes e Trabijú, que no período sofreu a maior crise de sua história, com a mudança em massa de sua população para outras cidades.

De qualquer forma, só a partir dos anos 70, com a criação do programa Proálcool e outros de incentivo à industrialização, é que a região começou a recuperar um pouco do prestigio dos tempos em que o café era a sua grande fonte de renda.

Abaixo, foram reproduzidos alguns gráficos que ilustram os reflexos da politica de incentivo aos transportes rodoviários nas possibilidades de deslocamento das cidades da zona douradense e o processo de substituição do transporte ferroviário pelo rodoviário.

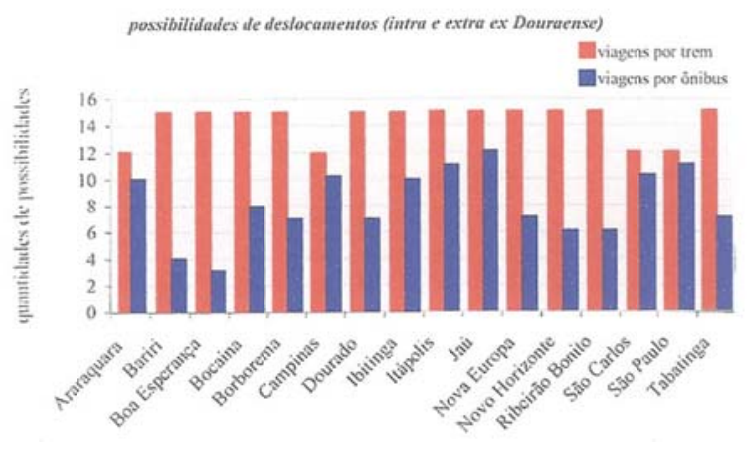

Comparativo entre as possibilidades de deslocamentos Fonte: NUNES, 2002, p. 12

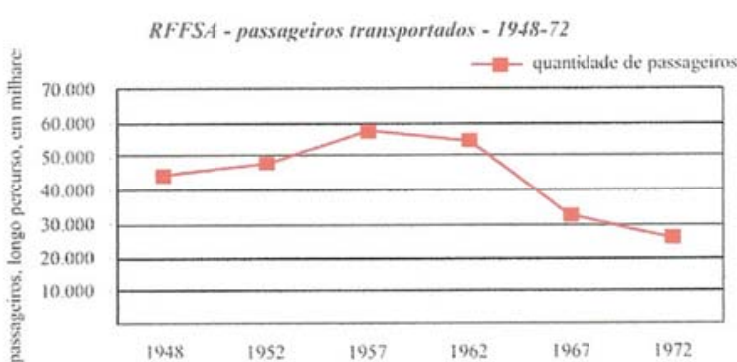

RFFSA: Passageiros transportados, 1948-72. Fonte: NUNES, 2002, p.12 


\section{2 - A política de povoamento e a implantação dos núcleos coloniais}

A necessidade de mão de obra para a lavoura cafeeira motivou a introdução a partir da década de 1840 do sistema de contratos por parcerias, que se desdobrou mais tarde, na década de 1870 , no regime de colonato, baseado no trabalho livre assalariado, onde os trabalhadores viviam nas colônias das fazendas e participavam dos ganhos e perdas da produção. Segundo Martins (1979) e Vioti da Costa (1988), a partir dos anos 1870, o regime de colonato foi o principal meio utilizado pelos grandes fazendeiros, de substituição da mão de obra escrava por trabalhadores assalariados.

Um terceiro projeto foi a implantação dos núcleos coloniais. Os primeiros núcleos foram implantados ainda no Império, nas primeiras décadas do século XIX, submetendo-se a variações no decorrer do tempo conforme os períodos políticos vigentes. Com objetivo de fomentar a imigração, fixar povoados, ocupar o território e garantir as fronteiras. Esta politica englobava diversas províncias e pressupunha os imigrantes como agentes civilizatórios.

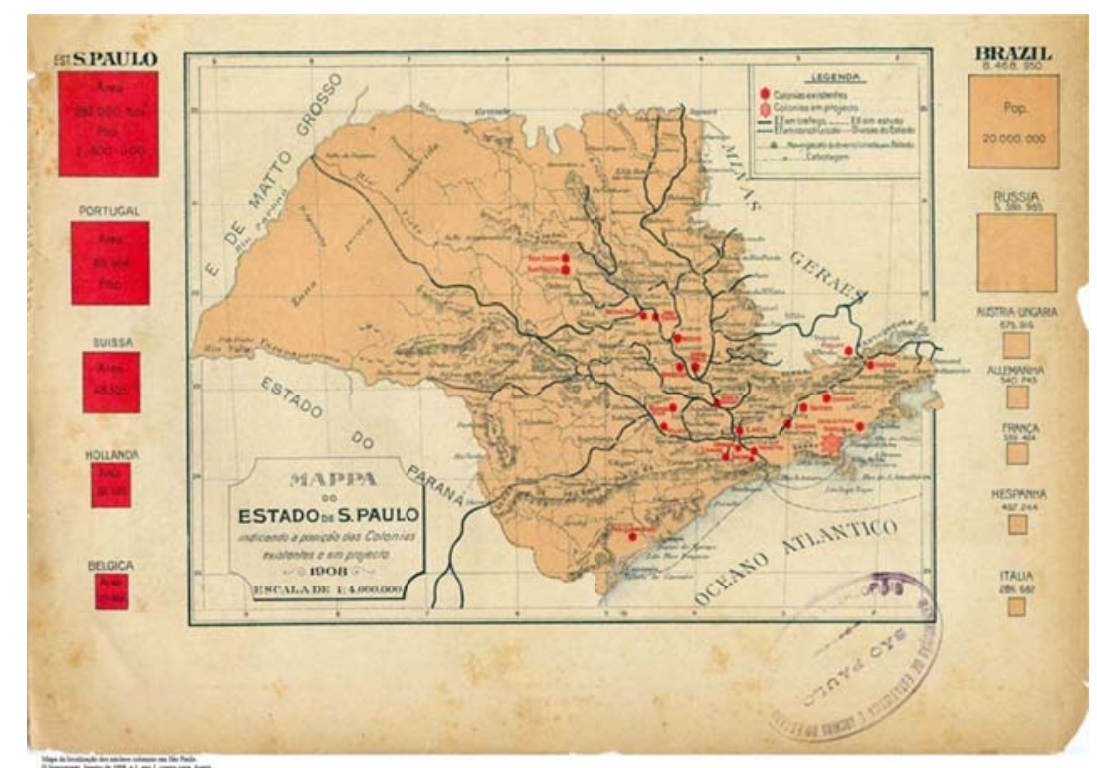

Mapa da localização dos núcleos coloniais em São Paulo, indicando os núcleos coloniais já implantados e os em projeto em 1908. Fonte: O Imigrante, janeiro de 1908, n. 1, ano 1, contra-capa. Aspesp - Arquivo do Estado de São Paulo.

Em 1854 foi criada a Repartição Geral de Terras públicas, órgão responsável pelo estabelecimento e desenvolvimento dos núcleos coloniais, com a aprovação em 1867 do primeiro regulamento para a criação dos núcleos coloniais e quatro anos depois, em 1871, 
foi fundada a Associação Auxiliadora de Colonização e Imigração, responsável pela instalação dos imigrantes em regiões mais acessíveis, já que os primeiros núcleos foram implantados em locais de difícil acesso.

No plano externo, a viabilização dos primeiros núcleos sofreu com a concorrência da politica imigratória norte-americana, mais atrativa ao imigrante europeu graças à similaridades de clima e paisagem e vantagens como menores custos de transporte e maior proximidade dos países de origem. Além dos EUA, Argentina, Chile e Uruguai possuíam politicas consistentes para atração de imigrantes.

No plano interno a maior dificuldade para viabilizar os núcleos eram os altos custos de sua implantação. Segundo Oliveira, os custos para "demarcação e regularização das propriedades, a abertura de vias de comunicação para os mercados consumidores, auxílio para a construção de casas para imigrantes e demais instalações produtivas além de subsídios para a implantação das lavouras de criação de animais", recairiam sobre o Estado, utilizando recursos então necessários para dar suporte à expansão cafeeira, contrariando os interesses das elites paulistas da época.

Para sua manutenção os núcleos enfrentaram dificuldades como a ausência de mercados consumidores, já que quase sempre foram implantados longe dos centros urbanos e as grandes fazendas possuíam uma estrutura autossuficiente. Ainda a baixa qualidade dos solos onde eram implantados, geralmente areníticos, já que as melhores terras já haviam sido ocupadas pela cafeicultura.

Essa situação se manteve até 1879, ano que Gadelha (1982) aponta como o início da diminuição da resistência das elites em relação à implantação dos núcleos coloniais, já que se iniciou o declínio da escravidão nas áreas cafeeiras e o esgotamento do trafico intraprovincial de escravos. A crise de mão de obra chama atenção para a importância dos núcleos coloniais como instrumento de atração à imigração.

De acordo com esse espírito foi aprovada em 1884 a lei que estabelecia o fornecimento dos fundos para o subsídio à imigração, autorizando o estabelecimento por parte do governo provincial de até cinco núcleos coloniais nos principais distritos agrícolas, próximos às estradas de ferro. 
Para Teixeira Junior (2007), essa intenção de atrair trabalhadores assalariados para a lavoura acenando com a propriedade da terra a médio e longo prazo já estava presente desde o momento da discussão da Lei de Terras.

Em São Paulo, o processo de implantação dos núcleos coloniais pode ser dividido em três fases. A primeira fase (1808-1877) é caracterizada pelas politicas da Corte para incrementar a imigração e o povoamento, sofrendo objeções por parte das elites paulistas que atuaram contrariamente à disseminação da iniciativa.

Na segunda fase (1877-1896), a proposta dos núcleos coloniais se torna conveniente aos interesses das elites cafeeiras que naquele momento passavam por uma crise de mão de obra, já que esses atuavam como centros de abastecimento alimentar e principalmente como instrumentos da politica oficial, que veiculava os núcleos como propaganda para atrair imigrantes.

A ideia das elites era utilizar os núcleos apenas pontualmente, como meio de acalentar os sonhos dos trabalhadores em ascender socialmente através da aquisição de terras a médio e longo prazo, a fim de atrair a imigração em massa necessária para o trabalho assalariado nas fazendas, mas de fato permitindo o acesso à terra apenas a um reduzido numero de imigrantes. Essa politica não visava ampliar o numero de proprietários, mas sim o numero de trabalhadores necessários à cultura cafeeira.

A partir dos anos 1880, a lavoura cafeeira buscava racionalizar sua produção e reduzir custos, especializando-se na monocultura cafeeira e restringindo as terras para a produção de outros gêneros. Neste momento os núcleos começaram a ser implantados em áreas mais próximas às regiões cafeeiras, nas terras inviáveis ou já de produção decadente para atrair imigrantes e prover o abastecimento alimentar. Produziam milho, feijão e outros alimentos que não tinham significativa importância comercial e assim, para adquirir outros itens necessários a sua manutenção, o colono tinha que vender sua força de trabalho para o fazendeiro.

A terceira fase é a mais importante no que se refere ao ordenamento e viabilidade dos núcleos coloniais paulistas. É a fase identificada por autores como Costa (2003) e Oliveira (1997) como fase do "planejamento científico". Os núcleos desta fase foram fomentados a partir de 1890 e estabelecidos entre 1896 e 1914, sempre atrelados aos 
interesses dos cafeicultores que propunham os núcleos como "viveiros de trabalhadores, celeiros alimentares e incubadores de novas culturas e criações". Oliveiira (1997, p.180)

É importante observar que entre 1885 e 1911, período de várias mudanças na política de formação desse tipo de empreendimento, foi implantado um total de 25 núcleos coloniais, que proporcionaram o estabelecimento de imigrantes e a oferta de mão de obra para as fazendas de café.

A imagem abaixo é bastante esclarecedora quanto à relação entre a marcha cafeeira e a implantação dos núcleos, próximos a importantes rios e ferrovias. Segundo Gadelha (1982, p.203), a localização dos núcleos próximos aos cursos d’água era parte da estratégia de favorecer a própria alimentação dos moradores desses núcleos, mas também atender aos interesses das elites agrárias, já que essas áreas eram improprias para a lavoura cafeeira.

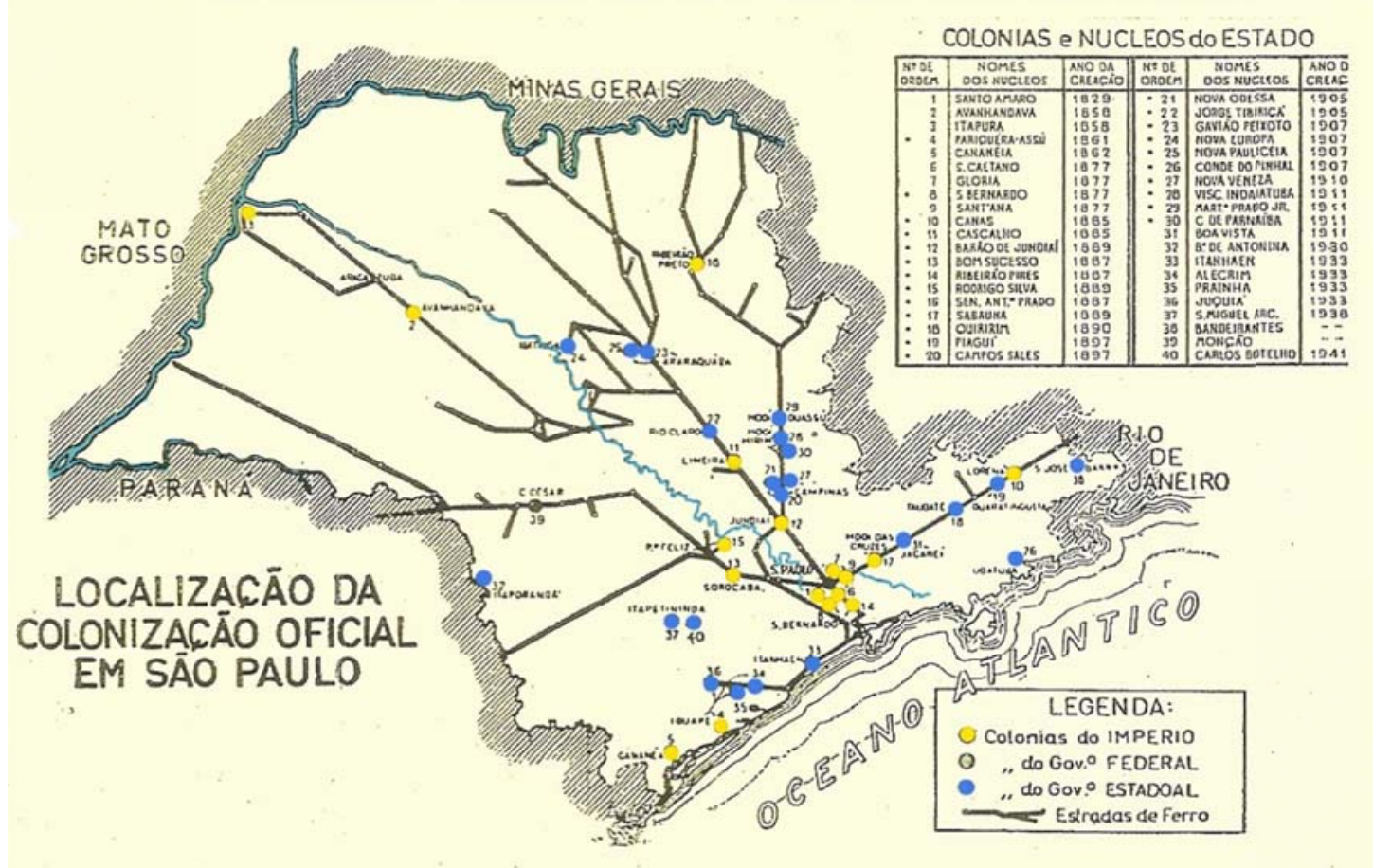

Localização dos Núcleos Coloniais em São Paulo. Elaborado a partir de SCHIMIDT, C. B. e REIS, J. Rasgando Horizontes. A Secretaria da Agricultura no seu cinquentenário. São Paulo, 1942.

Com a crise cafeeira da década de 1890, as elites buscavam novas alternativas econômicas para reduzir seus custos de produção, como a comercialização das terras secundárias ao café com a implantação dos núcleos, procurava-se reduzir custos com a moradia dos trabalhadores, com a edificação de escolas, igrejas, depósitos e outras 
benfeitorias, além de liberar os fazendeiros da remuneração indireta dos trabalhadores como a cessão de terras, empréstimo de mudas, animais e instrumentos produtivos.

No período havia uma demanda por terras de baixo custo, especialmente pelas que pudessem ser pagas durante anos com a produção das roças plantadas entre os pés de café (cultivo intercalar), enquanto estes cresciam. Dessa forma, antigos colonos conseguiam adquirir terras e se transformarem em pequenos proprietários.

Monbeig (1984) Gadelha (1982) e Oliveira (1997) ressaltam a importância da implantação do núcleos coloniais próximos às zonas produtivas cafeeiras como o primeiro passo para a introdução da pequena propriedade no território paulista. O parcelamento das terras secundárias ao café em pequenas glebas valorizou estas terras e favoreceu o processo de acumulação, sobretudo após a crise do café de 1892, desdobrando-se até 1902, já que representou um acréscimo considerável de capital, além da possibilidade para o cafeicultor de modernizar tecnicamente as fazendas.

É importante observar que em 1892, como resposta à crise do café, foi criada a Repartição de Terras, Colonização e Imigração, com o objetivo de validar títulos, fiscalizar e alienar terras públicas.
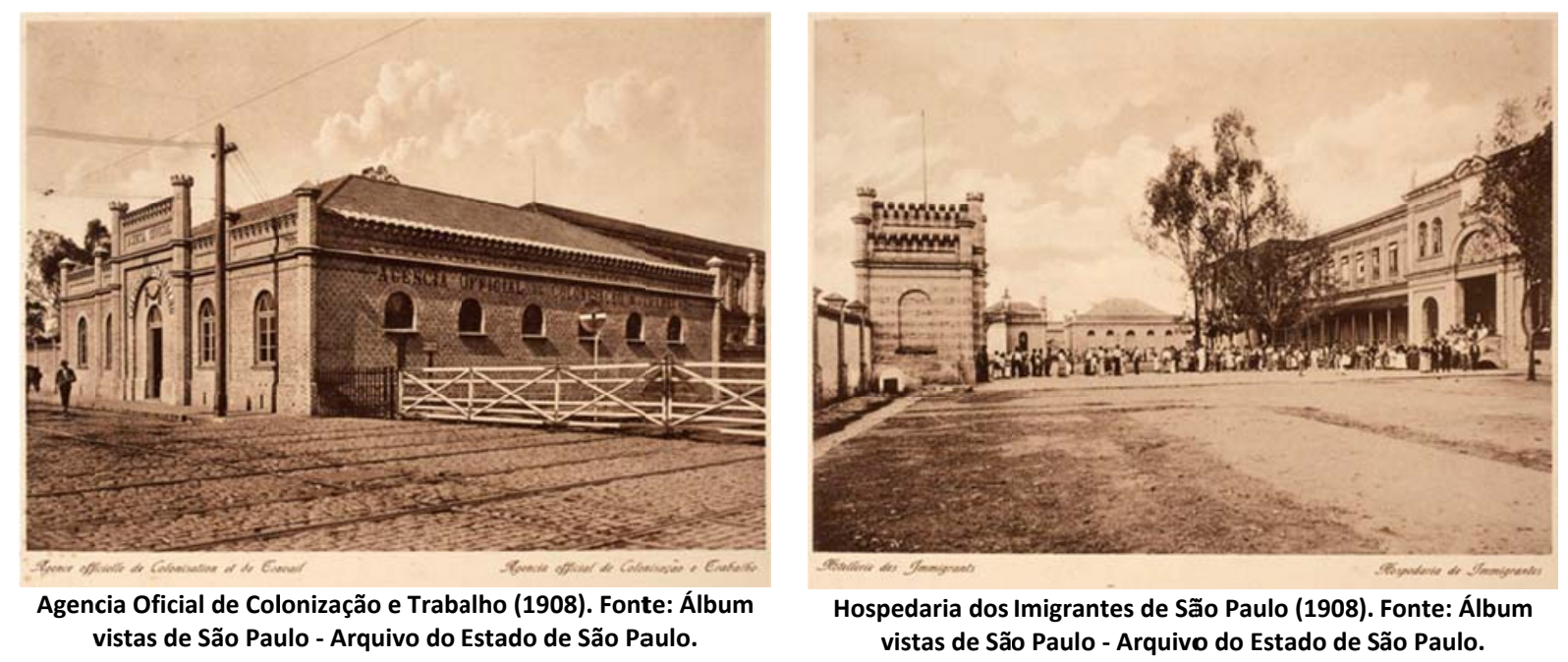

Segundo Gadelha (1982), a partir deste ano o governo do Estado de São Paulo procurou favorecer a imigração espontânea, incentivando a politica de atração da imigração, com objetivo de explorar o pecúlio dos camponeses mediante a venda de glebas. Para Iglesias (1981), a comercialização de parte das terras das grandes fazendas favoreceu outras 
práticas, como o arrendamento, o sistema de concessão de uso da terra em troca de parte da produção e também o próprio parcelamento das áreas em pequenas propriedades.

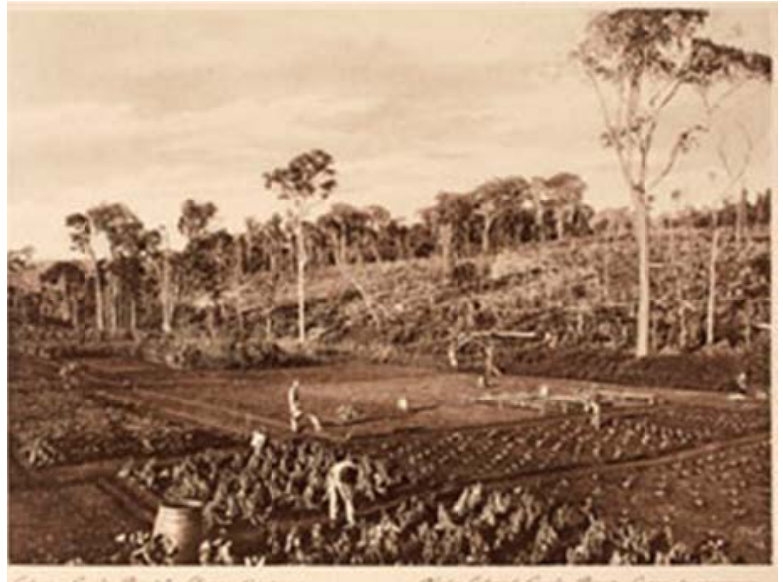

Campo de experimentação agrícola no Núcleo Colonial Gavião Peixoto (1908). Fonte: Álbum vistas de São Paulo - Arquivo do Estado de São Paulo.

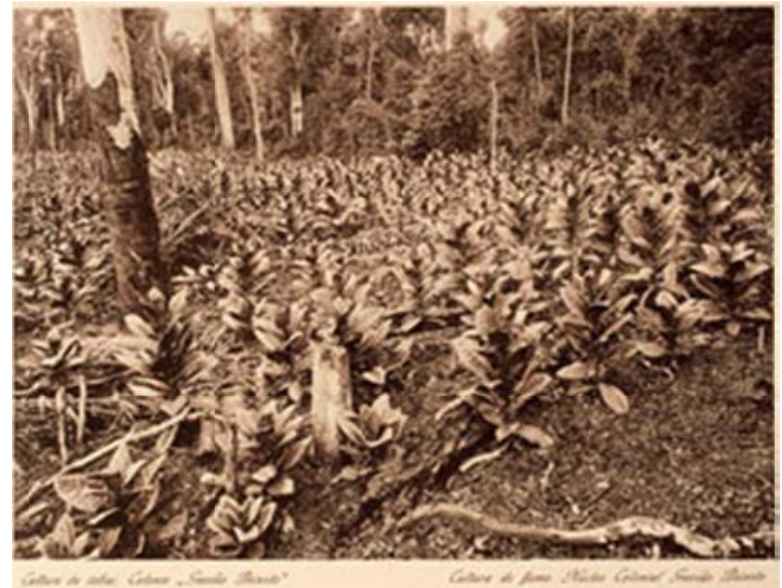

Plantação de fumo no Núcleo Ciolonial Gavião Peixoto (1908). Fonte: Álbum Vistas de São Paulo - Arquivo do Estado de São Paulo.

Estas pequenas propriedades passaram a desempenhar um importante papel de celeiros alimentares, desenvolvendo a policultura ao lado das grandes áreas de monocultura cafeeira, oferecendo alimentos básicos para o mercado regional, além de diminuir as importações de áreas e valorizar as terras secundárias ao café.

Outra função dessas pequenas propriedades era servir de viveiros de mão de obra, oferecendo braços complementares ao trabalho da fazenda, já que muitos pequenos produtores procuravam prestar serviços também importantes à atividade rural como carpintaria, marcenaria, olaria, etc., para complementar sua renda e saldar suas dividas contraídas com a aquisição da propriedade. Para o fazendeiro isso era interessante porque não precisava ter como seus empregados contratados esse tipo de profissional.

Para Oliveira (1997, p.210), uma das interpretações para o fomento dos núcleos desta ultima fase foi a necessidade de criar laboratórios de novas culturas no Estado de São Paulo como atividades alternativas ao café a médio e a longo prazo, além de aumentar a oferta de gêneros alimentícios. Para tanto era previsto a implantação de centros de experimentação agrícola (como o Instituto Agronômico de Campinas e a Escola Agrícola de Oiracicaba, por exemplo), instalação de engenhos para beneficiamento dos produtos, facilidades na aquisição aos colonos de animais reprodutores mais apropriados, locação de 
instrumentos e animais e oferta de serviços remunerados para o Estado ou nas fazendas de café.

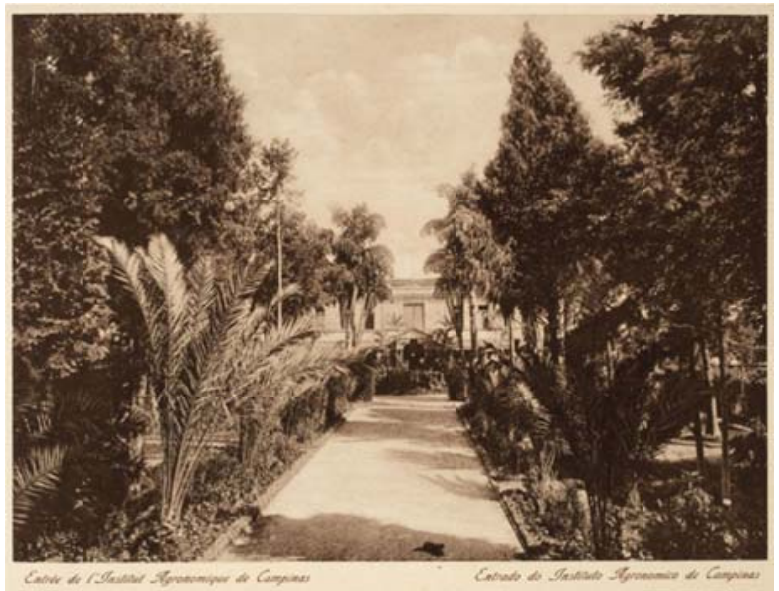

Entrada do Instituto Agronômico de Campinas (1908). Fonte: Álbum Vistas de São Paulo - Arquivo do Estado de São Paulo.

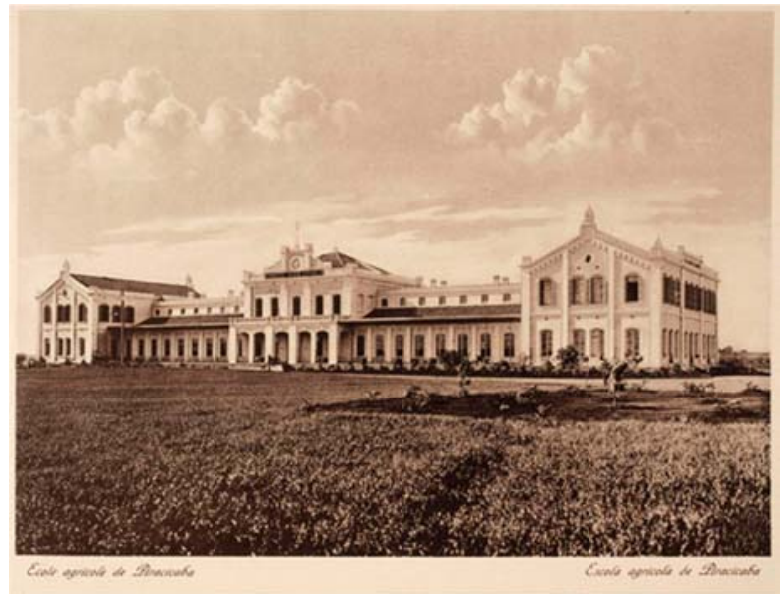

Escola Agrícola de Piracicaba (1908). Fonte: Álbum Vistas de São Paulo - Arquivo do Estado de São Paulo.

Segundo Queiróz (1969, p.72-3), o pequeno agricultor não tinha capital para montar a infra estrutura básica para a adaptação e beneficiamento do café, como despolpadores, secadoras, ensacadoras, lavadeiras, etc.. Estes teriam que recorrer ao aluguel dessas maquinas em beneficiadoras localizadas geralmente próximas às estações ferroviárias.

Neste contexto, os novos núcleos admitiam lavradores brasilleiros em até $20 \%$ da totalidade dos colonos, visando a participação dos nativos na transferência do conhecimento da agricultura local aos imigrantes. O acesso à terra agora era facilitado com maior flexibilidade no pagamento das terras a prazo e pela concessão de empréstimos para a construção da casa e compra de animais, mudas e equipamentos.

Assim, em 1894, foi promulgada a lei orgânica dos núcleos coloniais enquanto embrião da futura povoação ou vila e entre os anos 1904 e 1908, sob a administração de Carlos Botelho, então residente da Província, foram criados núcleos coloniais também mediante auxilio da iniciativa particular, como é o caso dos núcleos do Cambuhy, objetos de estudo desta dissertação. 


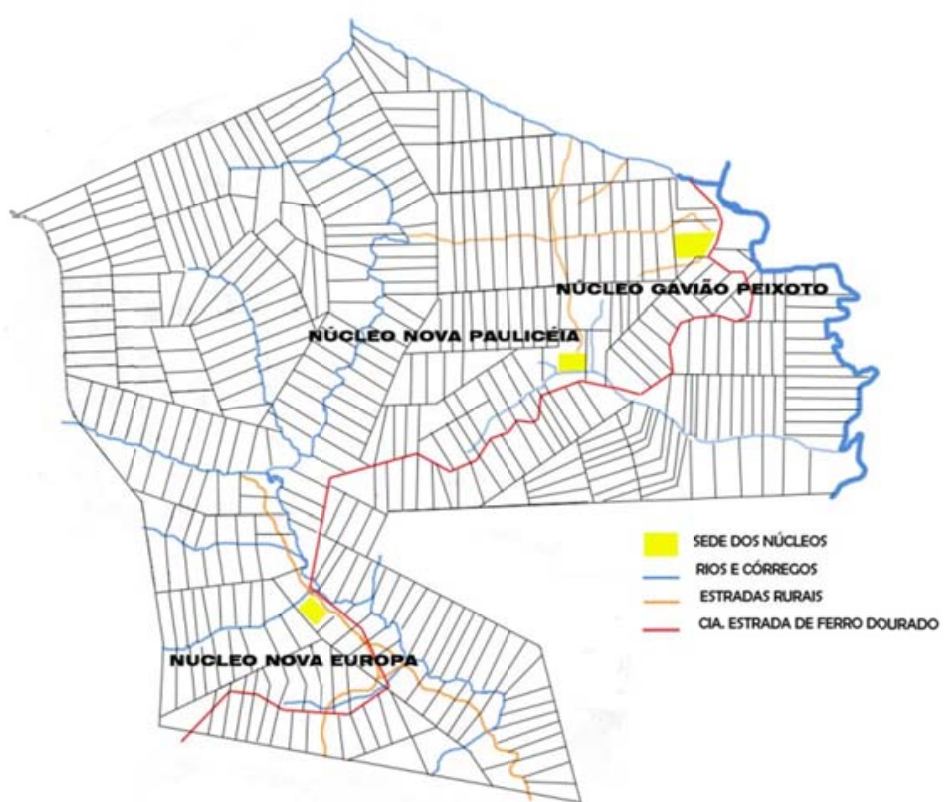

Planta esquemática dos Núcleos Coloniais do Cambuhy em 1913. Elaborado a partir de GADELHA, M. D. F. Os núcleos coloniais e o processo de acumulação cafeeira (1850-1920). São Paulo, IFLCH USP, 1982.

A escolha das áreas seria uma decisão técnica. Cada núcleo deveria ter a extensão máxima de 50 hectares ou 25 hectares quando próximas a vias férreas ou rios navegáveis. Sobre o planejamento dos núcleos, Oliveira (1997) nos fornece informações bastante precisas:

"O planejamento de uma área de 25 hectares previa: a) moradia e produção para o consumo familiar (2 hectares) mata para preservação do meio e consumo de madeiras $(5$ hectares) pastos e estábulos, criação de gado e composição de adubos (5 hectares) mantimentos para sobrevivência (5 hectares) culturas de rendimentos para comercialização (8 hectares)." Oliveira (1997, p.212)

Em termos espaciais o mesmo autor informa que o complexo de moradia deveria estar próximo a área de pasto, para vigilância e cuidados com a criação e as áreas mais planas e salubres, de preferencia no centro do lote, deveriam ser reservadas à horta, ao pomar e às edificações. Deveria-se reservar para pasto uma área de pouco declive, preferencialmente servida por agua corrente e as áreas mais altas para a reserva de matas. As áreas produtivas, tanto destinadas a culturas comerciais quanto a culturas de subsistência, seriam utilizadas através da rotação de culturas. 


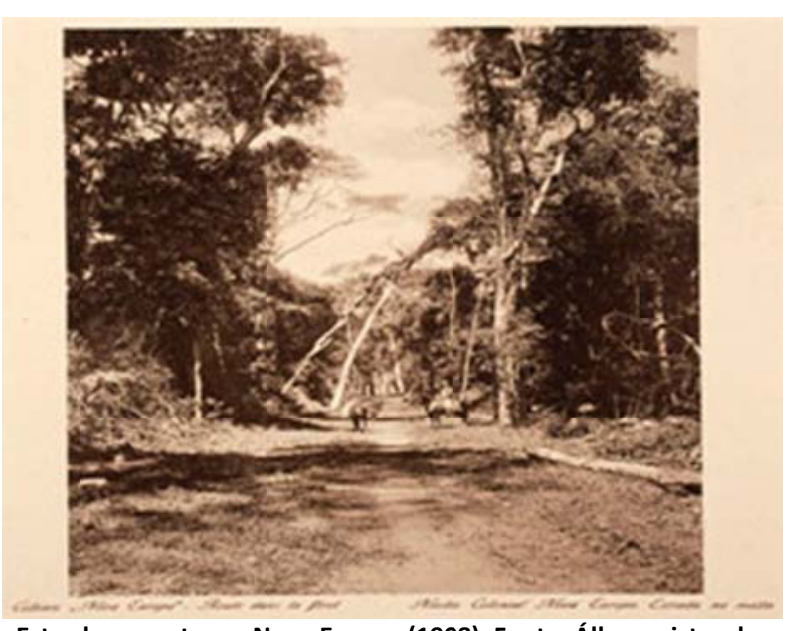

Estrada na mata em Nova Europa (1908). Fonte: Álbum vistas de São Paulo - Arquivo do Estado de São Paulo.

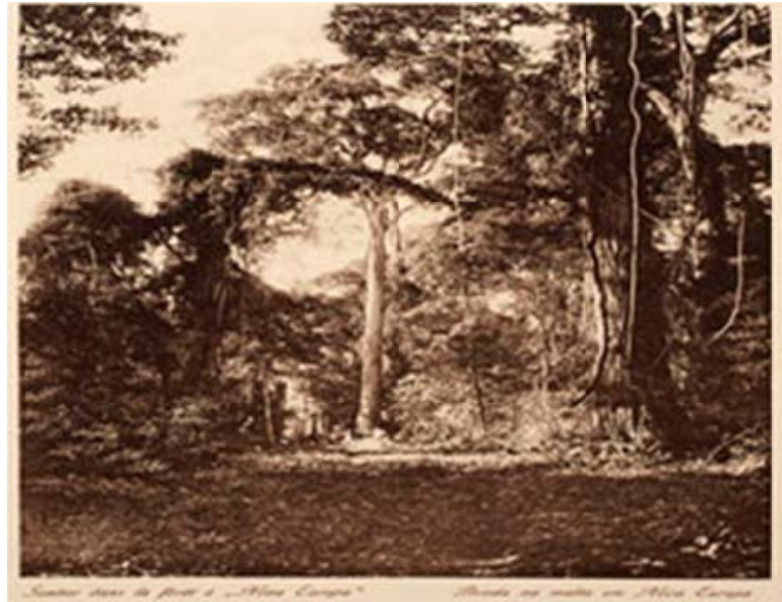

Picada na mata em Nova Europa (1908). Fonte: Álbum vistas de São Paulo - Arquivo do Estado de São Paulo.

Portanto, é importante salientar que o planejamento rural e urbano que se desenvolveu para a implantação dos núcleos coloniais foi um trabalho estratégico e pioneiro, que fazia parte de um planejamento em rede para o estado de São Paulo, planejamento este que foi norteado pela implantação das ferrovias e pela navegação fluvial. Este "grande projeto paulista" ultrapassou a economia do café e seu desenho determinou onde ocorreria o desenvolvimento das cidades e dos negócios agrícolas e industriais.

Assim, em 1906, dentro do que aqui chamamos de terceira fase, incorporam-se ao patrimônio do Estado as terras destinadas à fundação dos núcleos de Nova Europa, Nova Pauliceia e Gavião Peixoto, de fato criados três anos depois. O local esıcolhido para o projeto foram as terras da Sesmaria do Cambuhy, pertencentes ao Conselheiro Bernardo Avelino Gavião Peixoto, onde foram implantados dois núcleos rurais ao llado de três núcleos habitacionais.

Matos (1974) afirma que a região central do estado de São Paulo, entre o rio Tiete e a E. F. Araraquara, zona atendida pela Douradense, "representava uma das áreas mais férteis para a cultura do café", influenciando o governo a ali implantar no início do século XX, "importante sistema de utilização de terras por meio de núcleos coloniais".

Os lotes nesses núcleos se estruturavam basicamente a partir da presença de rios, ribeirões e córregos, com desenhos organicamente vinculados a essa rede hídrica.

A área foi dividida em 100 propriedades agrícolas, cada uma com aproximadamente 15 alqueires de área. Cada propriedade teria uma casa e cerca de 10 mil pés de café recentemente plantados, além de pequeno pasto para animais e outras necessidades. É 
curioso observar que parte do pagamento das prestações dos lotes poderia ser feito com a venda de cereais.

São raras as casas remanescentes nestes núcleos coloniais, tanto urbanas quanto rurais. As primeiras casas construídas nos núcleos rurais eram bastante frágeis e precárias, feitas com o que havia disponível no momento: pau a pique, madeiras roliças, sobras de materiais e bambus, como podemos constatar nas imagens do Museu Paulista e do Arquivo do Estado de São Paulo'. É provável que algumas destas 'construções pioneiras', rusticas e sem acabamentos, que abrigaram as famílias enquanto se construía a casa definitiva prevista em contrato, conservaram-se mesmo depois de concluída a casa principal e nesta ficaram agregadas ou foram conservadas como galinheiros, paiol para o milho, cocheiras, depósitos ou oficinas.

Também as casas dos núcleos urbanos hoje dificilmente ou com muito esforço podem ser vistas como conjunto. Mesmo a casa da diretoria geral dos núcleos do Cambuhy, localizada em Nova Paulicéia, apesar aparentar ser bem construída com materiais duráveis (pelas imagens do álbum de Araraquara de 1915), foi demolida.
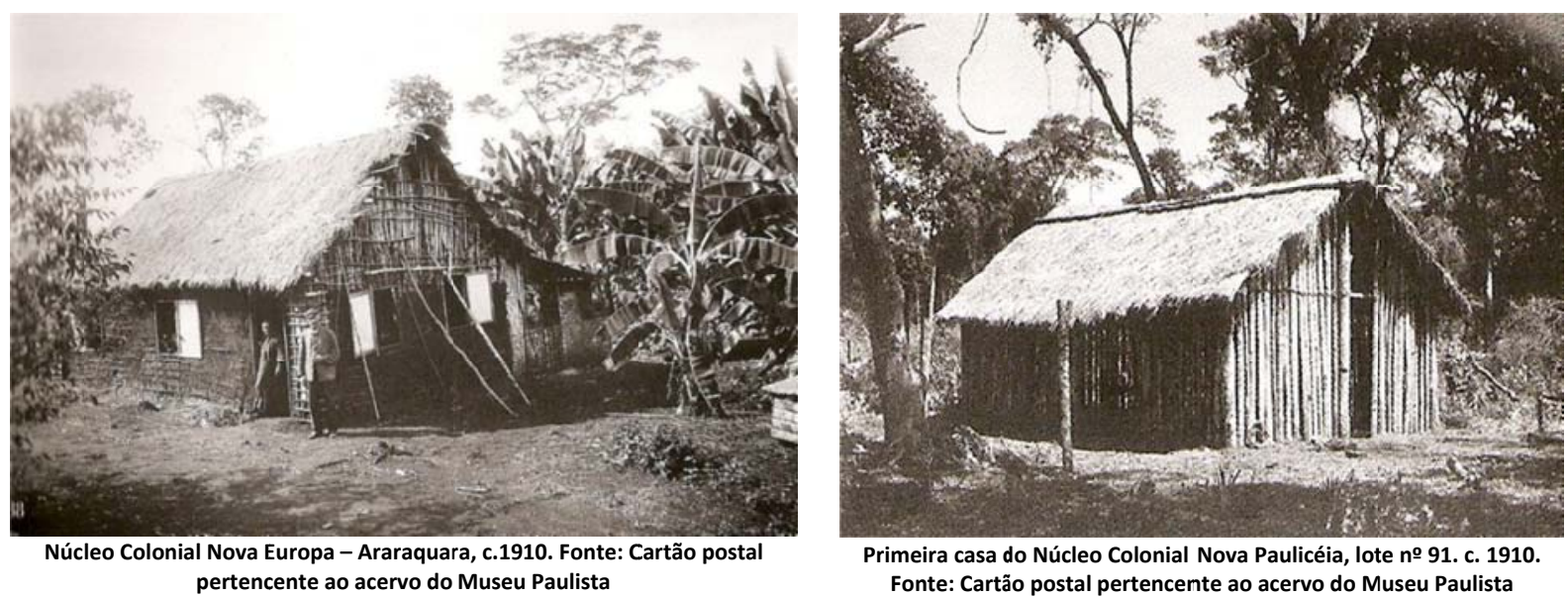

Sobre os primeiros colonos, a população local relata que seriam de origem russa (outros afirmam ser de origem alemã), em torno de 12 famílias, entre as quais as famílias Libert, Boman, Asman e Holshausen. Por volta de 1912 os núcleos de Gavião Peixoto e Nova

\footnotetext{
${ }^{7}$ Para se ter uma melhor noção da simplicidade e da perenidade das primeiras construções dos núcleos coloniais paulistas ver imagens reproduzidas no Anexo 03. Estas imagens são parte do acervo do Arquivo do Estado de São Paulo e retratam construções dos núcleos de Campos Salles, Nova Odessa e Jorge Tibiriçá, núcleos contemporâneos ao tratados nesta dissertação.
} 
Europa enfrentaram um grande surto de febre amarela, que matou grande parte dessa colônia.

Os estes núcleos urbanos, apesar da origem distinta em relação às outras cidades da Zona Douradense, sofreram o mesmo processo decadência e involução observado nas demais cidades quando da erradicação da ferrovia e nessas particularmente a quebra da lavoura de algodão alguns anos depois. São curiosos os relatos da população local sobre os equipamentos públicos, atividades culturais, centros comerciais com que contavam essas cidades em seu período áureo, e comparar com a situação atual. Nova Pauliceia, por exemplo, local que hoje não passa de um bairro rural, em 1915 além da estação ferroviária, contava com 12 armazéns, uma farmácia, um hotel, dois barbeiros, dois sapateiros, três açougues, três serrarias e cinco olarias, além de uma população urbana quatro vezes maior que a atual.

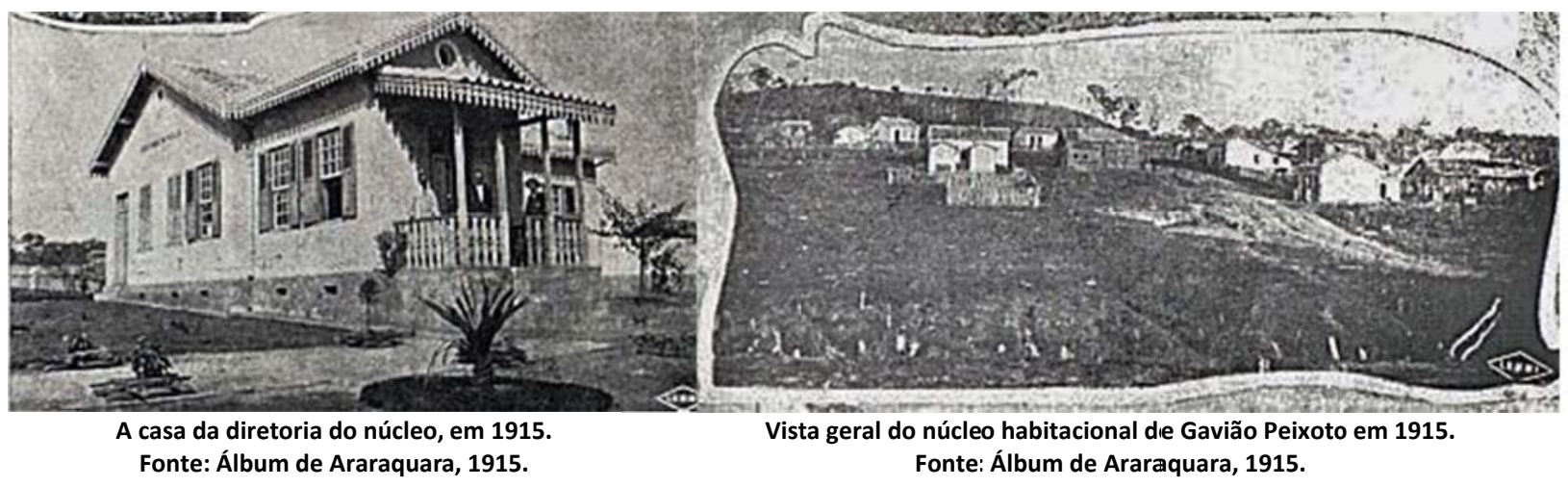




\section{3 - Características gerais de implantação das formações urbanas da Zona Douradense}

Neste capítulo faremos algumas observações a respeito do traçado das formações urbanas da Zona Douradense a fim de comprovar suas particulalidades e generalidades quanto à sua origem, traçado das vias, sua relação com os trilhos e com o sítio natural, e também sobre a localização de equipamentos urbanos importantes.

Essas observações serão feitas a partir dos mapas relativos a cada uma delas, pertencentes à coleção de mapas organizados em observância ao Decreto-Lei Nacional no 311 de 2 de março de 1938, elaborados pelo Serviço de Topografia e Limites do Instituto Geográfico e Geológico do estado de São Paulo, assim como da Coleção de Aerofotos Obliquas de 1939, material pertencente ao acervo do Instituto Geográfico e Cartográfico do Estado de São Paulo, e das imagens de satélite atuais. Esse material se mostrou bastante útil e adequado a essas análises já que a data em que foram produzidos, final da década de 1930, vem ao encontro da data aqui proposta como "data referencial" para o pré-inventario dos imóveis localizados dentro do perímetro urbano das cidades de Dourado e Nova Europa (capítulos 02 e 03).

Como a origem destas duas cidades teve motivações distintas, Dourado nasceu em solo sacro, a partir de um patrimônio religioso, enquanto Nova Europa nasceu em solo laico, projetada como núcleo urbano pertencente ao núcleo colonial do Cambuhy, a comparação das características destas com as demais povoações pertencentes à mesma zona ferroviária pode nos trazer importantes subsídios para a sua preservação.

Serão analisadas primeiro as cidades nascidas a partir de patrimônios religiosos e depois as nascidas em solo laico. Elas serão apresentadas na mesma sequencia em que estão localizadas na linha da E. F. Dourado. 
Ribeirão Bonito nasceu a partir da doação de 15 alqueires paulistas pelos irmãos Antônio, Thomaz e Ignácio Alves Costa, mineiros provenientes da região de Ouro Fino, para o patrimônio da igreja do Senhor Bom Jesus da Cana Verde, no sopé do Morro do Bom Jesus e entre o córrego Bom Jesus e o Ribeirão Bonito. A ocupação de seu perímetro urbano se deu com base na quadrícula, estruturada a partir do largo da matriz, que possui uma situação topográfica privilegiada que confere monumentalidade para a igreja. Além do próprio largo, foi destinada mais uma quadra defronte à igreja, a atual Praça Nove de Julho, que favorece ainda mais a visibilidade do edifício. Para essa praça estão voltados os principais edifícios da cidade, os dois grupos escolares que a cidade possuía na década de 1940, o Paço Municipal e a Matriz do Bom Jesus.

As quadras possuem laterais de $88 \times 88$ metros, com ocupação mais intensa em apenas duas das faces, mas ocorrendo também nas quatro faces da quadra e dividida em lotes estreitos e profundos de $11 \times 44$ metros. A sequência de quadras alinhadas na lateral leste do morro, que é o eixo central das quadras na cidade, as quadras são menores, com 60 X 88 metros, com faces menores divididas em cinco lotes de 12 metros. É interessante observar que em Ribeirão Bonito o arruamento segue a orientação dos pontos cardeais, sendo a única cidade, além de Boa Esperança do Sul a apresentar essa configuração. As ruas orientadas Norte-Sul possuem 20 metros de largura e as orientadas Leste-Oeste são mais estreitas, com 17 metros de largura.

Estas medidas foram constatadas a partir da observação do mapa de 1938 e da fotografia de 1939. A partir do conhecimento das medidas das quadras, dividimos esta medida pelo numero de edificações implantadas em cada face e assim a partir de medidas proporcionais e comprovação de certa regularidade neste calculo, chegamos ao módulo de 11 metros de frente para cada lote. Este mesmo procedimento foi feito para as análises das demais cidades tratadas nesta dissertação.

A posição da estação ferroviária não está localizada corretamente no mapa de 1938. Ali ela aparece dentro do limite urbano, mas defronte à cadeia, quando na verdade está defronte à Praça Coronel Sales, que é a praça da estação, próxima ao Largo de São Benedito. Apesar de dentro do limite urbano, a estação encontra-se além do primeiro limite dos córregos, em um sítio alto e salubre, mas não privilegiado. 
As construções eram implantadas sobre o alinhamento da rua e soltas das demais divisas, ou pelo menos de uma delas, com exceção dos edifícios públicos, que foram implantados soltos no lote e também quase os únicos com mais de um pavimento, já que a cidade ainda hoje é predominantemente térrea. Geralmente com telhados de duas ou quatro águas, com a cumeeira paralela à rua. Quanto às platibandas, elas predominam nos edifícios públicos, comerciais ou mistos, e nos residenciais encontramos quase sempre beirais, mas não de grande largura.

Pela imagem de 1939 podemos observar que era rara a arborização dos passeios, apesar da cidade ser bastante verde, já que os miolos de quadra eram pouco ocupados por construções e utilizados como pomares.

Apesar de o cemitério da cidade se localizar fora dos limites suburbanos, o matadouro municipal, contrariando a regra observada nas demais formações urbanas da zona, encontra-se dentro do perímetro urbano, próximo ao encontro dos córregos, certamente utilizados como locais de descarte para seus dejetos.

Na década de 1940, ainda não havia começado a ocupação da área suburbana e mesmo alguns equipamentos como armazéns e maquinário relativo ao café como tanques para lavagem do grão e despolpadoras, localizavam-se ao longo da linha, mas no perímetro urbano.

É importante lembrar que a estação de Ribeirão Bonito é uma estação final da Companhia Paulista e de onde parte a Cia. E. F. Dourado. A estação com tratamento eclético nas fachadas não mantém nenhuma relação com as estações da Douradense, muito mais simples e com características meramente utilitárias (com exceção da estação de Dourado e da Jaú-Velha), mas a cidade de Ribeirão Bonito mantem relação de solidariedade geográfica com a zona douradense, por isso ela faz parte desta análise. 


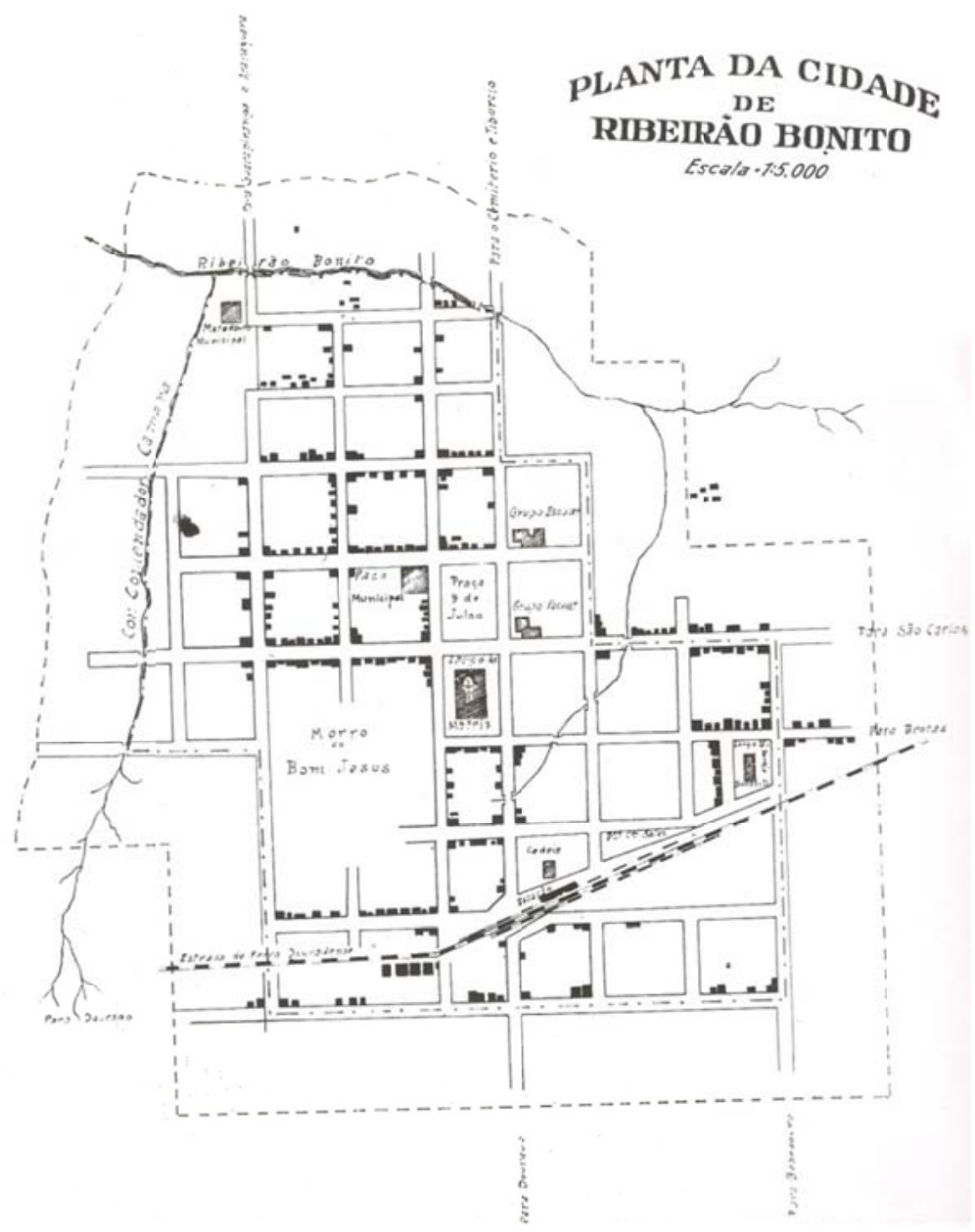

Detalhe do Mapa do Município de Ribeirão Bonito , organizado em observância ao Decreto-Lei Nacional no 311 de 2 de março de 1938, elaborado pelo Serviço de Topografia e Limites do Instituto Geográfico e Geológico - Secretaria da Agricultura, Indústria e Comércio. Fonte: Instituto Geográfico e Cartográfico de São Paulo.

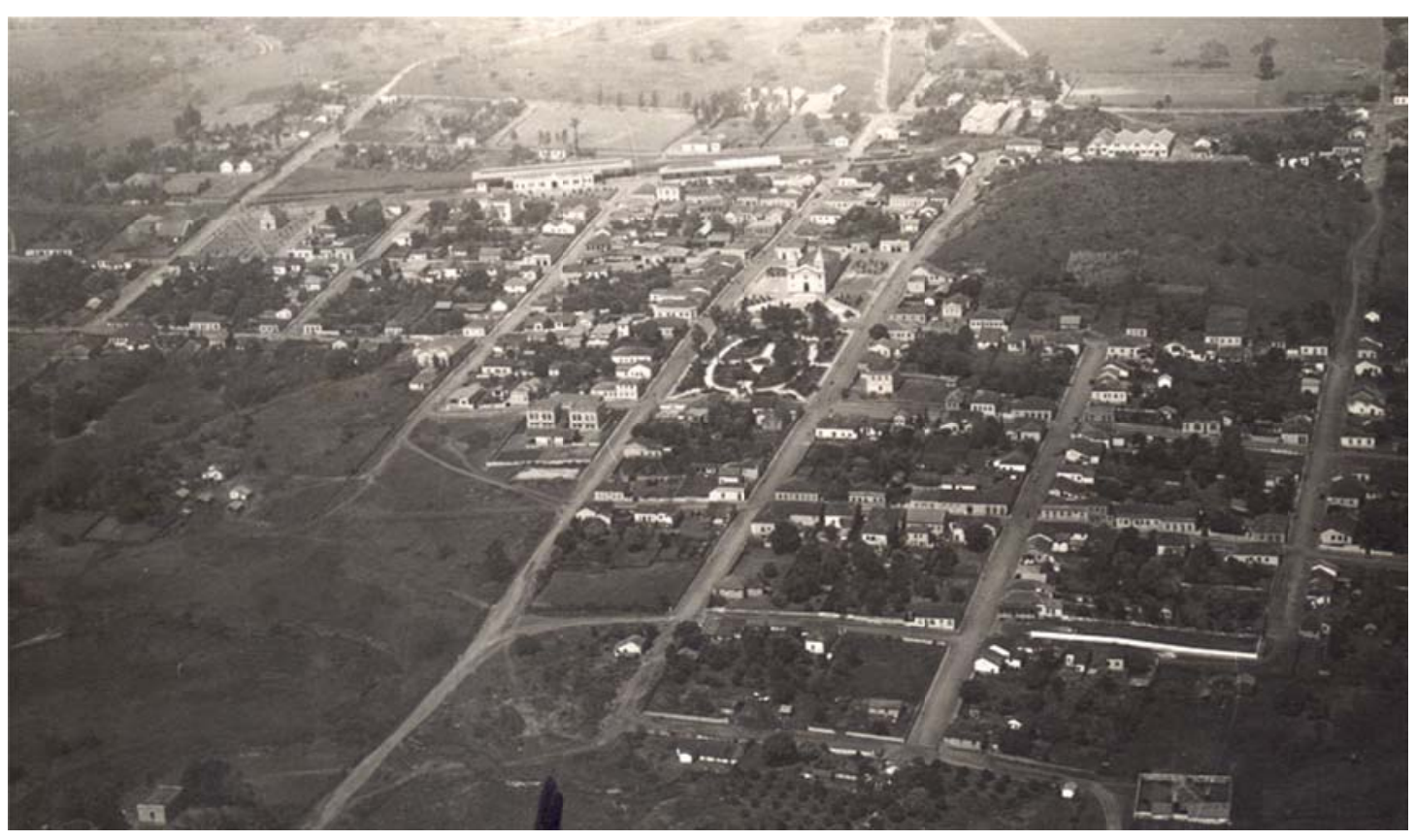

Vista de Ribeirão Bonito - Coleção de Aerofotos Obliquas de 1939. Fonte Instituto Geográfico e Cartográfico do Estado de São Paulo. 
A ocupação inicial de Dourado ocorreu às margens do Córrego Bebedouro, onde se fixaram os mineiros vindos do Vale do Rio das Mortes, primeiros moradores da região que fundaram o bairro do Bebedouro. Anos mais tarde, o capitão José Modesto de Abreu doou terras na Serra do Dourado para a capela de São João Batista dos Dourados, mas durante anos as duas localidades disputaram o privilégio de ter uma capela com um capelão curado. Como no período o bairro de São João Batista dos Dourados obteve maior prosperidade, foi escolhido para receber a capela.

Portanto a cidade atual se desenvolveu próxima ao córrego dos Dourados e ao redor da capela de São João Batista. O território foi ocupado com base na quadrícula de 80 X 80 metros, com ocupação das quatro faces da quadra a partir de lotes de 11 metros de frente, com variantes de 14,6 metros. Para a praça da matriz estão voltados o grupo escolar de Dourado e a cadeia. A partir da imagem de 1939 é possível observar a ausência de urbanização em contraponto com a ocupação dos miolos de quadra por pomares.

Os edifícios estão implantados sobre o alinhamento frontal e afastados em pelo menos uma das laterais. Nos edifícios comerciais localizados na rua do comércio, esse afastamento lateral sempre tem a dimensão mínima para a entrada de um carro ou charrete, sendo que esses edifícios geralmente são unidos 2 a dois.

A praça 24 de outubro localizada ao lado da das oficinas da ferrovia, era o antigo cemitério, transferido para uma região mais alta, fora do limite urbano. 0 matadouro municipal também foi construído além da área delimitada pelos córregos.

A estação ferroviária da Douradense e suas oficinas e armazéns ocupavam a parte mais alta da cidade, no limite urbano, como pode ser observado na imagem de 1939 pela proximidade da lavoura de café. Nas proximidades da estação foram implantados uma série de equipamentos de beneficiamento do grão do café que posteriormente foi ocupado para o beneficiamento de algodão e agora está desocupado. 


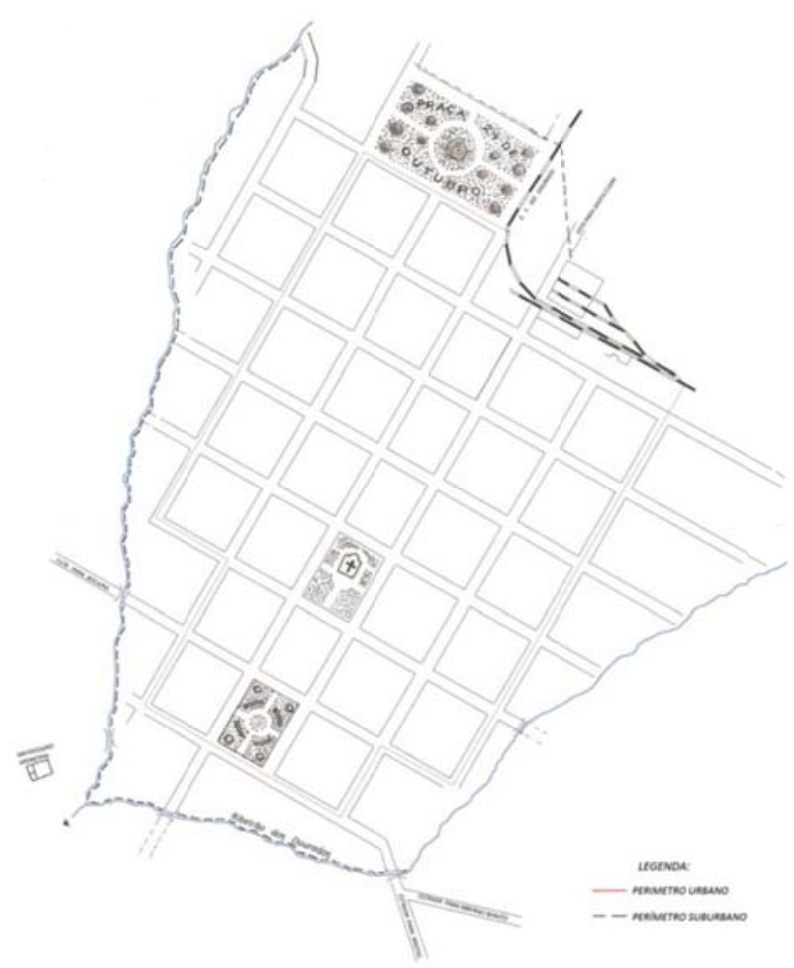

Planta da Cidade de detalhe do Mapa do Município de Dourado, organizado em observância ao Decreto-Lei Nacional no 311 de 2 de março de 1938 , elaborado pelo Serviço de Topografia e Limites do Instituto Geográfico e Geológico - Secretaria da Agricultura, Indüstria e Comércio. Fonte: Instituto Geográfico e Cartográfico de São Paulo.

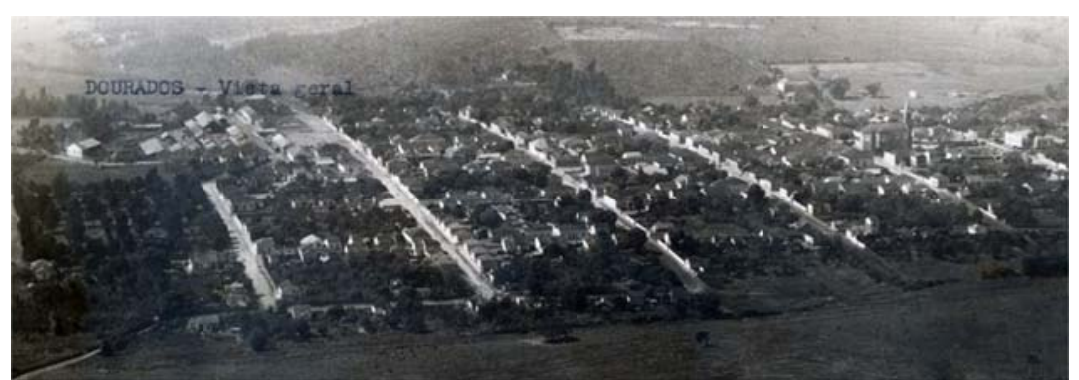

Vista de Dourado - Coleção de Aerofotos Obliquas de 1939. Fonte Instituto Geográfico e Cartográfico do Estado de São Paulo.

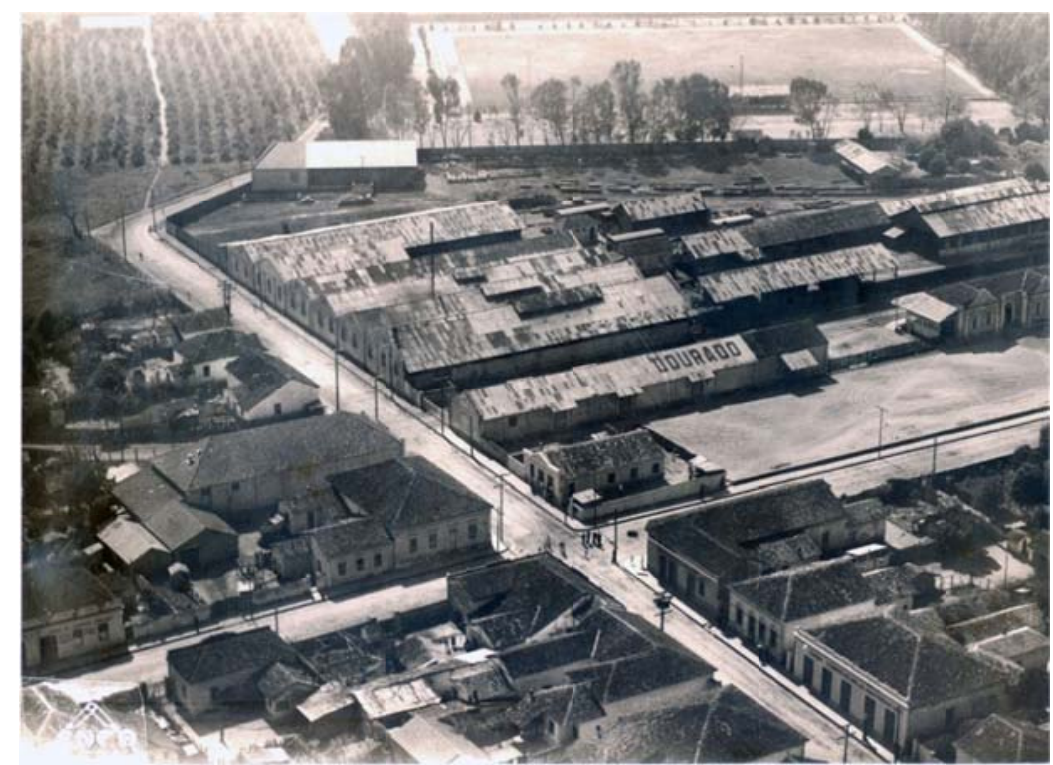

Vista da estação e oficinas da Douradense - Coleção de Aerofotos Obliquas de 1939. Fonte Instituto Geográfico e Cartográfico do Estado de São Paulo. 
Boa Esperança do Sul é mais uma típica cidade paulista fundada nos primeiros anos do século $X X$, com origem em um patrimônio religioso - a partir da doação de 109 alqueires para a capela de São Sebastião da Boa Esperança. A ocupação inicial se deu entre o córrego Agua Branca e Rio Boa Esperança, ao redor da Praça da Matriz, localizada à meia encosta, com base na quadrícula de $88 \times 88$ metros ou $44 \times 88$ metros. Todas as ruas possuíam 17 metros de largura.

A estação ferroviária foi construída em 1903, além do primeiro limite dos cursos d’água, em um dos limites do perímetro urbano, em um terreno alto, seco e bem ventilado, o que certamente incentivou a ocupação dessa nova porção da cidade, já que nesta porção, as quadras (com $88 \times 88$ metros ou $66 \times 88$ metros) e o arruamento (com 17 metros de largura) seguem a orientação da linha sentido Gavião Peixoto.

A estação conta com uma boa praça e próxima a ela está localizado o grupo escolar de Boa Esperança do Sul, ambos edifícios localizados em sítios de maior destaque que o ocupado pela própria praça da matriz. É interessante observar que de cada bairro, separado pelo rio, teve uma condicionante diferente - a porção leste se estruturou a partir da praça da matriz, enquanto a porção oeste, a partir da estação.

Até o inicio da década de 1940, a região suburbana da cidade ainda não havia sido ocupada, nessa área havia apenas um campo de futebol.

A partir da foto de 1939 é possível observar que as construções eram implantadas sobre o alinhamento frontal e soltas das demais divisas, ou pelo menos de uma delas, com exceção do que acreditamos ser edifícios comerciais (pela sequencia de portas) que formam bonitos conjuntos sem afastamento lateral e dos edifícios públicos, que foram implantados soltos no lote. Estes últimos também eram os poucos com mais de um pavimento. Predominam telhados com duas ou quatro águas, e as platibandas aparecem raramente com exceção dos edifícios públicos, comerciais ou mistos, localizados defronte à praça da matriz. 


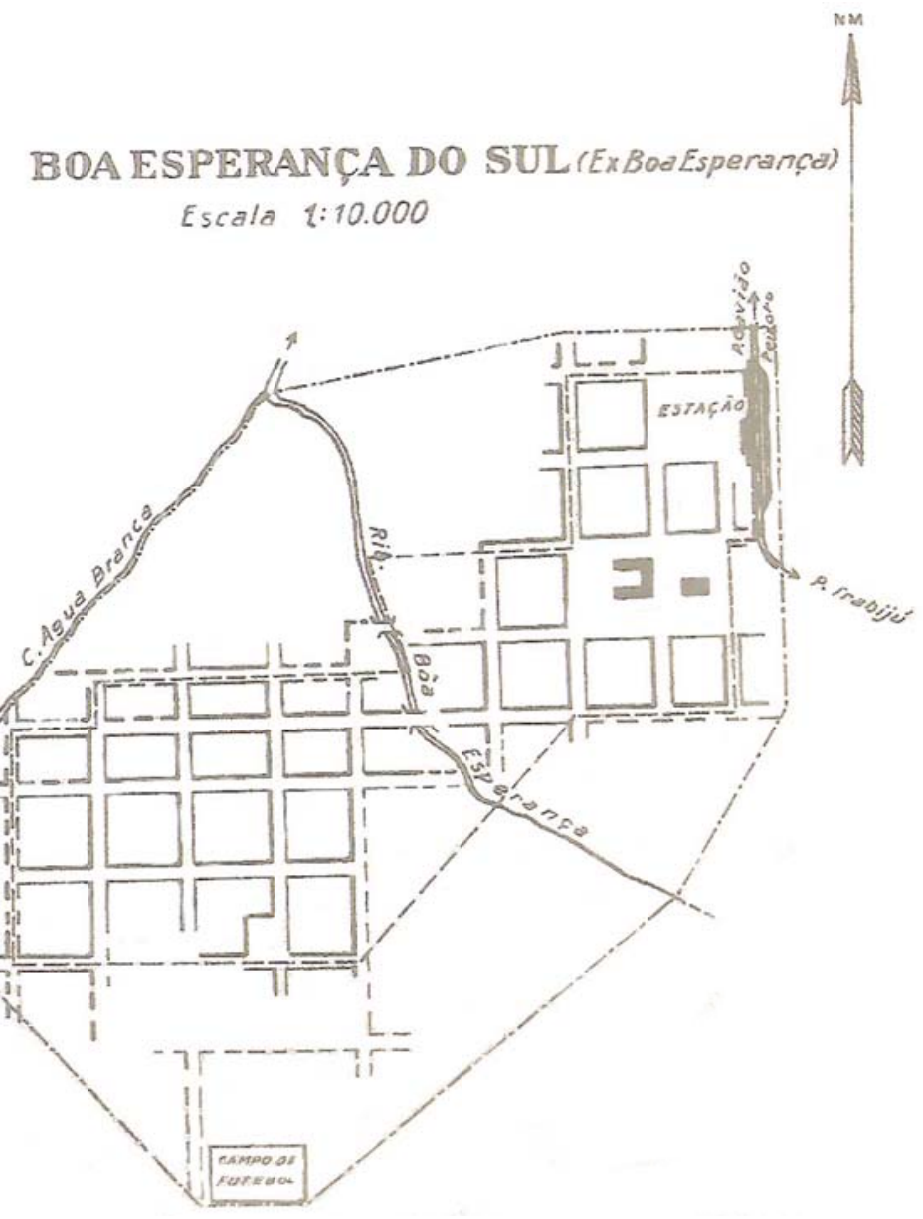

Planta da Cidade de Boa Esperança do Sul detalhe do Mapa do Município de Boa Esperança do Sul, organizado em observância ao Decreto-Lei Nacional no 311 de 2 de março de 1938, elaborado pelo Serviço de Topografia e Limites do Instituto Geográfico e Geológico - Secretaria da Agricultura, Indústria e Comércio. Fonte: Instituto Geográfico e Cartográfico de São Paulo.

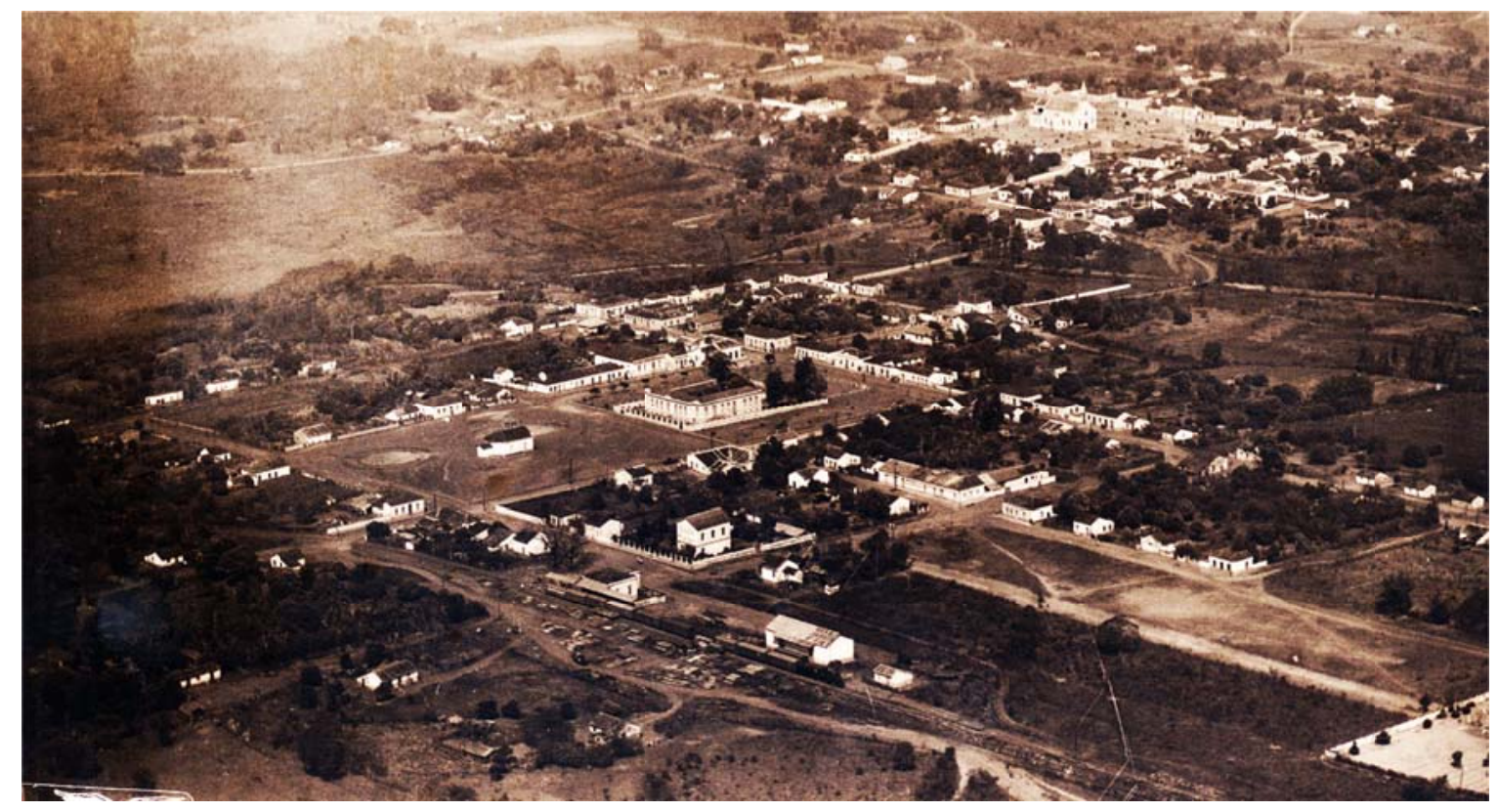

Vista de Boa Esperança do Sul - Coleção de Aerofotos Obliquas de 1939. Fonte Instituto Geográfico e Cartogrãfico do Estado de São Paulo. 
Tabatinga é mais uma cidade que teve origem a partir de um patrimônio religioso - o patrimônio de Nossa Senhora do Bom Conselho - e cuja ocupação do território teve por base a quadrícula com dimensões de 88 × 88 metros e variações desta (110 X 88 metros). Também confirmando a regra, ocupou inicialmente uma região baixa, delimitada pelos córregos do Cavalo e do Meio, sendo que o curso do primeiro orientou o arruamento, que se desenvolveu paralela e perpendicularmente a ele.

A estação da Douradense foi construída além do limite dos córregos, na região suburbana, em área distante do núcleo inicial e junto à estação final da Estrada de Ferro Araraquarense, também eu uma área de várzea. A localização das estações induziu a expansão do parcelamento em sua direção, seguindo as mesmas orientações válidas para o núcleo mais antigo. Entretanto até a década de 1940 esta era uma área muito pouco ocupada. Chama atenção a avenida aberta obliquamente ao eixo principal e termina defronte à estação ferroviária da Douradense.

No mapa podemos ver a indicação de uma área para expansão do povoado além das linhas férreas, mas agora com o traçado orientado paralela e perpendicularmente a elas.

Uma segunda área de expansão se formou além da linha da Douradense, na várzea do Córrego São João, a partir de quadras e ruas com as mesmas dimensões do núcleo inicial, com arruamento procurando seguir as orientações deste, talvez na expectativa de ocupação da área entre as duas ocupações.

Nestas duas áreas de expansão, assim como nas quadras mais afastadas da praça da matriz, já vemos muitas construções implantadas soltas nos lotes (lotes estes com 11 metros de frente), sendo que apenas as construções mais antigas, voltadas para a praça da matriz e ao longo da avenida que segue para as estações, estão implantadas sobre o alinhamento frontal.

Assim como já observado em Ribeirão Bonito, não há arborização ao longo das vias, mas ocupação dos miolos de quadra com pomares, inclusive arvores de grande porte como mangueiras e abacateiros.

Tabatinga também confirma a regra das cidades paulistas fundadas no inicio do século $X X$ no que se refere à origem dos seus diferentes nomes: inicialmente patrimônio de Nossa Senhora do Bom Conselho, denominação vinda de seu padroeiro, depois povoado de 
São João das Três Barras, em referencia à fazenda Três Barras, a mais importante da região no período e por fim Tabatinga, em referencia ao tipo de solo predominante no local.

O mesmo se repete em Ribeirão Bonito, que se originou como patrimônio do Senhor Bom Jesus da Cana Verde e posteriormente altera seu nome fazendo referencia ao ribeirão que passa pela cidade.

Ibitinga teve origem a partir da doação de 1/4 de légua para o patrimônio do Bom Jesus de Ibitinga, em área de várzea, entre os córregos São Joaquim e do Saltinho, ao redor da praça da matriz, que se localiza em uma área topograficamente privilegiada.

Seu arruamento constitui-se basicamente de traçado em xadrez, com quadras de 88 X 88 metros e lotes com 11 metros de frente, com construções em todos os lados da quadra. Aqui podemos observar a predominância de construções soltas nos lotes, enquanto as que foram construídas no alinhamento das ruas, sem afastamento lateral, são conjuntos comerciais e se localizam nas quadras diretamente vizinhas à praça da matriz ou nas avenidas próximas a ela. Afastando-se um pouco mais, ainda encontramos algumas construções residenciais implantadas sobre o alinhamento, mas já afastadas dos demais limites do lote.

A estação ferroviária foi construída nas proximidades do córrego São Joaquim, já no limite da área suburbana e sua localização parece até a década de 1940, não ter influenciado, restringindo ou incentivando a ocupação de determinadas áreas.

Quanto ao arruamento, este parece orientar-se paralelamente ao curso do córrego São Joaquim e perpendicular a ele. Suas ruas possuem 17 metros de largura, mas a cada quatro quadras, as ruas dispostas paralelamente ao córrego São Joaquim são mais largas, com 20 metros de largura. 


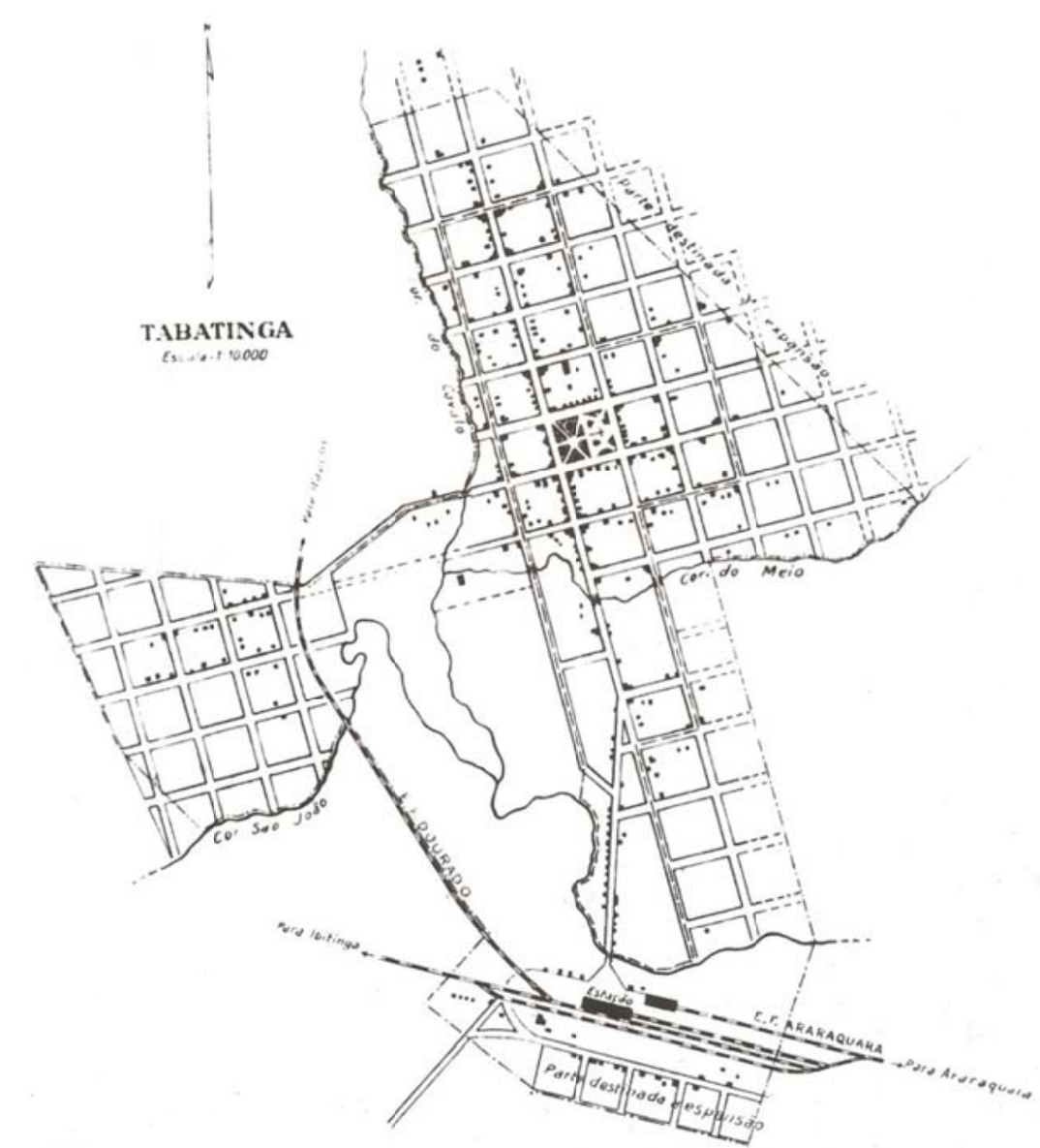

Planta da Cidade de Tabatinga elaborada a partir do detalhe do Mapa do Município deTabatinga, organizado em observância ao Decreto-Lei Nacional no 311 de 2 de março de 1938, elaborado pelo Serviço de Topografia e Limites do Instituto Geográfico e Geológico - Secretaria da Agricultura, Indústria e Comércio. Fonte: Instituto Geográfico e Cartográfico de São Paulo.

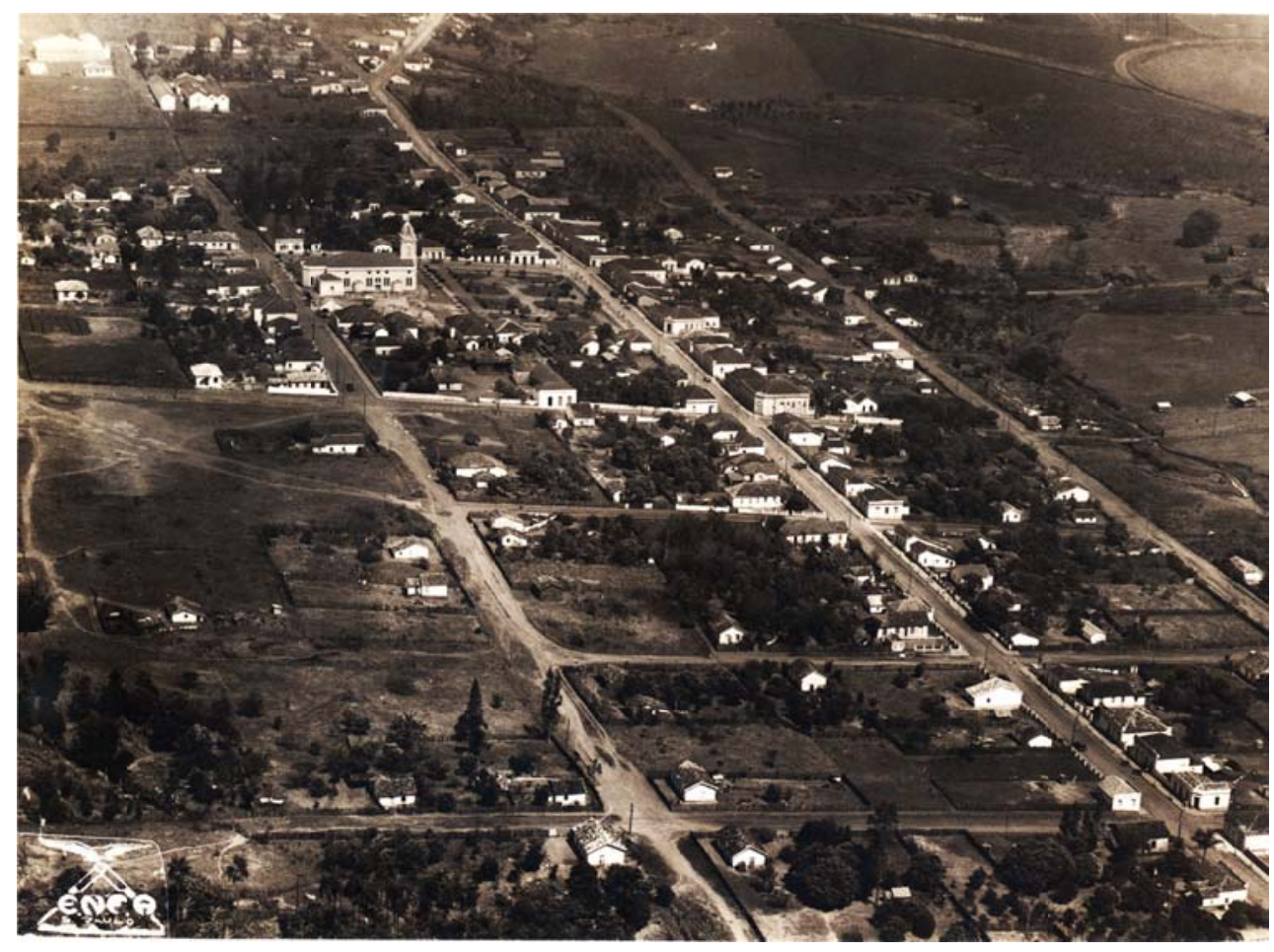

Vista de Tabatinga - Coleção de Aerofotos Obliquas de 1939. Fonte Instituto Geográfico e Cartográfico do Estado de São Paulo 


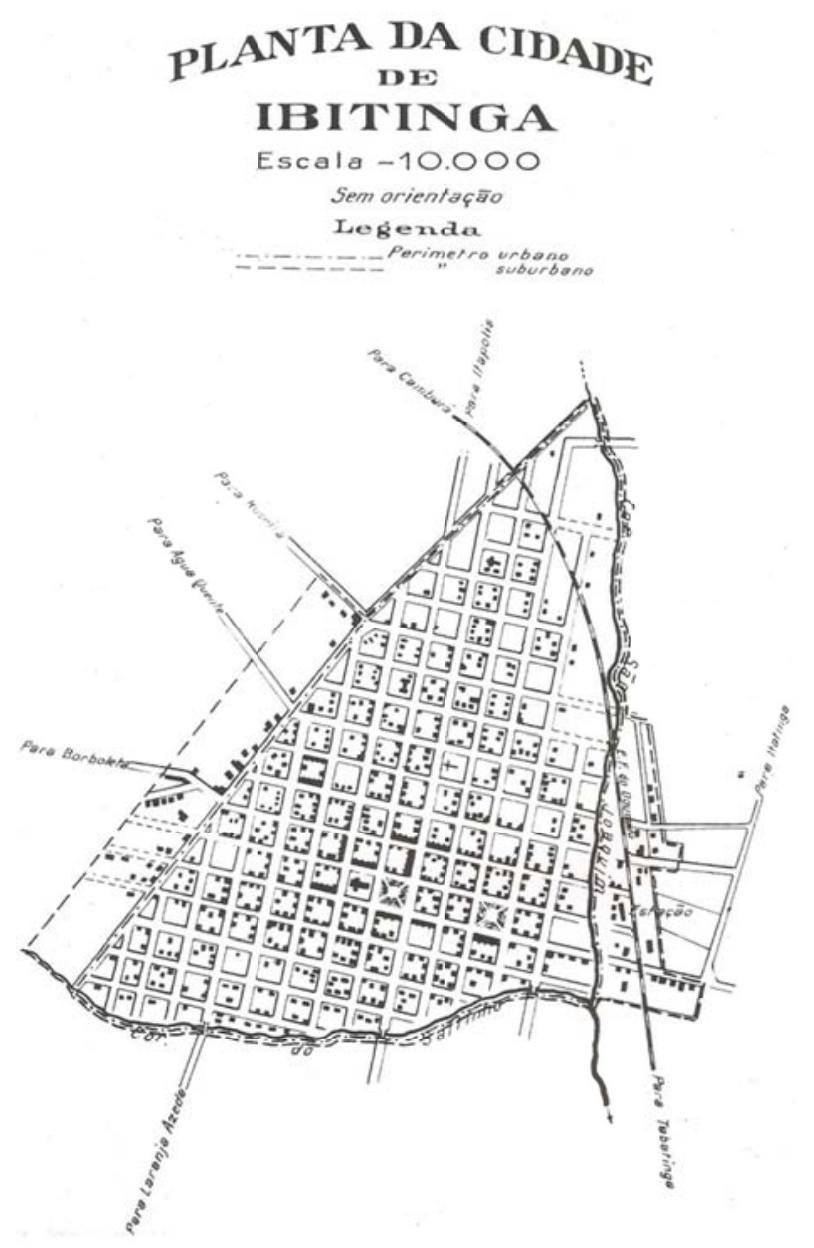

Planta da Cidade de Ibitinga detalhe do Mapa do Município de lbitinga, organizado em observância ao Decreto-Lei Nacional no 311 de 2 de março de 1938, elaborado pelo Serviço de Topografia e Limites do Instituto Geográfico e Geológico - Secretaria da Agricultura, Indústria e Comércio. Fonte: Instituto Geográfico e Cartográfico de São Paulo

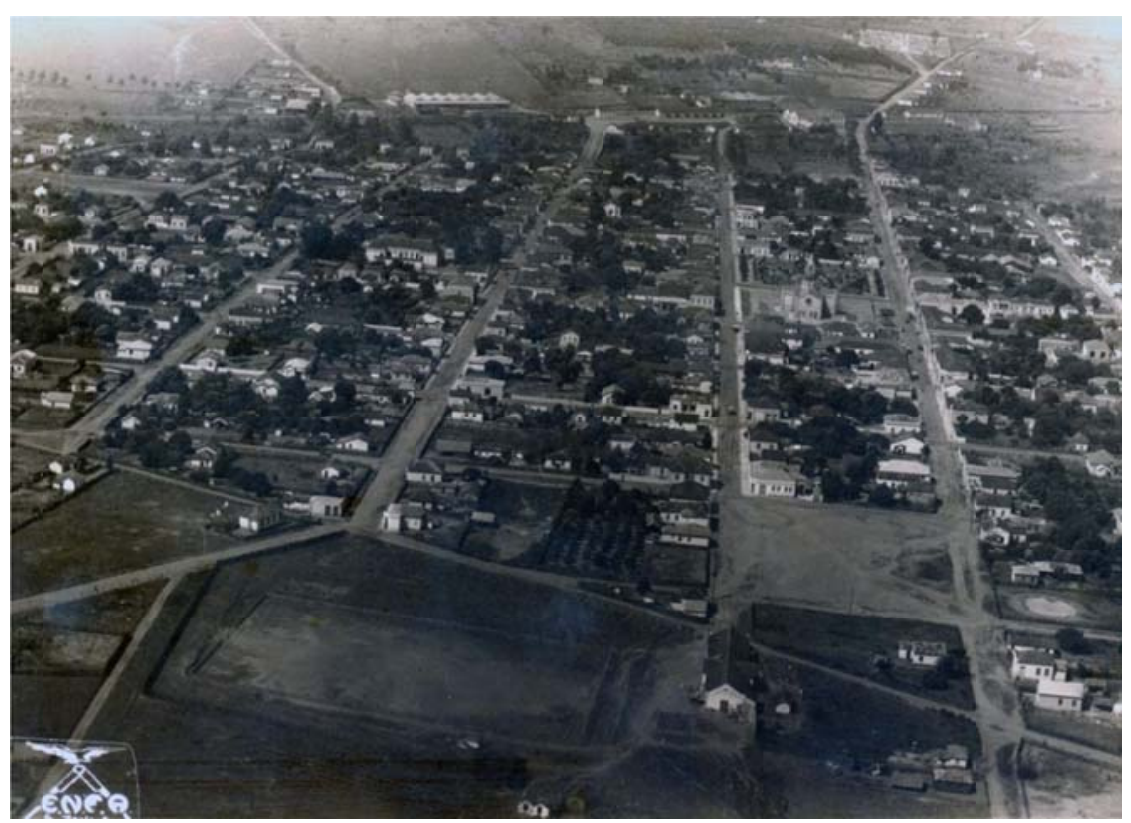

Vista de Ibitinga - Coleção de Aerofotos Obliquas de 1939. Fonte Instituto Geográfico e Cartográfico do Estado de São Paulo. 
Borborema tem origem no patrimônio de São Sebastião dos Fugidos, localizado na várzea do Ribeirão dos Fugidos, ao norte do córrego do Sapé. O território foi ocupado a partir da malha em xadrez, com quadras de $88 \times 88$ metros e ruas de 17 metros de largura, com exceção da avenida que margeia o carrego do Sapé em sua margem sul. Tais ruas foram orientadas pelo córrego do Sapé, já que foram traçadas paralela ou perpendicularmente a ele.

Apesar de observarmos ocupação nas quatro faces da quadra, é predominante a ocupação nos lotes voltados para as ruas laterais da praça da matriz e suas paralelas, o que indica que o padrão de profundidade dos lotes é de 44 metros, com 11 metros de frente.

Não há arborização dos passeios, apenas delimitando a praça da matriz, com os miolos de quadra ocupados por pomares.

A estação ferroviária foi construída na parte sul da cidade, no limite da área urbana, próximo ao ribeirão dos Fugidos. Por estar dividida por um córrego, Borborema lembra a configuração de Boa Esperança do Sul, entretanto neste caso, o desenho desta nova porção da cidade não ocorreu em função da ferrovia, mas sim seguindo as diretrizes da parte norte. A única alteração observada é que na sequencia de quadras que parte defronte à estação possui dimensões menores que as demais, repetindo uma situação que acontece em algumas cidades da Zona Douradense, mas na sequencia de quadras da praça da matriz.

O matadouro Municipal se localiza na área alagável do córrego dos fugidos e em sua parte posterior um pequeno cemitério municipal. 


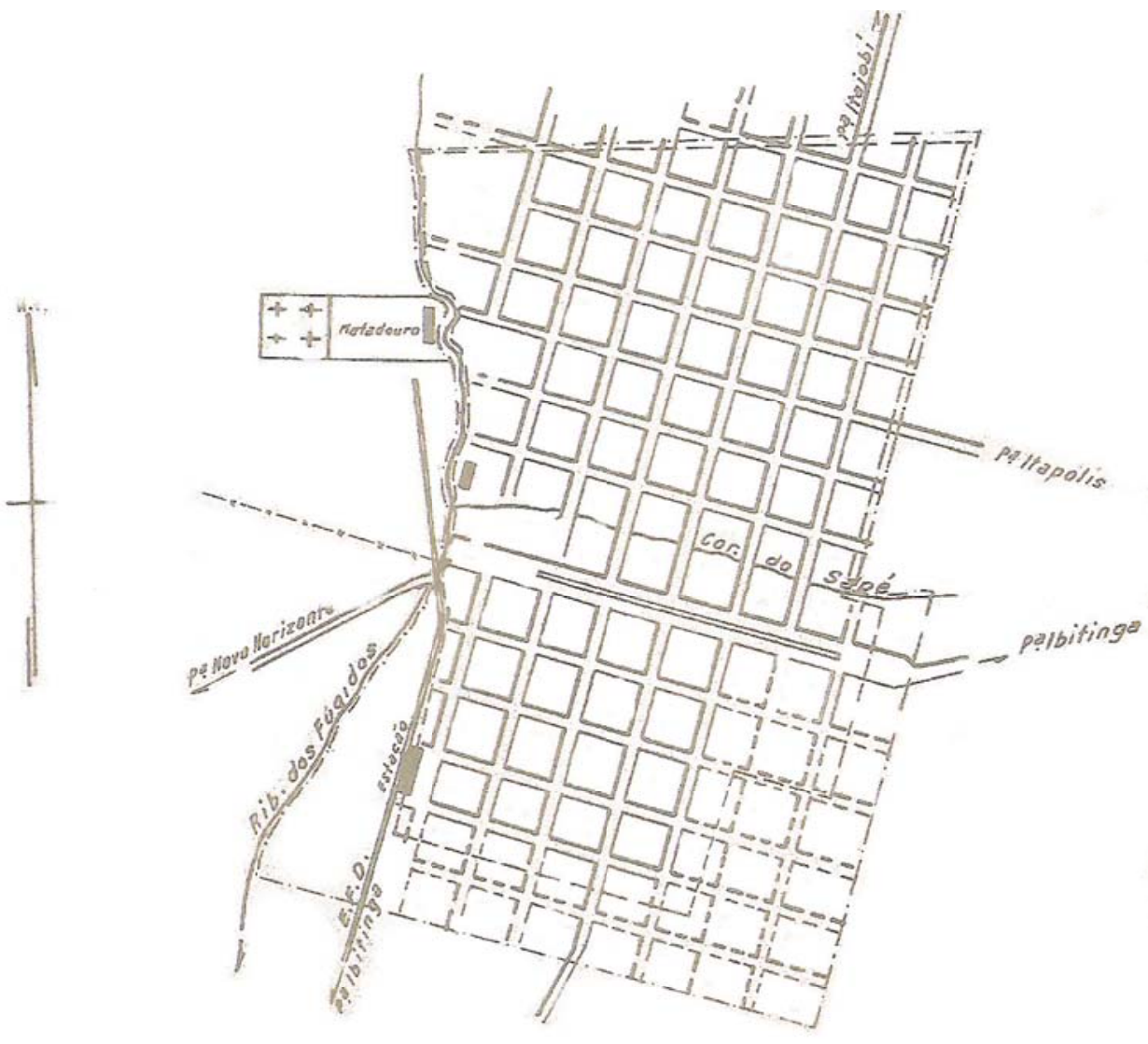

\section{BORTBOREMA \\ Eseala $=1: 10.000$}

Planta de Borborema detalhe do Mapa do Município de Borborema, organizado em observância ao Decreto-Lei Nacional no 311 de 2 de março de 1938 , elaborado pelo Serviço de Topografia e Limites do Instituto Geográfico e Geológico - Secretaria da Agricultura, Indústria e Comércio. Fonte: Instituto Geográfico e Cartográfico de São Paulo.

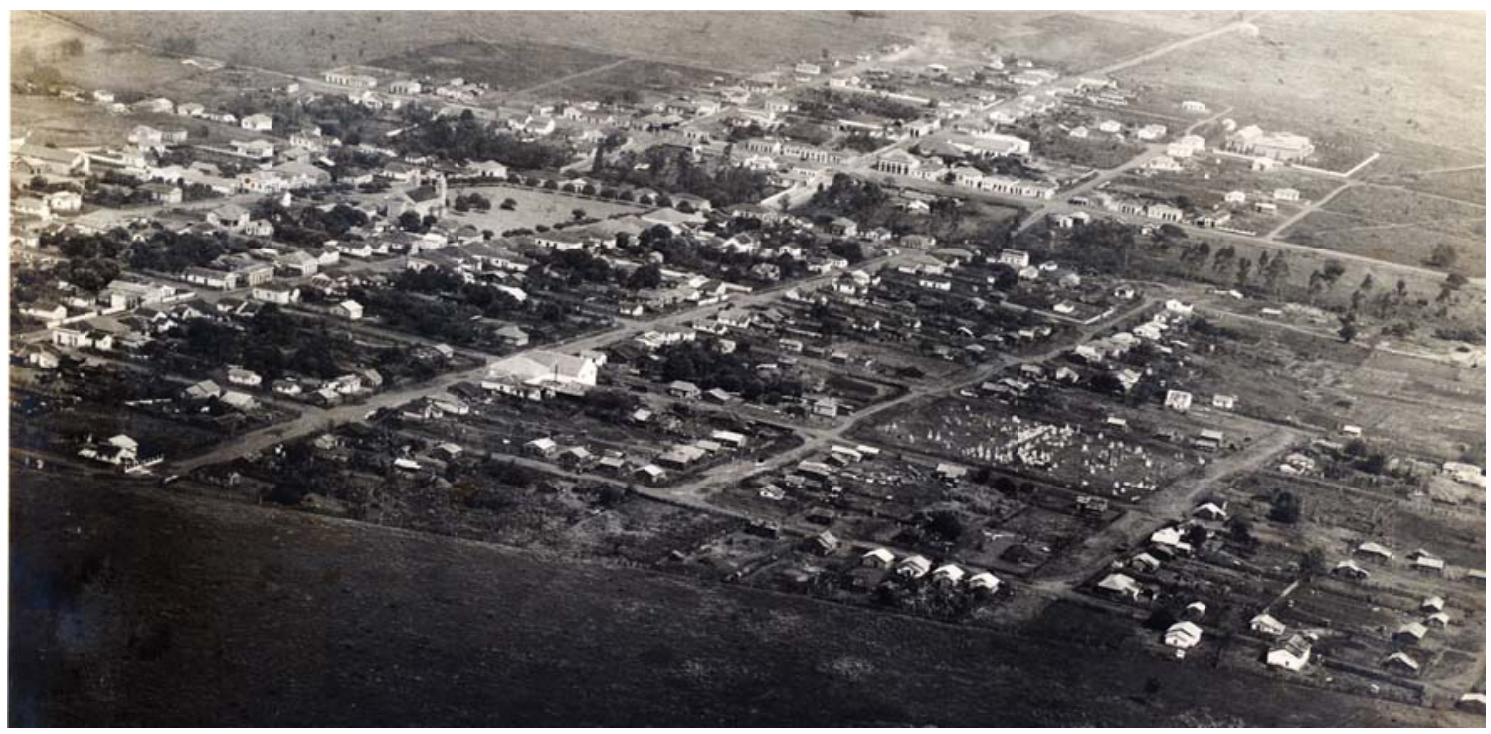

Vista de Borborema - Coleção de Aerofotos Obliquas de 1939. Fonte Instituto Geográfico e Cartográfico do Estado de São Paulo 
Novo horizonte é mais uma formação urbana a confirmar a regra das povoações da Zona Douradense: nasceu a partir do patrimônio religioso de São José da Trindade, posteriormente passa a se chamar São José da Estiva em referencia à fazenda Estiva, e por fim Novo Horizonte.

O arruamento parte da praça da matriz, localizada no ponto mais alto da povoação, e se estende até os limites dos córregos, ocupando o território com base na quadrícula de $88 \mathrm{X}$ 88 metros, com ocupação nas quatro faces da quadra. A partir da imagem de 1939, supomos que cada quadra seja subdividida em lotes com 11 metros de frente. As ruas possuem 17 metros de largura, com exceção da rua que leva à saída para Urupês, que possui 20 metros de largura.

É possível ainda observar a diferença na intensidade da ocupação: à esquerda, em direção ao córrego do Cardoso, ela é sensivelmente mais densa do que à direita, para os lados do córrego da estiva. Observar que em 1938 a cidade ainda não tinha ultrapassado o limite dos córregos e a ausência de arborização urbana em contraposição à ocupação dos miolos de quadra.

A maioria das edificações é térrea, implantadas sobre o alinhamento frontal, predominando telhados com cumeeira paralela à rua.

A Santa Casa, que geralmente é implantada na área suburbana, aqui aparece na área urbana, indicando que esse limite foi expandido. A santa casa foi construída para atendes aos doentes de febre amarela.

A estação ferroviária foi implantada fora do limite dos córregos, em uma área baixa e com urbanização ainda não consolidada. 


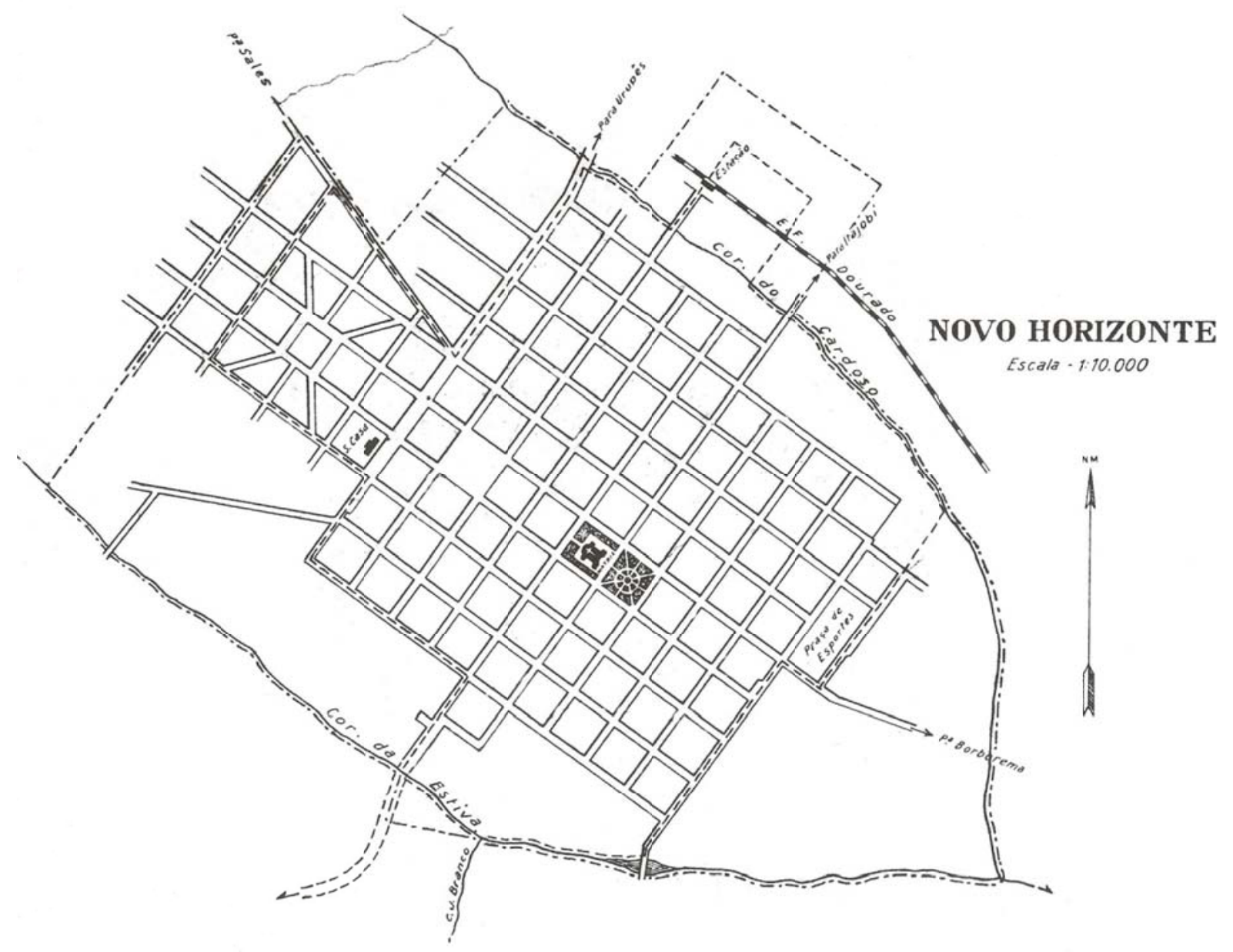

Planta da Cidade de Novo Horizonte, detalhe do Mapa do Município de Novo Horizonte, organizado em observância ao Decreto-Lei Nacional no 311 de 2 de março de 1938, elaborado pelo Serviço de Topografia e Limites do Instituto Geográfico e Geológico - Secretaria da Agricultura, Indústria e Comércio. Fonte: Instituto Geográfico e Cartográfico de São Paulo.

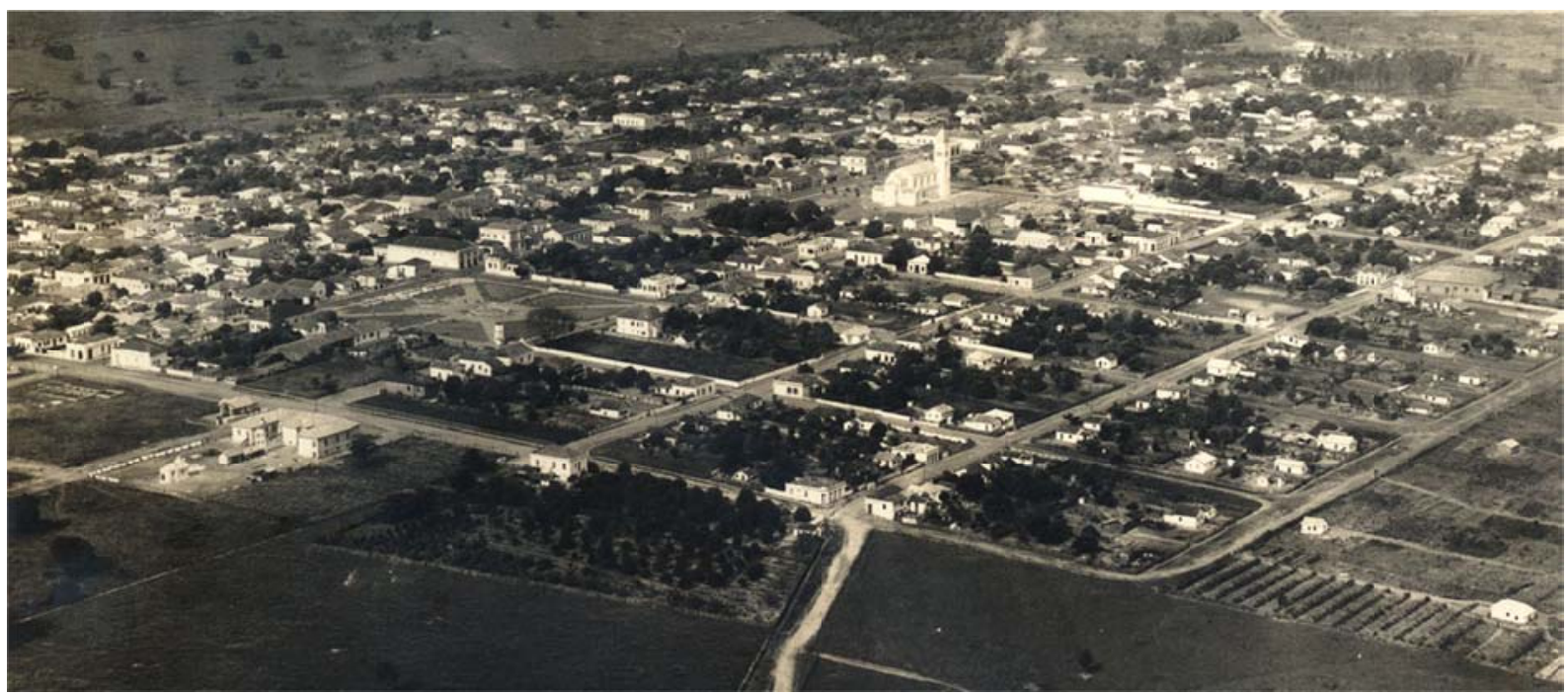

Vista de Novo Horizonte - Coleção de Aerofotos Obliquas de 1939. Fonte Instituto Geográfico e Cartográfico do Estado de São Paulo. 
Itápolis nasceu a partir do patrimônio do Divino Espirito Santo, chamando-se inicialmente Espirito Santo do Córrego das Pedras, depois Boa Vista das Pedras, Pedras e por fim Itápolis.

Contrariando a regra das cidades aqui analisadas que nasceram em solo sacro, esta não está localizada entre rios ou córregos.

O arruamento se deu a partir da praça da matriz, com base na quadrícula de $88 \times 88$ metros e a variação de $44 \times 88$ metros, com ocupação nas quatro faces, mas nas quadras mais próximas da igreja a ocupação é mais intensa em apenas duas faces, com lotes de $11 \mathrm{X}$ 44 metros. É interessante observar que a sequencia de quadras de que faz parte a quadra da matriz tem metade da largura das demais, assim como ocorre em outras localidades.

Em 1938 já havia uma considerável ocupação da área suburbana de Itápolis, especialmente ao longo das vias que seguiam para os bairros rurais. Nessas áreas predominam as construções soltas no lote enquanto na área urbana, as edificações foram, com raras exceções construídas sobre o alinhamento. As construções são térreas, exceto os edifícios públicos e outros exemplares pontuais, que possuem dois pavimentos. Não é possível generalizar quanto ao numero de águas dos telhados nem quanto a posição das cumeeiras.

A estação de Itápolis era a estação final do ramal de Itápolis e foi construída na área suburbana, mas bem próxima da praça da matriz, em zona de urbanização já consolidada, inclusive além da linha. Sua posição na cidade não influiu em suas relações de traçado.

Observar o matadouro municipal bem distante da cidade, fora inclusive dos limites suburbanos. 


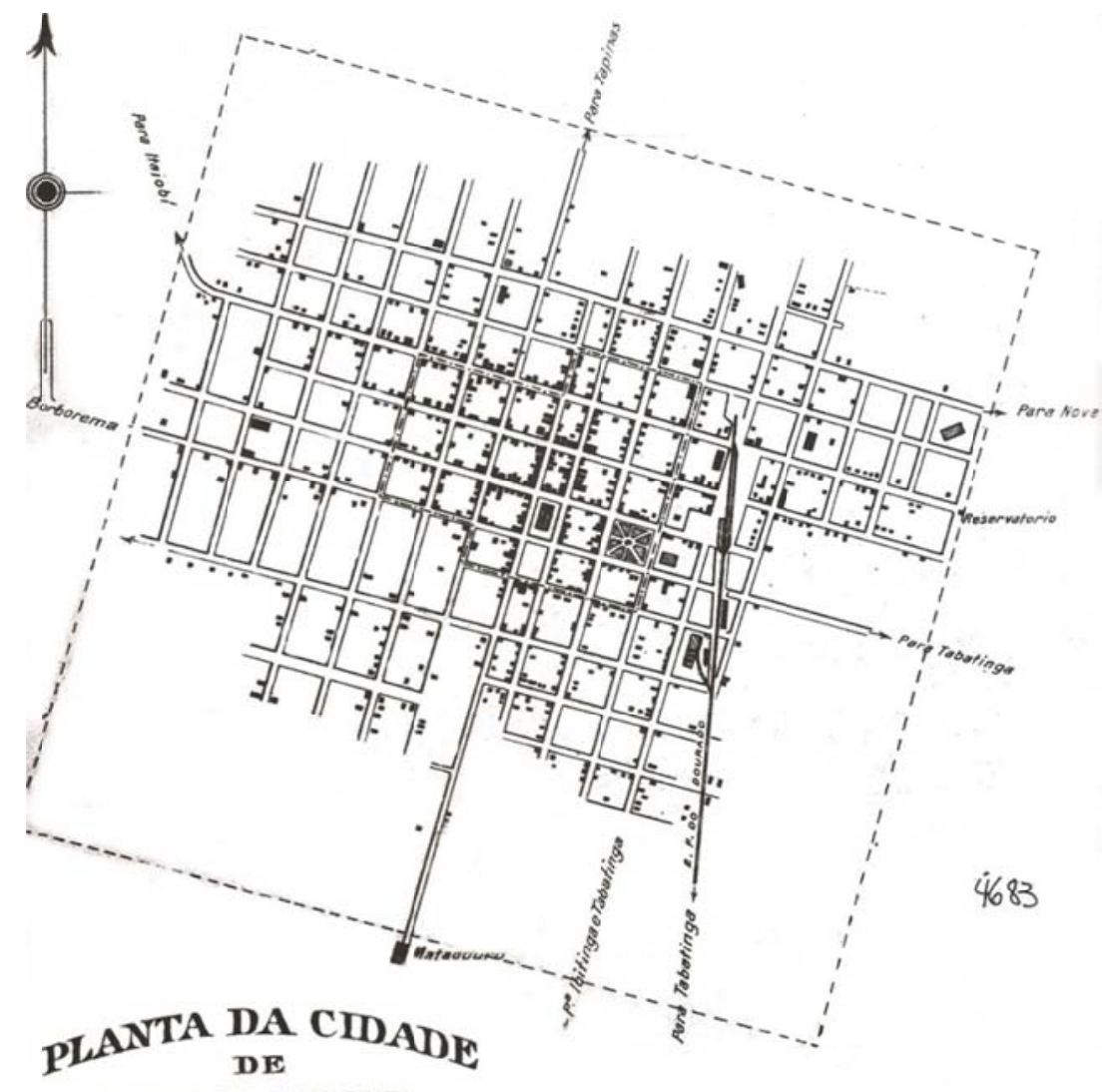

ITAPOLIS

Escala t10ooo

Planta da Cidade de Itápolis detalhe do Mapa do Município de Itápolis, organizado em observância ao Decreto-Lei Nacional no 311 de 2 de março de 1938, elaborado pelo Serviço de Topografia e Limites do Instituto Geográfico e Geológico - Secretaria da Agricultura, Indústria e Comércio. Fonte: Instituto Geográfico e Cartográfico de São Paulo.

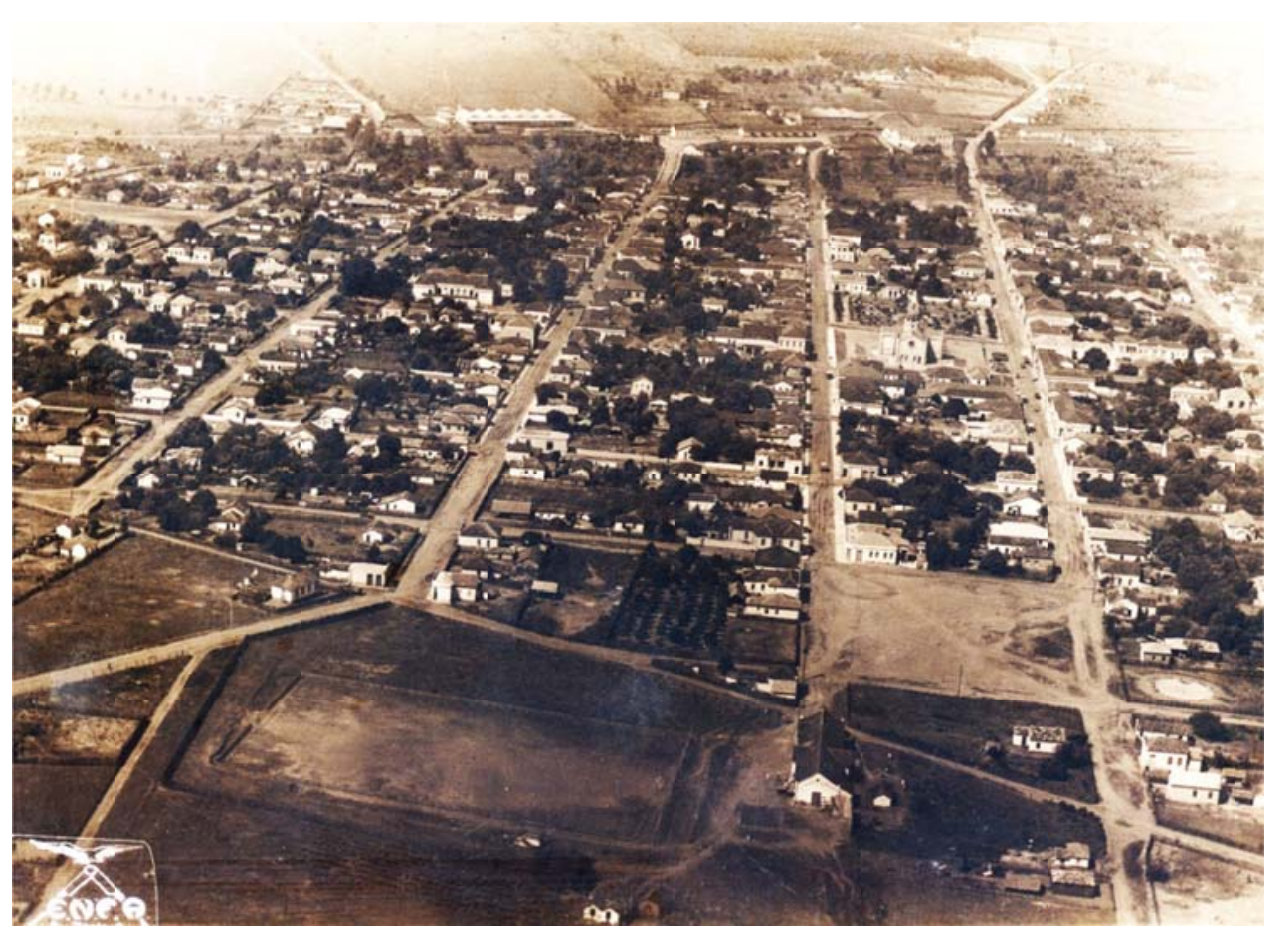

Vista de Itápolis - Coleção de Aerofotos Obliquas de 1939. Fonte Instituto Geográfico e Cartográfico do Estado de São Paulo. 
Bocaina é mais uma localidade que confirma a regra das povoações urbanas da Zona Douradense: nasceu em solo religioso do patrimônio de São João da Bocaina e teve seu solo ocupado com base na quadricula de $88 \times 88$ metros. A praça da matriz, localizada à meia encosta, orientou o arruamento.

Apesar de observarmos a ocupação nas quatro faces das quadras, é possível perceber que essa acontece de forma mais intensa em apenas duas, nas voltadas para as ruas que correm paralelas às laterais da praça da matriz. Todas as ruas do perímetro urbano possuem 17 metros de largura, não são arborizadas, mas os miolos de quadra são densamente ocupados por pomares.

No perímetro urbano predominam as construções implantadas sobre o alinhamento da rua e afastadas das divisas laterais, exceto na rua à direita da praça da Matriz, a 'rua do comercio', onde as edificações ocupam toda a frente do lote, formando um bonito conjunto, com aberturas em ritmo constante.

O grupo escolar e a Câmara Municipal ocupam a mesma quadra e além da igreja matriz, são os únicos edifícios com mais de um pavimento em todo o perímetro urbano.

Bocaina possuía uma santa casa construída fora do limite urbano, construída para tratar os doentes do surto de febre amarela que atingiu a região no inicio do século XX.

A estação ferroviária ocupou os terrenos mais altos da cidade, em uma situação bastante privilegiada, apesar de fora do limite urbano. Atraiu para o redor de sua grande praça (para os padrões dessas cidades) lojas de insumos agrícolas e pecuários e oficinas relacionadas ao beneficiamento do café.

Sua implantação não rompeu com o esquema preexistente das quadras e podemos observar a indicação de uma área de expansão além das linhas da Douradense, mas a partir da mesma orientação do restante da cidade.

Bariri nasceu sob a proteção de Nossa Senhora das Dores e posteriormente foi elevado à Freguesia de Nossa Senhora do Sapé do Jaú, fazendo referencia ao Ribeirão do Sapé que passa pela localidade. Seu arruamento constitui-se basicamente de um traçado em xadrez que parte da praça da matriz, localizada em um sítio mais alto e privilegiado e de lá para as áreas mais baixas. 
A dimensões de suas quadras e lotes também segue a regra das demais cidades: quadras com $88 \times 88$ metros (com variações apenas na área suburbana) e lotes com 11 metros de frente e nas áreas de ocupação posterior com 17,5 metros de frente, com ocupação nos quatro lados da quadra. Ruas com 17 metros de largura e avenidas com 20 metros.

$\mathrm{Na}$ área urbana predominam os edifícios construídos sobre o alinhamento frontal e afastados das demais divisas e telhados com cumeeiras paralelas à rua. Na área suburbana predominam edifícios soltos no lote. São poucas as construções com mais de um pavimento. Diferente das outras povoações, observar a ocupação já consolidada da área suburbana, ultrapassando inclusive áreas além do córrego dos Godinho.

$\mathrm{Na}$ área suburbana, na confluência do ribeirão do Sapé e o córrego da Igrejinha, se formou um novo bairro, que apresenta as mesmas características do núcleo inicial de Bariri.

A estação ferroviária foi implantada em área alta, distante e de urbanização ainda não consolidada, além do Ribeirão do Sapé.

Itapuí também se formou a partir da capela de Santo Antônio, na várzea do ribeirão Bica de Pedra. A praça da matriz que nessa localidade ocupou o equivalente a duas quadras, foi implantada à meia encosta e orientou a ocupação do território a partir de quadras de 88 x 88 metros e ruas com 17 metros de largura.

$\mathrm{Na}$ área urbana predominam construções térreas, edificadas sobre o alinhamento frontal e afastadas dos demais limites, mas aqui não é possível estabelecer uma regra quanto à forma dos telhados e a posição das cumeeiras, apenas as construções voltadas diretamente para a praça da matriz possuem platibandas, nas demais pequenos beirais.

Não há arborização nas ruas, mas ocupação dos miolos de quadra com pomares.

A estação ferroviária foi implantada distante do núcleo inicial, além do limite do ribeirão Bica de Pedra.

A formação urbana contava com dois cemitérios, um antigo pequeno e outro maior, chamado de cemitério novo, localizados na divisa da área urbana. Também nessa área alta da povoação havia um campo de futebol. 


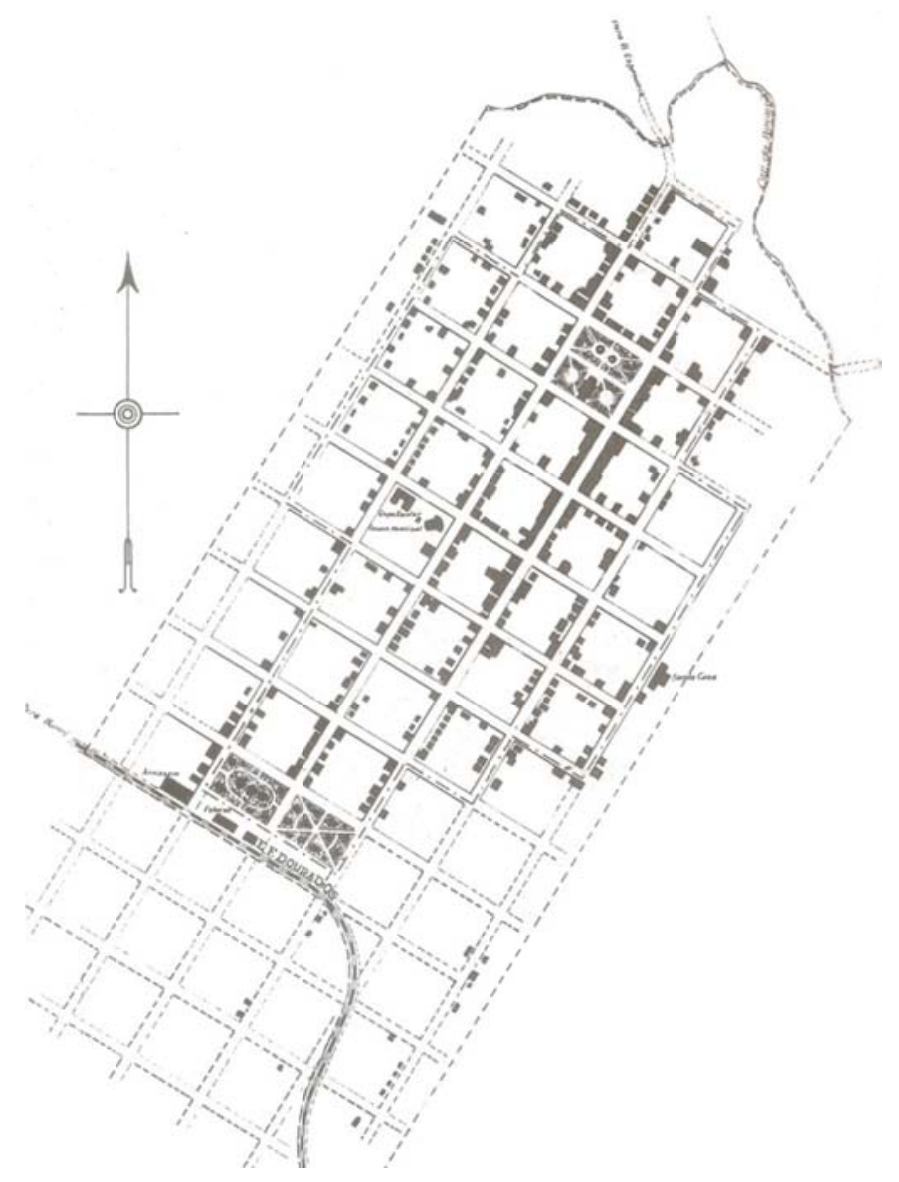

Planta da Cidade de Bocaina detalhe do Mapa do Município de Bocaina, organizado em observância ao Decreto-Lei Naccional no 311 de 2 de março de 1938, elaborado pelo Serviço de Topografia e Limites do Instituto Geográfico e Geológico - Secretaria da Agricultura, Indústria e Comércio. Fonte: Instituto Geográfico e Cartográfico de São Paulo.

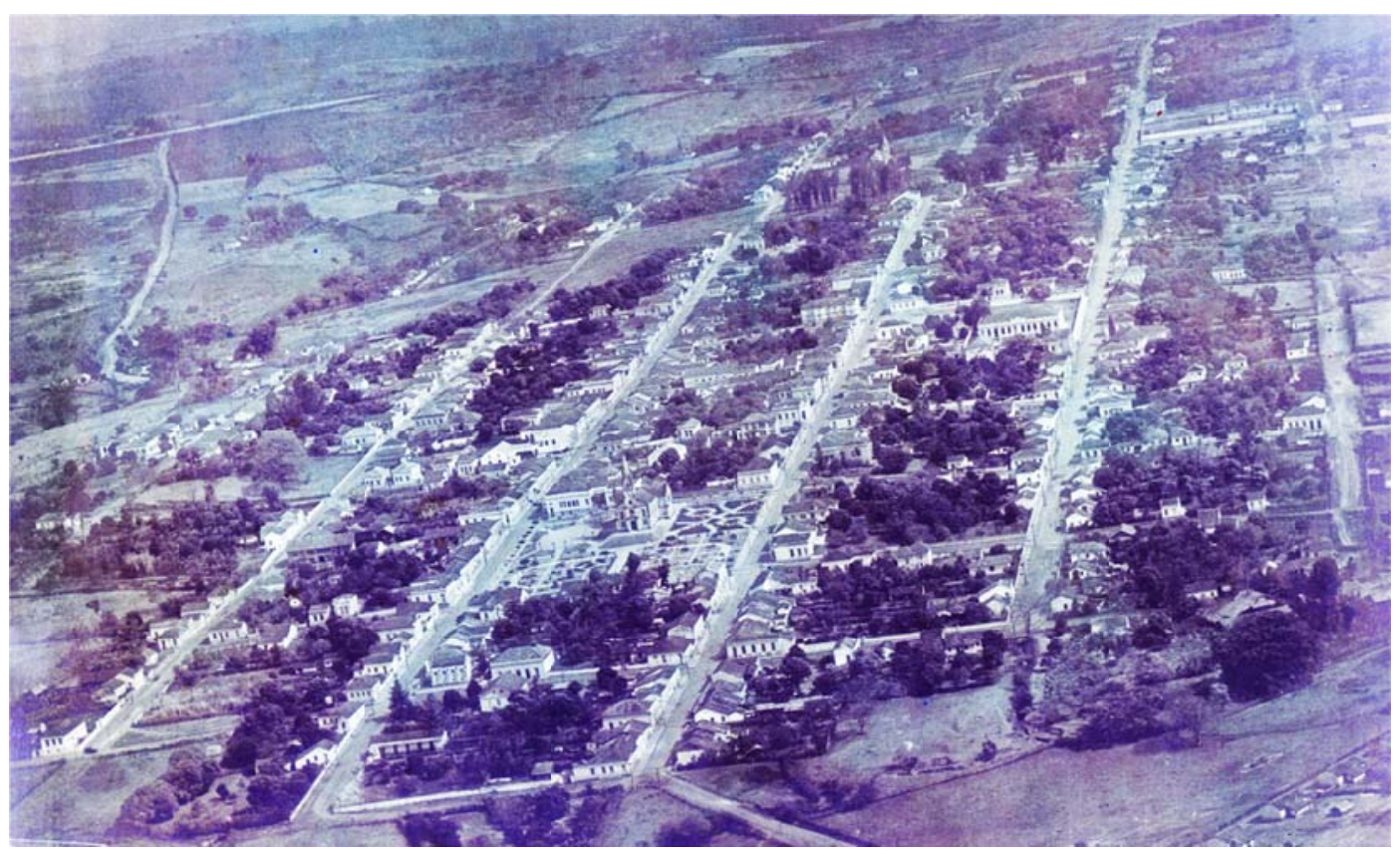

Vista de Bocaina - Coleção de Aerofotos Obliquas de 1939. Fonte Instituto Geográfico e Cartográfico do Estado de São Paulo 


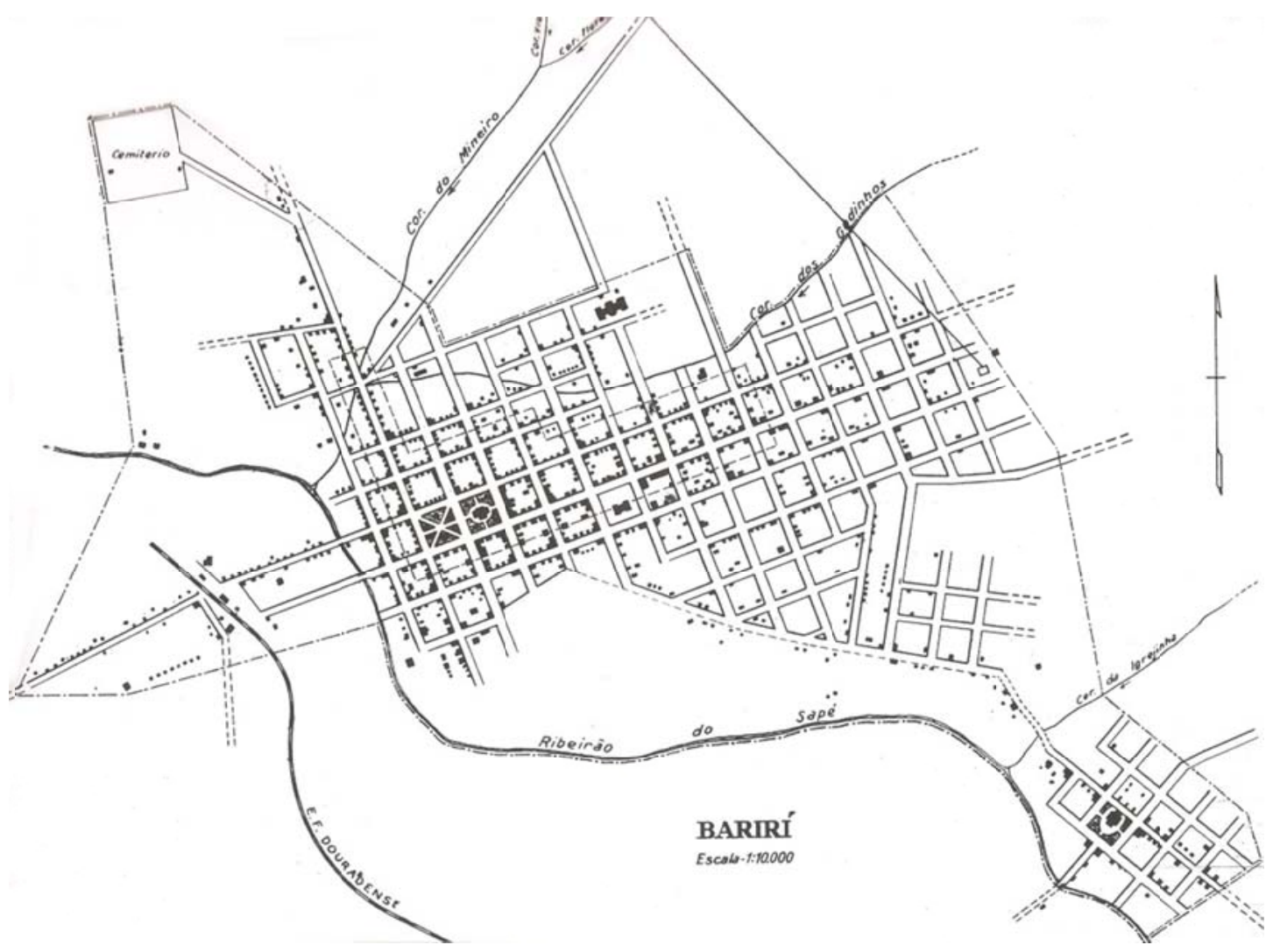

Planta da Cidade de Itápolis detalhe do Mapa do Município de Itápolis, organizado em observância ao Decreto-Lei Nacional no 311 de 2 de março de 1938 , elaborado pelo Serviço de Topografia e Limites do Instituto Geográfico e Geológico - Secretaria da Agricultura, Indústria e Comércio. Fonte: Instituto Geográfico e Cartográfico de São Paulo.

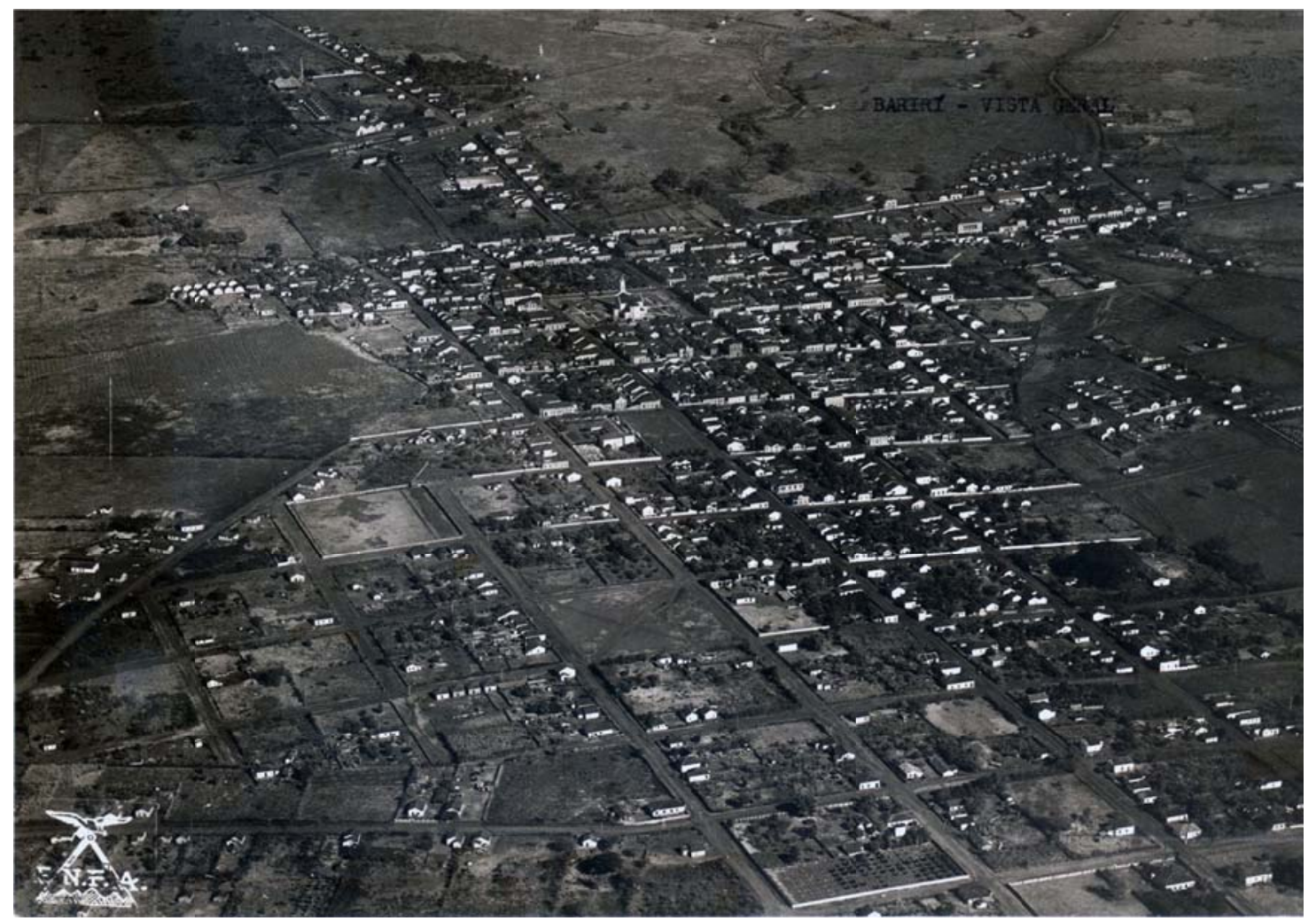

Vista de Bariri - Coleção de Aerofotos Obliquas de 1939. Fonte Instituto Geográfico e Cartográfico do Estado de São Paulo 


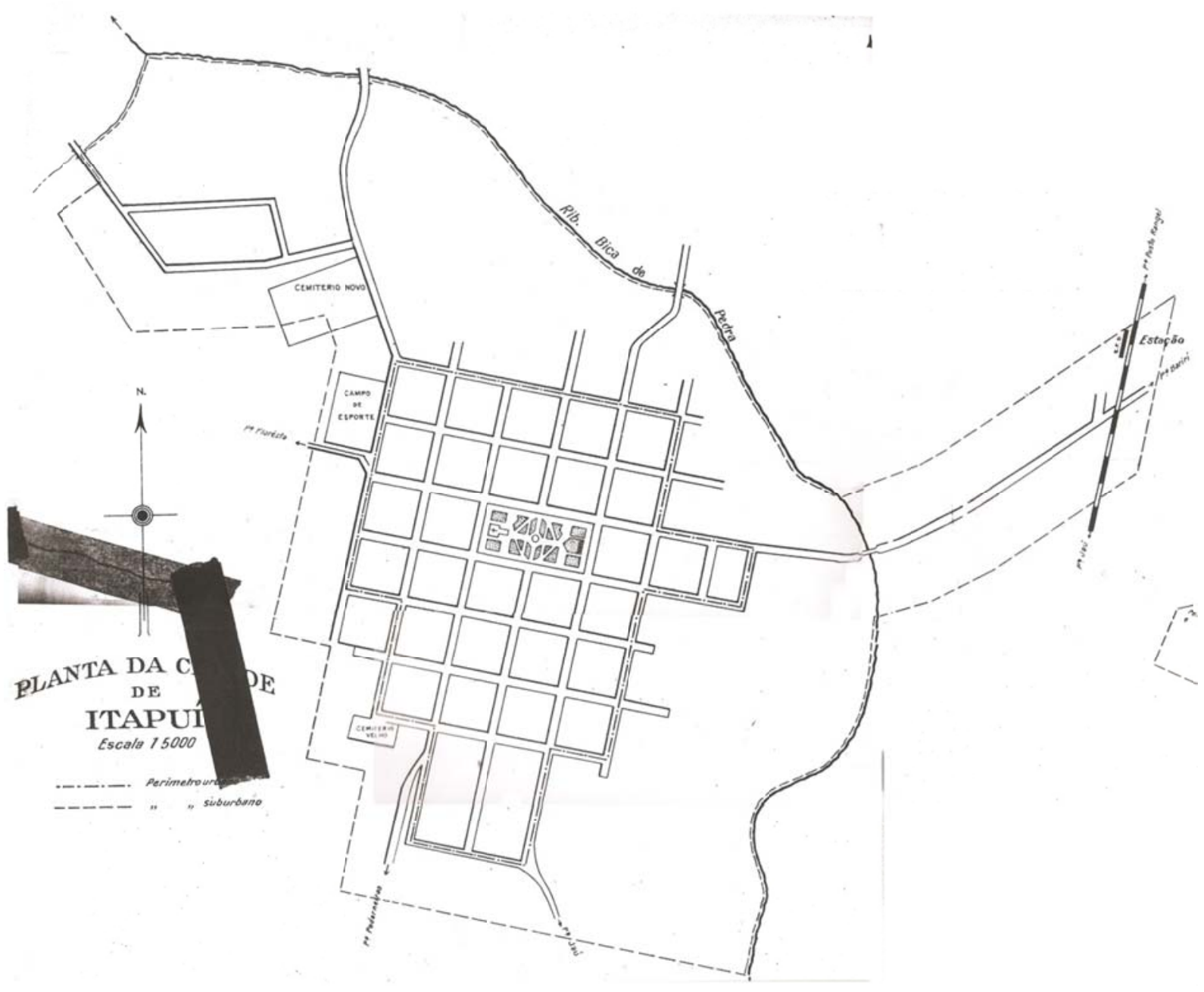

Planta da Cidade de Itapuí detalhe do Mapa do Município de Itapuí, organizado em observância ao Decreto-Lei Nacional no 311 de 2 de março de 1938, elaborado pelo Serviço de Topografia e Limites do Instituto Geográfico e Geológico - Secretaria da Agricultura, Indústria e Comércio. Fonte: Instituto Geográfico e Cartográfico de São Paulo.

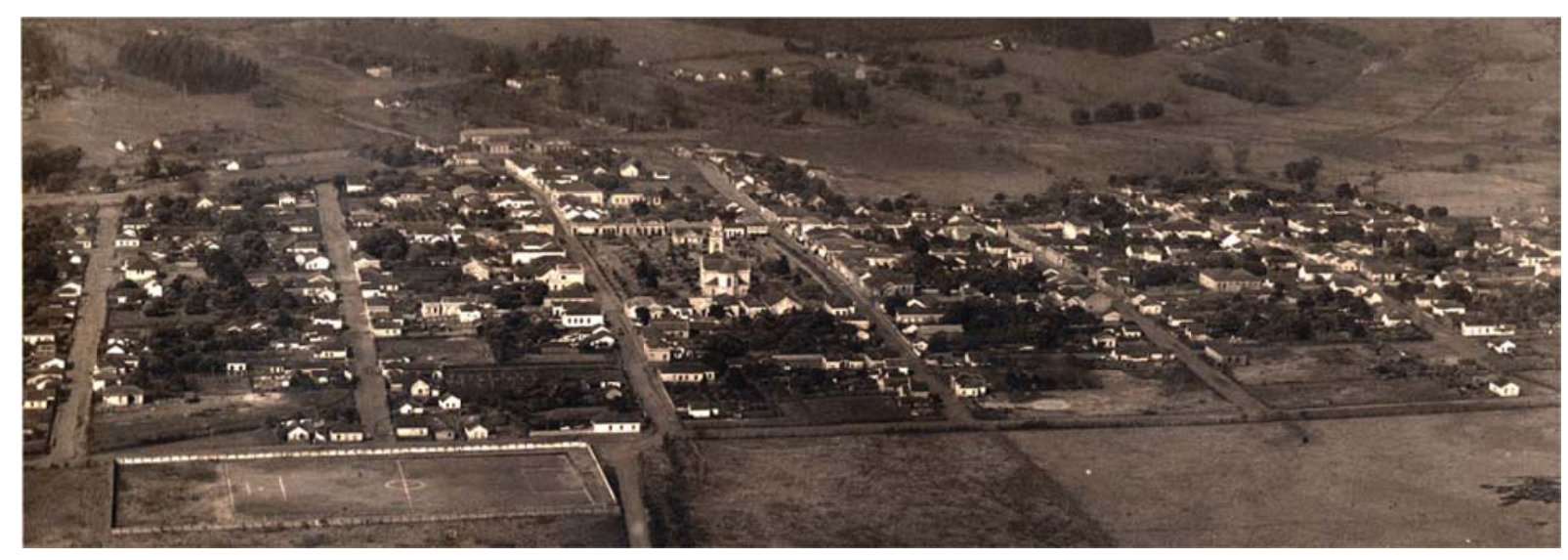

Vista de Itapuí - Coleção de Aerofotos Obliquas de 1939. Fonte Instituto Geográfico e Cartográfico do Estado de São Paulo 
Jaú é a maior cidade no período dentre as tratadas nesta dissertação. Também se originou em solo sacro, às margens do Rio Jaú, a partir da capela de Nossa Senhora do Patrocínio, cuja praça orientou a ocupação de território com base na quadrícula de $88 \times 88$ metros e variações desta, sendo que a sequencia de quadras da qual faz parte a praça da matriz é um pouco mais estreita, com 66 X 88 metros. A partir do mapa de 1938 e mesmo da imagem do ano seguinte reproduzidos abaixo, não é possível estabelecer a dimensão dos lotes.

É possível observar uma ocupação mais densa que nas demais cidades, mas sempre preservando os miolos de quadra vazios. Todas as edificações do perímetro urbano foram construídas sobre o alinhamento frontal, predominando inclusive as sem afastamentos laterais. Predominam telhados com duas águas e cumeeiras paralelas à rua.

A partir do mapa é possível ver que a estação da Douradense foi implantada em área bastante central da cidade com a ocupação avançando além de sua linha e seguindo a mesma orientação das quadras. Já a estação da Paulista foi construída fora dos limites suburbanos, em área ainda não urbanizada. 


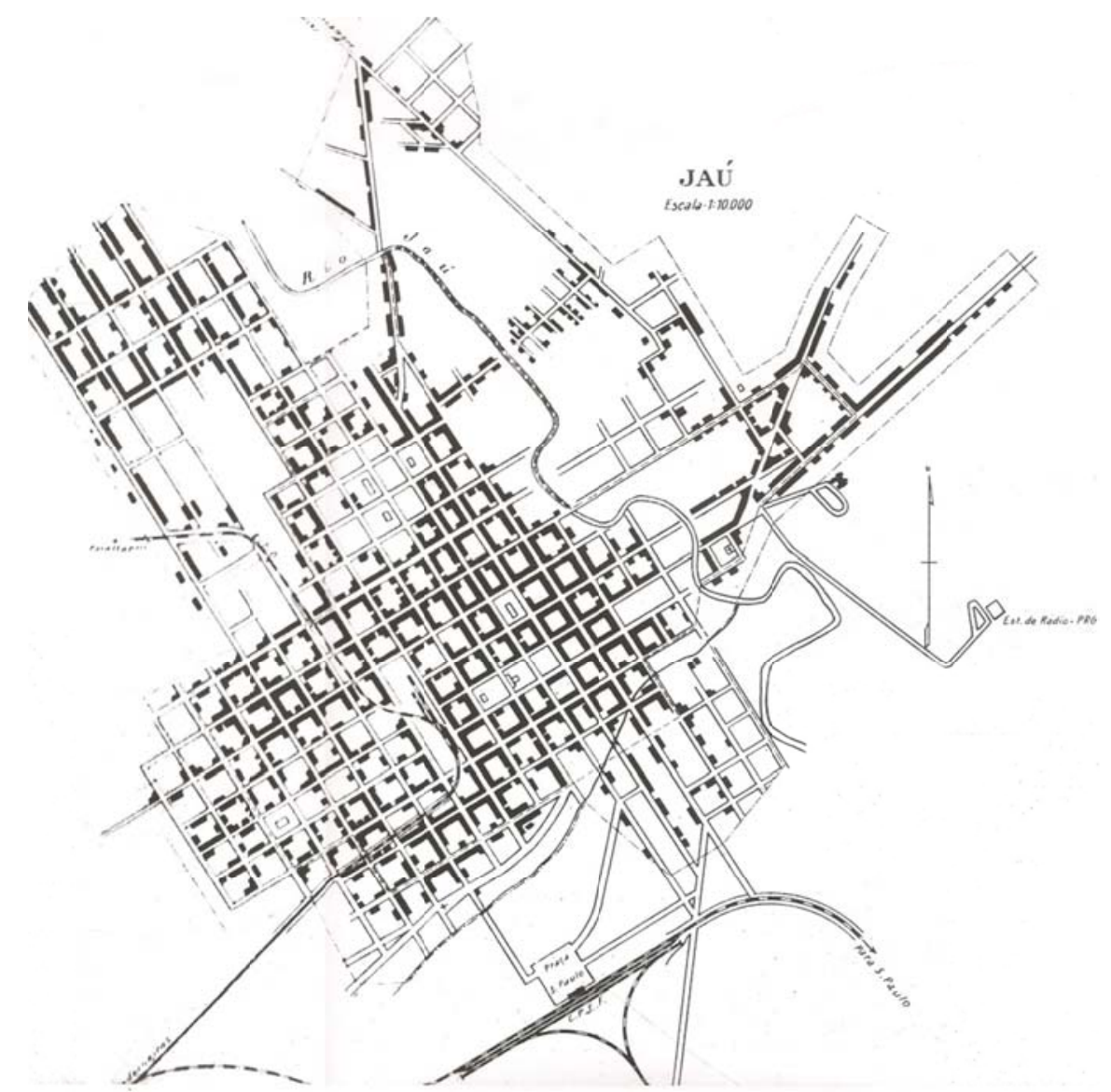

Planta da Cidade de Jaú detalhe do Mapa do Município de Jaú, organizado em observância ao Decreto-Lei Nacional no 311 de 2 de março de 1938, elaborado pelo Serviço de Topografia e Limites do Instituto Geográfico e Geológico - Secretaria da Agricultura, Indústria e Comércio.

Fonte: Instituto Geográfico e Cartográfico de São Paulo.

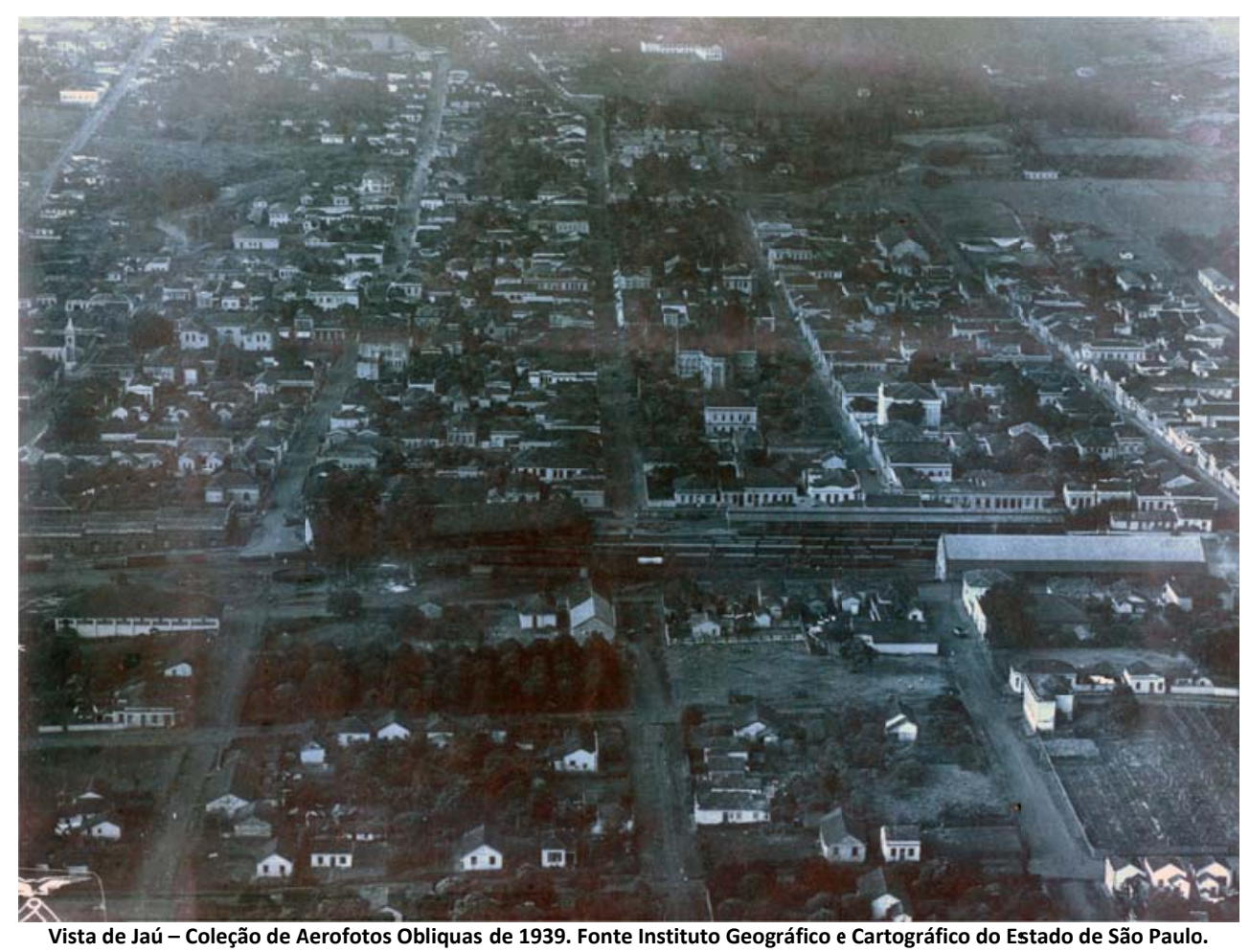


Nova Europa é um dos núcleos urbanos parte do Núcleo Colonial do Cambuhy, portanto nasceu em solo laico, a partir de um projeto pré-estabelecido pela Secretaria da Agricultura que seguia uma série de regras como já foi colocado no capítulo 01. Apesar de seguir estas condicionantes, a escolha do sitio para a ocupação inicial segue a regra das demais localidades originadas a partir das capelas, implantada em uma região de várzea, delimitada pelo córrego Nova Europa e pelo Rio Itaquerê. Entretanto a praça da matriz não se encontra em sítio privilegiado, pelo contrario, está na posição mais baixa da área urbana, próxima à linha férrea.

O projeto localiza a estação ferroviária em um dos limites urbanos e possui uma praça correspondente a meia quadra que apesar de não se localizar em posição central, será seu principal espaço urbano: o arruamento se desenvolve paralelo e perpendicularmente à longa reta originada pelos trilhos que seguem para Tabatinga, possuindo 17 metros de largura.

A ocupação da área se deu com base na quadrícula de 88 × 88 metros, subdividida em lotes de 11 metros de frente.

Possui um cemitério localizado fora dos limites suburbanos, mas ainda assim bastante próximo ao centro do povoamento, denotando negligencia das leis sanitárias.

Sobre as edificações, elas são em sua maioria térreas, residenciais, implantadas sobre o alinhamento da rua e afastadas das demais divisas.

Gavião Peixoto é outro núcleo urbano parte do Núcleo Colonial do Cambuhy, e repete as mesmas características já apontadas em Nova Europa. Entretanto neste caso a ocupação também com base nas quadras de $88 \times 88$ metros se orienta pelas divisas das propriedades rurais circundantes, já que neste trecho a Cia. E. F. Dourado faz um percurso bastante sinuoso.

Nova Paulicéia, o terceiro núcleo urbano pertencente do Núcleo Colonial do Cambuhy apresenta uma implantação bastante semelhante ao caso de Boa Esperança do Sul, com seu território dividido por um córrego, com a estação ferroviária da Douradense localizada de um lado e a praça da capela de outro. Na porção onde se localiza a estação, o arruamento de orienta paralelo e perpendicularmente à linha férrea, enquanto na porção 
onde se localiza a praça da capela, o arruamento foi aberto paralelamente à rodovia que segue exatamente o traçado da antiga ferrovia. Esta é uma porção de ocupação mais recente e ainda é bastante insipiente, tanto que a praça da capela é o fim da área urbanizada e uma de suas laterais faz divisa com a área rural. A própria capela e sua praça datam de fins da década de 1950.

Infelizmente não foi possível localizar para esta localidade o mesmo material utilizado para as análises das demais localidades.

Trabiju não faz parte no Núcleo Colonial do Cambuhy, entretanto nasceu em solo laico. Sua ocupação inicial do território de Trabijú acontece no século XIX com a vinda de mineiros após a decadência das minas em Goiás e Mato Grosso, mas o estabelecimento da vila só ocorreu em paralelo à chegada dos trilhos da Douradense por volta de 1900 . A primeira aglomeração se deu ao redor da antiga estação no local chamado 'Trabijú velho', um pouco mais a leste de onde foi implantada a estação definitiva. Portanto Trabijú nasce em solo laico.

Em 1910 a linha férrea foi substituída por outra de bitola métrica, seu traçado foi remanejado e uma nova estação construída em um local mais adequado. Com o remanejamento das linhas, Trabijú passou a ser o principal entroncamento da Cia. E. F. Dourado, ponto de partida de trens para mais de 30 cidades e recebeu as oficinas da Douradense, fato que para as dimensões do povoado foi um grande incentivo, ao mesmo tempo em que gerou uma crise para Dourado, que dessa forma passou a não fazer mais parte do ramal tronco e perdeu a sede dos armazéns e oficinas. Esse novo status de Trabijú na linha levou o governo estadual a implantar no local armazéns reguladores.

A fundação de Trabijú ocorreu em um sítio alto, afastado dos cursos d’água. Seu arruamento se orienta a partir da reta originada pela linha do ramal que segue para Boa Esperança do Sul, sendo que a primeira rua paralela à linha é mais larga, com 20 metros de largura, enquanto as demais possuem 17 metros de largura.

A ocupação se dá com base na quadrícula, mas estas se apresentam com dimensões variáveis, com laterais de 88, 66 e 44 metros, orientadas paralelamente à via férrea.

Aqui a estação presidiu o espaço urbano, apesar de se encontrar em um dos limites da povoação - foi o principal edifício do lugar, apesar da sua simplicidade. A capela, depois 
igreja matriz, foi construída posteriormente à estação e apesar de ocupar uma posição central, em um terreno 'nobre', a escolha de sua localização não sofreu com as determinantes específicas de uma capela de patrimônio religioso (como por exemplo, ter ao menos como um dos seus limites um curso d’água).

Até a década de 1940, como pode ser observado na imagem de 1939, apenas a área delimitada pela linha tronco e pelo ramal de Dourado foi ocupada. A área além do ramal de Dourado, só foi ocupada na década de 1970 com a demarcação de quatro quadras e com as ruas traçadas a partir desta linha férrea, além da ocupação ao longo do antigo traçado da linha tronco.

A ocupação sistemática da área ao norte da linha tronco só ocorreu no inicio dos anos 1990, incentivada por um loteamento de iniciativa da prefeitura municipal, onde foram construídas residências de interesse social. Nesse novo bairro a abertura das ruas seguiu a orientação da antiga linha férrea, com a rua principal correndo paralelamente a ela e as secundarias perpendicularmente.

A configuração das quadras indica uma urbanização seguindo os caminhos estabelecidos pela ferrovia. 


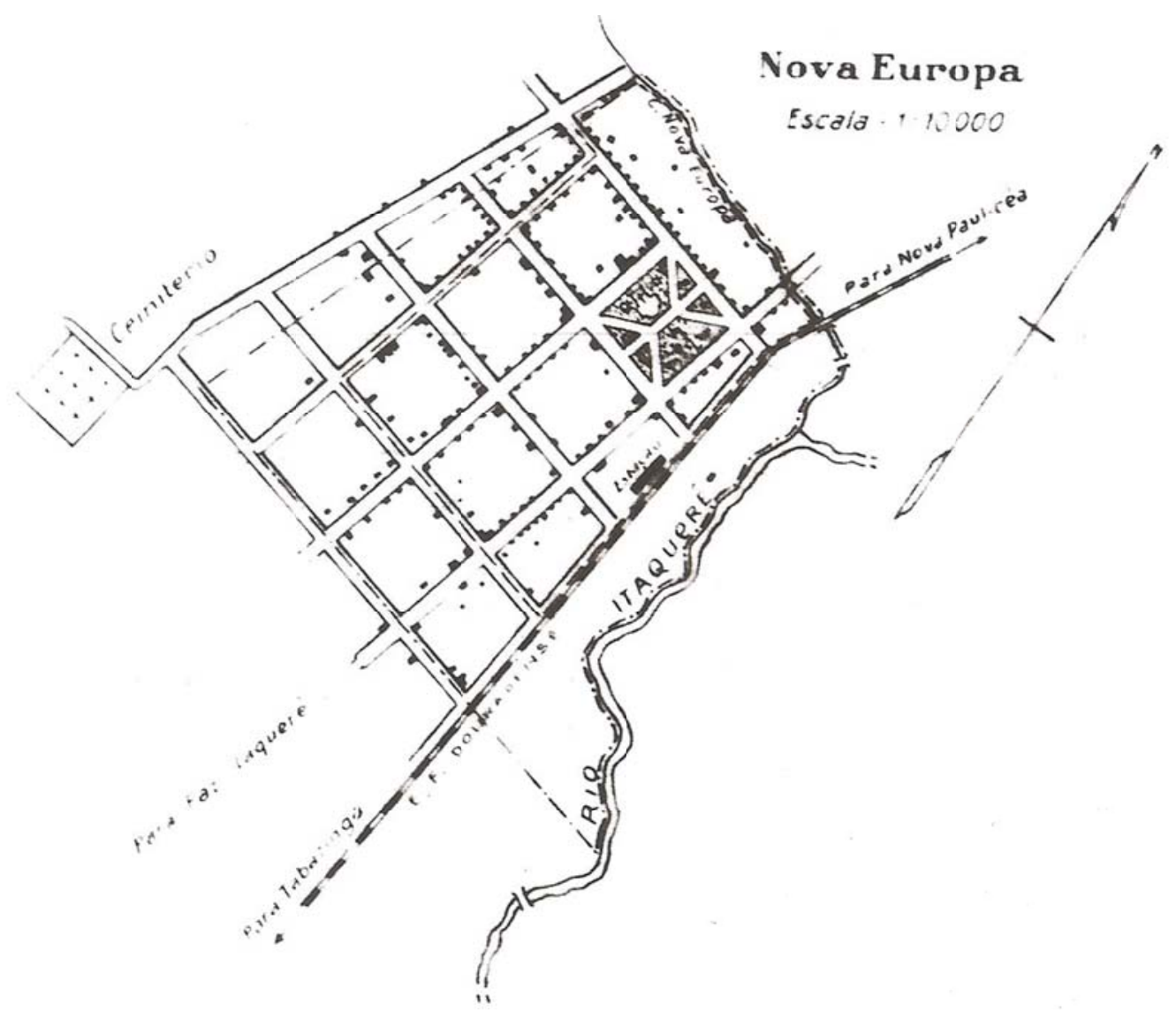

Planta da Cidade de Nova Europa, detalhe do Mapa do Município de Nova Europa, organizado em observância ao Drecreto-Lei Nacional no 311 de 2 de março de 1938, elaborado pelo Serviço de Topografia e Limites do Instituto Geográfico e Geológico - Secretaria da Agricultura, Indústria e Comércio. Fonte: Instituto Geográfico e Cartográfico de São Paulo.

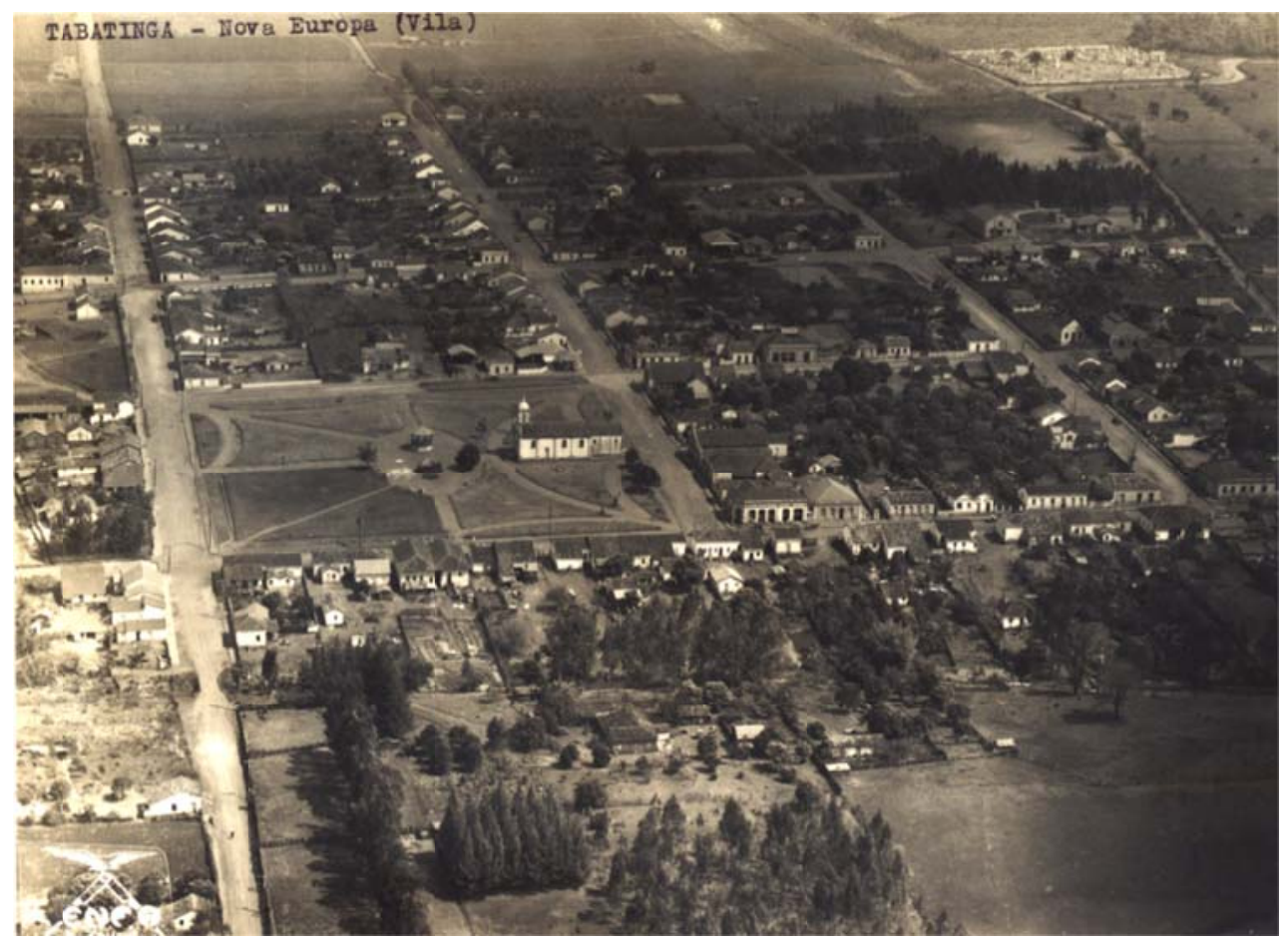

Vista de Nova Europa - Coleção de Aerofotos Obliquas de 1939. Fonte Instituto Geográfico e Cartográfico do Estado de São Paulo 


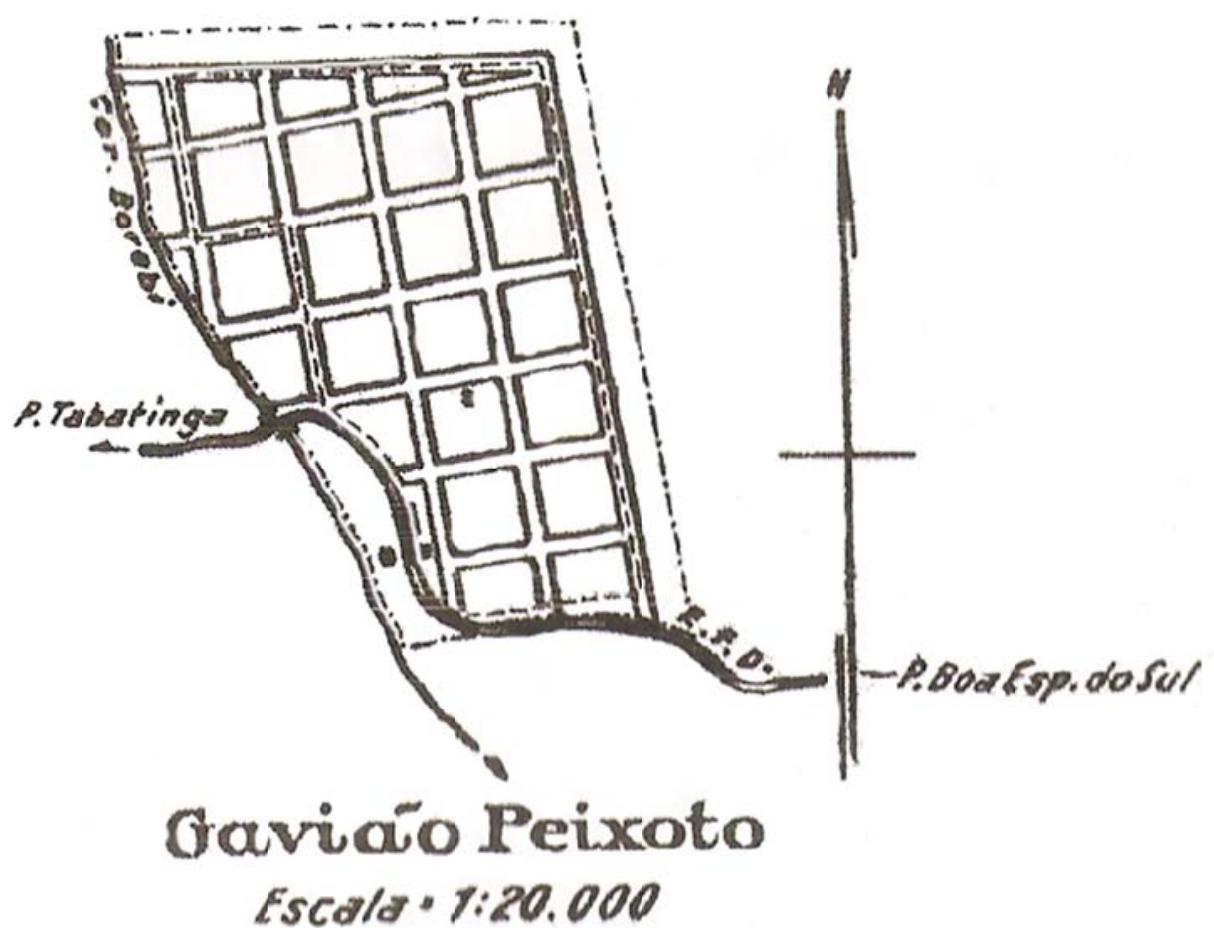

Planta de Gavião Peixoto detalhe do mapa do Município de Araraquara organizado pelo instituto Geográfico e geológico em observância ao decreto-lei nacional no 311 de 2 de março de 1938. Fonte Instituto Geográfico e Cartográfico do Estado de São Paulo.

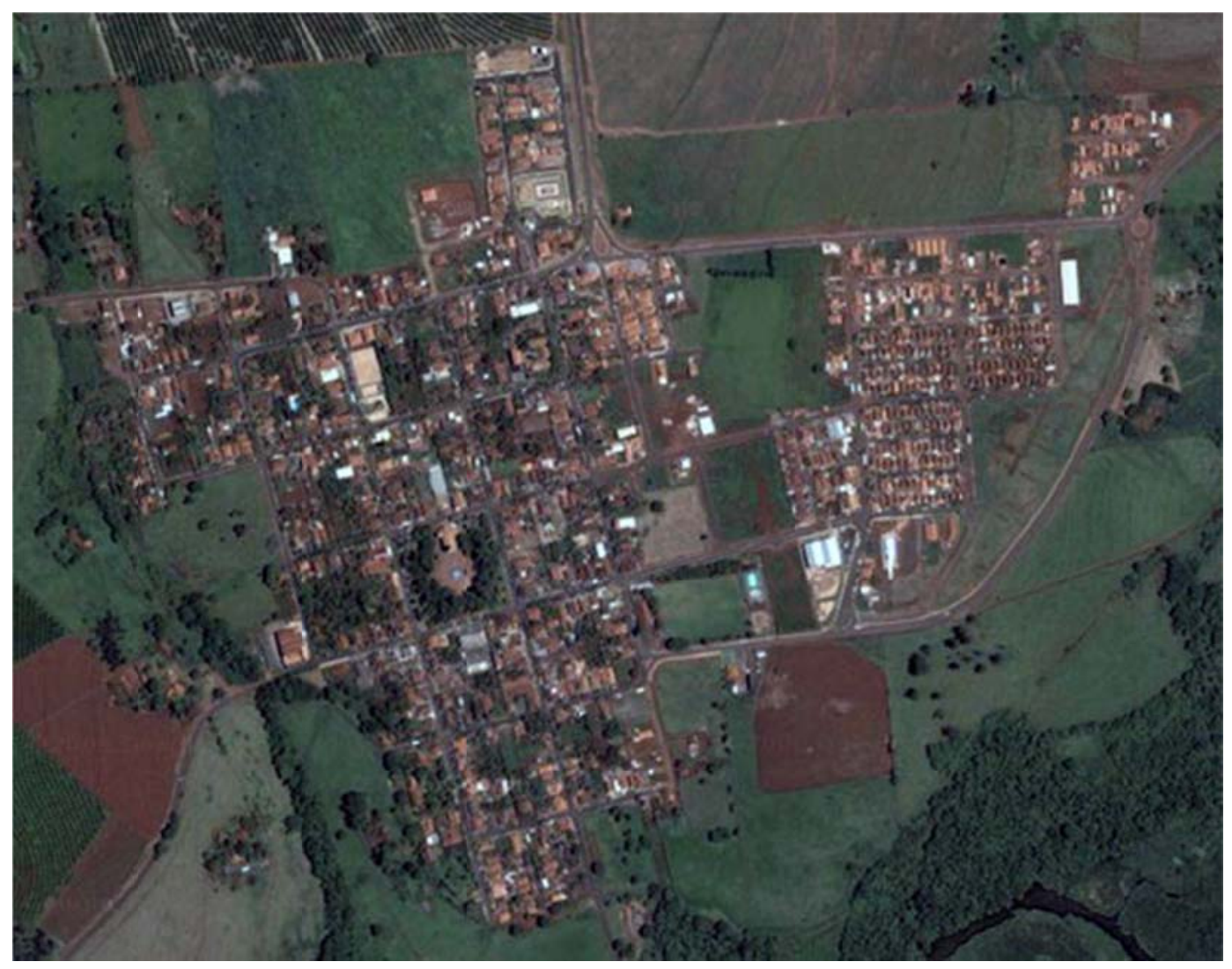

Vista aérea atual de Gavião Peixoto. Fonte: Google. Acesso jul. 2010 


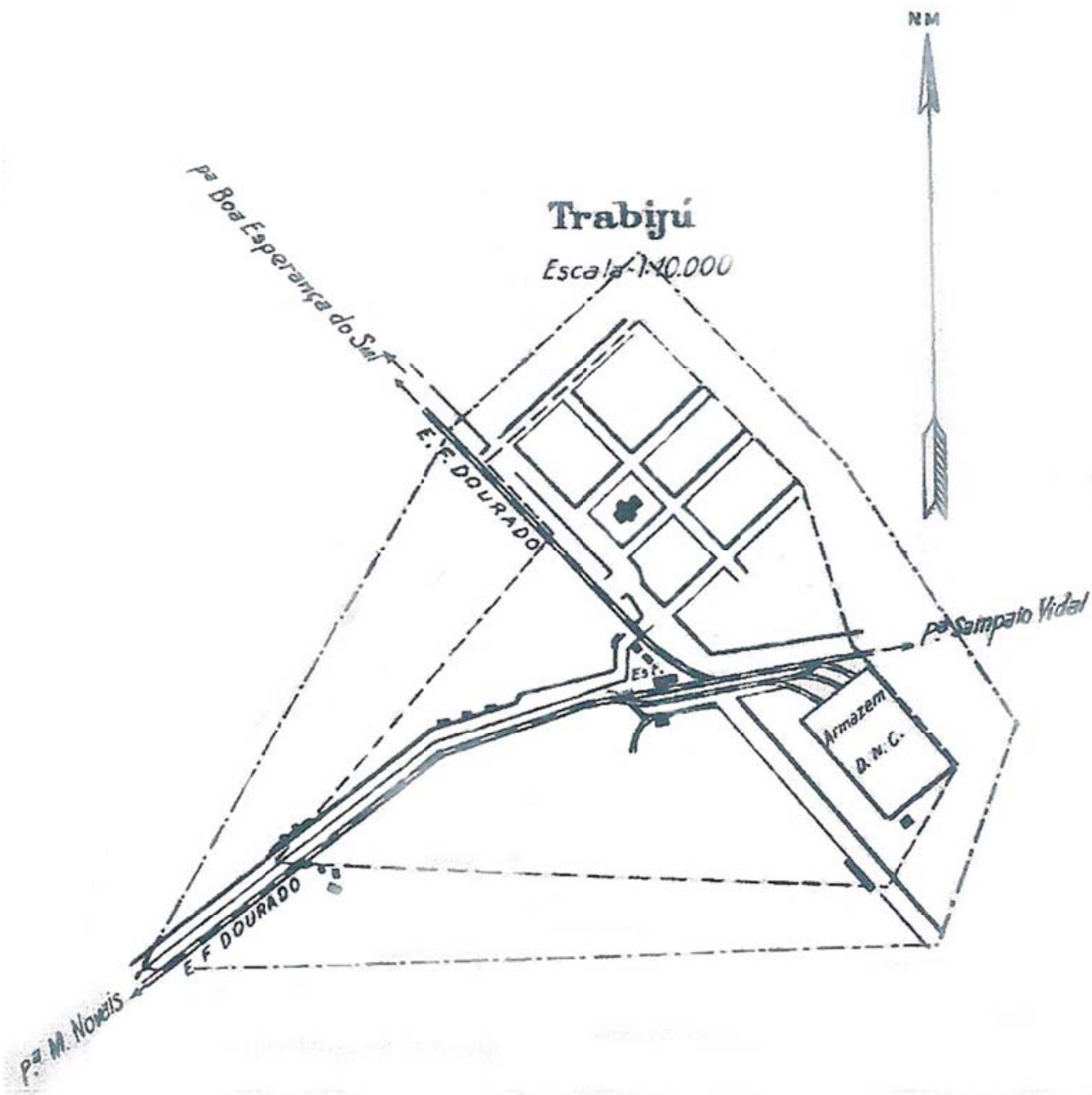

Planta de Trabijú, detalhe do Mapa do Município de Boa Esperança do Sul, organizado em observância ao Decreto-Lei Nacional no 311 de 2 de março de 1938, elaborado pelo Serviço de Topografia e Limites do Instituto Geográfico e Geológico - Secretaria da Agriciultura, Indústria e Comércio.

Fonte: Instituto Geográfico e Cartográfico de São Paulo.

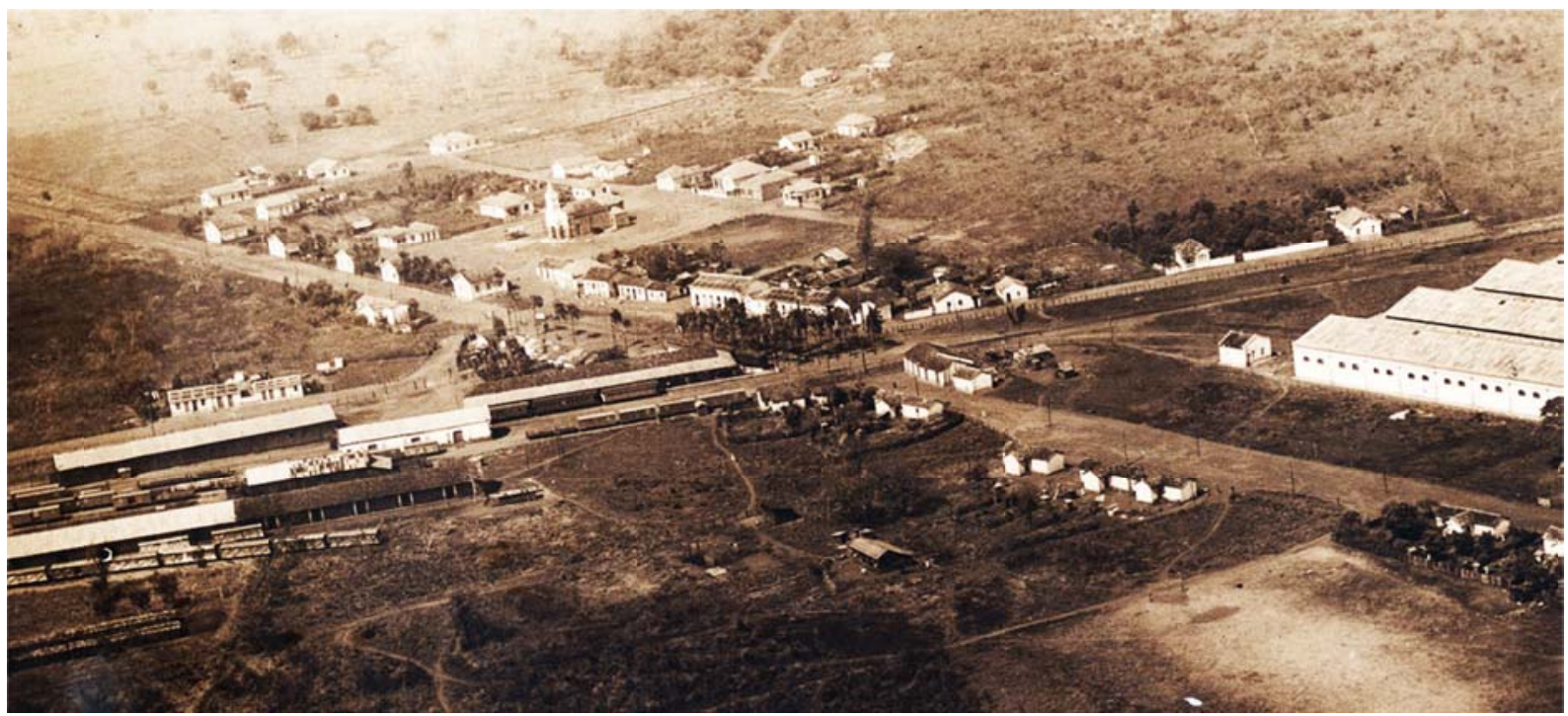

Vista de Trabijú - Coleção de Aerofotos Obliquas de 1939. Fonte Instituto Geográfico e Cartográfico do Estado de São Paulo. 
Pedra Branca, Pedro Alexandrino e Taboca são localidades nascidas em função da linha férrea da Douradense, mas nunca chegaram a se desenvolver. Nos três casos, foram implantadas em áreas altas, distantes dos cursos d’água, as construções iniciais foram nascendo ao longo da linha férrea, sendo o edifício da estação o centro destas localidades. As três localidades nasceram dentro de fazendas cafeeiras pertencentes a diretores da Cia. Douradense.

O distrito de Pedra Branca pertence ao município de Boa Esiperança do Sul e sua estação fazia parte da linha tronco da Cia. E. F. Dourado, localizada no km 52,91, entre as estações Java e Ponte Alta. A construção da estação Pedra Branca, inaugurada em outubro de 1924 é curiosa, pois segundo o Relatório no 09 de 1925 da Cia. E. F. Dourado foi feita à custa da população local a partir da iniciativa do Sr. Reginaldo Filpi que posteriormente a doaram através de escritura pública à ferrovia.

Essa iniciativa demonstra a forte intenção de se desenvolver este núcleo urbano a partir das vantagens da implantação de uma estação ferroviária no local. Não encontrei informações sobre volumes e especificações sobre quantidades de carga transportadas a partir dessa estação, mas acredito que sua função principal seria de transporte de pessoas, já que se encontra a aproximadamente $3 \mathrm{Km}$ da estação Java, localizada dentro da fazenda com o mesmo nome, importante produtora de café nos tempos áureos da ferrovia e da região, assim como da estação Ponte Alta, distante também apenas $6 \mathrm{Km}$ e que funcionou como ponta de linha até 1949, quando foi aberta a estação Gavião Peixoto. Portanto essa estação foi construída 18 anos após os trilhos chegarem ao núcleo.

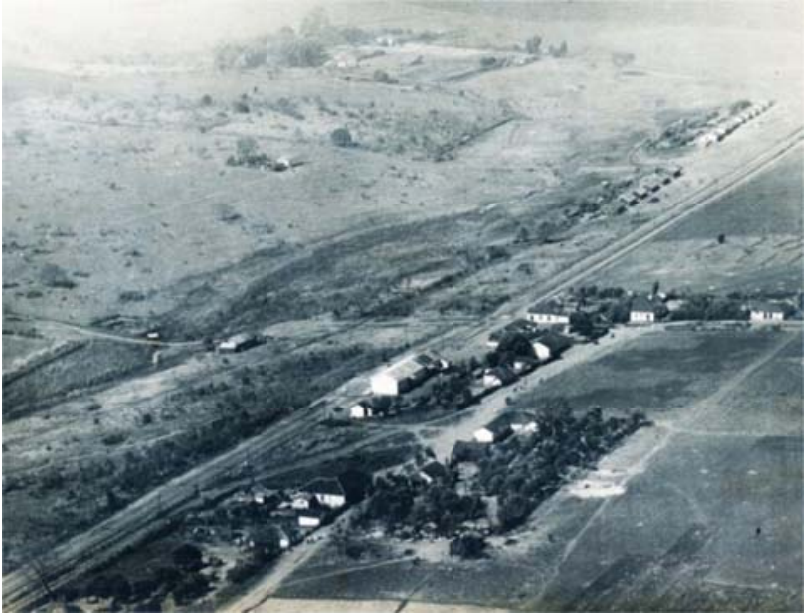

Vista de Pedra Branca - Coleção de Aerofotos Obliquas de 1939. Fonte Instituto Geográfico e Cartográfico do Estado de São Paulo.

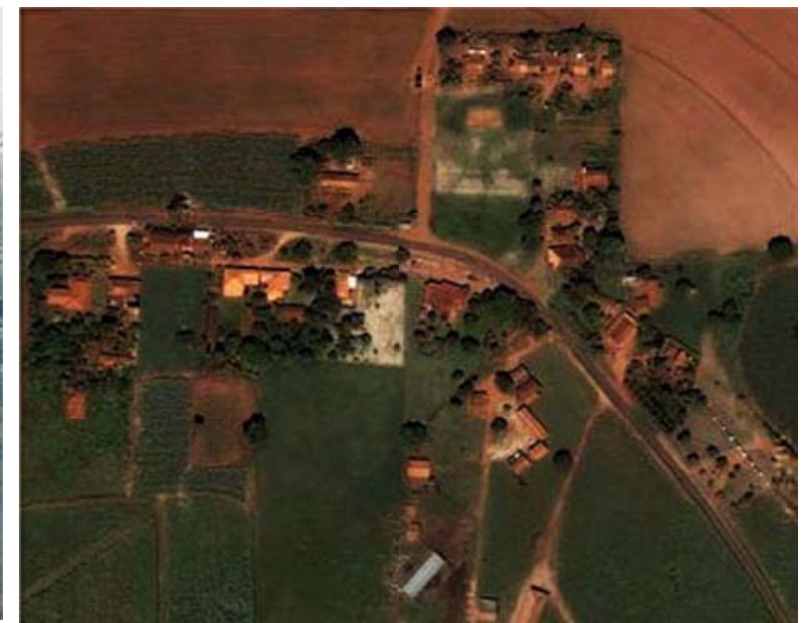

Vista aérea atual de Pedra Branca. Fonte: Google. Acesso jul. 2010 
A partir de comparações da imagem de 1939 com imagens de satélite atuais, é possível perceber que pouca coisa mudou nesses últimos setenta anos e que os planos de desenvolver o lugar não se concretizaram. No trecho do distrito a rodovia de acesso 105/255 Cottar Tannuri foi construída exatamente sobre o antigo traçado dos trilhos que depois segue na direção sudoeste.

A respeito de sua implantação e traçado podemos observar que as poucas ruas, ainda sem pavimentação, são delimitadas pelo alinhamento das casas, correndo paralelamente ou perpendicularmente à linha férrea. Apenas uma quadra pode ser claramente delimitada. A partir da imagem de 1939 é possível perceber a intenção de um parcelamento em quadrícula para o local, a partir de quadras mais largas paralelamente à linha férrea e estreita no outro sentido.

A estação está implantada em uma quadra mais estreita, com aproximadamente metade da profundidade das demais, entre a rodovia e a primeira rua. Na quadra em frente há um lote vogo que faria às vezes de praça da estação e por sua localização, também de centro do distrito.

A partir de observações das fachadas de algumas construções, é possível supor que a grande quadra paralela à ferrovia deveria ser subdividida em três quadras menores, de proporções quadradas, como assinalado no croqui da implantação do distrito. Essa suposição se deve ao fato de algumas dessas edificações terem suas fachadas 'principais' voltadas para o interior dessa quadra e outro conjunto ter um ângulo chanfrado, insinuando a abertura de uma rua que delimitaria o espaço frontal à estação.

Além da estação, o restante das edificações é residencial. As residências antigas, em sua maioria, são casas geminadas, implantadas sobre o alinhamento da rua, com cumeeiras paralelas à rua, com passeio estreito e elevado e preocupação de chanfrar as esquinas, numa situação similar à observada na Vila Santa Clara em Dourado. As novas construções são soltas no lote.

As poucas construções recentes se diferem das antigas apenas por suas relações de implantação, o que não é facilmente perceptível, já que os lotes não são claramente definidos, divididos apenas por cercas baixas o que faz com que os pomares acabem visualmente se unindo. Em outros núcleos urbanos analisados neste trabalho, os 
ornamentos, mesmo que poucos e simples podem ajudar o observador a distinguir as diferentes épocas de construção, o que nesse caso não é possível.

No alto da imagem de 1939 observa-se um renque de 16 casinhas de colonos, das quais hoje restam apenas 5, que foram recentemente incorporadas ao núcleo com a abertura de ruas pavimentadas e a delimitação de uma praça, que thoje é utilizada como campo de futebol.

O edifício da estação hoje é ocupado como residência de duas famílias. Externamente, apesar das descaracterizações, ainda é facilmente perceptível sua função original.

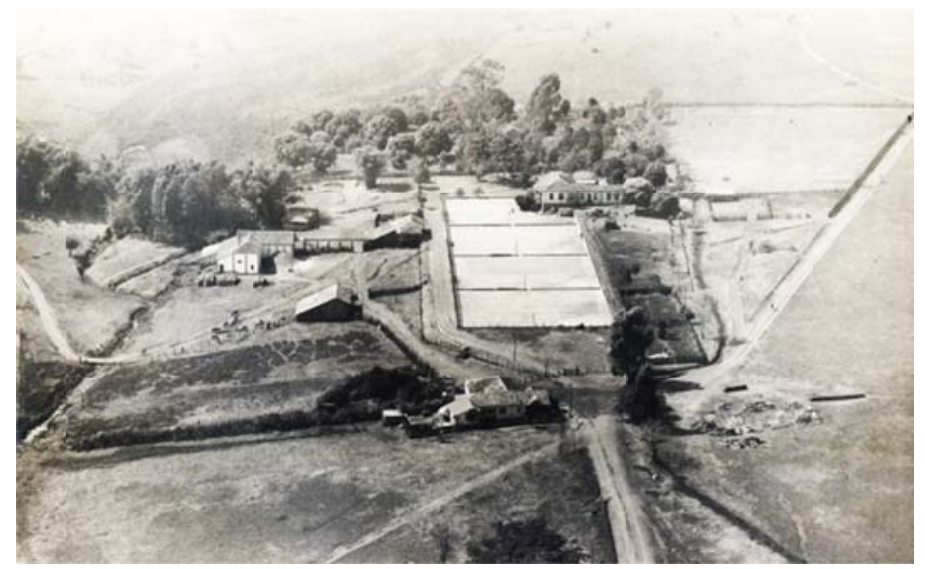

Exemplo de estação ferroviária da douradense localizada dentro de fazenda produtora de café para atender aos interesses de seus proprietários. Vista da fazenda Java - Coleção de Aerofotos Obliquas de 1939. Fonte Instituto Geográfico e Cartográfico do Estado de São Paulo.

O povoado de Pedro Alexandrino teve início com a construção da estação da Cia. Douradense em 1910, em terras da fazenda Estrela, pertencente a Pedro Alexandrino de Carvalho, um dos diretores da ferrovia. Nos trinta anos seguintes, como podemos observar na imagem do IGC, o povoado que pertence à cidade de Bocaina pouco se desenvolveu apenas umas poucas construções foram erguidas seguindo o traçado da linha férrea e da estrada de acesso entre Trabijú e Bocaina que corriam paralelamente.
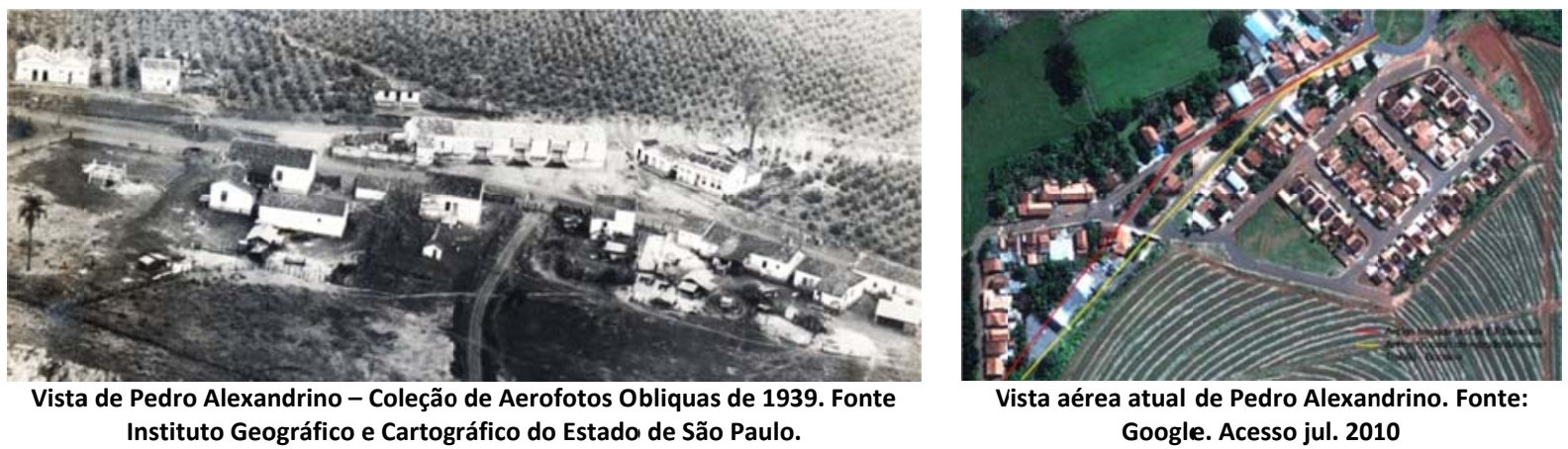

Vista aérea atual de Pedro Alexandrino. Fonte: Google. Acesso jul. 2010 
A estação era o centro do povoado, localizada em uma 'ilha' entre as duas estradas. A principio não houve preocupação em abertura de quadras para a expansão do povoado, que lentamente foi se expandindo ao longo dessas vias até o início dos anos 1990, quando foram abertas quatro novas quadras por iniciativa da prefeitura municipal para a construção de residências de interesse social. As novas ruas foram traçadas paralelas e ortogonalmente à antiga linha férrea.

É interessante observar na imagem antiga que algumas edificações não possuíam divisas de lote, já que a plantação de café chega a poucos metros das construções.

A partir da construção da estação Taboca da douradense formou-se um bairro rural, mas este nunca chegou a configurar-se como vila. Localizada em terras da fazenda Santa Helena, mas atendendo também a fazenda Primavera, teve todas as suas construções demolidas em 2009 para o plantio de cana de açúcar.

Suas poucas construções além da estação eram casas de empregados da fazenda Santa Helena, cocheiras e uma pequena capela dedicada ao Sagrado Coração de Jesus, que não é possível localizar na imagem do IGC, mas que pode ser verificada pela reprodução de um folheto de divulgação de uma quermesse local.

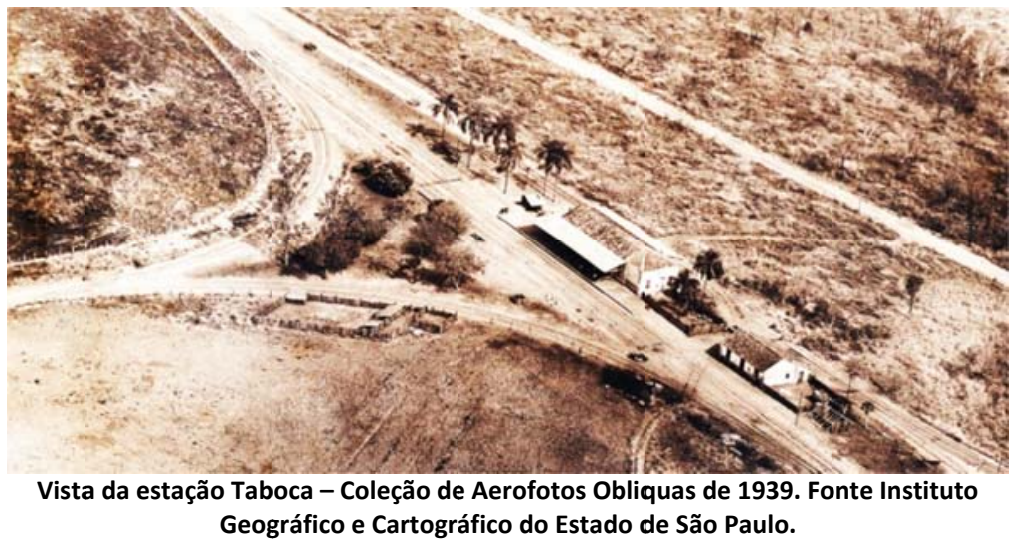

Folheto de divulgação da quermesse em louvor ao Sagrado Coração de Jesus Fonte: http://ferroviasdobrasil.blogspot.com/2010/03/estacao-de-taboca-baririsp.html

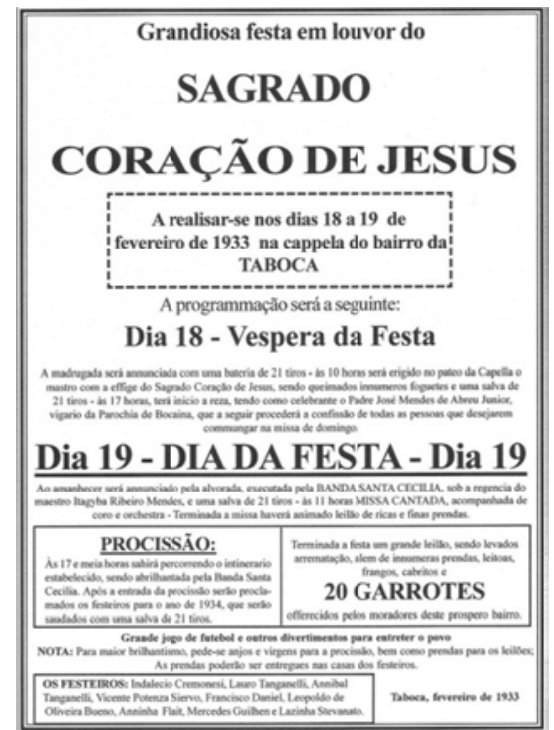

CORAÇÃO DE JESUS

Dia 18 - Vespera da Festa

Dia 19 - DIA DA FESTA - Dia 19

Assim, podemos estabelecer uma regra geral para essas formações urbanas: todas elas foram arruadas a partir do traçado em xadrez, com quadras de $88 \times 88$ metros e variações a partir dessas dimensões. As ruas também possuem dimensões semelhantes, sendo que a maioria possui 17 metros de largura, enquanto as avenidlas, preferencialmente nas laterais das praças da matriz, margeando córregos ou levando às saídas das povoações, 
possuem 20 metros de largura. Isso tanto para as formações nascidas em solo sacro quanto em solo laico.

As quadras são ocupadas em suas quatro faces, mas nas partes mais antigas das formações menores, a ocupação se concentra em apenas duas faces, geralmente nas voltadas para as ruas paralelas às laterais da praça da matriz. Nesses casos predominam lotes de 11X 44 metros, enquanto nas demais quadras a dimensão da frente dos lotes varia: 11 metros, 12,4 metros e 17,6 metros.

Os miolos de quadra raramente são ocupados até o inicio da década de 1940, sendo eles a área verde da cidade, já que via de regra ocupados por pomares, enquanto não se vê arborização nas ruas e mesmo nas praças essa existe, mas de forma muito rarefeita.

Nas formações originadas de patrimônio religioso ${ }^{8}$, a praça da matriz sempre é implantada em situação privilegiada, no divisor de aguas ou à meia encosta, ordenando o traçado das vias. Das formações estudadas, apenas Ribeirão Bonito e Boa esperança do Sul possuem as primeiras vias orientadas pelos pontos cardeais, nas demais, elas seguem paralelas e perpendicularmente a um dos córregos que delimitam as áreas iniciais.

É interessante observar que a quadra que abriga a igreja matriz geralmente apresenta dimensões menores que as demais quadras, geralmente são mais estreitas e ocupam duas quadras, divididas ou não por uma rua.

Quanto à localização das estações ferroviárias, nestas cidades elas foram construídas afastadas da área central, próximas ao limite da área urbana e algumas vezes até mesmo no limite das zonas suburbanas, e além do limite dos córregos - exceto nas cidades de Bocaina e Dourado, onde a ferrovia se instala na parte alta, Jaú, onde as linhas da Douradense estão bastante próximas da praça da matriz e absorvida pela malha urbana, entretanto as linha da Paulista confirma a regra das demais e em Itápolis, que não está próxima de nenhum curso d’água.

Quanto às praças das estações, elas apresentam diferentes tamanhos e tratamentos, mas sua importância nunca se iguala à da praça da matriz. Ela atrai um comercio e serviços mais "pesados" e especializados, ligados à manufatura do café e de insumos agropecuários, enquanto o comercio próximo à praça da matriz, localizado nas "ruas do comércio", é o que atende à maioria da população local.

\footnotetext{
${ }^{8}$ Sobre o processo de doação de terras rurais à Igreja Católica ver Ghirardello (2002), p. 125-8; Marx (1980), p.92-93; Marx (1991) p.12, p. 26 e p. 39.
} 
As cidades são térreas destacando-se em altura apenas os edifícios públicos e outros particulares, mas muito pontualmente e mesmo assim com apenas dois pavimentos. Quanto à ocupação dos lotes, predominam no perímetro urbano construções implantadas sobre o alinhamento, mas afastadas de pelo menos uma divisa lateral, com exceção novamente dos edifícios públicos que são soltos no lote e outros construídos nas áreas suburbanas.

Os edifícios comerciais, na verdade quase sempre são de uso misto, com o comercio na parte da frente e as parte residencial nos fundos. Esses edifícios geralmente são ligados dois a dois e afastados de uma das laterais a uma distancia mínima que permita a entrada de um carro ou carroça e o acesso à parte residencial se dá através desse corredor que se forma e que é também para onde se abrem as janelas.

Nas formações urbanas nascidas em solo laico - núcleos urbanos pertencentes a núcleos coloniais (Gavião Peixoto e Nova Paulicéia), implantados em terras rurais compradas pelo governo, parceladas e revendidas aos colonos ou originados a partir da chegada da ferrovia (Trabijú, Pedra Branca, Pedro Alexandrino e Taboca), a estação ferroviária presidirá o espaço urbano, ocupando agora posição de destaque na cidade e orientando o arruamento, já que esse toma por base a longa reta originada da linha férrea. Apesar da grande simplicidade das estações da Douradense, essas serão os principais edifícios dessas formações já que é a ferrovia que possibilita a vida econômica a esses povoados, garantindo escoamento de sua produção e possibilitando acessibilidade.

Nessas formações, a capela, depois matriz, ainda é implantada em sítios nobres e bem localizados, mas agora a escolha desses sítios não está atrelada à determinantes especificas da igreja, como no caso dos patrimônios religiosos. Nesses casos a praça da matriz possui as mesmas dimensões das quadras correntes.

Quanto a localização das estações no sitio, não é possível estabelecer uma regra, nos núcleos coloniais elas estão implantadas na várzea dos córregos enquanto em Trabijú, Pedro Alexandrino e Pedra Branca, no divisor de aguas. Nas demais cidades aqui tratadas, quando a estação, implantada distante da praça da matriz fomenta a ocupação de da área ao redor de onde foi construída, como no caso de Boa Esperança do Sul ou nas outras onde a ocupação já ultrapassou a barreira da linha férrea, essas novas porções da cidade agora são ocupadas com base na posição da estação, com estas em posição de destaque e ruas abertas paralelas ou perpendicularmente à linha. 
O que acontece é que o melhor guardião De um bem cultural é sempre seu dono (as comunidades locais)"

(Aloísio Magalhães) 


\section{0 - Evolução urbana de Dourado}

A historia da ocupação inicial do território de Dourado, sua elevação à Vila e posteriormente à cidade, assim como fatos relacionados ao seu apogeu, decadência e estagnação socioeconômicos, são similares ao ocorrido em tantas outras cidades nascidas no interior paulista no século XIX, como já tratado no capitulo anterior.

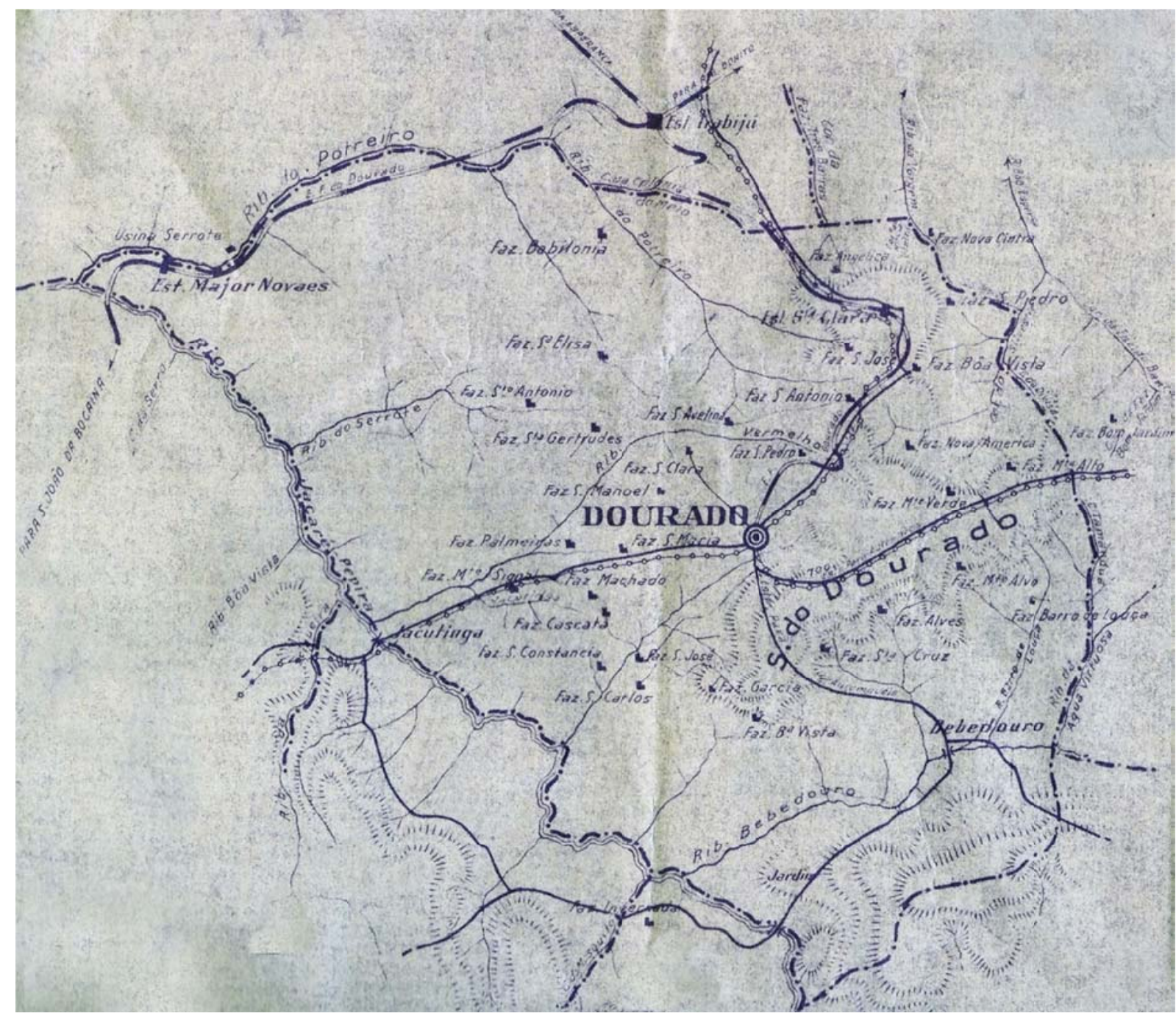

Mapa do território do Município de Dourado com a localização das fazendas, das estações ferroviárias e o sistema hídrico. Fonte: Mapa da Cidade de detalhe do Mapa do Município de Dourado, organizado em observância ao Decreto-Lei Nacional no 311 de 2 de março de 1938, elaborado pelo Serviço de Topografia e Limites do Instituto Geográfico e Geológico - Secretaria da Agricultura, Indústria e Comércio. Fonte: Instituto Geográfico e Cartográfico de São Paulo.

Os primeiros ocupantes da área que viria a ser o município de Dourado foram migrantes mineiros que se dirigiram para a região nos primeiros anos do século XIX em busca de novas pastagens para seus rebanhos e segundo o livro 20 do Registro Paroquial de Terras da Freguesia de Brotas, na década de 1839 já ocupavam as terras baixas próximo ao 
Córrego Bebedouro, que acabou dando nome ao bairro rural e outros sítios às margens do Rio Jacaré Pepira.

Por volta de 1860 o Sr. José Modesto de Abreu doou terras para a igreja no local conhecido como "Serra do Dourado" para a construção de uma capela em louvor à São João Batista e assim deu origem ao bairro rural de São João Batista dos Dourados.

Fazem parte do folclore do lugar as historias sobre as disputas entre os dois bairros, o do Bebedouro e o da serra sobre onde deveria ser construída a capela, já que sua construção traria inegáveis benefícios à população, disputa que frequentemente resultavam em tiroteios e sequestros da imagem do padroeiro durante a madrugada.

A capela inicial foi construída na porção mais baixa da cidade, defronte à Rua Bernardino de Campos, a única rua da cidade na ocasião e que foi aberta paralelamente ao curso do Ribeirão dos Dourados.

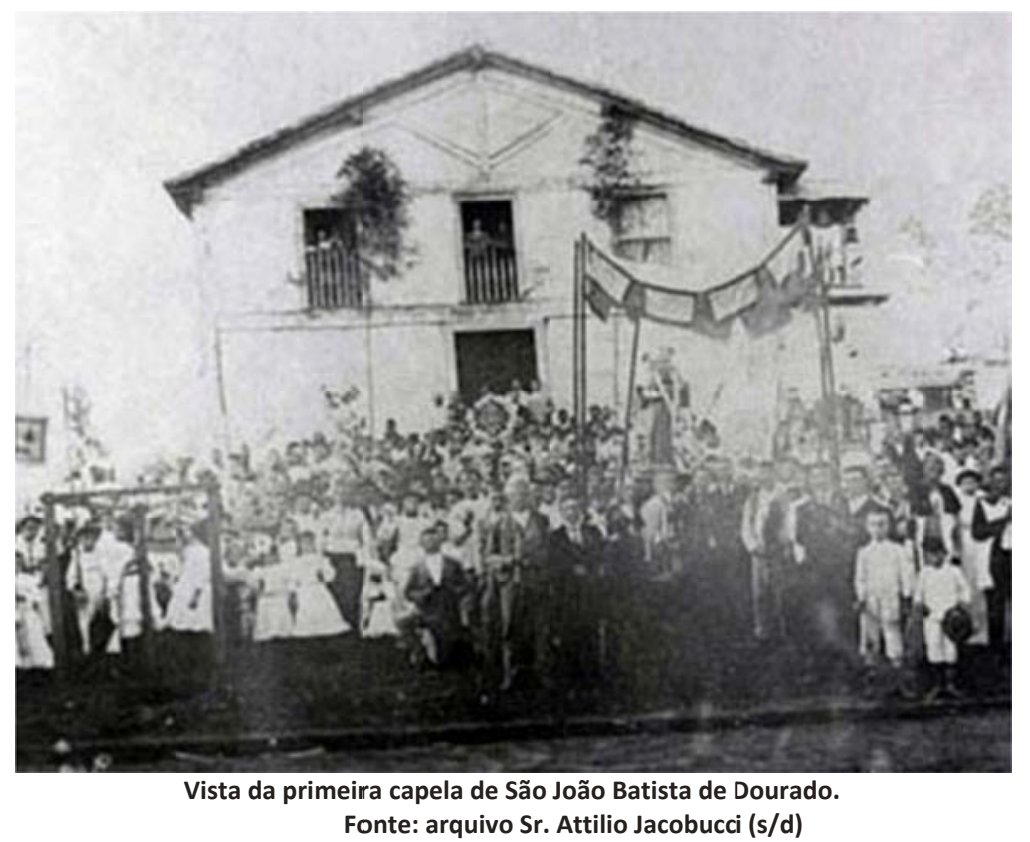

O bairro São João Batista dos Dourados conseguiu certa supremacia em relação ao Bebedouro e em 1876 sua capela recebe um capelão curado, possibilitando a oficialização de casamentos, batizados e o oferecimento de sacramentos aos enfermos. No mesmo ano a localidade recebeu uma cadeira de primeiras letras.

Na ocasião a capela primitiva foi demolida assim que terminaram as obras da nova igreja matriz localizada duas quadras acima, em um terreno melhor e mais alto. A partir da nova praça da matriz foi feito todo o arruamento da vila. Com a transferência da igreja para 
um local mais adequado, já que a rua Bernardino de Campos até os anos 1980 apresentava constantes alagamentos na época das chuvas, a igreja católica conseguiu um espaço importante na cidade, ocupando suas três quadras centrais - a quadra da antiga capela, a quadra acima a essa, ocupada pela casa paroquial e a próxima na sequencia, ocupada pela nova igreja matriz (ver mapa p. 94). O próprio poder municipal e mesmo a estação ferroviária não conseguiram ocupar fisicamente tamanha posição na cidade.

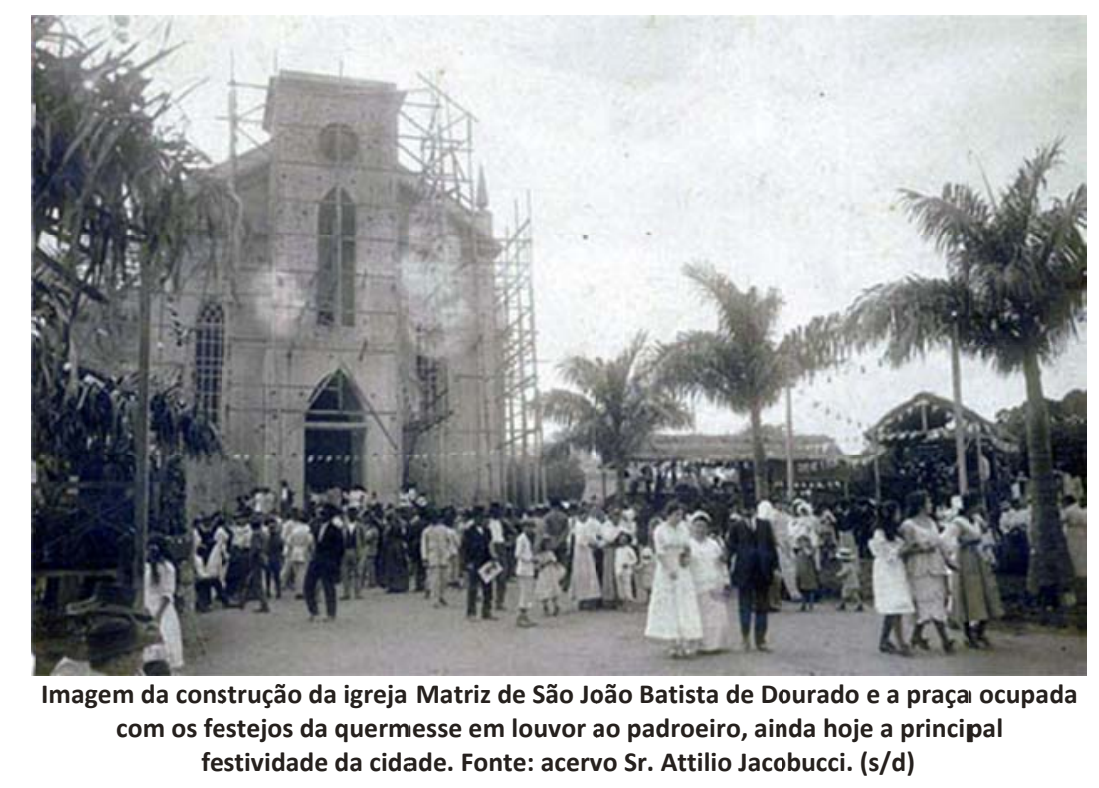

É interessante comparar as duas imagens acima e constatar as diferenças entre as duas construções: a mais antiga do inicio da década de 1870 é bastante simples e sua feição se assemelha à das primeiras construções da cidade, quase como um 'barracão'; a igreja matriz construída em meados da década de 1880, já apresenta uma maior preocupação arquitetônica. Na imagem que retrata a capela antiga, vemos a chegada de uma procissão que traz a imagem de seu padroeiro, São João Batista em um andor.

Em 1891 o Curato de São João Batista dos Dourados foi elevado à categoria de Distrito de Paz, passando a chamar-se Dourado e em 1897 passa a município de Dourado.

No período, segundo informações do Álbum dos Municípios Paulistas, o café já era cultivado em $60 \%$ das propriedades rurais da cidade e era a base de sua economia.

Impulsionada por esse fato, em 1900 foi inaugurada a Companhia Estrada de Ferro Dourado (Douradense) com sede na cidade, ligando uma série de novos municípios paulistas e seus distritos à linha da Cia. Paulista, que na região seguiu até Ribeirão Bonito. Seu traçado, com mais de $300 \mathrm{Km}$ de trilhos, seguiu a lógica do escoamento da produção agrícola 
e dos interesses dos grandes proprietários rurais da região, muitos deles diretores da própria ferrovia. A expansão de suas linhas aconteceu em sintonia com o avanço da cultura do café em direção ao interior paulista e sua chegada nas localidades era fator de incremento em todos os sentidos.

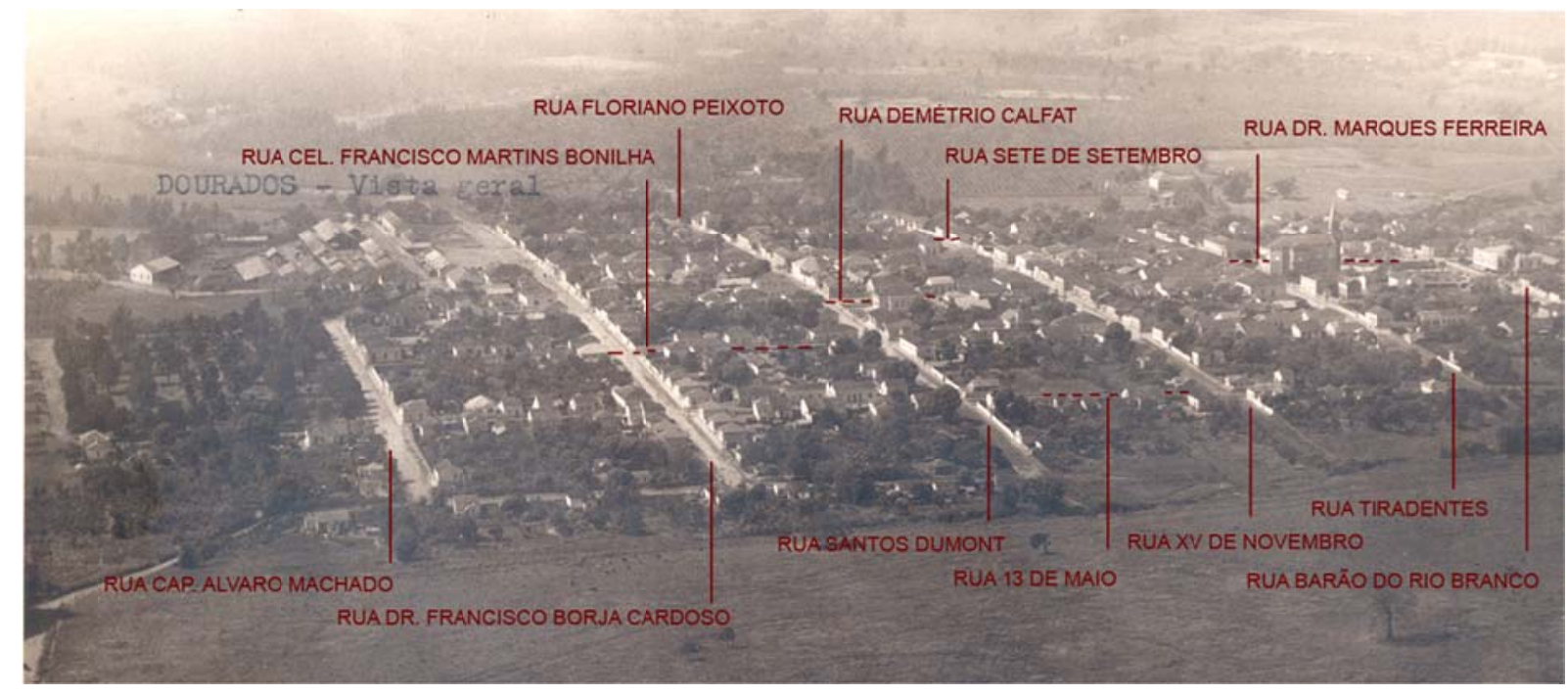

Vista geral da cidade de Dourado em 1939 com a indicação dos nomes atuais das ruas. Observar a matriiz de São João Batista à direita e os galpões da Cia E. F. Dourado à esquerda. Fonte: Coleção de Aerofotos Obliquas de 1939. Fonte Instituto Geográfico e Cartográfico do Estado de São Paulo.

Em Dourado não foi diferente. A estação foi construída na parte mais alta da cidade, no limite do perímetro urbano, ocupando uma grande área com suas oficinas e depósitos. Sua implantação atraiu para as proximidades um comercio de insumos agrícolas e empresas que alugavam maquinas de beneficiamento do café para os pequenos produtores, além de fabrica de sacaria utilizada para o transporte dos grãos.

Estes grandes galpões de depósitos, muitas vezes quando vazios em época fora da safra, abrigavam festas dançantes, fazendo as vezes dos típicos clubes do interior.

Apesar de sua importância na vida econômica da cidade e sua marcante presença física, a grande praça da estação não era um "ponto de encontro social" que fizesse frente à praça da Matriz, essa sim o coração de toda a vida da cidade, reforçada pelo evento social que eram as próprias missas e o transito de alunos do grupo escolar construído em 1909 defronte à praça da matriz.

O edifício do Grupo Escolar de Dourado, atual Escola Estadual de Primeiro Grau Senador Carlos José Botelho também se destaca na área central e é o único edifício da cidade que recebeu tombamento a nível estadual. 


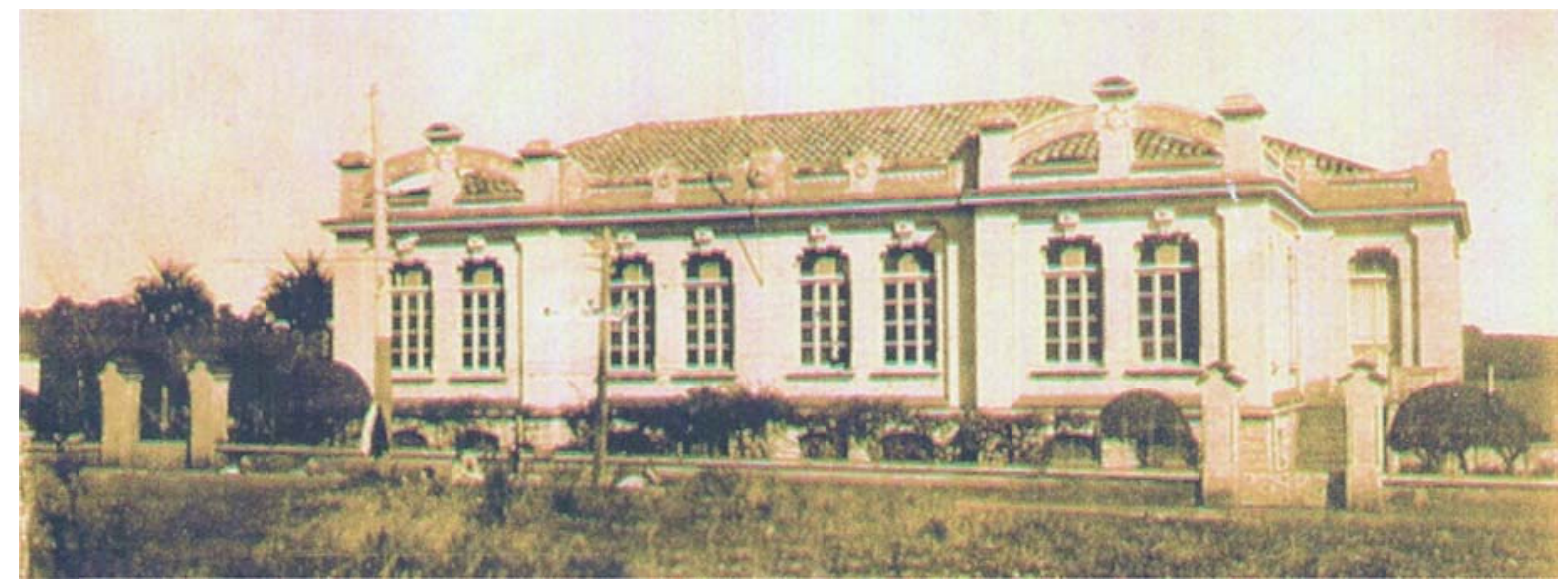

Imagem do Grupo Escolar de Dourado no ano de sua inauguração. Observar que a praça da Mattriz, defronte ao colégio Ainda não tinha sido urbanizada. Fonte: arquivo da Prefeitura Municipal de Dourado. (s/d)

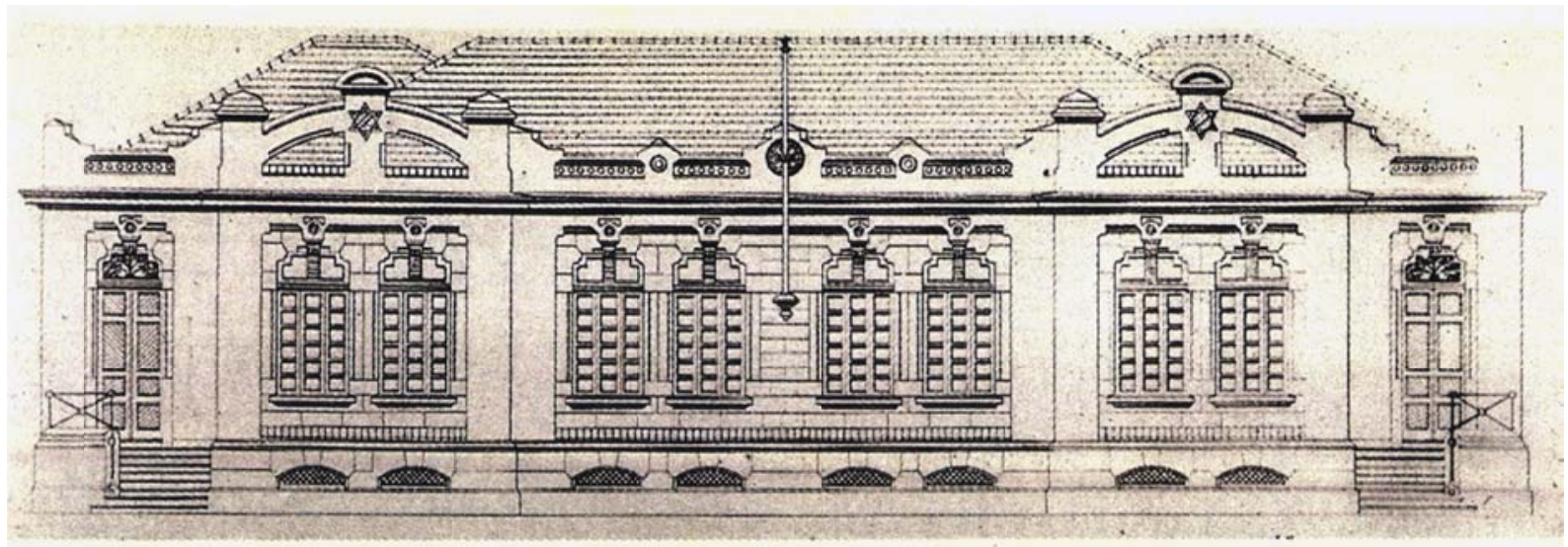

Projeto da Fachada do Grupo Escolar de Dourado (1908) de autoria da Manuel Sabater, apresentado à antiga Superintendência de Obras Públicas. Fonte: 1890-1920 Arquitetura Escolar Paulista, 1991.

O grupo escolar de Dourado foi construído em 1909 em um terreno doado pela municipalidade em frente à praça da Matriz, a partir do projeto de Manuel Sabater para a antiga Superintendência de Obras Publicas, repetindo um partido já adotado em outros grupos escolares da época, com oito salas separadas em duas alas por uma sala destinada aos professores.

Com raras exceções, os grupos escolares construídos entre 1890 e 1920 adotavam "projetos padrões", apenas com pequenas alterações nas fachadas e na implantação. 0 programa arquitetônico era composto basicamente de salas de aula e: um reduzido numero de ambientes administrativos.

É notável que todos douradenses com que conversei em busca de informações sobre a historia da cidade e seus costumes declararam grande afeto e orgulho do antigo grupo escolar, que mais tarde recebeu o nome de Senador Carlos José Botelho, proprietário de 
terras na cidade e secretário da agricultura de São Paulo no período e a quem se atribui a iniciativa da construção da escola.

Como pode ser observado nas imagens abaixo, a praça da estação, apesar de bastante ampla não recebeu qualquer tipo de tratamento, como calçamento ou arborização que convidasse à permanência. Era utilizada apenas como espaço utilitário onde paravam os animais que transportavam a produção agrícola e outros gêneros para a estação.

A rua de maior movimento da cidade era e ainda é a antiga Rua do Comércio, atual Rua Dr. Marques Ferreira, onde se concentravam os armazéns de secos e molhados e as lojas de tecidos e roupas, entre outros. Sobre esses dois tipos de comercio é curioso destacar que predominantemente estavam nas mãos de imigrantes sírios e atendiam além da população da própria cidade, também aos colonos que vinha à cidade nos fins de semana. Era comum que as compras feitas durante o mês fossem pagas quando do recebimento dos salários do mês seguinte. As compras eram anotadas em cadernetas, em um sistema de "fiado" que durou até o final dos anos 1980.

O ponto alto da cidade aconteceu em fins da década de 1930, quando o café ainda era o carro chefe de sua economia. A cidade sente duros reflexos da crise de 1929, com o inicio da substituição das lavouras cafeeiras por algodão, produto cuja manufatura veio inclusive a ocupar as antigas instalações originalmente destinadas ao café, entretanto não era uma produção tão lucrativa quanto a do primeiro produto.

Em 1949 a Douradense é encampada pela Cia Paulista, empresa que já possuía grande parte das ações da Douradense (sobre o processo de compra da Douradense ver Nunes, 2002), o que resultou na desativação do ramal de Dourado e a transferência de cerca de 300 ferroviários para outras cidades da região. É importante observar que a saída de 300 famílias para uma cidade daquele porte representava uma alteração socioeconômica significativa para a localidade. Outro fator importante foi a significativa redução nas possibilidades de deslocamento entre as cidades da zona douradense a partir da erradicação da linha férrea. 

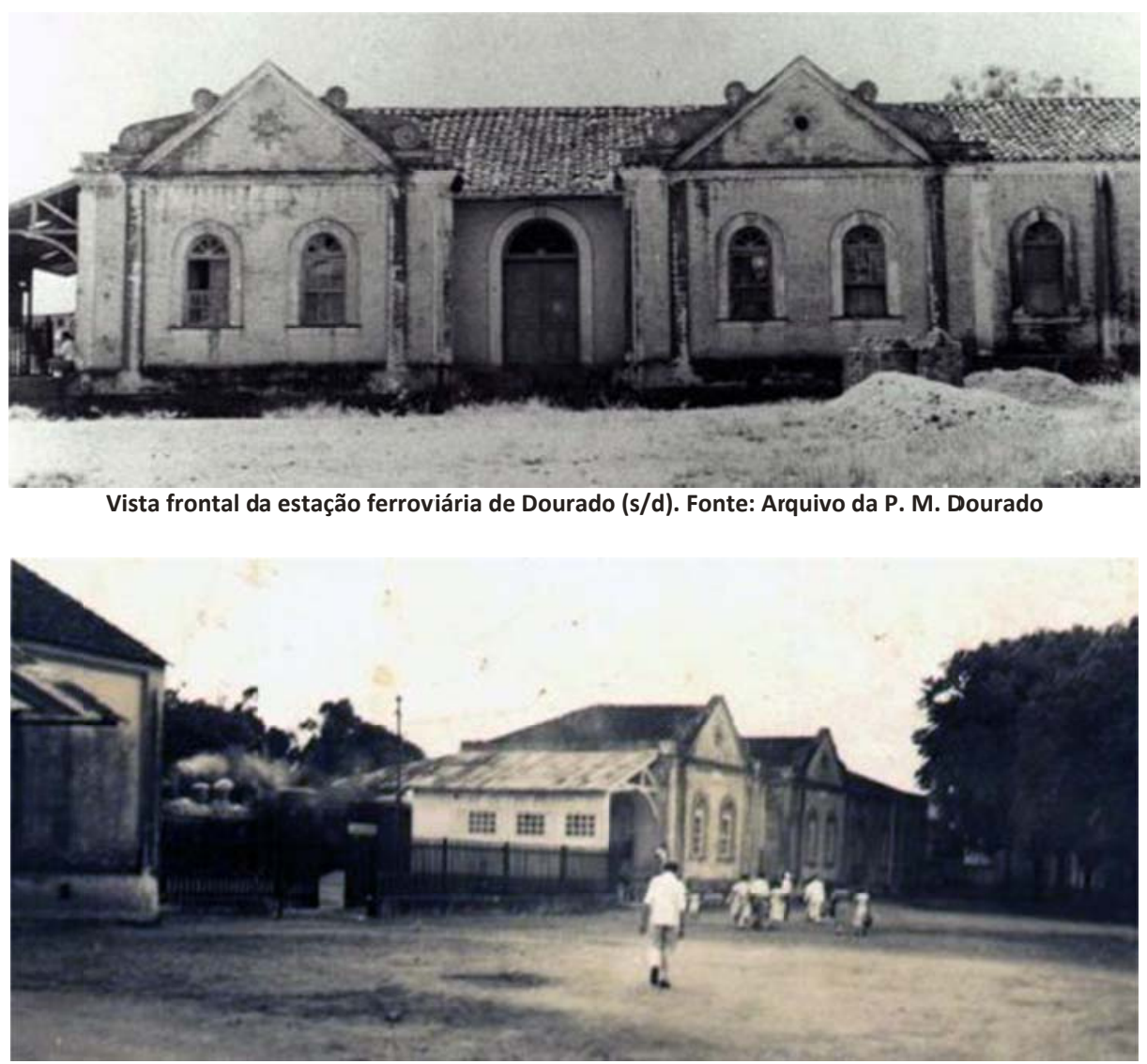

Aspecto da praça da estação ferroviária de Dourado. Fonte: Arquivo da P. M. Dlourado

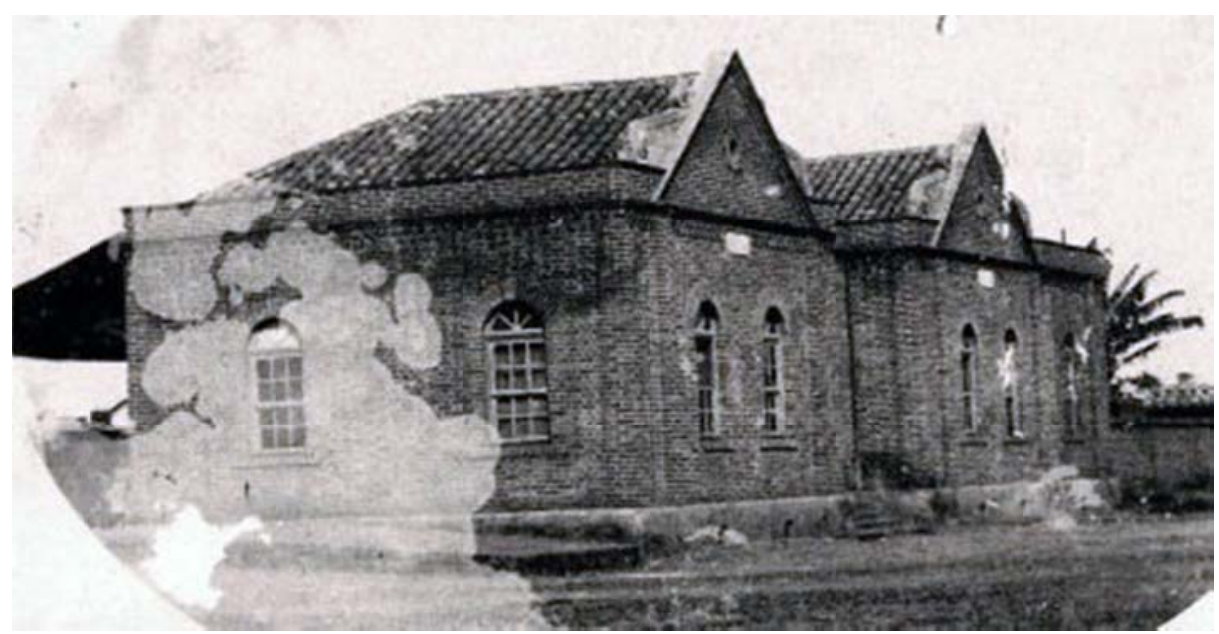

Vista da estação ferroviária de Dourado em 1951. Fonte: Arquivo da P. M. Dourado. 


\section{1 - Pré-inventário da área central de Dourado}

Os inventários têm como função constituir-se em uma ação de preservação do patrimônio, na medida em que conservam em outros suportes as informações contidas nos bens culturais, permitindo o acesso e a produção de conhecimento sobre os mesmos, independente dos seus suportes originais, especialmente no caso dos sítios urbanos e contribuindo diretamente para o estabelecimento de critérios e parâmetros de preservação.

Neste subcapítulo faremos um pré-inventário dos bens arquitetônicos da área central da cidade de Dourado. Seu objetivo é reunir e sistematizar o conjunto de informações que caracterizam esses bens arquitetônicos, coletadas a partir de levantamentos de campo e dos levantamentos de fontes documentais.

Estabelecemos como recorte geográfico a área central, área que corresponde a todo o município na década de 1940, como pode ser visto pelas imagens da página 50 desta dissertação.

O método utilizado foi o desenvolvido pelo IPHAN no "Formulário Geral do Sítio Urbano". Para a cidade de Dourado foram elaboradas fichas de levantamento das características arquitetônicas e a caracterização das edificações segundo grupos tipológicos.

Aqui vale destacar a dificuldade em se encontrar uma metodologia de análise morfológica urbana que atendesse às particularidades de nosso objeto de estudo e que este trabalho está em constante construção e atualização. Também é importante observar a falta de material oficial sobre a cidade, desde materiais básicos como plantas com o lançamento dos edifícios no lote e dados atualizados sobre a divisão das próprias quadras, arquivos históricos das plantas aprovadas, etc. Assim, as bases aqui utilizadas foram feitas a partir de observações de campo e fotos de satélite, que no caso de Dourado, por se tratar de uma cidade pequena, não apresentam uma aproximação e nitidez desejável.

O pré-inventário de Dourado teve como recorte geográfico as 30 quadras que compõe a área central da cidade e que correspondiam a todo seu perímetro urbano na década de 1940 (ver mapa da página 50). Estabelecemos o ano 1940 como data balizadora, considerando que todas construções anteriores a esta data deveriam a princípio serem preservadas.

Durante os levantamentos dividimos as edificações da área em três categorias distintas, como pode ser observado no mapa esquemático abaixo: as edificações assinaladas 
em cinza são recentes, as assinaladas em vermelho apresentam características construtivas, relações de implantação e altura semelhantes às verificadas nas edificações mais antigas, mas talvez por terem sofrido maiores alterações ou por já serem de um período posterior, não é possível estabelecer com certeza seu período construtivo e as edificações destacadas em azul são as que propomos preservar.

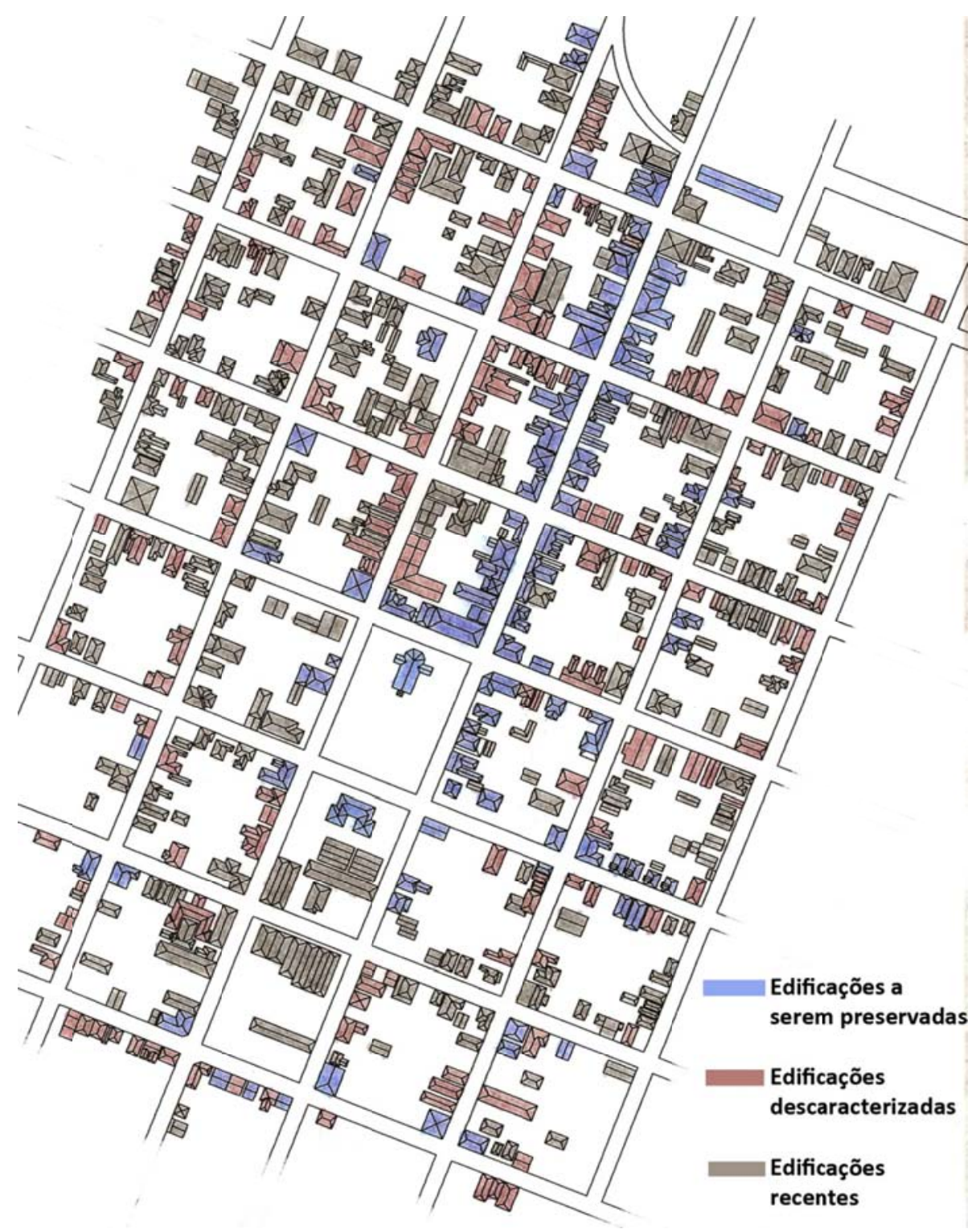

O mapa esquemático da página 94 aponta alguns dos espaços referenciais da área central da cidade enquanto o mapa da pagina 95 procura setorizar na cidade oito distintos grupos arquitetônicos. Essa localização dos diferentes tipos de edificações nos fornece indícios de como ocorreu a ocupação da área central. 
Na sequencia, construímos algumas vistas esquemáticas representativas do conjunto da área central de Dourado, onde procuramos observar alguns aspectos como forma da cobertura, relação da linha da cumeeira com a rua, proporções da fachada, alocação do edifício no lote, sua destinação funcional, relações entre atividades e composição, além da permeabilidade aos pedestres. Procuramos observar as fachadas tanto enquanto conjunto quanto individualmente.

O objetivo destes desenhos é nos auxiliar na percepção da forma como cada fachada se relaciona com sua fachada vizinha (contígua ou não). É importante observar que as análises aqui propostas só fazem sentido quando relacionadas entre si, já que são abstrações de caráter instrumental. Estes desenhos foram construídos a partir da tomada de medidas gerais e da observação fotográfica, portanto os desenhos apresentam imperfeições e imprecisões, mas que não comprometem o resultado das observações. A opção pelos desenhos ao invés de montagens fotográficas decorre da maior clareza e facilidade de leitura dos elementos compositivos proporcionados pelo desenho. 
Identificação - Igreja Matriz de São João Batista

Logradouro: Largo da Matriz s/n

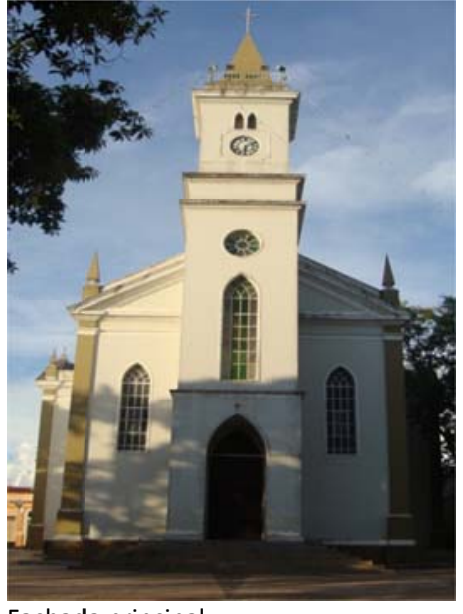

Fachada principal

Fachada principal e uso atual

1. Materiais empregados na cobertura

Destruição total

Francesa X

Vidro

Plástico / fibra

Outros:

3. Materiais do coroamento

Argamassa X

Azulejo antigo

Madeira

Outros:

5. Material das molduras dos vãos de portas e janelas Não tem

Argamassa X

Azulejo antigo

Madeira

7. Cores predominantes da fachada principal

Coroamento: verde

Molduras dos vãos: branco

Guarda-corpos: não tem
Canal

Fibrocimento

Laje

Cantaria

Azulejo novo

Concreto aparente

Acabam. da fachada: verde

Outros relevos: branco

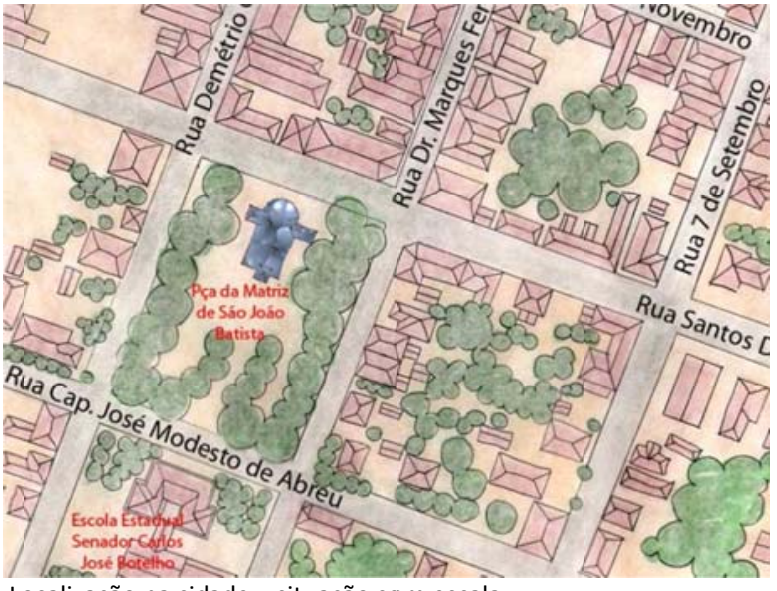

Localização na cidade - situação sem escala

2. Coroamento

Destruição total Platibanda $X$

Frontão X Cimalha

Cachorros Beira seveira

Laje de beiral Guarda pó

Beiral simples Outros:

4. Materiais de acabamento da fachada principal

Argamassa X Chapisco

Cantaria Azulejo novo

Azulejo Madeira

Vidros Outros:

6. Material das esquadrias da fachada principal

Destruição total Madeira X

Vidro $X \quad$ Alumínio

Ferro laminado / solda $X$ Outros:

8. Uso atual - quantificar

Residência: Vago:

Comércio: Culto:

Serviço: $\quad$ Instituição: igreja 100\%

Dados volumétricos

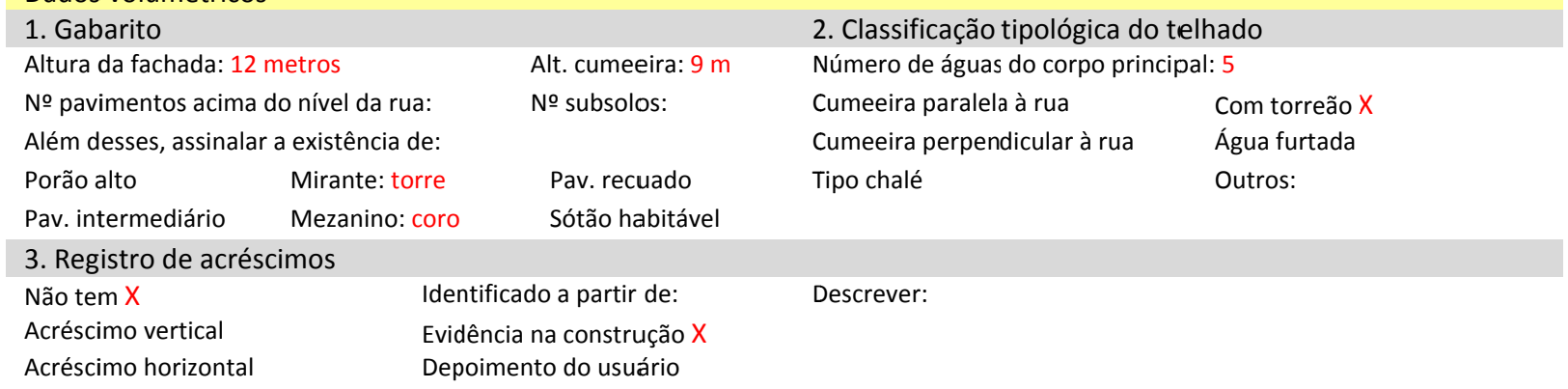


Identificação - Escola Estadual de primeiro Grau Senador Carlos José Botelho

Logradouro: Rua Cap. José Modesto de Abreu s/n

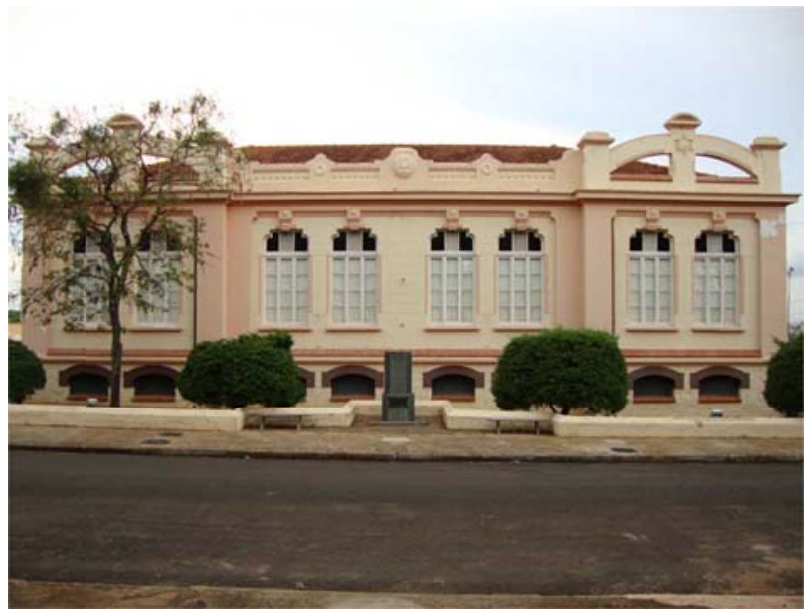

Fachada principal

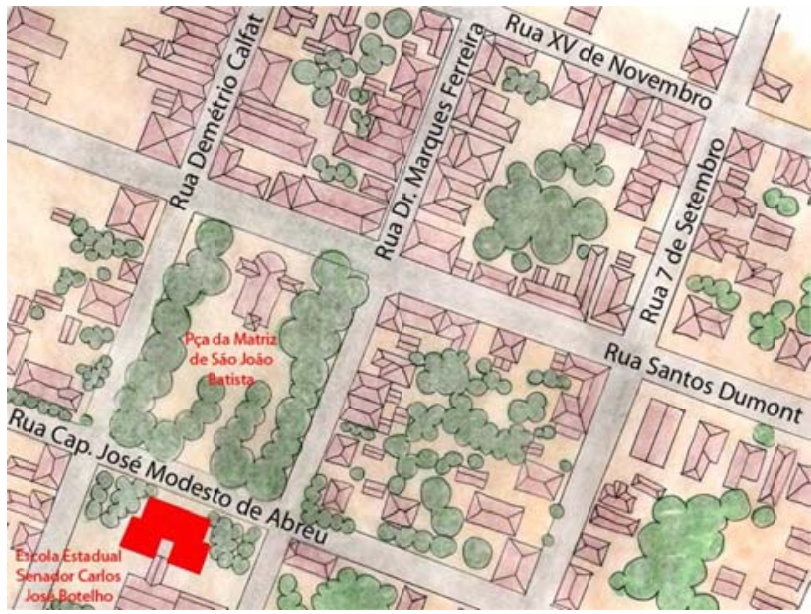

Localização na cidade - situação se m escala

Fachada principal e uso atual

1. Materiais empregados na cobertura

2. Coroamento

Destruição total Canal

Francesa X

Fibrocimento

Metal

Vidro

Laje

Destruição total

Frontão X

Cachorros

Laje de beiral

Beiral simples

Platibanda $X$

Cimalha

Beira seveira

Guarda pó

Outros:

3. Materiais do coroamento

Argamassa $X$

Cantaria

4. Materiais de acabamento da fachada principal

Azulejo antigo

Azulejo novo

Argamassa $X$

Chapisco

Madeira

Concreto aparente

Cantaria

Azulejo

Azulejo novo

Outros:

Madeira

6. Material das esquadrias da fachada principal

Destruição total Madeira $X$

Vidro $X \quad$ Alumínio

Ferro laminado / solda Outros:

$\begin{array}{ll}\text { Argamassa } X & \text { Cantaria } \\ \text { Azulejo antigo } & \text { Azulejo novo } \\ \text { Madeira } & \text { Concreto aparente }\end{array}$

7. Cores predominantes da fachada principal

Coroamento: rosa

Esquadrias: branco

Molduras dos vãos: rosa

Acabam. da fachada: rosa

8. Uso atual - quantificar

Residência:

Comércio:

Vago:

Outros relevos: rosa

Serviço:

Instituição: escola estadual

Dados volumétricos

\section{Gabarito \\ Altura da fachada:}

№ pavimentos acima do nível da rua:

Além desses, assinalar a existência de:

Porão alto Mirante

Pav. intermediário mezanino
2. Classificação tipológica do telhado

Número de águas do corpo principal:

Cumeeira paralela à rua

Com torreão

Cumeeira perpendicular à rua Água furtada

Tipo chalé

Outros:

3. Registro de acréscimos

Não tem

Acréscimo vertical

Acréscimo horizontal
Identificado a partir de:

Pav. recuado

Sótão habitável
Descrever:
Evidência na construção

Depoimento do usuário 


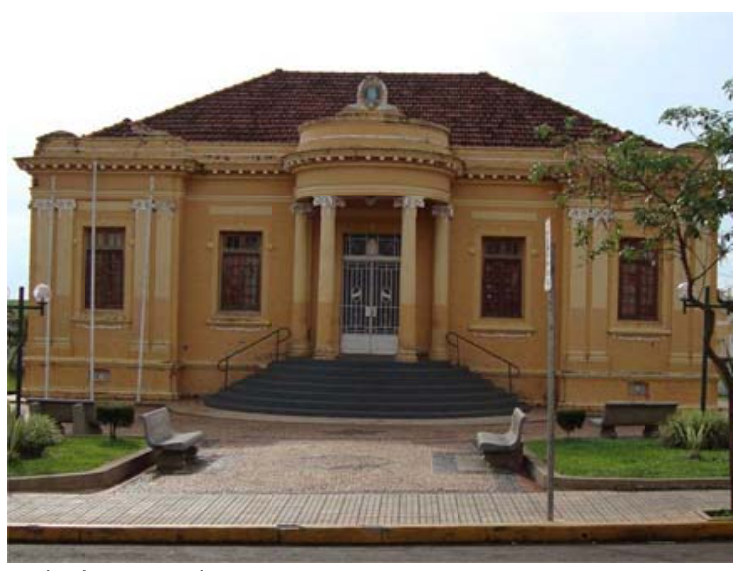

Fachada principal

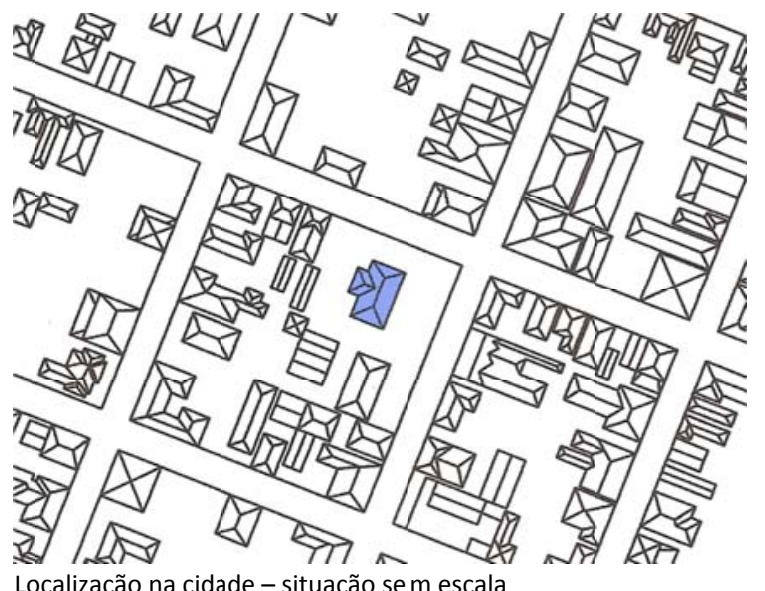

Localização na cidade - situação se m escala

Fachada principal e uso atual

1. Materiais empregados na cobertura

Destruição total Canal

Francesa $\mathrm{X}$

Vidro

Fibrocimento

Metal

Plástico / fibra

Laje

Outros:

3. Materiais do coroamento

Argamassa X

Azulejo antigo

Cantaria

Azulejo novo

Madeira

Concreto aparente

Outros:

5. Material das molduras dos vãos de portas e janelas Não tem Destruição total

Argamassa X

Cantaria

Azulejo antigo

Azulejo novo

Madeira

Concreto aparente

7. Cores predominantes da fachada principal

Coroamento: amarelo

Molduras dos vãos: branco

Esquadrias: branco / madeira

Guarda-corpos: não tem

Acabam. da fachada: amarelo

Outros relevos: branco

2. Coroamento
Destruição total
Frontão $X$
Cachorros
Laje de beiral
Beiral simples

Platibanda X

Cimalha

Beira seveira

Beiral simple

Guarda pó

4. Materiais de acabamento da fachada principal

Argamassa X Chapisco

Cantaria Azulejo novo

Azulejo Madeira

Vidros Outros:

6. Material das esquadrias da fachada principal

Destruição total Madeira X

Vidro $X \quad$ Alumínio

Ferro laminado / solda $X$ Outros:

8. Uso atual - quantificar

Residência: Vago:

Comércio: Culto:

Serviço: $\quad$ Instituição: 100\%

Dados volumétricos

\begin{tabular}{|c|c|c|c|}
\hline & \multirow{2}{*}{\multicolumn{2}{|c|}{$\begin{array}{l}\text { 2. Classificação tipológica do telhado } \\
\text { Número de águas do corpo principal: } 04\end{array}$}} \\
\hline \multirow{2}{*}{ Altura da fachada: $06 \mathrm{~m}$} & \multirow{2}{*}{$\begin{array}{l}\text { Alt. cumeeira: } 09 \mathrm{~m} \\
\text { № subsolos: não tem }\end{array}$} & & \\
\hline & & Cumeeira paralela à rua $\mathrm{X}$ & Com torreão \\
\hline Além desses, assinalar a existência de: & & Cumeeira perpendicular à rua & Água furtada \\
\hline $\begin{array}{l}\text { Porão alto X } \\
\text { Pav. intermediário }\end{array}$ & $\begin{array}{l}\text { Pav. recuado } \\
\text { Sótão habitável }\end{array}$ & Tipo chalé & Outros: \\
\hline
\end{tabular}

3. Registro de acréscimos

Não tem

Acréscimo vertical

Acréscimo horizontal

Identificado a partir de:

Evidência na construção $X$

Depoimento do usuário
Descrever: 
Ficha de pré-inventário do patrimônio arquitetônico e urbanístico de Dourado - SP Características Arquitetônicas - Ficha 04

Identificação

Logradouro: Rua Dr. Marques Ferreira X Rua Cap. José Modesto de Abreu

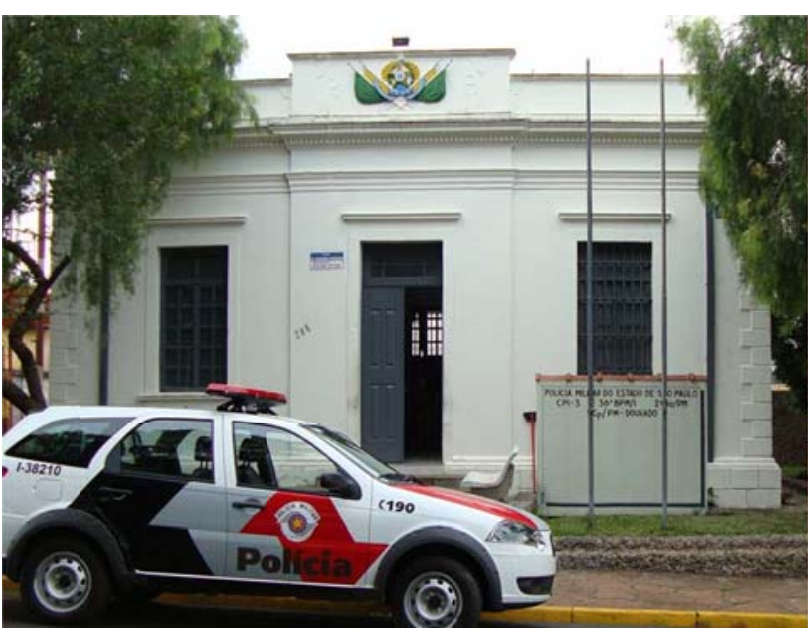

Fachada principal

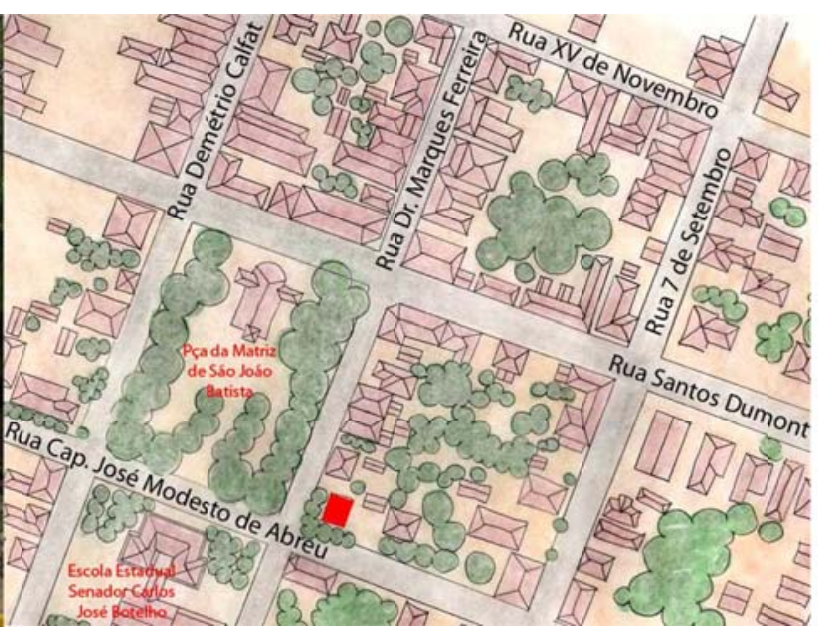

Localização na cidade - situação se:m escala

Fachada principal e uso atual

1. Materiais empregados na cobertura

Destruição total Canal

Francesa X

Vidro

Plástico / fibra

Outros:

\section{Materiais do coroamento}

Argamassa X

Azulejo antigo

Madeira

Outros:

5. Material das molduras dos vãos de portas e janelas Não tem

Argamassa $X$

Azulejo antigo

Madeira

Fibrocimento

Metal

Laje

\section{Cantaria}

Azulejo novo

Concreto aparente

Destruição total

Cantaria

Azulejo novo

Concreto aparente

7. Cores predominantes da fachada principal

Coroamento: cinza

Molduras dos vãos: cinza

Guarda-corpos: não tem

\section{Esquadrias: cinza}

Acabam. da fachada: cinza

Outros relevos: cinza

\section{Coroamento}

Destruição total

Frontão

Cachorros

Laje de beiral

Beiral simples

4. Materiais de acabamento da fachada principal

Argamassa X Chapisco

Cantaria Azulejo novo

Azulejo novo Madeira

Vidros Outros:

6. Material das esquadrias da fachada principal

Destruição total Madeira $X$

Vidro $X \quad$ Alumínio

Ferro laminado / solda $X$ Outros:

8. Uso atual - quantificar

Residência:

Comércio:

Vago:

Culto:

Serviço:

Dados volumétricos

\section{Gabarito}

Altura da fachada:

№ pavimentos acima do nível da rua: 01

Além desses, assinalar a existência de:

Porão alto Mirante

Pav. intermediário mezanino

\section{Classificação tipológica do telhado}

Alt. cumeeira:

Número de águas do corpo principal: 04

Cumeeira paralela à rua

Cumeeira perpendicular à rua

Tipo chalé

Pav. recuado

Sótão habitável
Com torreão

Água furtada

Outros:

3. Registro de acréscimos

Não tem $X$

Acréscimo vertical

Acréscimo horizontal
Identificado a partir de:

Evidência na construção $X$

Depoimento do usuário
Descrever: 
Identificação - Delegacia de Polícia de Dourado

Logradouro: Rua Cap. José Modesto de Abreu

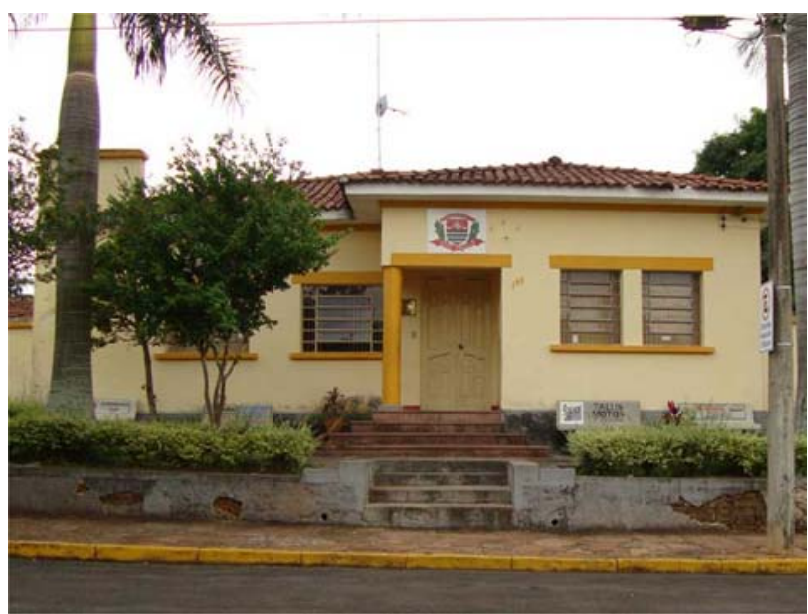

Fachada principal

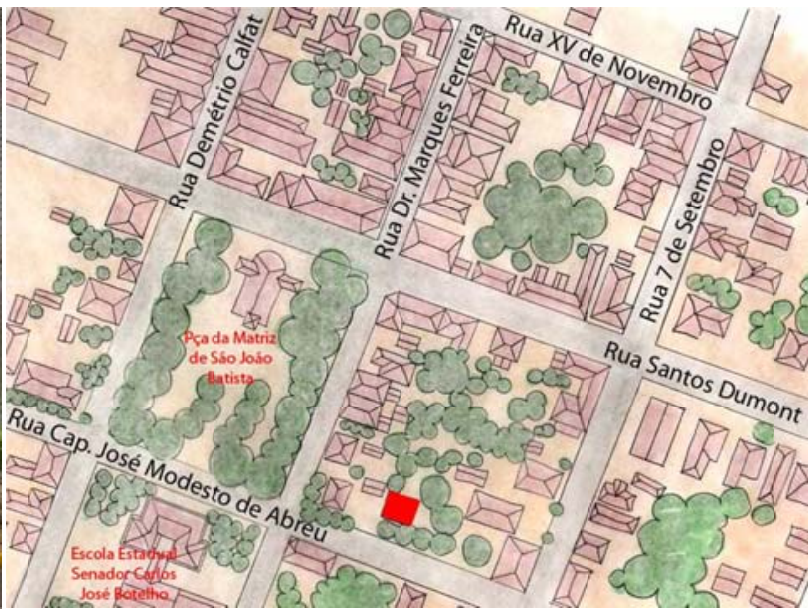

Localização na cidade - situação se m escala

Fachada principal e uso atual

1. Materiais empregados na cobertura

2. Coroamento

Destruição total Canal X

Vidro

Fibrocimento

Destruição total

Frontão

Cachorros

Platibanda

Plástico / fibra

Meta

Laje de beiral $X$

Beiral simples

Cimalha

Beira seveira

Outros:

4. Materiais de acabamento da fachada principal

\section{Materiais do coroamento}

Argamassa $\mathrm{X}$

Cantaria

Argamassa $X$

Guarda pó

Azulejo antigo

Azulejo novo

Cantaria

Madeira

Concreto aparente

Azulejo novo

Chapisco

Outros:

Vidros

Azulejo novo

Madeira

6. Material das esquadrias da fachada principal

5. Material das molduras dos vãos de portas e janelas

Não tem

Destruição total

Argamassa $X$

Cantaria

Azulejo antigo

Azulejo novo

Madeira

Concreto aparente

7. Cores predominantes da fachada principal

Coroamento: branco

Esquadrias: bege

Acabam. da fachada: bege

Destruição total

Madeira X

Vidro $X$

Alumínio

Ferro laminado / solda X

Outros:

8. Uso atual - quantificar

Residência:

Comércio:

Vago:

Outros relevos: amarelo

Serviço: 100\% - delegacia

Guarda-corpos: não tem

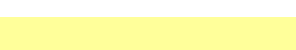

Dados volumétricos

\section{Gabarito}

Altura da fachada:

№ pavimentos acima do nível da rua: 01

Alt. cumeeira:

2. Classificação tipológica do telhado

Além desses, assinalar a existência de:

Porão alto $X \quad$ Mirante

Pav. intermediário

$$
\text { mezanino }
$$

Número de águas do corpo principal: 0

№ subsolos:

Pav. recuado

Cumeeira paralela à rua

Cumeeira perpendicular à rua

Tipo chalé

Sótão habitável
3. Registro de acréscimos

Não tem $X$

Acréscimo vertical

Acréscimo horizontal
Identificado a partir de:

Evidência na construção $X$

Depoimento do usuário

\section{Descrever:}

Com torreão

Água furtada

Outros: 
Identificação

Logradouro: Rua Bernardino de Campos s/n

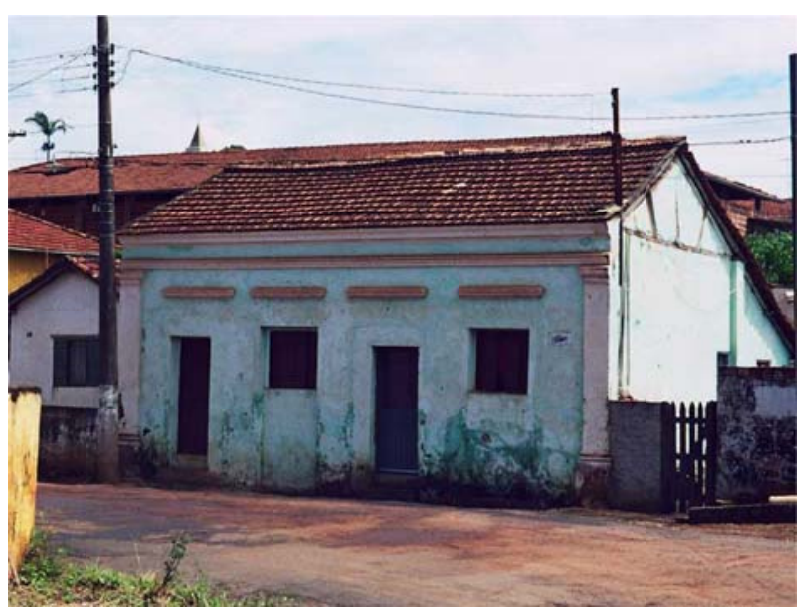

Fachada principal

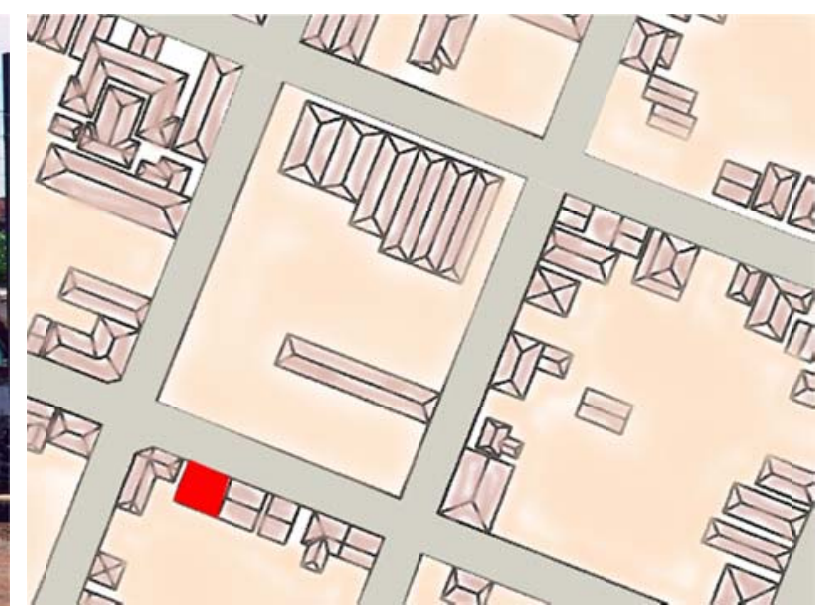

Localização na cidade - situação sem escala

Fachada principal e uso atual

1. Materiais empregados na cobertura

Destruição total Canal X

Francesa Fibrocimento

Vidro

Metal

Plástico / fibra

Laje

Outros:

\section{Materiais do coroamento}

Argamassa $X$

Azulejo antigo

\section{Cantaria}

Azulejo novo

Madeira

Concreto aparente

Outros:

5. Material das molduras dos vãos de portas e janelas

Não tem X

Argamassa

Azulejo antigo

Madeira Destruição total

Cantaria

Azulejo novo

Concreto aparente

7. Cores predominantes da fachada principal

Coroamento: branco

Molduras dos vãos: não tem

Guarda-corpos: não tem

Esquadrias: cinza

Acabam. da fachada: azul

Outros relevos: branco

\section{Coroamento}

Destruição total

Frontão

Cachorros

Laje de beiral

Beiral simples

4. Materiais de acabamento da fachada principal

Argamassa X Chapisco

Cantaria Azulejo novo

Azulejo novo Madeira

Vidros

Outros:

6. Material das esquadrias da fachada principal

Destruição total Madeira

Vidro Alumínio $X$

Ferro laminado / solda Outros:

8. Uso atual - quantificar

Residência: $100 \%$ Vago:

Comércio: Culto:

Serviço: Instituição:

Dados volumétricos

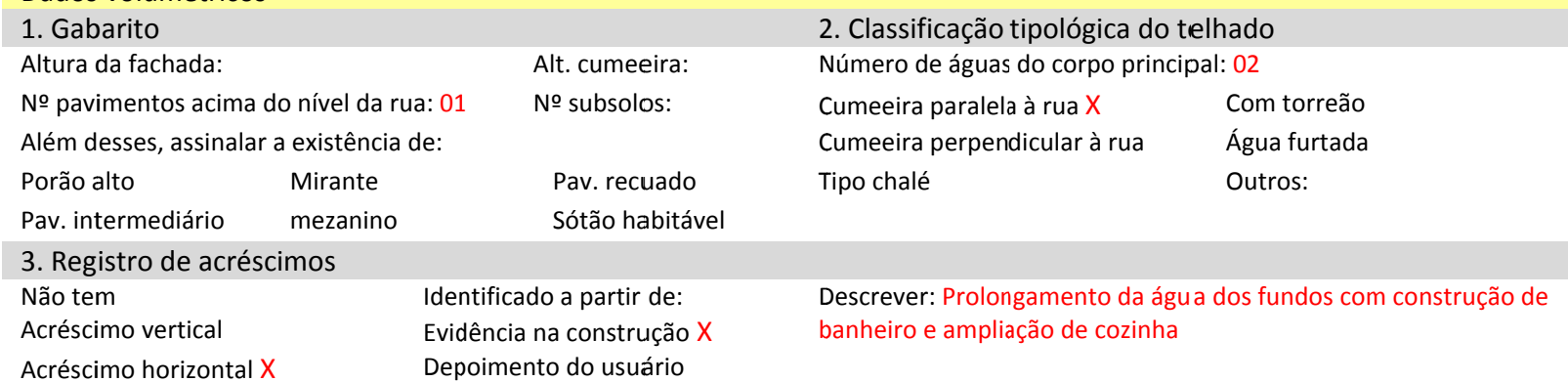


Identificação

Logradouro: Rua Bernardino de Campos

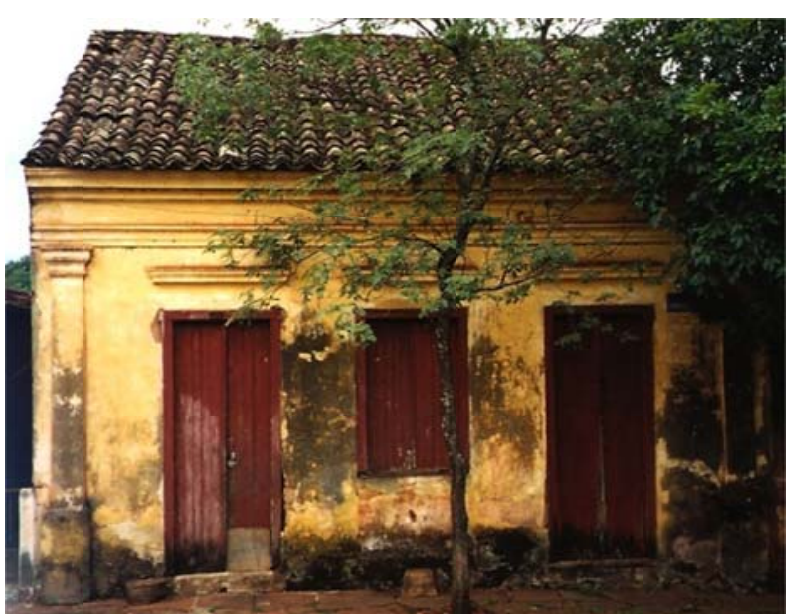

Fachada principal

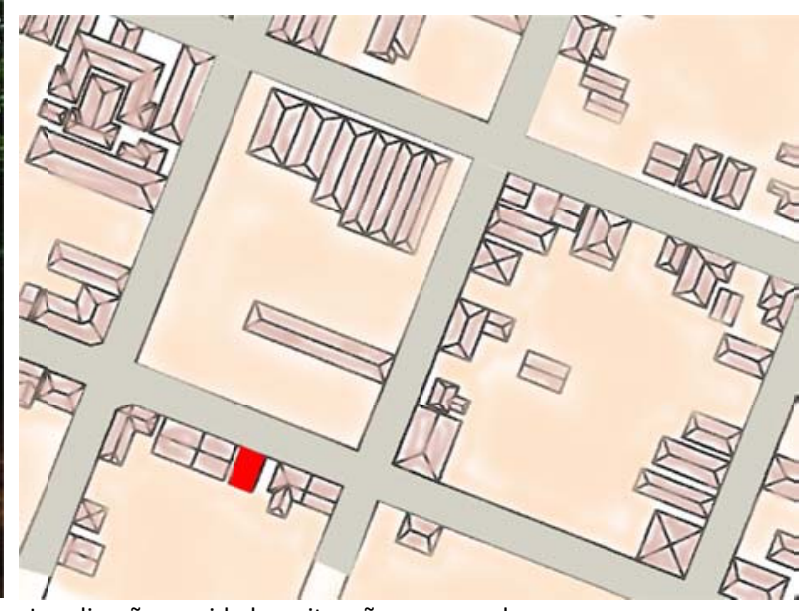

Localização na cidade - situação se:m escala

Fachada principal e uso atual

$\begin{array}{ll}\text { 1. Materiais empregados na cobertura } \\ \text { Destruição total } & \text { Canal X } \\ \text { Francesa } & \text { Fibrocimento } \\ \text { Vidro } & \text { Metal } \\ \text { Plástico / fibra } & \text { Laje } \\ \text { Outros: } & \end{array}$

3. Materiais do coroamento Argamassa

Cantaria

Azulejo antigo

Azulejo novo

Madeira X

Concreto aparente

\section{Coroamento}

Destruição total

Frontão

Cachorros

Platibanda

Laje de beiral

Beiral simples

Cimalha $X$

Beira seveira

Outros:

Argamassa $X \quad$ Chapisco

Cantaria Azulejo novo

Azulejo novo Madeira

Vidros Outros:

5. Material das molduras dos vãos de portas e janelas

6. Material das esquadrias da fachada principal

Não tem $X$

Destruição total

Argamassa

Cantaria

Destruição tota

Madeira X

Azulejo antigo

Azulejo novo

Vidro

Alumínio

Madeira

Concreto aparente

7. Cores predominantes da fachada principal

Ferro laminado / solda

Outros:

Coroamento: amarelo
Molduras dos vãos: vermelho

Esquadrias: vermelho

8. Uso atual - quantificar

Acabam. da fachada: amarelo

Residência: $100 \%$

Comércio:

Vago:

Guarda-corpos: não tem

Outros relevos: amarelo

Serviço:

Culto:

Instituição:

Dados volumétricos

\section{Gabarito}

Altura da fachada: $4 \mathrm{~m}$

№ pavimentos acima do nível da rua: 01

Além desses, assinalar a existência de:

Porão alto Mirante

Pav. intermediário mezanino

\section{Alt. cumeeira: $6 \mathrm{~m}$}

№ subsolos:

Pav. recuado Sótão habitável
2. Classificação tipológica do telhado Número de águas do corpo principal: 02

Cumeeira paralela à rua $X$

Cumeeira perpendicular à rua

Tipo chalé

Com torreão

Água furtada

Outros:

\section{Registro de acréscimos}

Não tem X

Acréscimo vertical

Acréscimo horizontal
Identificado a partir de:

Evidência na construção $X$

Depoimento do usuário
Descrever: 
Ficha de pré-inventário do patrimônio arquitetônico e urbanístico de Dourado - SP Características Arquitetônicas - Ficha 08

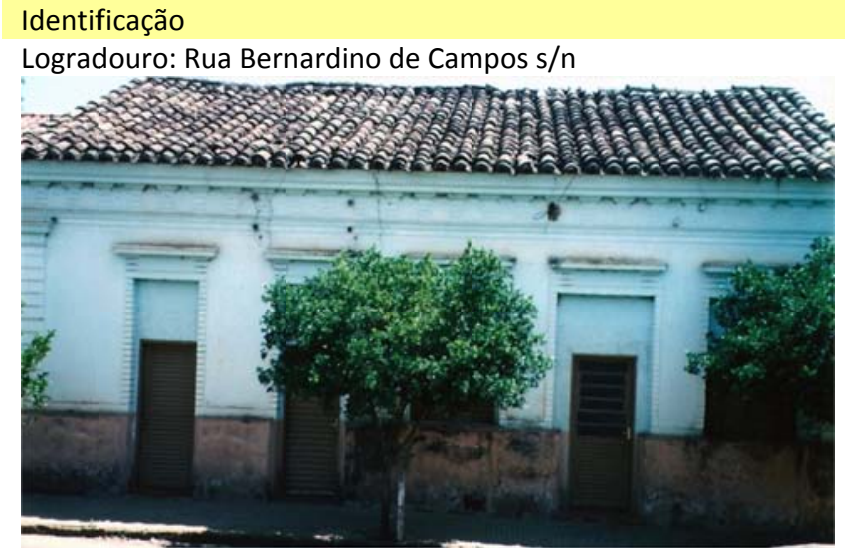

Fachada principal

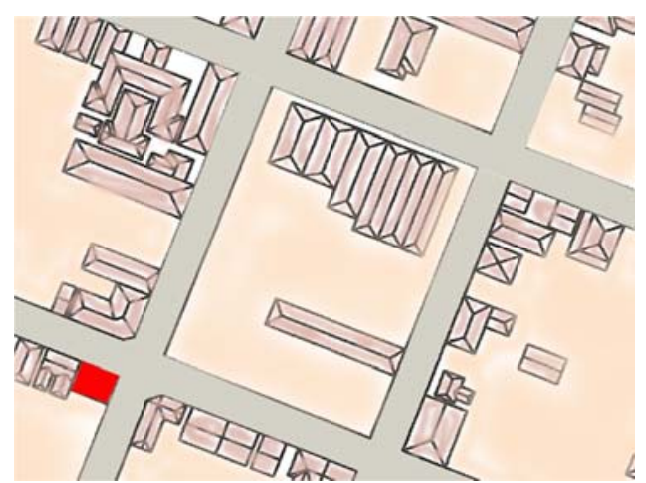

Localização na cidade - situação sem escala

Fachada principal e uso atual

1. Materiais empregados na cobertura

Destruição total Canal X

$\begin{array}{ll}\text { Francesa } & \text { Fibrocimento } \\ \text { Vidro } & \text { Metal }\end{array}$

Metal

Plástico / fibra

Laje

Outros:

3. Materiais do coroamento

Argamassa $X$

Azulejo antigo

Cantaria

Madeira

Azulejo novo

Outros:

Concreto aparente

\section{Coroamento}

Destruição total

Frontão

Cachorros

Laje de beiral

Beiral simples

\section{Platibanda}

Cimalha $X$

Beira seveira

Outros:

4. Materiais de acabamento da fachada principal

Argamassa $X \quad$ Chapisco

Cantaria Azulejo novo

Azulejo novo Madeira

Vidros Outros:

5. Material das molduras dos vãos de portas e janelas $\quad 6$. Material das esquadrias da fachada principal

Não tem

Destruição total

Destruição total

Madeira

Vidro

Argamassa X

Cantaria

Azulejo antigo

Azulejo novo

Ferro laminado / solda

Alumínio $X$

Concreto aparente

7. Cores predominantes da fachada principal

8. Uso atual - quantificar

Coroamento: azul

Esquadrias: marrom

Residência: 100\%

Comércio:

Serviço:

Vago:

Acabam. da fachada: azu

Outros relevos: vermelho

\section{Culto:}

Guarda-corpos: não tem

(n)

Dados volumétricos

\section{Gabarito}

Altura da fachada: $4 \mathrm{~m}$

№ pavimentos acima do nível da rua: 01

Além desses, assinalar a existência de:

$\begin{array}{ll}\text { Porão alto } & \text { Mirante } \\ \text { Pav intermediário } & \text { mezanino }\end{array}$

3. Registro de acréscimos

Não tem $X$

Acréscimo vertical

Acréscimo horizontal
Alt. cumeeira: $6 \mathrm{~m}$

№ subsolos:

Pav. recuado

Sótão habitável
2. Classificação tipológica do telhado Número de águas do corpo principal: 02

Cumeeira paralela à rua $\mathrm{X}$
Cumeeira perpendicular à rua

Tipo chalé

Água furtada

Outros: 
Identificação

Logradouro: Rua 7 de Setembro s/n

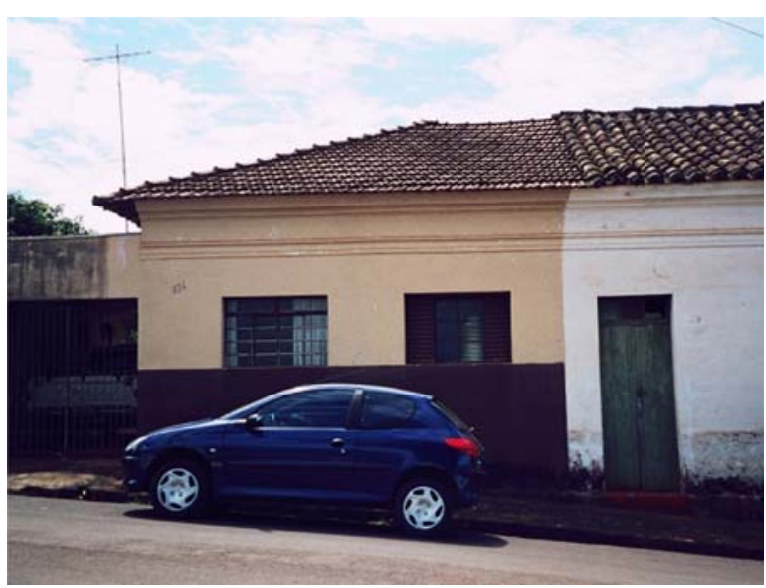

Fachada principal

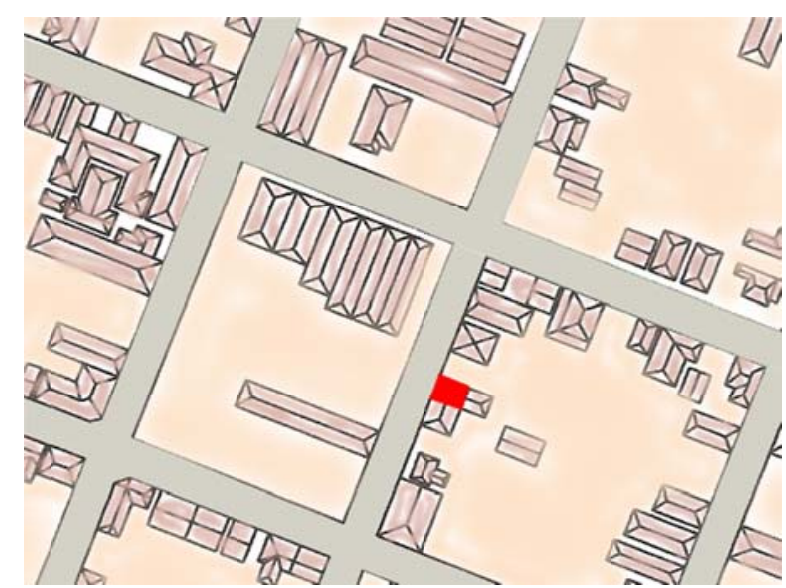

Localização na cidade - situação sem escala

Fachada principal e uso atual

1. Materiais empregados na cobertura

Destruição total Canal

Francesa X

Vidro

Fibrocimento

Metal

Plástico / fibra

Laje

Outros:

3. Materiais do coroamento

Argamassa $X$

Azulejo antigo

Cantaria

Azulejo novo

Madeira

Concreto aparente

Outros:

5. Material das molduras dos vãos de portas e janelas

Não tem X

Argamassa

Azulejo antigo

Destruição total

Cantaria

Azulejo novo

Madeira

Concreto aparente

7. Cores predominantes da fachada principal

Coroamento: bege

Esquadrias: marrom

Molduras dos vãos: não tem

Acabam. da fachada: bege

Guarda-corpos: não tem

Outros relevos: marrom

\section{Coroamento}

Destruição total

Frontão

Cachorros

Laje de beiral

Beiral simples

Platibanda
Cimalha X
Beira seveira
Guarda pó
Outros:

4. Materiais de acabamento da fachada principal

Argamassa $X \quad$ Chapisco $X$

Cantaria Azulejo novo

Azulejo novo Madeira

Vidros Outros:

6. Material das esquadrias da fachada principal

Destruição total Madeira

Vidro Alumínio $X$

Ferro laminado / solda Outros:

\section{Uso atual - quantificar}

Residência: $100 \%$ Vago:

Comércio: Culto:

Serviço: Instituição:

Dados volumétricos

\begin{tabular}{|c|c|c|c|c|}
\hline \multicolumn{3}{|l|}{ 1. Gabarito } & \multicolumn{2}{|c|}{ 2. Classificação tipológica do telhado } \\
\hline Altura da fachada: & & Alt. cumeeira: 5,5 m & \multicolumn{2}{|c|}{ Número de águas do corpo principal: 03} \\
\hline \multicolumn{2}{|c|}{ № pavimentos acima do nível da rua: 01} & № subsolos: & Cumeeira paralela à rua $X$ & Com torreão \\
\hline Além desses, assin & existência de: & & Cumeeira perpendicular à rua & Água furtada \\
\hline Porão alto & Mirante & Pav. recuado & Tipo chalé & Outros: \\
\hline Pav. intermediário & mezanino & Sótão habitável & & \\
\hline
\end{tabular}

Sótão habitáve

3. Registro de acréscimos

Não tem

Acréscimo vertical

Acréscimo horizontal $X$
Identificado a partir de:

Evidência na construção $X$

Depoimento do usuário
Descrever: Prolongamento da água dos fundos com construção de banheiro e ampliação de cozinha 
Identificação

Logradouro: Rua 7 de Setembro s/n

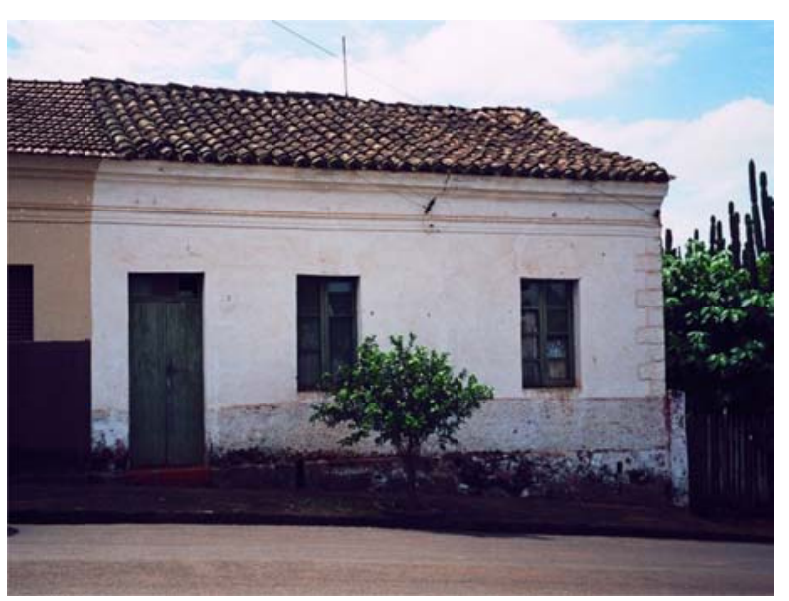

Fachada principal

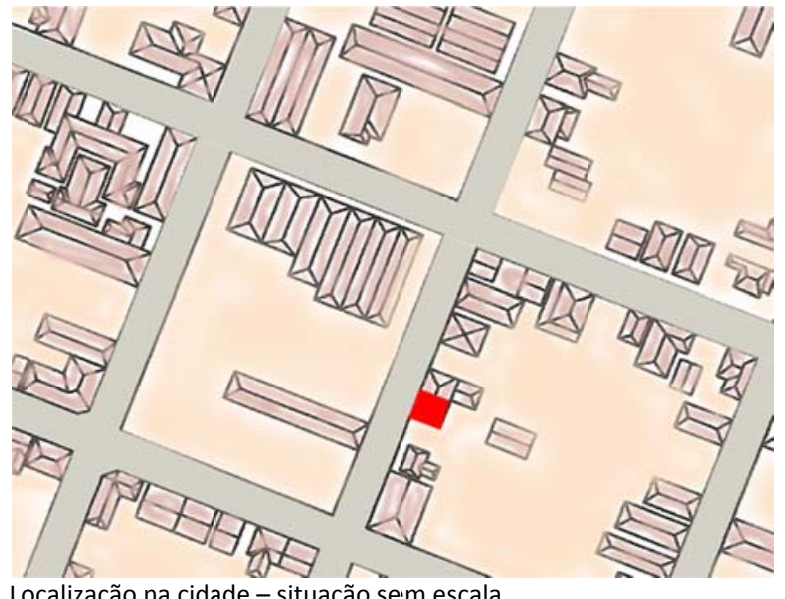

Localização na cidade - situação sem escala

\section{Coroamento}

Destruição total

Frontão

Cachorros

Laje de beiral

Beiral simples

4. Materiais de acabamento da fachada principal

Argamassa $X \quad$ Chapisco $X$

Cantaria Azulejo novo

Azulejo novo Madeira

Vidros Outros:

6. Material das esquadrias da fachada principal

Destruição total Madeira $X$

Vidro $X \quad$ Alumínio

Ferro laminado / solda Outros:

8. Uso atual - quantificar

Residência: $100 \% \quad$ Vago:

Comércio: Culto:

Serviço: Instituição:

Dados volumétricos

\section{Gabarito}

Altura da fachada: $4 \mathrm{~m}$

№ pavimentos acima do nível da rua: 01

Além desses, assinalar a existência de:

Porão alto Mirante

Pav. intermediário mezanino

3. Registro de acréscimos

Não tem

Acréscimo vertical

Acréscimo horizontal $X$
Identificado a partir de:

Evidência na construção $X$

Depoimento do usuário
2. Classificação tipológica do telhado Número de águas do corpo principal: 02

Cumeeira paralela à rua $X$

Com torreão

Cumeeira perpendicular à rua

Tipo chalé

Água furtada

Outros: 
Ficha de pré-inventário do patrimônio arquitetônico e urbanístico de Dourado - SP Características Arquitetônicas - Ficha 11

Identificação

Logradouro: Rua 7 de Setembro X Rua Cap. José Modesto de Abreu

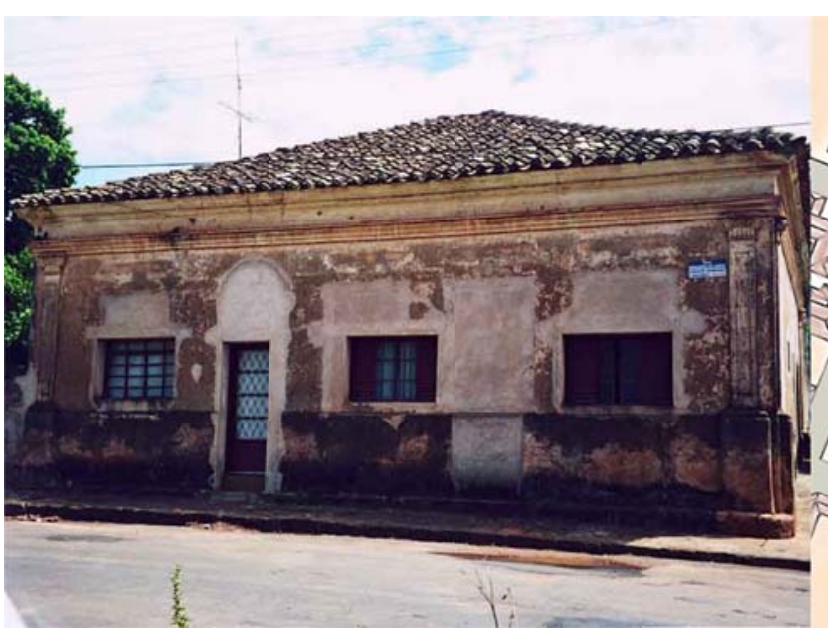

Fachada principal

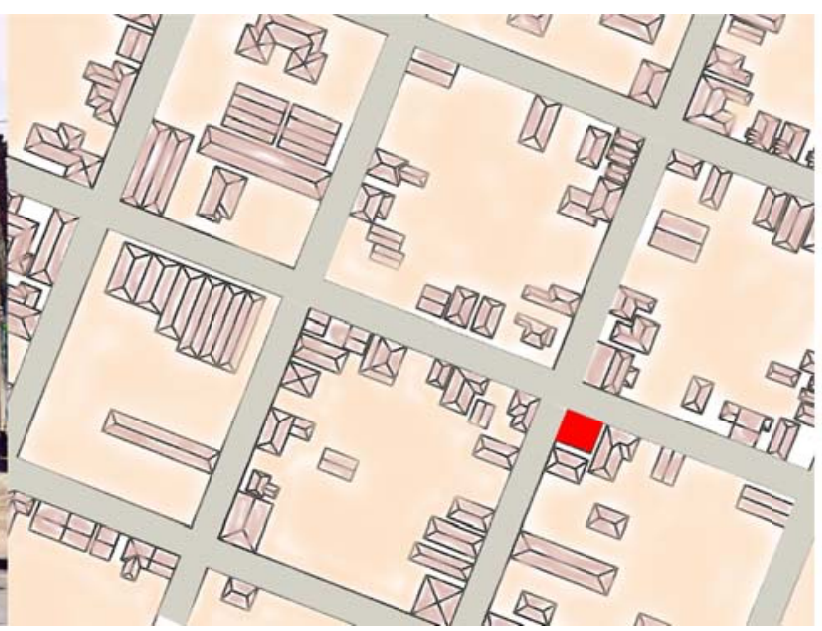

Localização na cidade - situação sem escala

Fachada principal e uso atual

1. Materiais empregados na cobertura

Destruição total Canal X

Francesa Fibrocimento

Vidro

Metal

Destruição total

Frontão

Platibanda

Laje

Cachorros

Cimalha X

Plástico / fibra

Laje de beiral

Beiral simples

Beira seveira

Guarda pó

4. Materiais de acabamento da fachada principal

3. Materiais do coroamento

Argamassa $X$

Azulejo antigo

Cantaria

Argamassa X

Outros:

Madeira

Azulejo novo

Cantaria

Azulejo novo

Chapisco

Concreto aparente

Vidros

Azulejo novo

Madeira

6. Material das esquadrias da fachada principal

5. Material das molduras dos vãos de portas e janelas

Não tem X

Destruição total

Argamassa

Cantaria

Azulejo antigo

Azulejo novo

Madeira

Concreto aparente

7. Cores predominantes da fachada principal

Coroamento: amarelo

Esquadrias: marrom

Molduras dos vãos: não tem

Acabam. da fachada: marrom

Destruição total

Madeira

Vidro $X$

Alumínio X

Ferro laminado / solda X

Outros:

8. Uso atual - quantificar

Residência: $100 \%$

Comércio:

Vago:

Outros relevos:

Serviço:

Instituição:

Dados volumétricos

\section{Gabarito \\ Altura da fachada: $5 \mathrm{~m}$}

№ pavimentos acima do nível da rua: 01

Alt. cumeeira: $7 \mathrm{~m}$

№ subsolos:

Além desses, assinalar a existência de:

Porão alto Mirante

Pav. intermediário

mezanino

Pav. recuado

Sótão habitável
2. Classificação tipológica do telhado Número de águas do corpo principal: 04

Cumeeira paralela à rua $\mathrm{X}$
Cumeeira perpendicular à

Tipo chalé

Com torreão

Água furtada

Outros:

3. Registro de acréscimos

Não tem $X$

Acréscimo vertical

Acréscimo horizontal
Identificado a partir de:

Evidência na construção $X$

Depoimento do usuário
Descrever: 
Ficha de pré-inventário do patrimônio arquitetônico e urbanístico de Dourado - SP Características Arquitetônicas - Ficha 12

Identificação

Logradouro: Rua Barão do Rio Branco X Rua Coronel Francisco Borja Cardoso

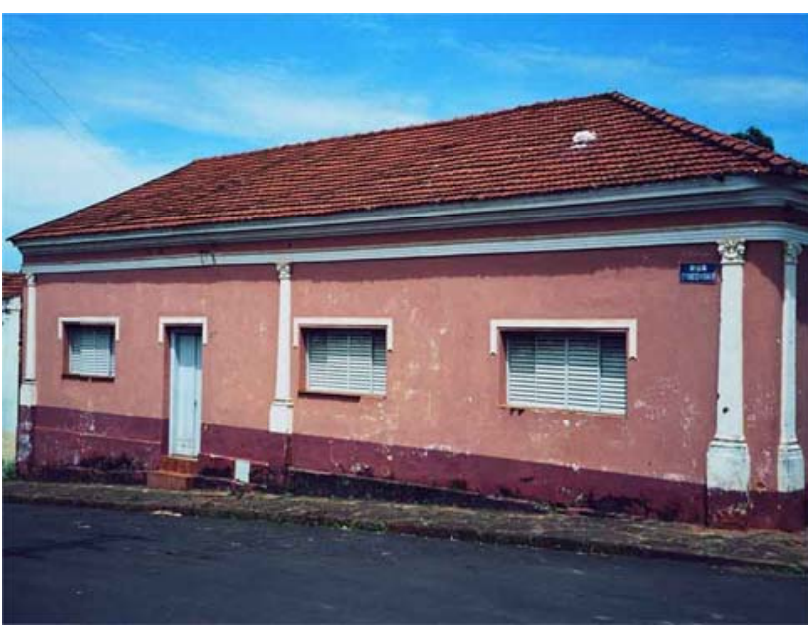

Fachada principal

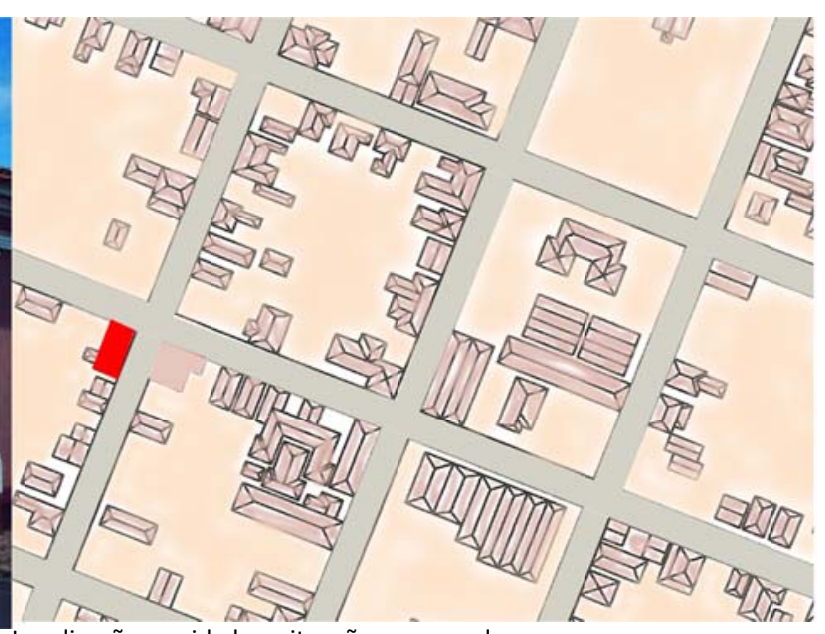

Localização na cidade - situação sem escala

Fachada principal e uso atual

1. Materiais empregados na cobertura

Destruição total Canal

Francesa X

Vidro

Plástico / fibra

Fibrocimento

Metal

Laje

Outros:

3. Materiais do coroamento

Argamassa X

Azulejo antigo

Cantaria

Azulejo novo

Madeira

Concreto aparente

Outros:

5. Material das molduras dos vãos de portas e janelas Não tem

Argamassa $X$

Azulejo antigo

Destruição total

Cantaria

Azulejo novo

Madeira

Concreto aparente

7. Cores predominantes da fachada principal

Coroamento: branco

Molduras dos vãos: branco

Esquadrias: cinza

Guarda-corpos: não tem

Acabam. da fachada: marrom

Outros relevos: branco

2. Coroamento
Destruição total
Frontão
Cachorros
Laje de beiral
Beiral simples

Platibanda

Cimalha X

Beira seveira

Guarda pó

4. Materiais de acabamento da fachada principal

Argamassa $X \quad$ Chapisco

Cantaria Azulejo novo

Azulejo novo Madeira

Vidros Outros:

6. Material das esquadrias da fachada principal

Destruição total Madeira $X$

Vidro Alumínio $X$

Ferro laminado / solda Outros:

8. Uso atual - quantificar

Residência: $100 \%$ Vago:

Comércio: Culto:

Serviço: Instituição:

Dados volumétricos

\section{Gabarito \\ Altura da fachada:}

№ pavimentos acima do nível da rua: 01

Além desses, assinalar a existência de:

Porão alto $X \quad$ Mirante

Pav. intermediário

mezanino
2. Classificação tipológica do telhado Número de águas do corpo principal:

Alt. cumeeira:
№ subsolos:

Pav. recuado

Sótão habitável
3. Registro de acréscimos

Não tem $X$

Acréscimo vertical

Acréscimo horizontal
Identificado a partir de:

Evidência na construção $X$

Depoimento do usuário
Cumeeira paralela à rua $X$

Cumeeira perpendicular à rua

Tipo chalé

Descrever:

Com torreão

Água furtada

Outros: 
Ficha de pré-inventário do patrimônio arquitetônico e urbanístico de Dourado - SP Características Arquitetônicas - Ficha 13

Identificação

Logradouro: Rua Coronel Francisco Borja Cardoso X Rua Barão do Rio Branco

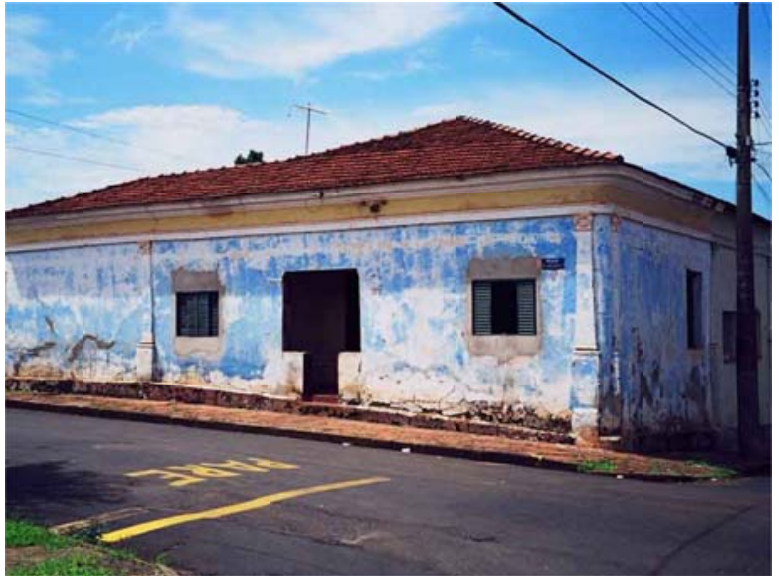

Fachada principal

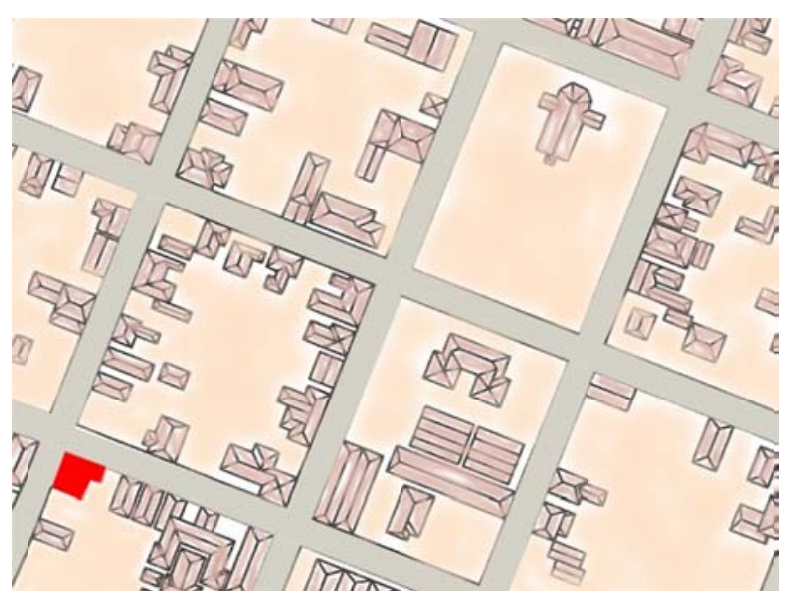

Localização na cidade - situação sem escala

Fachada principal e uso atual

\section{Materiais empregados na cobertura}

Destruição total

Francesa X

Vidro

Plástico / fibra

Outros:

\section{Materiais do coroamento}

Argamassa

Azulejo antigo

Madeira

Outros:

5. Material das molduras dos vãos de portas e janelas

Não tem

Argamassa

Azulejo antigo

Madeira

Destruição total

Cantaria

Azulejo novo

Concreto aparente

7. Cores predominantes da fachada principal

Coroamento:

Molduras dos vãos:

Esquadrias:

Acabam. da fachada:

Guarda-corpos:
Outros relevos:

\section{Coroamento}

Destruição total

Frontão

Cachorros

Laje de beiral

Beiral simples

4. Materiais de acabamento da fachada principal

Argamassa $X \quad$ Chapisco

Cantaria Azulejo novo

Azulejo novo Madeira

Vidros Outros:

6. Material das esquadrias da fachada principal

Destruição total Madeira

Vidro Alumínio $X$

Ferro laminado / solda Outros:

8. Uso atual - quantificar

Residência: $100 \% \quad$ Vago:

Comércio: Culto:

Serviço: Instituição:

\section{Dados volumétricos}

\section{Gabarito}

Altura da fachada:

№ pavimentos acima do nível da rua: 01

Além desses, assinalar a existência de:

Porão alto $X \quad$ Mirante

Pav. intermediário mezanino
2. Classificação tipológica do telhado Número de águas do corpo principal: 07

Cumeeira paralela à rua $X$

Cumeeira perpendicular à rua

Tipo chalé
Com torreão

Água furtada

Outros:

3. Registro de acréscimos

Não tem $X$

Acréscimo vertical

Acréscimo horizontal

Identificado a partir de: Descrever:

Evidência na construção $X$

Depoimento do usuário
Descrever: 
Identificação

Logradouro: Rua Sete de Setembro X Rua Cap. José Modesto de Abreu

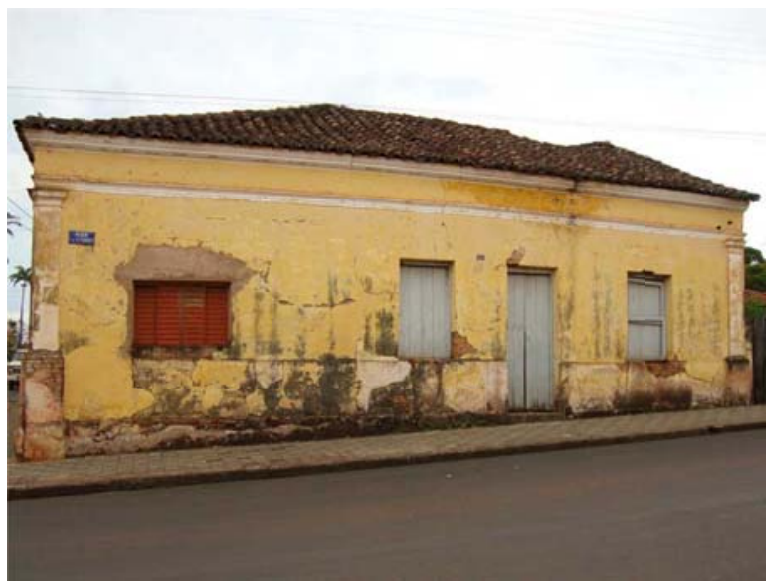

Fachada principal

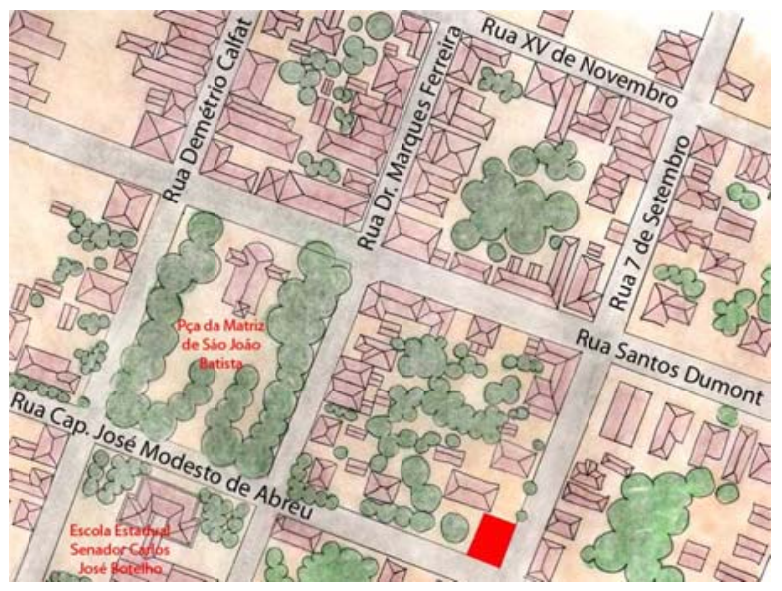

Localização na cidade - situação se:m escala

Fachada principal e uso atual

1. Materiais empregados na cobertura

Destruição total Canal X

Francesa

Vidro

Plástico / fibra

Fibrocimento

Metal

Laje

Outros:

3. Materiais do coroamento

Argamassa X

Azulejo antigo

Cantaria

Madeira

Azulejo novo

Outros:

Concreto aparente

5. Material das molduras dos vãos de portas e janelas

Não tem $X$

Argamassa

Azulejo antigo

Destruição total

Cantaria

Azulejo novo

Madeira

Concreto aparente

7. Cores predominantes da fachada principal

Coroamento: branco

Molduras dos vãos: não tem

Esquadrias: cinza / marrom

Guarda-corpos: não tem

Acabam. da fachada: amarelo

Outros relevos: branco

2. Coroamento
Destruição total
Frontão
Cachorros
Laje de beiral
Beiral simples

Platibanda

Cimalha $X$

Beira seveira

Guarda pó

4. Materiais de acabamento da fachada principal

Argamassa X Chapisco

Cantaria Azulejo novo

Azulejo novo Madeira

Vidros Outros:

6. Material das esquadrias da fachada principal

Destruição total Madeira X

Vidro Alumínio $X$

Ferro laminado / solda Outros:

8. Uso atual - quantificar

Residência: $100 \% \quad$ Vago:

Comércio: Culto:

Serviço: Instituição:

Dados volumétricos

\begin{tabular}{|c|c|}
\hline 1. Gabarito & 2. Classificação tipológica do telhado \\
\hline
\end{tabular}

Altura da fachada:

№ subsolos:

Além desses, assinalar a existência de:

Porão alto Mirante

Pav. intermediário

mezanino

Pav. recuado

Sótão habitável

\section{Registro de acréscimos}

Não tem $X$

Acréscimo vertical

Acréscimo horizontal
Identificado a partir de:

Evidência na construção $X$

Depoimento do usuário
Cumeeira paralela à rua

Cumeeira perpendicular à rua

Tipo chalé

Descrever:

Com torreão

Água furtada

Outros: 
Identificação

Logradouro: Rua Santos Dumont X Rua Dr. Marques Ferreira s/n

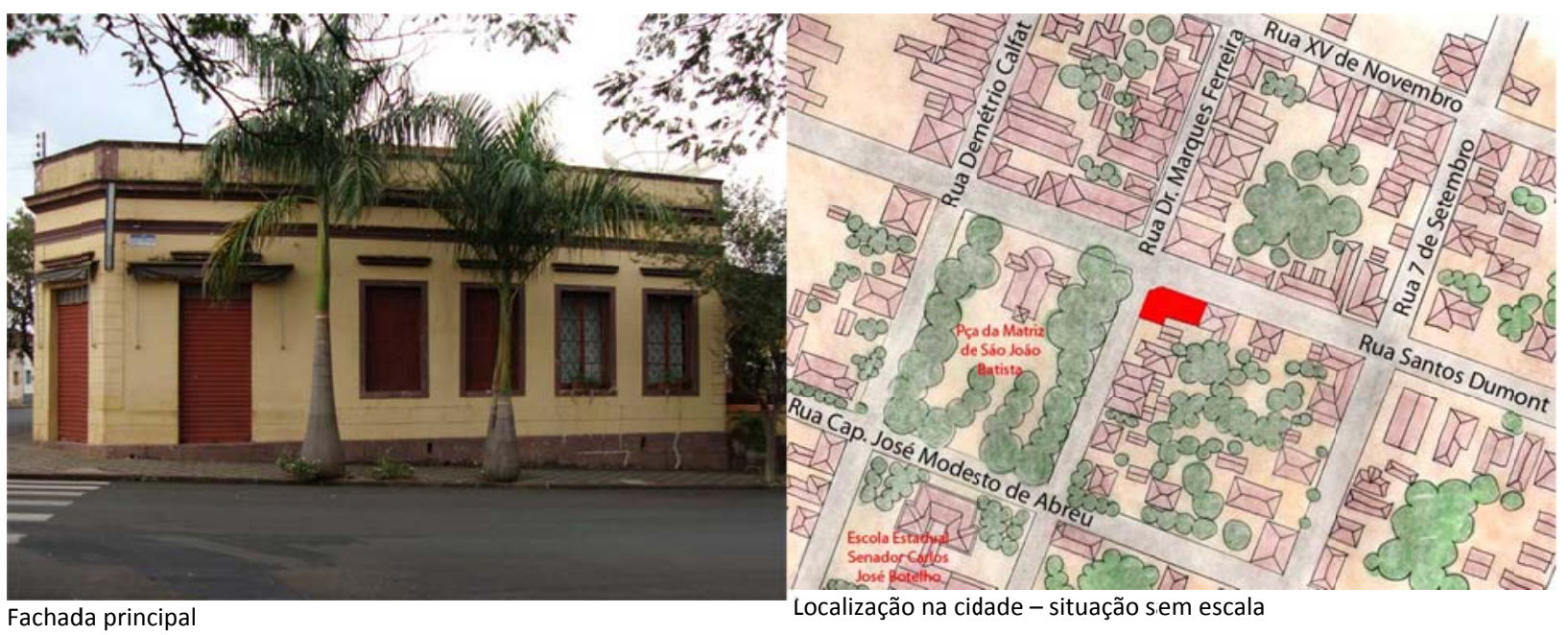

Fachada principal e uso atual

\begin{tabular}{|c|c|c|c|}
\hline \multicolumn{2}{|c|}{ 1. Materiais empregados na cobertura } & \multicolumn{2}{|l|}{ 2. Coroamento } \\
\hline Destruição total & Canal & Destruição total & Platibanda X \\
\hline Francesa $X$ & Fibrocimento & Frontão & Cimalha \\
\hline Vidro & Metal & Cachorros & Beira seveira \\
\hline Plástico / fibra & Laje & Laje de beiral & Guarda pó \\
\hline Outros: & & Beiral simples & Outros: \\
\hline \multicolumn{2}{|l|}{ 3. Materiais do coroamento } & \multicolumn{2}{|c|}{ 4. Materiais de acabamento da fachada principal } \\
\hline Argamassa $X$ & Cantaria & Argamassa $\mathrm{X}$ & Chapisco \\
\hline Azulejo antigo & Azulejo novo & Cantaria & Azulejo novo \\
\hline Madeira & Concreto aparente & Azulejo novo & Madeira \\
\hline Outros: & & Vidros & Outros: \\
\hline \multicolumn{2}{|c|}{ 5. Material das molduras dos vãos de portas e janelas } & \multicolumn{2}{|c|}{ 6. Material das esquadrias da fachada principal } \\
\hline Não tem & Destruição total & Destruição total & Madeira X \\
\hline Argamassa $X$ & Cantaria & Vidro X & Alumínio \\
\hline Azulejo antigo & Azulejo novo & Ferro laminado / solda & Outros: \\
\hline Madeira & Concreto aparente & & \\
\hline \multicolumn{2}{|c|}{ 7. Cores predominantes da fachada principal } & \multicolumn{2}{|c|}{ 8. Uso atual - quantificar } \\
\hline Coroamento: marrom / amarelo & Esquadrias: marrom & Residência: 50\% & Vago: \\
\hline Molduras dos vãos: marrom & Acabam. da fachada: amarelo & Comércio: 50\% & Culto: \\
\hline Guarda-corpos: não tem & Outros relevos: amarelo & Serviço: & Instituição: \\
\hline
\end{tabular}

Dados volumétricos

\begin{tabular}{|c|c|c|c|c|}
\hline \multicolumn{3}{|l|}{ 1. Gabarito } & \multicolumn{2}{|c|}{ 2. Classificação tipológica do telhado } \\
\hline \multicolumn{2}{|c|}{ Altura da fachada: } & Alt. cumeeira: & \multicolumn{2}{|c|}{ Número de águas do corpo principal: 05} \\
\hline \multicolumn{2}{|c|}{ № pavimentos acima do nível da rua: 01} & № subsolos: & Cumeeira paralela à rua $\mathrm{X}$ & Com torreão \\
\hline Além desses, assin & existência de: & & Cumeeira perpendicular à rua & Água furtada \\
\hline Porão alto X & Mirante & Pav. recuado & Tipo chalé & Outros: \\
\hline
\end{tabular}

3. Registro de acréscimos

Não tem X

Acréscimo vertical

Acréscimo horizontal

Identificado a partir de:

Descrever:

Depoimento do usuário 
Identificação

Logradouro: Rua Dr. Marques Ferreira s/n

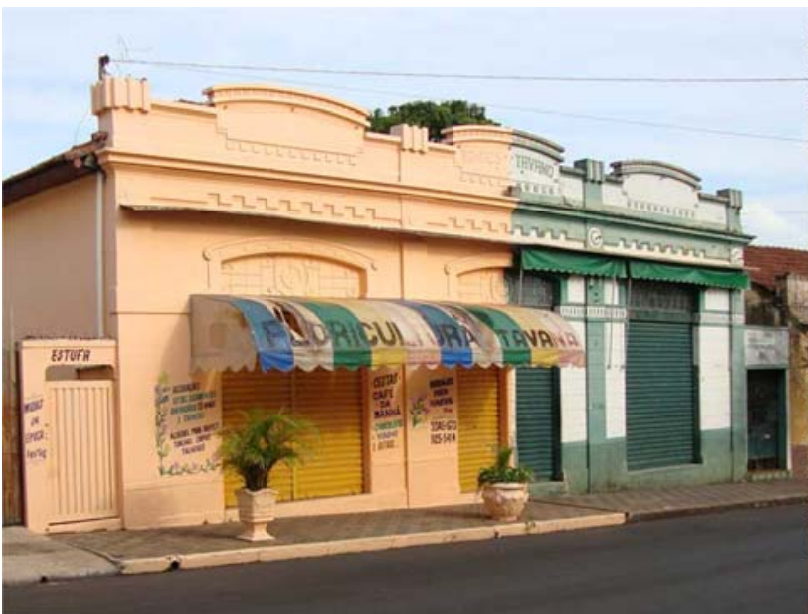

Fachada principal

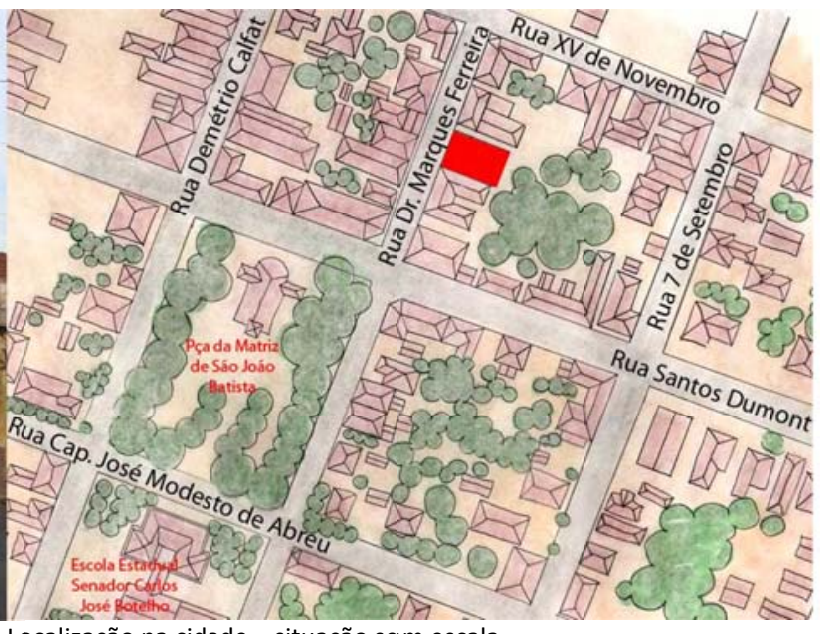

Localização na cidade - situação sem escala

Fachada principal e uso atual

\begin{tabular}{|c|c|c|c|}
\hline \multicolumn{2}{|c|}{ 1. Materiais empregados na cobertura } & \multicolumn{2}{|l|}{ 2. Coroamento } \\
\hline Destruição total & Canal & Destruição total & Platibanda X \\
\hline Francesa $X$ & Fibrocimento & Frontão & Cimalha \\
\hline Vidro & Metal & Cachorros & Beira seveira \\
\hline Plástico / fibra & Laje & Laje de beiral & Guarda pó \\
\hline Outros: & & Beiral simples & Outros: \\
\hline \multicolumn{2}{|l|}{ 3. Materiais do coroamento } & \multicolumn{2}{|c|}{ 4. Materiais de acabamento da fachada principal } \\
\hline Argamassa $X$ & Cantaria & Argamassa X & Chapisco \\
\hline Azulejo antigo & Azulejo novo & Cantaria & Azulejo novo \\
\hline Madeira & Concreto aparente & Azulejo novo & Madeira \\
\hline Outros: & & Vidros & Outros: \\
\hline \multicolumn{2}{|c|}{ 5. Material das molduras dos vãos de portas e janelas } & \multicolumn{2}{|c|}{ 6. Material das esquadrias da fachada principal } \\
\hline Não tem & Destruição total & Destruição total & Madeira \\
\hline Argamassa X & Cantaria & Vidro X & Alumínio X \\
\hline Azulejo antigo & Azulejo novo & Ferro laminado / solda X & Outros: \\
\hline Madeira & Concreto aparente & & \\
\hline \multicolumn{2}{|c|}{ 7. Cores predominantes da fachada principal } & \multicolumn{2}{|l|}{ 8. Uso atual - quantificar } \\
\hline Coroamento:verde/branco/rosa & Esquadrias:verde / branco / rosa & Residência: & Vago: \\
\hline Molduras dos vãos: verde /rosa & Acabam. da fachada: rosa/branco & Comércio: $100 \%$ & Culto: \\
\hline Guarda-corpos: não tem & Outros relevos: verde / rosa & Serviço: & Instituição: \\
\hline
\end{tabular}

Dados volumétricos

\section{Gabarito} Altura da fachada:

№ pavimentos acima do nível da rua: 01 Além desses, assinalar a existência de:

Porão alto Mirante

Pav. intermediário mezanino

\section{Alt. cumeeira: \\ № subsolos:}

Pav. recuado Sótão habitável

\section{Classificação tipológica do telhado} Número de águas do corpo principal: 04

Cumeeira paralela à rua $X$

Com torreão

Cumeeira perpendicular à rua

Tipo chalé

Água furtada

Outros:

3. Registro de acréscimos

Não tem $X$

Acréscimo vertical

Acréscimo horizontal
Identificado a partir de: Descrever:

Evidência na construção $X$

Depoimento do usuário

Outros: 
Identificação

Logradouro: Rua Dr. Marques Ferreira X Rua XV de Novembro s/n

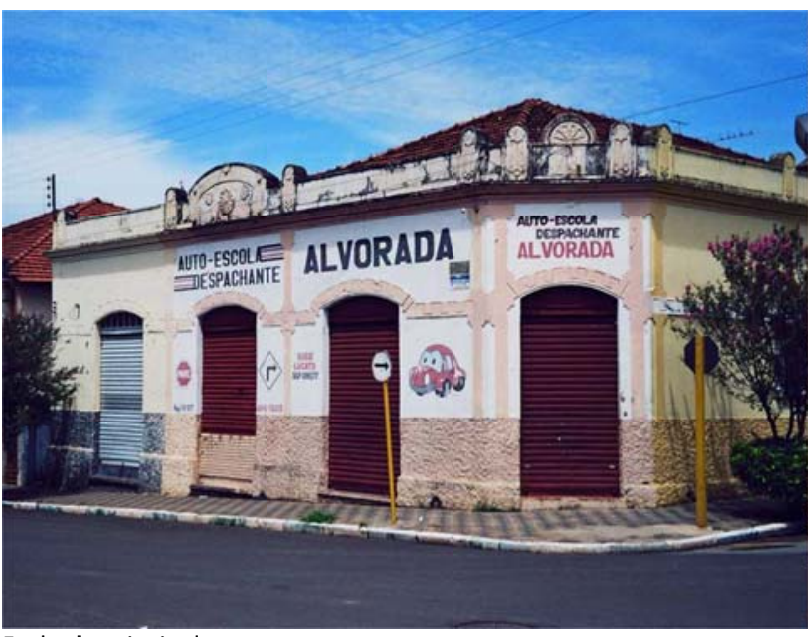

Fachada principal

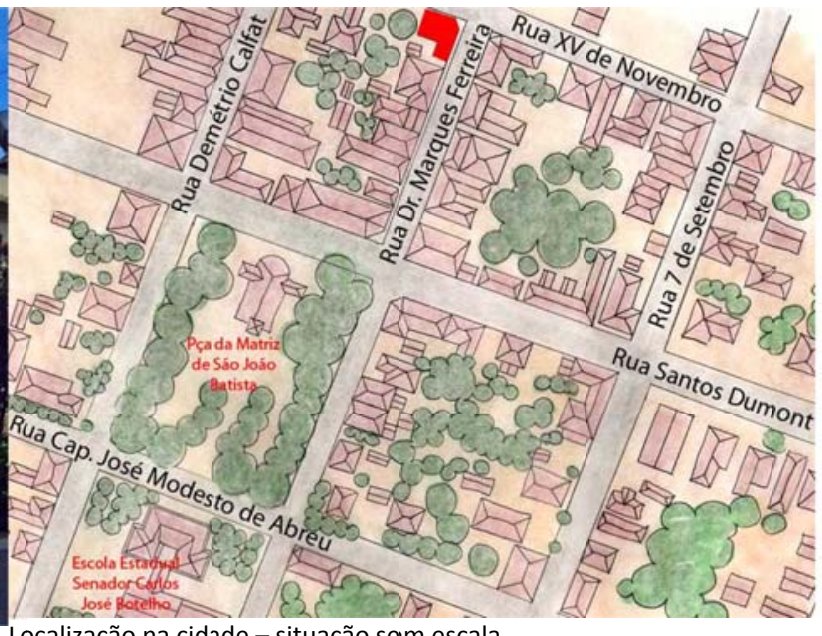

Localização na cidade - situação sem escala

Fachada principal e uso atual

1. Materiais empregados na cobertura Destruição total Canal

Francesa X

Vidro

Plástico / fibra

Fibrocimento

Metal

Outros:

Laje

\section{Materiais do coroamento}

Argamassa $X$

Azulejo antigo

Cantaria

Madeira

Azulejo novo

Outros:

Concreto aparente

5. Material das molduras dos vãos de portas e janelas

Não tem

Destruição total

Argamassa $X$

Azulejo antigo

Cantaria

Azulejo novo

Madeira

Concreto aparente

Outros:

\section{Cores predominantes da fachada principal}

Coroamento: branco/rosa/amare

Molduras dos vãos: rosa

Esquadrias: marrom / cinza

Acabam. da fachada: branco

Guarda-corpos: não tem

\section{Coroamento}

Destruição total

Frontão X

Cachorros

Laje de beiral

Beiral simples

4. Materiais de acabamento da fachada principal

Argamassa $X \quad$ Chapisco $X$

Cantaria Azulejo novo

Azulejo novo Madeira

Vidros

Outros:

6. Material das esquadrias da fachada principal

Destruição total Madeira

Vidro Alumínio $X$

Ferro laminado / solda $X \quad$ Outros:

\section{Uso atual - quantificar}

Residência: $30 \% \quad$ Vago:

Comércio: $70 \% \quad$ Culto:

Serviço: Instituição:
Dados volumétricos

\section{Gabarito}

Altura da fachada:

№ pavimentos acima do nível da rua: 01

Além desses, assinalar a existência de:

Porão alto Mirante

Pav. intermediário mezanino

3. Registro de acréscimos

Não tem X

Acréscimo vertical

Acréscimo horizontal
Identificado a partir de: Descrever:

Evidência na construção $X$

Depoimento do usuário
2. Classificação tipológica do telhado Número de águas do corpo principal: 07

Cumeeira paralela à rua $X \quad$ Com torreão

Cumeeira perpendicular à rua Água furtada

Tipo chalé Outros: 
Identificação

Logradouro: Rua Demétrio Calfat X Rua Santos Dumont s/n

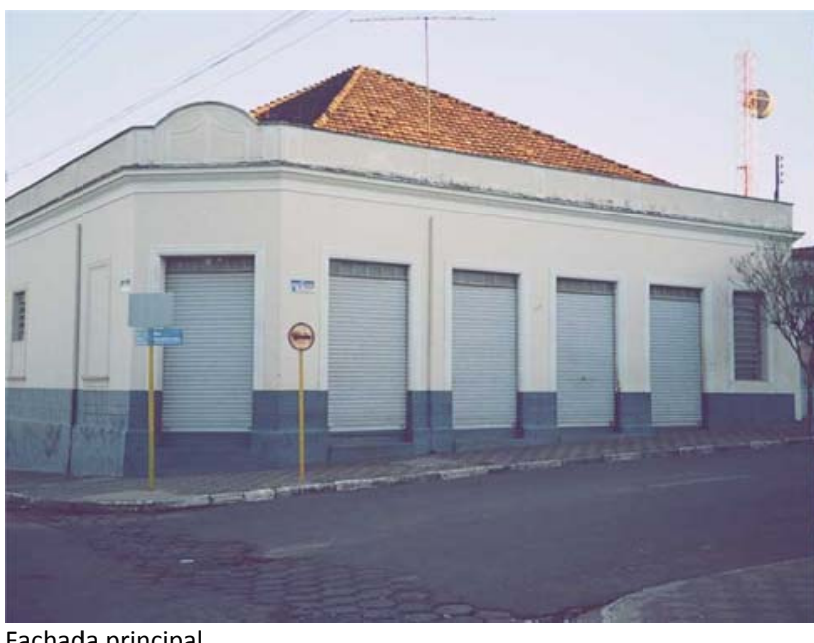

Fachada principal

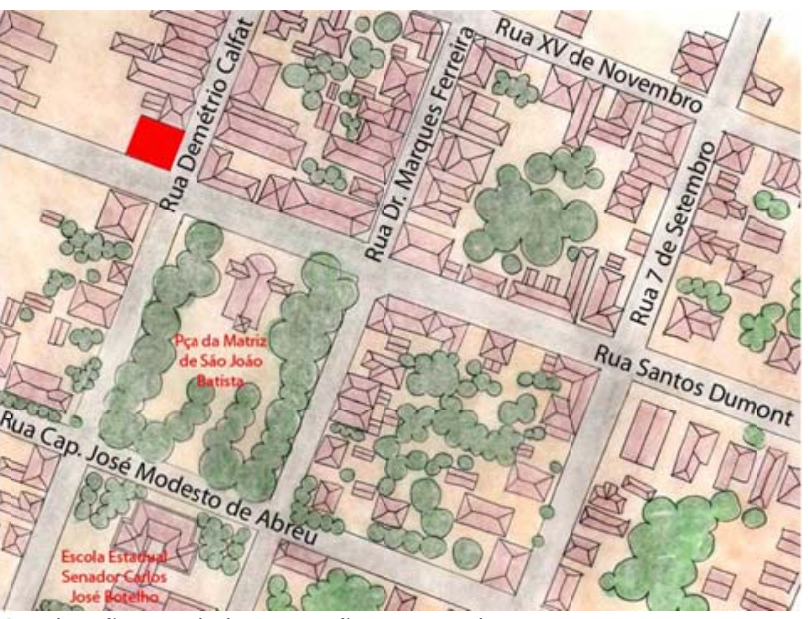

Localização na cidade - situação siem escala

Fachada principal e uso atual

\begin{tabular}{|c|c|c|c|}
\hline \multicolumn{2}{|c|}{ 1. Materiais empregados na cobertura } & \multicolumn{2}{|l|}{ 2. Coroamento } \\
\hline Destruição total & Canal & Destruição total & Platibanda X \\
\hline Francesa X & Fibrocimento & Frontão X & Cimalha \\
\hline Vidro & Metal & Cachorros & Beira seveira \\
\hline Plástico / fibra & Laje & Laje de beiral & Guarda pó \\
\hline Outros: & & Beiral simples & Outros: \\
\hline \multicolumn{2}{|c|}{ 3. Materiais do coroamento } & \multicolumn{2}{|c|}{ 4. Materiais de acabamento da fachada principa } \\
\hline Argamassa $X$ & Cantaria & Argamassa X & Chapisco X \\
\hline Azulejo antigo & Azulejo novo & Cantaria & Azulejo novo \\
\hline Madeira & Concreto aparente & Azulejo novo & Madeira \\
\hline Outros: & & Vidros & Outros: \\
\hline \multicolumn{2}{|c|}{ 5. Material das molduras dos vãos de portas e janelas } & \multicolumn{2}{|c|}{ 6. Material das esquadrias da fachada principal } \\
\hline Não tem & Destruição total & Destruição total & Madeira \\
\hline Argamassa $X$ & Cantaria & Vidro & Alumínio $X$ \\
\hline Azulejo antigo & Azulejo novo & Ferro laminado / solda X & Outros: \\
\hline Madeira & Concreto aparente & & \\
\hline \multicolumn{2}{|c|}{ 7. Cores predominantes da fachada principal } & \multicolumn{2}{|l|}{ 8. Uso atual - quantificar } \\
\hline Coroamento: rosa & Esquadrias: cinza & Residência: & Vago: \\
\hline Molduras dos vãos: branco & Acabam. da fachada: cinza/rosa & Comércio: $100 \%$ & Culto: \\
\hline Guarda-corpos: não tem & Outros relevos: branco & Serviço: & Instituição: \\
\hline
\end{tabular}

Dados volumétricos

1. Gabarito

Altura da fachada:

№ pavimentos acima do nível da rua: 01

Além desses, assinalar a existência de:

$\begin{array}{ll}\text { Porão alto } X & \text { Mirante } \\ \text { Pav. intermediário } & \text { mezanino }\end{array}$

3. Registro de acréscimos

Não tem $X$

Acréscimo vertical

Acréscimo horizontal

\section{Classificação tipológica do trelhado}

Alt. cumeeira: Número de águas do corpo principal: 04

№ subsolos: Cumeeira paralela à rua Com torreão

Cumeeira perpendicular à rua Água furtada

Pav. recuado Tipo chalé Outros:

Sótão habitável

dentificado a partir de: Descrever:

Evidência na construção $X$

Depoimento do usuário 
Identificação

Logradouro: Rua Marques Ferreira s/n

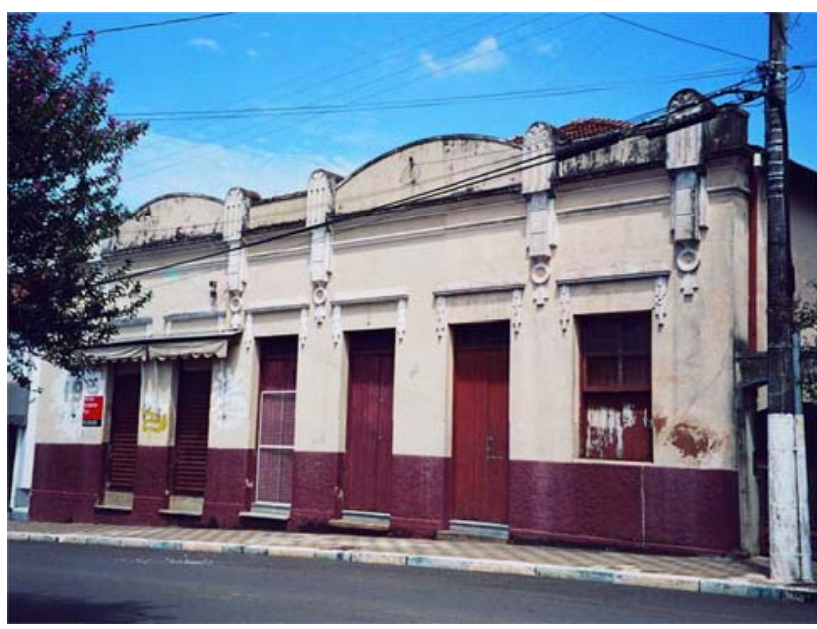

Fachada principal

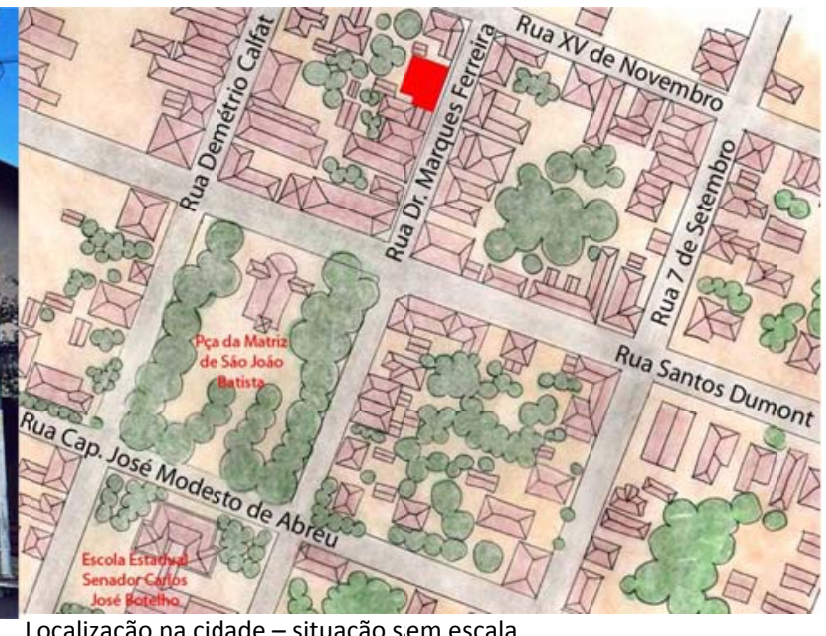

Localização na cidade - situação sem escala

Fachada principal e uso atual

\begin{tabular}{|c|c|c|c|}
\hline \multicolumn{2}{|c|}{ 1. Materiais empregados na cobertura } & \multicolumn{2}{|l|}{ 2. Coroamento } \\
\hline Destruição total & Canal & Destruição total & Platibanda X \\
\hline Francesa $X$ & Fibrocimento & Frontão & Cimalha \\
\hline Vidro & Metal & Cachorros & Beira seveira \\
\hline Plástico / fibra & Laje & Laje de beiral & Guarda pó \\
\hline Outros: & & Beiral simples & Outros: \\
\hline \multicolumn{2}{|c|}{ 3. Materiais do coroamento } & \multicolumn{2}{|c|}{ 4. Materiais de acabamento da fachada principa } \\
\hline Argamassa $X$ & Cantaria & Argamassa X & Chapisco X \\
\hline Azulejo antigo & Azulejo novo & Cantaria & Azulejo novo \\
\hline Madeira & Concreto aparente & Azulejo novo & Madeira \\
\hline Outros: & & Vidros & Outros: \\
\hline \multicolumn{2}{|c|}{ 5. Material das molduras dos vãos de portas e janelas } & \multicolumn{2}{|c|}{ 6. Material das esquadrias da fachada principal } \\
\hline Não tem & Destruição total & Destruição total & Madeira X \\
\hline Argamassa $X$ & Cantaria & Vidro $X$ & Alumínio $X$ \\
\hline Azulejo antigo & Azulejo novo & Ferro laminado / solda X & Outros: \\
\hline Madeira & Concreto aparente & & \\
\hline \multicolumn{2}{|c|}{ 7. Cores predominantes da fachada principal } & \multicolumn{2}{|l|}{ 8. Uso atual - quantificar } \\
\hline Coroamento: branco & Esquadrias: marrom & Residência: $30 \%$ & Vago: \\
\hline Molduras dos vãos: branco & Acabam. da fachada: rosa & Comércio: 70\% & Culto: \\
\hline Guarda-corpos: não tem & Outros relevos: branco & Serviço: & Instituição: \\
\hline
\end{tabular}

Dados volumétricos

\section{Gabarito} Altura da fachada:

№ pavimentos acima do nível da rua: 01

Além desses, assinalar a existência de:

$\begin{array}{lll}\text { Porão alto } & \text { Mirante } & \text { Pav. recuado } \\ \text { Pav. intermediário } & \text { mezanino } & \text { Sótão habitável }\end{array}$

2. Classificação tipológica do telhado Número de águas do corpo principal: 04

Cumeeira paralela à rua

Com torreão

Cumeeira perpendicular à rua $X$ Tipo chalé
Água furtada

Outros:

3. Registro de acréscimos

Não tem X

Acréscimo vertical

Acréscimo horizontal
Identificado a partir de:

Evidência na construção $X$

Depoimento do usuário 
Identificação

Logradouro: Rua Dr. Marques Ferreira X Rua Santos Dumont s/n

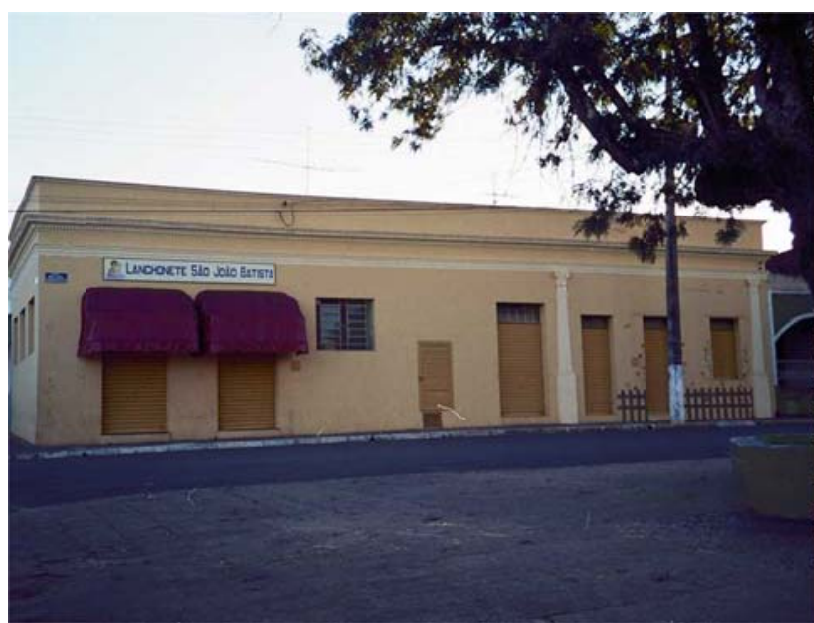

Fachada principal

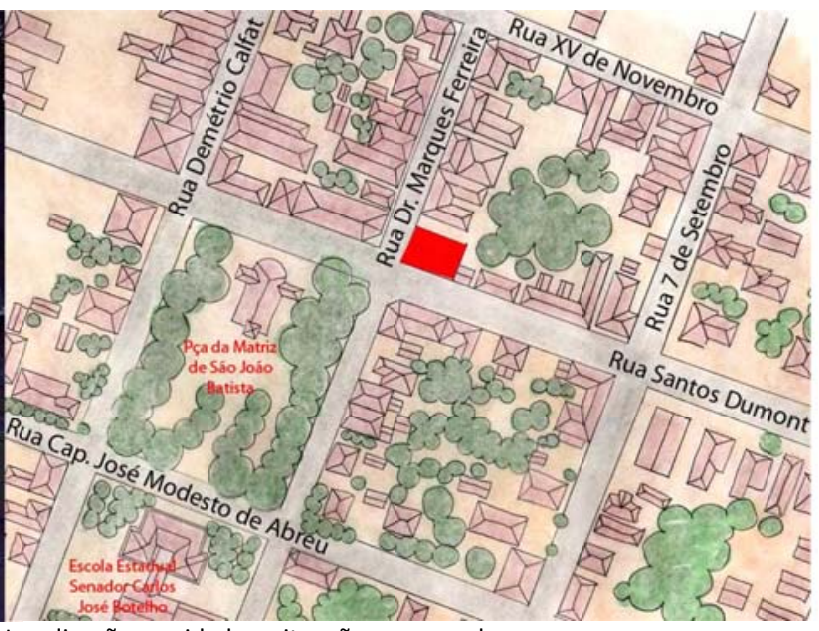

Localização na cidade - situação sem escala

Fachada principal e uso atual

$\begin{array}{ll}\text { 1. Materiais empregados na cobertura } \\ \text { Destruição total } & \text { Canal } \\ \text { Francesa X } & \text { Fibrocimento } \\ \text { Vidro } & \text { Metal } \\ \text { Plástico / fibra } & \text { Laje } \\ \text { Outros: } & \end{array}$

Outros:

2. Coroamento

Destruição total

Frontão

Cachorros

Laje de beiral

Beiral simples

4. Materiais de acabamento da fachada principal

Argamassa $\mathrm{X}$

Azulejo antigo

Madeira

Cantaria

Azulejo novo

Concreto aparente

Outros:

5. Material das molduras dos vãos de portas e janelas Não tem $X$

Argamassa

Azulejo antigo

Madeira Destruição total

Cantaria

Azulejo novo

Concreto aparente

7. Cores predominantes da fachada principal Coroamento: amarelo

Molduras dos vãos: não tem

Guarda-corpos: não tem
Esquadrias: marrom

Acabam. da fachada: amarelo

Outros relevos: branco

$\begin{array}{ll}\text { Argamassa X } & \text { Chapisco } \\ \text { Cantaria } & \text { Azulejo novo } \\ \text { Azulejo novo } & \text { Madeira } \\ \text { Vidros } & \text { Outros: }\end{array}$

6. Material das esquadrias da fachada principal

Destruição total Madeira

Vidro $X \quad$ Alumínio $X$

Ferro laminado / solda Outros:

\section{Uso atual - quantificar} Residência: Vago:

Comércio: $100 \%$ - lanchonete Culto:

Serviço: Instituição:

Dados volumétricos

\section{Gabarito} Altura da fachada:

№ pavimentos acima do nível da rua: 01 Além desses, assinalar a existência de:

Porão alto Mirante

Pav. intermediário mezanino
2. Classificação tipológica do telhado Número de águas do corpo principal: 06

Cumeeira paralela à rua $X$

Com torreão № subsolos: Cumeeira perpendicular à rua

Pav. recuado Tipo chalé Água furtada Outros:

\section{Registro de acréscimos}

Não tem $X$

Acréscimo vertical

Acréscimo horizontal
Identificado a partir de: Descrever:

Evidência na construção $X$

Depoimento do usuário 
Identificação

Logradouro: Rua Santos Dumont X Rua Dr. Marques Ferreira s/n

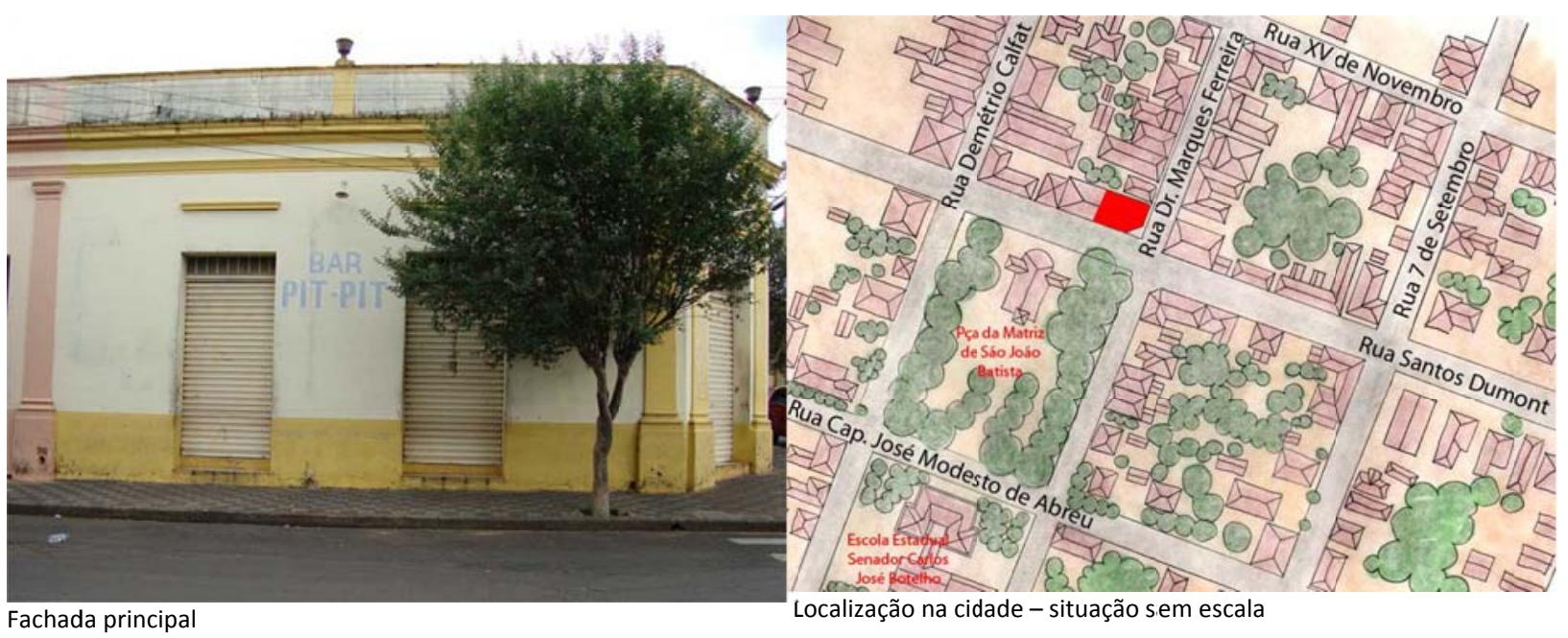

Fachada principal e uso atual

\begin{tabular}{|c|c|c|c|}
\hline \multicolumn{2}{|c|}{ 1. Materiais empregados na cobertura } & \multicolumn{2}{|l|}{ 2. Coroamento } \\
\hline Destruição total & Canal & Destruição total & Platibanda X \\
\hline Francesa $X$ & Fibrocimento & Frontão & Cimalha \\
\hline Vidro & Metal & Cachorros & Beira seveira \\
\hline Plástico / fibra & Laje & Laje de beiral & Guarda pó \\
\hline Outros: & & Beiral simples & Outros: \\
\hline \multicolumn{2}{|l|}{ 3. Materiais do coroamento } & \multicolumn{2}{|c|}{ 4. Materiais de acabamento da fachada principal } \\
\hline Argamassa $\mathrm{X}$ & Cantaria & Argamassa $\mathrm{X}$ & Chapisco \\
\hline Azulejo antigo & Azulejo novo & Cantaria & Azulejo novo \\
\hline Madeira & Concreto aparente & Azulejo novo & Madeira \\
\hline Outros: & & Vidros & Outros: \\
\hline \multicolumn{2}{|c|}{ 5. Material das molduras dos vãos de portas e janelas } & \multicolumn{2}{|c|}{ 6. Material das esquadrias da fachada principal } \\
\hline Não tem $X$ & Destruição total & Destruição total & Madeira \\
\hline Argamassa & Cantaria & Vidro $X$ & Alumínio $X$ \\
\hline Azulejo antigo & Azulejo novo & Ferro laminado / solda X & Outros: \\
\hline Madeira & Concreto aparente & & \\
\hline \multicolumn{2}{|c|}{ 7. Cores predominantes da fachada principal } & \multicolumn{2}{|l|}{ 8. Uso atual - quantificar } \\
\hline Coroamento: amarelo & Esquadrias: branco & Residência: & Vago: \\
\hline Molduras dos vãos: não tem & Acabam. da fachada: branco & Comércio: $100 \%$ - bar & Culto: \\
\hline Guarda-corpos: não tem & Outros relevos: amarelo & Serviço: & Instituição: \\
\hline
\end{tabular}

Dados volumétricos

\begin{tabular}{|c|c|c|c|c|}
\hline \multicolumn{3}{|l|}{ 1. Gabarito } & \multicolumn{2}{|c|}{ 2. Classificação tipológica do telhado } \\
\hline \multicolumn{2}{|l|}{ Altura da fachada: } & Alt. cumeeira: & \multicolumn{2}{|c|}{ Número de águas do corpo principal: 05} \\
\hline \multicolumn{2}{|c|}{ № pavimentos acima do nível da rua: 01} & № subsolos: & Cumeeira paralela à rua $\mathrm{X}$ & Com torreão \\
\hline Além desses, assina & existência de: & & Cumeeira perpendicular à rua & Água furtada \\
\hline Porão alto & Mirante & Pav. recuado & Tipo chalé & Outros: \\
\hline
\end{tabular}

3. Registro de acréscimos

Não tem X

Acréscimo vertical

Acréscimo horizontal

Identificado a partir de:

Descrever:

Depoimento do usuário 
Identificação

Logradouro: Rua Santos Dumont no 350

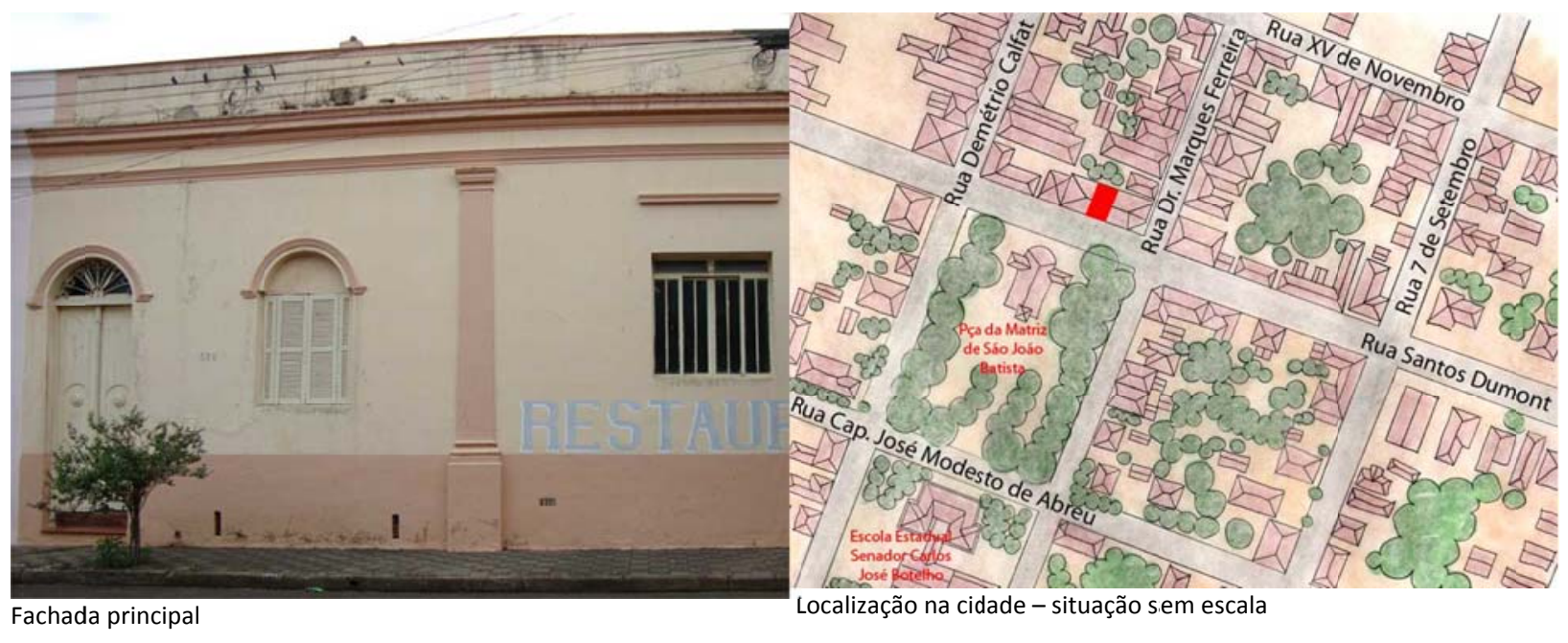

Fachada principal e uso atual

\begin{tabular}{|c|c|c|c|}
\hline \multicolumn{2}{|c|}{ 1. Materiais empregados na cobertura } & \multicolumn{2}{|l|}{ 2. Coroamento } \\
\hline Destruição total & Canal & Destruição total & Platibanda X \\
\hline Francesa $X$ & Fibrocimento & Frontão & Cimalha \\
\hline Vidro & Metal & Cachorros & Beira seveira \\
\hline Plástico / fibra & Laje & Laje de beiral & Guarda pó \\
\hline Outros: & & Beiral simples & Outros: \\
\hline \multicolumn{2}{|c|}{ 3. Materiais do coroamento } & \multicolumn{2}{|c|}{ 4. Materiais de acabamento da fachada principal } \\
\hline Argamassa $X$ & Cantaria & Argamassa $\mathrm{X}$ & Chapisco \\
\hline Azulejo antigo & Azulejo novo & Cantaria & Azulejo novo \\
\hline Madeira & Concreto aparente & Azulejo & Madeira \\
\hline Outros: & & Vidros & Outros: \\
\hline \multicolumn{2}{|c|}{ 5. Material das molduras dos vãos de portas e janelas } & \multicolumn{2}{|c|}{ 6. Material das esquadrias da fachada principal } \\
\hline Não tem & Destruição total & Destruição total & Madeira X \\
\hline Argamassa $X$ & Cantaria & Vidro X & Alumínio \\
\hline Azulejo antigo & Azulejo novo & Ferro laminado / solda & Outros: \\
\hline Madeira & Concreto aparente & & \\
\hline \multicolumn{2}{|c|}{ 7. Cores predominantes da fachada principal } & \multicolumn{2}{|c|}{ 8. Uso atual - quantificar } \\
\hline Coroamento: rosa & Esquadrias: branco & Residência: 100\% & Vago: \\
\hline Molduras dos vãos: rosa & Acabam. da fachada: rosa & Comércio: & Culto: \\
\hline Guarda-corpos: não tem & Outros relevos: rosa & Serviço: & Instituição: \\
\hline
\end{tabular}

Dados volumétricos

\begin{tabular}{|c|c|c|c|c|}
\hline \multicolumn{3}{|l|}{ 1. Gabarito } & \multicolumn{2}{|c|}{ 2. Classificação tipológica do telhado } \\
\hline \multicolumn{2}{|l|}{ Altura da fachada: } & Alt. cumeeira: & \multicolumn{2}{|c|}{ Número de águas do corpo principal: 03} \\
\hline \multicolumn{2}{|c|}{ № pavimentos acima do nível da rua: 01} & № subsolos: & Cumeeira paralela à rua $\mathrm{X}$ & Com torreão \\
\hline Além desses, assina & existência de: & & Cumeeira perpendicular à rua & Água furtada \\
\hline $\begin{array}{l}\text { Porão alto } X \\
\text { Pav. intermediário }\end{array}$ & $\begin{array}{l}\text { Mirante } \\
\text { mezanino }\end{array}$ & $\begin{array}{l}\text { Pav. recuado } \\
\text { Sótão habitável }\end{array}$ & Tipo chalé & Outros: \\
\hline
\end{tabular}

3. Registro de acréscimos

Não tem X

Acréscimo vertical

Acréscimo horizontal

Identificado a partir de:

Descrever:

Depoimento do usuário 
Identificação

Logradouro: Rua Santos Dumont no 352

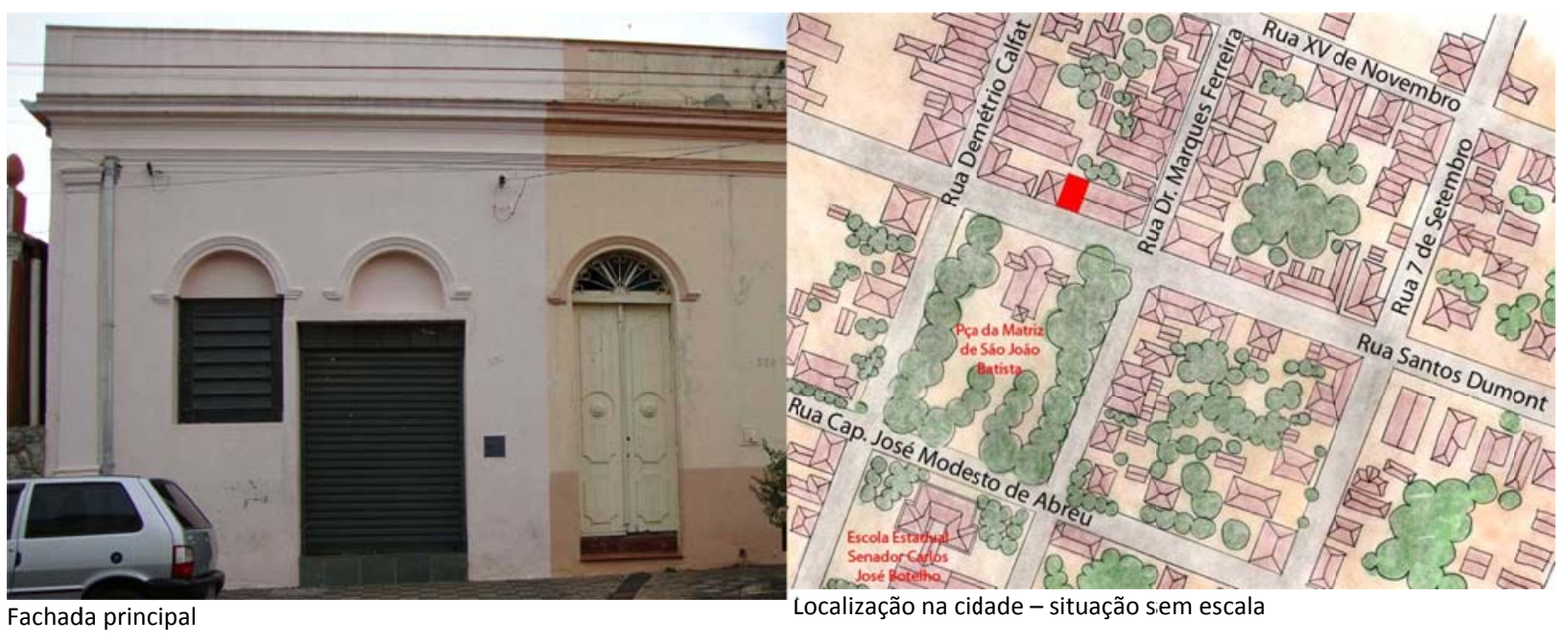

Fachada principal e uso atual

\begin{tabular}{|c|c|c|c|}
\hline \multicolumn{2}{|c|}{ 1. Materiais empregados na cobertura } & \multicolumn{2}{|l|}{ 2. Coroamento } \\
\hline Destruição total & Canal & Destruição total & Platibanda \\
\hline Francesa X & Fibrocimento & Frontão & Cimalha X \\
\hline Vidro & Metal & Cachorros & Beira seveira \\
\hline Plástico / fibra & Laje & Laje de beiral & Guarda pó \\
\hline Outros: & & Beiral simples & Outros: \\
\hline \multicolumn{2}{|c|}{ 3. Materiais do coroamento } & \multicolumn{2}{|c|}{ 4. Materiais de acabamento da fachada principal } \\
\hline Argamassa X & Cantaria & Argamassa X & Chapisco \\
\hline Azulejo antigo & Azulejo novo & Cantaria & Azulejo novo \\
\hline Madeira & Concreto aparente & Azulejo novo & Madeira \\
\hline Outros: & & Vidros & Outros: \\
\hline \multicolumn{2}{|c|}{ 5. Material das molduras dos vãos de portas e janelas } & \multicolumn{2}{|c|}{ 6. Material das esquadrias da fachada principal } \\
\hline Não tem & Destruição total & Destruição total & Madeira \\
\hline Argamassa X & Cantaria & Vidro X & Alumínio $X$ \\
\hline Azulejo antigo & Azulejo novo & Ferro laminado / solda X & Outros: \\
\hline Madeira & Concreto aparente & & \\
\hline \multicolumn{2}{|c|}{ 7. Cores predominantes da fachada principal } & \multicolumn{2}{|l|}{ 8. Uso atual - quantificar } \\
\hline Coroamento: rosa & Esquadrias: cinza & Residência: & Vago: \\
\hline Molduras dos vãos: rosa & Acabam. da fachada: rosa & Comércio: $100 \%$ & Culto: \\
\hline Guarda-corpos: & Outros relevos: rosa & Serviço: & Instituição: \\
\hline
\end{tabular}

Dados volumétricos

\begin{tabular}{|c|c|c|c|c|}
\hline \multicolumn{3}{|l|}{ 1. Gabarito } & \multicolumn{2}{|c|}{ 2. Classificação tipológica do telhado } \\
\hline \multicolumn{2}{|c|}{ Altura da fachada: } & \multirow{2}{*}{$\begin{array}{l}\text { Alt. cumeeira: } \\
\text { № subsolos: }\end{array}$} & \multicolumn{2}{|c|}{ Número de águas do corpo principal: 03} \\
\hline № pavimentos acir & o nível da rua: 01 & & Cumeeira paralela à rua $\mathrm{X}$ & Com torreão \\
\hline \multicolumn{3}{|c|}{ Além desses, assinalar a existência de: } & Cumeeira perpendicular à rua & Água furtada \\
\hline Porão alto & Mirante & Pav. recuado & Tipo chalé & Outros: \\
\hline Pav. intermediário & mezanino & Sótão habitável & & \\
\hline
\end{tabular}

3. Registro de acréscimos

Não tem X

Acréscimo vertical

Acréscimo horizontal

Identificado a partir de:

Descrever: 
Identificação

Logradouro: Rua Dr. Marques Ferreira no 411

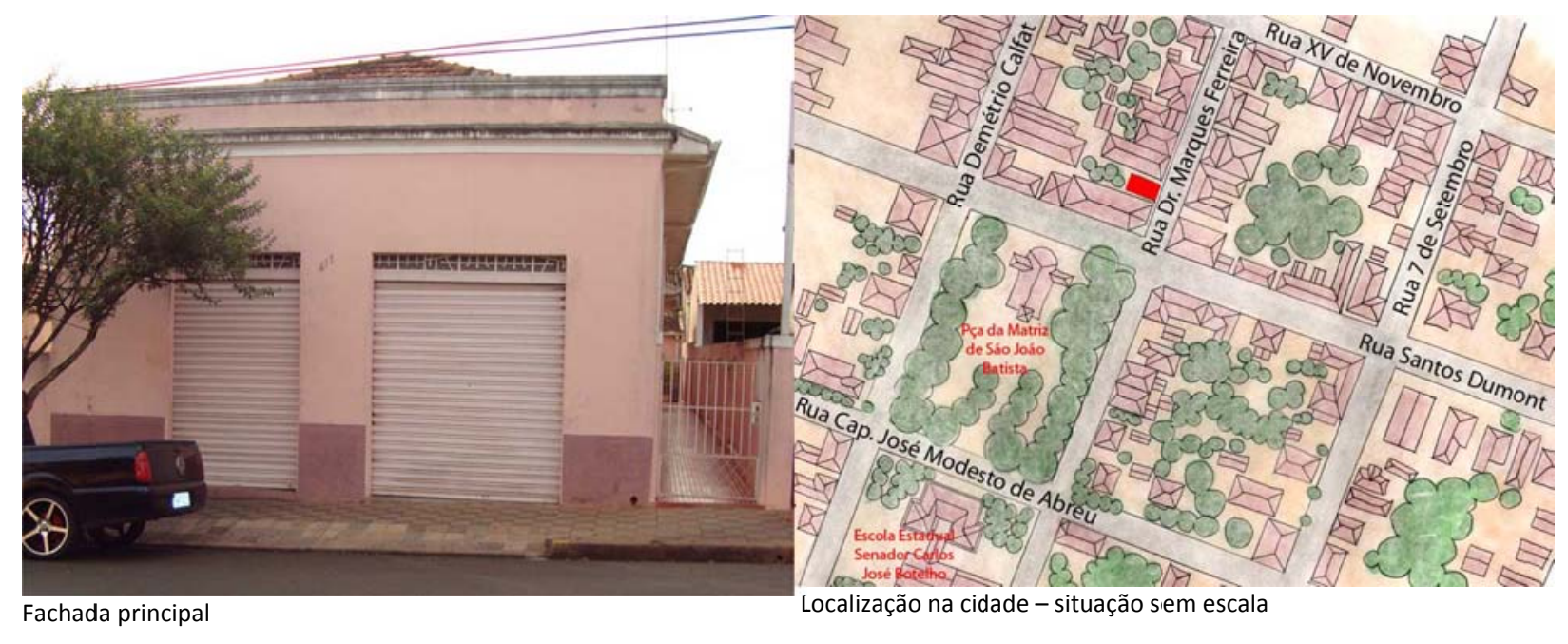

Fachada principal e uso atual

$\begin{array}{ll}\text { 1. Materiais empregados na cobertura } & \text { Canal } \\ \text { Destruição total } & \text { Fibrocimento } \\ \text { Francesa X } & \text { Metal } \\ \text { Vidro } & \text { Laje } \\ \text { Plástico / fibra } & \end{array}$

\section{Materiais do coroamento}

Argamassa $X$

Azulejo antigo

Cantaria

Madeira

Azulejo novo

Concreto aparente

\section{Coroamento}

Destruição total

Frontão

Cachorros

Laje de beiral

Beiral simples

4. Materiais de acabamento dal fachada principal

Argamassa $X \quad$ Chapisco $X$

Cantaria Azulejo novo

Azulejo novo Madeira

Vidros

Outros:

6. Material das esquadrias da fachada principal

5. Material das molduras dos vãos de portas e janelas

Não tem $X$

Argamassa

Azulejo antigo

Destruição total

Cantaria

Madeira

Azulejo novo

Concreto aparente

7. Cores predominantes da fachada principal

Coroamento: rosa

Esquadrias: branco

Molduras dos vãos: não tem

Acabam. da fachada: rosa

Outros relevos: rosa

Madeira

Vidro Alumínio $X$

Ferro laminado / solda $X \quad$ Outros:

$\begin{array}{ll}\text { 8. Uso atual - quantificar } & \\ \text { Residência: } 50 \% & \text { Vago: } \\ \text { Comércio: } 50 \% & \text { Culto: } \\ \text { Serviço: } & \text { Instituição: }\end{array}$

Dados volumétricos

\section{Gabarito}

Altura da fachada:

№ pavimentos acima do nível da rua: 01

Além desses, assinalar a existência de:

Porão alto Mirante

Pav. intermediário mezanino

3. Registro de acréscimos

Não tem $X$

Acréscimo vertical

Acréscimo horizontal
Identificado a partir de:

Evidência na construção $X$

Depoimento do usuário
2. Classificação tipológica do telhado Número de águas do corpo principal: 04

Cumeeira paralela à rua

Com torreão

Cumeeira perpendicular à rua $X$

Tipo chalé

Água furtada

Outros: 
Identificação

Logradouro: Rua Dr. Marques Ferreira s/n

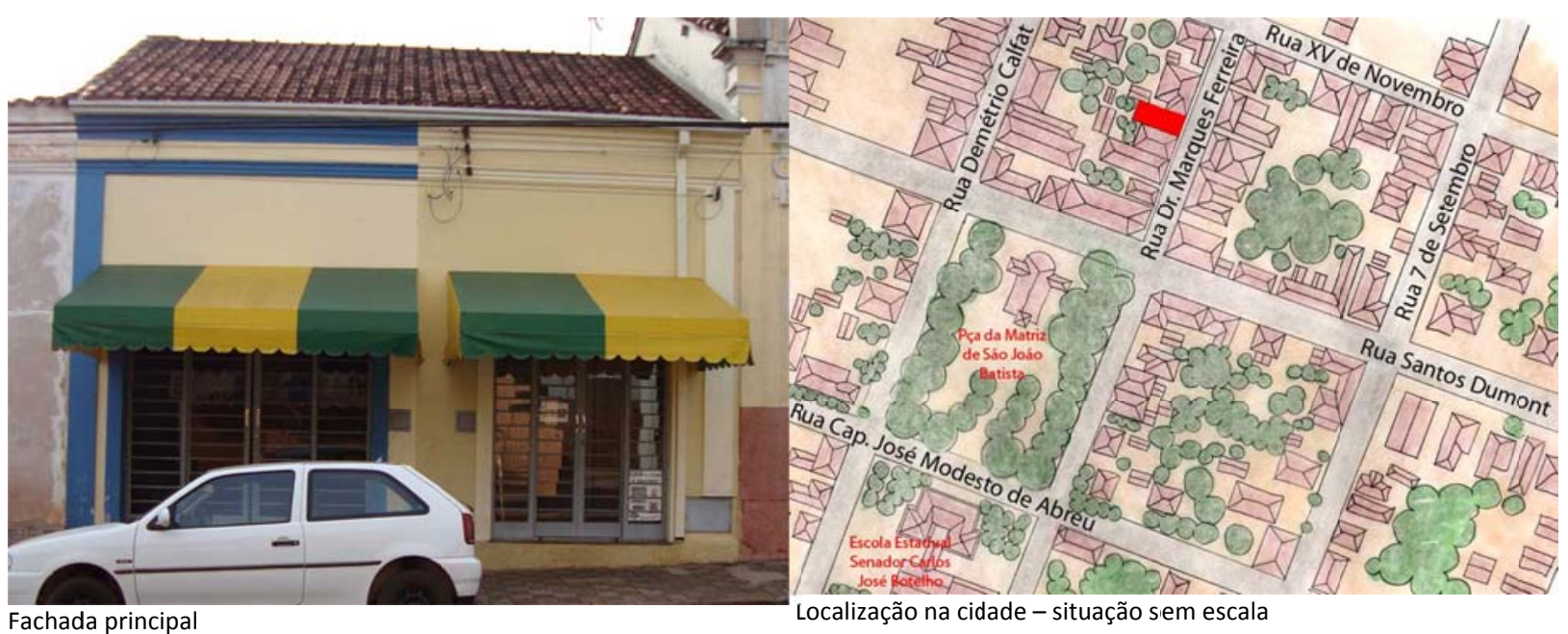

Fachada principal e uso atual

1. Materiais empregados na cobertura

Destruição total

Francesa

Vidro

\section{Canal X}

Fibrocimento

Metal

Plástico / fibra

Laje

Outros:

3. Materiais do coroamento

Argamassa X

Azulejo antigo

Madeira

Outros:

5. Material das molduras dos vãos de portas e janelas Não tem

Argamassa $X$

Azulejo antigo

Madeira

Coroamento: azul/branco/bege Esquadrias: cinza

Molduras dos vãos: branco/azul

Guarda-corpos: não tem

Acabam. da fachada: bege

Outros relevos:

Cantaria

Azulejo novo

Concreto aparente

Destruição total

Cantaria

Azulejo novo

2. Coroamento
Destruição total
Frontão
Cachorros
Laje de beiral
Beiral simples

4. Materiais de acabamento da fachada principal

Argamassa X Chapisco

Cantaria Azulejo novo

Azulejo novo Madeira

Vidros Outros:

6. Material das esquadrias da fachada principal

Destruição total Madeira

Vidro $X \quad$ Alumínio $X$

Ferro laminado / solda Outros:

8. Uso atual - quantificar

Residência: Vago:

Comércio: $100 \% \quad$ Culto:

Serviço: Instituição:
Dados volumétricos

\section{Gabarito}

Altura da fachada:

№ pavimentos acima do nível da rua: 01

Além desses, assinalar a existência de:

Porão alto Mirante

Pav. intermediário mezanino

3. Registro de acréscimos

Não tem $X$

Acréscimo vertical

Acréscimo horizontal

\section{Alt. cumeeira: \\ № subsolos:}

Pav. recuado

Sótão habitável
2. Classificação tipológica do telhado Número de águas do corpo principal:

Cumeeira paralela à rua $\mathrm{X}$
Cumeeira perpendicular à rua

Tipo chalé

Com torreão

Água furtada

Outros:
Identificado a partir de: Descrever:

Evidência na construção $X$

Depoimento do usuário 
Ficha de pré-inventário do patrimônio arquitetônico e urbanístico de Dourado - SP Características Arquitetônicas - Ficha 27

Identificação

Logradouro: Rua Dr. Marques Ferreira s/n

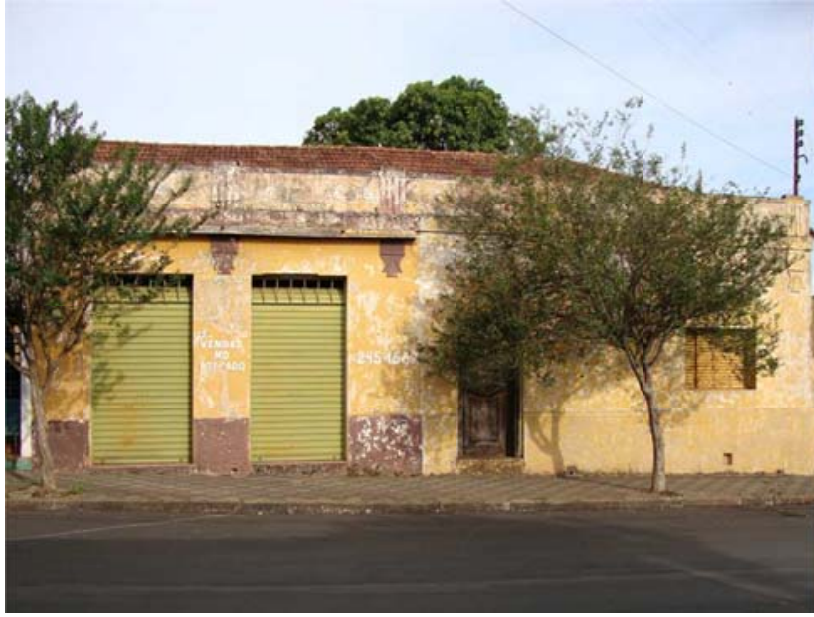

Fachada principal

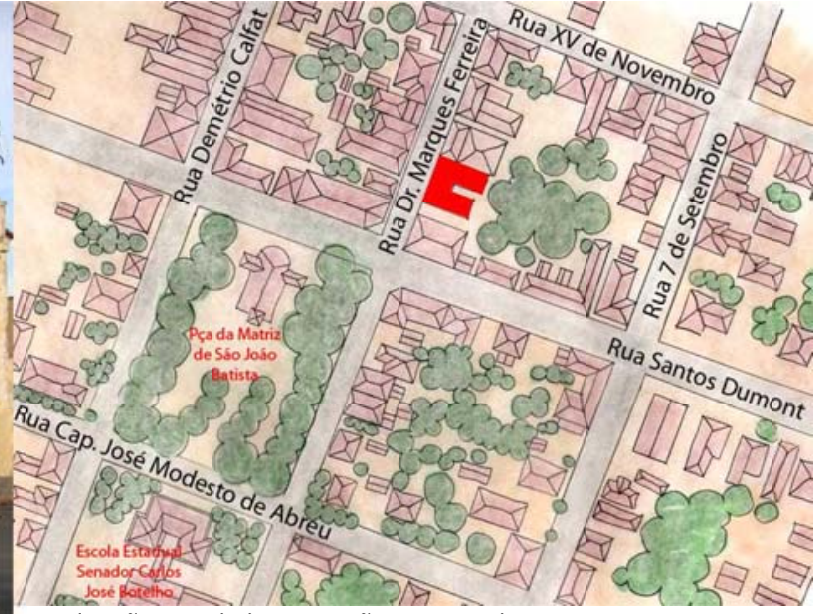

Localização na cidade - situação sem escala

Fachada principal e uso atual

1. Materiais empregados na cobertura

Destruição total Canal

Francesa X

Fibrocimento

Vidro

Metal

Plástico / fibra

Laje

Outros:

3. Materiais do coroamento

Argamassa X

Azulejo antigo

Madeira

Cantaria

Azulejo novo

Outros:

Concreto aparente

5. Material das molduras dos vãos de portas e janelas

Não tem X

Argamassa

Azulejo antigo

Destruição total

Cantaria

Azulejo novo

Concreto aparente

7. Cores predominantes da fachada principal

Coroamento: amarelo/marrom Esquadrias: verde/bege/natual

Molduras dos vãos: não tem

Acabam. da fachada: amarelo

Guarda-corpos: não tem

\section{Coroamento}

Destruição total

Frontão

Cachorros

Laje de beiral

Beiral simples

4. Materiais de acabamento da fachada principal

Argamassa X Chapisco

Cantaria Azulejo novo

Azulejo novo Madeira

Vidros Outros:

6. Material das esquadrias da fachada principal

Destruição total Madeira $X$

Vidro Alumínio $X$

Ferro laminado / solda $X$ Outros:

\section{Uso atual - quantificar}

Residência: $50 \%$

Comércio: $50 \%$

Serviço:

Vago:

Culto:

Instituição:

Dados volumétricos

\section{Gabarito}

Altura da fachada:

№ pavimentos acima do nível da rua: 01

Além desses, assinalar a existência de:

Porão alto Mirante

Pav. intermediário mezanino

\section{Classificação tipológica do telhado}

Alt. cumeeira: $\quad$ Número de águas do corpo principal: 04

№ subsolos:

Cumeeira paralela à rua $X$

Com torreão

Cumeeira perpendicular à rua

Água furtada

Tipo chalé

Outros:

Pav. recuado

3. Registro de acréscimos

Não tem $X$

Sótão habitável

Acréscimo vertical

Acréscimo horizontal

\section{Identificado a partir de:}

Evidência na construção $X$

Depoimento do usuário

\section{Descrever:}


Ficha de pré-inventário do patrimônio arquitetônico e urbanístico de Dourado - SP Características Arquitetônicas - Ficha 28

Identificação

Logradouro: Rua Dr. Marques Ferreira s/n

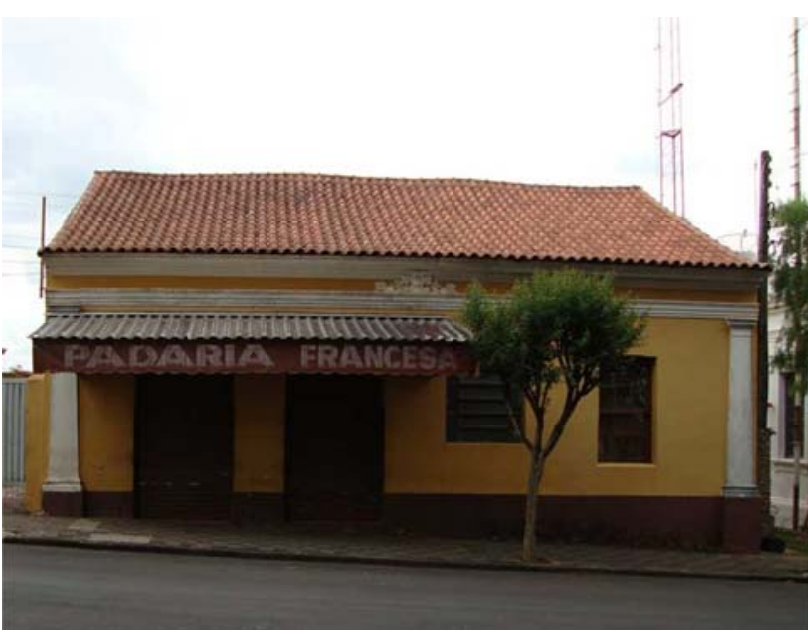

Fachada principal

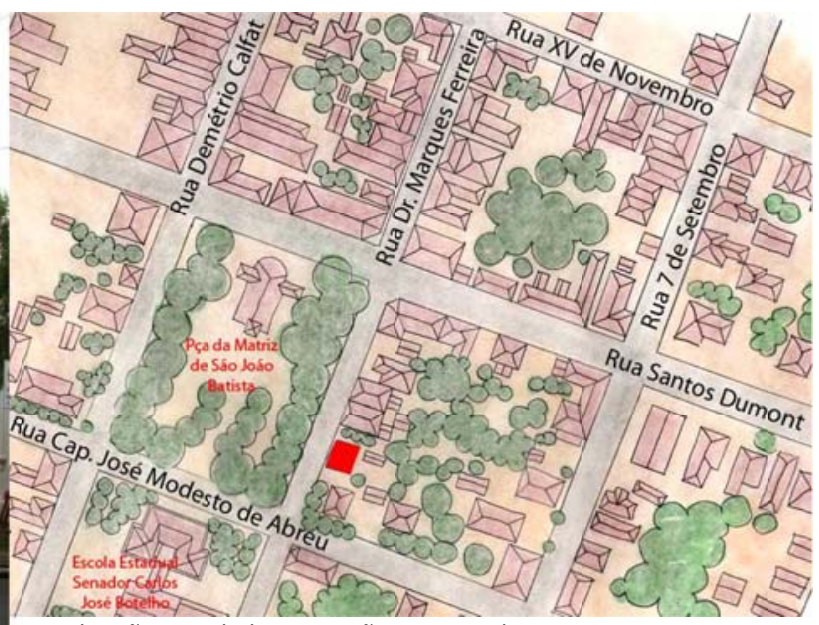

Localização na cidade - situação sem escala

Fachada principal e uso atual

1. Materiais empregados na cobertura

2. Coroamento

Destruição total Canal X

Francesa Fibrocimento

Vidro Metal

Plástico / fibra Laje

Outros:

Laje Laje de beiral

3. Materiais do coroamento

Argamassa $X$

Azulejo antigo

Cantaria

Beiral simples

Platibanda

Destruição total

Frontão

Cimalha $X$

Beira seveira

Guarda pó

Outros:

4. Materiais de acabamento da fachada principal

Madeira

Azulejo novo

Argamassa $X$

Chapisco

Cantaria Azulejo novo

Azulejo novo Madeira

Outros:

Vidros

Outros:

5. Material das molduras dos vãos de portas e janelas

Não tem $X$

Destruição total

Argamassa

Cantaria

6. Material das esquadrias da fachada principal

Destruição total

Madeira

Azulejo antigo

Azulejo novo

Vidro

Alumínio X

Madeira

Concreto aparente

7. Cores predominantes da fachada principal

Coroamento: branco

Esquadrias: marrom

Molduras dos vãos: marrom

Acabam. da fachada: amarelo

Ferro laminado / solda X

Outros:

Guarda-corpos: não tem

Outros relevos: branco

8. Uso atual - quantificar

Residência:

Comércio: 100\%

Vago:

Serviço:

Culto:

Instituição:

Dados volumétricos

\section{Gabarito}

Altura da fachada:

№ pavimentos acima do nível da rua: 01

\section{Alt. cumeeira:}

№ subsolos:

Além desses, assinalar a existência de:

Porão alto Mirante

Pav. intermediário mezanino
Pav. recuado

Sótão habitável

\section{Classificação tipológica do telhado} Número de águas do corpo principal: 02

Cumeeira paralela à rua $X$

Com torreão

Cumeeira perpendicular à rua

Água furtada

Tipo chalé

Outros:

3. Registro de acréscimos

\section{Não tem $X$}

Acréscimo vertical

Acréscimo horizontal
Identificado a partir de: Descrever:

Evidência na construção $X$

Depoimento do usuário 
Ficha de pré-inventário do patrimônio arquitetônico e urbanístico de Dourado - SP

Características Arquitetônicas - Ficha 29

Identificação

Logradouro: Rua Dr. Marques Ferreira X Rua XV de Novembro

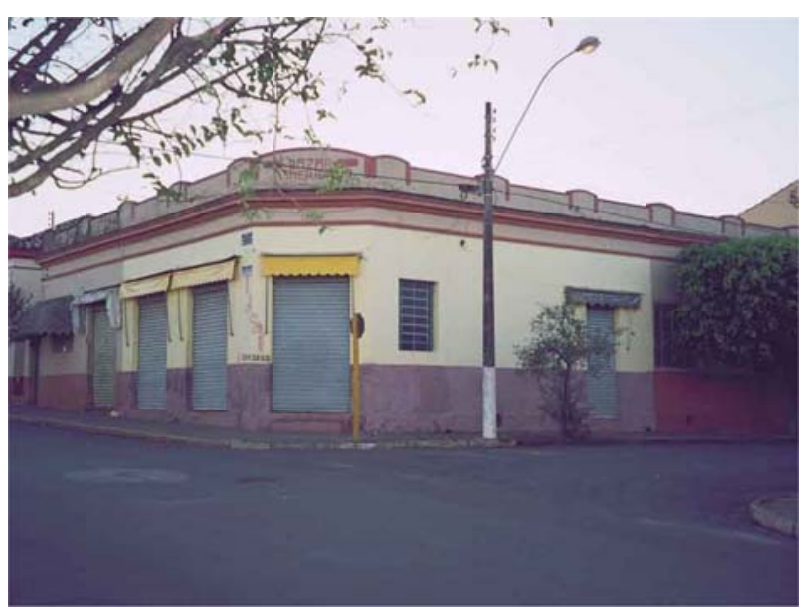

Fachada principal

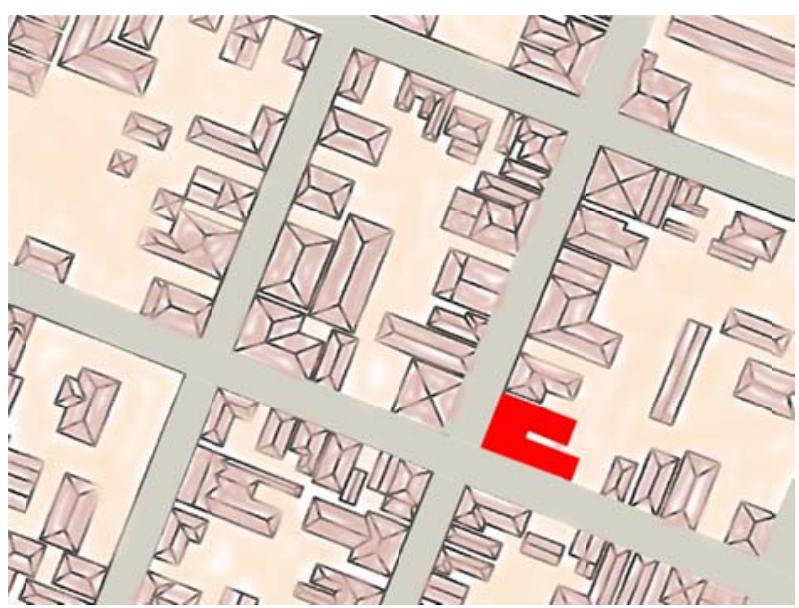

Localização na cidade - situação sem escala

Fachada principal e uso atual

1. Materiais empregados na cobertura

Destruição total Canal

Francesa X

Vidro

Fibrocimento

Metal

Plástico / fibra

Laje

Outros:

3. Materiais do coroamento

Argamassa $X$

Azulejo antigo

Cantaria

Azulejo novo

Madeira

Concreto aparente

Outros:

5. Material das molduras dos vãos de portas e janelas

Não tem X

Argamassa

Azulejo antigo

Destruição total

Cantaria

Azulejo novo

Madeira

Concreto aparente

7. Cores predominantes da fachada principal

Coroamento: bege / marrom

Molduras dos vãos: não tem

Esquadrias: cinza

Acabam. da fachada: amarelo

Guarda-corpos: não tem

Outros relevos: marrom

\section{Coroamento}

Destruição total

Frontão

Cachorros

Laje de beiral

Beiral simples

4. Materiais de acabamento da fachada principal

Argamassa Chapisco $X$

Cantaria Azulejo novo

Azulejo novo Madeira

Vidros

Outros:

6. Material das esquadrias da fachada principal

Destruição total Madeira

Vidro $X \quad$ Alumínio $X$

Ferro laminado / solda $X$ Outros:

8. Uso atual - quantificar

Residência: $20 \%$

Comércio: $80 \%$

Vago:

Serviço:

Instituição:

Dados volumétricos

\begin{tabular}{|c|c|c|c|c|}
\hline \multicolumn{3}{|l|}{ 1. Gabarito } & \multicolumn{2}{|c|}{ 2. Classificação tipológica do telhado } \\
\hline Altura da fachada: & & Alt. cumeeira: & \multicolumn{2}{|c|}{ Número de águas do corpo principal: 07} \\
\hline \multicolumn{2}{|c|}{ № pavimentos acima do nível da rua: 01} & № subsolos: & Cumeeira paralela à rua $X$ & Com torreão \\
\hline \multicolumn{3}{|c|}{ Além desses, assinalar a existência de: } & Cumeeira perpendicular à rua & Água furtada \\
\hline Porão alto & Mirante & Pav. recuado & Tipo chalé & Outros: \\
\hline Pav. intermediário & mezanino & Sótão habitável & & \\
\hline
\end{tabular}

Pav intermediário mezanino

Sótão habitável

3. Registro de acréscimos

Não tem X

Acréscimo vertical

Acréscimo horizontal
Identificado a partir de:

Evidência na construção

Depoimento do usuário
Descrever: 
Identificação

Logradouro: Rua Dr. Marques Ferreira X Rua Dr. Borja Cardoso

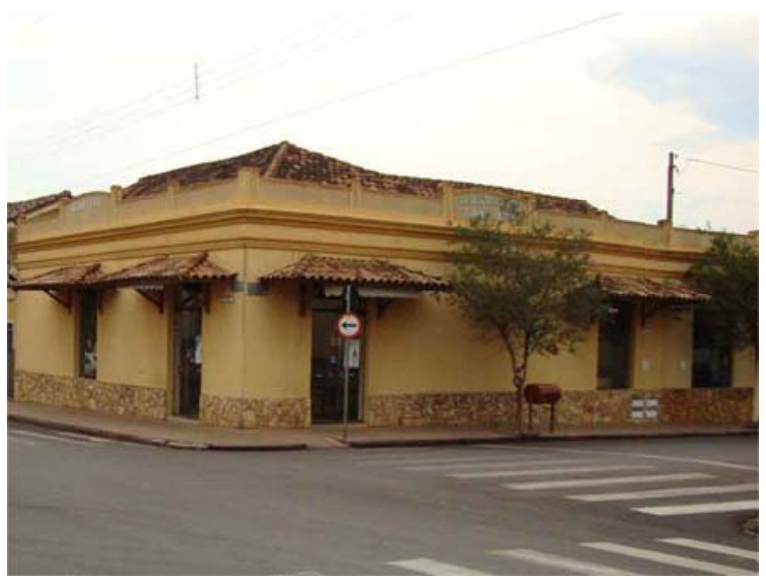

Fachada principal

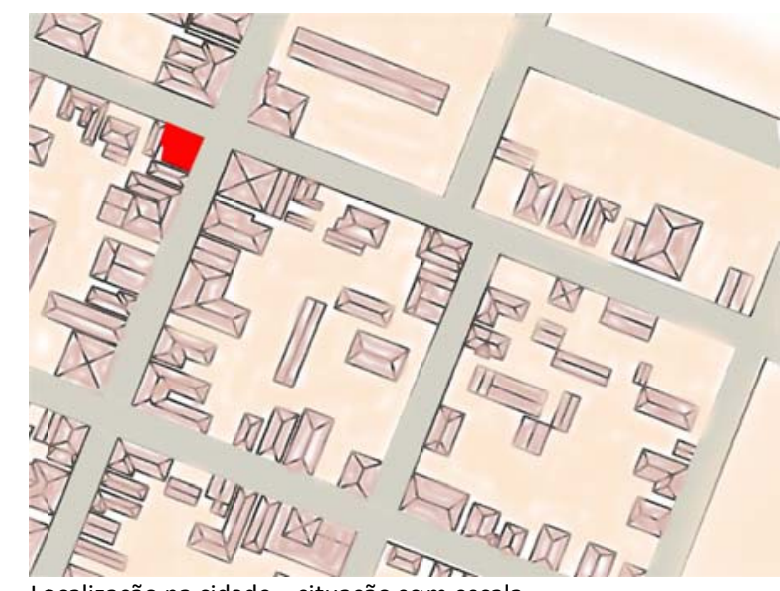

Localização na cidade - situação sem escala

Fachada principal e uso atual

$\begin{array}{ll}\text { 1. Materiais empregados na cobertura } \\ \text { Destruição total } & \text { Canal X } \\ \text { Francesa } & \text { Fibrocimento } \\ \text { Vidro } & \text { Metal } \\ \text { Plástico / fibra } & \text { Laje } \\ \text { Outros: } & \end{array}$

\section{Materiais do coroamento}

Argamassa $X$

Cantaria

Azulejo antigo

Azulejo novo

Madeira

Concreto aparente

\section{Coroamento}

Destruição total

Frontão

Cachorros

Laje de beiral

Beiral simples

Platibanda X

Cimalha

Beira seveira

Guarda pó

Outros:

4. Materiais de acabamento da fachada principal

Argamassa X Chapisco

Cantaria Azulejo novo

Azulejo novo Madeira

Vidros Outros: pedra

\begin{tabular}{|c|c|c|c|}
\hline \multicolumn{2}{|c|}{ 5. Material das molduras dos vãos de portas e janelas } & \multicolumn{2}{|c|}{ 6. Material das esquadrias da fachada principal } \\
\hline Não tem X & Destruição total & Destruição total & Madeira \\
\hline Argamassa & Cantaria & Vidro $X$ & Alumínio \\
\hline Azulejo antigo & Azulejo novo & Ferro laminado / solda X & Outros: \\
\hline Madeira & Concreto aparente & & \\
\hline \multicolumn{2}{|c|}{ 7. Cores predominantes da fachada principal } & \multicolumn{2}{|l|}{ 8. Uso atual - quantificar } \\
\hline Coroamento: amarelo & Esquadrias: ---- & Residência: & Vago: \\
\hline Molduras dos vãos: não tem & Acabam. da fachada: amarelo & Comércio: $100 \%$ & Culto: \\
\hline Guarda-corpos: não tem & Outros relevos: amarelo & Serviço: & Instituição: \\
\hline
\end{tabular}

Dados volumétricos

\section{Gabarito}

Altura da fachada:

№ pavimentos acima do nível da rua: 01

Além desses, assinalar a existência de:

Porão alto Mirante

Pav. intermediário mezanino
2. Classificação tipológica do telhado Número de águas do corpo principal: 06

Cumeeira paralela à rua $X$

Com torreão

№ subsolos:

Pav. recuado

Cumeeira perpendicular à rua

Tipo chalé

Água furtada

Outros:

3. Registro de acréscimos

Não tem X

Acréscimo vertical

Acréscimo horizontal
Identificado a partir de:

Descrever:
Evidência na construção $X$

Depoimento do usuário 
Identificação

Logradouro: Rua Dr. Marques Ferreira X Rua XV de Novembro

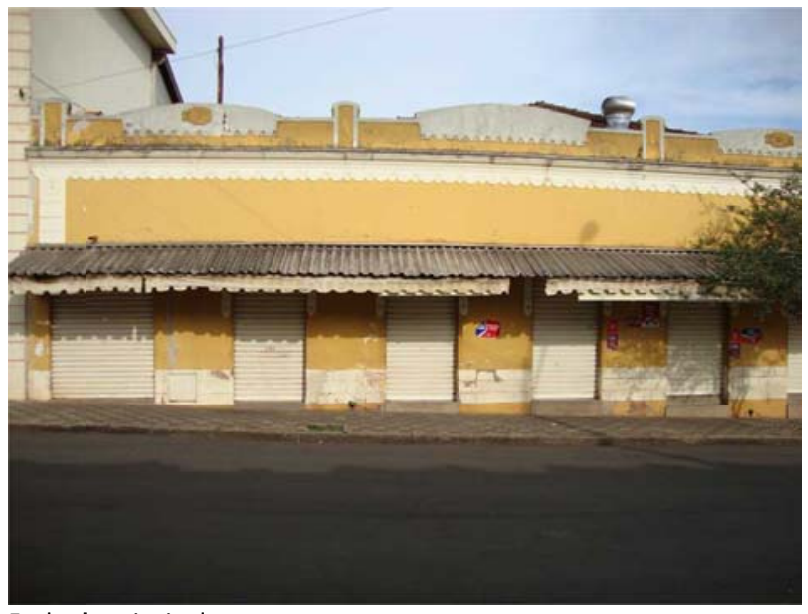

Fachada principal

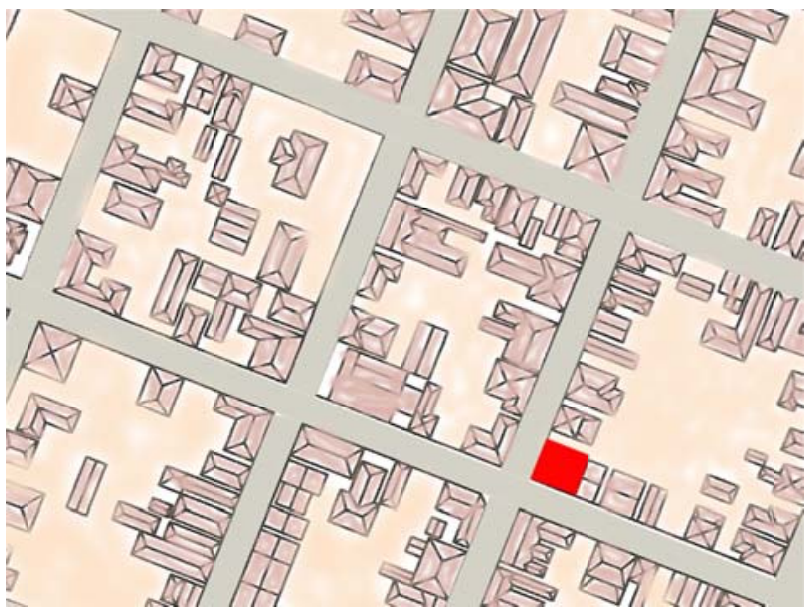

Localização na cidade - situação se m escala

Fachada principal e uso atual

$\begin{array}{ll}\text { 1. Materiais empregados na cobertura } \\ \text { Destruição total } & \text { Canal } \\ \text { Francesa X } & \text { Fibrocimento } \\ \text { Vidro } & \text { Metal } \\ \text { Plástico / fibra } & \text { Laje } \\ \text { Outros: } & \end{array}$

\section{Coroamento}

Destruição total Platibanda X

Frontão Cimalha

Cachorros Beira seveira

Laje de beiral Guarda pó

Beiral simples Outros:

3. Materiais do coroamento Argamassa $X$

\section{Cantaria}

Azulejo novo

Azulejo antigo

Concreto aparente

Outros:

5. Material das molduras dos vãos de portas e janelas Não tem X

Argamassa

Azulejo antigo

Madeira

7. Cores predominantes da fachada principal

Coroamento: amarelo / branco

Molduras dos vãos: não tem

Acabam. da fachada: amarelo

Guarda-corpos: não tem
4. Materiais de acabamento da fachada principal

Argamassa $X \quad$ Chapisco

Cantaria Azulejo novo

Azulejo novo Madeira

Vidros Outros:

6. Material das esquadrias da fachada principal

Destruição total Madeira

Vidro Alumínio $X$

Ferro laminado / solda $X$ Outros:

8. Uso atual - quantificar

Residência:

Serviço: Instituição:
Dados volumétricos

\section{Gabarito}

Altura da fachada:

№ pavimentos acima do nível da rua: 01

Além desses, assinalar a existência de:

Porão alto Mirante

Pav. intermediário

mezanino

3. Registro de acréscimos

Não tem $X$

Acréscimo vertical

Acréscimo horizontal

\section{Alt. cumeeira: \\ № subsolos:}

Pav. recuado

Sótão habitável
2. Classificação tipológica do telhado Número de águas do corpo principal: 04

$\begin{array}{ll}\text { Cumeeira paralela à rua } X & \text { Com torreão } \\ \text { Cumeeira perpendicular à rua } & \text { Água furtada } \\ \text { Tipo chalé } & \text { Outros: }\end{array}$


Identificação

Logradouro: Rua Dr. Marques Ferreira s/n

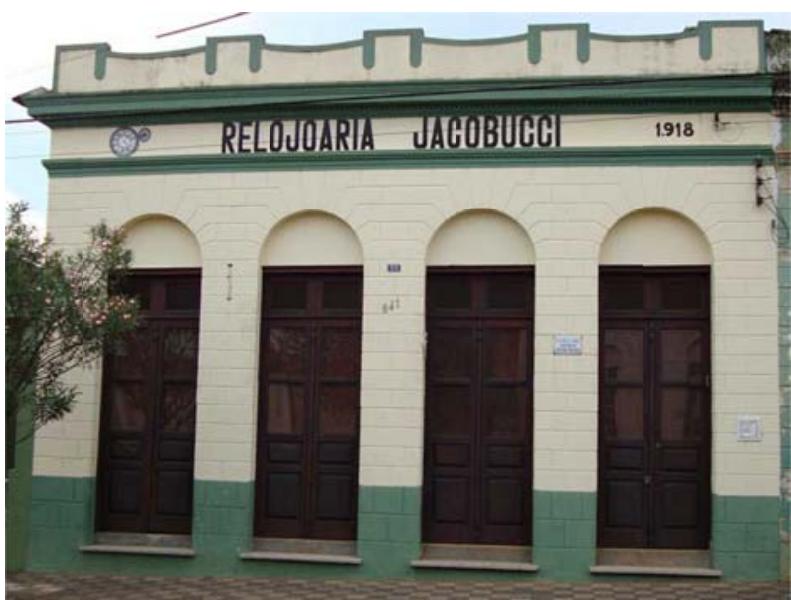

Fachada principal

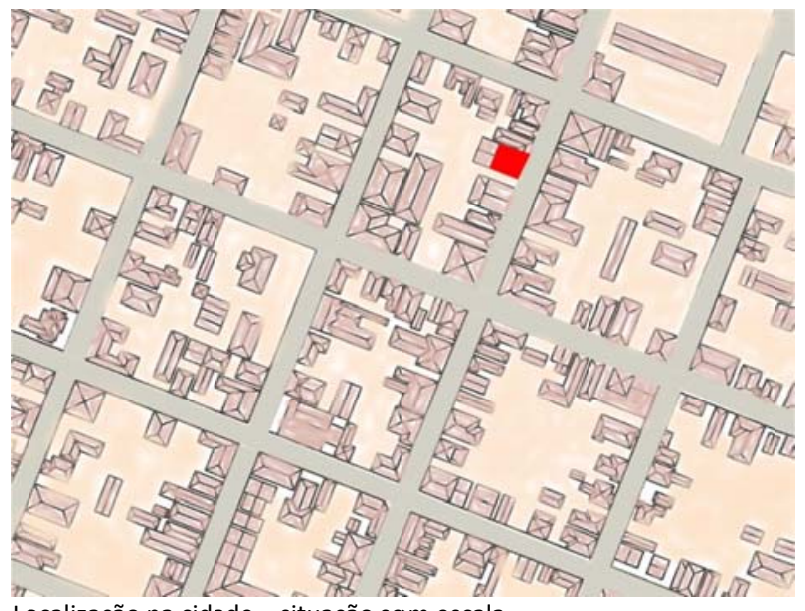

Localização na cidade - situação sem escala

2. Coroamento

Destruição total

Frontão

Cachorros

Platibanda X

Fibrocimento

Laje de beiral

Beiral simples

Cimalha

Beira seveira

Guarda pó

Outros:

4. Materiais de acabamento da fachada principal

3. Materiais do coroamento

Argamassa $X$

Azulejo antigo

Cantaria

Argamassa $X$

Cantaria

Azulejo novo

Chapisco

Azulejo novo

Concreto aparente

Vidros

Madeira

Outros:

6. Material das esquadrias da fachada principal

Destruição total Madeira $X$

Vidro $X \quad$ Alumínio

Ferro laminado / solda Outros:

Cantaria

Azulejo novo

7. Cores predominantes da fachada principal

Coroamento: bege / verde

Molduras dos vãos: não tem

Esquadrias: natural

Acabam. da fachada: bege

Outros relevos: verde

8. Uso atual - quantificar

Residência:

Comércio: 100\%

Serviço:

Vago:

Culto:

Instituição:

Dados volumétricos

\section{Gabarito}

Altura da fachada:

№ pavimentos acima do nível da rua: 01

Além desses, assinalar a existência de:

$\begin{array}{ll}\text { Porão alto } & \text { Mirante } \\ \text { Pav. intermediário } & \text { mezanino }\end{array}$

3. Registro de acréscimos

Não tem X

Acréscimo vertical

Acréscimo horizontal

\section{Classificação tipológica do telhado} Número de águas do corpo principal: 02

Cumeeira paralela à rua $X$ Cumeeira perpendicular à rua Tipo chalé

Com torreão

Água furtada

Pav. recuado Sótão habitável

Outros:
Identificado a partir de: Descrever:

Evidência na construção $X$

Depoimento do usuário 
Identificação

Logradouro: Rua Dr. Marques Ferreira s/n

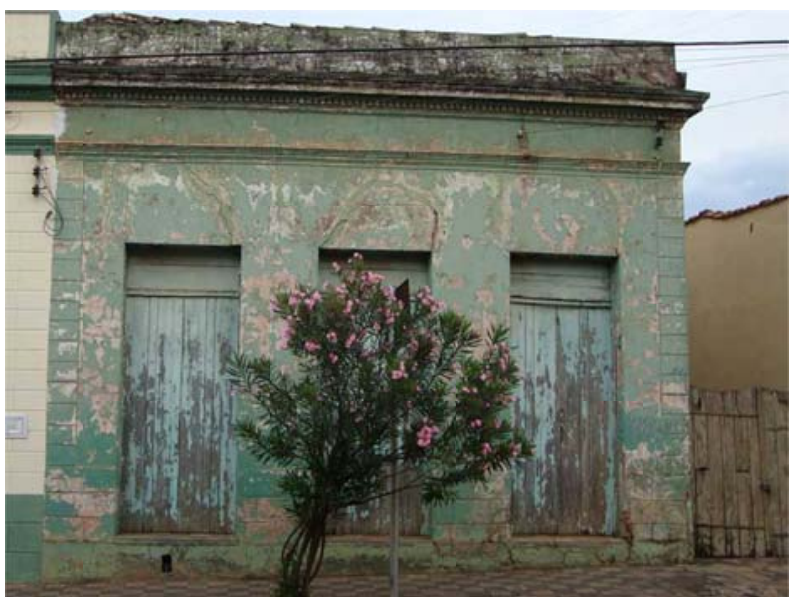

Fachada principal

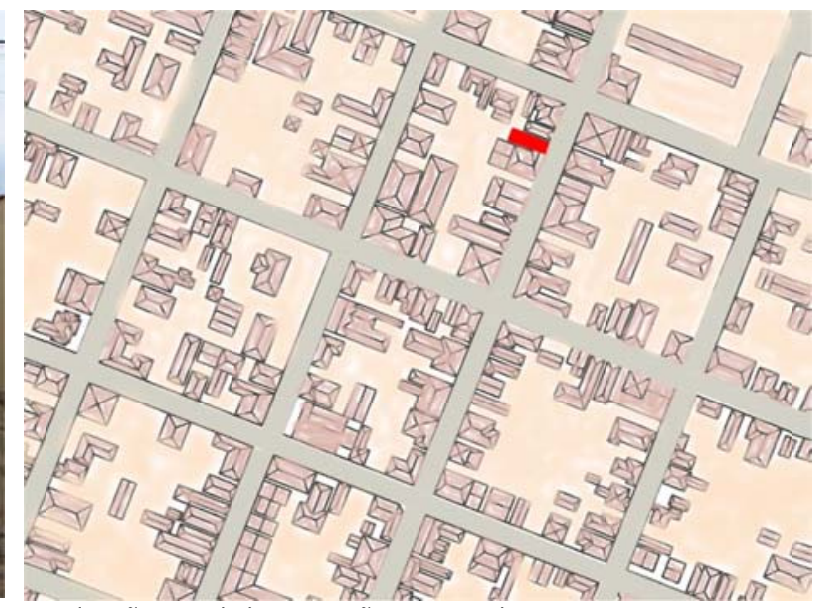

Localização na cidade - situação se m escala

Fachada principal e uso atual

$\begin{array}{ll}\text { 1. Materiais empregados na cobertura } \\ \text { Destruição total } & \text { Canal X } \\ \text { Francesa } & \text { Fibrocimento } \\ \text { Vidro } & \text { Metal } \\ \text { Plástico / fibra } & \text { Laje } \\ \text { Outros: } & \end{array}$

3. Materiais do coroamento

Argamassa $X$

Azulejo antigo

Cantaria

Madeira

Azulejo novo

Outros:

Concreto aparente

\section{Coroamento}

Destruição total Platibanda X

Frontão

Cachorros

Cimalha

Laje de beiral

Beiral simples

Beira seveira

Guarda pó

4. Materiais de acabamento da fachada principal

Argamassa $X \quad$ Chapisco

Cantaria Azulejo novo

Azulejo novo Madeira

Vidros Outros:

5. Material das molduras dos vãos de portas e janelas

6. Material das esquadrias da fachada principal

Não tem $X$

Destruição total

Argamassa

Cantaria

Destruição total

Madeira X

Azulejo antigo

Azulejo novo

Vidro

Alumínio

Madeira

Concreto aparente

7. Cores predominantes da fachada principal 8. Uso atual - quantificar

Coroamento: verde Esquadrias: azul

Molduras dos vãos: não tem

Acabam. da fachada: verde

Residência:

Comércio:

Vago: $100 \%$

Outros relevos: verde

Serviço:

Culto:

Instituição:

Dados volumétricos

\section{Gabarito}

Altura da fachada:

№ pavimentos acima do nível da rua: 01

Além desses, assinalar a existência de:

Porão alto Mirante

Pav. intermediário mezanino
2. Classificação tipológica do telhado

Alt. cumeeira: $\quad$ Número de águas do corpo principal: 02

№ subsolos: não tem

Cumeeira paralela à rua $X$

Com torreão

Cumeeira perpendicular à rua

Pav. recuado

Sótão habitável
Água furtada

Outros:

\section{Registro de acréscimos}

Não tem $X$

Acréscimo vertical

Acréscimo horizontal
Identificado a partir de:

Evidência na construção $X$

Depoimento do usuário

Descrever: 
Ficha de pré-inventário do patrimônio arquitetônico e urbanístico de Dourado - SP Características Arquitetônicas - Ficha 34

Identificação

Logradouro: Rua Dr. Marques Ferreira X Rua XV de Novembro

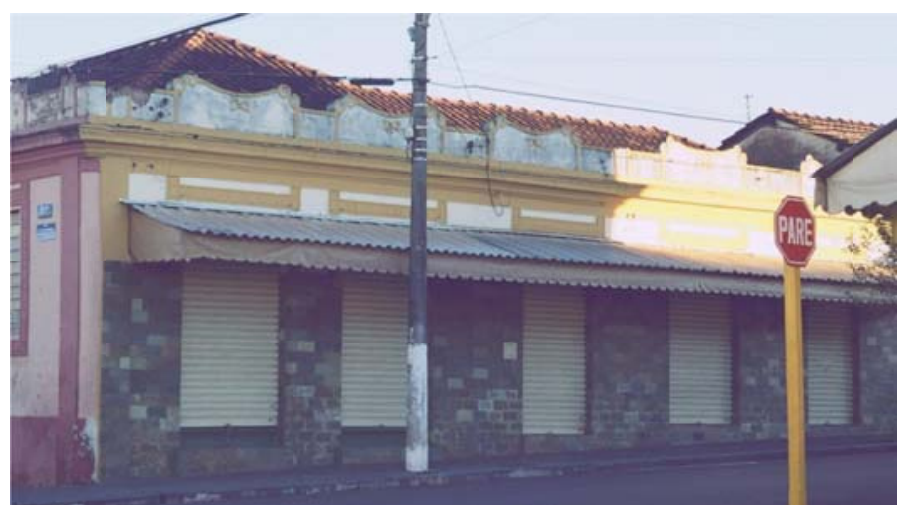

Fachada principal

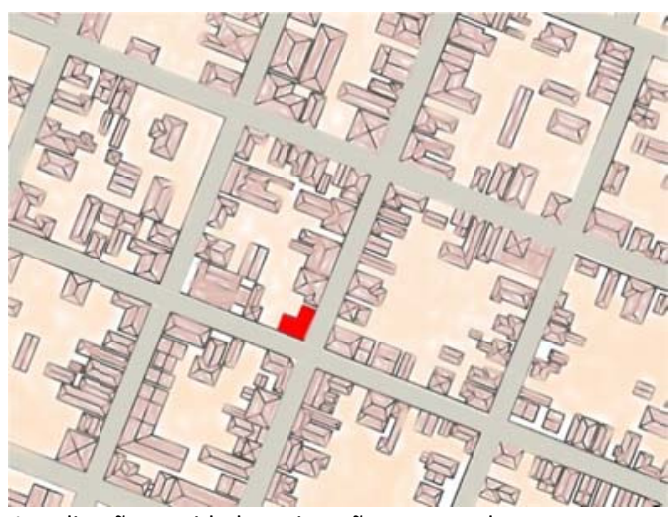

Localização na cidade - situação sem escala

Fachada principal e uso atual

\begin{tabular}{|c|c|c|c|}
\hline \multicolumn{2}{|c|}{ 1. Materiais empregados na cobertura } & \multicolumn{2}{|l|}{ 2. Coroamento } \\
\hline Destruição total & Canal X & Destruição total & Platibanda X \\
\hline Francesa & Fibrocimento & Frontão & Cimalha \\
\hline Vidro & Metal & Cachorros & Beira seveira \\
\hline Plástico / fibra & Laje & Laje de beiral & Guarda pó \\
\hline Outros: & & Beiral simples & Outros: \\
\hline \multicolumn{2}{|l|}{ 3. Materiais do coroamento } & \multicolumn{2}{|c|}{ 4. Materiais de acabamento da fachada principal } \\
\hline Argamassa X & Cantaria & Argamassa X & Chapisco \\
\hline Azulejo antigo & Azulejo novo & Cantaria & Azulejo novo \\
\hline Madeira & Concreto aparente & Azulejo novo & Madeira \\
\hline Outros: & & Vidros & Outros: pedra decorativa \\
\hline \multicolumn{2}{|c|}{ 5. Material das molduras dos vãos de portas e janelas } & \multicolumn{2}{|c|}{ 6. Material das esquadrias da fachada principal } \\
\hline Não tem & Destruição total & Destruição total & Madeira \\
\hline Argamassa X & Cantaria & Vidro & Alumínio $X$ \\
\hline Azulejo antigo & Azulejo novo & Ferro laminado / solda X & Outros: \\
\hline Madeira & Concreto aparente & & \\
\hline \multicolumn{2}{|c|}{ 7. Cores predominantes da fachada principal } & \multicolumn{2}{|l|}{ 8. Uso atual - quantificar } \\
\hline Coroamento: branco & Esquadrias: branco & Residência: & Vago: \\
\hline Molduras dos vãos: amarelo & Acabam. da fachada: branco & Comércio: $100 \%$ & Culto: \\
\hline Guarda-corpos: não tem & Outros relevos: amarelo & Serviço: & Instituição: \\
\hline
\end{tabular}

Dados volumétricos

\section{Gabarito}

Altura da fachada: $06 \mathrm{~m}$

№ pavimentos acima do nível da rua: 01

Além desses, assinalar a existência de:

Porão alto Mirante

Pav. intermediário mezanino

3. Registro de acréscimos

Não tem $X$

Acréscimo vertical

Acréscimo horizontal
Identificado a partir de:

Evidência na construção $X$

Depoimento do usuário
2. Classificação tipológica do telhado Número de águas do corpo principal: 04

Cumeeira paralela à rua $X$

Com torreão

Cumeeira perpendicular à rua

Água furtada

Tipo chalé

Outros:

Sótão habitável

Descrever: 
Identificação

Logradouro: Rua Dr. Marques Ferreira s/n

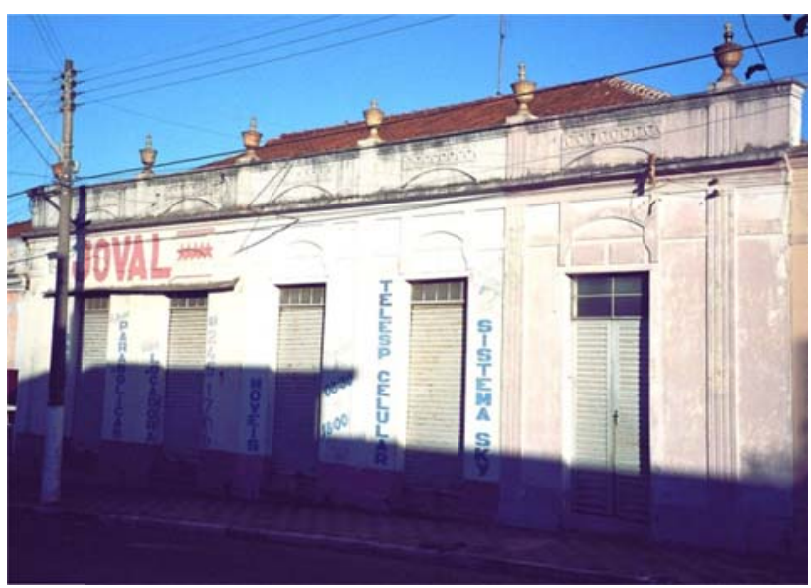

Fachada principal

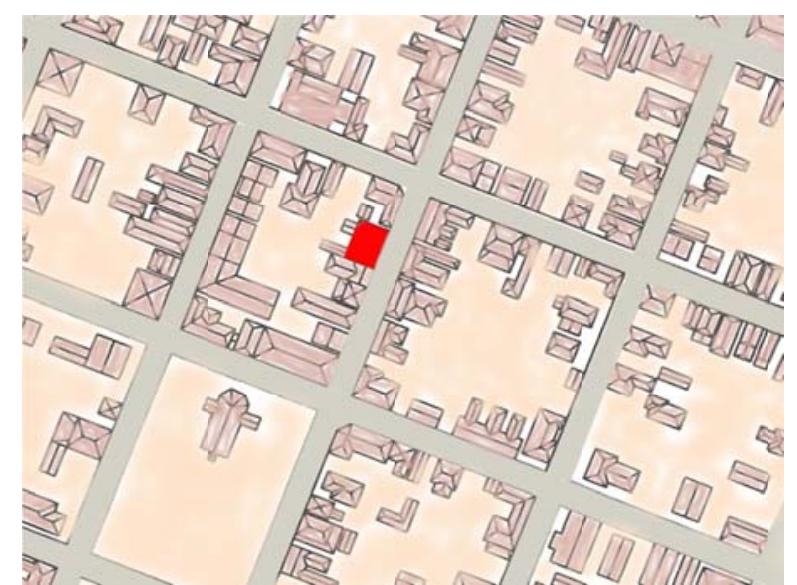

Localização na cidade - situação sem escala

Fachada principal e uso atual

1. Materiais empregados na cobertura

2. Coroamento

Destruição total Canal

Francesa X

Fibrocimento

Metal

Vidro

Laje

Destruição total

Frontão

Platibanda X

Plástico / fibra

Cachorros

Laje de beiral

Beiral simples

Cimalha

Beira seveira

Guarda pó

Outros:

\section{Materiais do coroamento}

Argamassa X

Cantaria

4. Materiais de acabamento da fachada principal

Azulejo antigo

Azulejo novo

Argamassa $X$

Chapisco

Madeira

Concreto aparente

Cantaria

Azulejo novo

Azulejo novo

Outros:

Vidros

Madeira

6. Material das esquadrias da fachada principal

5. Material das molduras dos vãos de portas e janelas

Destruição total

Madeira

Argamassa $X$

Destruição total

Vidro

Alumínio $X$

Azulejo antigo

Ferro laminado / solda $\mathrm{X}$

Outros:

Madeira

Concreto aparente

7. Cores predominantes da fachada principal

Coroamento: branco

Esquadrias: cinza

8. Uso atual - quantificar

Molduras dos vãos: branco

Acabam. da fachada: branco

Residência: $\mathbf{5 0 \%}$

Comércio: $50 \%$

Vago:

Outros relevos: branco

Serviço:

Culto:

Instituição:

Dados volumétricos

\section{Gabarito}

Altura da fachada: $6 \mathrm{~m}$

№ pavimentos acima do nível da rua: 01

Além desses, assinalar a existência de:

Porão alto Mirante

Pav. intermediário mezanino

3. Registro de acréscimos

Não tem $X$

Acréscimo vertical

Acréscimo horizontal

\section{Classificação tipológica do telhado}

Alt. cumeeira: $8 \mathrm{~m} \quad$ Número de águas do corpo principal: 02

№ subsolos:

Pav. recuado

Cumeeira paralela à rua $X$

Com torreão

Cumeeira perpendicular à rua

Água furtada

Tipo chalé

Outros:

Sótão habitável

Identificado a partir de: Descrever:

Evidência na construção $X$

Depoimento do usuário 
Identificação

Logradouro: Rua Dr. Marques Ferreira s/n

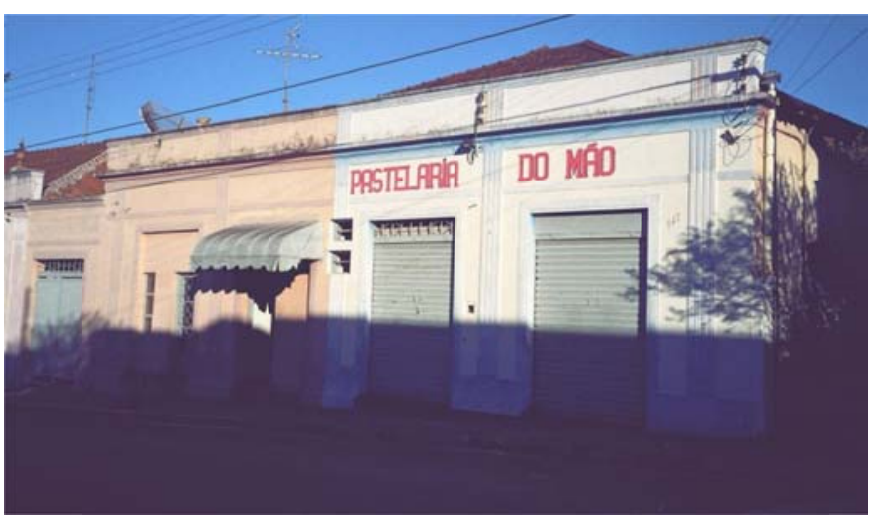

Fachada principal

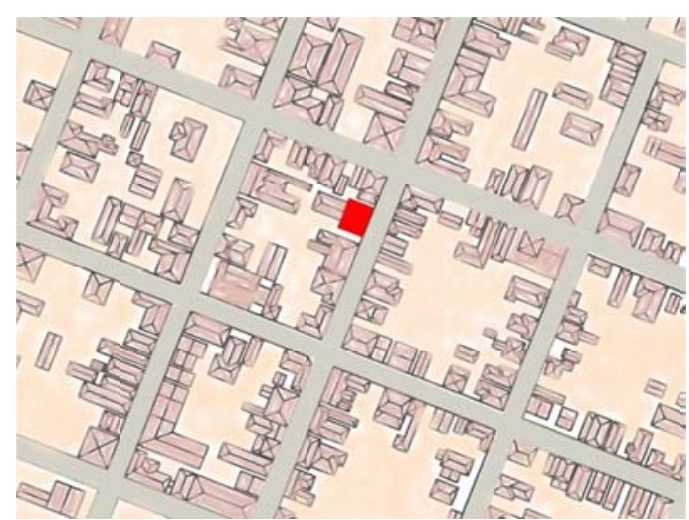

Localização na cidade - situação sem escala

Fachada principal e uso atual

1. Materiais empregados na cobertura

Destruição total Canal

Francesa X

Vidro

Plástico / fibra

Outros:

\section{Materiais do coroamento}

Argamassa X

Azulejo antigo

Madeira

Outros:

5. Material das molduras dos vãos de portas e janelas Não tem

Argamassa $X$

Azulejo antigo

Madeira

7. Cores predominantes da fachada principal

Coroamento: branco/bege

Molduras dos vãos: bege/azul

Guarda-corpos: não tem
Metal

Laje

\section{Cantaria}

Azulejo novo

Concreto aparente

Destruição total

Cantaria

Azulejo novo

Concreto aparente

\section{Esquadrias: cinza}

Acabam. da fachada: branco

Outros relevos: bege/azul

\section{Fibrocimento}

\section{Coroamento}

Destruição total

Frontão

Cachorros

Laje de beiral

Beiral simples

4. Materiais de acabamento da fachada principal

Argamassa X Chapisco

Cantaria Azulejo novo

Azulejo novo Madeira

Vidros Outros:

6. Material das esquadrias da fachada principal

Destruição total Madeira

Vidro Alumínio $X$

Ferro laminado / solda $X$ Outros:

\section{Uso atual - quantificar}

Residência: 50\%

Comércio: $50 \%$

Vago:

Serviço:

Culto:

Instituição:

Dados volumétricos

\begin{tabular}{|c|c|c|c|}
\hline \multicolumn{2}{|l|}{ 1. Gabarito } & \multicolumn{2}{|c|}{ 2. Classificação tipológica do telhado } \\
\hline Altura da fachada: $6 \mathrm{~m}$ & Alt. cumeeira: $8 \mathrm{~m}$ & \multicolumn{2}{|c|}{ Número de águas do corpo principal: 04} \\
\hline № pavimentos acima do nível da rua: 01 & № subsolos: & Cumeeira paralela à rua $X$ & Com torreão \\
\hline Além desses, assinalar a existência de: & & Cumeeira perpendicular à rua & Água furtada \\
\hline $\begin{array}{ll}\text { Porão alto } & \text { Mirante } \\
\text { Pav intermediário } & \text { mezanino }\end{array}$ & $\begin{array}{l}\text { Pav. recuado } \\
\text { Sótão habitável }\end{array}$ & Tipo chalé & Outros: \\
\hline
\end{tabular}

3. Registro de acréscimos

Não tem

Acréscimo vertical

Acréscimo horizontal $\mathrm{X}$
Descrever:

Identificado a partir de:

Evidência na construção $X$

Depoimento do usuário 
Identificação

Logradouro: Rua Dr. Marques Ferreira X Rua Santos Dumont

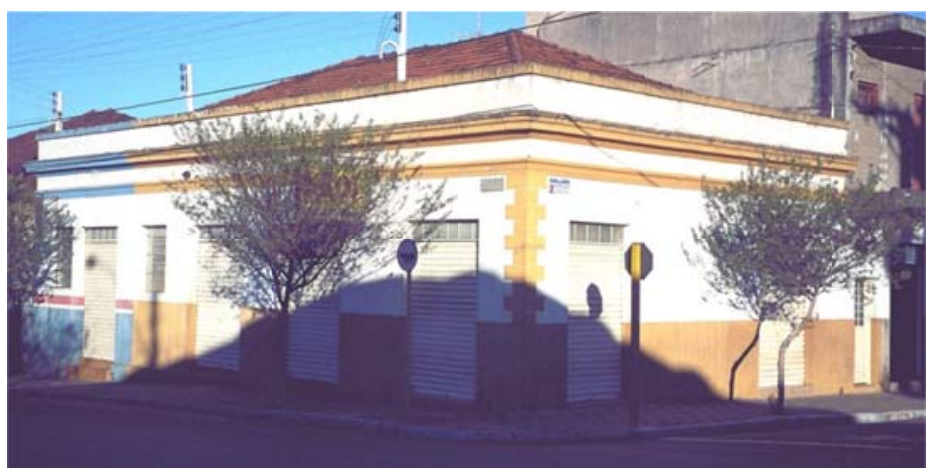

Fachada principal

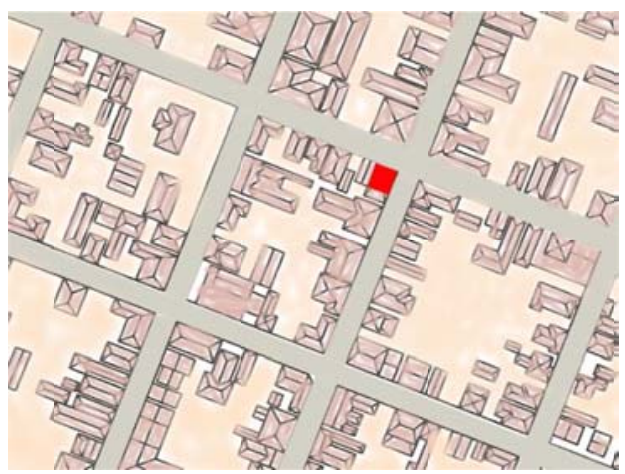

Localização na cidade - situação sem escala

Fachada principal e uso atual

1. Materiais empregados na cobertura Destruição total

Francesa $X$

Vidro

Plástico / fibra

Outros:

3. Materiais do coroamento Argamassa $X$

Azulejo antigo

Madeira

Outros:

5. Material das molduras dos vãos de portas e janelas Não tem

Argamassa $X$

Azulejo antigo

Madeira

7. Cores predominantes da fachada principal

Coroamento: branco

Molduras dos vãos: amarelo

Guarda-corpos: não tem

\section{Coroamento}

Destruição total

Frontão

Cachorros

Laje de beiral

Beiral simples

4. Materiais de acabamento da fachada principal

Argamassa $X \quad$ Chapisco $X$

Cantaria Azulejo novo

Azulejo novo Madeira

Vidros

Outros:

6. Material das esquadrias da fachada principal

Destruição total Madeira

Vidro Alumínio $X$

Ferro laminado / solda $X \quad$ Outros:

8. Uso atual - quantificar

Residência:

$\begin{array}{lll}\text { Acabam. da fachada: branco } & \text { Comércio: } 100 \% & \text { Culto: } \\ \text { Outros relevos: amarelo } & \text { Serviço: } & \text { Instituição: }\end{array}$

Dados volumétricos

\section{Gabarito \\ Altura da fachada: $5 \mathrm{~m}$}

№ pavimentos acima do nível da rua: 01

Alt. cumeeira: $7 \mathrm{~m}$

2. Classificação tipológica do telhado

Além desses, assinalar a existência de:

Porão alto Mirante

Pav. intermediário mezanino

№ subsolos:

Número de águas do corpo principal: 04

Cumeeira paralela à rua $X$
Cumeeira perpendicular à rua

Tipo chalé

Com torreão

Água furtada

Pav. recuado

Sótão habitável

3. Registro de acréscimos

Não tem $X$

Acréscimo vertical

Identificado a partir de:

Descrever:

Acréscimo horizonta

Evidência na construção $X$

Depoimento do usuário 
Ficha de pré-inventário do patrimônio arquitetônico e urbanístico de Dourado - SP Características Arquitetônicas - Ficha 38

Identificação

Logradouro: Rua Francisco Borja Cardoso X Rua Demétrio Calfat

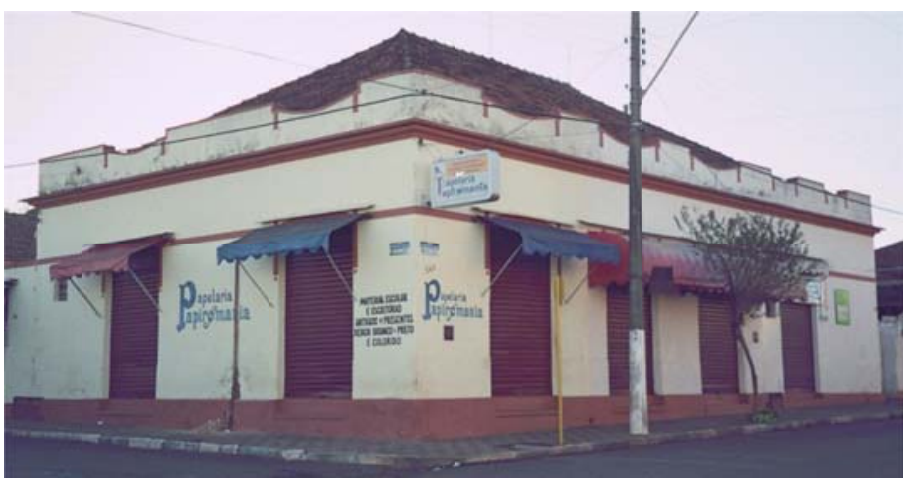

Fachada principal

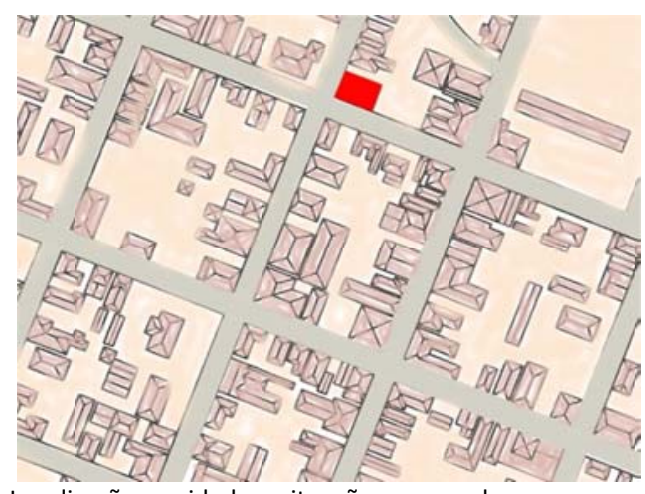

Localização na cidade - situação sem escala

Fachada principal e uso atual

1. Materiais empregados na cobertura Destruição total

Francesa $X$

Vidro

Plástico / fibra

Outros:

\section{Materiais do coroamento}

Argamassa $X$

Azulejo antigo

Madeira

Outros:

5. Material das molduras dos vãos de portas e janelas

Não tem $X$

Argamassa

Azulejo antigo

Madeira

7. Cores predominantes da fachada principal

Coroamento: bege

Molduras dos vãos: não tem

Guarda-corpos: não tem
Esquadrias: vermelho

Acabam. da fachada: bege

Outros relevos: marrom
2. Coroamento

Destruição total

Frontão

Cachorros

Laje de beiral

Beiral simples

4. Materiais de acabamento da fachada principal

Argamassa $X \quad$ Chapisco

Cantaria Azulejo novo

Azulejo novo Madeira

Vidros Outros:

6. Material das esquadrias da fachada principal

Destruição total Madeira

Vidro Alumínio $X$

Ferro laminado / solda $X \quad$ Outros:

8. Uso atual - quantificar

Residência: Vago:

Comércio: $100 \% \quad$ Culto:

Serviço: Instituição:

Dados volumétricos

\section{Gabarito}

2. Classificação tipológica do telhado

Altura da fachada: $6 \mathrm{~m}$

№ pavimentos acima do nível da rua: 01

Alt. cumeeira: $8 \mathrm{~m}$

№ subsolos:

Além desses, assinalar a existência de:

Porão alto Mirante

Pav. intermediário mezanino

3. Registro de acréscimos

Não tem $X$

Acréscimo vertical

Acréscimo horizontal

Sótão habitável

Evidência na construção $X$

Depoimento do usuário
Número de águas do corpo principal: 04

Cumeeira paralela à rua $X$

Cumeeira perpendicular à rua

Pav. recuado

Tipo chalé

Com torreão

Água furtada

Outros:

Identificado a partir de: Descrever: 
Ficha de pré-inventário do patrimônio arquitetônico e urbanístico de Dourado - SP Características Arquitetônicas - Ficha 39

Identificação

Logradouro: Rua Francisco Borja Cardoso X Rua Demétrio Calfat

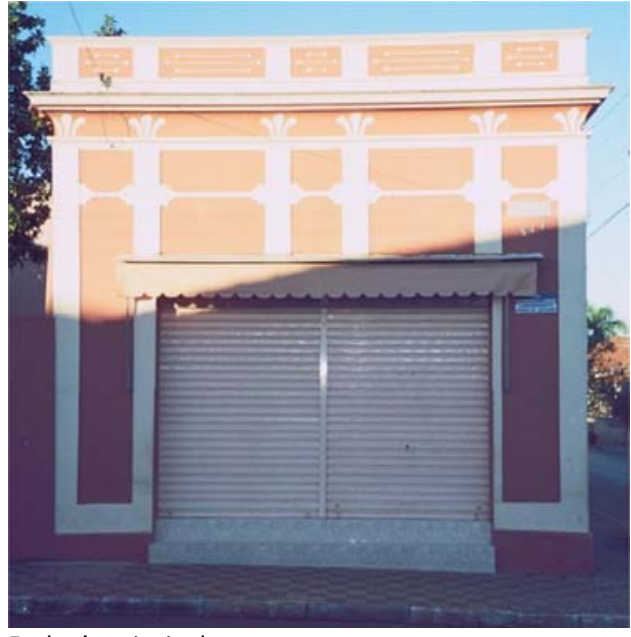

Fachada principal

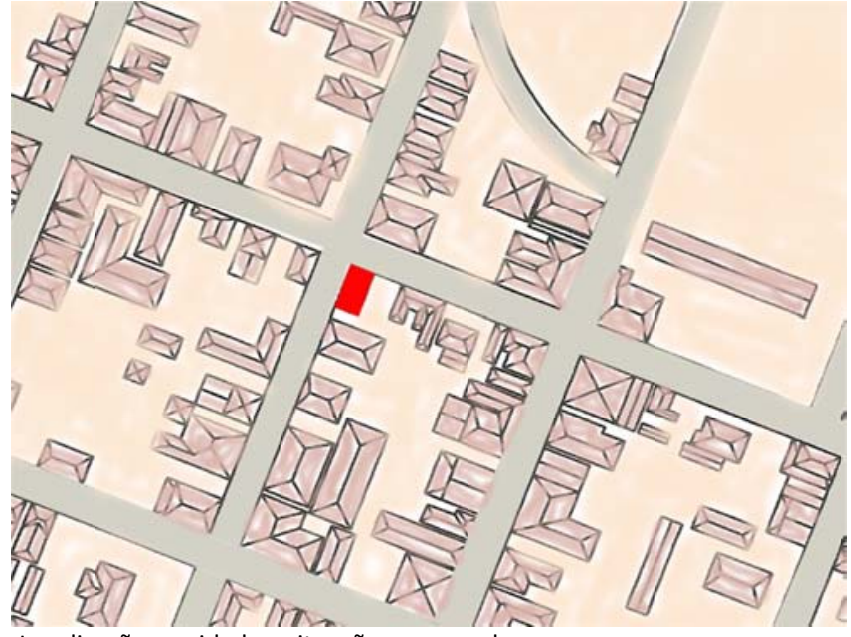

Localização na cidade - situação sem escala

Fachada principal e uso atual

1. Materiais empregados na cobertura Destruição total

Francesa X

Canal

Fibrocimento

Vidro

Metal

Plástico / fibra

Laje

Outros:

\section{Materiais do coroamento}

Argamassa X

Azulejo antigo

Cantaria

Madeira

Azulejo novo

Outros:

Concreto aparente

5. Material das molduras dos vãos de portas e janelas Não tem

Argamassa X

Azulejo antigo

Destruição total

Madeira

Cantaria

Azulejo novo

Concreto aparente

7. Cores predominantes da fachada principal Coroamento: marrom

Molduras dos vãos: branco

Esquadrias: cinza

Guarda-corpos: não tem

Acabam. da fachada: marrom

Outros relevos: branco

2. Coroamento

Destruição total

Frontão

Cachorros

Laje de beiral

Beiral simples

\section{Materiais de acabamento da fachada principal}

Argamassa $X \quad$ Chapisco

Cantaria Azulejo novo

Azulejo novo Madeira

Vidros Outros:

6. Material das esquadrias da fachada principal

Destruição total Madeira

Vidro Alumínio $X$

Ferro laminado / solda $X$ Outros:

\section{Uso atual - quantificar}

Residência:

Comércio: $100 \%$

Serviço:

Vago:

Culto:

Instituição:

Dados volumétricos

\section{Gabarito}

Altura da fachada: $6 \mathrm{~m}$

№ pavimentos acima do nível da rua: 01

Além desses, assinalar a existência de:

$\begin{array}{ll}\text { Porão alto } & \text { Mirante } \\ \text { Pav. intermediário } & \text { mezanino }\end{array}$

3. Registro de acréscimos

Não tem X

Acréscimo vertical

Acréscimo horizontal

\section{Classificação tipológica do telhado}

Alt. cumeeira: $8 \mathrm{~m} \quad$ Número de águas do corpo principal: 04

№ subsolos:

Cumeeira paralela à rua

Com torreão

Cumeeira perpendicular à rua X Água furtada

Tipo chalé

Outros:

Sótão habitável

Identificado a partir de: Descrever:

Evidência na construção $X$

Depoimento do usuário 
Ficha de pré-inventário do patrimônio arquitetônico e urbanístico de Dourado - SP Características Arquitetônicas - Ficha 40

Identificação

Logradouro: Rua Dr. Marques Ferreira s/n

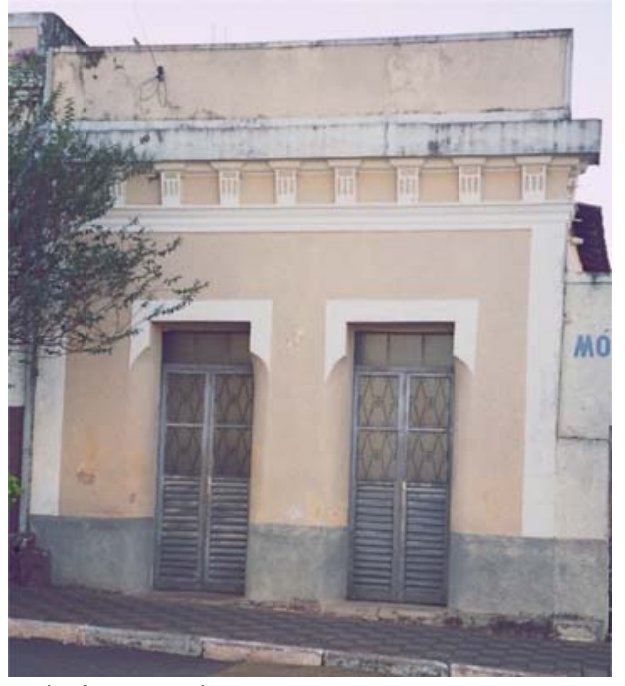

Fachada principal

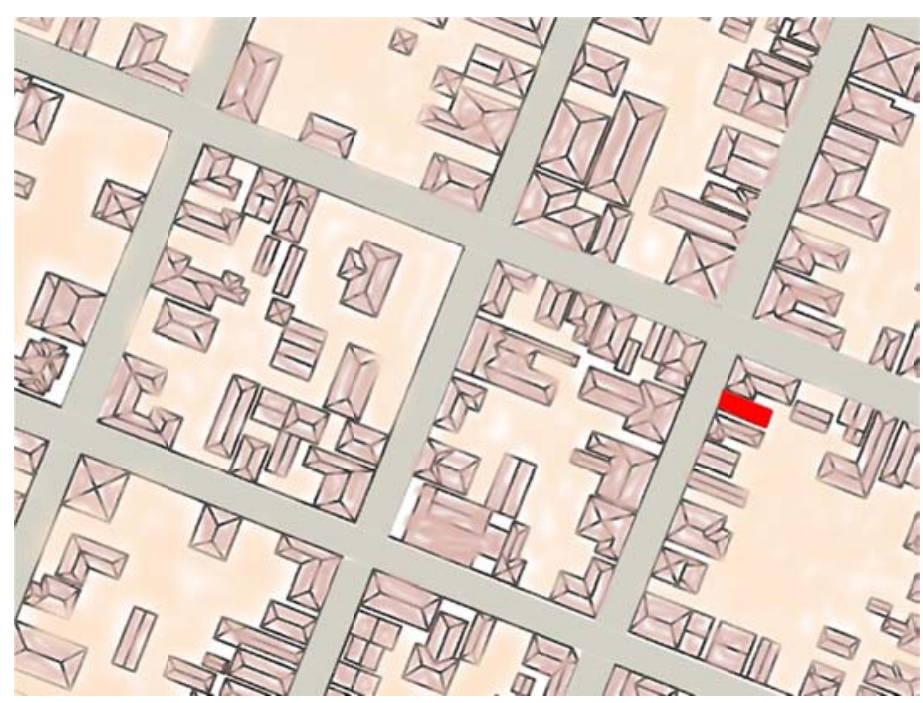

Localização na cidade - situação sem escala

Fachada principal e uso atual

1. Materiais empregados na cobertura

Destruição total

Francesa $X$

Vidro

Plástico / fibra

Outros:

3. Materiais do coroamento

Argamassa X

Azulejo antigo

Madeira

Outros:

5. Material das molduras dos vãos de portas e janelas

\section{Não tem}

Argamassa X

Azulejo antigo

Madeira

7. Cores predomin

Coroamento: bege

Molduras dos vãos: branco

Guarda-corpos: não tem

Dados volumétricos

\section{Gabarito \\ Altura da fachada: $5 \mathrm{~m}$}

№ pavimentos acima do nível da rua: 01

Além desses, assinalar a existência de:

Porão alto Mirante

Pav. intermediário

mezanino

\section{Coroamento}

Destruição total

Frontão

Cachorros

Laje de beiral

Beiral simples

4. Materiais de acabamento da fachada principal

Argamassa X Chapisco

Cantaria Azulejo novo

Azulejo novo Madeira

Vidros Outros:

6. Material das esquadrias da fachada principal

Destruição total Madeira

Vidro Alumínio $X$

Ferro laminado / solda Outros:

8. Uso atual - quantificar

Residência: Vago:

Comércio: $100 \% \quad$ Culto:

Serviço: Instituição:

\section{Registro de acréscimos}

Não tem $X$

Acréscimo vertical

Acréscimo horizontal
Azulejo novo

Concreto aparente

Esquadrias: cinza

Acabam. da fachada: bege

Outros relevos: branco

2. Classificação tipológica do telhado Número de águas do corpo principal: 04

Alt. cumeeira: $7 \mathrm{~m}$

№ subsolos:

Pav. recuado

Sótão habitável
Cumeeira paralela à rua $X$

Cumeeira perpendicular à rua

Tipo chalé
Com torreão

Água furtada

Outros:
Descrever:

Identificado a partir de: Descrever:

Evidência na construção $X$

Depoimento do usuário 
Identificação

Logradouro: Rua Dr. Marques Ferreira s/n

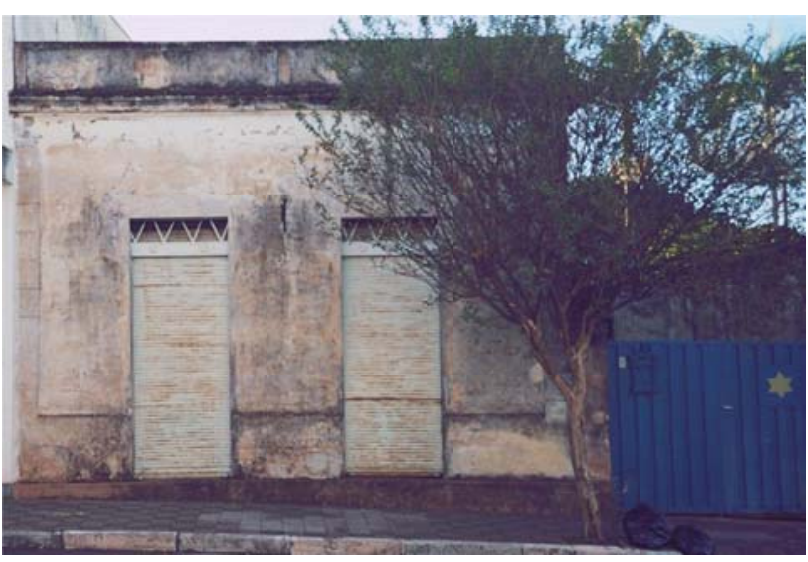

Fachada principal

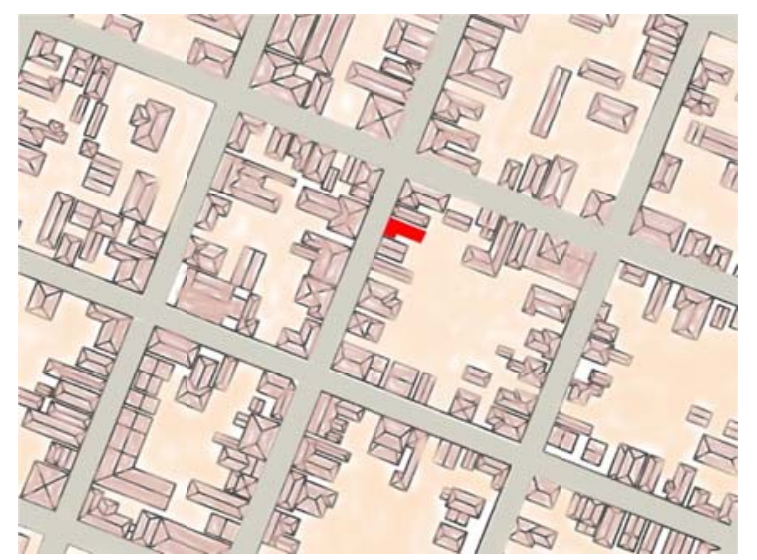

Localização na cidade - situaçãı sem escala

Fachada principal e uso atual

1. Materiais empregados na cobertura

Destruição total Canal X

Francesa

Vidro

Fibrocimento

Metal

Coroamento

Plástico / fibra

Laje

Destruição total

Outros:

3. Materiais do coroamento

Argamassa X

Azulejo antigo

Cantaria

Frontão

Cachorros

Laje de beiral

Beiral simples

Platibanda X

Platibanda

Beira seveira

Guarda pó

4. Materiais de acabamento da fachada principal

Madeira

Azulejo novo

Argamassa $X$

Cantaria

Chapisco

Concreto aparente

Azulejo novo

Azulejo novo

Outros:

Vidros

Madeira

6. Material das esquadrias da fachada principal

5. Material das molduras dos vãos de portas e janelas

Não tem X

Destruição total

Argamassa

Cantaria

Azulejo antigo

Azulejo novo

Vidro

Concreto aparente

7. Cores predominantes da fachada principal

Ferro laminado / solda $\mathrm{X}$

Alumínio $X$

7. Cores predominar

Esquadrias: branco

8. Uso atual - quantificar

Molduras dos vãos: não tem

Acabam. da fachada: branco

Residência:

Guarda-corpos: não tem

Outros relevos: branco

Comércio: 100\%

Vago:

Serviço:

Culto:

Instituição:

Dados volumétricos

\section{Gabarito \\ Altura da fachada: $5 \mathrm{~m}$}

№ pavimentos acima do nível da rua: 01

Além desses, assinalar a existência de:

Porão alto Mirante

Pav. intermediário

mezanino
2. Classificação tipológica do telhado

Alt. cumeeira: $7 \mathrm{~m} \quad$ Número de águas do corpo principal: 02

№ subsolos:

Cumeeira paralela à rua

Com torreão

Cumeeira perpendicular à rua $X$

Pav. recuado

Tipo chalé

Água furtada

Outros:

\section{Registro de acréscimos}

Não tem $X$

Acréscimo vertical

Acréscimo horizontal

Identificado a partir de: Descrever:

Evidência na construção $X$

Depoimento do usuário 
Ficha de pré-inventário do patrimônio arquitetônico e urbanístico de Dourado - SP Características Arquitetônicas - Ficha 42

Identificação

Logradouro: Rua Dr Marques Ferreira s/n

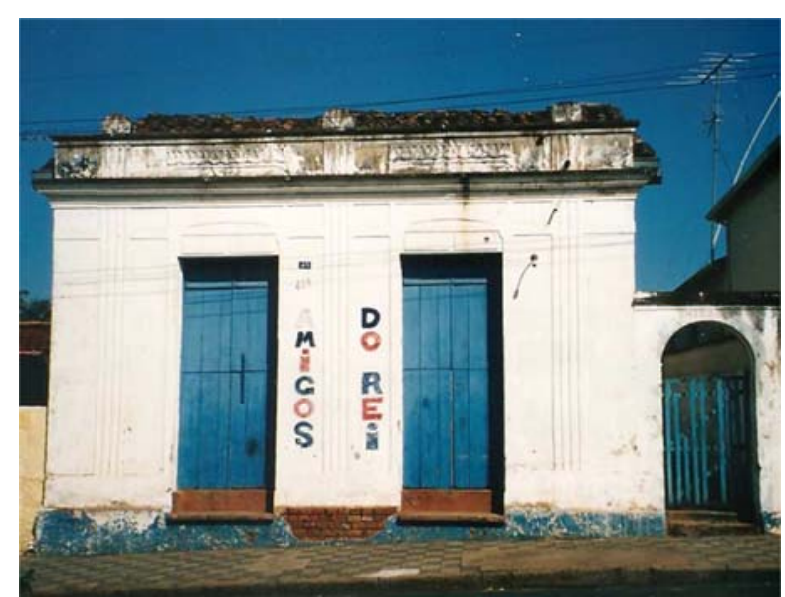

Fachada principal

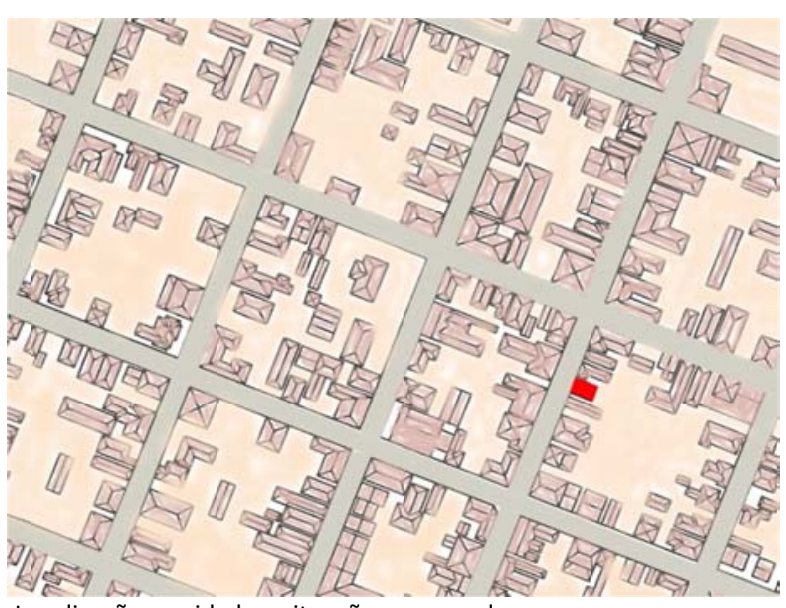

Localização na cidade - situação sem escala

2. Coroamento

Destruição total

Frontão

Cachorros

Laje de beiral

Beiral simples

4. Materiais de acabamento da fachada principal

Argamassa X Chapisco

Cantaria Azulejo novo

Azulejo novo Madeira

Vidros Outros:

6. Material das esquadrias da fachada principal

Destruição total Madeira $X$

Vidro Alumínio

Ferro laminado / solda Outros:

8. Uso atual - quantificar

Residência: Vago:100\%

Comércio: Culto:

Serviço: Instituição:

Dados volumétricos

1. Gabarito

Altura da fachada:

№ pavimentos acima do nível da rua: 01

Além desses, assinalar a existência de:

Porão alto Mirante

Pav. intermediário mezanino

3. Registro de acréscimos

Não tem X

Acréscimo vertical

Acréscimo horizontal
Identificado a partir de:

Evidência na construção $X$

Depoimento do usuário
2. Classificação tipológica do telhado Número de águas do corpo principal: 02

Cumeeira paralela à rua $X$

Com torreão

Cumeeira perpendicular à rua

Água furtada

Tipo chalé

Outros:

Sótão habitável

Descrever: 
Ficha de pré-inventário do patrimônio arquitetônico e urbanístico de Dourado - SP Características Arquitetônicas - Ficha 43

Identificação

Logradouro: Rua Francisco Borja Cardoso s/n

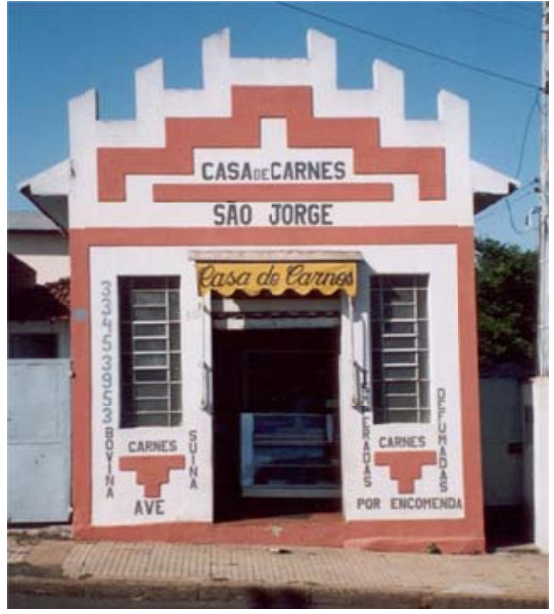

Fachada principal

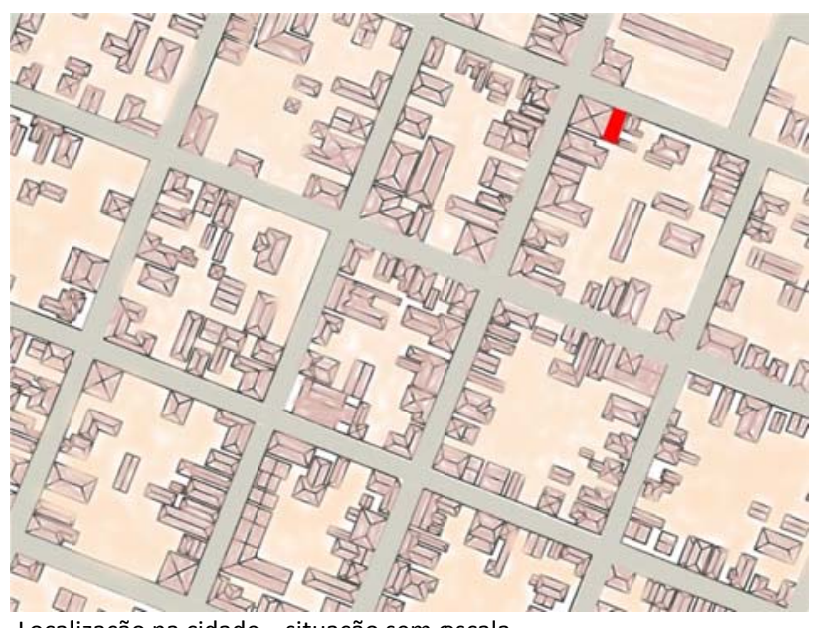

Localização na cidade - situação sem escala

Fachada principal e uso atual

1. Materiais empregados na cobertura

Canal

2. Coroamento Destruição total

Francesa X

Vidro

Fibrocimento

Metal

Plástico / fibra

Laje

Destruição total

Frontão $X$

Cachorros

Outros:

Laje de beiral

Beiral simples

\section{Platibanda}

Cimalha

Beira seveira

Guarda pó

Outros:

4. Materiais de acabamento da fachada principal

Materiais do coroamento

Argamassa $X$

Azulejo antigo

Cantaria

Azulejo novo

Madeira

Concreto aparente

Argamassa $X$

Cantaria

Azulejo novo

Chapisco

Azulejo novo

Vidros

Madeira

Outros:

5. Material das molduras dos vãos de portas e janelas Não tem Destruição total

Argamassa $X$

Azulejo antigo

Cantaria

Azulejo novo

Madeira

Concreto aparente

7. Cores predominantes da fachada principal

Coroamento: branco/bege

Molduras dos vãos: não tem

Esquadrias: branco

Guarda-corpos: não tem

Acabam. da fachada: branco

Outros relevos: marrom

6. Material das esquadrias da fachada principal Destruição total Madeira

Vidro

Ferro laminado / solda X

Alumínio X

Outros:

8. Uso atual - quantificar

Residência:

Comércio: 100\%

Serviço:

Vago:

Culto:

Instituição:

Dados volumétricos

\begin{tabular}{|c|c|c|c|}
\hline 1. Gabarito & & \multicolumn{2}{|c|}{ 2. Classificação tipológica do telhado } \\
\hline Altura da fachada: $5 \mathrm{~m}$ & Alt. cumeeira: $6 \mathrm{~m}$ & \multicolumn{2}{|c|}{ Número de águas do corpo principal: 02} \\
\hline № pavimentos acima do nível da rua: 01 & № subsolos: & Cumeeira paralela à rua & Com torreão \\
\hline \multicolumn{2}{|l|}{ Além desses, assinalar a existência de: } & Cumeeira perpendicular à rua $X$ & Água furtada \\
\hline Porão alto $\quad$ Mirante & Pav. recuado & Tipo chalé & Outros: \\
\hline
\end{tabular}

3. Registro de acréscimos

Não tem $X$

Acréscimo vertical

Acréscimo horizontal

Identificado a partir de: Descrever:

Evidência na construção $X$ Depoimento do usuário 
Identificação

Logradouro: Rua Demétrio Calfat no 359

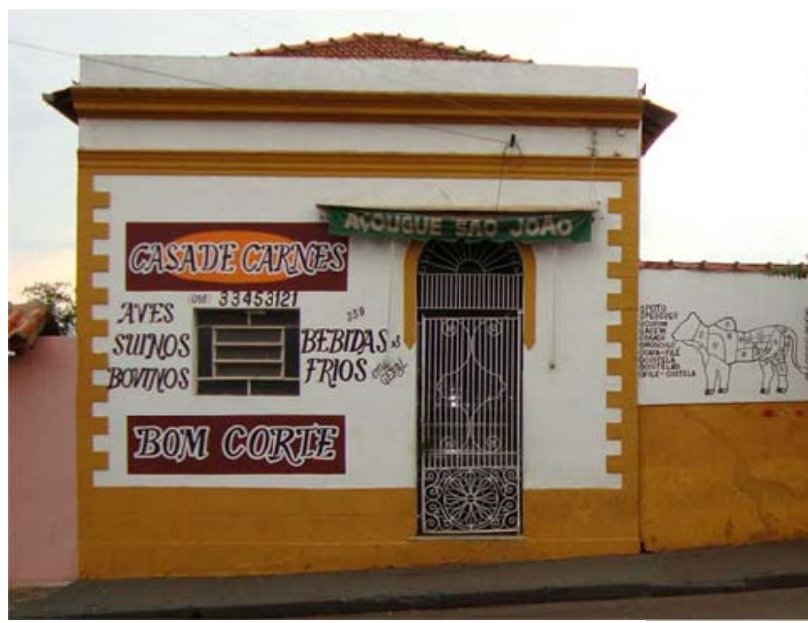

Fachada principal

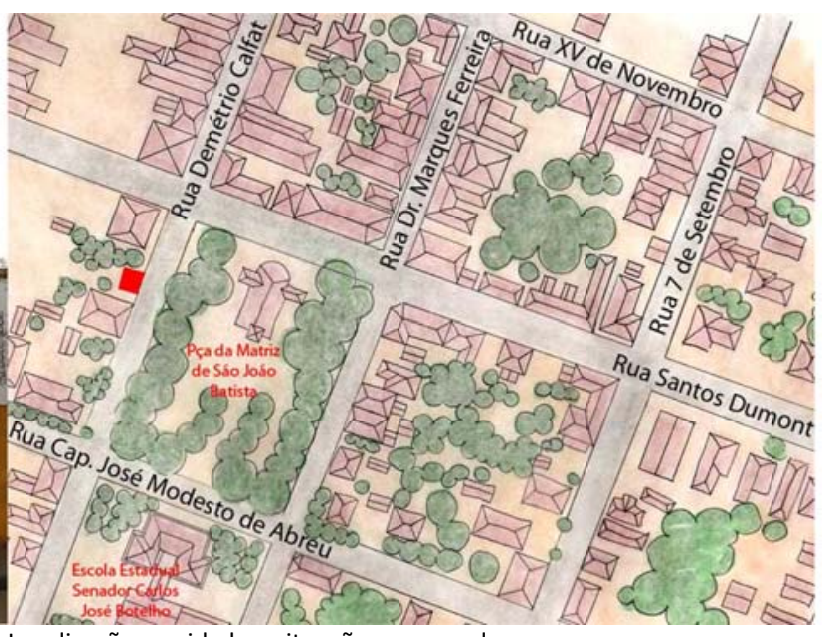

Localização na cidade - situação se:m escala

Fachada principal e uso atual

$\begin{array}{ll}\text { 1. Materiais empregados na cobertura } \\ \text { Destruição total } & \text { Canal } \\ \text { Francesa X } & \text { Fibrocimento } \\ \text { Vidro } & \text { Metal } \\ \text { Plástico / fibra } & \text { Laje } \\ \text { Outros: } & \end{array}$

\section{Materiais do coroamento}

Argamassa $\mathrm{X}$

Azulejo antigo

Cantaria

Madeira

Azulejo novo

Outros:

Concreto aparente

\section{Coroamento}

Destruição total

Frontão

Cachorros

Platibanda X

Laje de beiral

Beiral simples

Cimalha

Beira seveira

Guarda pó

4. Materiais de acabamento da fachada principal

Argamassa $X \quad$ Chapisco $X$

Cantaria Azulejo novo

Azulejo novo Madeira

Vidros Outros:

5. Material das molduras dos vãos de portas e janelas

Não tem Destruição total

Cantaria

Azulejo novo

7. Cores predominantes da fachada principal

Coroamento: branco/amarelo

Esquadrias: branco

6. Material das esquadrias da fachada principal

Destruição total

Vidro

Madeira

Alumínio

Ferro laminado / solda $X \quad$ Outros:

Molduras dos vãos: amarelo

Acabam. da fachada: branco

Outros relevos: amarelo

8. Uso atual - quantificar

Residência:

Guarda-corpos: não tem

Serviço:

\section{Vago:}

Culto:

Instituição:

Dados volumétricos

\section{Gabarito}

Altura da fachada:

№ pavimentos acima do nível da rua: 01

Além desses, assinalar a existência de:
Porão alto $X$
Mirante
Pav. intermediário mezanino
Pav. recuado
Sótão habitável

\section{Alt. cumeeira: \\ № subsolos:}

2. Classificação tipológica do telhado Número de águas do corpo principal: 04

Cumeeira paralela à rua

Com torreão

Cumeeira perpendicular à rua $X$

Tipo chalé

Água furtada

Outros:

3. Registro de acréscimos

Não tem $X$

Acréscimo vertical

Acréscimo horizontal
Identificado a partir de:

Evidência na construção $X$

Depoimento do usuário
Descrever: 
Identificação

Logradouro: Rua Cap. José Modesto de Abreu X Rua Dr. Marques Ferreira

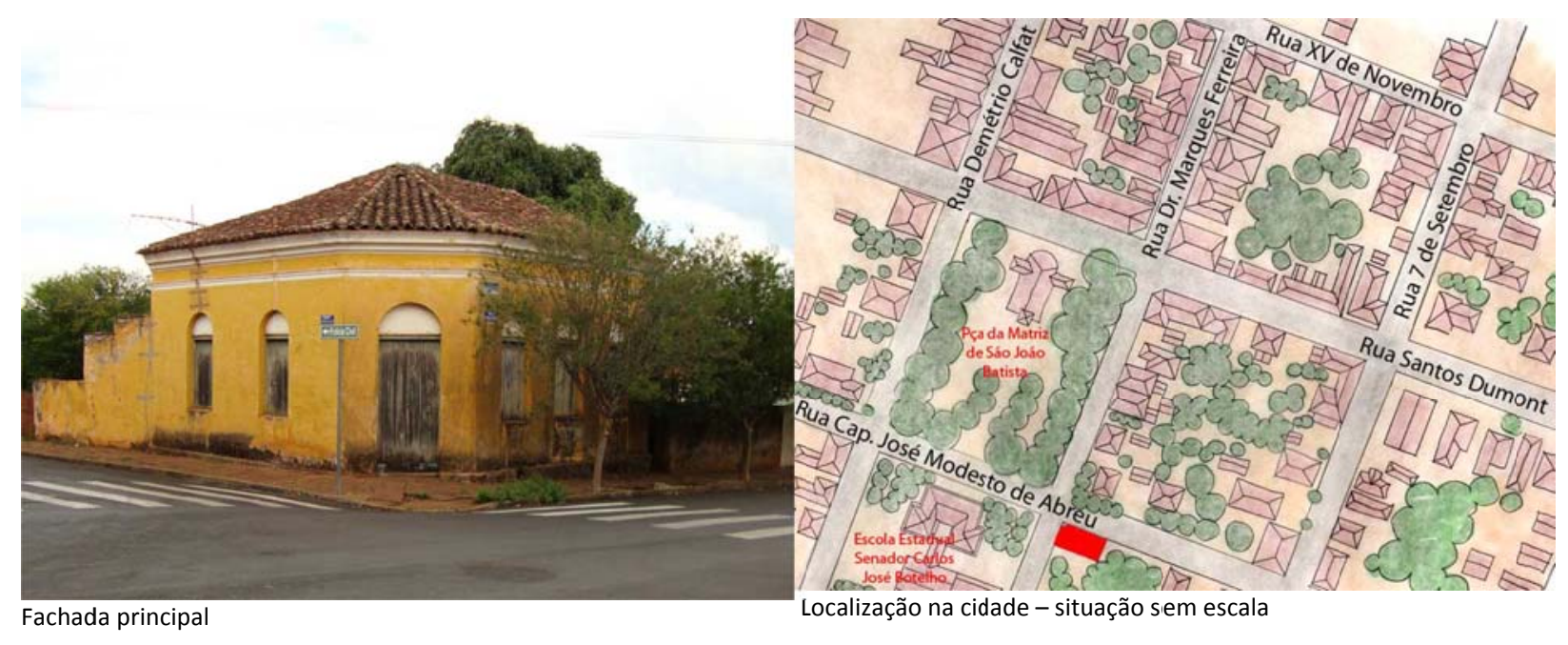

Fachada principal e uso atual

$\begin{array}{ll}\text { 1. Materiais empregados na cobertura } \\ \text { Destruição total } & \text { Canal X } \\ \text { Francesa } & \text { Fibrocimento } \\ \text { Vidro } & \text { Metal } \\ \text { Plástico / fibra } & \text { Laje } \\ \text { Outros: } & \end{array}$

2. Coroamento

Destruição total

Frontão

Cachorros

Laje de beiral

Beiral simples

4. Materiais de acabamento da fachada principal

3. Materiais do coroamento

Argamassa $\mathrm{X}$

Cantaria

Azulejo antigo

Azulejo novo

Madeira

Concreto aparente

Outros:

5. Material das molduras dos vãos de portas e janelas

Não tem X

Argamassa

Azulejo antigo

Destruição total

Cantaria

Madeira

Azulejo novo

Concreto aparente

7. Cores predominantes da fachada principal

Coroamento: branco

Esquadrias: natural

Acabam. da fachada: amarelo

Guarda-corpos: não tem

Argamassa X

Cantaria

Azulejo novo

Vidros

6. Material das esquadrias da fachada principal

Destruição total Madeira $X$

Vidro Alumínio

Ferro laminado / solda Outros:

8. Uso atual - quantificar

Residência: $X$

Comércio:

Vago: $100 \%$

Serviço:

Instituição:

Dados volumétricos

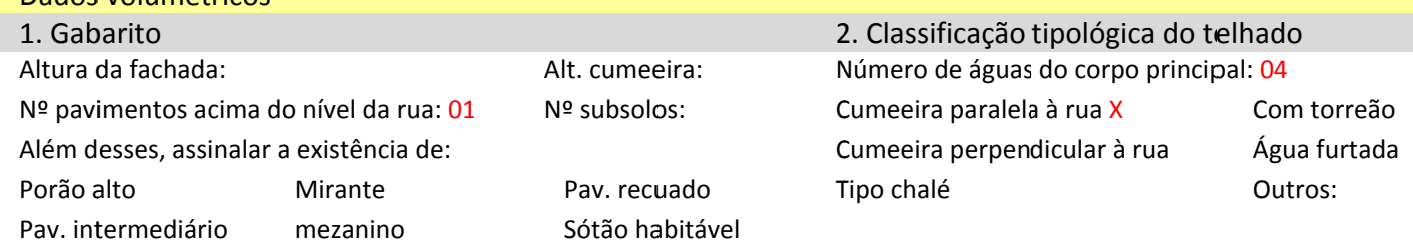

3. Registro de acréscimos Não tem $X$

Identificado a partir de:

Descrever:

Acréscimo vertical

Evidência na construção $X$

Acréscimo horizontal

Depoimento do usuário 
Identificação

Logradouro: Rua Santos Dumont no 346

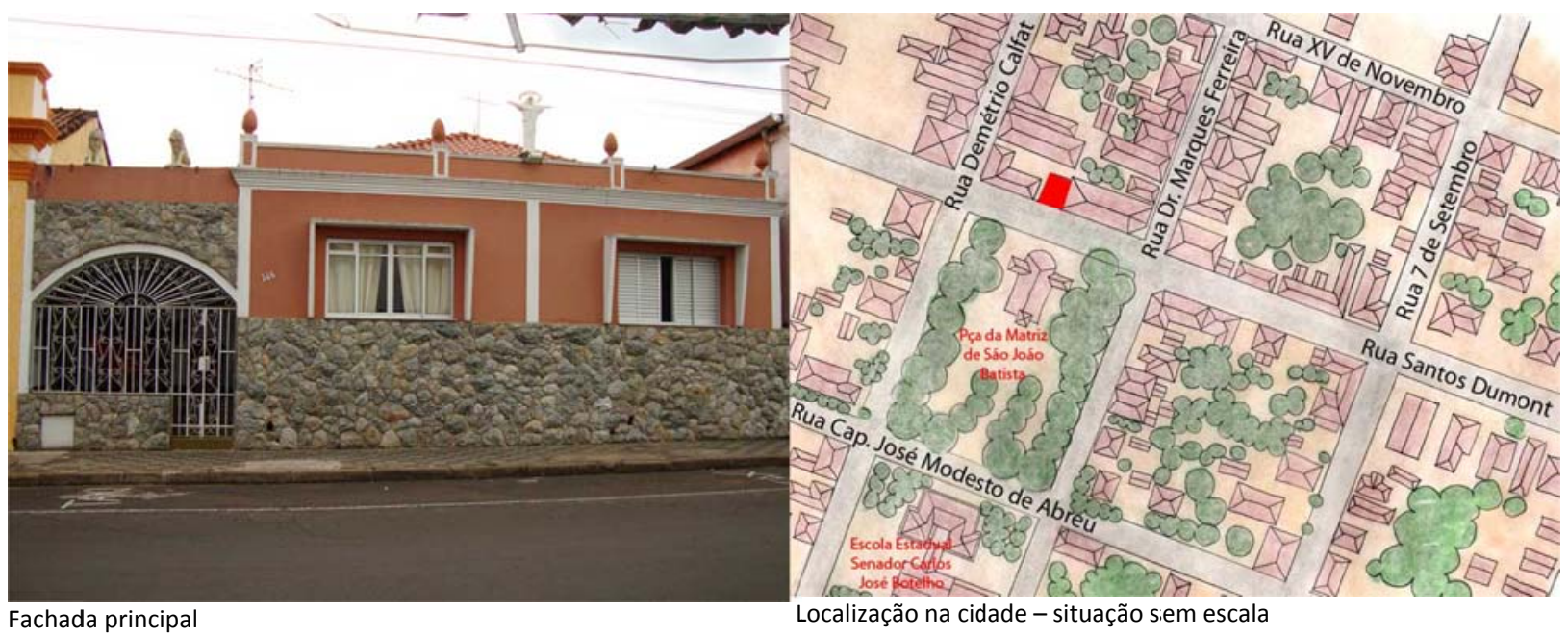

Fachada principal e uso atual

\begin{tabular}{|c|c|c|c|}
\hline \multicolumn{2}{|c|}{ 1. Materiais empregados na cobertura } & \multicolumn{2}{|l|}{ 2. Coroamento } \\
\hline Destruição total & Canal & Destruição total & Platibanda X \\
\hline Francesa $X$ & Fibrocimento & Frontão & Cimalha \\
\hline Vidro & Metal & Cachorros & Beira seveira \\
\hline Plástico / fibra & Laje & Laje de beiral & Guarda pó \\
\hline Outros: & & Beiral simples & Outros: \\
\hline \multicolumn{2}{|c|}{ 3. Materiais do coroamento } & \multicolumn{2}{|c|}{ 4. Materiais de acabamento da fachada principal } \\
\hline Argamassa $X$ & Cantaria & Argamassa X & Chapisco \\
\hline Azulejo antigo & Azulejo novo & Cantaria & Azulejo novo \\
\hline Madeira & Concreto aparente & Azulejo & Madeira \\
\hline Outros: & & Vidros & Outros: pedra \\
\hline \multicolumn{2}{|c|}{ 5. Material das molduras dos vãos de portas e janelas } & \multicolumn{2}{|c|}{ 6. Material das esquadrias da fachada principal } \\
\hline Não tem & Destruição total & Destruição total & Madeira \\
\hline Argamassa X & Cantaria & Vidro X & Alumínio X \\
\hline Azulejo antigo & Azulejo novo & Ferro laminado / solda X & Outros: \\
\hline Madeira & Concreto aparente & & \\
\hline \multicolumn{2}{|c|}{ 7. Cores predominantes da fachada principal } & \multicolumn{2}{|l|}{ 8. Uso atual - quantificar } \\
\hline Coroamento: marrom & Esquadrias: branco & Residência: $100 \%$ & Vago: \\
\hline Molduras dos vãos: branco & Acabam. da fachada: marrom & Comércio: & Culto: \\
\hline Guarda-corpos: não tem & Outros relevos: branco & Serviço: & Instituição: \\
\hline
\end{tabular}

Dados volumétricos

\begin{tabular}{|c|c|c|c|c|}
\hline \multicolumn{3}{|l|}{ 1. Gabarito } & \multicolumn{2}{|c|}{ 2. Classificação tipológica do telhado } \\
\hline \multicolumn{2}{|l|}{ Altura da fachada: } & Alt. cumeeira: & \multicolumn{2}{|c|}{ Número de águas do corpo principal: 04} \\
\hline № pavimentos aci & o nível da rua: 01 & № subsolos: & Cumeeira paralela à rua & Com torreão \\
\hline \multicolumn{3}{|c|}{ Além desses, assinalar a existência de: } & Cumeeira perpendicular à rua $X$ & Água furtada \\
\hline $\begin{array}{l}\text { Porão alto } X \\
\text { Pav. intermediário }\end{array}$ & $\begin{array}{l}\text { Mirante } \\
\text { mezanino }\end{array}$ & $\begin{array}{l}\text { Pav. recuado } \\
\text { Sótão habitável }\end{array}$ & Tipo chalé & Outros: \\
\hline
\end{tabular}

3. Registro de acréscimos

Não tem

Identificado a partir de: Descrever:

Acréscimo vertical

Evidência na construção $X$

Acréscimo horizontal $\mathrm{X}$

Depoimento do usuário 
Identificação

Logradouro: Rua Demétrio Calfat s/n

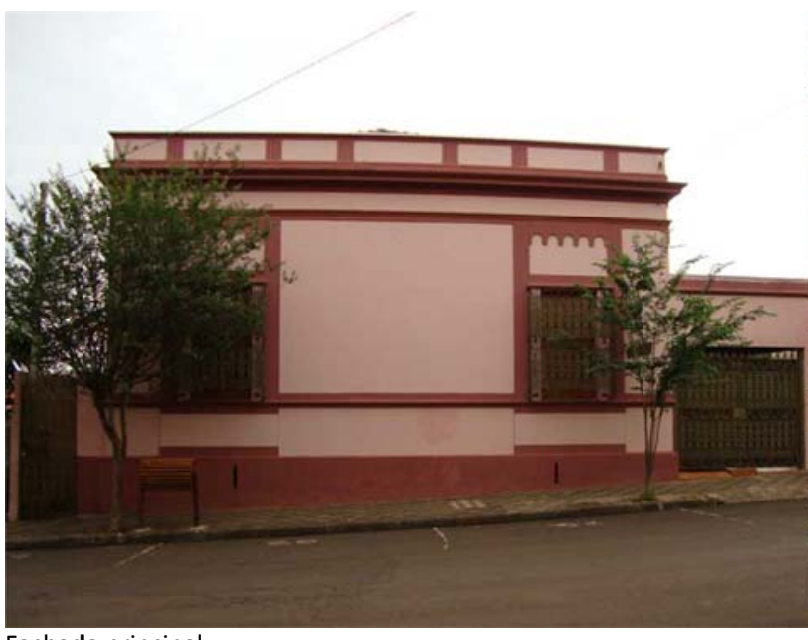

Fachada principal

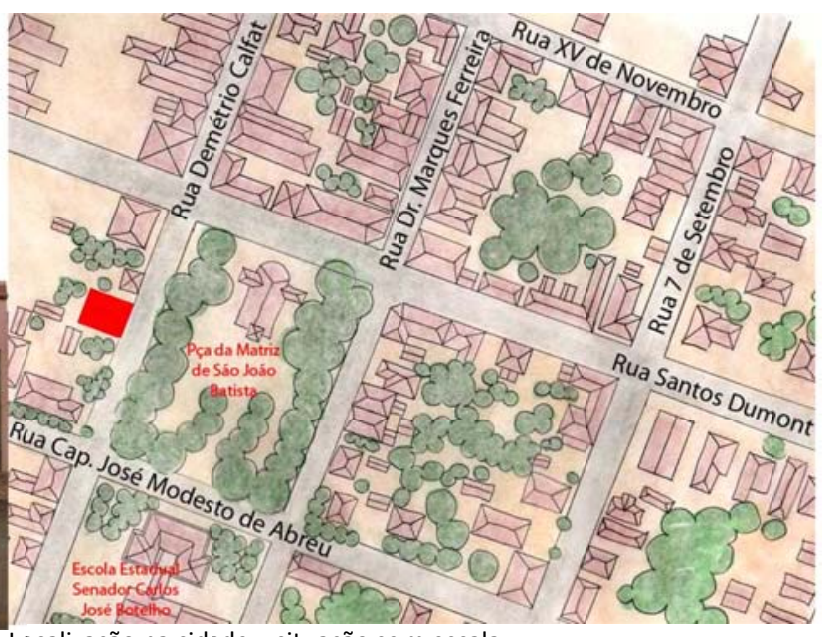

Localização na cidade - situação sem escala

Fachada principal e uso atual

1. Materiais empregados na cobertura

2. Coroamento

Destruição total

Francesa $X$

Canal

Vidro

Fibrocimento

Destruição total

Frontão

Plástico / fibra

Metal

Cachorros

Outros:

Laje

Laje de beiral

Beiral simples

\section{Platibanda X}

Cimalha

Beira seveira

Guarda pó

Outros:

4. Materiais de acabamento da fachada principal

Argamassa $X$

Azulejo antigo

Cantaria

Azulejo novo

Argamassa $X$

Cantaria

Azulejo novo

Chapisco X

Azulejo novo

Concreto aparente

Vidros

Madeira

6. Material das esquadrias da fachada principal

Destruição total Madeira $X$

Vidro $X \quad$ Alumínio

Ferro laminado / solda $X \quad$ Outros:

8. Uso atual - quantificar

Residência: $100 \%$ Vago:

Comércio: Culto:

Serviço: Instituição:
Cantaria

zulejo novo

Concreto aparente

squadrias: cinza

Acabam. da fachada: rosa

Outros relevos: marrom
Dados volumétricos

\section{Gabarito}

Altura da fachada:

№ pavimentos acima do nível da rua: 01

Além desses, assinalar a existência de:

$\begin{array}{ll}\text { Porão alto } X & \text { Mirante } \\ \text { Pav. intermediário } & \text { mezanino }\end{array}$

3. Registro de acréscimos

Não tem

Acréscimo vertical

Acréscimo horizontal $X$

\section{os}

2. Classificação tipológica do telhado

Alt. cumeeira: Número de águas do corpo principal: 04

№ subsolos:

Pav. recuado

Sótão habitável
Cumeeira paralela à rua

Com torreão

Cumeeira perpendicular à rua $X$

Tipo chalé

Água furtada

Outros:

Identificado a partir de:

Evidência na construção $X$

Depoimento do usuário 
Identificação

Logradouro: Rua Santos Dumont no 235

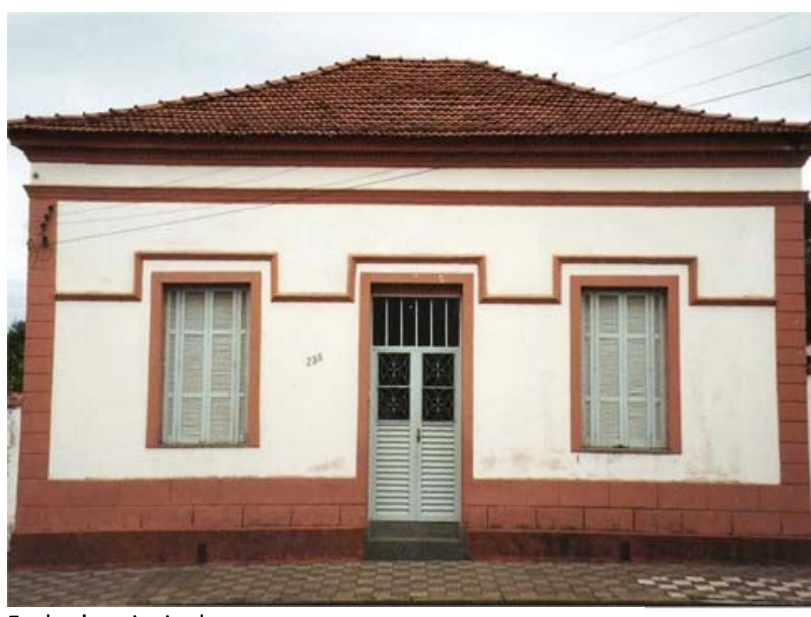

Fachada principal

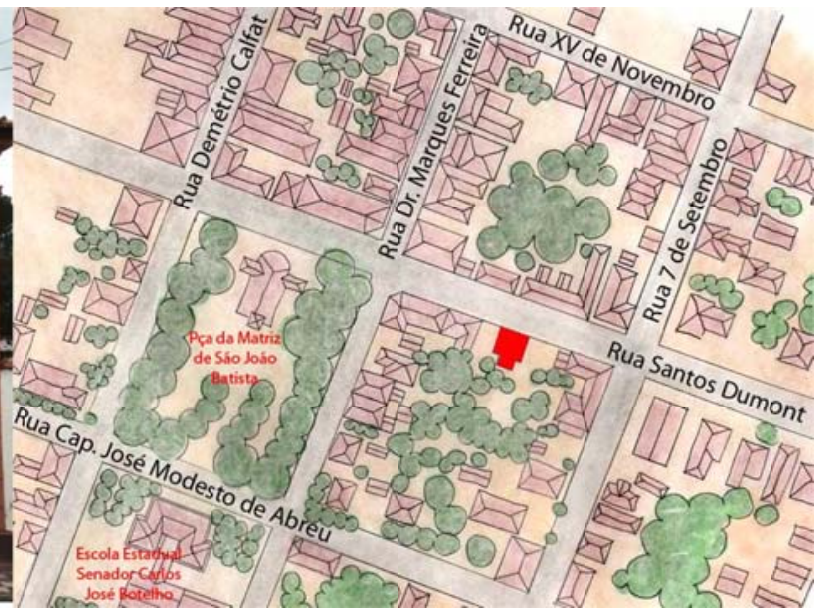

Localização na cidade - situação sem escala

Fachada principal e uso atual

1. Materiais empregados na cobertura

Destruição total

Canal

Francesa $X$

Vidro

Fibrocimento

Metal

Destruição total

Plástico / fibra

Laje

Frontão

Cachorros

Outros:

Laje de beiral

Beiral simples

Platibanda

Cimalha $X$

Beira seveira

Guarda pó

Outros:

4. Materiais de acabamento da fachada principal

3. Materiais do coroamento

Argamassa $\mathrm{X}$

Azulejo antigo

Cantaria

Argamassa $\mathrm{X}$

Chapisco

Azulejo novo

Cantaria

Azulejo novo

Azulejo novo

Concreto aparente

Vidros

Madeira

6. Material das esquadrias da fachada principal

Destruição total Madeira $X$

Vidro $X \quad$ Alumínio $X$

Ferro laminado / solda Outros:

$\begin{array}{ll}\text { Azulejo antigo } & \text { Azulejo novo } \\ \text { Madeira } & \text { Concreto aparente }\end{array}$

7. Cores predominantes da fachada principal

Coroamento:

Esquadrias:

Molduras dos vãos:

Acabam. da fachada:

8. Uso atual - quantificar

Residência: 100\%

Comércio:

Vago:

Serviço:

Culto:

Instituição:

Dados volumétricos

\section{Gabarito \\ Altura da fachada:}

№ pavimentos acima do nível da rua: 01

Além desses, assinalar a existência de:

Porão alto Mirante

Pav. intermediário mezanino

3. Registro de acréscimos

Não tem $X$

Acréscimo vertical

Acréscimo horizontal
2. Classificação tipológica do telhado

Alt. cumeeira: $\quad$ Número de águas do corpo principal: 04

№ subsolos:

Cumeeira paralela à rua $X$

Cumeeira perpendicular à rua

Pav. recuado

Tipo chalé

Com torreão

Água furtada

Outros:

Sótão habitável

Descrever:

Evidência na construção $X$

Depoimento do usuário 
Ficha de pré-inventário do patrimônio arquitetônico e urbanístico de Dourado - SP Características Arquitetônicas - Ficha 49

Identificação

Logradouro: Rua Tiradentes X Rua Francisco Martins Bonilha

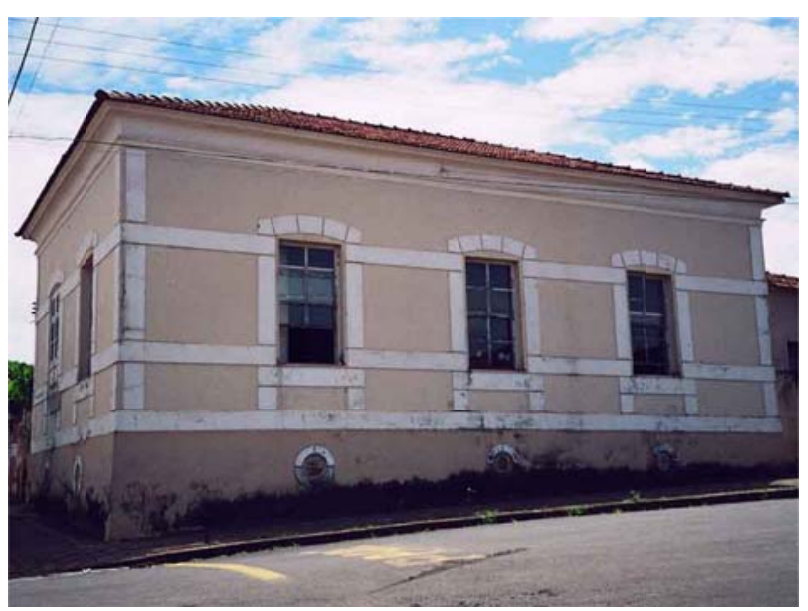

Fachada principal

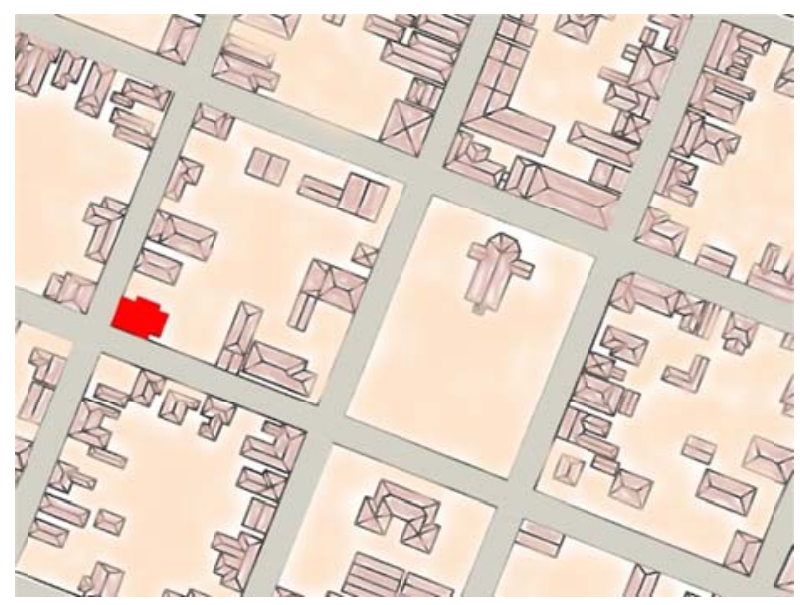

Localização na cidade - situação sem escala

Fachada principal e uso atual

$\begin{array}{ll}\text { 1. Materiais empregados na cobertura } \\ \text { Destruição total } & \text { Canal X } \\ \text { Francesa } & \text { Fibrocimento } \\ \text { Vidro } & \text { Metal } \\ \text { Plástico / fibra } & \text { Laje } \\ \text { Outros: } & \end{array}$

\section{Coroamento}

Destruição total Platibanda

Frontão Cimalha $X$

Cachorros Beira seveira

Laje de beiral Guarda pó

Beiral simples Outros:

3. Materiais do coroamento Argamassa $X$

Cantaria

4. Materiais de acabamento da fachada principal

Azulejo antigo

Azulejo novo

Argamassa $X$

Chapisco

Madeira

Concreto aparente

Cantaria

Azulejo novo

Azulejo novo

Outros:

Vidros

Madeira

Outros:

\begin{tabular}{|c|c|c|c|}
\hline \multicolumn{2}{|c|}{ 5. Material das molduras dos vãos de portas e janelas } & \multicolumn{2}{|c|}{ 6. Material das esquadrias da fachada principal } \\
\hline Não tem & Destruição total & Destruição total & Madeira X \\
\hline Argamassa X & Cantaria & Vidro $X$ & Alumínio \\
\hline Azulejo antigo & Azulejo novo & Ferro laminado / solda & Outros: \\
\hline Madeira & Concreto aparente & & \\
\hline \multicolumn{2}{|c|}{ 7. Cores predominantes da fachada principal } & \multicolumn{2}{|c|}{ 8. Uso atual - quantificar } \\
\hline Coroamento: branco & Esquadrias: branco & Residência: $100 \%$ & Vago: \\
\hline Molduras dos vãos: branco & Acabam. da fachada: bege & Comércio: & Culto: \\
\hline Guarda-corpos: não tem & Outros relevos: branco & Serviço: & Instituição: \\
\hline
\end{tabular}

Dados volumétricos

\begin{tabular}{|c|c|c|c|}
\hline 1. Gabarito & & \multicolumn{2}{|c|}{ 2. Classificação tipológica do telhado } \\
\hline Altura da fachada: & Alt. cumeeira: & \multicolumn{2}{|c|}{ Número de águas do corpo principal: 04} \\
\hline № pavimentos acima do nível da rua: 01 & № subsolos: & Cumeeira paralela à rua $X$ & Com torreão \\
\hline Além desses, assinalar a existência de: & & Cumeeira perpendicular à rua & Água furtada \\
\hline Porão alto $X \quad$ Mirante & Pav. recuado & Tipo chalé & Outros: \\
\hline
\end{tabular}

\section{Registro de acréscimos}

Não tem

Acréscimo vertical

Acréscimo horizontal $X$
Identificado a partir de:

Evidência na construção $X$

Depoimento do usuário
Descrever: acréscimo de banheiro e ampliação de cozinha nos fundos, recuado do alinhamento da rua 
Identificação

Logradouro: Rua Dr. Marques Ferreira s/n

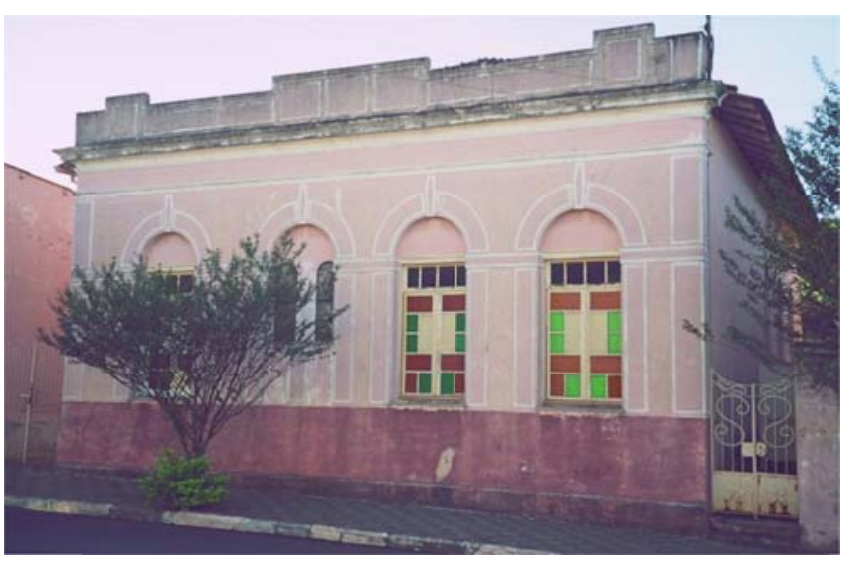

Fachada principal

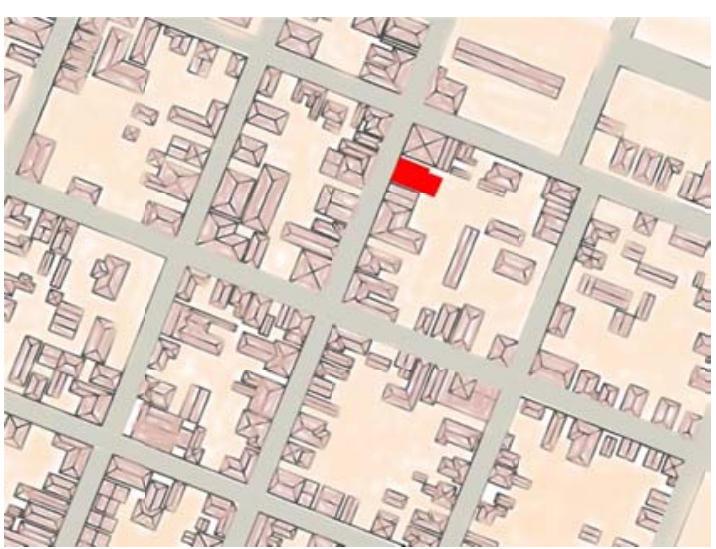

Localização na cidade - situalção sem escala

Fachada principal e uso atual

1. Materiais empregados na cobertura

Destruição total

Francesa $X$

Vidro

Plástico / fibra

Outros:

3. Materiais do coroamento Argamassa $\mathrm{X}$

Azulejo antigo

Madeira

Outros:

5. Material das molduras dos vãos de portas e janelas

Não tem

Argamassa X

Azulejo antigo

Madeira

7. Cores predominantes da fachada principal

Coroamento: rosa

Molduras dos vãos: branco

Guarda-corpos: não tem

Esquadrias: bege

Acabam. da fachada: rosa

Outros relevos: branco

\section{Coroamento}

Destruição total

Frontão

Cachorros

Laje de beiral

Beiral simples

4. Materiais de acabamento da fachada principal

Argamassa $X \quad$ Chapisco

Cantaria Azulejo novo

Azulejo novo Madeira

Vidros Outros:

6. Material das esquadrias da fachada principal

Destruição total Madeira $X$

Vidro Alumínio

Ferro laminado / solda Outros:

8. Uso atual - quantificar

Residência: 100\% Vago:

Comércio: Culto:

Serviço: Instituição:

Dados volumétricos

\begin{tabular}{|c|c|c|c|c|}
\hline \multicolumn{3}{|l|}{ 1. Gabarito } & \multicolumn{2}{|c|}{ 2. Classificação tipológica do telhado } \\
\hline \multicolumn{2}{|c|}{ Altura da fachada: $5 \mathrm{~m}$} & Alt. cumeeira: $7 \mathrm{~m}$ & \multicolumn{2}{|c|}{ Número de águas do corpo principal: 04} \\
\hline \multicolumn{2}{|c|}{ № pavimentos acima do nível da rua: 01} & № subsolos: & Cumeeira paralela à rua $X$ & Com torreão \\
\hline \multicolumn{2}{|c|}{ Além desses, assinalar a existência de: } & & Cumeeira perpendicular à rua & Água furtada \\
\hline Porão alto & Mirante & Pav. recuado & Tipo chalé & Outros: \\
\hline Pav. intermediário & mezanino & Sótão habitável & & \\
\hline \multicolumn{5}{|c|}{ 3. Registro de acréscimos } \\
\hline \multirow{2}{*}{\multicolumn{2}{|c|}{$\begin{array}{l}\text { Não tem } X \\
\text { Acréscimo vertical }\end{array}$}} & Identificado a partir de: & \multicolumn{2}{|l|}{ Descrever: } \\
\hline & & \multirow{2}{*}{$\begin{array}{l}\text { Evidência na construção } X \\
\text { Depoimento do usuário }\end{array}$} & & \\
\hline Acréscimo horizont & & & & \\
\hline
\end{tabular}


Identificação

Logradouro: Rua Santos Dumont no 352

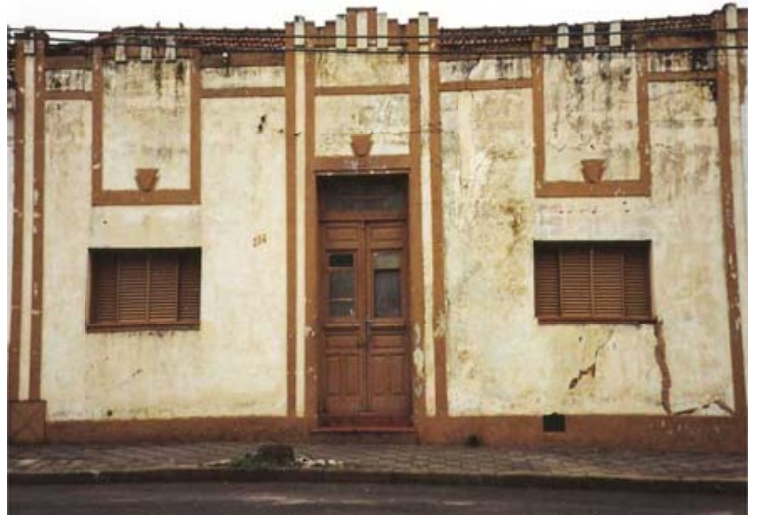

Fachada principal

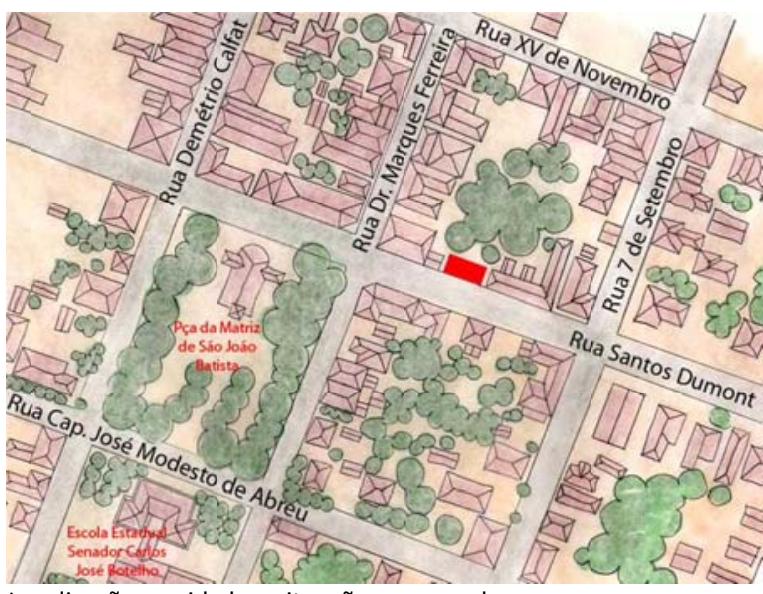

Localização na cidade - situação sem escala

Fachada principal e uso atual

1. Materiais empregados na cobertura

Destruição total Canal

Francesa $X$

Vidro

Plástico / fibra

Fibrocimento

Metal

Laje

Outros:

3. Materiais do coroamento

Argamassa X

Azulejo antigo

Madeira

Cantaria

Azulejo novo

Outros:

Concreto aparente

5. Material das molduras dos vãos de portas e janelas Não tem Destruição total

Argamassa $X$

Azulejo antigo

Cantaria

Azulejo novo

Madeira

Concreto aparente

7. Cores predominantes da fachada principal

Coroamento: bege/marrom

Molduras dos vãos: marrom

Esquadrias: marrom

Acabam. da fachada: bege

Guarda-corpos: não tem

Outros relevos: marrom

\section{Coroamento}

Destruição total

Frontão

Cachorros

Laje de beiral

Beiral simples

Platibanda X

Cimalha

Beira seveira

Guarda pó

Outros:

4. Materiais de acabamento da fachada principal

Argamassa $X \quad$ Chapisco

Cantaria Azulejo novo

Azulejo novo Madeira

Vidros Outros:

6. Material das esquadrias da fachada principal

Destruição total Madeira X

Vidro Alumínio $X$

Ferro laminado / solda Outros:

8. Uso atual - quantificar

Residência: $100 \% \quad$ Vago:

Comércio: Culto:

Serviço: Instituição:

Dados volumétricos

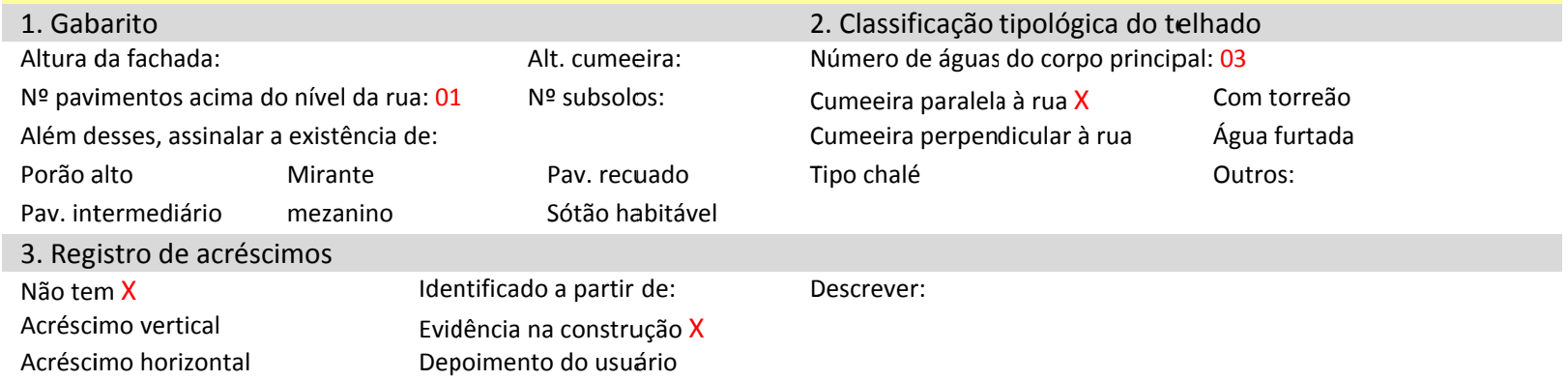


Identificação

Logradouro: Rua Santos Dumont X Rua 7 de Setembro

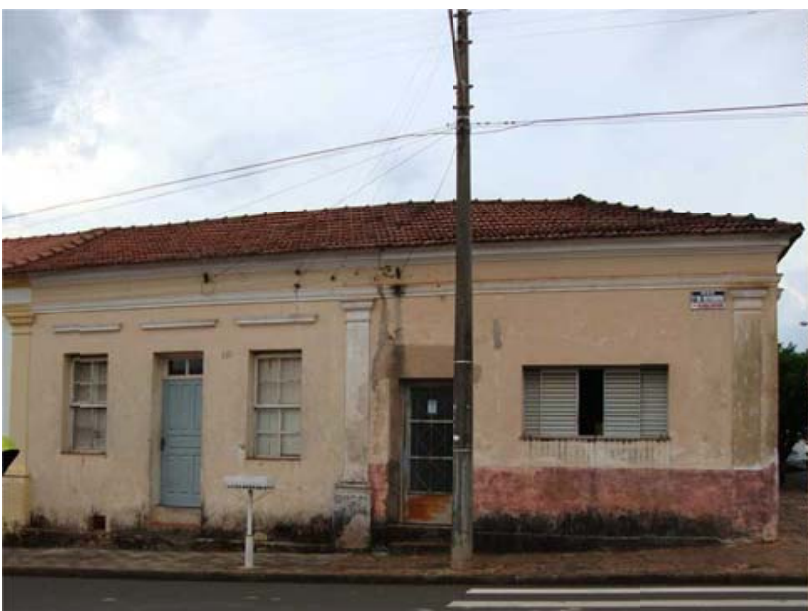

Fachada principal

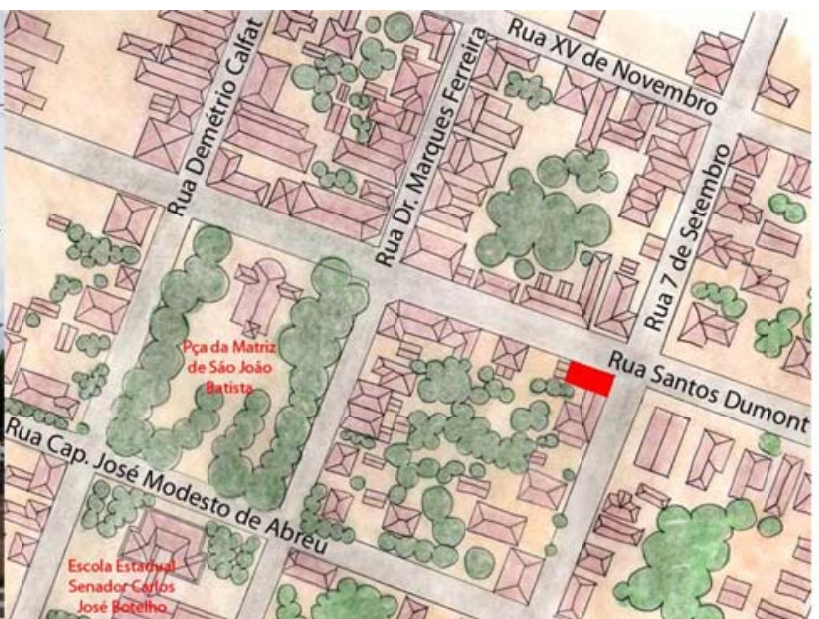

Localização na cidade - situação sem escala

Fachada principal e uso atual

$\begin{array}{ll}\text { 1. Materiais empregados na cobertura } \\ \text { Destruição total } & \text { Canal } \\ \text { Francesa X } & \text { Fibrocimento } \\ \text { Vidro } & \text { Metal } \\ \text { Plástico / fibra } & \text { Laje } \\ \text { Outros: } & \end{array}$

3. Materiais do coroamento Argamassa $X$

Cantaria

Azulejo antigo

Azulejo novo

Madeira

Concreto aparente

\section{Coroamento}

Destruição total

Frontão

Cachorros

Laje de beiral

Beiral simples

Platibanda

Cimalha $X$

Beira seveira

Guarda pó

4. Materiais de acabamento da fachada principal

Argamassa $X \quad$ Chapisco $X$

Cantaria Azulejo novo

Azulejo novo Madeira

Vidros Outros:

5. Material das molduras dos vãos de portas e janelas

6. Material das esquadrias da fachada principal

Não tem X

Destruição total

Argamassa

Cantaria

Destruição total

Vidro $X$

Madeira X

Azulejo antigo

Azulejo novo

Ferro laminado / solda $X$

Alumínio $X$

Madeira

Concreto aparente

7. Cores predominantes da fachada principal

Coroamento: branco

Esquadrias: cinza

Molduras dos vãos: não tem

Acabam. da fachada: bege

8. Uso atual - quantificar

Guarda-corpos: não tem

Outros relevos:

Residência: $100 \%$

Comércio:

Serviço:

\section{Vago:}

Culto:

Instituição:

Dados volumétricos

\section{Gabarito}

Altura da fachada:

№ pavimentos acima do nível da rua: 01

Além desses, assinalar a existência de:

Porão alto Mirante

Pav. intermediário

mezanino
2. Classificação tipológica do telhado Número de águas do corpo principal: 04

Cumeeira paralela à rua $X$

Com torreão

№ subsolos:

Cumeeira perpendicular à rua

Pav. recuado

Tipo chalé

Água furtada

Outros:

\section{Registro de acréscimos}

Não tem $X$

Acréscimo vertical

Acréscimo horizontal
Identificado a partir de:

Evidência na construção $X$

Depoimento do usuário
Descrever: 
Identificação

Logradouro: Rua 7 de Setembro

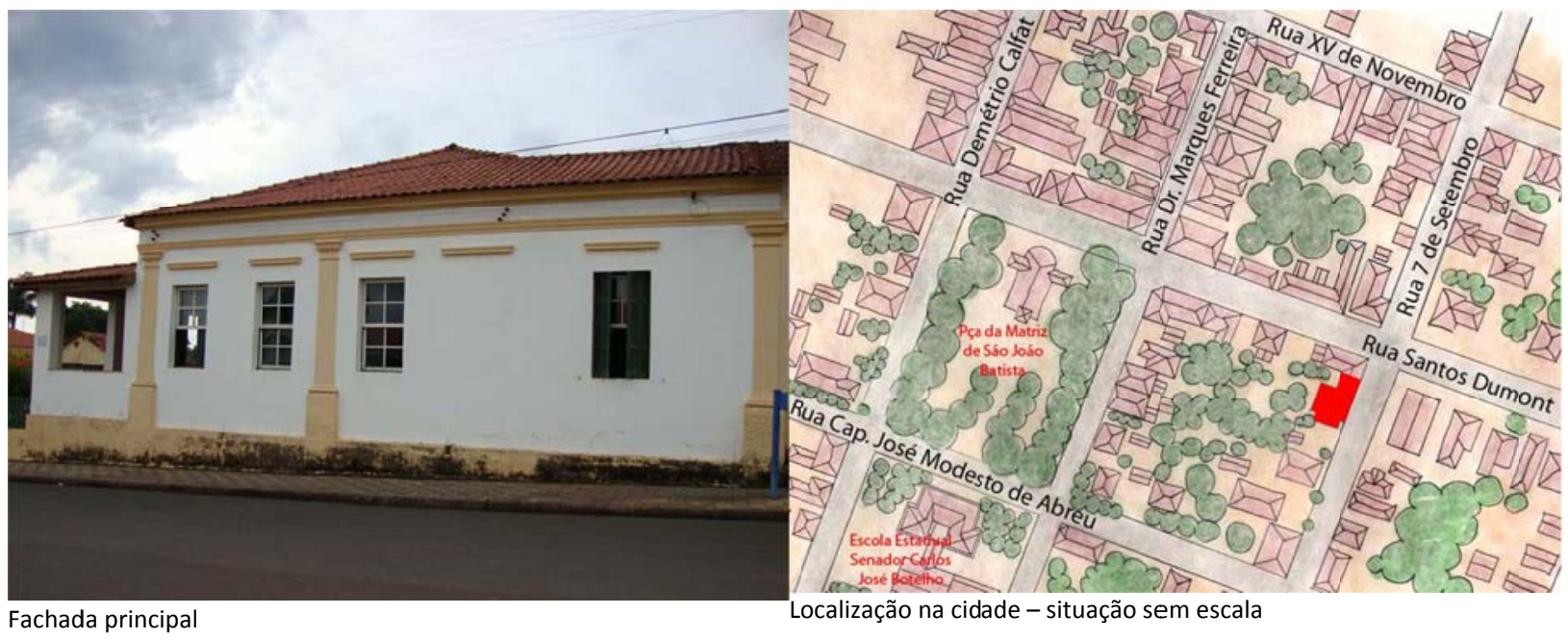

Fachada principal e uso atual

1. Materiais empregados na cobertura

2. Coroamento Destruição total

Frontão

Francesa

Vidro

Plástico / fibra

Outros:

3. Materiais do coroamento

Argamassa $X$

Azulejo antigo

Madeira

Outros:

\section{Canal X}

Fibrocimento

Metal

Laje

\section{Cachorros}

Laje de beiral

Beiral simples

4. Materiais de acabamento da fachada principal

Argamassa $X \quad$ Chapisco $X$

Cantaria Azulejo novo

Azulejo novo Madeira

Vidros Outros:

5. Material das molduras dos vãos de portas e janelas Não tem

Argamassa X

Azulejo antigo

\section{Cantaria}

Azulejo novo

Concreto aparente

6. Material das esquadrias da fachada principal

Destruição total Madeira $X$

Vidro $X \quad$ Alumínio

Ferro laminado / solda Outros:
Madeira

\section{Concreto aparente}

Azulejo novo

7. Cores predominantes da fachada principal Coroamento: amarelo

Molduras dos vãos: amarelo

Guarda-corpos: não tem

Esquadrias: branco / verde

Acabam. da fachada: branco

Outros relevos: amarelo

Residência: 100\%

Comércio:

Serviço:
Vago:

Culto:

Instituição:

Dados volumétricos

\section{Gabarito}

Altura da fachada:

№ pavimentos acima do nível da rua: 01

Além desses, assinalar a existência de:

$\begin{array}{ll}\text { Porão alto } X & \text { Mirante } \\ \text { Pav. intermediário } & \text { mezanino }\end{array}$

3. Registro de acréscimos

Não tem X

Acréscimo vertical

Acréscimo horizontal

\section{Classificação tipológica do telhado}

Alt. cumeeira: Número de águas do corpo principal: 06

№ subsolos:

Cumeeira paralela à rua

Com torreão

Cumeeira perpendicular à rua

Pav. recuado

Tipo chalé

Água furtada

Sótão habitável

Outros:

Identificado a partir de: Descrever:

Evidência na construção $X$

Depoimento do usuário 
Ficha de pré-inventário do patrimônio arquitetônico e urbanístico de Dourado - SP Características Arquitetônicas - Ficha 54

Identificação

Logradouro:

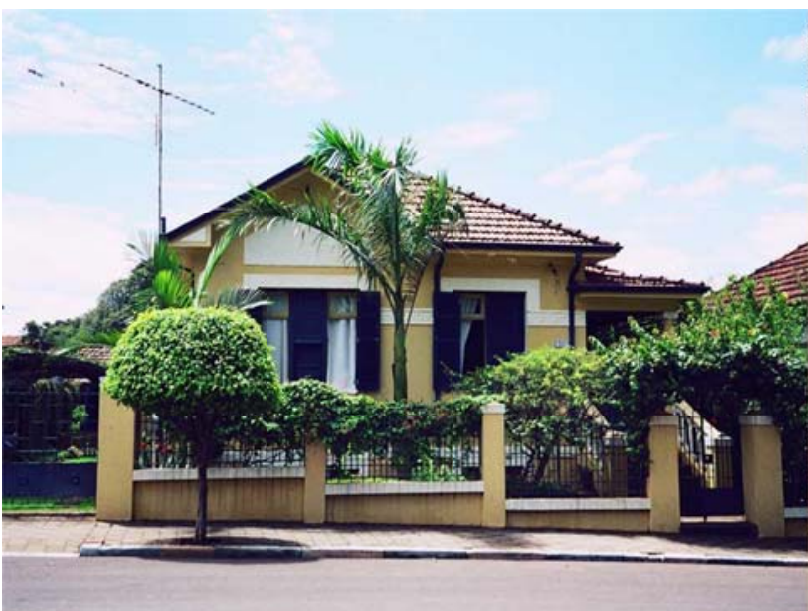

Fachada principal

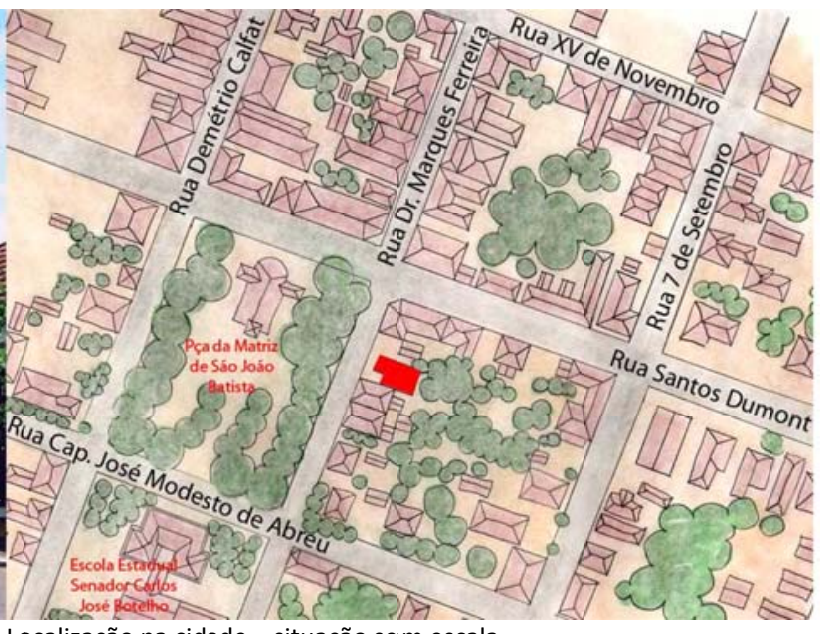

Localização na cidade - situação sem escala

Fachada principal e uso atual

$\begin{array}{ll}\text { 1. Materiais empregados na cobertura } & \text { Canal } \\ \text { Destruição total } & \text { Fibrocimento } \\ \text { Francesa X } & \text { Metal } \\ \text { Vidro } & \text { Laje } \\ \text { Plástico / fibra } & \end{array}$

3. Materiais do coroamento Argamassa

Cantaria

Azulejo antigo

Azulejo novo

2. Coroamento

Destruição total

Frontão

Cachorros

Laje de beiral

Beiral simples

Platibanda

Cimalha

Beira seveira

Guarda pó $X$

Outros:

4. Materiais de acabamento da fachada principal

Madeira X

Concreto aparente

Argamassa $X$

Chapisco

Cantaria Azulejo novo

Azulejo novo Madeira

5. Material das molduras dos vãos de portas e janelas

6. Material das esquadrias da fachada principal

Não tem

Destruição total

Destruição tota

Madeira X

Argamassa $X$

Cantaria

Vidro $\mathrm{X}$

Alumínio

Azulejo antigo

Azulejo novo

Ferro laminado / solda

Outros:

Madeira

Concreto aparente

7. Cores predominantes da fachada principal

Coroamento:

Esquadrias: azul

8. Uso atual - quantificar

Residência: $X-100 \%$

Comércio:

Vago:

Acabam. da fachada: amarelo

Serviço:

Instituição:

Dados volumétricos

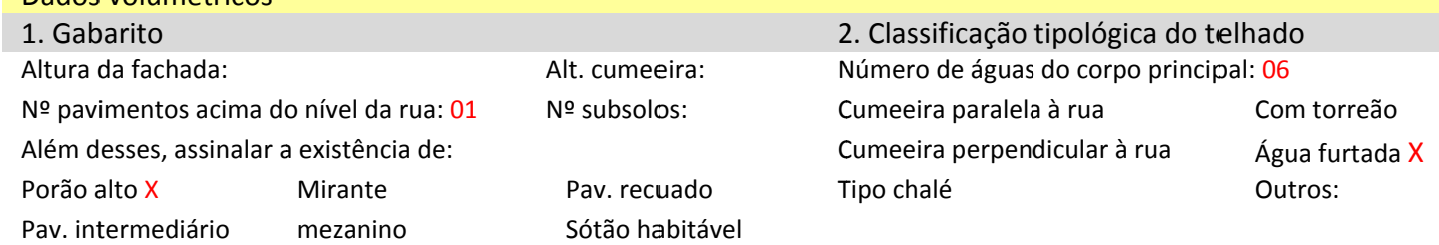

3. Registro de acréscimos Não tem $X$

Identificado a partir de:

Descrever:

Acréscimo vertical

Evidência na construção $X$

Acréscimo horizontal

Depoimento do usuário 
Identificação

Logradouro: Rua Dr. Marques Ferreira s/n
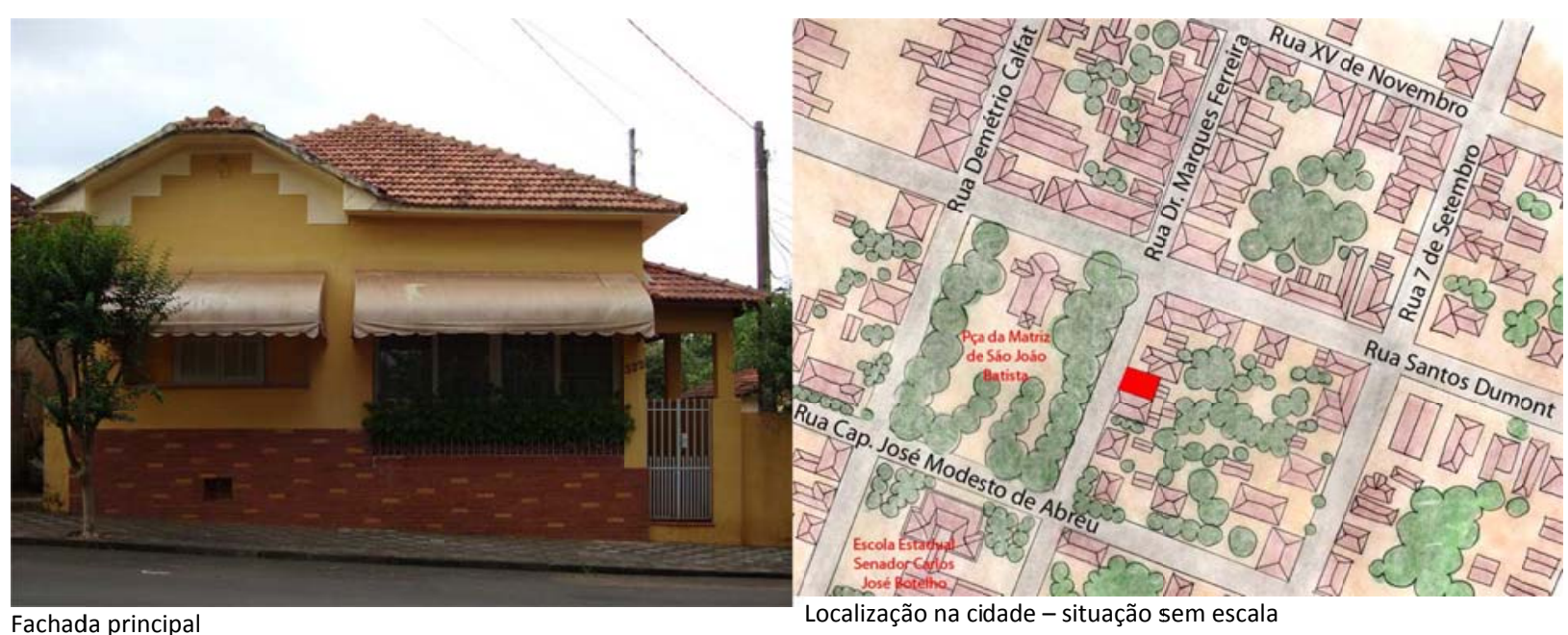

Localização na cidade - situação sem escala

Fachada principal e uso atual

\begin{tabular}{|c|c|c|c|}
\hline \multicolumn{2}{|c|}{ 1. Materiais empregados na cobertura } & \multicolumn{2}{|l|}{ 2. Coroamento } \\
\hline Destruição total & Canal & Destruição total & Platibanda \\
\hline Francesa X & Fibrocimento & Frontão & Cimalha \\
\hline Vidro & Metal & Cachorros & Beira seveira \\
\hline Plástico / fibra & Laje & Laje de beiral & Guarda pó X \\
\hline Outros: & & Beiral simples & Outros: \\
\hline \multicolumn{2}{|l|}{ 3. Materiais do coroamento } & \multicolumn{2}{|c|}{ 4. Materiais de acabamento da fachada principal } \\
\hline Argamassa & Cantaria & Argamassa X & Chapisco \\
\hline Azulejo antigo & Azulejo novo & Cantaria & Azulejo novo \\
\hline Madeira & Concreto aparente & Azulejo novo & Madeira \\
\hline Outros: & & Vidros & Outros: lajota cerâmica \\
\hline \multicolumn{2}{|c|}{ 5. Material das molduras dos vãos de portas e janelas } & \multicolumn{2}{|c|}{ 6. Material das esquadrias da fachada principal } \\
\hline Não tem & Destruição total & Destruição total & Madeira \\
\hline Argamassa & Cantaria & Vidro X & Alumínio $X$ \\
\hline Azulejo antigo & Azulejo novo & Ferro laminado / solda X & Outros: \\
\hline Madeira & Concreto aparente & & \\
\hline \multicolumn{2}{|c|}{ 7. Cores predominantes da fachada principal } & \multicolumn{2}{|l|}{ 8. Uso atual - quantificar } \\
\hline Coroamento: branco & Esquadrias: cinza & Residência: $100 \%$ & Vago: \\
\hline Molduras dos vãos: não tem & Acabam. da fachada: amarelo & Comércio: & Culto: \\
\hline Guarda-corpos: não tem & Outros relevos: vermelho & Serviço: & Instituição: \\
\hline
\end{tabular}

Dados volumétricos

\begin{tabular}{|c|c|c|c|c|}
\hline \multicolumn{3}{|l|}{ 1. Gabarito } & \multicolumn{2}{|c|}{ 2. Classificação tipológica do telhado } \\
\hline \multicolumn{2}{|c|}{ Altura da fachada: } & Alt. cumeeira: & \multicolumn{2}{|c|}{ Número de águas do corpo principal: 06} \\
\hline \multicolumn{2}{|c|}{ № pavimentos acima do nível da rua: 01} & № subsolos: & Cumeeira paralela à rua & Com torreão \\
\hline Além desses, assin & a existência de: & & Cumeeira perpendicular à rua & Água furtada $X$ \\
\hline Porão alto X & Mirante & Pav. recuado & Tipo chalé & Outros: \\
\hline Pav. intermediário & mezanino & Sótão habitável & & \\
\hline
\end{tabular}

3. Registro de acréscimos

Não tem $X$

Acréscimo vertical

Acréscimo horizontal

Identificado a partir de:

Descrever:

Depoimento do usuário 
Identificação

Logradouro: Rua Dr. Marques Ferreira s/n

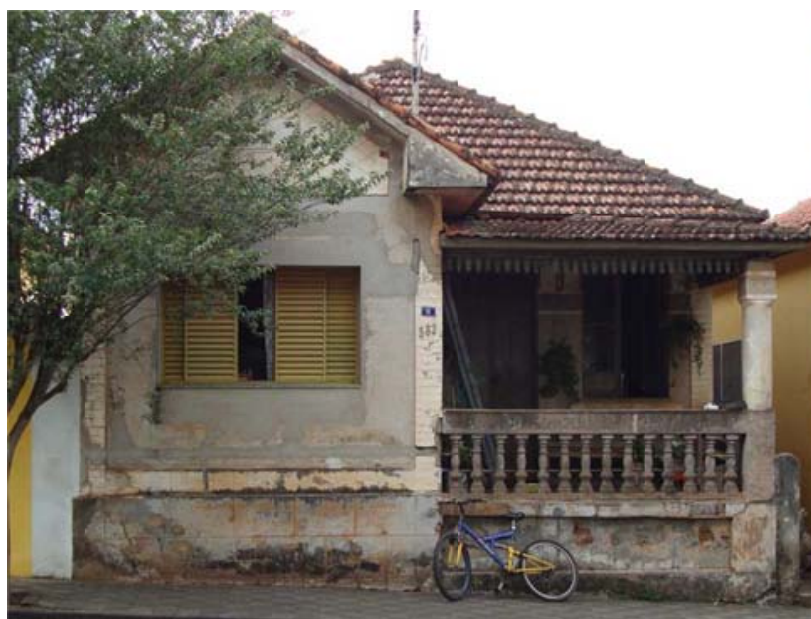

Fachada principal

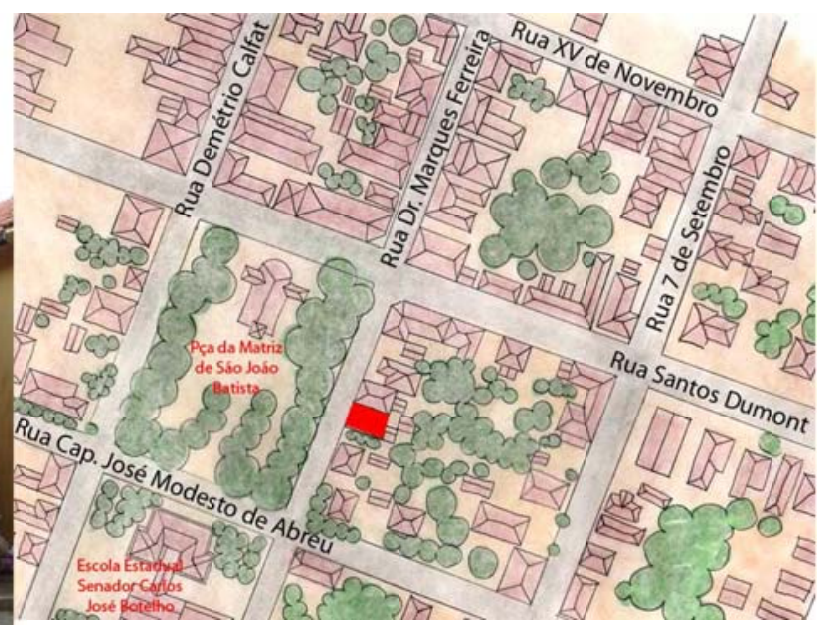

Localização na cidade - situação sem escala

Fachada principal e uso atual

$\begin{array}{ll}\text { 1. Materiais empregados na cobertura } \\ \text { Destruição total } & \text { Canal } \\ \text { Francesa X } & \text { Fibrocimento } \\ \text { Vidro } & \text { Metal } \\ \text { Plástico / fibra } & \text { Laje } \\ \text { Outros: } & \end{array}$

\section{Materiais do coroamento}

Argamass

Azulejo antigo

Cantaria

Madeira X

Azulejo novo

Concreto aparente

\section{Coroamento}

Destruição total

Frontão

Cachorros

Platibanda

Laje de beiral

Beiral simples

Cimalha

Beira seveira

Guarda pó X

4. Materiais de acabamento da fachada principal

Argamassa $X \quad$ Chapisco

Cantaria Azulejo novo

Azulejo novo Madeira

Vidros Outros:

5. Material das molduras dos vãos de portas e janelas

Não tem X

Argamassa Destruição total

Cantaria

Azulejo antigo

Azulejo novo

Concreto aparente

7. Cores predominantes da fachada principal

Coroamento: branco

Esquadrias: amarelo/cinza

Molduras dos vãos: não tem

Acabam. da fachada: cinza

Outros relevos: branco

6. Material das esquadrias da fachada principal

Destruição total

Madeira X

Vidro $X \quad$ Alumínio $X$

Ferro laminado / solda Outros:

\section{Uso atual - quantificar}

Residência: $100 \%$

Comércio:

Vago:

Serviço:

Culto:

Instituição:

\section{Dados volumétricos}

\section{Gabarito}

Altura da fachada:

№ pavimentos acima do nível da rua: 01

Além desses, assinalar a existência de:

$\begin{array}{ll}\text { Porão alto } X & \text { Mirante } \\ \text { Pav. intermediário } & \text { mezanino }\end{array}$

3. Registro de acréscimos

Não tem $X$

Acréscimo vertical

Acréscimo horizontal
2. Classificação tipológica do telhado Número de águas do corpo principal: 06

Cumeeira paralela à rua

Com torreão

№ subsolos:

Pav. recuado

Sótão habitável
Cumeeira perpendicular à rua

Tipo chalé

Água furtada X

Outros:

dentificado a partir de: Descrever:

Evidência na construção $X$

Depoimento do usuário 
Identificação

Logradouro: Rua Dr Marques Ferreira s/n

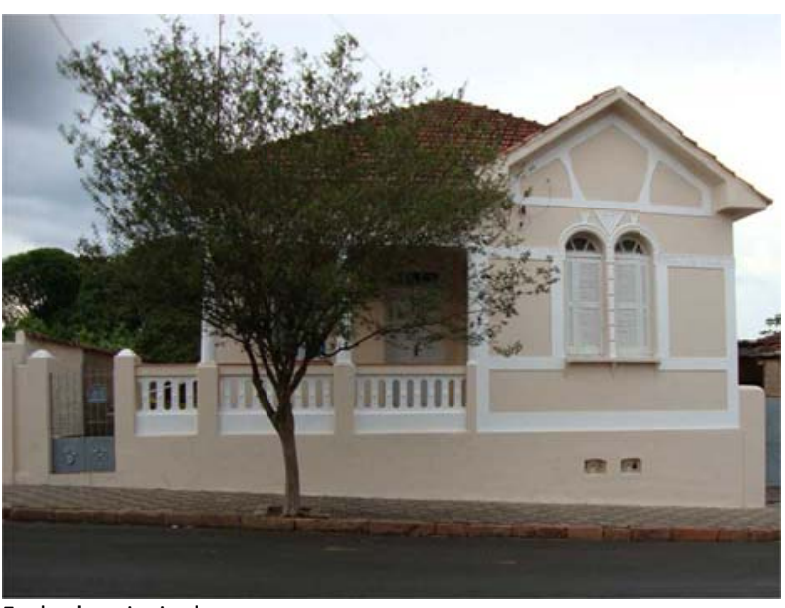

Fachada principal

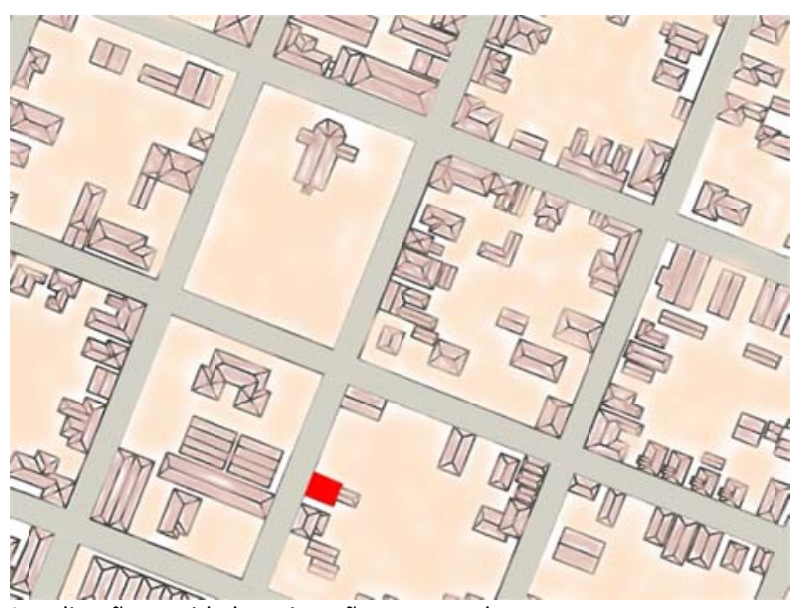

Localização na cidade - situação sem escala

\section{Coroamento}

Destruição total Platibanda

Frontão Cimalha

Cachorros Beira seveira

Laje de beiral Guarda pó $X$

Beiral simples Outros:

4. Materiais de acabamento da fachada principal

Argamassa $X \quad$ Chapisco

Cantaria Azulejo novo

Azulejo novo Madeira

Vidros Outros:

6. Material das esquadrias da fachada principal

Destruição total Madeira $X$

Vidro Alumínio

Ferro laminado / solda Outros:

8. Uso atual - quantificar

Residência: $100 \%$ Vago:

Comércio: Culto:

Serviço: Instituição:
Dados volumétricos

\section{Gabarito}

Altura da fachada: $6 \mathrm{~m}$

№ pavimentos acima do nível da rua: 01

Além desses, assinalar a existência de:

$\begin{array}{ll}\text { Porão alto } X & \text { Mirante } \\ \text { Pav. intermediário } & \text { mezanino }\end{array}$

3. Registro de acréscimos

Não tem $X$

Acréscimo vertical

Acréscimo horizontal

\section{Classificação tipológica do trelhado}

Alt. cumeeira: $7.5 \mathrm{~m} \quad$ Número de águas do corpo principal: 06

№ subsolos:

Pav. recuado

Sótão habitável
Cumeeira paralela à rua

Cumeeira perpendicular à rua

Tipo chalé
Com torreão

Água furtada $X$

Outros:

Identificado a partir de:

Descrever:

Evidência na construção $X$

Depoimento do usuário 
Ficha de pré-inventário do patrimônio arquitetônico e urbanístico de Dourado - SP Características Arquitetônicas - Ficha 58

Identificação

Logradouro: Rua XV de Novembro X Rua Floriano Peixoto

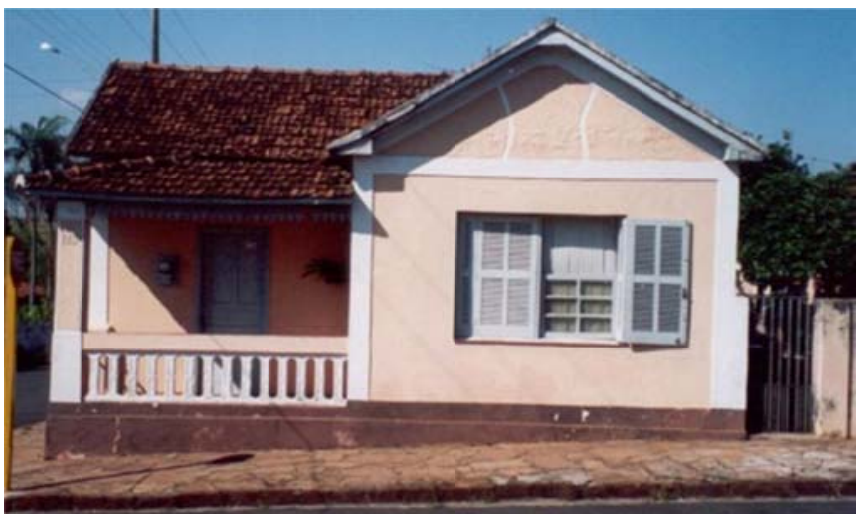

Fachada principal

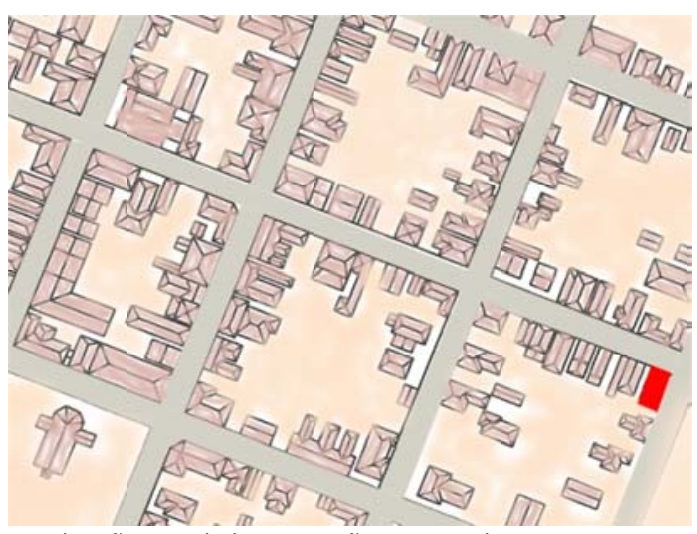

Localização na cidade - situação sem escala

Fachada principal e uso atual

1. Materiais empregados na cobertura

\section{Destruição total}

Francesa X

Vidro

Plástico / fibra

Outros:

3. Materiais do coroamento

Argamassa

Azulejo antigo

Madeira

Outros:

5. Material das molduras dos vãos de portas e janelas

Não tem $X$

Argamassa

Azulejo antigo

Madeira

7. Cores predominantes da fach

Coroamento: branco

Molduras dos vãos: branco

Guarda-corpos: não tem

\section{Canal \\ Fibrocimento \\ Metal}

Laje

\section{Cantaria}

Azulejo novo

Concreto aparente
Cantaria

Azulejo novo

hada principal

Acabam. da fachada: rosa

Outros relevos: branco
2. Coroamento

Destruição total

Frontão

Cachorros

Laje de beiral

Beiral simples $X$

4. Materiais de acabamento da fachada principal

Argamassa X Chapisco

Cantaria Azulejo novo

Azulejo novo Madeira

Vidros Outros:

6. Material das esquadrias da fachada principal

Destruição total Madeira X

Vidro Alumínio

Ferro laminado / solda Outros:

Dados volumétricos

\section{Gabarito}

Altura da fachada: $5 \mathrm{~m}$

№ pavimentos acima do nível da rua: 01

Além desses, assinalar a existência de:

$\begin{array}{ll}\text { Porão alto } & \text { Mirante } \\ \text { Pav. intermediário } & \text { mezanino }\end{array}$ 3. Registro de acréscimos

Não tem $X$

Acréscimo vertical

Acréscimo horizontal

(d)

8. Uso atual - quantificar

Residência: $100 \%$

Comércio:

Serviço:
Vago:

Culto:

Instituição:
2. Classificação tipológica do telhado Alt. cumeeira: $6 \mathrm{~m} \quad$ Número de águas do corpo principal: 04

№ subsolos:

Pav. recuado

Sótão habitável
Cumeeira paralela à rua $X$

Cumeeira perpendicular à rua

Tipo chalé
Com torreão

Água furtada

Outros:

Identificado a partir de:

Evidência na construção $X$

Depoimento do usuário 
Identificação

Logradouro: Rua Floriano Peixoto s/n

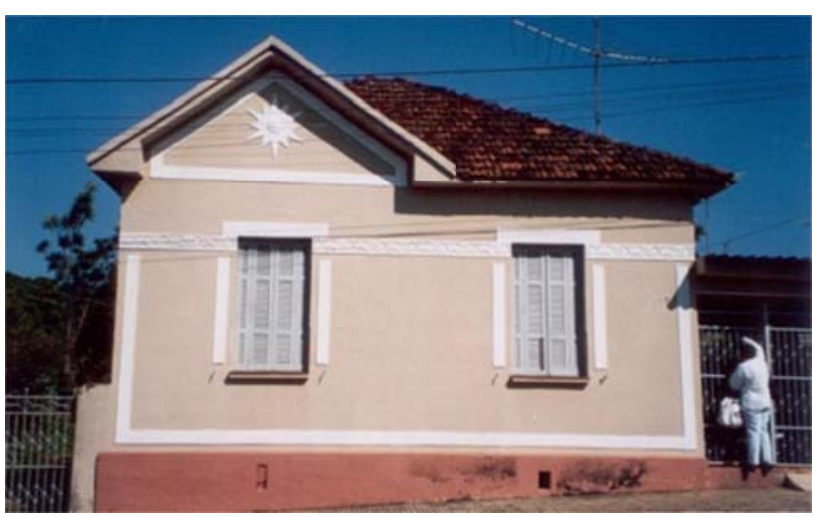

Fachada principal

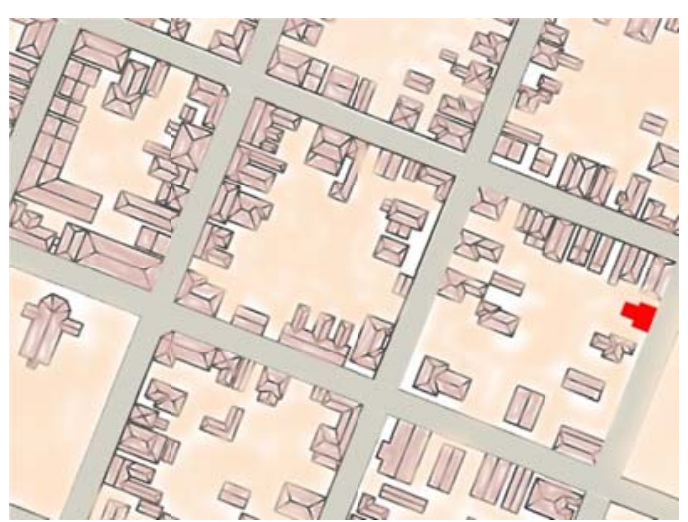

Localização na cidade - situação sem escala

Fachada principal e uso atual

1. Materiais empregados na cobertura

Destruição total

Francesa $X$

Vidro

Plástico / fibra

Outros:

\section{Materiais do coroamento}

Argamassa

Azulejo antigo

Madeira X

Outros:

5. Material das molduras dos vãos de portas e janelas

Não tem

Argamassa $X$

Azulejo antigo

Madeira

7. Cores predominantes da facha

Coroamento: branco/bege

Molduras dos vãos: branco

Guarda-corpos: não tem

Canal
Fibrocimento
Metal
Laje

Laje

\section{Cantaria}

Azulejo novo

Concreto aparente

\section{Coroamento}

Destruição total

Frontão

Cachorros

Laje de beiral

Beiral simples $X$

4. Materiais de acabamento da fachada principal

Argamassa $X \quad$ Chapisco

Cantaria Azulejo novo

Azulejo novo Madeira

Vidros Outros:

6. Material das esquadrias da fachada principal

Destruição total Madeira X

Vidro Alumínio

Ferro laminado / solda Outros:

8. Uso atual - quantificar

Residência: $100 \% \quad$ Vago:

Comércio: Culto:

Serviço: Instituição:
Dados volumétricos

\section{Gabarito}

Altura da fachada: $4 \mathrm{~m}$

№ pavimentos acima do nível da rua: 01

Além desses, assinalar a existência de:

Porão alto

Mirante

Pav. intermediário

mezanino

\section{Classificação tipológica do telhado}

Alt. cumeeira: $5.5 \mathrm{~m}$ № subsolos:

Pav. recuado

Sótão habitável

\section{Número de águas do corpo principal: 06}

Cumeeira paralela à rua $X$

Cumeeira perpendicular à rua

Tipo chalé

Com torreão

Água furtada $\mathrm{X}$

Outros:

3. Registro de acréscimos

Não tem $X$

Acréscimo vertical

Acréscimo horizontal

Identificado a partir de: Descrever:

Evidência na construção $X$

Depoimento do usuário

\section{Descrever:}


Identificação

Logradouro: Rua Santos Dumont s/n

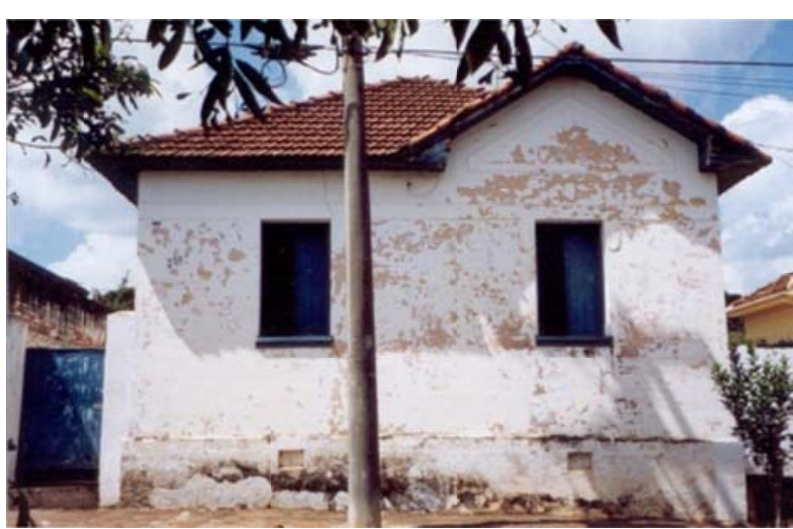

Fachada principal

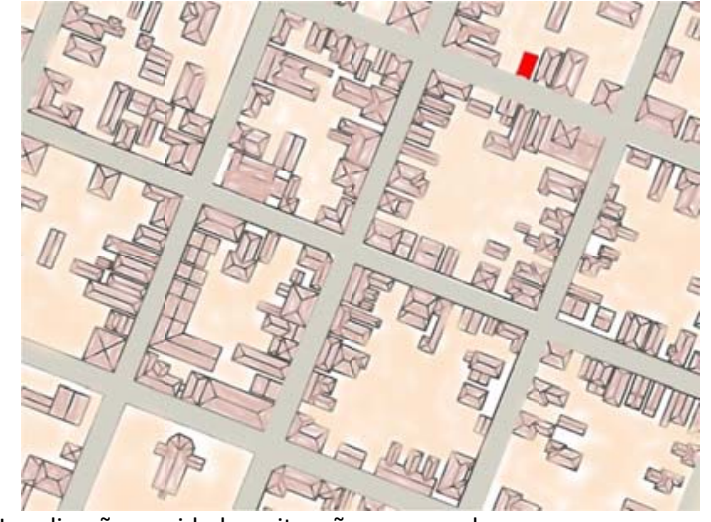

Localização na cidade - situação sem escala

Fachada principal e uso atual

1. Materiais empregados na cobertura

Destruição total

Francesa $\mathrm{X}$

Vidro

Plástico / fibra

Outros:

\section{Materiais do coroamento}

Argamassa

Azulejo antigo

Madeira X

Outros:

5. Material das molduras dos vãos de portas e janelas

Não tem X

Argamassa

Azulejo antigo

Madeira

7. Cores predominantes da fachada principal

Coroamento: branco

Molduras dos vãos: não tem

Guarda-corpos: não tem
Cana

Fibrocimento

Metal

Laje

\section{Cantaria}

Azulejo novo

Concreto aparente Destruição total

Cantaria

Azulejo novo

Esquadrias: azul

Acabam. da fachada: branco

Outros relevos: branco
2. Coroamento

Destruição total

Frontão

Cachorros

Laje de beiral

Beiral simples $X$

4. Materiais de acabamento da fachada principal

Argamassa X Chapisco

Cantaria Azulejo novo

Azulejo novo Madeira

Vidros Outros:

6. Material das esquadrias da fachada principal

Destruição total Madeira $X$

Vidro Alumínio

Ferro laminado / solda Outros:
Dados volumétricos

\section{Gabarito}

Altura da fachada: $5 \mathrm{~m}$

№ pavimentos acima do nível da rua: 01

Além desses, assinalar a existência de:

$\begin{array}{ll}\text { Porão alto } & \text { Mirante } \\ \text { Pav. intermediário } & \text { mezanino }\end{array}$

3. Registro de acréscimos

Não tem X

Acréscimo vertical

Acréscimo horizontal
Identificado a partir de: Descrever:

Evidência na construção $X$

Depoimento do usuário

\section{Classificação tipológica do telhado} Número de águas do corpo principal: 06

Cumeeira paralela à rua

Com torreão

Cumeeira perpendicular à rua

Tipo chalé

Água furtada $X$

Outros:

av. recuado

Vago:

Culto:

Instituição: 
Ficha de pré-inventário do patrimônio arquitetônico e urbanístico de Dourado - SP Características Arquitetônicas - Ficha 61

Identificação

Logradouro: Logradouro: Rua Santos Dumont s/n

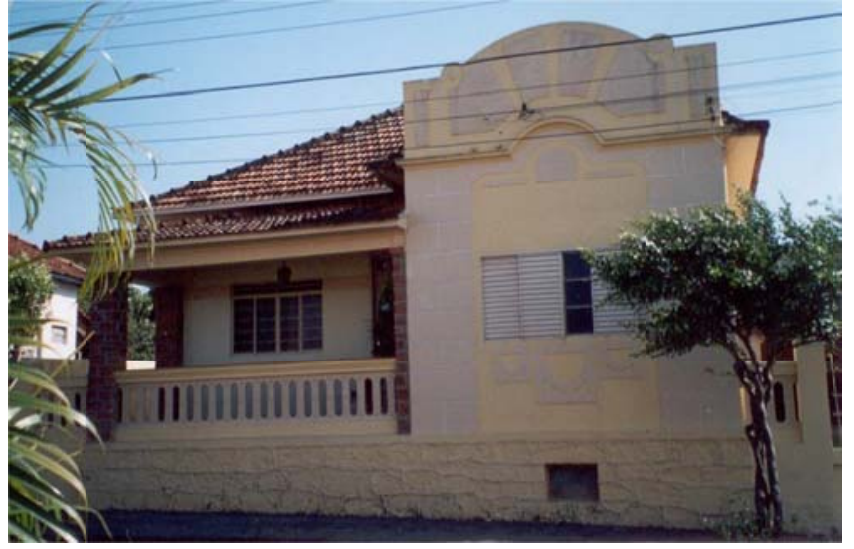

Fachada principal

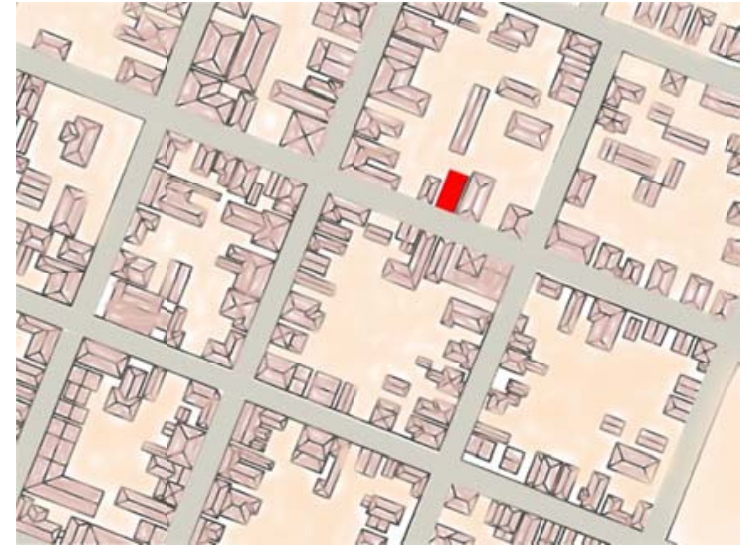

Localização na cidade - situação sem escala

Fachada principal e uso atual

1. Materiais empregados na cobertura

Destruição total

Francesa X

Vidro

Plástico / fibra

Outros:

\section{Materiais do coroamento}

\section{Argamassa $X$}

Azulejo antigo

Madeira

Outros:

5. Material das molduras dos vãos de portas e janelas

Não tem

Argamassa X

Azulejo antigo

Madeira

7. Cores predominantes da fachada principal

Coroamento: amarelo/rosa

Molduras dos vãos: rosa

Guarda-corpos: não tem

Canal
Fibrocimento
Metal
Laje

\section{Cantaria}

Azulejo novo

Concreto aparente

Destruição total

Cantaria

Azulejo novo

Concreto aparente

Esquadrias: branco

Acabam. da fachada: amarelo

Outros relevos: rosa

2. Coroamento
Destruição total
Frontão
Cachorros
Laje de beiral

Beiral simples $X$

4. Materiais de acabamento da fachada principal

Argamassa $X \quad$ Chapisco

Cantaria Azulejo novo

Azulejo novo

Vidros Outros: pedra

6. Material das esquadrias da fachada principal

Destruição total Madeira $X$

Vidro Alumínio $X$

Ferro laminado / solda $X \quad$ Outros:

8. Uso atual - quantificar

Residência: $100 \% \quad$ Vago:

Comércio: Culto:

Serviço: Instituição:

Dados volumétricos

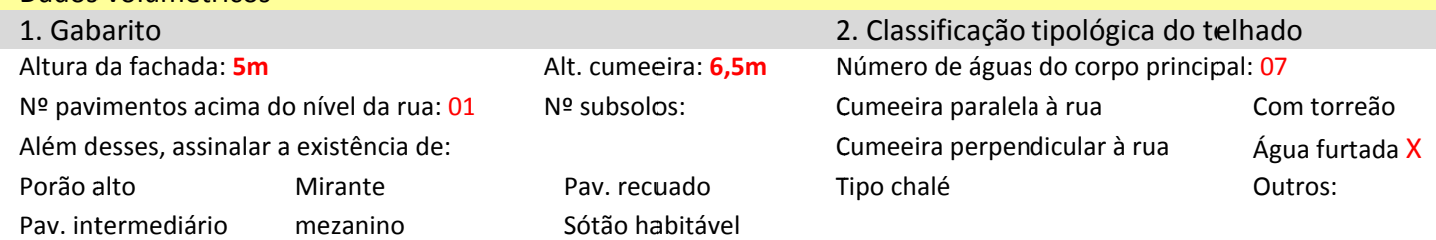

Pav. intermediário mezanino Sótão habitável

3. Registro de acréscimos

Não tem X

Acréscimo vertical

Acréscimo horizontal

\section{Descrever:}

\section{Identificado a partir de:}

Evidência na construção $X$

Depoimento do usuário 
Identificação

Logradouro: Rua XV de Novembro s/n

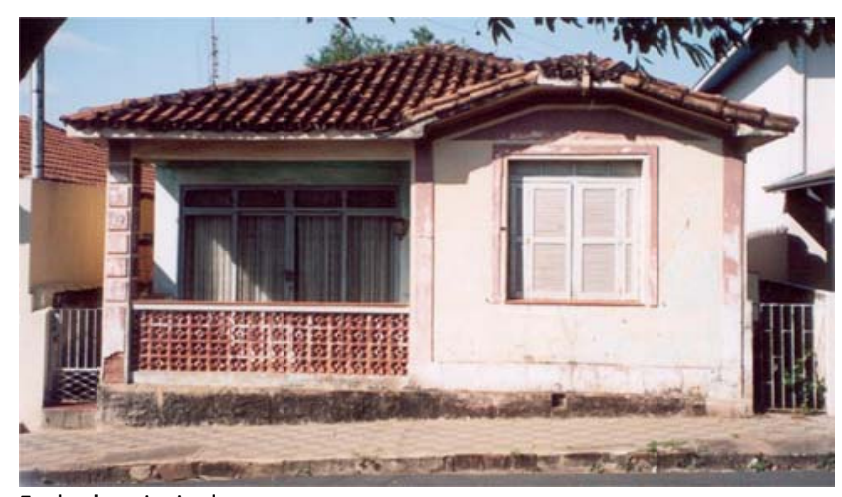

Fachada principal

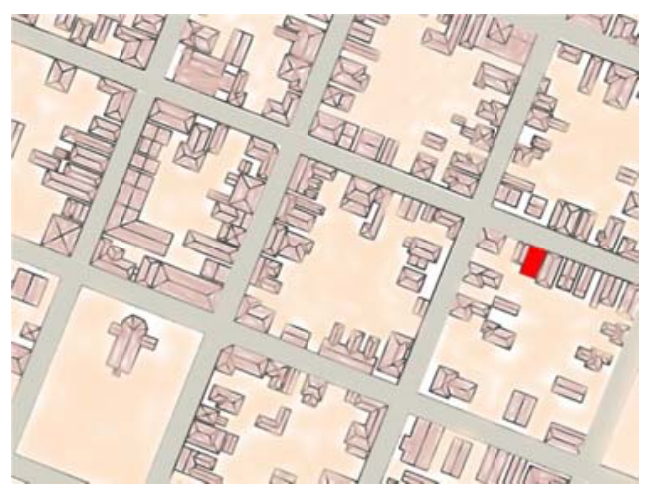

Localização na cidade - situação sem escala

Fachada principal e uso atual

1. Materiais empregados na cobertura

2. Coroamento

Destruição total

Canal X

Francesa

Fibrocimento

Destruição total

Vidro

Metal

Frontão

Plástico / fibra

Laje

Cachorros

Outros:

Laje de beiral

Beiral simples

Platibanda

Cimalha

Beira seveira

Guarda pó X

Outros:

3. Materiais do coroamento

Argamassa $X$

Azulejo antigo

Cantaria

4. Materiais de acabamento da fachada principal

Madeira X

Azulejo novo

Argamassa $X$

Cantaria

Outros:

Concreto aparente

Azulejo novo

Chapisco

Azulejo novo

Vidros

Madeira

Outros:

5. Material das molduras dos vãos de portas e janelas

Não tem

Destruição total

Argamassa $X$

Azulejo antigo

Cantaria

Azulejo novo

Madeira

Concreto aparente

7. Cores predominantes da fachada principal

Coroamento: branco

Molduras dos vãos: marrom

Esquadrias: cinza

Guarda-corpos: não tem

6. Material das esquadrias da fachada principal

Destruição total Madeira X

Vidro Alumínio $X$

Ferro laminado / solda $X \quad$ Outros:

8. Uso atual - quantificar

Residência: $100 \% \quad$ Vago:

Comércio:

Outros relevos: marrom Serviço: Instituição:

Culto:

Dados volumétricos

\section{Gabarito}

Altura da fachada: $4,5 \mathrm{~m}$

№ pavimentos acima do nível da rua: 01

Alt. cumeeira: $6,5 \mathrm{~m}$

№ subsolos:

Além desses, assinalar a existência de:

Porão alto Mirante

Pav. intermediário

mezanino
Pav. recuado

Sótão habitável
2. Classificação tipológica do telhado Número de águas do corpo principal: 02

Cumeeira paralela à rua $X$
Cumeeira perpendicular à $r u a$

Tipo chalé

Com torreão

Água furtada

Outros:

\section{Registro de acréscimos}

Não tem $X$

Acréscimo vertical

Acréscimo horizontal

\section{Identificado a partir de:}

Evidência na construção $X$

Depoimento do usuário
Descrever: 
Identificação

Logradouro: Rua XV de Novembro s/n

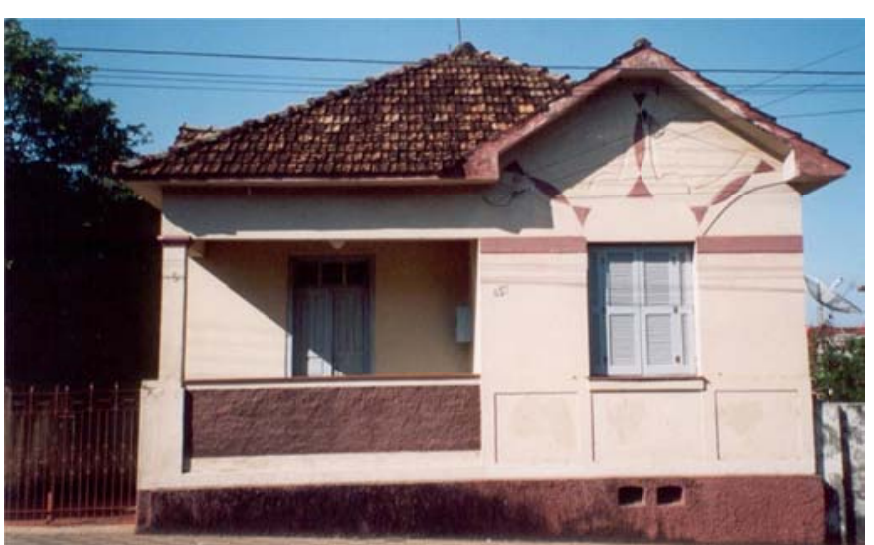

Fachada principal

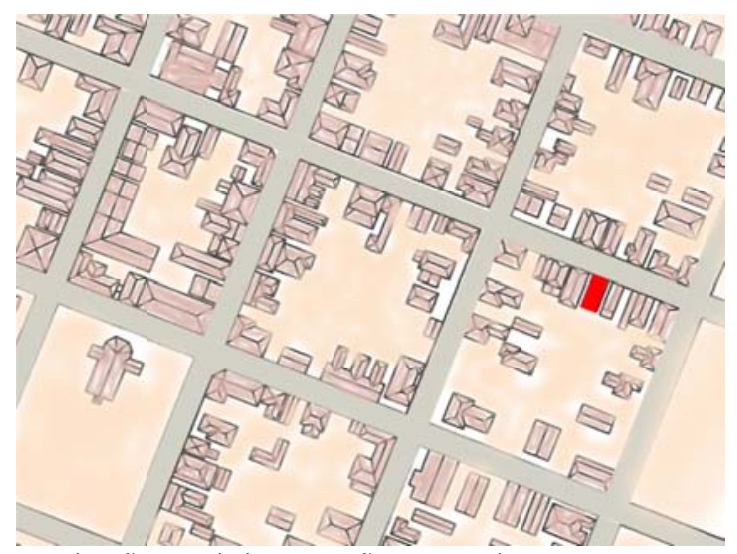

Localização na cidade - situiação sem escala

Fachada principal e uso atual

\begin{tabular}{|c|c|c|c|}
\hline \multicolumn{2}{|c|}{ 1. Materiais empregados na cobertura } & \multicolumn{2}{|l|}{ 2. Coroamento } \\
\hline Destruição total & Canal & Destruição total & Platibanda \\
\hline Francesa X & Fibrocimento & Frontão & Cimalha \\
\hline Vidro & Metal & Cachorros & Beira seveira \\
\hline Plástico / fibra & Laje & Laje de beiral & Guarda pó X \\
\hline Outros: & & Beiral simples & Outros: \\
\hline \multicolumn{2}{|l|}{ 3. Materiais do coroamento } & \multicolumn{2}{|c|}{ 4. Materiais de acabamento da fachada principal } \\
\hline Argamassa X & Cantaria & Argamassa $X$ & Chapisco \\
\hline Azulejo antigo & Azulejo novo & Cantaria & Azulejo novo \\
\hline Madeira & Concreto aparente & Azulejo novo & Madeira \\
\hline Outros: & & Vidros & Outros: \\
\hline \multicolumn{2}{|c|}{ 5. Material das molduras dos vãos de portas e janelas } & \multicolumn{2}{|c|}{ 6. Material das esquadrias da fachada principal } \\
\hline Não tem & Destruição total & Destruição total & Madeira X \\
\hline Argamassa X & Cantaria & Vidro & Alumínio \\
\hline Azulejo antigo & Azulejo novo & Ferro laminado / solda & Outros: \\
\hline Madeira & Concreto aparente & & \\
\hline \multicolumn{2}{|c|}{ 7. Cores predominantes da fachada principal } & \multicolumn{2}{|c|}{ 8. Uso atual - quantificar } \\
\hline Coroamento: bege & Esquadrias: cinza & Residência: 100\% & Vago: \\
\hline Molduras dos vãos: marrom & Acabam. da fachada: bege & Comércio: & Culto: \\
\hline Guarda-corpos: não tem & Outros relevos: marrom & Serviço: & Instituição: \\
\hline
\end{tabular}

Dados volumétricos

\section{Gabarito}

Altura da fachada: $4,5 \mathrm{~m}$

№ pavimentos acima do nível da rua: 01

Além desses, assinalar a existência de:

Porão alto Mirante

Pav. intermediário mezanino

3. Registro de acréscimos

Não tem X

Acréscimo vertical

Acréscimo horizontal
Identificado a partir de:

Evidência na construção $X$

Depoimento do usuário
2. Classificação tipológica do telhado Número de águas do corpo principal: 06

Cumeeira paralela à rua

Com torreão

Cumeeira perpendicular à rua Tipo chalé

Água furtada $\mathrm{X}$

Outros:

Pav. recuado

Descrever: 
Identificação

Logradouro: Rua XV de Novembro s/n

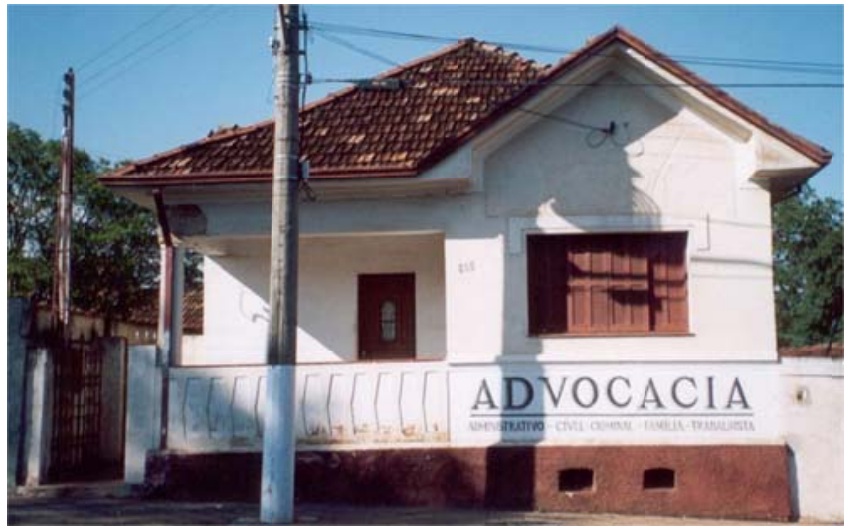

Fachada principal

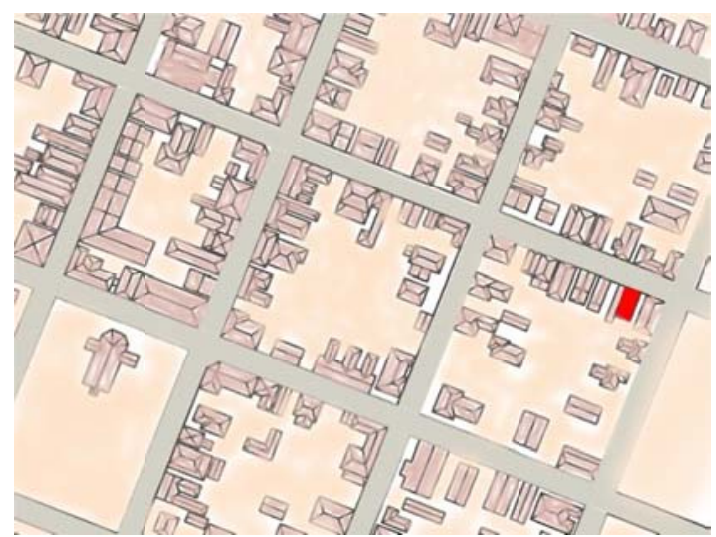

Localização na cidade - situação sem escala

Fachada principal e uso atual

1. Materiais empregados na cobertura

Destruição total

Francesa $X$

Vidro

Plástico / fibra

Outros:

\section{Materiais do coroamento}

Argamassa $X$

Azulejo antigo

Madeira

Outros:

5. Material das molduras dos vãos de portas e janelas

Não tem

Argamassa $X$

Azulejo antigo

Madeira

7. Cores predominantes da fachada principa

Coroamento: bege

Molduras dos vãos: branco

Guarda-corpos: não tem

Canal
Fibrocimento
Metal
Laje

Cantaria

Azulejo novo

Concreto aparente

\section{Cantaria}

Azulejo novo

Concreto aparente

Esquadrias: marrom

Acabam. da fachada: bege

Outros relevos: branco/marrom

.

$\begin{array}{ll}\text { 2. Coroamento } & \text { Platibanda } \\ \text { Destruição total } & \text { Cimalha } \\ \text { Frontão } & \text { Beira seveira } \\ \text { Cachorros } & \text { Guarda pó X } \\ \text { Laje de beiral } & \text { Outros: }\end{array}$

4. Materiais de acabamento da fachada principal

Argamassa $X \quad$ Chapisco

Cantaria Azulejo novo

Azulejo novo Madeira

Vidros Outros:

6. Material das esquadrias da fachada principal

Destruição total Madeira X

Vidro Alumínio

Ferro laminado / solda Outros:

8. Uso atual - quantificar

Residência: Vago:

Comércio: $100 \% \quad$ Culto:

Serviço: Instituição:
Dados volumétricos

\section{Gabarito}

Altura da fachada: $5 \mathrm{~m}$

№ pavimentos acima do nível da rua: 01

Além desses, assinalar a existência de:

Porão alto Mirante

Pav. intermediário mezanino

3. Registro de acréscimos

Não tem $X$

Acréscimo vertical

Acréscimo horizontal

\section{Classificação tipológica do telhado}

Alt. cumeeira: 6,5m Número de águas do corpo principal: 06

№ subsolos: Cumeeira paralela à rua Com torreão

Cumeeira perpendicular à rua Água furtada $\mathrm{X}$

Tipo chalé Outros:
Pav. recuado

Sótão habitável 
Identificação

Logradouro: Rua Demétrio Calfat s/n

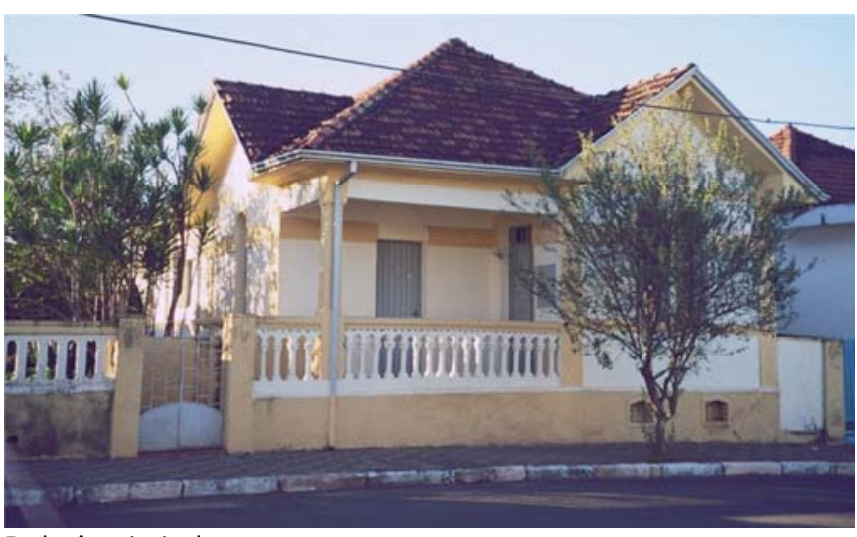

Fachada principal

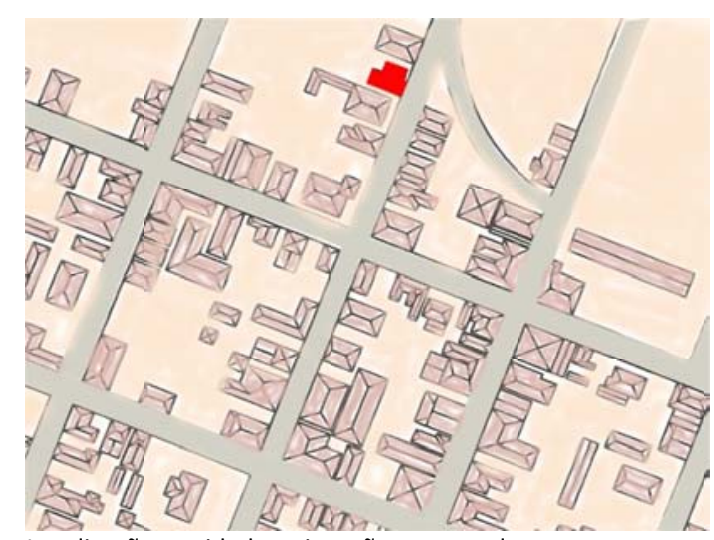

Localização na cidade - situação sem escala

Fachada principal e uso atual

1. Materiais empregados na cobertura Destruição total

Francesa $\mathrm{X}$

Vidro

Plástico / fibra

Outros:

3. Materiais do coroamento

Argamassa $X$

Azulejo antigo

Madeira

Outros:

5. Material das molduras dos vãos de portas e janelas Não tem

Argamassa X

Azulejo antigo

Madeira

7. Cores predominantes da fachada principal

Coroamento: branco

Molduras dos vãos: amarelo

Guarda-corpos: não tem

Esquadrias: cinza

Acabam. da fachada: branco

Outros relevos: amarelo

Destruição total

Cantaria

Azulejo novo

\section{Coroamento}

Destruição total

Frontão

Cachorros

Laje de beiral

Beiral simples

4. Materiais de acabamento da fachada principal

Argamassa Chapisco $X$

Cantaria Azulejo novo

Azulejo novo Madeira X

Vidros Outros:

6. Material das esquadrias da fachada principal

Destruição total Madeira $X$

Vidro Alumínio $X$

Ferro laminado / solda $X \quad$ Outros:

8. Uso atual - quantificar

Residência: 100\% Vago:

Comércio: Culto:

Serviço: Instituição:
Dados volumétricos

\section{Gabarito}

Altura da fachada: $4,5 \mathrm{~m}$

№ pavimentos acima do nível da rua: 01

Além desses, assinalar a existência de:

$\begin{array}{ll}\text { Porão alto } & \text { Mirante } \\ \text { Pav, intermediário } & \text { mezanino }\end{array}$

3. Registro de acréscimos

Não tem $X$

Acréscimo vertical

Acréscimo horizontal

\section{Classificação tipológica do telhado}

Alt. cumeeira: $6 \mathrm{~m} \quad$ Número de águas do corpo principal: 08

№ subsolos:

Cumeeira paralela à rua $X$

Com torreão

Cumeeira perpendicular à rua

Água furtada $X$

Tipo chalé

Outros:

Sótão habitáve

Identificado a partir de: Descrever:

Evidência na construção $X$

Depoimento do usuário 
"Uma casa tem muita vez as suas relíquias, lembranças de um dia ou de outro, da tristeza que passou, da felicidade que se perdeu. Supõe que o dono pense em as arejar e expor para teu e meu desenfado. Nem todas serão interessantes, não raras serão aborrecidas, mas, se o dono tiver cuidado, pode extrair uma dúzia delas que mereçam sair cá fora."

(Machado de Assis, Relíquias da casa velha) 


\section{0 - Evolução urbana de Nova Europa}

As terras onde se localiza o município de Nova Europa faziam parte da Sesmaria do Cambuhy, originalmente pertencente ao Coronel Joaquim José Pinto de Moraes Leme e passadas por herança a dona Brites Maria Pinto Gavião e posteriormente a Bernardo Gavião Peixoto.

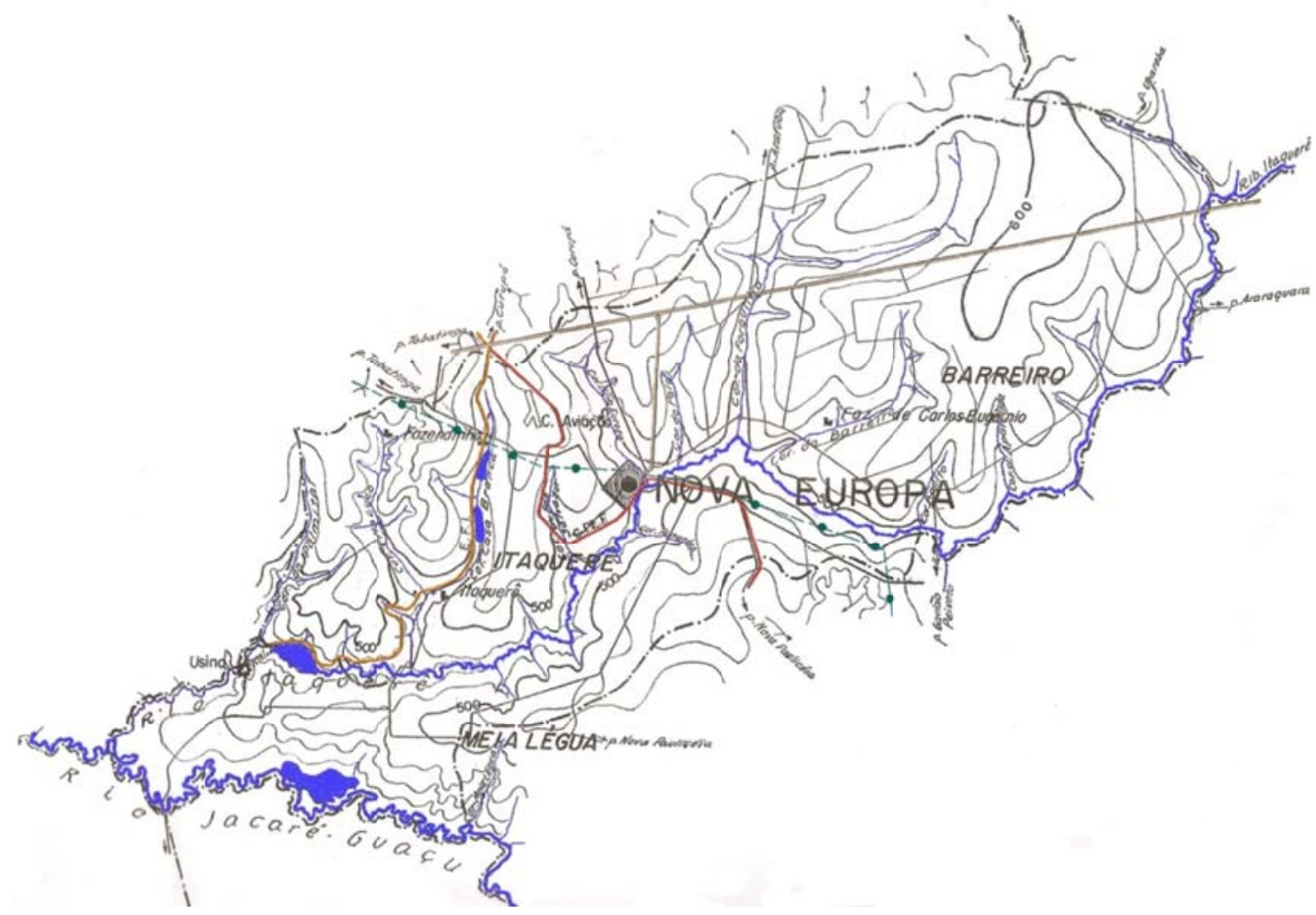

Mapa do território do Município de Nova Europa com a localização das fazendas, das estações ferroviárias e o sistema hídrico Fonte: Mapa da Cidade de detalhe do Mapa do Município de Dourado, organizado em observância ao Decreto-Lei Nacional no 311 de 2 de março de 1938, elaborado pelo Serviço de Topografia e Limites do Instituto Geográfico e Geológico - Secretaria da Agricultura, Indústria e Comércio. Fonte: Instituto Geográfico e Cartográfico de São Paulo.

O povoamento destas terras teve início na segunda metade do século XIX a partir de sua compra por parte do Governo do Estado de São Paulo para a formação de núcleos coloniais destinados a imigrantes europeus. As terras foram divididas em três núcleos coloniais: Nova Europa, Nova Paulicéia e Gavião Peixoto, que recebeu o nome do antigo proprietário das terras.

A iniciativa da criação destes núcleos partiu do próprio latifundiário que tinha como objetivos obter renda com a comercialização de terras não adequadas ao cultivo do café e garantir mão de obra para as fazendas durante a safra do café e oferta de outros serviços especializados durante a entressafra. 
Os três núcleos foram criados simultaneamente, todos fundados em 1907 a partir de condicionantes comuns (ver capitulo 1.2), por isso a história dos três segue paralelamente e por vezes se entrelaçam e exatamente por isso, aliado à dificuldade de obtenção de dados históricos, aqui usaremos exemplos de outros núcleos para se tentar dar uma noção das características e da dimensão da vida social de Nova Europa.

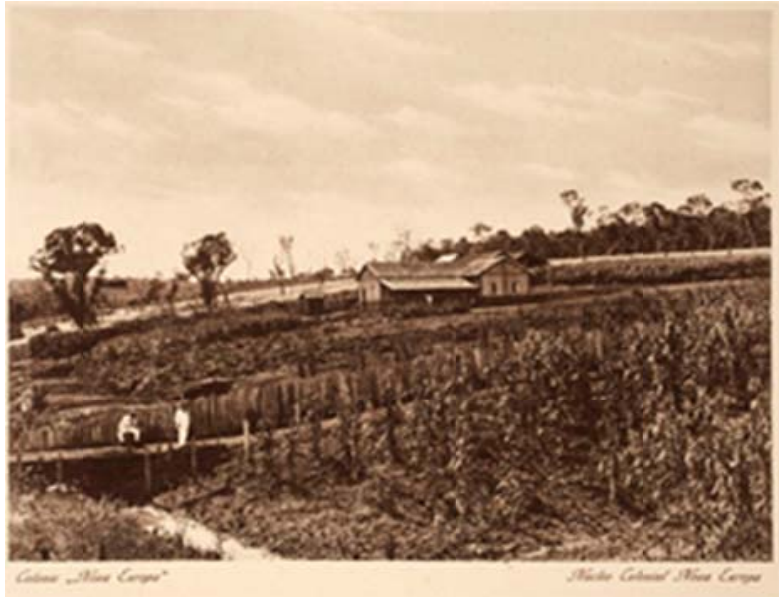

Vista de um lote rural do Núcleo Colonial Nova Europa (1908). Fonte: Álbum vistas de São Paulo - Arquivo do Estado de São Paulo.

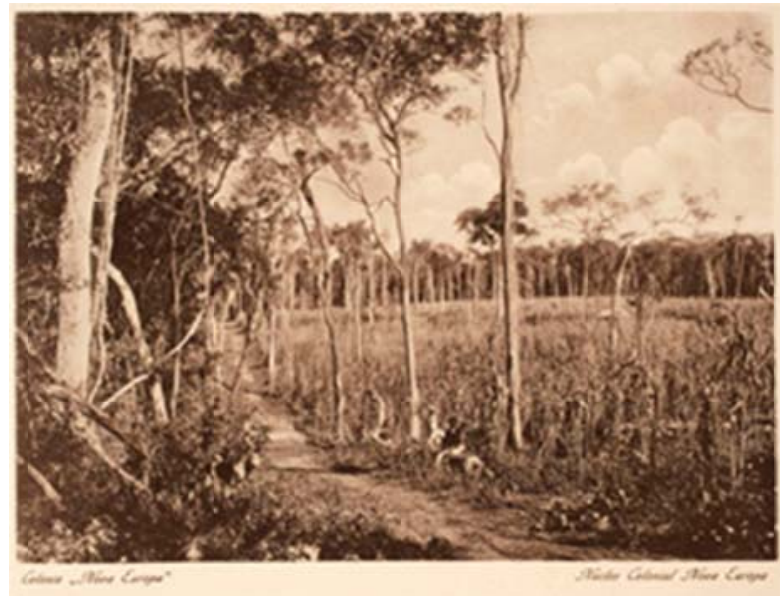

Vista do limite entre um lote rural e a área de mata do Núcleo Colonial Nova Europa (1908). Fonte: Álbum vistas de São Paulo Arquivo do Estadlo de São Paulo.

É importante observar que poucos anos após a inauguração dos núcleos, em 1908, as estações ferroviárias de Nova Paulicéia e Gavião Peixoto, pertencentes à Cia. E. F. Dourado, já estavam prontas e foram importante fator de atração populacional e do desenvolvimento econômico para a região.

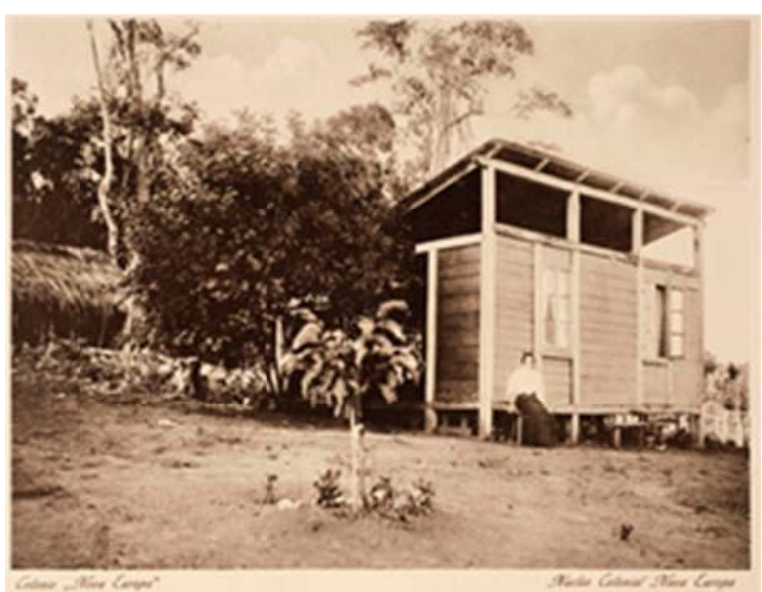

Casa de colono em um lote rural do Núcleo Colonial Nova Europa (1908). Fonte: Álbum vistas de São Paulo - Arquivo do Estado de São Paulo.

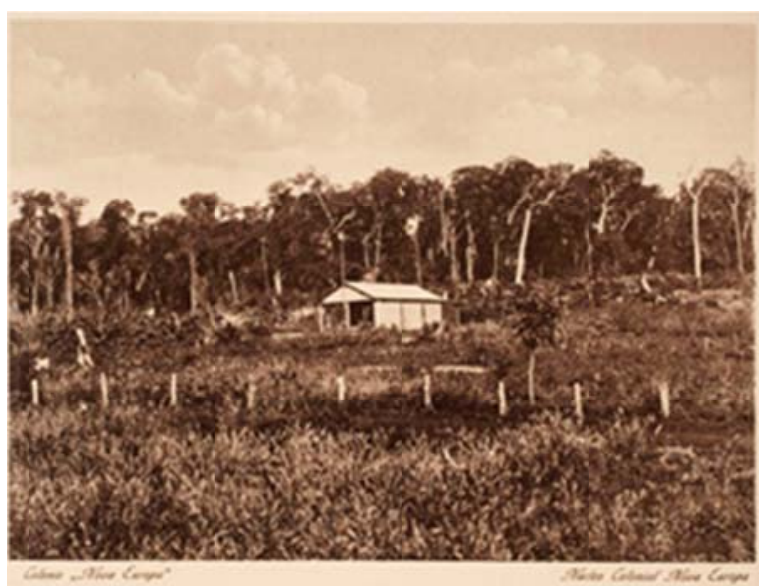

Casa de colono em um lote rural dlo Núcleo Colonial Nova Europa (1908). Fonte: Álbum vistas de São Paulo - Arquivo do Estado de São Paulo. 
Os núcleos possuíam uma parte rural, composta por pequenas propriedades agrícolas, com aproximadamente 10 alqueires de área e uma parte urbana onde foram instalados os equipamentos como a estação ferroviária, a capela, casas comerciais e a administração do núcleo. O corpo administrativo do núcleo era composto pelo diretor do núcleo, um ajudante de diretor e diversos auxiliares, além de um médico.

Entre as funções do diretor do núcleo, além das atividades administrativas, estava a orientação aos colonos quanto ao preparo da terra (semeadura, cultivo e colheita), "empregando todos os esforços para o progresso da lavoura do núcleo". Entretanto, segundo depoimento do Sr. Willi Koeler, colono alemão residente em Nova Europa ao pesquisador Mivaldo Ferrari, nem todos os diretores dos núcleos posisuíam conhecimentos mínimos de agricultura - o próprio pai do Sr. Willi, que foi o primeiro diretor do núcleo de Nova Europa, era sapateiro na Alemanha e nunca havia sequer visto uma espiga de milho até chegar ao Brasil.

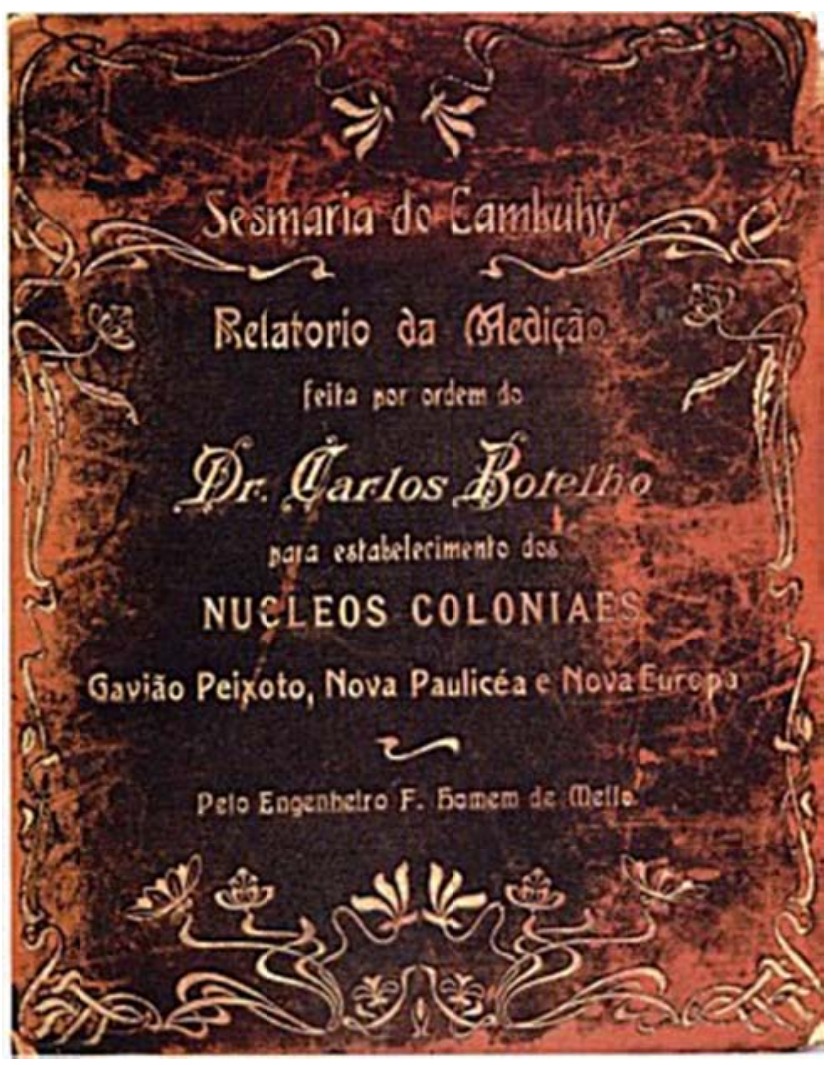

Capa do relatório de medição feita para o estabelecimento dos núcleos coloniais Gavião Peixoto, Nova Paulicéia e Nova Europa (1906). Fonte: Arquivo do Estado de São Paulo.

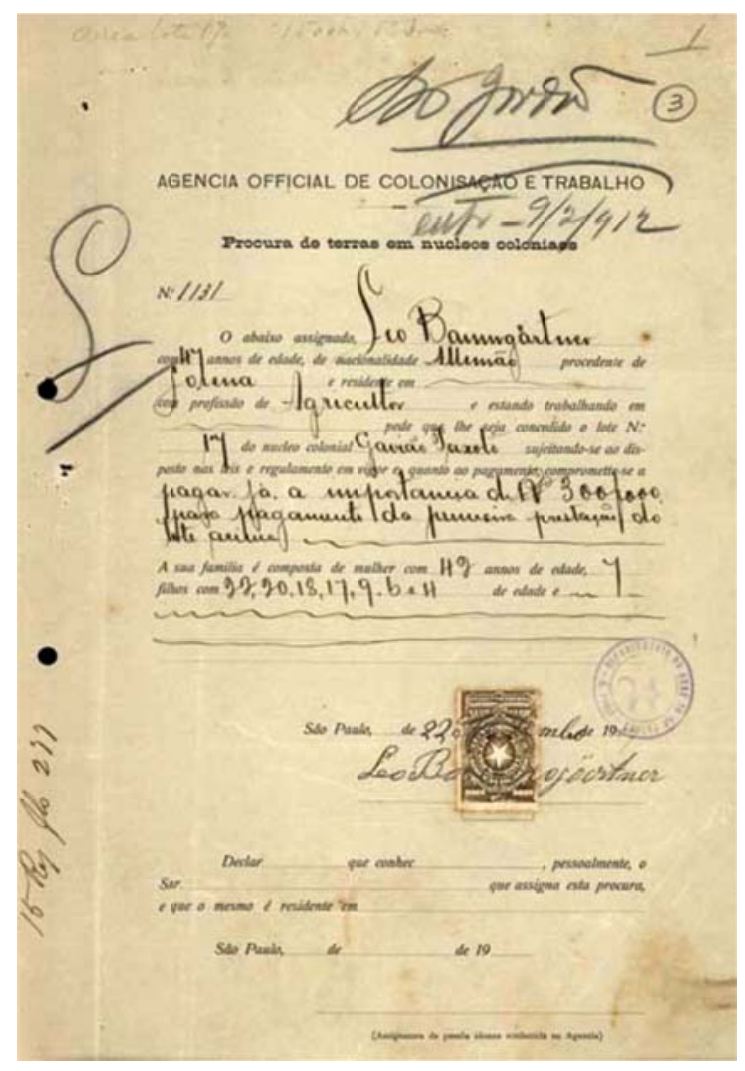

Pedido de concessão de lote rural no núcleo colonial de Gavião Peixoto feito em 1912 pelo agricultor alemão Leo Baunngartnen à Agencia Ofiicial de Colonização e Trabalho. Fonte: Arquivo do Estado de São Paulo.

Os lotes rurais eram vendidos de forma facilitada aos imigrantes mediante empréstimos e parcelamentos a perder de vista do valor dos lotes, a fim de atraí-los e fixa- 
los na terra, mas segundo Ferrari, tais facilidades não eram oferecidas aos colonos brasileiros.

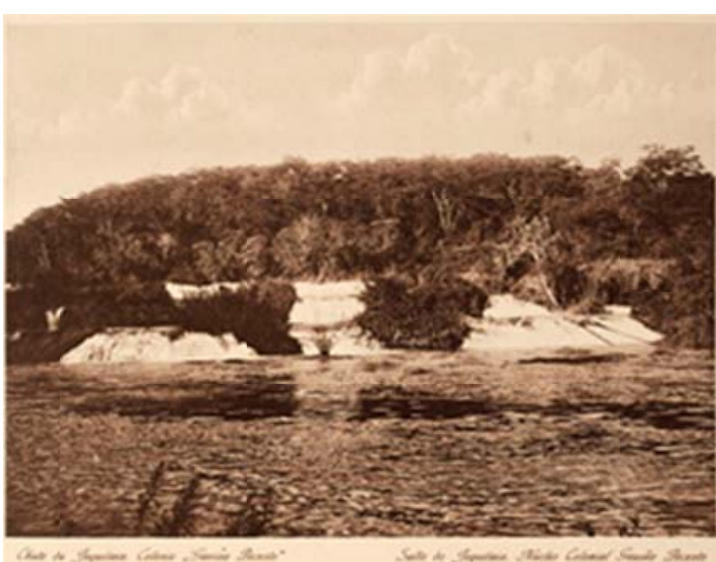

Vista do Salto do Juquitiba, onde veio a se instalar a usina hidrelétrica no núcleo colonial de Gavião Peixoto (1908). Fonte: Álbum vistas de São Paulo - Arquivo do Estado de São Paulo.

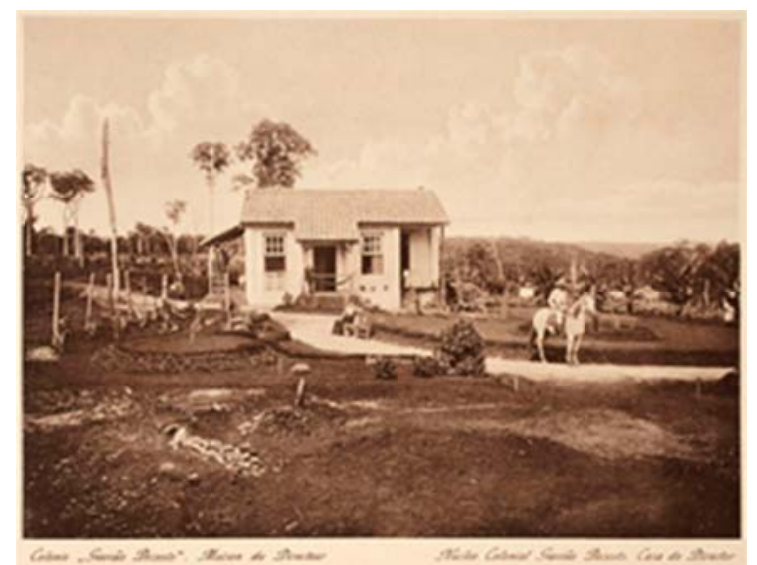

Casa do diretor do núcleo de Gavião Peixoto (1908). Fonte: Álbum vistas de São Paulo - Arquivo do Estado de São Paulo.

Ainda segundo Ferrari, entre 1908 e 1911 a população dos núcleos do Cambuhy era composta por colonos de mais de 12 nacionalidades: russos, alemães, polacos, italianos, austríacos, franceses, portugueses, espanhóis, suíços, dinamarqueses, sírios e brasileiros, entre outros. O mesmo autor chama atenção para as dificuldades culturais enfrentadas a principio por essas populações, ressaltando que entre 1914 e 1923 os casamentos aconteciam em sua grande maioria entre colonos da mesma nacionalidade. Nova Europa particularmente recebeu um numero maior de famílias russas, colônia que foi praticamente dizimada por um surto de febre amarela.

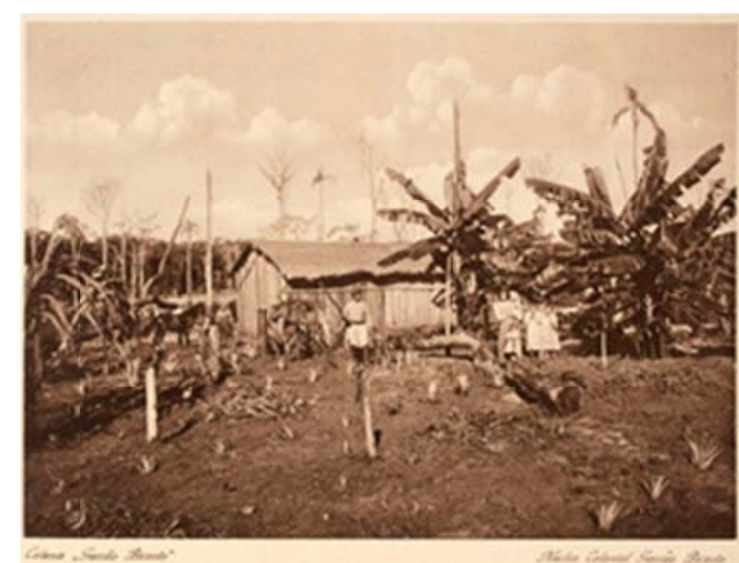

Casa de colono com sua pequena plantação de gêneros alimentícios ao redor, no núcleo Gavião Peixoto (1908). Fonte: Álbum vistas de São Paulo - Arquivo do Estado de São Paulo.

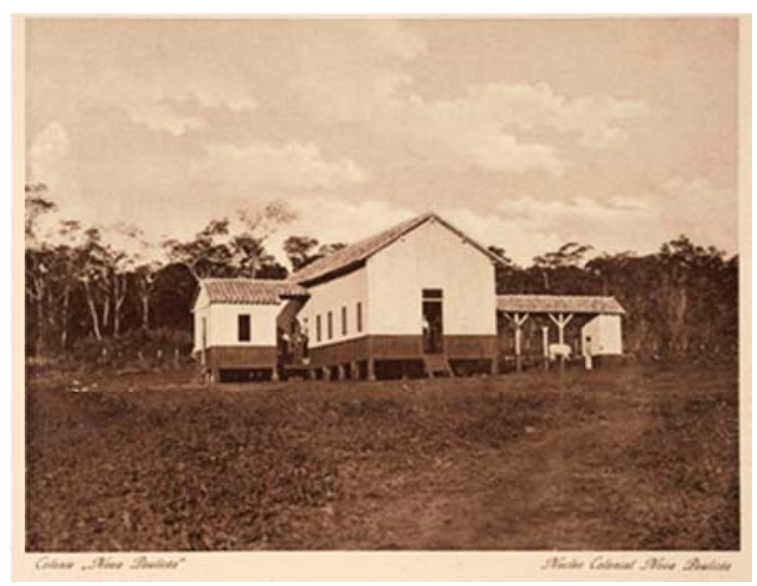

Casa de colono do núcleo coloniall Nova Paulicéia (1908). Fonte: Álbum vistas de São Paulo - Arquivo do Estado de São Paulo.

Apesar dos esforços para fixar os colonos estrangeiros, rapidamente ocorreu uma substituição destes por outros, só que agora colonos brasileiros. Outra expectativa que não se cumpriu foi de que os núcleos servissem de reserva de mão de obra, enquanto na pratica 
os núcleos passaram a ser ponto de atração para os colonos ligados às fazendas de café estes colonos, depois de trabalharem um período para os fazendeiros, adquiriram certa experiência agrícola, além de alguma poupança para dar a entrada nas prestações do lote rural.

Ferrari nos informa que os núcleos do Cambuhy obtiveram uma ótima produtividade quando comparados aos demais núcleos oficiais do Estado e que sua fase mais próspera ocorreu quando quase toda sua população já havia sido substituída por brasileiros.

A desativação da ferrovia em 1969 foi um fator importante para o declínio da economia local, situação agravada pela quebra da lavoura do algodão, principal produto agrícola dos núcleos no período.

Embora não tenham atendido aos objetivos originais dos cafeicultores, os núcleos constituíram-se em comunidades particulares e autônomas em relação às grandes fazendas.

Nova Europa foi emancipada em 1920, passando a pertencer ao município de Ibitinga e mais tarde ao município de Tabatinga e apenas em 1953 tornou-se município. 


\section{1 - Pré-inventário da área central de Nova Europa}

O pré-inventário de Nova Europa teve como recorte geográfico sua área central, que segundo o mapa de 1938 (ver pagina 73) correspondia a toda sua área urbana. Como o que aqui propomos é um pré-inventário, estabelecemos o ano de 1940 como nossa data balizadora, considerando que todas as construções anteriores a esta data deveriam ser levantadas e a princípio preservadas. Entretanto, durante a fase de levantamentos constatamos que muito pouco desta arquitetura foi preservada.

Como pode ser observado no mapa abaixo, dividimos as edificações em três grupos distintos: as edificações assinaladas em cinza são construções recentes, sem qualquer relação com a arquitetura que queremos preserva; as edificações assinaladas em vermelho ainda apresentam características construtivas e as mesmas relações de implantação e gabarito de altura semelhante às encontradas nas edificações mais antigas, entretanto ou por um maior grau de alterações ou por realmente já serem construções posteriores, não é possível estabelecer com clareza seu período construtivo; as edificações destacadas em azul são as que propomos preservar.

As edificações selecionadas concentram-se nas proximidades da Praça da Matriz e ao longo da Rua XV de Novembro e apesar de terem sofrido pequenas alterações, em sua maioria substituição dos caixilhos antigos (ver fichas 06, 07, e 08 por exemplo), geralmente feitos em madeira por outros recentes, quase sempre metálicos, além de alteração na posição e dimensões de aberturas de portas e janelas (ficha 12), ocasionadas ou não por mudanças do uso residencial para comercial, acréscimo de cobertura lateral para servir de garagem (ver ficha 03), colocação de toldos (ver fichas 07, 09, 13, 14) , etc., não interferem ao ponto de impossibilitar a leitura destas edificações enquanto conjunto. E do nosso ponto de vista essa leitura do conjunto é o mais importante se considerarmos a simplicidade desta arquitetura, que só faz sentido ser preservada enquanto conjunto.

Também é possível observar uma tipologia especifica para as edificações comerciais localizadas nas esquinas (fichas 10, 13 e 14), que recebem uma maior ornamentação das fachadas, ornamentação que a partir das edificações que se mantiveram, podemos perceber que não era comum nas residências, assim como as platibandas, que aparecem nos edifícios comerciais (ficha 11) e em uma única residência (ficha 04). 
Sobre as construções mais antigas, do primeiro momento de ocupação do núcleo, não encontramos nenhum exemplar. Essa ausência pode ser consequência da maior perenidade destas, já que segundo as imagens do Arquivo do Estado, estas muitas vezes eram construídas de madeira, entretanto, não explica a ausência de da arquitetura construída nas três décadas seguintes.

Assim como em Dourado, a área central de Nova Europa ainda mantem a função de centro, é praticamente toda ocupada e não apresenta diferenças de infra estrutura em relação aos demais bairros, é predominantemente térrea, pouco adensada e de uso misto.

É importante observar a partir do que foi levantado, que a preservação deste patrimônio deva ocorrer a partir da regulamentação do uso do solo urbano e da busca de usos e atividades econômicas compatíveis com os edifícios, de forma a compatibilizar sua vitalidade econômica com a preservação. Por outro lado essa regulamentação deve ser feita com muito cuidado, já que a preservação não deve ser um entrave para o desenvolvimento, o que neste caso poderia tornar a área central não mais interessante para moradia, por exemplo, o que teria um efeito contrario do esperado, levando ao seu esvaziamento ou perda de sua diversidade de usos, que é uma de suas características importantes.

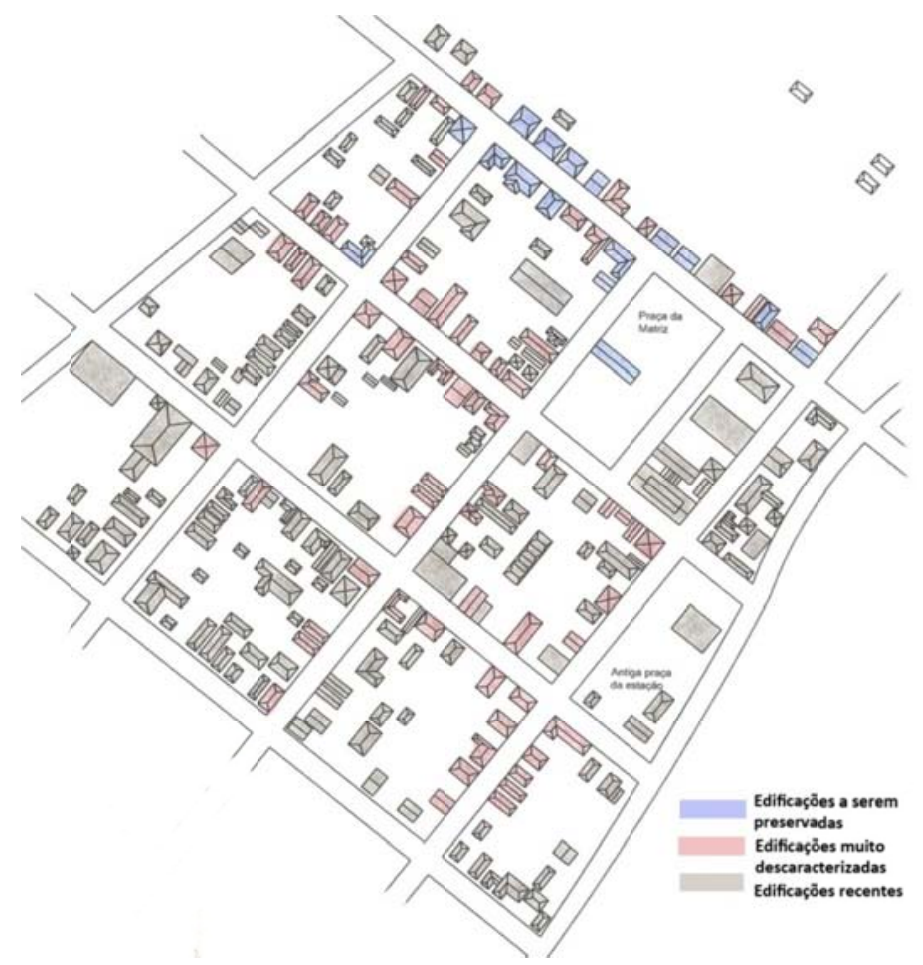


Identificação: Igreja Matriz de Santa Teresinha

Praça da Matriz, s/n
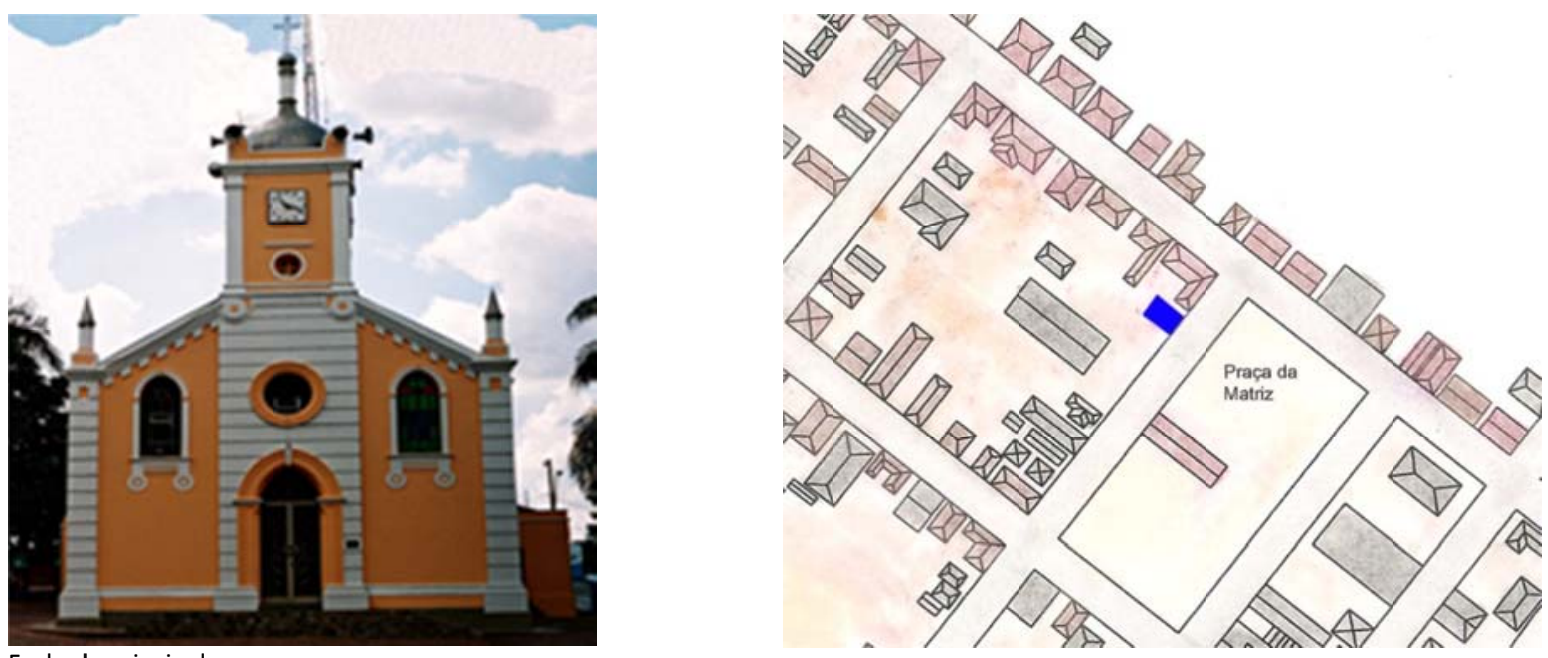

Fachada principal

Fachada principal e uso atual

\section{Materiais empregados na cobertura}

Destruição total

Francesa X

Vidro

Plástico / fibra

Outros:

\section{Materiais do coroamento}

\section{Argamassa $X$}

Azulejo antigo

Madeira

Outros:

\section{Material das molduras dos vãos de portas e janelas}

Não tem

Argamassa X

Azulejo antigo

Madeira

Destruição total

Cantaria

Azulejo novo

Concreto aparente

7. Cores predominantes da fachada principal

Coroamento: branco

Molduras dos vãos: branco

Esquadrias: preto / dourado

Acabam. da fachada: amarelo

Outros relevos: branco

\section{Coroamento \\ Destruição total \\ Frontão}

Cachorros

Laje de beiral

Beiral simples

4. Materiais de acabamento da fachada principal

Argamassa X Chapisco

Cantaria Azulejo novo

Azulejo novo Madeira

Vidros Outros:

6. Material das esquadrias da fachada principal

Destruição total Madeira

Vidro Alumínio

Ferro laminado / solda $X \quad$ Outros:

8. Uso atual - quantificar

Residência:

Comércio:

Serviço:

Vago:

Culto:

Instituição: 100\%

Dados volumétricos

\section{Gabarito \\ Altura da fachada:}

№ pavimentos acima do nível da rua: 02

Além desses, assinalar a existência de:

Porão alto

Mirante

Pav. intermediário

Mezanino

\section{Classificação tipológica do telhado}

Número de águas do corpo principal: 02

Cumeeira paralela à rua

Com torreão

Cumeeira perpendicular à rua Água furtada

Tipo chalé

Outros:

3. Registro de acréscimos

Não tem

Acréscimo vertical

Acréscimo horizontal
Identificado a partir de:

Sótão habitável

\section{Descrever:}

Evidência na construção

Depoimento do usuário 
Identificação

Rua XV de Novembro, 351
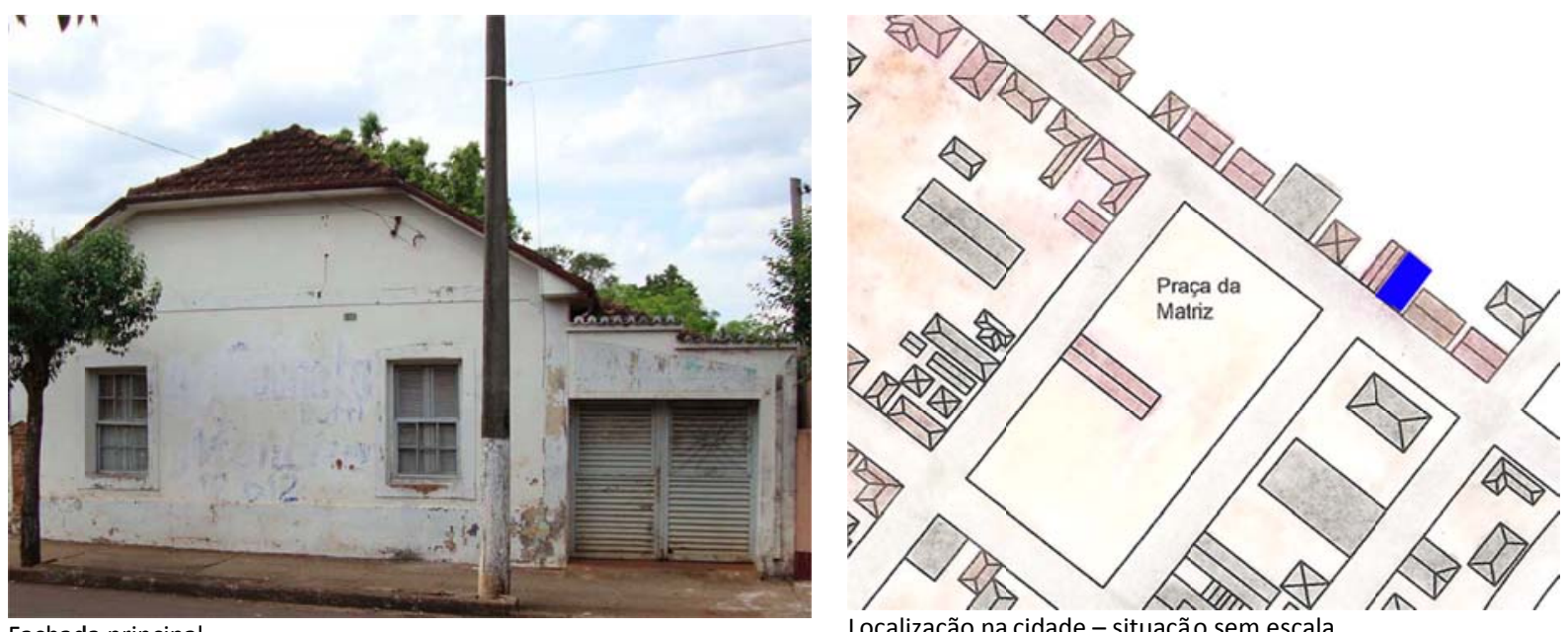

Fachada principal

Localização na cidade - situação sem escala

Fachada principal e uso atual

1. Materiais empregados na cobertura

Destruição total Canal

Francesa X

Vidro

Plástico / fibra

Outros:

\section{Materiais do coroamento}

Argamassa

Azulejo antigo

Madeira X

Outros:

5. Material das molduras dos vãos de portas e janelas

Não tem

Argamassa $X$

Azulejo antigo

Madeira

7. Cores predominantes da fachada principal

Coroamento: branco

Molduras dos vãos: branco

Guarda-corpos: não tem
Destruição total

Cantaria

Azulejo novo

Concreto aparente
Acabam. da fachada: branco

Outros relevos: branco

\section{Coroamento}

Destruição total

Frontão

Cachorros

Laje de beiral

Beiral simples

4. Materiais de acabamento da fachada principal

Argamassa X Chapisco

Cantaria Azulejo novo

Azulejo novo Madeira

Vidros Outros:

6. Material das esquadrias da fachada principal

Destruição total Madeira $X$

Vidro Alumínio

Ferro laminado / solda Outros:

\section{Uso atual - quantificar}

Residência: $100 \%$

Comércio:

Vago:

Serviço:

Instituição:

Dados volumétricos

\section{Gabarito \\ Altura da fachada:}

№ pavimentos acima do nível da rua: 01

Alt. cumeeira:

2. Classificação tipológica do telhado

Além desses, assinalar a existência de:

Porão alto Mirante

Pav. intermediário mezanino

№ subsolos:

Número de águas do corpo principal: 03

3. Registro de acréscimos

Não tem $X$

Acréscimo vertical

Acréscimo horizontal
Pav. recuado

Sótão habitável

\section{Cumeeira paralela à rua}

Cumeeira perpendicular à rua $X$

Tipo chalé

Descrever:
Identificado a partir de:

Evidência na construção $X$

Depoimento do usuário
Com torreão

Água furtada

Outros: 
Identificação

Rua XV de Novembro, 362

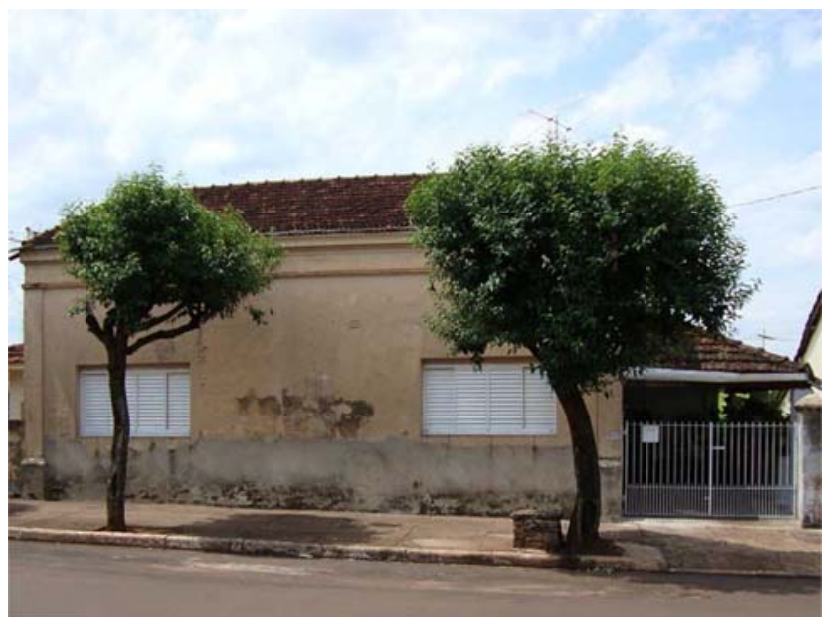

Fachada principal

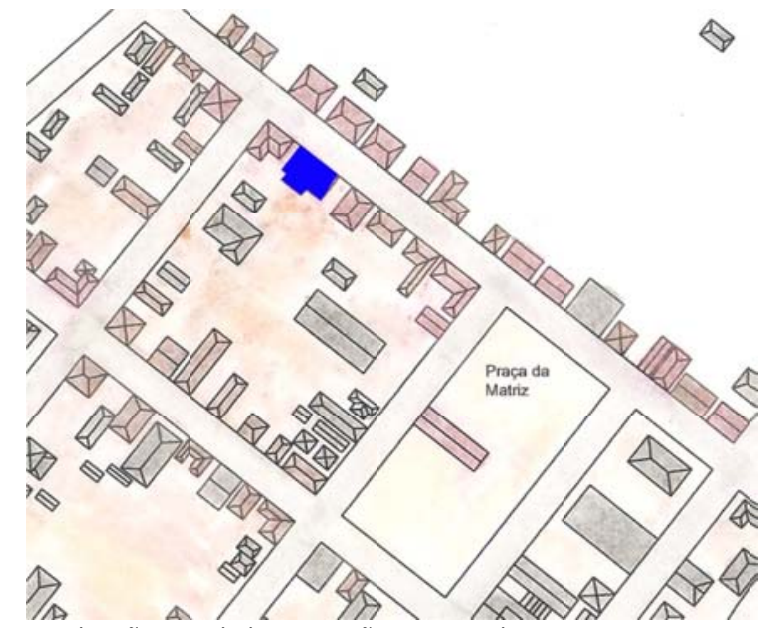

Localização na cidade - situação sem escala

Fachada principal e uso atual

$\begin{array}{ll}\text { 1. Materiais empregados na cobertura } \\ \text { Destruição total } & \text { Canal } \\ \text { Francesa X } & \text { Fibrocimento } \\ \text { Vidro } & \text { Metal } \\ \text { Plástico / fibra } & \text { Laje } \\ \text { Outros: } & \end{array}$

2. Coroamento

Destruição total

Frontão

Cachorros

Laje de beiral

Beiral simples

4. Materiais de acabamento da fachada principal

3. Materiais do coroamento

Argamassa $X$

Azulejo antigo

Cantaria

Madeira

Azulejo novo

Concreto aparente

Outros:

5. Material das molduras dos vãos de portas e janelas

Não tem X

Argamassa

Azulejo antigo

Destruição total

Cantaria

Azulejo novo

Concreto aparente

Madeira

hada principal

Coroamento: bege

Esquadrias: branco

Acabam. da fachada: bege

Outros relevos: não tem

Argamassa X

Cantaria

Azulejo novo

Vidros

6. Material das esquadrias da fachada principal

Destruição total Madeira

Vidro Alumínio $X$

Ferro laminado / solda Outros:

8. Uso atual - quantificar

Residência: $100 \%$ Vago:

Comércio:

Serviço: Instituição:
Dados volumétricos

\section{Gabarito \\ Altura da fachada:}

№ pavimentos acima do nível da rua: 01

Além desses, assinalar a existência de:

Porão alto Mirante

Pav. intermediário Mezanino

3. Registro de acréscimos

Não tem

Acréscimo vertical

Acréscimo horizontal $X$

Identificado a partir de:

Evidência na construção $X$

Depoimento do usuário

Sótão habitável
2. Classificação tipológica do telhado

Alt. cumeeira: Número de águas do corpo principal: 02

№ subsolos:

Cumeeira paralela à rua $X$

Com torreão

Cumeeira perpendicular à rua Água furtada

Tipo chalé

Outros: 
Identificação

Rua XV de Novembro, no345

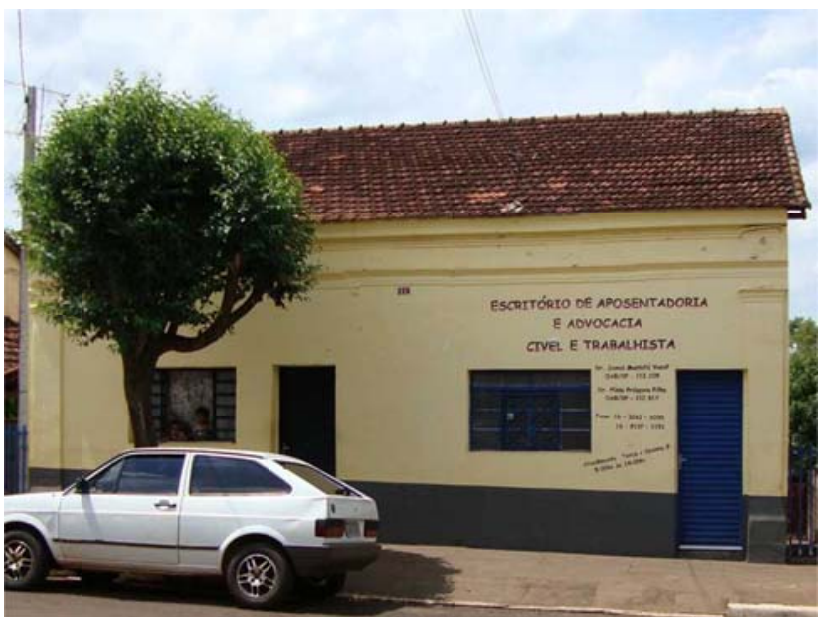

Fachada principal

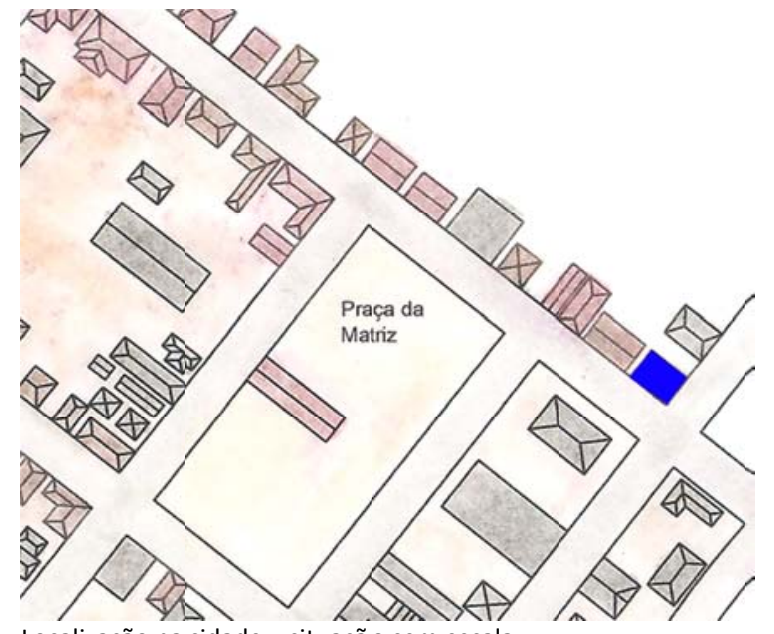

Localização na cidade - situação sem escala

Fachada principal e uso atual

$\begin{array}{ll}\text { 1. Materiais empregados na cobertura } \\ \text { Destruição total } & \text { Canal } \\ \text { Francesa X } & \text { Fibrocimento } \\ \text { Vidro } & \text { Metal } \\ \text { Plástico / fibra } & \text { Laje } \\ \text { Outros: } & \end{array}$

\section{Materiais do coroamento}

Argamassa $X$

Cantaria

Azulejo antigo

Azulejo novo

Madeira

Concreto aparente

\section{Coroamento}

Destruição total

Frontão

Cachorros

Laje de beiral

Beiral simples

Platibanda
Cimalha X

Beira seveira

Guarda pó

Outros:

4. Materiais de acabamento da fachada principal

Argamassa $X \quad$ Chapisco

Cantaria Azulejo novo

Azulejo novo Madeira

Vidros Outros:

\begin{tabular}{|c|c|c|c|}
\hline \multicolumn{2}{|c|}{ 5. Material das molduras dos vãos de portas e janelas } & \multicolumn{2}{|c|}{ 6. Material das esquadrias da fachada principal } \\
\hline Não tem X & Destruição total & Destruição total & Madeira \\
\hline Argamassa & Cantaria & Vidro & Alumínio X \\
\hline Azulejo antigo & Azulejo novo & Ferro laminado / solda X & Outros: \\
\hline Madeira & Concreto aparente & & \\
\hline \multicolumn{2}{|c|}{ 7. Cores predominantes da fachada principal } & \multicolumn{2}{|l|}{ 8. Uso atual - quantificar } \\
\hline Coroamento: amarelo & Esquadrias: azul & Residência: 50\% & Vago: \\
\hline Molduras dos vãos: não tem & Acabam. da fachada: amarelo & Comércio: 50\% & Culto: \\
\hline Guarda-corpos: não tem & Outros relevos: cinza & Serviço: & Instituição: \\
\hline
\end{tabular}

Dados volumétricos

\section{Gabarito}

Altura da fachada:

№ pavimentos acima do nível da rua: 01

Além desses, assinalar a existência de:

Porão alto Mirante

Pav. intermediário

\section{Alt. cumeeira:}

№ subsolos:

Pav. recuado

Sótão habitável
2. Classificação tipológica do telhado Número de águas do corpo principal: 02

Cumeeira paralela à rua $X$

Com torreão

Cumeeira perpendicular à rua

Tipo chalé

Água furtada

Outros:

3. Registro de acréscimos

\section{Não tem}

Acréscimo vertical $X$

Acréscimo horizontal
Identificado a partir de:

Evidência na construção

Depoimento do usuário
Descrever: 
Identificação

Rua XV de Novembro, 361

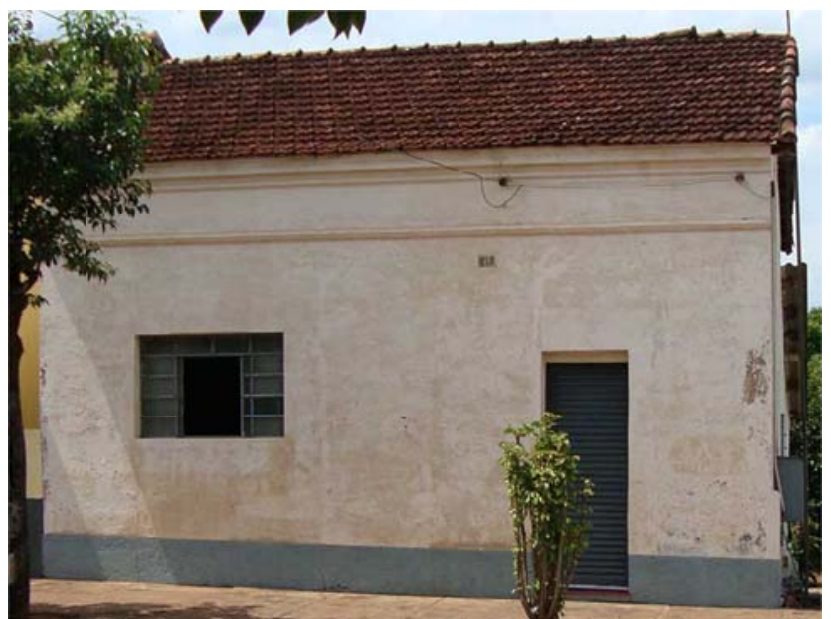

Fachada principal

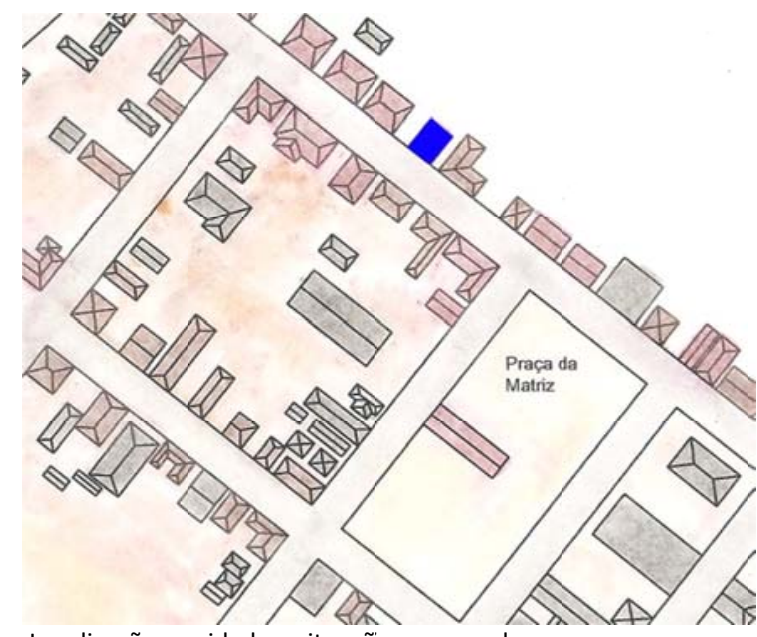

Localização na cidade - situaçãio sem escala

Fachada principal e uso atual

$\begin{array}{ll}\text { 1. Materiais empregados na cobertura } \\ \text { Destruição total } & \text { Canal } \\ \text { Francesa X } & \text { Fibrocimento } \\ \text { Vidro } & \text { Metal } \\ \text { Plástico / fibra } & \text { Laje } \\ \text { Outros: } & \end{array}$

\section{Materiais do coroamento}

Argamassa $X$

Cantaria

Azulejo antigo

Azulejo novo

Madeira

Concreto aparente

\section{Coroamento}

Destruição total

Frontão

Cachorros

Laje de beiral

Beiral simples

Platibanda
Cimalha $X$

Beira seveira

Guarda pó

Outros:

4. Materiais de acabamento da fachada principal

Argamassa X Chapisco

Cantaria Azulejo novo

Azulejo novo Madeira

Vidros Outros:

5. Material das molduras dos vãos de portas e janelas

6. Material das esquadrias da fachada principal

Não tem X

Destruição total

Destruição total

Madeira

Argamassa

Cantaria

Vidro

Aluminio $x$

$\begin{array}{ll}\text { Azulejo antigo } & \text { Azulejo novo } \\ \text { Madeira } & \text { Concreto aparente }\end{array}$

7. Cores predominantes da fachada principal

Coroamento: rosa

Esquadrias: cinza

Ferro laminado / solda $X$

Outros:

Molduras dos vãos: não tem

Acabam. da fachada: rosa

8. Uso atual - quantificar

Residência: $100 \%$

Comércio:

Vago:

Outros relevos: cinza

Serviço:

Instituição:

Dados volumétricos

\section{Gabarito}

Altura da fachada:

№ pavimentos acima do nível da rua: 01

Além desses, assinalar a existência de:

Porão alto

Mirante

Pav. intermediário

\section{Alt. cumeeira:}

№ subsolos:

Pav. recuado

Sótão habitável
2. Classificação tipológica do telhado Número de águas do corpo principal: 02

Cumeeira paralela à rua $X$

Com torreão

Cumeeira perpendicular à rua

Tipo chalé

Água furtada

Outros:

3. Registro de acréscimos

Não tem $X$

Acréscimo vertical

Acréscimo horizontal
Identificado a partir de:

Evidência na construção $X$

Depoimento do usuário
Descrever: 
Identificação

Rua XV de Novembro, 365

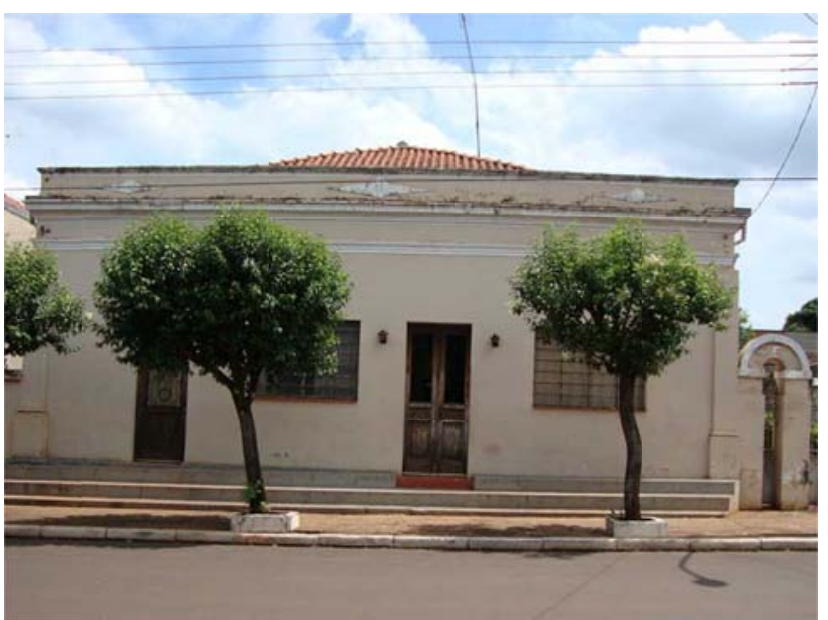

Fachada principal

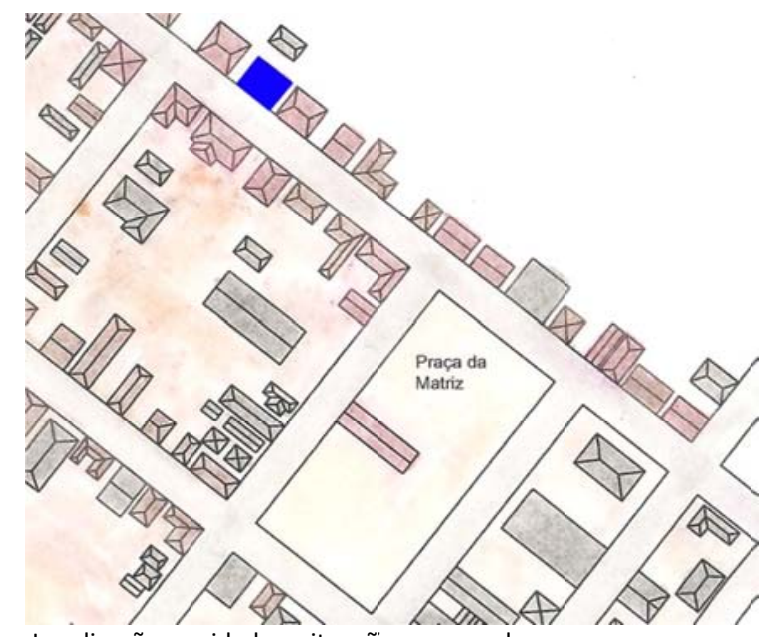

Localização na cidade - situaçãio sem escala

Fachada principal e uso atual

$\begin{array}{ll}\text { 1. Materiais empregados na cobertura } \\ \text { Destruição total } & \text { Canal } \\ \text { Francesa X } & \text { Fibrocimento } \\ \text { Vidro } & \text { Metal } \\ \text { Plástico / fibra } & \text { Laje } \\ \text { Outros: } & \end{array}$

2. Coroamento

Destruição total

Frontão

Cachorros

Laje de beiral

Beiral simples

4. Materiais de acabamento da fachada principal

3. Materiais do coroamento

Argamassa $X$

Azulejo antigo

Cantaria

Madeira

Azulejo novo

Concreto aparente

Outros:

5. Material das molduras dos vãos de portas e janelas

Não tem $X$

Argamassa

Azulejo antigo

Madeira

Destruição total

Cantaria

Azulejo novo

Concreto aparente

7. Cores predominantes da fachada principal

Coroamento:

Molduras dos vãos:

Esquadrias:

Acabam. da fachada:

Outros relevos:

$\begin{array}{ll}\text { Argamassa X } & \text { Chapisco } \\ \text { Cantaria } & \text { Azulejo novo } \\ \text { Azulejo novo } & \text { Madeira } \\ \text { Vidros } & \text { Outros: }\end{array}$

6. Material das esquadrias da fachada principal Destruição total Madeira $X$

Vidro $X \quad$ Alumínio

Ferro laminado / solda $X \quad$ Outros:

8. Uso atual - quantificar

Residência: $100 \%$ Vago:

Comércio: Culto:

Serviço: Instituição:
Dados volumétricos

\section{Gabarito}

Altura da fachada:

№ pavimentos acima do nível da rua: 01

Além desses, assinalar a existência de:

Porão alto Mirante

Pav. intermediário mezanino
3. Registro de acréscimos

Não tem $X$

Acréscimo vertical

Acréscimo horizontal
2. Classificação tipológica do telhado

Alt. cumeeira: Número de águas do corpo principal: 04

№ subsolos:

Cumeeira paralela à rua

Com torreão

Cumeeira perpendicular à rua $X$ Água furtada

Tipo chalé

Outros:

Sótão habitável

Identificado a partir de: Descrever:

Evidência na construção $X$

Depoimento do usuário 
Identificação

Rua XV de Novembro, 353

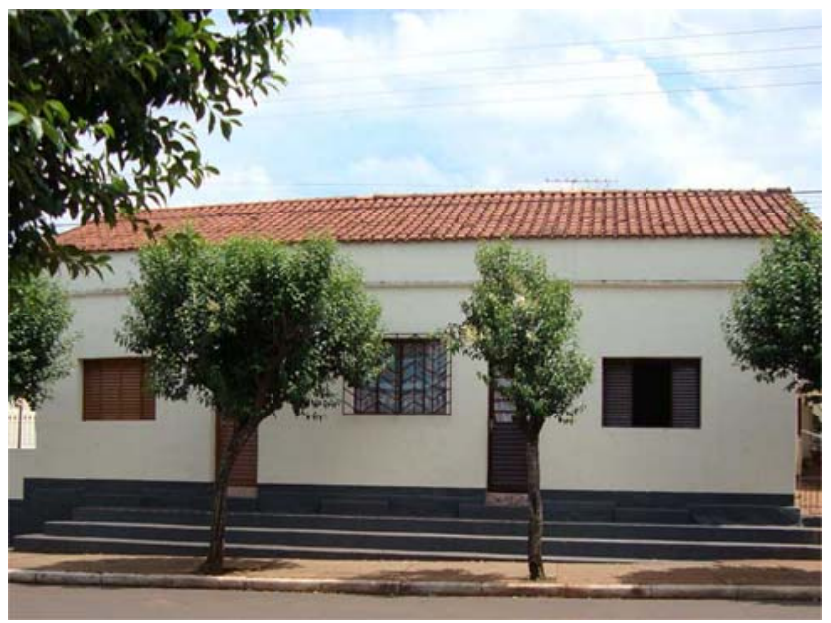

Fachada principal

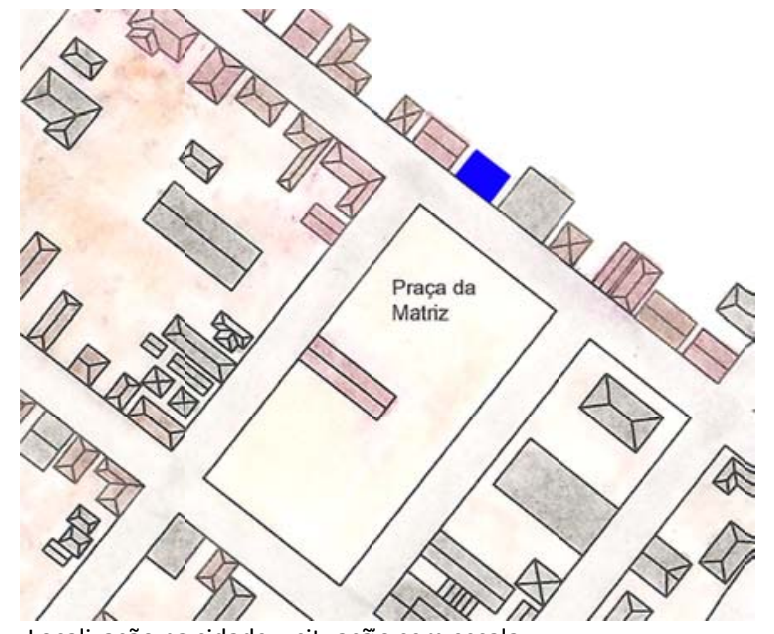

Localização na cidade - situação sem escala

Fachada principal e uso atual

$\begin{array}{ll}\text { 1. Materiais empregados na cobertura } \\ \text { Destruição total } & \text { Canal } \\ \text { Francesa X } & \text { Fibrocimento } \\ \text { Vidro } & \text { Metal } \\ \text { Plástico / fibra } & \text { Laje } \\ \text { Outros: } & \end{array}$

\section{Materiais do coroamento}

Argamassa

Cantaria

Azulejo antigo

Azulejo novo

Madeira

Concreto aparente

2. Coroamento

Destruição total $X$

Frontão

Cachorros

Laje de beiral

Beiral simples

Platibanda

Cimalha

Beira seveira

Guarda pó

4. Materiais de acabamento da fachada principal

Argamassa $X \quad$ Chapisco

Cantaria Azulejo novo

Azulejo novo Madeira

utros: não tem

5. Material das molduras dos vãos de portas e janelas $\quad 6$. Material das esquadrias da fachada principal

Não tem $X$

Argamassa

Azulejo antigo

Madeira

Destruição total

Cantaria

Azulejo novo

Concreto aparente

7. Cores predominantes da fachada principal

Coroamento: não tem

Molduras dos vãos: não tem

Esquadrias: marrom

Acabam. da fachada: bege

Guarda-corpos: não tem

\section{Destruição total}

Vidro

Ferro laminado / solda X

8. Uso atual - quantificar

Residência: $100 \%$

Comércio:

Serviço:
Madeira X

Alumínio $X$

Outros:

Dados volumétricos

\section{Gabarito}

Altura da fachada:

№ pavimentos acima do nível da rua: 01

Além desses, assinalar a existência de:

Porão alto

Mirante

Pav. intermediário

\section{Vago:}

Culto:

Instituição:

3. Registro de acréscimos

Não tem X

Acréscimo vertical

Identificado a partir de:

Evidência na construção $X$

Acréscimo horizontal

\section{Alt. cumeeira:}

№ subsolos:

Pav. recuado

Sótão habitável
2. Classificação tipológica do telhado Número de águas do corpo principal: 02

Cumeeira paralela à rua $X$

Com torreão

Cumeeira perpendicular à rua

Tipo chalé

Água furtada

Outros:

\section{Descrever:}

Depoimento do usuário 
Rua

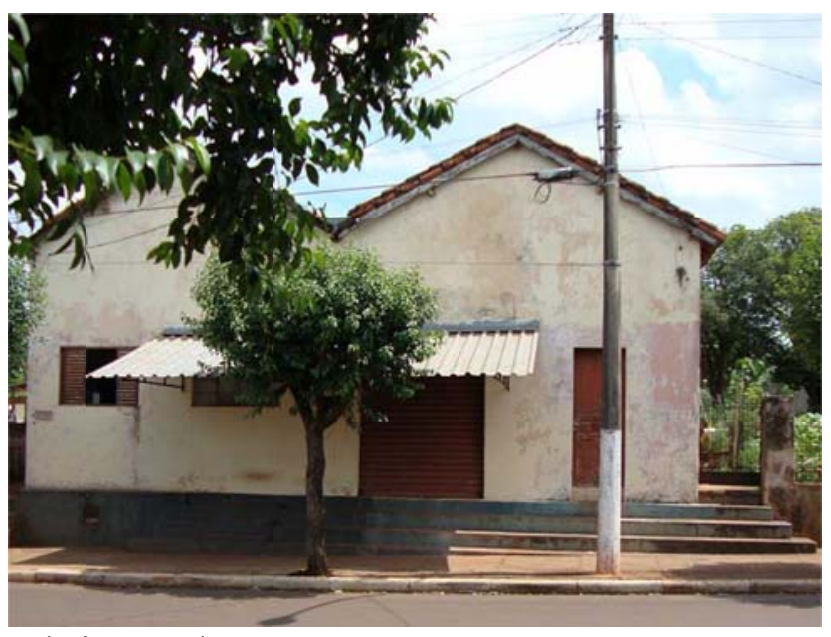

Fachada principal

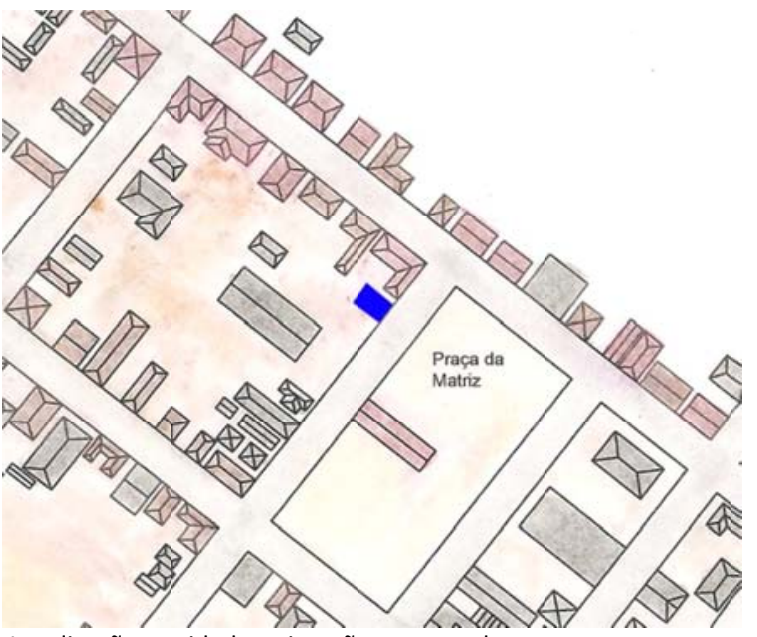

Localização na cidade - situaçãı sem escala

Fachada principal e uso atual

1. Materiais empregados na cobertura

2. Coroamento

Destruição total

Canal

Francesa X

Fibrocimento

Destruição total

Vidro

Metal

Plástico / fibra

Laje

Outros:

\section{Materiais do coroamento}

Argamassa

Azulejo antigo

Cantaria

Madeira X

Azulejo novo

Outros:

Concreto aparente

Frontão

Cachorros

Laje de beiral

Beiral simples $X$

\section{Platibanda}

Cimalha

Beira seveira

Guarda pó

4. Materiais de acabamento da fachada principal

Argamassa $X \quad$ Chapisco

Cantaria Azulejo novo

Azulejo novo Madeira

Vidros Outros:

5. Material das molduras dos vãos de portas e janelas Não tem X

Argamassa

Azulejo antigo Destruição total

Cantaria

Azulejo novo

Concreto aparente

7. Cores predominantes da fachada principal Coroamento: branco

Esquadrias: marrom

Acabam. da fachada: branco

Outros relevos: não tem

Molduras dos vãos: não tem

Guarda-corpos: não tem

6. Material das esquadrias da fachada principal

Destruição total Madeira $X$

Vidro Alumínio $X$

Ferro laminado / solda Outros:

$\begin{array}{ll}\text { 8. Uso atual - quantificar } & \\ \text { Residência: } 50 \% & \text { Vago: } \\ \text { Comércio: } 50 \% & \text { Culto: } \\ \text { Serviço: } & \text { Instituição: }\end{array}$

Dados volumétricos

\section{Gabarito}

Altura da fachada:

№ pavimentos acima do nível da rua: 01

Além desses, assinalar a existência de:

$\begin{array}{ll}\text { Porão alto } & \text { Mirante } \\ \text { Pav. intermediário } & \text { mezanino }\end{array}$

3. Registro de acréscimos

Não tem X

Acréscimo vertical

Acréscimo horizontal

\section{Alt. cumeeira:}

№ subsolos:

Pav. recuado

Sótão habitável

\section{Classificação tipológica do telhado} Número de águas do corpo principal: 02

Cumeeira paralela à rua

Com torreão

Cumeeira perpendicular à rua $X$

Tipo chalé

Água furtada

Outros: 
Identificação

Rua XV de Novembro, 355

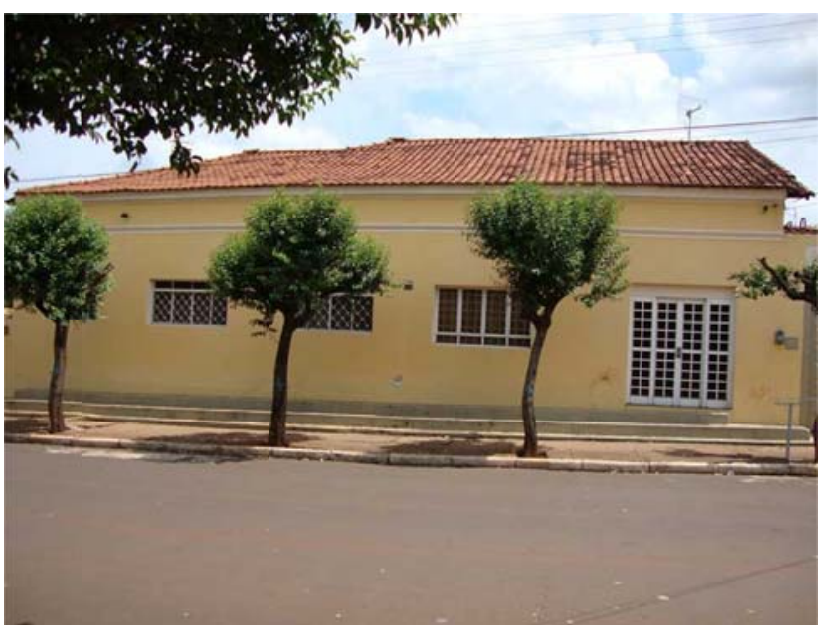

Fachada principal

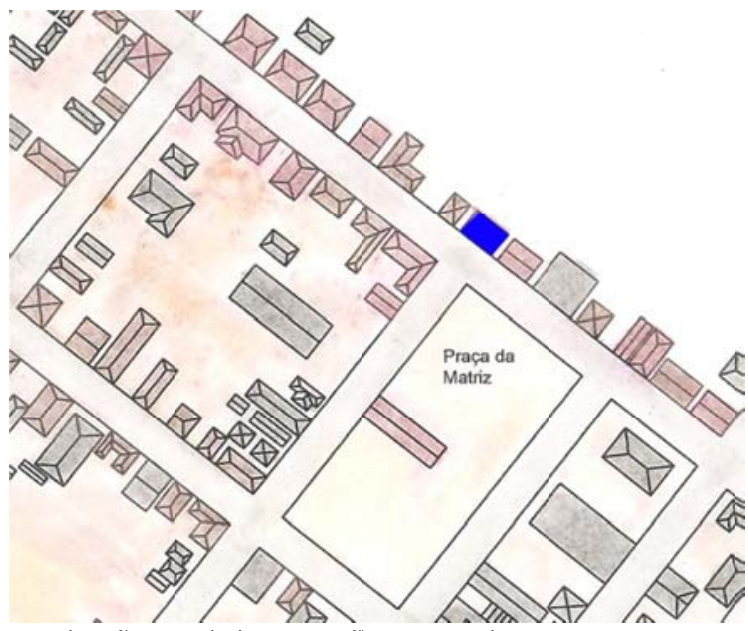

Localização na cidade - situaçãio sem escala

Fachada principal e uso atual

1. Materiais empregados na cobertura

2. Coroamento

Destruição total

Francesa $\mathrm{X}$

Canal

Fibrocimento

Destruição total

Vidro

Metal

Frontão

Laje

Cachorros

Platibanda

Plástico / fibra

Laje de beiral

Beiral simples

Cimalha $X$

Outros:

4. Materiais de acabamento da fachada principal

Argamassa $X$

Cantaria

Azulejo antigo

Azulejo novo

Madeira

Concreto aparente

Argamassa $X$

Cantaria

Outros:

Azulejo novo

Beira seveira

5. Material das molduras dos vãos de portas e janelas

Não tem $X$

Argamassa

Destruição total

Azulejo antigo

Cantaria

Madeira

Azulejo novo

Concreto aparente

7. Cores predominantes da fachada principal

Coroamento: branco

Esquadrias: branco

Vidros

Guarda pó

Outros:

Molduras dos vãos: não tem

Acabam. da fachada: amarelo

6. Material das esquadrias da fachada principal

Guarda-corpos: não tem

Outros relevos: não tem

Destruição total

Vidro

Chapisco

Madeira

Outros:

Dados volumétricos

\section{Gabarito}

Altura da fachada:

№ pavimentos acima do nível da rua: 01

Além desses, assinalar a existência de:

$\begin{array}{ll}\text { Porão alto } & \text { Mirante } \\ \text { Pav. intermediário } & \text { Mezanino }\end{array}$

3. Registro de acréscimos

Não tem $X$

Acréscimo vertical

Acréscimo horizontal dentificado a partir de:

Evidência na construção $X$

Depoimento do usuário
2. Classificação tipológica do telhado Número de águas do corpo principal: 02

Cumeeira paralela à rua $X \quad$ Com torreão

Cumeeira perpendicular à rua Água furtada

Tipo chalé Outros:

\section{Uso atual - quantificar

Residência: $100 \%$ Vago:

Comércio: Culto:

Serviço: Instituição: 
Identificação

Rua XV de Novembro 371

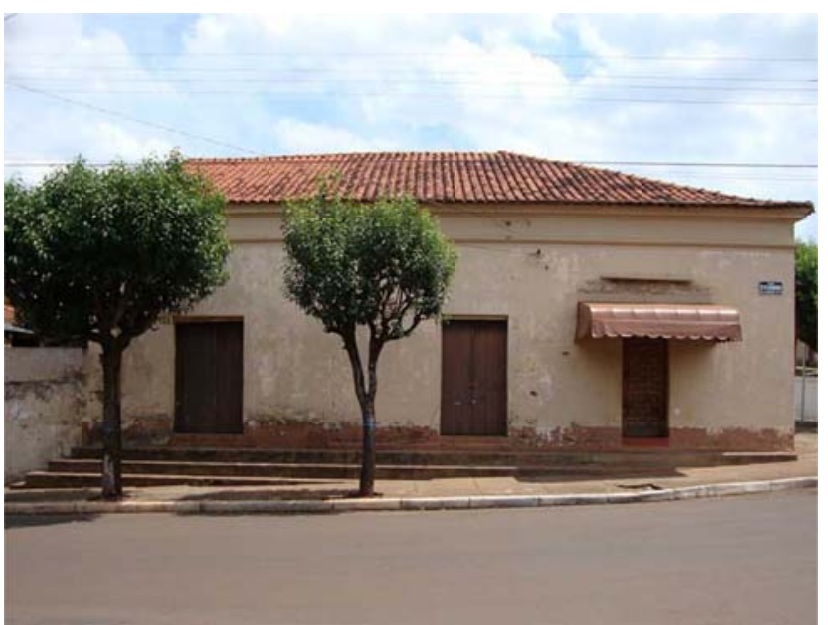

Fachada principal

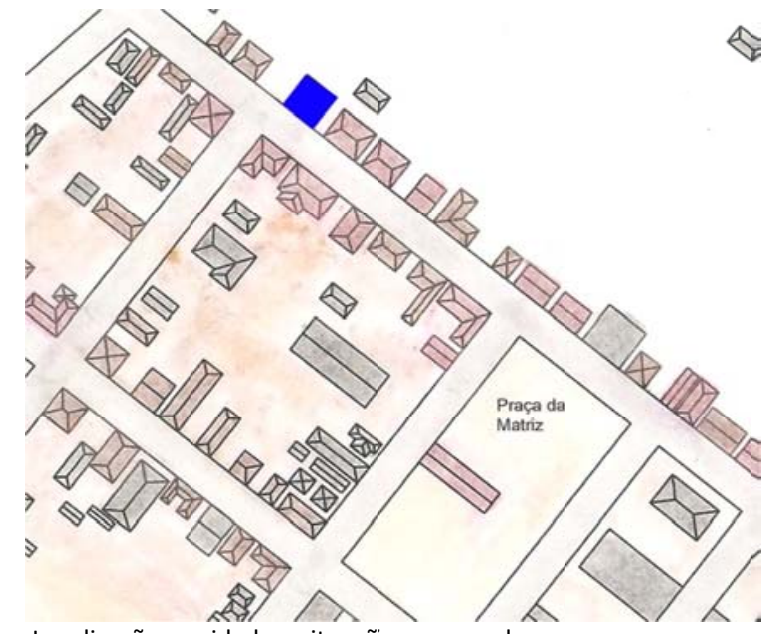

Localização na cidade - situaçãio sem escala

Fachada principal e uso atual

1. Materiais empregados na cobertura

2. Coroamento

Destruição total

Francesa $\mathrm{X}$

Canal

Fibrocimento

Destruição total

Vidro

Metal

Frontão

Laje

Cachorros

Platibanda

Plástico / fibra

Laje de beiral

Beiral simples

Cimalha $X$

Outros:

\section{Materiais de acabamento da fachada principal}

Argamassa X

Cantaria

Azulejo antigo

Azulejo novo

Argamassa $X$

Chapisco

Madeira

Concreto aparente

Cantaria

Outros:

Azulejo novo

Azulejo novo

Vidros

Madeira

6. Material das esquadrias da fachada principal

Não tem X

Argamassa

Destruição total

Cantaria

Azulejo antigo

Azulejo novo

Destruição total

Vidro

Madeira X

Madeira

Concreto aparente

7. Cores predominantes da fachada principal

Coroamento: bege

Esquadrias: marrom

Acabam. da fachada: bege

Molduras dos vãos: não tem

Outros relevos: não tem

Ferro laminado / solda X

Alumínio

Outros:

Guarda-corpos: não tem

\section{Uso atual - quantificar}

Residência: $50 \%$

Comércio: 50\%

Serviço:
Vago:

Culto:

Instituição:

Dados volumétricos

\section{Gabarito}

Altura da fachada:

№ pavimentos acima do nível da rua: 01

Além desses, assinalar a existência de:

Porão alto Mirante

Pav. intermediário mezanino
2. Classificação tipológica do telhado Número de águas do corpo principal: 04

Cumeeira paralela à rua $X$

Com torreão

№ subsolos:

Pav. recuado Cumeeira perpendicular à rua Tipo chalé

Água furtada

Sótão habitável

\section{Registro de acréscimos}

Não tem $X$

Acréscimo vertical

Acréscimo horizonta
Identificado a partir de:

Evidência na construção $X$

Depoimento do usuário
Descrever: 
Rua

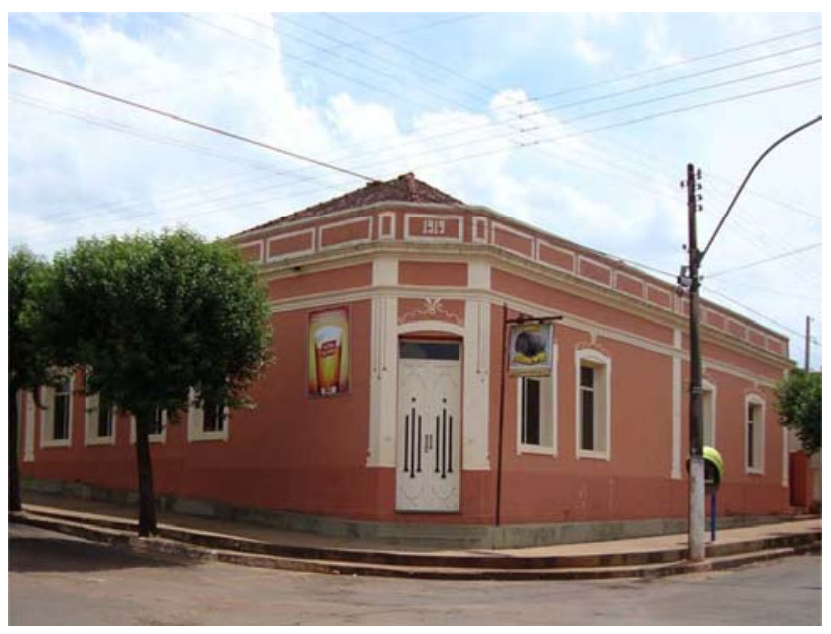

Fachada principal

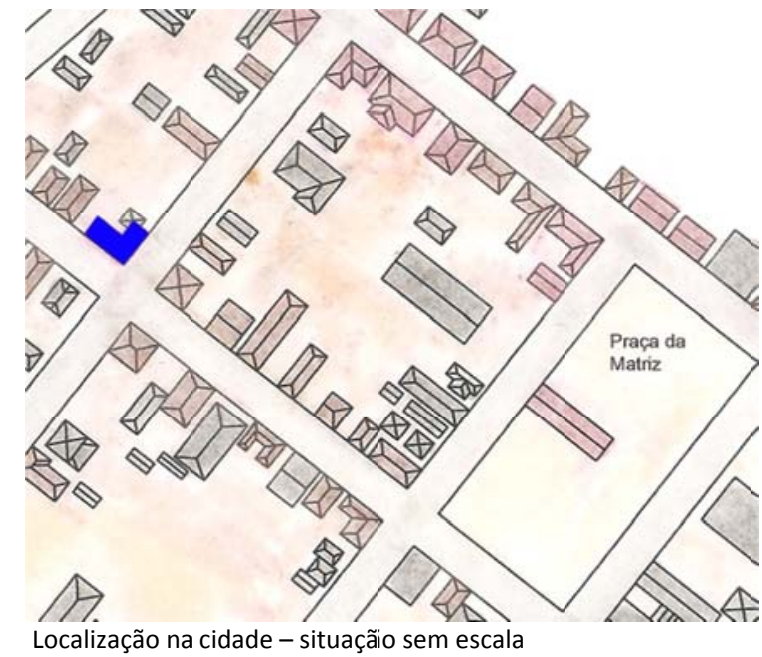

2. Coroamento

Destruição total Platibanda X

Frontão Cimalha

Cachorros Beira seveira

Laje de beiral Guarda pó

Beiral simples Outros:

4. Materiais de acabamento da fachada principal

Argamassa X Chapisco

Cantaria Azulejo novo

Azulejo novo Madeira

Vidros Outros:

6. Material das esquadrias da fachada principal

Destruição total Madeira $X$

Vidro $X \quad$ Alumínio

Ferro laminado / solda Outros:

Azulejo antigo Azulejo novo Ferrolaminado / solda Outros:

Madeira Concreto aparente

7. Cores predominantes da fachada principal 8. Uso atual - quantificar

Coroamento: vermelho Esquadrias: branco

Molduras dos vãos: branco Acabam. da fachada: vermelho

Guarda-corpos: não tem

Acabam. da fachada: vermelho Comério: 100\% - bar

Vago:

Comércio: $100 \%$ - bar Culto:

Serviço: Instituição:

Dados volumétricos

\begin{tabular}{|c|c|c|c|c|}
\hline \multicolumn{3}{|l|}{ 1. Gabarito } & \multicolumn{2}{|c|}{ 2. Classificação tipológica do trelhado } \\
\hline \multicolumn{2}{|l|}{ Altura da fachada: } & Alt. cumeeira: & \multicolumn{2}{|c|}{ Número de águas do corpo principal: 07} \\
\hline \multicolumn{2}{|c|}{ № pavimentos acima do nível da rua: 01} & № subsolos: & Cumeeira paralela à rua $X$ & Com torreão \\
\hline \multicolumn{3}{|c|}{ Além desses, assinalar a existência de: } & Cumeeira perpendicular à rua & Água furtada \\
\hline Porão alto $X$ & Mirante & Pav. recuado & Tipo chalé & Outros: \\
\hline Pav. intermediário & Mezanino & Sótão habitável & & \\
\hline
\end{tabular}

3. Registro de acréscimos

Não tem X

Acréscimo vertical

Acréscimo horizontal

Identificado a partir de:

Descrever: 
Identificação

Rua XV de Novembro s/n

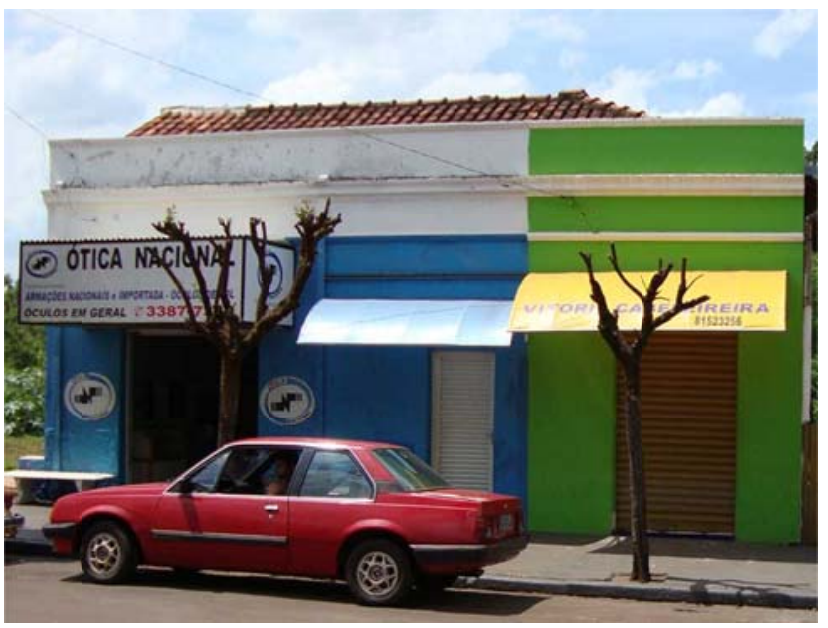

Fachada principal

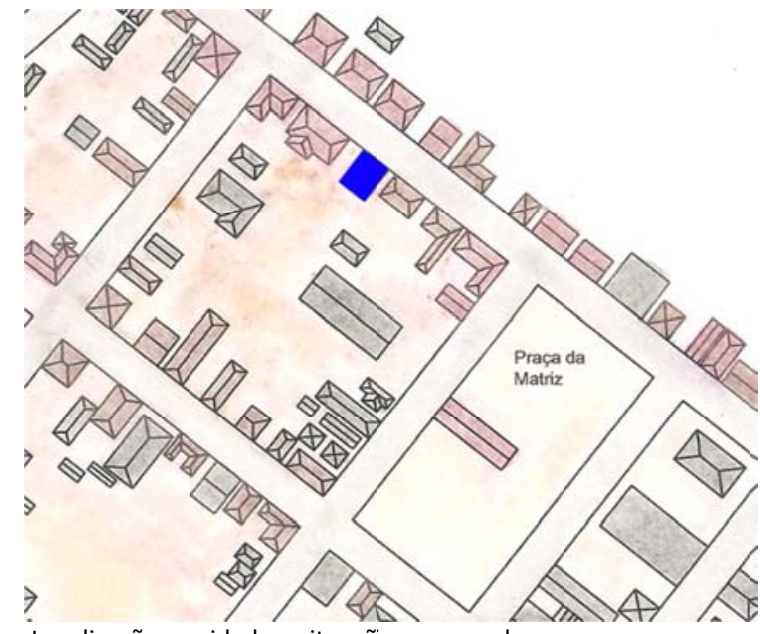

Localização na cidade - situaçãio sem escala

Fachada principal e uso atual

1. Materiais empregados na cobertura

2. Coroamento

Destruição total

Francesa $\mathrm{X}$

Canal

Fibrocimento

Destruição total

Vidro

Metal

Frontão

Laje

Cachorros

Platibanda X

Plástico / fibra

Laje de beiral

Beiral simples

Cimalha

3. Materiais do coroamento

Argamassa $\mathrm{X}$

Cantaria

Azulejo antigo

Azulejo novo

4. Materiais de acabamento da fachada principal

Madeira

Concreto aparente

Argamassa $X$

Cantaria

Outros:

Azulejo novo

Vidros

Beira seveira

Guarda pó

Outros:

5. Material das molduras dos vãos de portas e janelas

Não tem X

Argamassa

Destruição total

Azulejo antigo

Cantaria

Madeira

Azulejo novo

Concreto aparente

7. Cores predominantes da fachada principal

Coroamento: branco/verde

Molduras dos vãos: não tem

Esquadrias: marrom/branco

Acabam. da fachada: azul/verde

Guarda-corpos: não tem

Outros relevos: não tem

6. Material das esquadrias da fachada principal

Destruição total Madeira

Vidro Alumínio $\mathrm{X}$

Ferro laminado / solda Outros:

\section{Uso atual - quantificar}

Residência:

Comércio: $100 \%$

Vago:

Serviço:

Culto:

Instituição:

Dados volumétricos

\section{Gabarito}

Altura da fachada:

№ pavimentos acima do nível da rua: 01

Além desses, assinalar a existência de:

Porão alto Mirante

Pav. intermediário mezanino

\section{Alt. cumeeira:}

№ subsolos:

Pav. recuado

Sótão habitável

\section{Classificação tipológica do telhado} Número de águas do corpo principal: 03

Cumeeira paralela à rua $X$

Com torreão

Cumeeira perpendicular à rua

Tipo chalé

Água furtada

Outros:

\section{Registro de acréscimos}

Não tem $X$

Acréscimo vertical

Acréscimo horizonta
Identificado a partir de:

Evidência na construção $X$

Depoimento do usuário
Descrever: 


\section{Ficha de pré-inventário do patrimônio arquitetônico e urbanístico de Nova Europa Características Arquitetônicas - Ficha 12}

Identificação

Rua XV de Novembro s/n

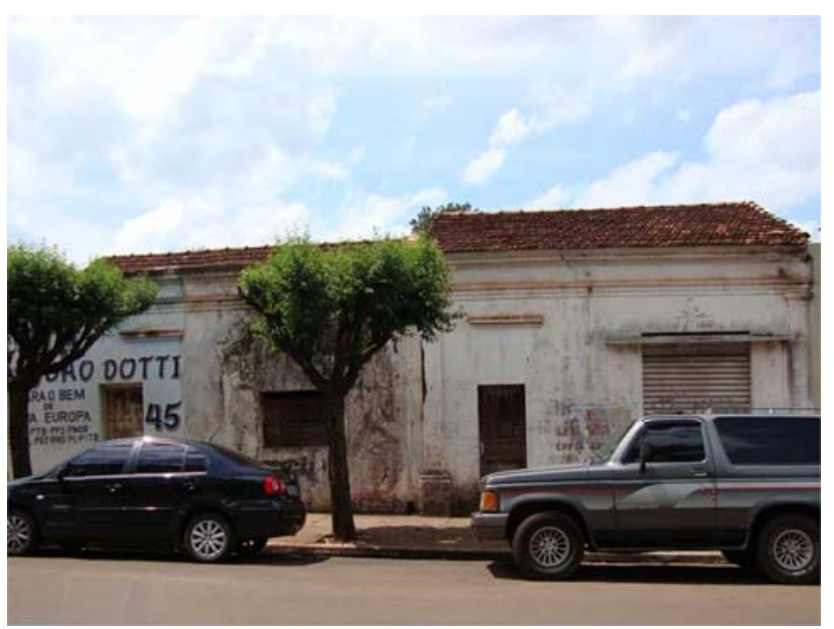

Fachada principal

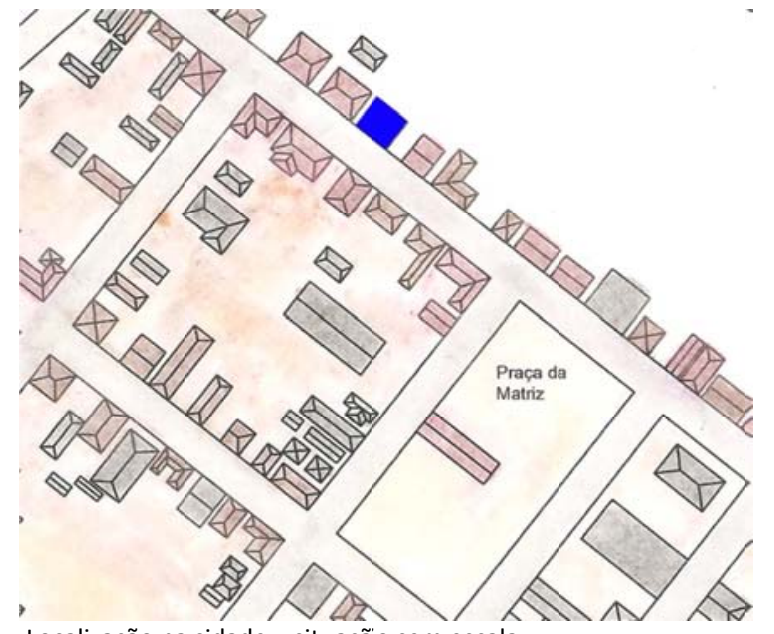

Localização na cidade - situaçãio sem escala

Fachada principal e uso atual

$\begin{array}{ll}\text { 1. Materiais empregados na cobertura } \\ \text { Destruição total } & \text { Canal } \\ \text { Francesa X } & \text { Fibrocimento } \\ \text { Vidro } & \text { Metal } \\ \text { Plástico / fibra } & \text { Laje } \\ \text { Outros: } & \end{array}$

\section{Materiais do coroamento}

Argamassa $X$

Cantaria

Azulejo antigo

Azulejo novo

Madeira

Concreto aparente

\section{Coroamento}

Destruição total

Frontão

Cachorros

Laje de beiral

Beiral simples

Platibanda
Cimalha X

Beira seveira

Guarda pó

Outros:

4. Materiais de acabamento da fachada principal

Argamassa X Chapisco

Cantaria Azulejo novo

Azulejo novo Madeira

Vidros Outros:

5. Material das molduras dos vãos de portas e janelas $\quad$ 6. Material das esquadrias da fachada principal

$\begin{array}{llll}\text { Não tem X } & \text { Destruição total } & \text { Destruição total } & \text { Madeira X } \\ \text { Argamassa } & \text { Cantaria } & \text { Vidro } & \text { Alumínio X } \\ \text { Azulejo antigo } & \text { Azulejo novo } & \text { Ferro laminado / solda } & \text { Outros: }\end{array}$

Madeira Concreto aparente

7. Cores predominantes da fachada principal

Coroamento: branco Esquadrias: branco

Molduras dos vãos: não tem

Acabam. da fachada: branco

8. Uso atual - quantificar

Guarda-corpos: não tem

Residência:

Comércio: $100 \%$

Serviço:

Vago:

Culto:

Instituição:

Dados volumétricos

\section{Gabarito \\ Altura da fachada:}

№ pavimentos acima do nível da rua: 01

Além desses, assinalar a existência de:

Porão alto

Mirante

Pav. intermediário

\section{Alt. cumeeira:}

№ subsolos:

Pav. recuado

Sótão habitável
2. Classificação tipológica do telhado Número de águas do corpo principal: 02

Cumeeira paralela à rua $X$

Com torreão

Cumeeira perpendicular à rua

Tipo chalé

Água furtada

Outros:

3. Registro de acréscimos Não tem $X$

Identificado a partir de:

Descrever:

Acréscimo vertical

Evidência na construção $X$

Acréscimo horizontal

Depoimento do usuário 
Identificação

Rua XV de novembro s/n

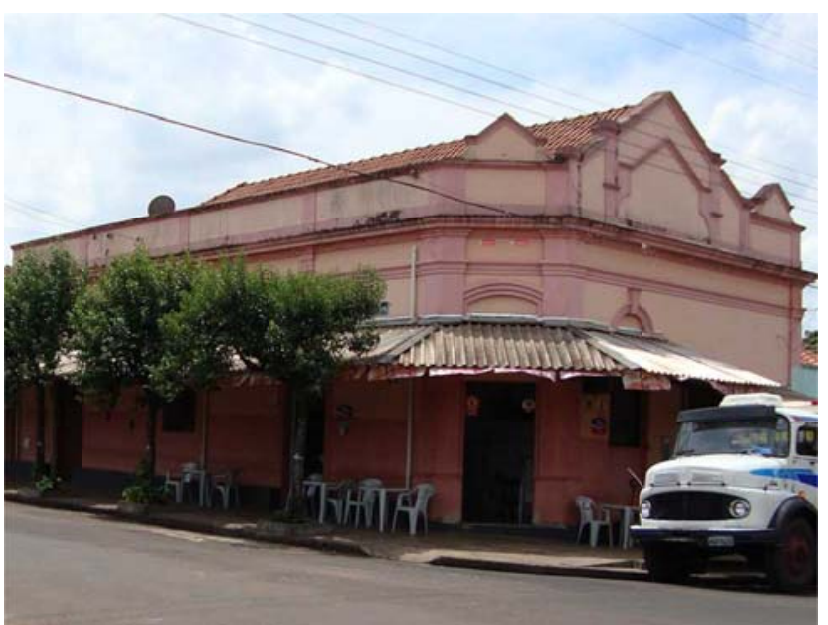

Fachada principal

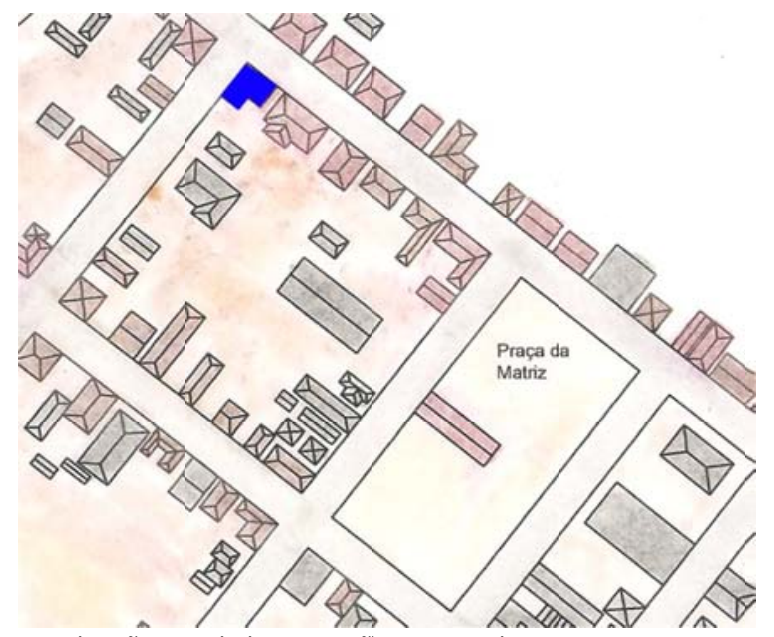

Localização na cidade - situaçãio sem escala

Fachada principal e uso atual

1. Materiais empregados na cobertura

2. Coroamento

Destruição total

Francesa $\mathrm{X}$

Canal

Fibrocimento

Destruição total

Vidro

Metal

Frontão

Laje

Cachorros

Laje de beiral

Plástico / fibra

Beiral simples

4. Materiais de acabamento da fachada principal

3. Materiais do coroamento

Argamassa $X$

Cantaria

Azulejo antigo

Azulejo novo

Madeira

Concreto aparente

Argamassa $X$

Cantaria

Outros:

Azulejo novo

Vidros

Platibanda X

Cimalha

Beira seveira

Guarda pó

Outros:

5. Material das molduras dos vãos de portas e janelas

Não tem

Destruição total

Argamassa $X$

Cantaria

Azulejo antigo

Azulejo novo

Concreto aparente

7. Cores predominantes da fachada principal

Coroamento: rosa

Esquadrias: marrom

Molduras dos vãos: rosa

Acabam. da fachada: rosa

6. Material das esquadrias da fachada principal

Guarda-corpos: não tem

Outros relevos: rosa

Destruição total

Vidro

Ferro laminado / solda $X \quad$ Outros:

Dados volumétricos

\section{Gabarito}

Altura da fachada:

№ pavimentos acima do nível da rua: 01

Além desses, assinalar a existência de:

$\begin{array}{ll}\text { Porão alto } & \text { Mirante } \\ \text { Pav. intermediário } & \text { mezanino }\end{array}$

3. Registro de acréscimos

Não tem $X$

Acréscimo vertical

Acréscimo horizontal

\section{Uso atual - quantificar}

Residência:

Comércio: 100\%

Serviço:

\section{Vago:}

Culto:

Instituição:
2. Classificação tipológica do telhado Número de águas do corpo principal: 02

Cumeeira paralela à rua $X$

Com torreão

№ subsolos:

Pav. recuado Cumeeira perpendicular à rua Tipo chalé

Água furtada

Sótão habitável

Outros: 
Identificação

Rua XV de Novembro s/n

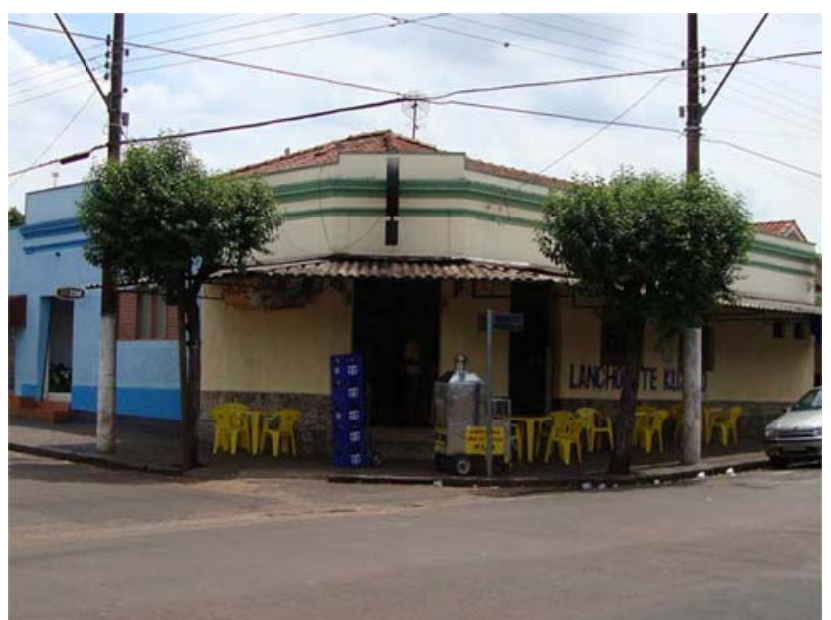

Fachada principal

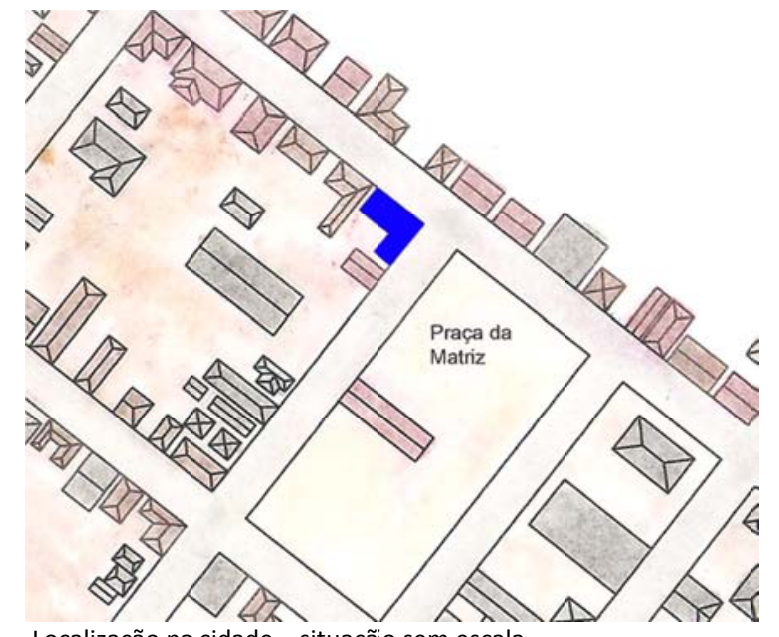

Localização na cidade - situaçãio sem escala

Fachada principal e uso atual

$\begin{array}{ll}\text { 1. Materiais empregados na cobertura } \\ \text { Destruição total } & \text { Canal } \\ \text { Francesa X } & \text { Fibrocimento } \\ \text { Vidro } & \text { Metal } \\ \text { Plástico / fibra } & \text { Laje } \\ \text { Outros: } & \end{array}$

\section{Materiais do coroamento}

Argamassa X

Cantaria

Azulejo antigo

Azulejo novo

Madeira

Concreto aparente

\section{Coroamento}

Destruição total

Frontão

Cachorros

Laje de beiral

Beiral simples

\section{Platibanda X \\ Cimalha \\ Beira seveira \\ Guarda pó \\ Outros:}

4. Materiais de acabamento da fachada principal

Argamassa $X \quad$ Chapisco

Cantaria Azulejo novo

Azulejo novo Madeira

Vidros Outros:

6. Material das esquadrias da fachada principal

Destruição total Madeira

Vidro Alumínio $X$

Ferro laminado / solda $X$ Outros:

8. Uso atual - quantificar

Residência: Vago:

Comércio: $100 \% \quad$ Culto:

Serviço: Instituição:

\section{Dados volumétricos}

\section{Gabarito}

Altura da fachada:

№ pavimentos acima do nível da rua: 01

Além desses, assinalar a existência de:

$$
\text { Porão alto Mirante }
$$

Pav. intermediário Mezanino

3. Registro de acréscimos

$$
\text { Não tem X }
$$

Acréscimo vertical

Acréscimo horizontal
2. Classificação tipológica do telhado

Alt. cumeeira: Número de águas do corpo principal: 05

№ subsolos:

Cumeeira paralela à rua $X$

Com torreão

Cumeeira perpendicular à rua

Pav. recuado

Tipo chalé

Água furtada

Outros:

Sótão habitável

Identificado a partir de:

Evidência na construção $X$

Depoimento do usuário
Descrever: 
Identificação

Rua

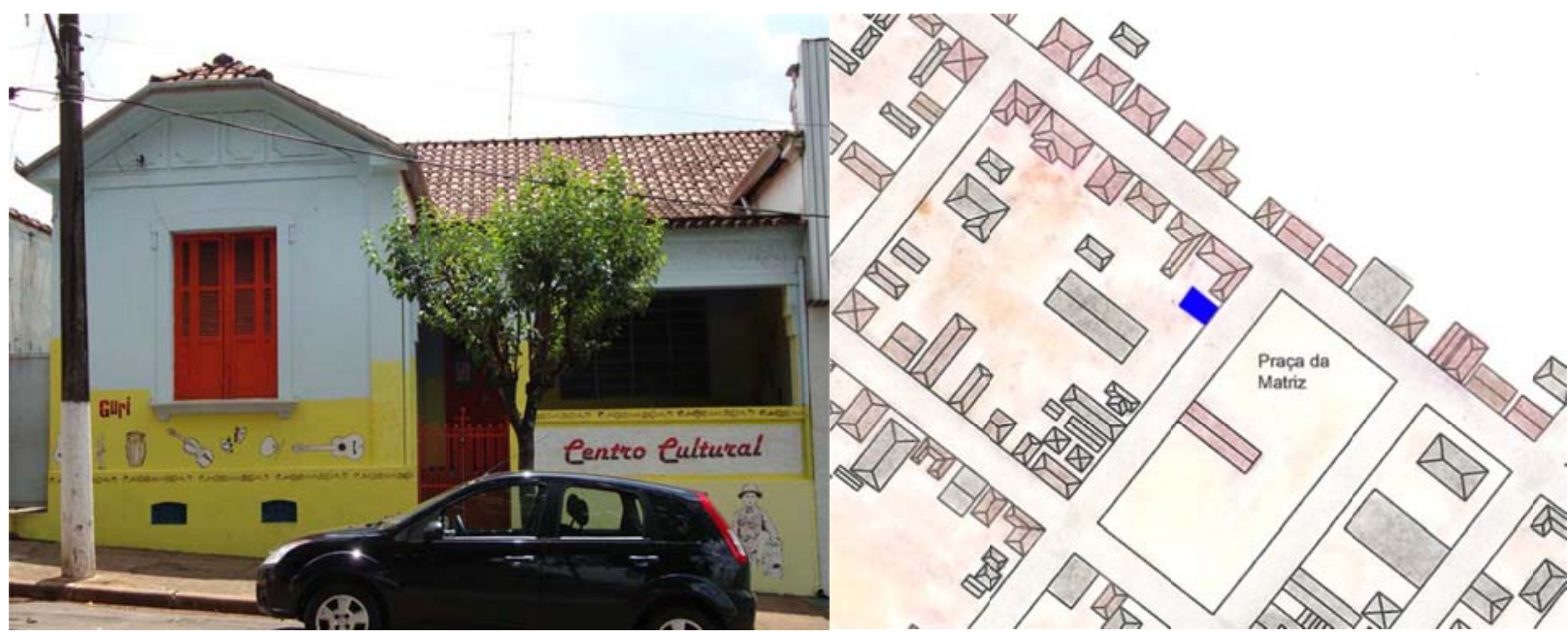

Fachada principal

Fachada principal e uso atual

1. Materiais empregados na cobertura

Destruição total

Francesa X

Vidro

Plástico / fibra

Outros:

\section{Materiais do coroamento}

Argamassa

Azulejo antigo

Madeira X

Outros:

5. Material das molduras dos vãos de portas e janelas

Não tem

Argamassa $X$

Azulejo antigo

Madeira

Canal

Fibrocimento

Metal

Laje

Cantaria

Azulejo novo

Concreto aparente

Cantaria

Azulejo novo

Concreto aparente

\section{Cores predominantes da fachada principal}

Coroamento: branco

Esquadrias: vermelho

Molduras dos vãos: branco

Acabam. da fachada: branco

Guarda-corpos: não tem

\section{Coroamento}

Destruição total

Frontão

Cachorros

Laje de beiral

Beiral simples

4. Materiais de acabamento da fachada principal

Argamassa $X \quad$ Chapisco

Cantaria Azulejo novo

Azulejo novo Madeira

Vidros Outros:

6. Material das esquadrias da fachada principal

Destruição total Madeira $X$

Vidro Alumínio

Ferro laminado / solda Outros:

8. Uso atual - quantificar

Residência:

Culto:

Serviço: $\quad$ Instituição: 100\%

Dados volumétricos

\section{Gabarito}

Altura da fachada:

№ pavimentos acima do nível da rua: 01

Além desses, assinalar a existência de:

Porão alto $X \quad$ Mirante

Pav. intermediário

mezanino
2. Classificação tipológica do telhado Número de águas do corpo principal: 05

Cumeeira paralela à rua

Com torreão

№ subsolos:

Cumeeira perpendicular à rua

Pav. recuado Tipo chalé

Água furtada X

Sótão habitável

\section{Registro de acréscimos}

Não tem

Acréscimo vertical

Acréscimo horizontal
Identificado a partir de:

Evidência na construção

Depoimento do usuário
Descrever: 
"Assim como falham as palavras quando querem exprimir qualquer pensamento, assim falham os pensamentos quando querem exprimir qualquer realidade." (Alberto Caeiro, Assim Como) 


\section{0 - Considerações finais}

A partir do entendimento das diferentes origens das cidades de Dourado e Nova Europa, podemos constatar que suas histórias se desenvolveram de forma semelhante: são cidades equivalentes em numero de população (em torno de 10.000 habitantes), tiveram seu desenvolvimento vinculado às atividades agrícolas, especialmente o café em seu período mais próspero, passando por um curto período onde predominou a cultura do algodão. Hoje Dourado ainda dependente da cultura da cana de açúcar e Nova Europa, da cana de açúcar e da laranja.

Ambas as cidades sentiram fortemente a desativação da ferrovia Cia. E. F. Dourado e no período passaram pela maior crise de suas histórias, inclusive com grandes perdas populacionais. Quanto à população inicial, Dourado foi ocupada por brasileiros, migrantes mineiros, mas a partir da virada do século recebeu importante fluxo de imigrantes, especialmente italianos, espanhóis e sírios; já Nova Europa desde o inicio foi ocupada por imigrantes, mas apesar da grande diversidade de origens, predominou a alemã e a russa.

Apesar desta grande parcela da população ter origem europeia, ela não deixou marcas físicas nas cidades que fizesse referencia aos seus países de origem, esta cultura também não se refletiu em festas típicas. Em Dourado, por exemplo, onde a grande maioria dos construtores atuantes no inicio do século XX tem origem italiana como pode ser observada pelo anexo 04, a arquitetura encontrada hoje em nada difere das de outras cidades vizinhas que não receberam o mesmo fluxo migratório. Também quanto as festas e costumes, estes estão ligados às tradições mineiras e portuguesas, especialmente as festas religiosas, que ainda são as principais datas comemorativas para ambas as cidades.

A realidade de ambas as cidades reflete a falta de planejamento urbano e a falta de preocupação com a preservação de seu patrimônio construído. As áreas centrais das duas cidades ainda exercem o papel de centro, são as áreas mais vivas e dinâmicas destas cidades, já que misturam as funções de comércio, serviços e residência. Também são quase totalmente ocupadas e planas.

A partir dos levantamentos efetuados nos capítulos 02 e 03, pudemos constatar que da arquitetura das áreas centrais aqui tratadas, pequena parcela foi literalmente demolida e substituída por novas edificações, sendo a maioria alvo de sucessivas reformas e alterações 
que acabaram por descaracterizar essa arquitetura a ponto de perdermos inclusive sua referência temporal.

Se compararmos as duas cidades, em Dourado ainda podemos encontrar um numero maior de exemplares do que em Nova Europa. Esta arquitetura que se manteve, apesar de na maioria dos casos ter sofrido pequenas descaracterizações como substituição de caixilhos, alterações de vãos de portas e janelas, acréscimo de toldos de publicidade, etc., ainda conservam características que possibilitam a leitura do conjunto.

É importante destacar que as nossas cidades são em grande parte construídas por essa arquitetura banal e corriqueira que aqui propomos preservar e que vem se perdendo, já que as arquiteturas excepcionais, os monumentos, representam apenas uma pequena fração do todo construído e são protegidas por leis que não se aplicam aos nossos objetos de estudos.

A partir dos levantamentos e de conversas com as populações locais pudemos perceber que a principal ameaça à preservação destes imóveis é o não reconhecimento do valor deste patrimônio construído por essas populações - a população em geral não se envolve nas questões da preservação do patrimônio cultural por não ver sua própria cultura como matéria da preservação.

O que pudemos perceber em ambas as cidades é que o reconhecimento por parte da população local de um edifício que merece ou não ser preservado está diretamente relacionado à quantidade de ornamentos que o edifício apresenta, já que este é o elemento que a primeira vista, difere as construções mais antigas das atuais, considerando a proximidade temporal do conjunto que propomos preservar e a similaridade de técnicas construtivas com as empregadas nas construções atuais.

Outra ameaça que estas edificações vem sofrendo são as alterações decorrentes de alterações de usos, como por exemplo, edifícios originalmente de uso misto, comerciais e residenciais, que agora passaram a abrigar apenas o uso residencial, tem suas amplas portas fechadas e substituídas por outras menores ou em outros casos, ampliação destes vãos para possibilitar o uso dos cômodos frontais como garagem.

Entendemos como justo o desejo por parte da população em ter acesso à infraestrutura moderna e a melhores condições de vida, porem isso não é incompatível com a preservação dos edifícios. Por isso entendemos que o primeiro passo para que estes 
conjuntos continuem em pé e mantendo sua unidade é uma mudança na forma de se relacionar com este patrimônio.

A partir da constatação destas ameaças, acreditamos que a preservação destes conjuntos deva partir da regulamentação do solo urbano e da busca de soluções para o convívio harmonioso dos valores culturais, materializados no tecido urbano e nas edificações, com o desenvolvimento de atividades que vitalizem economicamente as cidades.

Acreditamos que o turismo possa ser uma atividade adequada para conciliar a vitalidade econômica e a preservação dos lugares, além de possibilitar a aproximação entre as pessoas e o meio cultural.

Concordamos com Simão (2001) sobre o turismo quando encarado como um possibilitador da preservação de bens culturais e da qualidade de vida local, potencializa a apropriação da cidade pelos seus cidadãos "renovando o espirito cívico e o orgulho pelo lugar".

"A atividade turística, para realizar-se como um meio de vida promissor e honesto, somente deve ser encorajada na medida em que puder oferecer à população local vantagens econômicas e sociais, principalmente sob a forma de geração de empregos e renda, evitando que se crie um ambiente de exploração econômica." Simão ( p. 74)

Entretanto, segundo Damiani (1997, p. 48) é importante saber discernir "até que ponto o aperfeiçoamento do turismo pode vir a destruir as diferenças do lugar e esgotar os significados turísticos do lugar desejado", pois o turismo "deve em primeiro lugar garantir a qualidade de vida da população local e preservar o patrimônio cultural e ambiental". Ainda segundo o mesmo autor, "se ele [o turismo] se sobrepuser à cultura local e fizer com que essa se descaracterize, ele acabará com sua própria razão de existir naquele lugar."

Portanto se faz necessário e urgente trabalhar para que as populações locais resgatem o gosto, o orgulho pelas suas áreas centrais e entendam todo o referencial que é guardado no local.

A construção ou a modificação da imagem que os moradores tem da sua cidade com objetivo de restabelecer o orgulho e o gosto pelo lugar pode ser uma estratégia para a mobilização desta população e um instrumento para a promoção da cidade e especialmente para a preservação de seu patrimônio construíd 


\section{Referencias bibliográficas}

ANDRADE, Antonio Luiz Dias de. Um Estado Completo que Pode Jamais ter Existido. São Paulo, Faculdade de Arquitetura e Urbanismo da Universidade de São Paulo, Tese de Doutoramento, 1993.

ARANTES, Antonio Augusto (org.). Produzindo o passado: Estratégias de Construção do Patrimônio

Cultural. São Paulo, Brasiliense, 1984.

ARGAN, Giulio Carlo. História da Arte como História da Cidade. São Paulo, Martins Fontes, 1998.

BASILE, Giuseppe. A atualidade da Teoria da Restauração de Cesare Brandi: alguns exemplos. Pós: Revista do Programa de Pós-Graduação em Arquitetura e Urbanismo da FAU USP, 2004, n. 16.

BARTHELRMY, Jean. Nosso patrimônio no ano 2000. Revista do Patrimônio Histórico e Artístico Nacional, 1984, n. 20.

BENEVOLO, Leonardo. História de la Arquitectura Moderna. Barcelona, Ed. Gustavo Gili, 1974

BENINCASA, V. Velhas fazendas: arquitetura e cotidiano nos campos de Araraquara 1830-1930. São Carlos: EdUFSCar; São Paulo: Imprensa Oficial do Estado, 2003.

BOITO, Camillo. Os Restauradores. São Paulo, Ateliê, 2002.

BRANDI, Cesare. Teoria da Restauração. São Paulo, Ateliê, 2004.

CANO, W. Raízes da concentração industrial em São Paulo. Rio de Janeiro/São Paulo: DIFEL, 1977.

CASTILHO, Ana Luisa Howard de e VARGAS, Heliana Comin (orgs.). Intervenções em Centros Urbanos: objetivos, estratégias e resultados. Barueri, SP: Manole, 2006.

CHOAY, Françoise. A Alegoria do Patrimônio. São Paulo, UNESP. 2001.

CHOAY, Françoise. EL Urbanismo: utopias y realidades. Paris, Seuil (c. I 965).

COSTA, E. V. Da Monarquia à República: momentos decisivos. São Paulo: Brasiliense, 1977.

COSTA, L. A. M. O ideário urbano paulista na virada do século: O engenheiro Theodoro Sampaio e as questões territoriais e urbanas modernas (1886-1903). São Carlos: RiMa, Fapesp, 2003.

CULLEN, Gordon. The concise townspace. London, The Architectural Press, 1971.

CULLEN, Gordon. Townscape. Londres: Architectural Press, 1961.

CULLEN, Gordon. Paisagem urbana. Lisboa: Edições 70, 1971.

CUNHA, Maria Clementina Pereira (org). O Direito à Memória - Patrimônio Histórico e Cidadania. São

Paulo: Departamento do Patrimônio Histórico, 1992.

DAMIANI, A. L. Turismo e lazer em espaços urbanos. In. RODRIGUES, A. B. Turismo, Modernidade, Globalização. São Paulo: Hucitec, 1997, p. 119-135.

DEL BIANCO, A. H. Cia Estrada de Ferro Dourado. http://sites.uol.com.br/mtalamo/cd.htm.

DEL RIO, Vicente. Introdução ao desenho urbano no processo de planejamento. São Paulo, Pini, 1990.

DEL RIO, V. \& OLIVEIRA, L. (orgs.): Percepção Ambiental: A Experiência Brasileira. São Paulo: Ed. StudioNobel, 1996. 
ENCICLOPÉDIA DOS MUNICÍPIOS BRASILEIROS. Rio de Janeiro, IBGE, 1958, v.XXX.

FONSECA, Maria Cecília Londres. O Patrimônio em Processo - Trajetória Política Federal de Preservação no Brasil. Rio de Janeiro, UFRJ/Minc/IPHAN, 1997.

GADELHA, M. D. F. Os núcleos coloniais e o processo de acumulação cafeeira (1850-1920): contribuição ao estudo da colonização em São Paulo. São Paulo, 1982. Tese (Doutorado em História) - IFLCH USP (Mimeogr).

GHIRARDELLO, N. À beira da linha: formações urbanas da Noroeste paulista. São Paulo: Editora UNESP, 2002.

GORDINHO, Margarida Cintra. A casa do Pinhal. São Paulo, Ed. C H Knapp, 1985, p. 91.

HALL, Stuart. A identidade cultural na pós-modernidade. Rio de Janeiro, D P \& A, 2005.

GUTIERREZ, Ramón. Arquitetura Latino-Americana: Textos para Reflexão e polêmica. São Paulo, Nobel, 1989

HALL, Stuart.A questão da identidade cultural, Campinas, IFICH, 2003.

HOBSBAWM, Eric; RANGER, Terence. A invenção das tradições. São Paulo, Paz e Terra, 2002.

IGLESIAS, F. Historia e ideologia. São Paulo: Perspectiva. 1981.

KOHLSDORF, Maria Elaine. A apreensão da forma da cidade. Brasília, Editora UnB, 1996.

KÜHL, Beatriz Mugayar. Arquitetura do Ferro e Arquitetura Ferroviária em São Paulo: Reflexões

sobre a sua Preservação. São Paulo, Ateliê/FAPESP/SEC, 1998.

KÜHL, Beatriz Mugayar. História e Ética na Conservação e na Restauração de Monumentos Históricos, Revista CPC, 2005, v. 1., n. 1. (www.usp/cpc/v1)

Preservação do patrimônio arquitetônico da industrialização: problemas teóricos de restauro São Paulo, FAUUSP, Tese de livre-docência, 2006.

A restauração de monumentos históricos na França após a Revolução Francesa e durante o século XIX: um período crucial para o amadurecimento teórico, Revista CPC, 2006, v.1, n. 3, pp. 110-144 (www.usp/cpc/v1)

As transformações na maneira de se intervir na arquitetura do passado entre os séculos $15 \mathrm{e}$ 18: o período de formação da restauração, Sinopses, 2001, n. 36, pp. 24-36.

LE CORBUSIER. A Carta de Atenas, São Paulo, Hucitec / EDUSP, 1993.

LE GOFF, Jacques. História e Memória. Campinas, Ed. Unicamp, 1996

LEITE, M. da Silva (org). Urbanismo no Brasil (1895-1965). São Paulo. FUPAM, Nobel ed. 1999.

LEITE, M. Paulistas e mineiros plantadores de cidades. São Paulo: Edart, 1961.

LEITE, Rogério Proença. Contra-usos da cidade: lugares e espaço público na experiência urbana contemporânea. Campinas: Ed. Unicamp, 2004.

LEMOS, Carlos A. C. O que é Patrimônio Histórico. São Paulo, Brasiliense, 1981.

. Proteção e Revitalização do Patrimônio Cultural no Brasil: uma Trajetória.Brasília, 1980.

MEC/SPHAN/Pró-Memória 
. Restauração e Revitalização de Núcleos Históricos. Análise Face à Experiência Francesa.

Brasília, 1980.

LIRA, José Tavares Correia de. Mocambo e cidade. Regionalismo na arquitetura e ordenação do espaço habitado. São Paulo, FAU-USP (tese de doutoramento), 1996.

LYNCH, Kevin. A imagem da cidade. São Paulo, Martins Fontes, 1997

MAGALHÃES, Aloísio - Bens Culturais: Instrumento para um desenvolvimento harmonioso. Revista do Patrimonio Histórico e Artístico Nacional, Rio de Janeiro, 1984, n. 20.

MALUF, M. Ruídos da memoria. São Paulo, Siciliano, 1995.

MARTINS, A. L. Império do café: A grande lavoura no Brasil - 1850 a 1890. São Paulo, Atual Editora, 4a Ed., 1991, p.3.

MARX, Murilo. Cidade Brasileira. São Paulo, Melhoramentos, 1980.

MARX, M. Cidade no Brasil: terra de quem? São Paulo: Edusp, Nobel, 1991.

MATOS, O. N. de. Café e ferrovias: a evolução ferroviária de São Paulo e o desenvolvimento da cultura cafeeira. São Paulo: Alfa-Ômega, 1974.

MAYUMI, Lia. Restauração e revitalização de nucleos históricos. Brasília, MEC/SPHAN/Pró Memória, 1980.

MEURS, Paul. Modernismo e Tradição: Preservação no Brasil. Óculum, Campinas, 1995, n. 5/6.

MENESES, Ulpiano Bezerra de. A História, cativa da memória? Revista do Instituto de Estudos

Brasileiros, 1992, v. 34, pp. 9-23

Identidade Cultural e Arqueologia, Revista do Patrimônio Histórico e Artístico Nacional, Rio de

Janeiro, 1984, n. 20, pp. 33-36.

MILET, Vera. A teimosia das Pedras: um estudo sobre a preservação do Patrimônio Ambiental do Brasil. Olinda, Prefeitura de Olinda, 1988.

MILLIET, S. Roteiro do café e outros ensaios. 4. ed. São Paulo: Hucitec, INL, 1982.

MONBEIG, P. Pioneiros e fazendeiros de São Paulo. São Paulo: Hucitec, Polis, 1984.

MONNIER, Gérard. O edificio-evento e a história contemporânea. Desígnio, 2006 (2007), n. 6.

MOTTA, Lia; SILVA, Maria Beatriz de Resende (org.) Inventários de identificação: Um programa da experiencia brasileira. Rio de Janeiro, IPHAN, 1998.

NUNES, I. Douradense: a agonia de uma ferrovia. Araraquara, 2002. Dissertação (Mestrado em Economia), Departamento de Economia, Universidade Estadual Paulista.

OHTAKE, M. F. G. O processo de urbanização em São Paulo: dois momentos, duas faces. 1982. Dissertação (Mestrado) - Programa de Pós Graduação em Ciências Sociais, Pontifícia Universidade Católica, São Paulo. OLIVEIRA, J. O. S. de. Contribuição ao estudo das origens da ideologia do planejamento moderno no Brasil: Domingos Jaguaribe e as propostas dos núcleos coloniais - 1874-1900: faces do planejamento territorial no processo de modernização sob o complexo cafeeiro paulista. 1997. Tese (Doutorado) Faculdade de Arquitetura e Urbanismo, Universidade de São Paulo, São Paulo. 
PACHECO, C. A. Café e cidades em São Paulo: um estudo de caso da urbanização na região de Araraquara e São Carlos, 1880-1930. 1988. Dissertação (Mestrado em Economia) - Instituto de Economia, Universidade de Campinas.

PARENT, Michel. O futuro do Patrimonio Arquitetônico. Revista do Patrimonio Histórico e Artistico Nacional, 1984, n. 18.

PINHEIRO, Maria Lucia Bressan. Reflexões sobre a Preservação da Capela N. Sra. do Rosário dos Homens Pretos em São Paulo. In: Desígnio Revista de História da Arquitetura e do Urbanismo, No. 6, setembro/2006. São Paulo, Annablume, pp. 87-93. ISSN 1806-2741

Origens da noção de preservação do patrimônio cultural no Brasil. In: Revista Risco no. 3. São Carlos, 2006. (www.risco)

A História da Arquitetura Brasileira e a Preservação do Patrimônio Cultural. In: Revista CPC v.1, n.1. Novembro 2005/abril 2006. (www.usp.br/cpc)

PIRES, Maria Coeli Simões. Da Proteção ao Patrimônio Cultural. Belo Horizonte, Del Rey, 1994.

QUEIROZ, P. R. C. Uma ferrovia entre dois mundos: a E F Noroeste do Brasil na construção histórica de Mato Grosso, 1918-1956. São Paulo, 1999. Tese (Doutorado), Departamento de História, Universidade de São Paulo.

REIS FILHO, N. G. Contribuição ao estudo da evolução urbana do Brasil (1500-1720). São Paulo: Edusp, 1968.

Algumas experiências urbanísticas do início da República: 1890-1920. São Paulo: FAU-USP, 1994.

Urbanização e planejamento no Brasil: 1960?1983. São Paulo: Cadernos de Pesquisa do LAPFAU-USP, 1996.

RODRIGUES, Marly. Imagens do Passado: a instituição do patrimônio em São Paulo: 1969-1987. São Paulo: Ed. Unesp / Imprensa Oficial / Condephaat / FAPESP, 2000.

ROSSI, Aldo. Arquitetura da cidade. São Paulo. Martins Fontes, 2001

SAES, F. A. M. de. A grande empresa de serviços públicos na economia cafeeira 1850-1930. São Paulo: Hucitec, 1986.

As ferrovias de São Paulo 1870 - 1940. São Paulo, Hucitec/INL-MEC, 1981.

SÁNCHEZ, F. Cidade espetáculo: política, planejamento e city marketing. Curitiba: editora Palavra.

SANTOS, Milton. Espaço e Método. Sâo Paulo, Nobel, 1985.

A Urbanização Brasileira. São Paulo, Ed. Hucitec,1993.

SCHIMIDT, C. B., REIS, J. Rasgando horizontes: a Secretaria da Agricultura no seu cinquentenário. São Paulo: Rotschild Loureiro, 1942.

SILVA, L. M. O. A lei da terra: um estudo sobre a historia da propriedade da terra no Brasil. São Paulo, 1990. Tese (Doutorado) - Faculdade de Ciências Sociais, Pontifícia Universidade Católica de São Paulo. SILVA, S. Expansão cafeeira e as origens da indústria no Brasil. São Paulo: Alfa-Omega, 1976. 
SIMÃO, M. C. R. Preservação de patrimônio cultural em cidades. Belo Horizonte: Autentica, 2001.

SIMÕES JR., José Geraldo. Revitalização de Centros Urbanos, São Paulo, Publicações Polis, 1994.

SOUZA, M. L. Mudar a Cidade: Uma crítica ao planejamento e à gestão urbanos. Rio de Janeiro: Bertrand Brasil

STOLCKE, V. Cafeicultura, homens, mulheres e capital (1850-1980). São Paulo: Brasiliense, 1986.

SZMRECSÁNYI, M. I. de Q. F. Produção, apropriação e organização do espaço na economia cafeeira: contrastes entre o Vale do Paraíba e o Oeste Paulista (1800-1930). Sinopses 5. São Paulo: FAU-USP, 1984. Rio e São Paulo. Revista USP, São Paulo: USP, n. 17, 1993.

TAUNAY, A. de E. Relatos sertanistas. São Paulo, Belo Horizonte, EDUSP/Itatiaia, 1981.

TELLES, Augusto C. da Silva. Centros históricos: Notas sobre a política brasileira de preservação. Revista do Patrimônio Histórico e Artístico Nacional, Rio de Janeiro, 1984, n. 19.

TOLEDO, Benedito Lima de. Bem cultural e identidade cultural. Revista do Patrimonio Histórico e Artistico Nacional, 1984, n. 20.

TOLEDO, Benedito Lima de. Patrimônio Cultural: graus de intervenção nos monumentos históricos, Sinopses , 2001, n. 35 (junho), pp. 32-38

TRUZZI, O. Café e indústria - São Carlos: 1850-1950. Arquivo de História Contemporânea - UFSCar, 1986.

VAINER, C. B. Pátria, empresa e mercadoria: notas sobre a estratégia discursiva do planejamento estratégico urbano. In: ARANTES, O.; VAINER, C. C.; MARICATO, E. A cidade do pensamento único: desmanchando consensos. Petrópolis: Vozes, 2000.

VALLIM, P. E. Álbum dos municípios do estado de São Paulo - 1940. São Paulo, Empresa gráfica da Revista dos Tribunais, 1940.

VILLAÇA, Flávio. Espaço Intra-urbano no Brasil, São Paulo, Studio Nobel, 1998.

ZANCHETI, Silvio Mendes. Conservação integrada e planejamento urbano na atualidade. In: Espaço e Debates. São Paulo, v. 23, n. 43-4, jan.-dez./2003.

ZUKIN, Sharon. Paisagens urbanas pós-modernas: mapeando cultura e poder. In: ARANTES, Antonio (Org.). O espaço da diferença. Campinas: Papirus, 2000. p. 80-103. 


\section{Anexo 01: Imagens da cultura cafeeira}

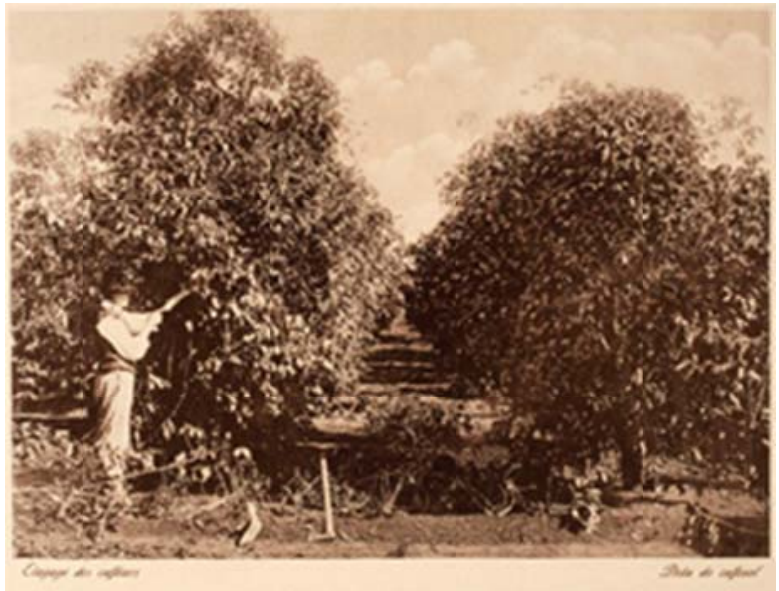

Imagem do período de poda dos cafeeiros. Fonte: Álbum vistas de São Paulo - Arquivo do Estado de São Paulo.

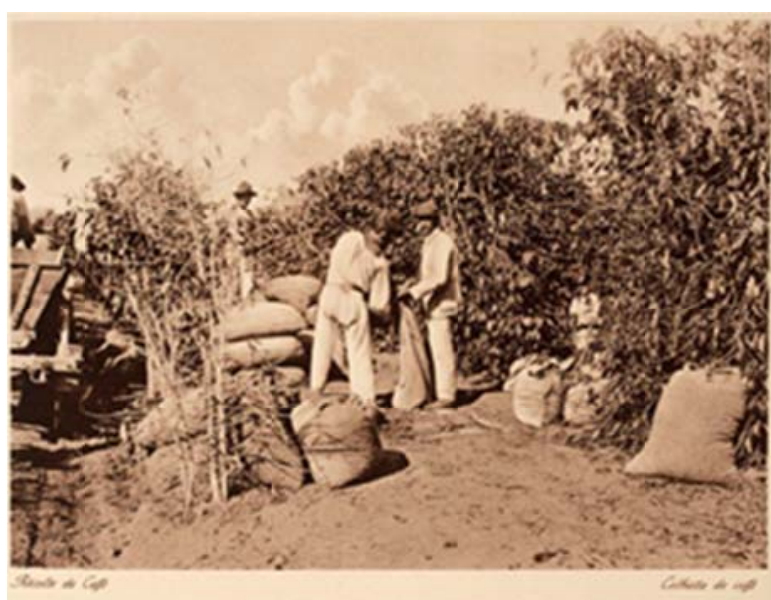

Imagem da colheita do café. Fonte: Álbum vistas de São Paulo Arquivo do Estado de São Paulo.

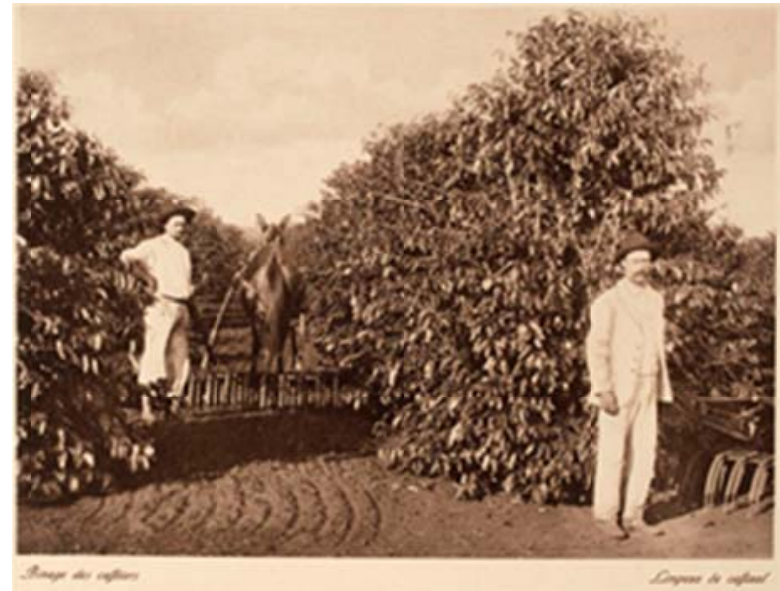

Imagem do trabalho de limpeza do cafezal. Fonte: Álbum vistas de São Paulo - Arquivo do Estado de São Paulo.

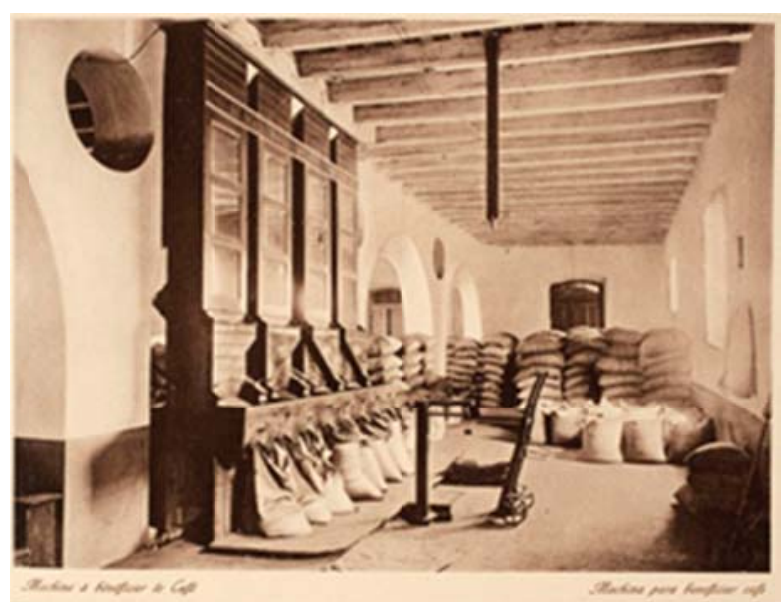

Máquinas utilizadas no beneficiamento do café. Fonte: Álbum vistas de São Paulo - Arquivo do Estado de São Paulo. 
Anexo 02: Sequencia histórica da divisão politico-administrativa do Estado de São Paulo de 1600 a 1997 Fonte: Fundação SEADE
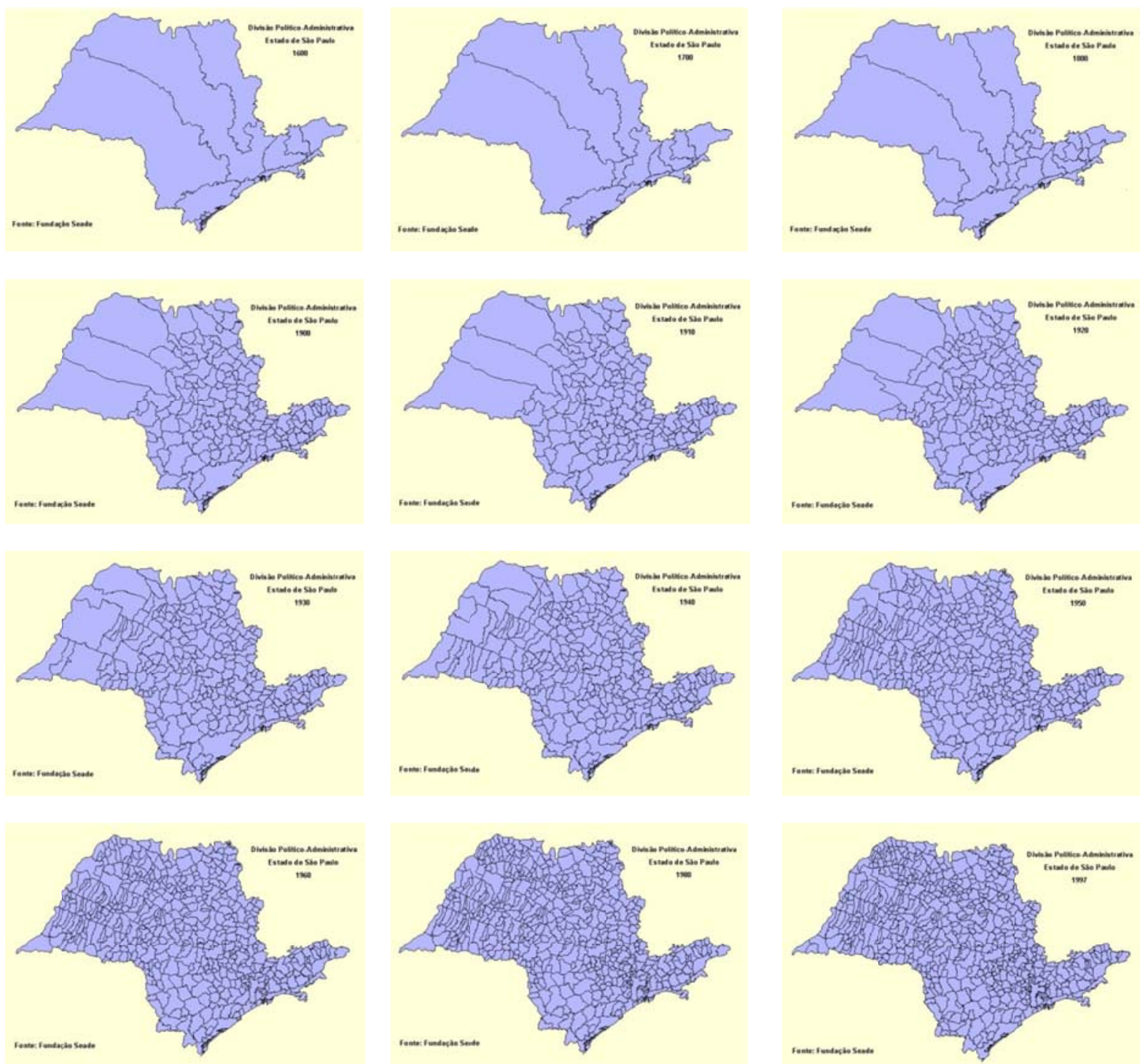
Anexo 03: Imagens dos núcleos coloniais Jorge Tibiriçá, Campos Salles e Nova Odessa
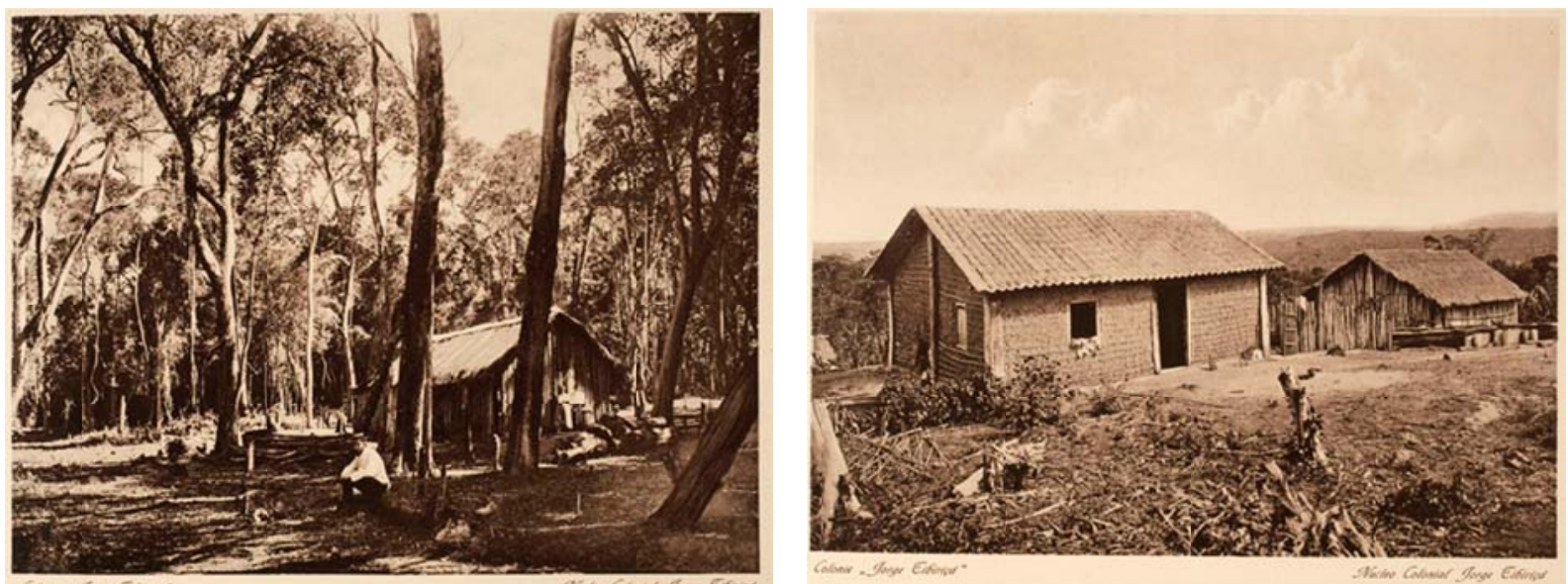

Casas de colonos em lotes rurais do núcleo colonial Jorge Tibiriçá - observar o uso das técnicas construttivas tradicionais como taipa de mão e a utilização de madeira roliça com cobertura em palha (1908). Fonte: Álbum vistas de São Paulo - Arquivo do Estado de São Paulo.
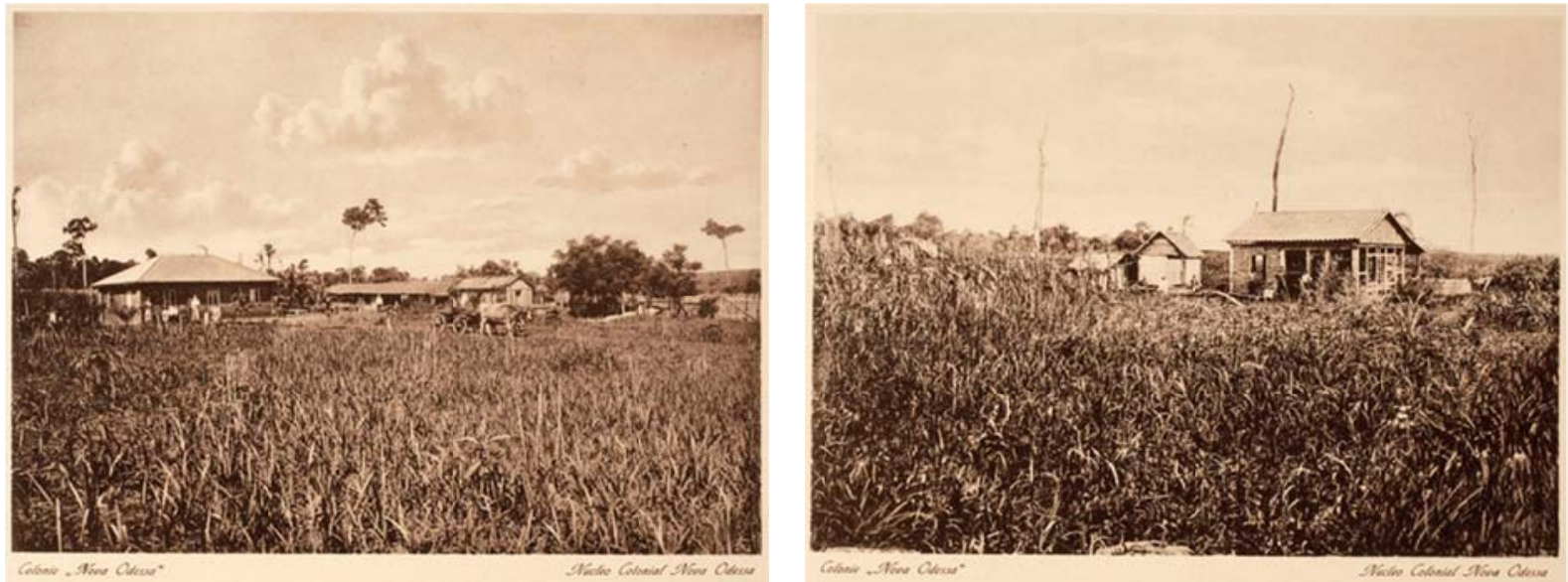

Casas de colonos em lotes rurais do núcleos colonial Nova Odessa - observar que estas construções se comparadas com as apresentadas acima, pertencentes ao núcleo Jorge Tibiriçá, são construídas com outros materiais e técnicas; apesar as construções ainda serem feitas de madeira, agora esta madeira é aparelhada em tábuas, utiliza telhas cerâmicas e já podemos encontrar vidraças nas janelas. Fonte: Álbum vistas de São Paulo - Arquivo do Estado de São Paulo (1908).
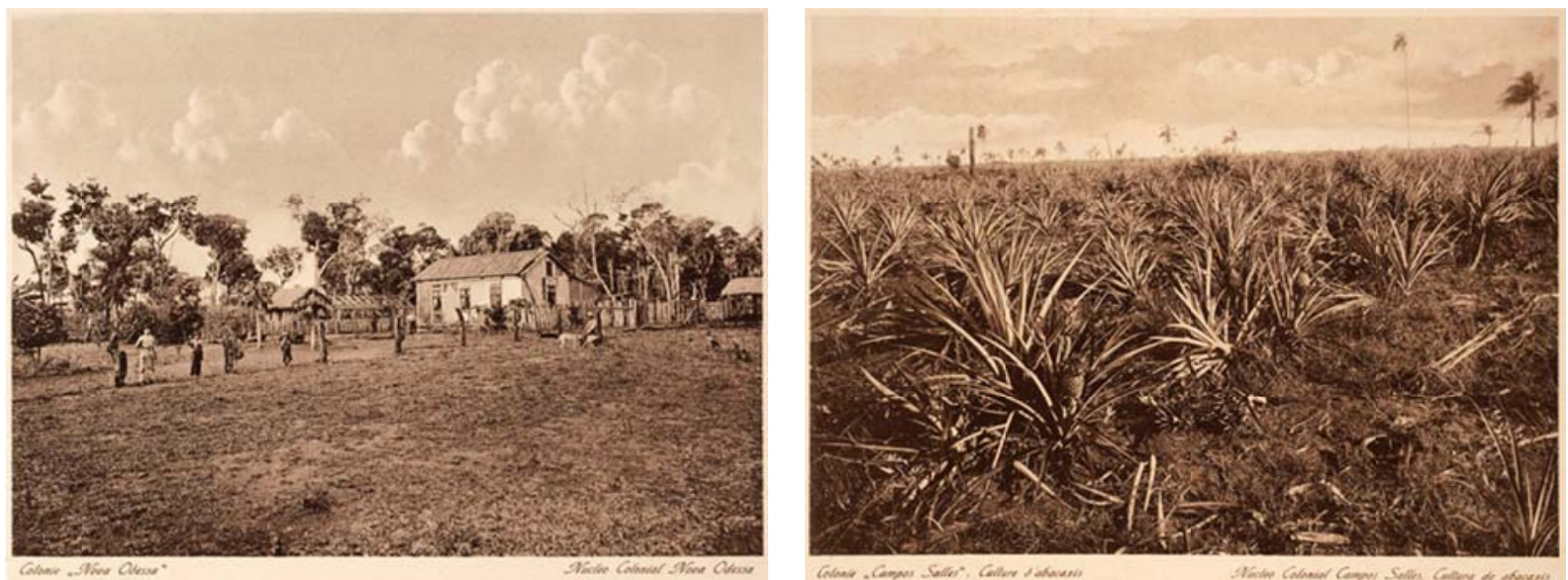

Imagens de lotes rurais de Nova Odessa (direita) e Campos Salles (esquerda) - observar a plantação de abacaxis, ilustrando a inserção de novas culturas nessas terras não apropriadas ao cultivo do café. Fonte: Álbum vistas de São Paulo - Arquivo do Estado de São Paulo. 

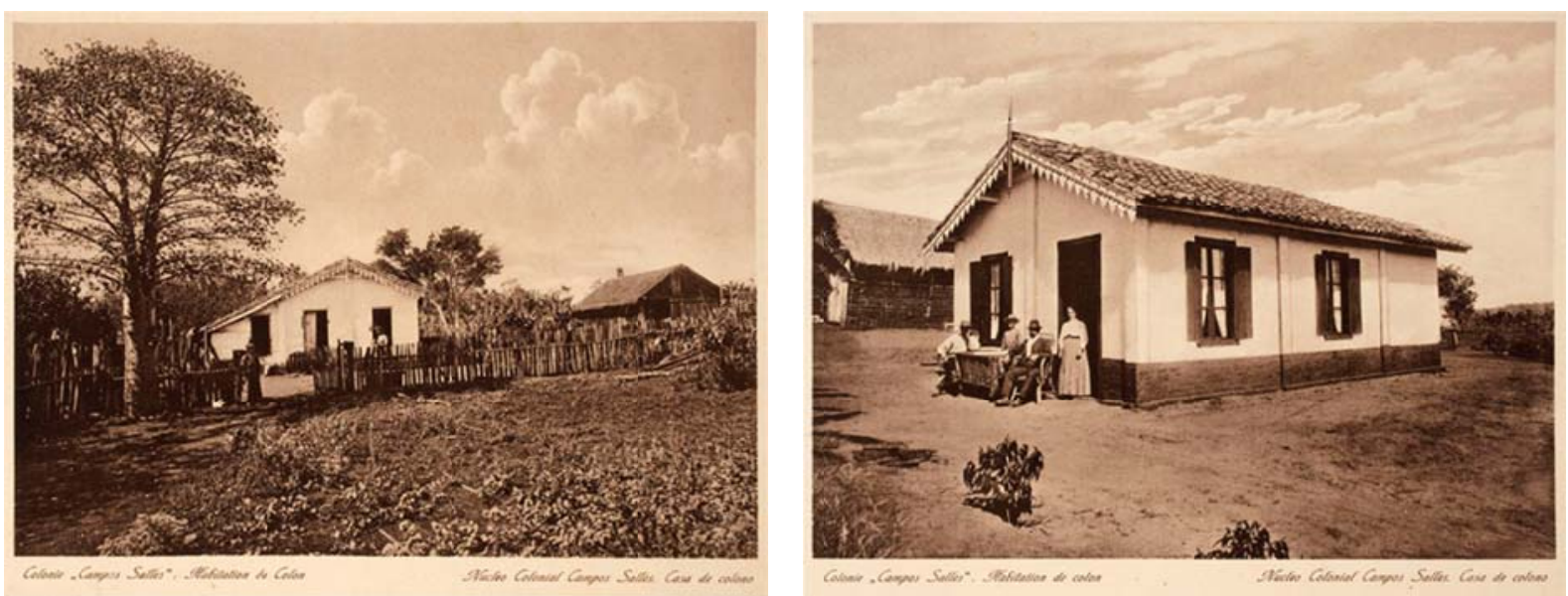

Casas de colonos em lote rural do nucleos colonial Campos Salles - observar que ao fundo destas edificações melhores construidas, inclusive com lambrequins arrematando o telhado, que já emprega telhas ceramicas, vemos edivicações construidas com madeiras roliças e cobertura em palha. Fonte: Álbum vistas de São Paulo (1908) - Arquivo do Estado de São Paulo.
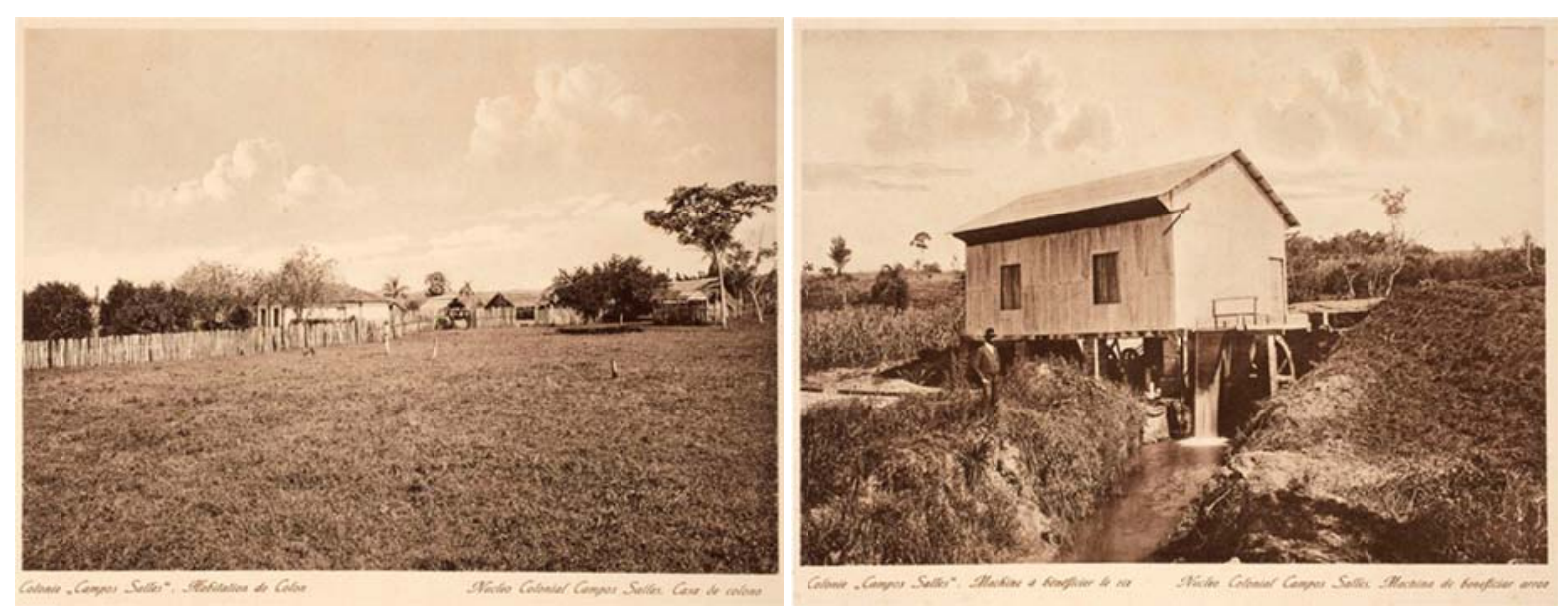

Vistas de lotes rurais do núcleo colonial Campos Salles - observar na imagem à esquerda a plantação de um pequeno pomar ao redor das casas e à direita uma maquina de beneficiamento de arroz, aproveitando a força d'água. Fonte: Álbum vistas de São Paulo (1908) Arquivo do Estado de São Paulo. 


\section{Anexo 04 - Levantamento das origens da mão de obra ligada à construção civil na cidade de Dourado no início do século XX}

A fim de encontrar informações sobre a mão de obra ligada à construção civil no período estudado neste trabalho, em abril de 2009, realizei pesquisa junto à Delegacia de Polícia de Dourado, consultando os arquivos do Serviço de Registro de Estrangeiros, que cadastrou os imigrantes residentes na cidade entre 1939 e 1942. Os profissionais encontrados foram:

- Antonio Vanucchi, nascido em 18/06/1894, natural de Grote de Castro - Itália; desembarque em Santos em 18/09/1894. Profissão: pedreiro.

- Miguel Vernaglia, nascido em 11/06/1885, natural de Monte San Giacomo, Salermo Itália; desembarque em Santos em 11/06/1900. Profissão: pedreiro da Cia. Douradense.

- José Salvagni, nascido em 1\%/05/1894, natural de Gasiolo - Itália; desembarque em Santos em 27/04/1897. Profissão: pedreiro.

- Henrique Laurenti, nascido em 12/04/1882, natural de Arian Polesi, Rovigo - Itália; desembarque em Santos em 20/10/1894. Profissão: carpinteiro.

- João Caron, nascido em 24/06/1876, natural da província de Padova - Itália; desembarque em Santos em 10/1888. Profissão: carpinteiro.

- Luiz D’Abruzzo, nascido em 21/04/1886, natural de Santo Ângelo - Itália; desmbarque em Santos em 1890. Profissão: construtor.

Esses registros nos informam que todos os profissionais imigrantes, ligados à construção civil, residentes na cidade e cadastrados na delegacia de polícia, são de origem italiana, porém chegaram muito jovens ao Brasil. A intenção dessa pesquisa era tentar traçar um paralelo entre o que se construía na região natal desses profissionais e o que foi construído na cidade; entretanto imagino, pelas datas de nascimento e desembarque, que os mesmos não trabalhavam com arquitetura antes de chegar ao Brasil. Por outro lado, os imigrantes com mais de 60 anos não eram obrigados a se cadastrarem e pela idade com que os profissionais em questão chegaram ao Brasil, certamente vieram acompanhados por seus pais, esses sim talvez ligados à construção na Itália e possivelmente ensinaram o ofício aos filhos. 
Dos registros consultados, pude observar que a grande maioria dos imigrantes era de origem espanhola, seguido pelos italianos e em número um pouco menor os portugueses, mas havia também um número considerável de sírios. A profissão mais indicada pelos os homens era lavrador ou operário agrícola, exceto para os sírios que eram comerciantes; as mulheres indicavam prendas domésticas (não encontrei nenhum registro de mulher com outra profissão, nem mesmo lavradoras). Dentre as profissões, um pouco mais de espanhóis trabalhavam para a Cia. Douradense e os poucos profissionais liberais eram de origem portuguesa em sua maioria. 


\section{Anexo 05 - Pré-inventário da Vila Santa Clara - experimento para aplicação de técnicas}

de apreensão do espaço.

\section{Levantamento fotográfico - Vila Santa Clara - Dourado / SP}

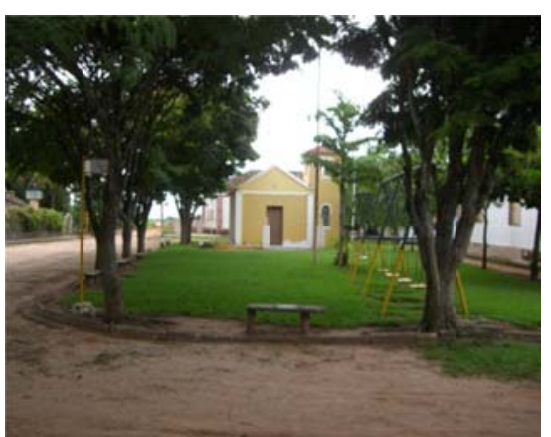

Foto $01-\mathrm{jan} / 2009$

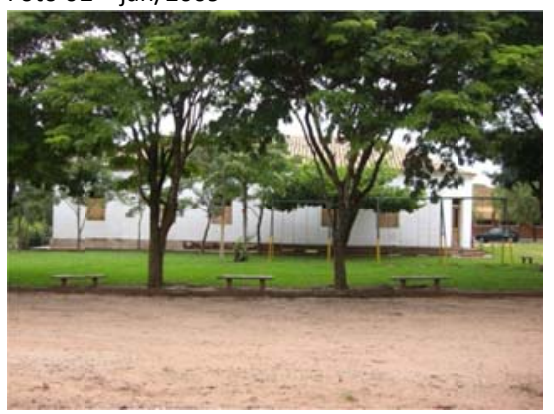

Foto $02-$ jan/2009

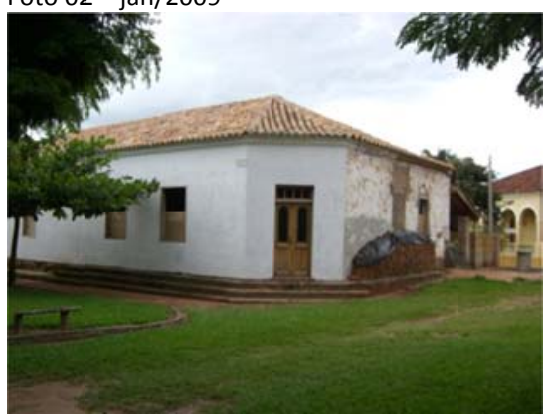

Foto $03-$ jan/2009

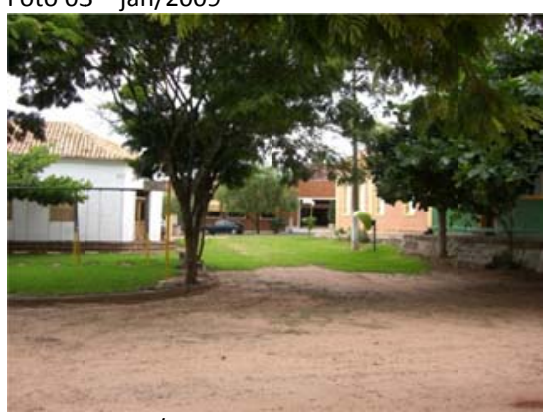

Foto $04-$ jan/2009
Vista frontal da capela de Santa Clara e da Praça dos Braga;

A praça não recebe nenhum tratamento de calçamento ou ajardinamento, apenas paus-ferro nos limites da praça, uma palmeira real alinhada com a torre da capela e um chapéu de sol e quatro ipês recentemente plantados em alinhamento com o edifício à direita;

Quanto a equipamentos públicos, a praça possui apenas bancos de concreto, já bastante desgastados, voltados para as ruas Nhonho Borges e dos Tomazini e balanços;

Iluminação da praça feita apenas por um holofote sobre um poste localizado na lateral da capela;

Vista da Praça dos Braga; ao fundo, edifício on de originalmente funcionava um armazém, cujas portas se voltavam para a praça, mantendo com ela uma relação de permeabilidade; atualmente o edifício passia por uma reforma e terá uso apenas residencial;

As portas do antigo armazém foram fechadas e substituídas por janelas e uma fileira de ipês recentemente plantados no alinhamento do edifício preservando seu interior da vista a partir da praça, privacidade pretendida pela nova função, mas que interrompe em certo grau sua relação com aquele espaço;

Assim como os outros antigos edifícios comerciais da vila, este apresenta sua entrada principal pela esquina chanfrada; neste caso, com a reforma, a porta foi substituída;

Edifício, assim como outros da vila, foi construído sobre um platô feito de pedras e tijolos cozidos, o que nas faces voltadas para a praça e para a Rua dos Tomazini, eleva um pouco o edifício em relação à rua e messe caso, na parte utilizada como armazém, esse platô é escalonado em três degraus para facilitar o acesso;

Guias novas de concreto indicam uma rua estreita que separa o edifício da praça, entretanto essa delimitação termina alinhada ao limite do edifício;

Vista da esquina da Rua dos Gomes com a Rual dos Tomazini, tendo a Rua 6 de Fevereiro ao fundo; observar que a Rua dos Gomes, parte da estrada municipal Dourado - Trabijú, que recebe algum transito de carros e caminhões, não tem nenhum tipo de pavimentação, é de chão batido, enquanto na Rua dos Tomazini, onde o transito é local e mínimo, a grama invadiu a rua;

As árvores mais antigas são paus- ferro, já as mais recentes são chorões, chapéusde-sol e quaresmeiras, de menor porte e cujas, mudas são distribuídas pelo viveiro da prefeitura de Dourado; 


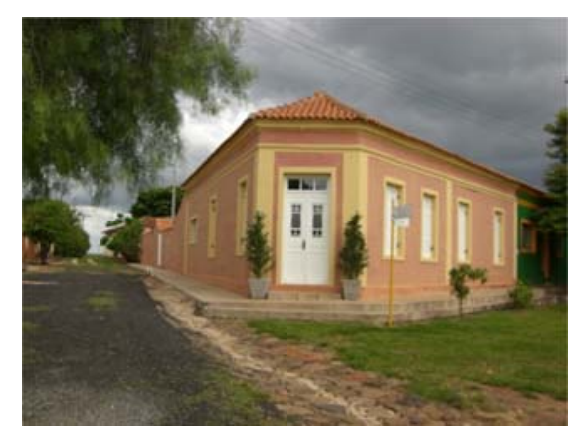

Foto05 - jan/2009

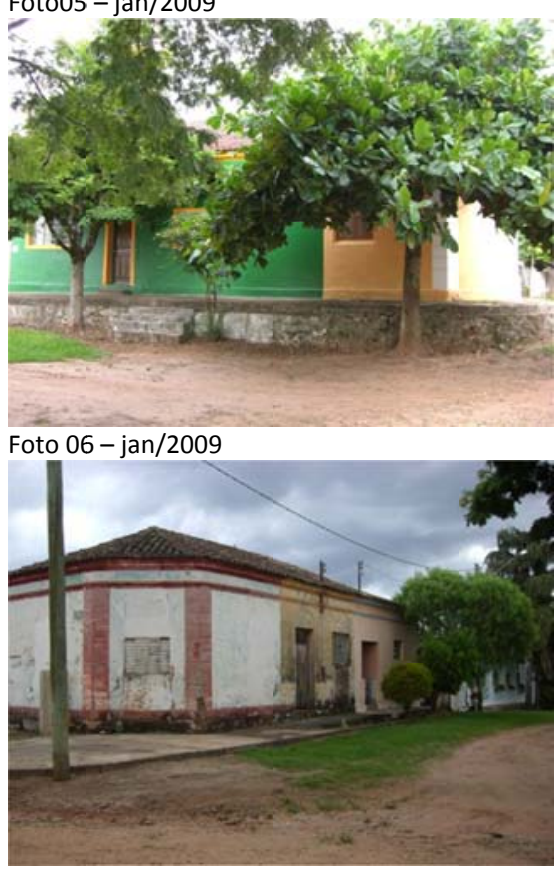

Foto $07-\mathrm{jan} / 2009$

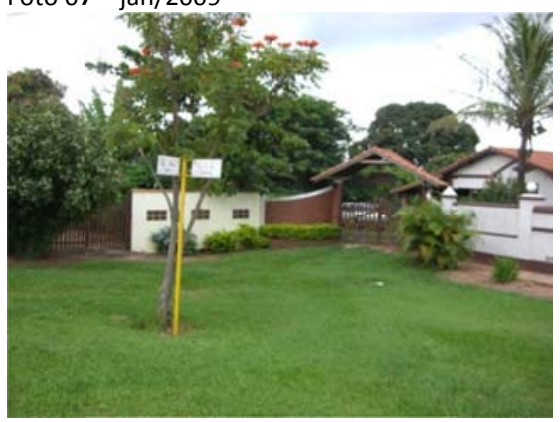

Foto $08-$ jan/2009

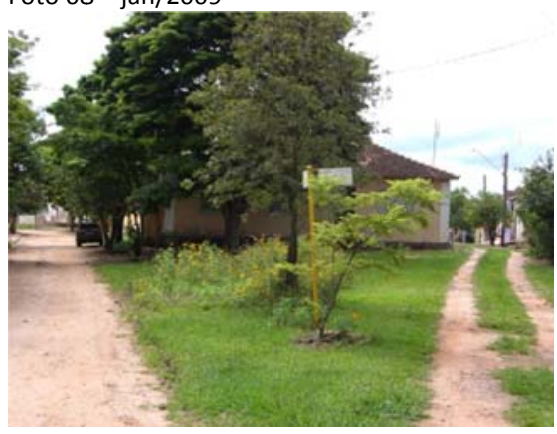

Foto $09-$ jan/2009
Esquina das ruas 6 de fevereiro e Rua dos Tomazini, tendo em primeiro plano um antigo edifício comercial, que assim como os demais que apresentavam essa função, tem a esquina chanfrada;

Faz parte de um conjunto de três casas geminadas, construídas sobre um platô de nivelamento feito de pedras e tijolos; esse platô é escalonado em degraus em frente à parte comercial do conjunto e pequenas escadas de acesso em frente às residências; neste trecho, o passeio estreito corre sobre o platô;

Na reforma recente, a porta da esquina foi trocada, assim como o entelhamento (telhas romanas), mas a geometria da cobertura e dos vãos foi mantida;

Nessa casa ainda vive a família Tomazini, que dá nome à rua.

Esse conjunto do início da década de 1930 apresenta características de diferentes épocas: o platô de regularização do terreno para a construção, que já era usado nas casas bandeiristas, ao invés de porão alto, como já era comum; implantação sobre os limites do lote, definindo a rua, sem passeios e arborização (a que encontramos foi recentemente plantada) como nas cidades coloniais;

Essas discretas adaptações das receitas coloniais visavam garantir a continuidade de sua aplicação em uma época e em uma região onde as inovações não eram muito profundas - as alterações ocorreram lentamente;

A arquitetura da vila apresenta aspecto uniforme e propriedades bastante definidas; todas as construções têm características urbanas;

Neste conjunto, originalmente implantado sobre os limites do lote, graças à retificação da Rua dos Gomes, uma faixa lateral foi incorporada ao lote e um passeio mais largo do que no restante da vila;

Observar os passeios estreitos, a arborização de pequeno porte recentemente plantada no espaço da sarjeta e a maior degra dação nas partes desocupadas do conjunto;

Não há elementos nas fachadas que Ihes garantam identificabilidade

Os conjuntos passam a sensação de rudeza e solidez, apesar da inexpressividade estilística

Vista da esquina das ruas Nhonho Borges e 6 de fevereiro, a partir da praça, onde não há delimitação da praça, rua ou passeio e o gramado se estende até o limite dos muros;

Os lotes não possuem dimensões padronizadas;

Apenas esta residência apresenta jardim frontial. É muito semelhante às construções de Dourado, já com telhado mais complicado, com calhas e condutores. Construção solta no lote.

Primeira vista que se tem da vila a partir da estrada rural municipal, sentido Dourado - Trabijú, que nesse trecho da vila recebe o nome de Rua dos Gomes, à esquerda na foto; à direita, a Rua 6 de fevereiro, de trafego local;

Não há delimitação do leito carroçável por guias e sarjetas neste trecho nem de passeios, apenas as marcas da passagem dos carros;

A diferença de fluxos fica evidente pela largura das vias pela grama na rua 6 de fevereiro; este tipo de tratamento dado às ruas cria uma paisagem condizente com a escala humana do lugar; 

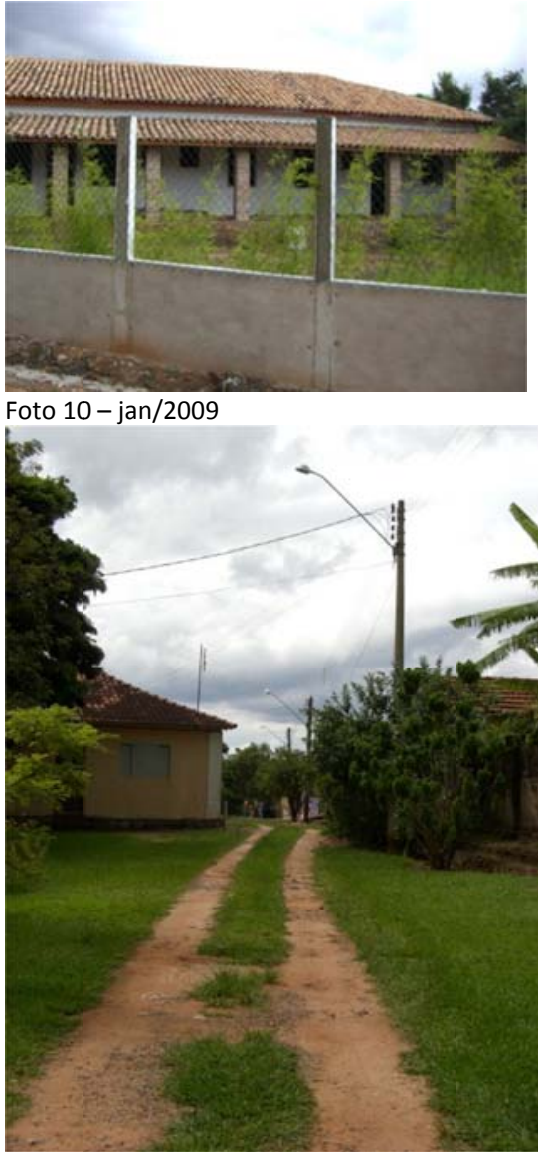

Foto $11-\mathrm{jan} / 2009$

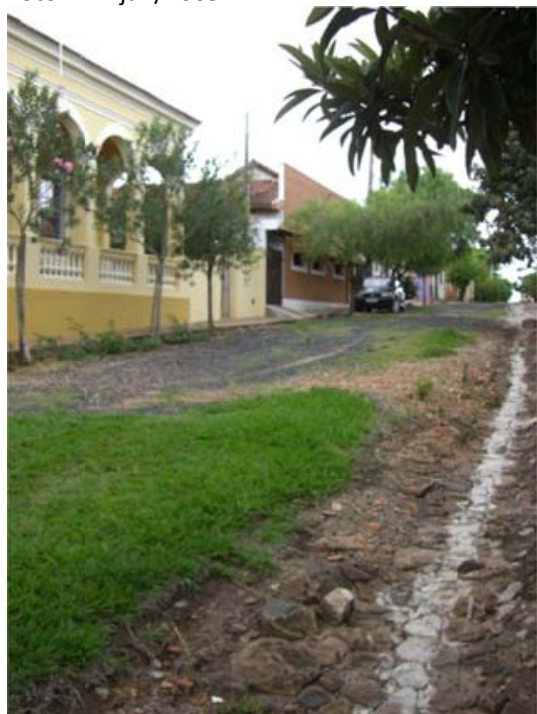

Foto $12-\mathrm{jan} / 2009$
Vista a partir da Rua 6 de fevereiro, do antigo arma zém, que antes estava implantado solto na praça e se apresentava em um único volume; agora com a reforma, recebeu uma varanda ao longo de toda essa fachada, que teve inclusive todas as aberturas modificadas;

O terreno foi cercado, alterando completamente a relação desse edifício com a praça e com toda a vila, já que pela sua posição central e paralela à estação e à rua principal, porte maior do que o da própria capela e compatível ao da estação é o ponto central e estruturador desse espaço; o telhado foi refeito com telhas capa e canal.

Não há sinalização que forneça qualquer informaçãio sobre a vila, apenas postes com a indicação do nome das ruas, que receberam os nomes das primeiras famílias da vila;

As pessoas caminham pela rua, já que as calçadas são estreitas e mal cuidadas, servindo apenas para delimitar a rua. O pequeno fluxo de veículos não interfere no trânsito dos pedestres.

A escassez de automóveis reforça ainda mais o carăter essencialmente doméstico $e$ residencial da vila, o que permite que as pessoas se reúnam na rua para uma conversa, para se apropriarem socialmente das ruas;

Os vários componentes da paisagem - construções da vila, os pomares e as plantações ao redor - não podem ser dissociados, há uma continuidade espacial;

De acordo com a época do ano, a vila se relaciona de diferentes formas com o entorno quando a cana está alta, ela forma uma massa que envolve a vila e ela se fecha sobre si mesma; depois do corte da cana, o entorno torna-sie um nada extenso;

Vista da Rua 6 de fevereiro, onde se observa à direita uma valeta antiga, feita de pedras irregulares, para o escoamento da água das chuvas e que segundo os moradores, ainda cumpre satisfatoriamente sua função;

Não observamos platibandas nas construções antigas, a - beirais em todas as construções, menos na reformada

Mesmo em edifícios de épocas distintas, se mantém em toda a vila a mesma relação de escala;

A residência ao fundo foi recentemente reformada, destoando material e geometricamente das construções mais antigas da vila: tijolos aparentes, platibanda escondendo o beiral dos telhados, toldos e garagem não fazem parte do repertorio arquitetônico corrente nas demais edificações;

Em primeiro plano, uma casa de porão alto, um novo tipo de residência, ainda de frente da rua, que teve larga difusão - representava a transição entre os sobrados e as casas térreas - preservavam a intimidade através de uma altura discreta em relação à rua, assim como a transferência da entrada para a fachada lateral.

Vista da Rua dos Gomes, tendo ao fundo um antigo edifício comercial e atualmente desocupado, que recentemente recebeu um muro, fechando a visual a rua; 
Implantação esquemática da Vila Santa Clara em Dourado - SP

Localização das fotos do levantamento fotográfico

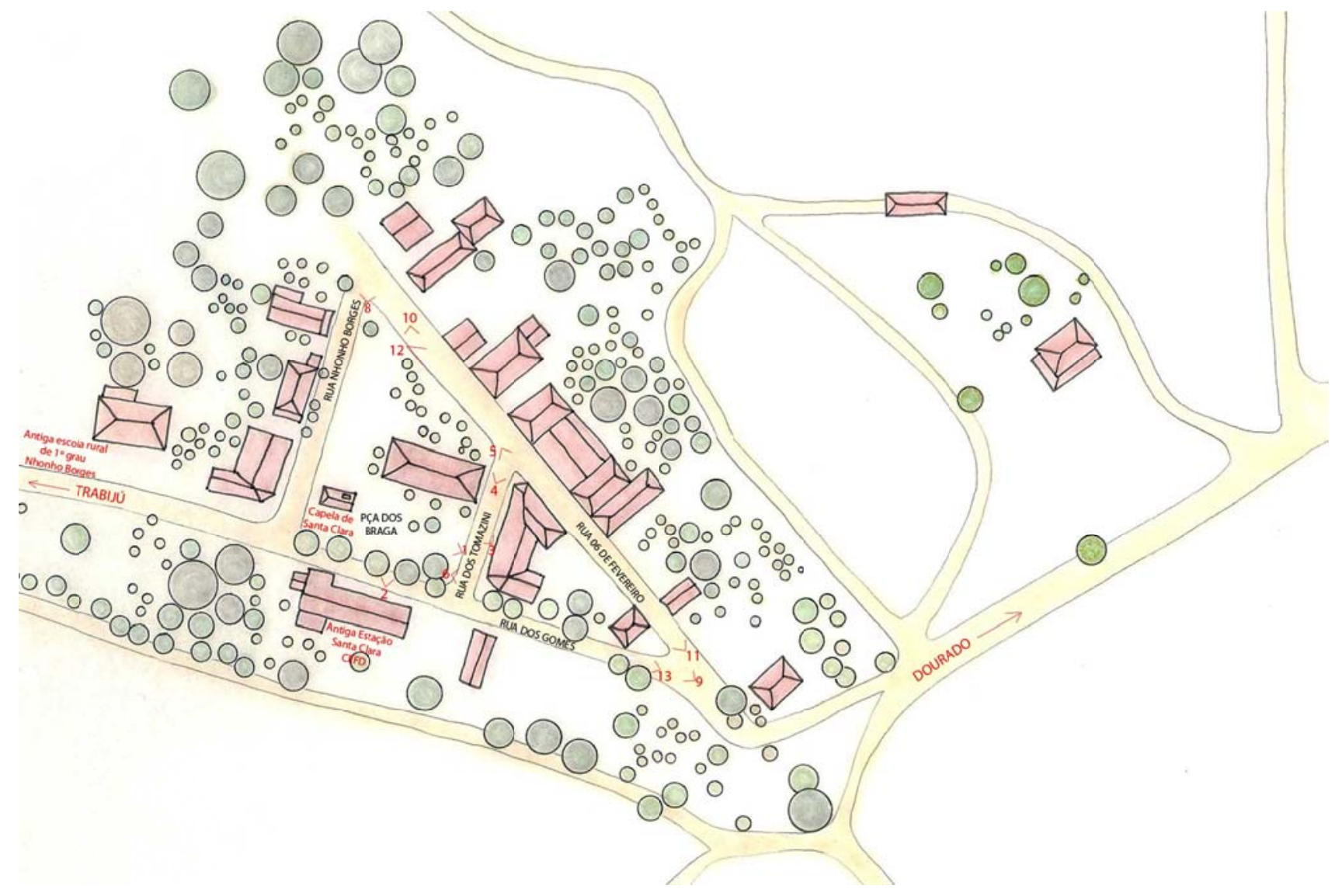

Situação sem escala 
Ficha de pré-inventário do patrimônio arquitetônico e urbanístico de Dourado - SP Vila Santa Clara: Características Arquitetônicas - Ficha 01

Identificação

Logradouro: Praça dos Braga s/n - Vila Santa Clara

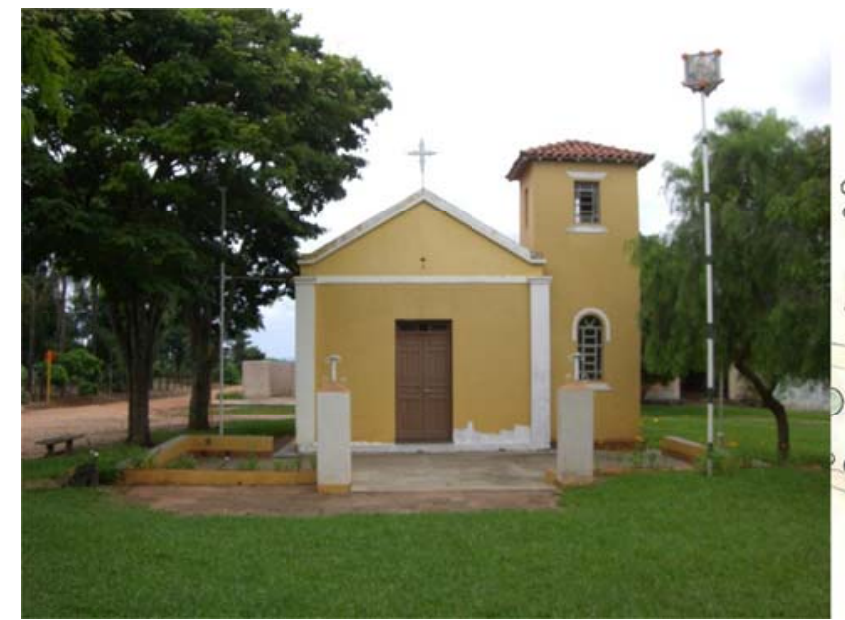

Fachada principal

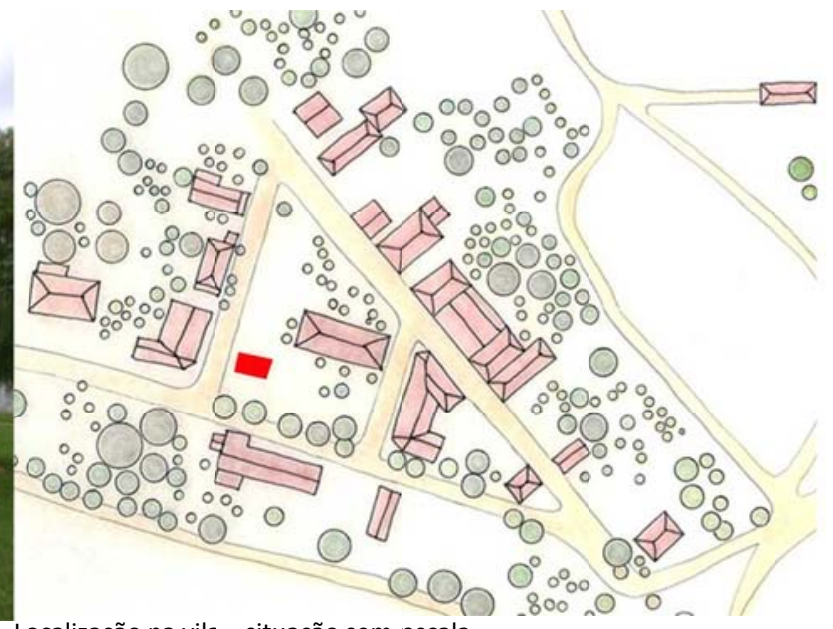

Localização na vila - situação sem escala

Fachada principal e uso atual

1. Materiais empregados na cobertura

Destruição total

Francesa $\mathrm{X}$ no corpo da capela

Vidro

Canal X na torre

Destruição total

Frontão $X$

Metal Cachorros

Plástico / fibra

Laje

Laje de beiral

Beiral simples $X$

Platibanda

Cimalha

Beira seveira

Outros:

4. Materiais de acabamento da fachada principal

3. Materiais do coroamento

Argamassa $X$ fachada frontal

Cantaria

Argamassa $X$

Cantaria

Madeira $X$

Azulejo novo

Azulejo novo

Guarda pó

Outros:

Outros:

Concreto aparente

Vidros

Chapisco

Azulejo novo

Madeira

6. Material das esquadrias da fachada principal

5. Material das molduras dos vãos de portas e janelas

Destruição total Madeira - porta

Não tem

Destruição total

Argamassa $X$

Cantaria

Azulejo antigo

Azulejo novo

Vidro

Alumínio

Madeira

Concreto aparente

Ferro - janelas

Outros:

Outros:

7. Cores predominantes da fachada principal

Coroamento: amarelo

Esquadrias: cinza

Molduras dos vãos: branco

Acabam. da fachada: amarelo

8. Uso atual - quantificar

Guarda-corpos: não tem

Outros relevos: branco

Residência:

Comércio:

Serviço:

Instituição:
Vago:

Culto: Capela de Santa Clara

Outros:

Dados volumétricos

\section{Gabarito}

Altura da fachada: $3,75 \mathrm{~m}$

№ pavimentos acima do nível da rua: 01

Além desses, assinalar a existência de:

$\begin{array}{lll}\text { Porão alto } & \text { Mirante } & \text { Pav. recuado } \\ \text { Pav. intermediário } & \text { mezanino } & \text { Sótão habitável }\end{array}$

Pav. intermediário mezanino Sótão habitável

Alt. cumeeira: $1,70 \mathrm{~m}$

№ subsolos: 0

Identificado a partir de:

Evidência na construção $X$

Depoimento do usuário

Outros:

\section{Classificação tipológica do telhado}

Número de águas do corpo principal: 3 águas

Cumeeira paralela à rua $\mathrm{X}$

Com torreão

Cumeeira perpendicular à rua

Tipo chalé

Água furtada

Outros:

3. Registro de acréscimos

Não tem $X$

Acréscimo vertical

Acréscimo horizontal

\section{Descrever:}


Ficha de pré-inventário do patrimônio arquitetônico e urbanístico de Dourado - SP Vila Santa Clara: Características Arquitetônicas - Ficha 02

Identificação

Logradouro: Rua dos Gomes s/n - Vila Santa Clara
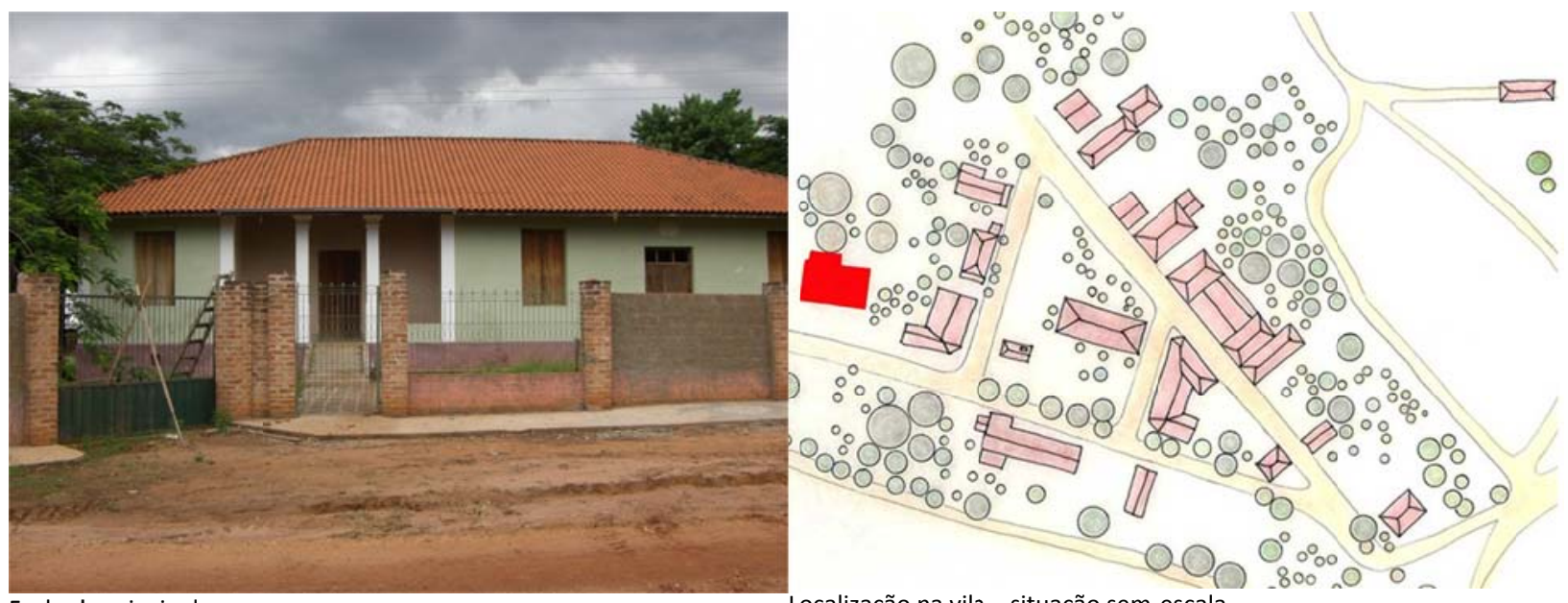

Fachada principal

Localização na vila - situação sem escala

Fachada principal e uso atual

1. Materiais empregados na cobertura

2. Coroamento

Destruição total

Canal X

Destruição total

Francesa

Fibrocimento

Frontão

Plástico / fibra

Metal

Cachorros

Platibanda

Laje

Laje de beiral

Beiral simples $X$

Cimalha

Outros:

4. Materiais de acabamento da fachada principal

3. Materiais do coroamento

Argamassa

Azulejo antigo

Cantaria

Argamassa X

Cantaria

Madeira X

Azulejo novo

Azulejo novo

Beira seveira

Outros:

Concreto aparente

Vidros

Chapisco

Azulejo novo

5. Material das molduras dos vãos de portas e janelas

6. Material das esquadrias da fachada principal

Não tem X

Argamassa

Destruição total

Azulejo antigo

Cantaria

Destruição total

Madeira X

Vidro

Alumínio

Madeira

Azulejo novo

Ferro

Outros:

Outros:

7. Cores predominantes da fachada principal

Coroamento: branco

Esquadrias: natural

8. Uso atual - quantificar

Molduras dos vãos: Não tem

Acabam. da fachada: verde

Residência: X 100\%

Vago:

Comércio:

Culto:

Guarda-corpos: Não tem

Outros relevos: branco

Serviço:

Instituição:

Outros:

Dados volumétricos

\section{Gabarito}

Altura da fachada:

№ pavimentos acima do nível da rua: 01

Além desses, assinalar a existência de:

Porão alto $X \quad$ Mirante

Pav. intermediário mezanino

Outros:

\section{Classificação tipológica do telhado}

Alt. cumeeira: Número de águas do corpo principal: 04

Cumeeira paralela à rua $\mathrm{X}$

Com torreão

Cumeeira perpendicular à rua

Água furtada

Pav. recuado

Sótão habitável
3. Registro de acréscimos

Não tem

Acréscimo vertical

Acréscimo horizontal $\mathrm{X}$
Identificado a partir de:

Evidência na construção $X$

Depoimento do usuário

Outros:
Tipo chalé

Descrever:

Outros: 
Ficha de pré-inventário do patrimônio arquitetônico e urbanístico de Dourado - SP Vila Santa Clara: Características Arquitetônicas - Ficha 03

Identificação

Logradouro: Rua dos Tomazini s/n - Vila Santa Clara

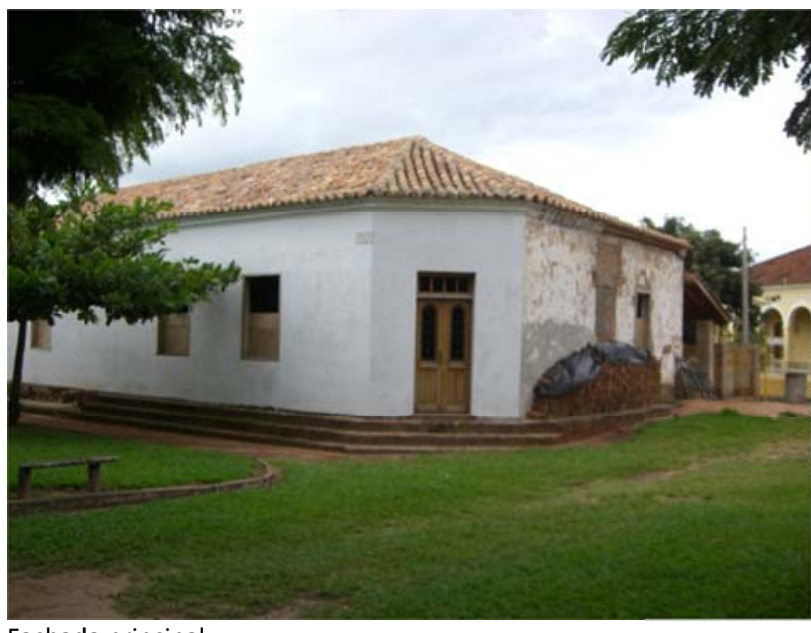

Fachada principal

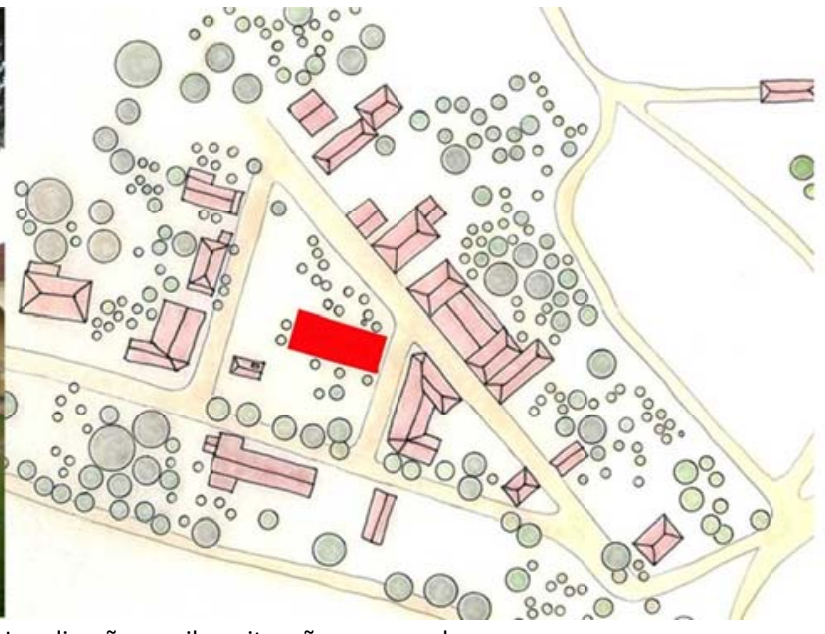

Localização na vila - situação sem escala

Fachada principal e uso atual

1. Materiais empregados na cobertura

2. Coroamento

Destruição total Canal X

Francesa Fibrocimento

Vidro Metal

Plástico / fibra Laje

Outros:

\section{Materiais do coroamento}

Argamassa $X$

Azulejo antigo

Madeira

Cantaria

Destruição tota

Frontão

Cachorros

Laje de beiral

Beiral simples

Platibanda

Cimalha $\mathrm{X}$

Beira seveira

4. Materiais de acabamento da fachada principal

Argamassa $X \quad$ Chapisco

Cantaria Azulejo novo

Azulejo novo Madeira

Vidros

Outros:

6. Material das esquadrias da fachada principal

5. Material das molduras dos vãos de portas e janelas

Não tem X

Argamassa

Azulejo antigo

Destruição total

Cantaria

Destruição total

Madeira X

Vidro Alumínio

Ferro Outros:

Madeira

Azulejo novo

Concreto aparente

Outros:

7. Cores predominantes da fachada principal

Coroamento: em reforma

Molduras dos vãos: Não tem

Esquadrias: natural

Guarda-corpos: Não tem

8. Uso atual - quantificar

Residência:

Comércio:

Serviço:

Outros: em reforma
Vago:

Culto:

Instituição:

Dados volumétricos

\section{Gabarito \\ Altura da fachada:}

№ pavimentos acima do nível da rua: 01

Além desses, assinalar a existência de:

Porão alto Mirante

Pav. intermediário mezanino

Outros: embasamento mistos de pedra e tijolos
3. Registro de acréscimos

Não tem

Acréscimo vertical

Acréscimo horizontal X
Identificado a partir de:

Evidência na construção $X$

Depoimento do usuário

Outros:
2. Classificação tipológica do telhado Número de águas do corpo principal: 04

№ subsolos: Não tem

Cumeeira paralela à rua $X$

Com torreão

Cumeeira perpendicular à rua

Água furtada

Pav. recuado

Tipo chalé

Outros:

Sótão habitável

Descrever: Ao longo te toda a fachada voltada para a rua 6 de Fevereiro foi acrescida uma varanda. 
Ficha de pré-inventário do patrimônio arquitetônico e urbanístico de Dourado - SP Vila Santa Clara: Características Arquitetônicas - Ficha 04

Identificação

Logradouro: Rua dos Tomazini s/n - Vila Santa Clara
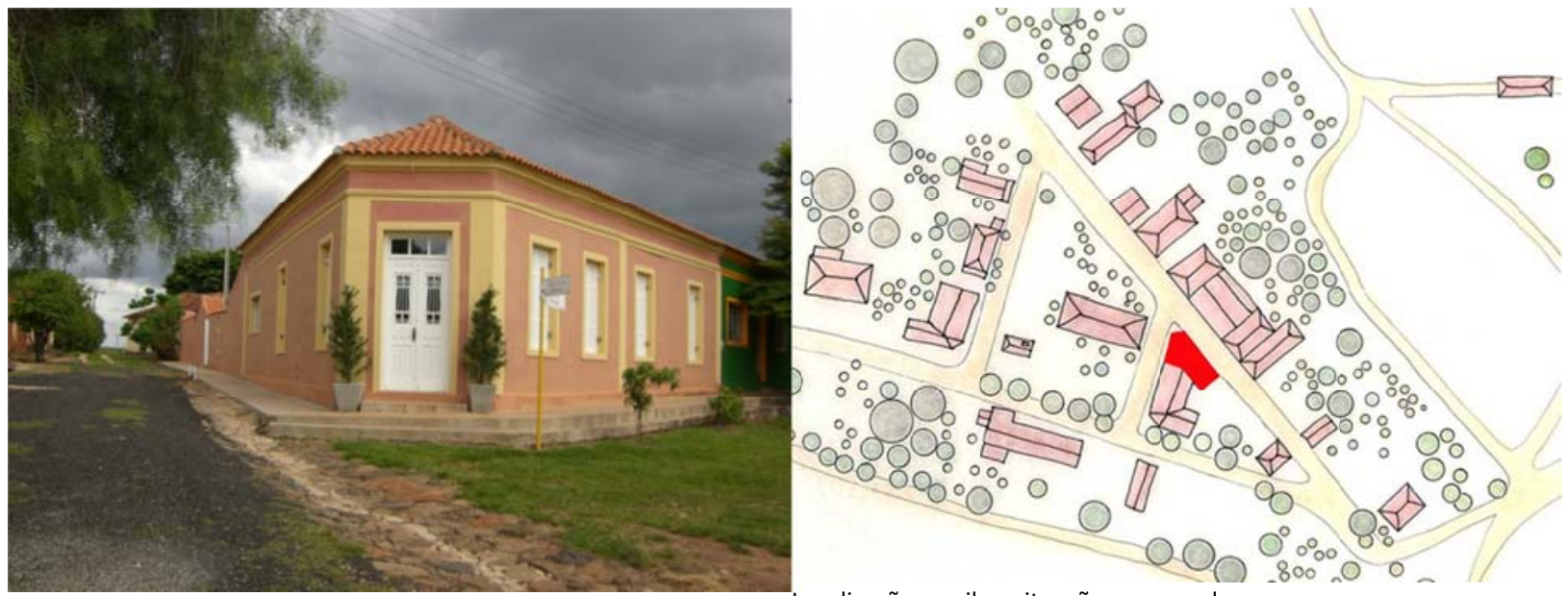

Fachada principal

Localização na vila - situação sem escala

Fachada principal e uso atual

1. Materiais empregados na cobertura

Destruição total Canal

Francesa Fibrocimento

Vidro

Metal

Destruição total

Frontão

Cachorros

Plástico / fibra

Laje

Laje de beiral

Beiral simples

Platibanda
Cimalha $X$

Outros: telha romana

4. Materiais de acabamento da fachada principal

3. Materiais do coroamento

Argamassa $X$

Azulejo antigo

Cantaria

Argamassa $X$

Beira seveira

Madeira

Azulejo novo

Cantaria

Outros:

Concreto aparente

Azulejo novo

Vidros

Azulejo novo

6. Material das esquadrias da fachada principal

5. Material das molduras dos vãos de portas e janelas

Não tem

Destruição total

Destruição total

Vidro

Cantaria

Argamassa X

Azulejo novo

Ferro

Alumínio

Concreto aparente

Madeira

Outros:

7. Cores predominantes da fachada principal

Coroamento: amarelo

Esquadrias: branco

Molduras dos vãos: amarelo

Acabam. da fachada: terra

8. Uso atual - quantificar

Guarda-corpos: não tem

Outros relevos: amarelo

Residência: X 100\%

Vago:

Comércio:

Culto:

Serviço:

Instituição:

Outros:

Dados volumétricos

\section{Gabarito}

Altura da fachada:

№ pavimentos acima do nível da rua: 01

Além desses, assinalar a existência de:

$\begin{array}{lll}\text { Porão alto } & \text { Mirante } & \text { Pav. recuado } \\ \text { Pav. intermediário } & \text { mezanino } & \text { Sótão habitável } \\ \text { Outros: embasamento mistos de pedra e tijolos } & \end{array}$

Outros: embasamento mistos de pedra e tijolos

3. Registro de acréscimos

Não tem

Acréscimo vertical

Acréscimo horizontal $X$
Identificado a partir de:

Evidência na construção $X$

Depoimento do usuário

Outros:
2. Classificação tipológica do telhado Número de águas do corpo principal: 06

Cumeeira paralela à rua $X$

Com torreão

Cumeeira perpendicular à rua

Tipo chalé

Água furtada

Outros: 
Ficha de pré-inventário do patrimônio arquitetônico e urbanístico de Dourado - SP Vila Santa Clara: Características Arquitetônicas - Ficha 05

Identificação

Logradouro: Rua 06 de Fevereiro s/n - Vila Santa Clara

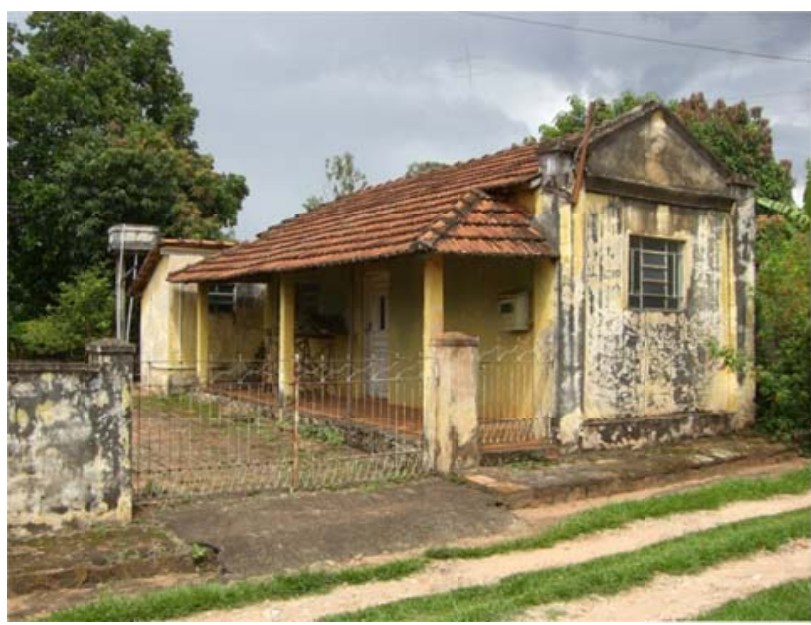

Fachada principal

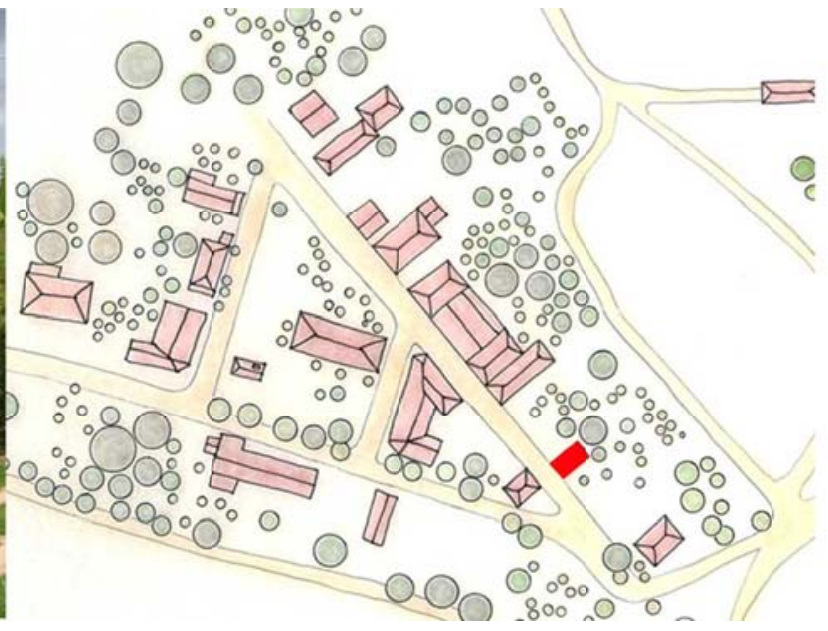

Localização na vila - situação sem escala

Fachada principal e uso atual

1. Materiais empregados na cobertura

Destruição total Canal

Francesa $X$

Vidro

Plástico / fibra

Fibrocimento

Metal

Laje

Outros:

\section{Materiais do coroamento}

Argamassa $X$

Azulejo antigo

Madeira

\section{Cantaria}

Azulejo novo

Concreto aparente

Outros:

5. Material das molduras dos vãos de portas e janelas

Não tem não tem

Argamassa

Azulejo antigo

Destruição total

Cantaria

Azulejo novo

Madeira

Concreto aparente

Outros:

7. Cores predominantes da fachada principal

Coroamento: amarelo

Molduras dos vãos: não tem

Esquadrias: cinza

Guarda-corpos: não tem

Acabam. da fachada: amarelo

Outros relevos: amarelo

2. Coroamento

Destruição total Platibanda

Frontão $X$

Cachorros

Laje de beiral

Beiral simples

Cimalha

Beira seveira

Guarda pó

Outros:

4. Materiais de acabamento da fachada principa

Argamassa $X \quad$ Chapisco

Cantaria Azulejo novo

Azulejo novo Madeira

Vidros Outros:

6. Material das esquadrias da fachada principal

Destruição total Madeira

Vidro Alumínio

Ferro laminado / solda X Outros:

8. Uso atual - quantificar

Residência: Vago: $X$

Comércio: Culto:

Serviço: Instituição:

Outros:
Dados volumétricos

\section{Gabarito}

Altura da fachada:

№ pavimentos acima do nível da rua: 01

Além desses, assinalar a existência de:

Porão alto Mirante

Pav. intermediário mezanino

Outros:

\section{Alt. cumeeira: \\ № subsolos: não tem}

Pav. recuado

Sótão habitável
2. Classificação tipológica do telhado Número de águas do corpo principal: 02

Cumeeira paralela à rua

Com torreão

Cumeeira perpendicular à rua $X$ Água furtada

Tipo chalé

Outros:

3. Registro de acréscimos

Não tem

Acréscimo vertical

Acréscimo horizontal X
Identificado a partir de:

Evidência na construção $X$

Depoimento do usuário

Outros:
Descrever: acréscimo para construção de banheiro, nos fundos 
Ficha de pré-inventário do patrimônio arquitetônico e urbanístico de Dourado - SP Vila Santa Clara: Características Arquitetônicas - Ficha 06

Identificação

Logradouro: Rua 06 de Fevereiro s/n - Vila Santa Clara
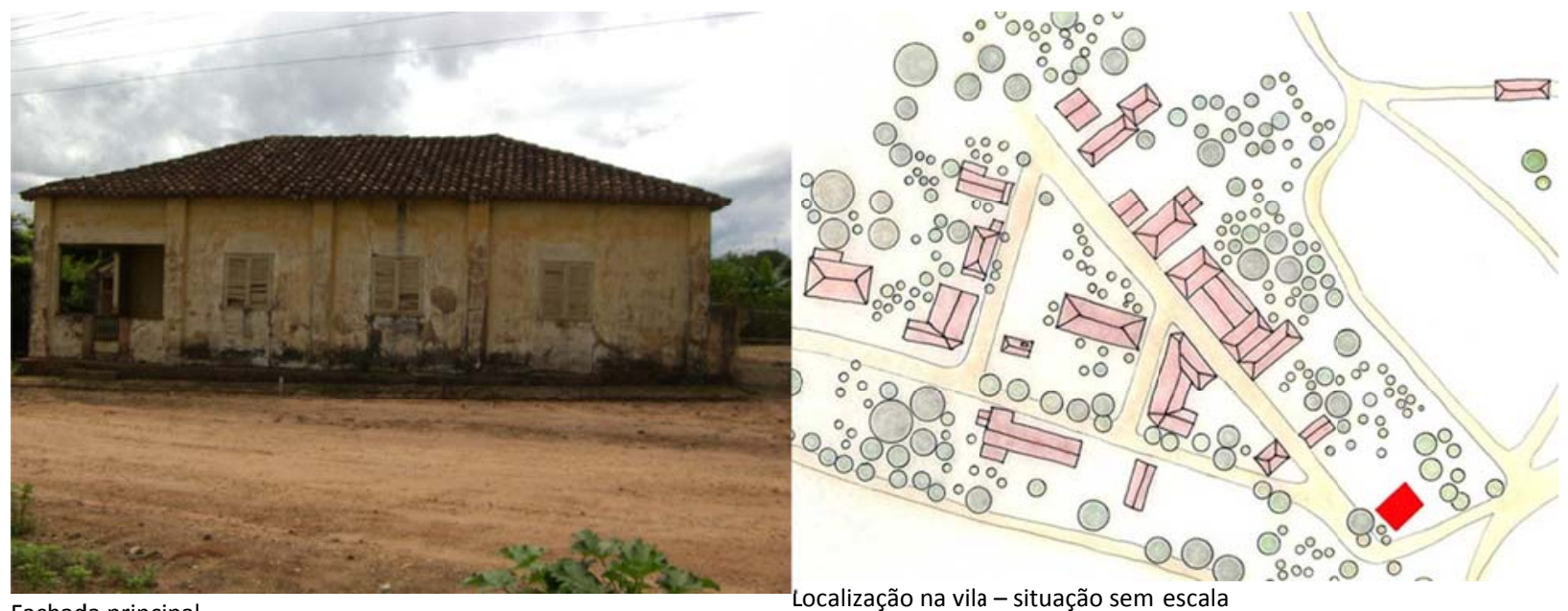

Fachada principal

ocalização na vila - situação sem escala

Fachada principal e uso atual

1. Materiais empregados na cobertura

Destruição total Canal X

Francesa Fibrocimento

Vidro

Metal

2. Coroamento

Laje

Frontão

Cachorros

Platibanda

Plástico / fibra

Laje de beiral

Cimalha

Outros:

Beiral simples $X$

Beira seveira

3. Materiais do coroamento

Argamassa

Cantaria

Argamassa X

Guarda pó

Azulejo antigo

Azulejo novo

Cantaria

Outros:

Madeira X

Concreto aparente

Azulejo novo

fachada principal

Outros:

Vidros

Chapisco

Azulejo novo

5. Material das molduras dos vãos de portas e janelas

Não tem $X$

Destruição total

6. Material das esquadrias da fachada principal

Argamassa

Cantaria

Azulejo antigo

Azulejo novo

Vidro

Madeira

Madeira

Concreto aparente

Outros:

7. Cores predominantes da fachada principal

Coroamento: natural

Esquadrias: branco

Molduras dos vãos: não tem

Acabam. da fachada: amarelo

Outros relevos: não tem

\section{Residência:}

8. Uso atual - quantificar

Comércio:

Vago: X 100\%

Serviço:

Culto:

Outros:

Madeira X

Alumínio

Outros:

Dados volumétricos

\section{Gabarito}

Altura da fachada:

№ pavimentos acima do nível da rua: 01

\section{Alt. cumeeira:}

№ subsolos: não tem

Além desses, assinalar a existência de:

Porão alto Mirante

Pav. intermediário

mezanino

Outros:

3. Registro de acréscimos

Não tem

Acréscimo vertical

Acréscimo horizontal $X$
Identificado a partir de:

Evidência na construção $X$

Depoimento do usuário

Outros:
Sótão habitáve
2. Classificação tipológica do telhado

Cumeeira paralela à rua $X$

Com torreão

Cumeeira perpendicular à rua

Tipo chalé

Água furtad

Outros:

Instituição: 
Ficha de pré-inventário do patrimônio arquitetônico e urbanístico de Dourado - SP Vila Santa Clara: Características Arquitetônicas - Ficha 07

Identificação

Logradouro: Rua 06 de fevereiro s/n - Vila Santa Clara
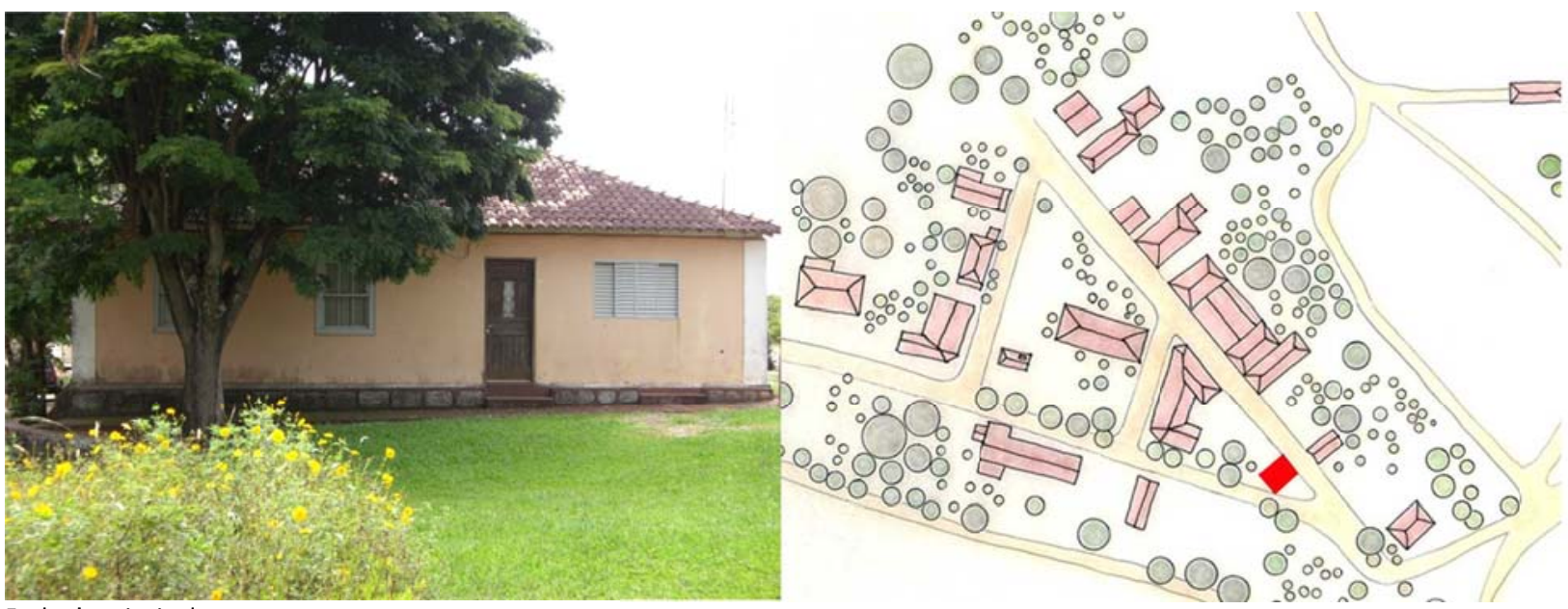

Fachada principal

Localização na vila - situação sem escala

Fachada principal e uso atual

1. Materiais empregados na cobertura

2. Coroamento

Destruição total

Canal

Fibrocimento

Destruição total

Francesa

Metal

Frontão

Platibanda

Vidro

Laje

Cachorros

Cimalha

Plástico / fibra

Laje de beiral

Beiral simples $X$

Beira seveira

Outros: telha romana

4. Materiais de acabamento da fachada principal

3. Materiais do coroamento

Argamassa

Cantaria

Azulejo antigo

Azulejo novo

Cantaria

Azulejo novo

Madeira X

Concreto aparente

Cantaria

Azulejo novo

Madeira

Outros:

6. Material das esquadrias da fachada principal

5. Material das molduras dos vãos de portas e janelas

Não tem X

Destruição total

Argamassa

Azulejo antigo

Cantaria

Destruição tota

Madeira X

Vidro

Alumínio X

Madeira

Azulejo novo

Ferro

Outros:

Outros:

7. Cores predominantes da fachada principal

Coroamento: branco

Esquadrias: cinza

Molduras dos vãos: não tem

Acabam. da fachada: salmão

Guarda-corpos: não tem

8. Uso atual - quantificar

Residência: $\mathrm{X}-100 \%$ Vago:

Comércio:

Serviço:

Outros:
Culto:

Instituição:

Dados volumétricos

\section{Gabarito}

\section{Altura da fachada:}

№ pavimentos acima do nível da rua: 01

Além desses, assinalar a existência de:

Porão alto Mirante

Pav. intermediário mezanino

Outros:
2. Classificação tipológica do telhado Número de águas do corpo principal: 04

№ subsolos: não tem

Cumeeira paralela à rua

Com torreão

Cumeeira perpendicular à rua

Pav. recuado

Tipo chalé

Água furtada

Outros:

3. Registro de acréscimos

Não tem

Acréscimo vertical

Acréscimo horizonta
Identificado a partir de:

Evidência na construção $X$

Depoimento do usuário

Outros:
Descrever: 
Ficha de pré-inventário do patrimônio arquitetônico e urbanístico de Dourado - SP Vila Santa Clara: Características Arquitetônicas - Ficha 08

Identificação

Logradouro: Rua 06 de fevereiro s/n - Vila Santa Clara

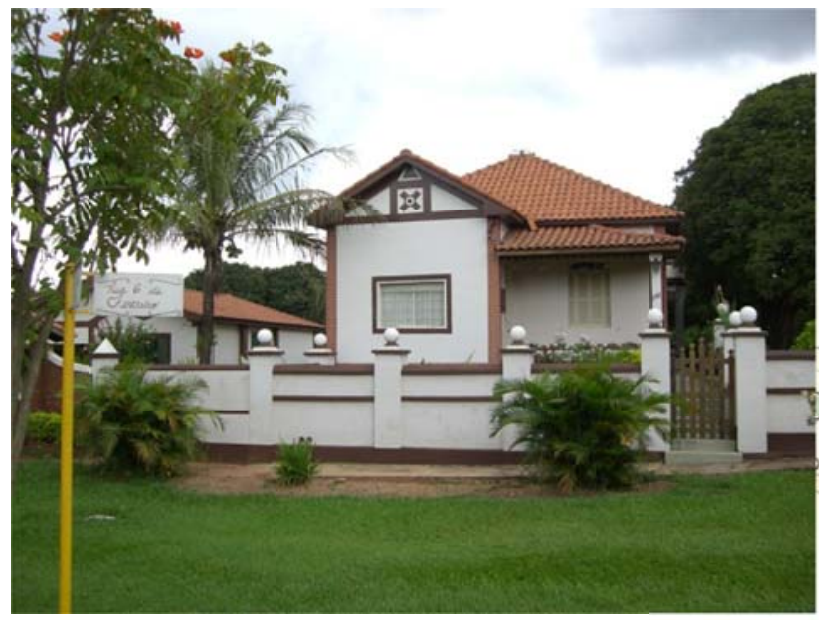

Fachada principal

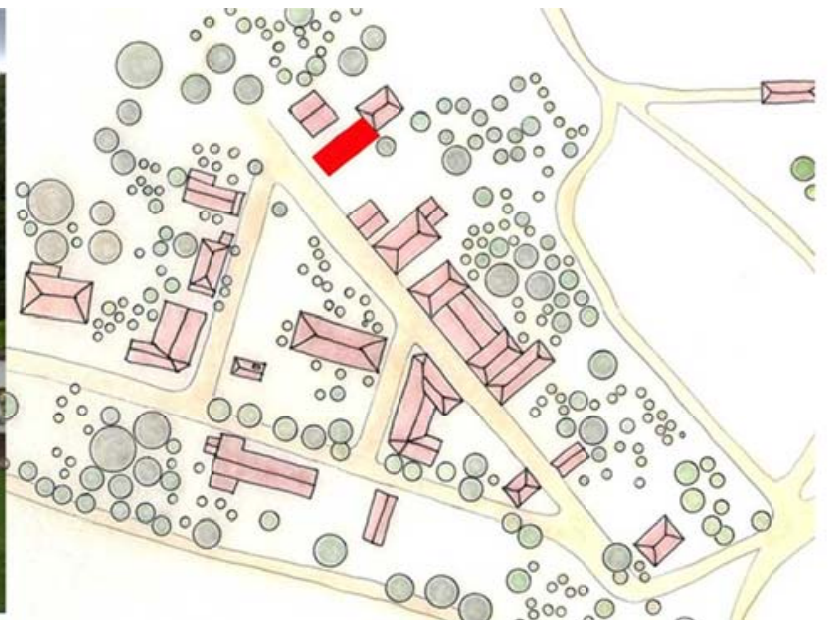

Localização na vila - situação sem escala

Fachada principal e uso atual

1. Materiais empregados na cobertura

2. Coroamento

Destruição total Canal

Francesa Fibrocimento

Vidro Metal

Destruição total

Frontão

Cachorros

Plástico / fibra

Laje

Outros: telha romana

3. Materiais do coroamento

Argamassa

Azulejo antigo

Cantaria

Laje de beiral

Beiral simples

Platibanda

Cimalha

Beira seveira

4. Materiais de acabamento da fachada principal

Madeira X

Azulejo novo

Concreto aparente

Argamassa $X$

Cantaria

Outros:

Azulejo novo

Vidros

Guarda pó $X$

Outros:

5. Material das molduras dos vãos de portas e janelas

Não tem

Destruição total

Argamassa $X$

Cantaria

6. Material das esquadrias da fachada principal

Azulejo antigo

Azulejo novo

Destruição total

Chapisco

Azulejo novo

Madeira

Outros: tijolos aparentes

Madeira

Concreto aparente

Outros:

7. Cores predominantes da fachada principal

Coroamento: marrom

Molduras dos vãos: marrom

Esquadrias: banco

Guarda-corpos: não tem

Acabam. da fachada: branco

Outros relevos: marrom

Vidro

Madeira X

Ferro

Alumínio

Outros:

8. Uso atual - quantificar

Residência: $X-100 \% \quad$ Vago:

Comércio: Culto:

Serviço: Instituição:

Outros:

Dados volumétricos

\section{Gabarito}

\section{Altura da fachada:}

№ pavimentos acima do nível da rua: 01

Além desses, assinalar a existência de:

Porão alto $X \quad$ Mirante

Pav. intermediário mezanino

Outros:

\section{Alt. cumeeira: \\ № subsolos: não tem}

Pav. recuado

Sótão habitável
2. Classificação tipológica do telhado Número de águas do corpo principal: 07

Cumeeira paralela à rua

Cumeeira perpendicular à rua

Tipo chalé $X$

Com torreão

Água furtada

Outros:

3. Registro de acréscimos

Não tem $X$

Acréscimo vertical

Acréscimo horizontal
Identificado a partir de:

Evidência na construção $X$

Depoimento do usuário

Outros:

Descrever: 
Ficha de pré-inventário do patrimônio arquitetônico e urbanístico de Dourado - SP Vila Santa Clara: Características Arquitetônicas - Ficha 09

Identificação

Logradouro: Rua Nhonho Borges s/n - Vila Santa Clara

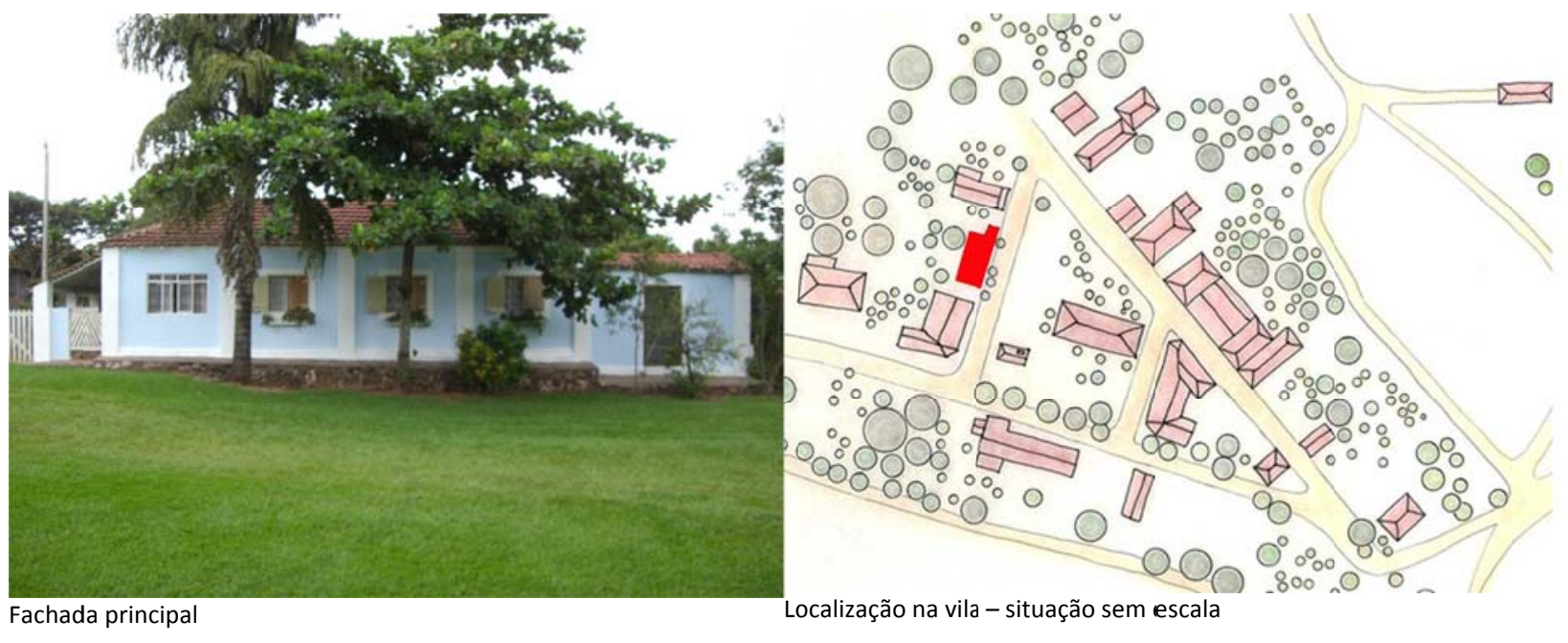

Fachada principal e uso atual

1. Materiais empregados na cobertura

Destruição total Canal

Francesa X Fibrocimento

Vidro

Metal

Destruição total

Laje

Frontão

Cachorros

Platibanda

Plástico / fibra

Laje de beiral

Cimalha

Outros:

Beiral simples $X$

Beira seveira

3. Materiais do coroamento

Argamassa

Cantaria

4. Materiais de acabamento da fachada principal

Azulejo antigo

Azulejo novo

Argamassa $X$

Cantaria

Madeira X

Concreto aparente

Azulejo novo

Outros:

Vidros

Azulejo novo

5. Material das molduras dos vãos de portas e janelas

6. Material das esquadrias da fachada principal

Não tem

Destruição total

Argamassa $X$

Cantaria

Azulejo antigo

Azulejo novo

Destruição total

Vidro

Madeira

Concreto aparente

Ferro laminado / solda X

Alumínio

Outros:

7. Cores predominantes da fachada principal

Coroamento: branco

Esquadrias: branco

Molduras dos vãos: branco

Acabam. da fachada: azul claro

8. Uso atual - quantificar

Guarda-corpos: não tem

Outros relevos: não tem

Comércio:

Vago:

Serviço:

Instituição:

Outros:

Dados volumétricos

\section{Gabarito}

Altura da fachada: $4,50 \mathrm{~m}$

№ pavimentos acima do nível da rua: 01

Além desses, assinalar a existência de:

$\begin{array}{lll}\text { Porão alto } & \text { Mirante } & \text { Pav. recuado } \\ \text { Pav. intermediário } & \text { mezanino } & \text { Sótão habitável }\end{array}$

\section{Classificação tipológica do telhado}

Alt. cumeeira: 1,70 m Número de águas do corpo principal: 04

Cumeeira paralela à rua $X \quad$ Com torreão

Cumeeira perpendicular à rua Água furtada

Tipo chalé

Outros:

Outros: embasamento misto de pedra e tijolos

3. Registro de acréscimos

Não tem $X$

Acréscimo vertical

Acréscimo horizontal
Identificado a partir de:

Evidência na construção $X$

Depoimento do usuário

Outros:
Descrever: 
Ficha de pré-inventário do patrimônio arquitetônico e urbanístico de Dourado - SP Vila Santa Clara: Características Arquitetônicas - Ficha 10

Identificação

Logradouro: Rua do Tomazini s/n - Vila Santa Clara

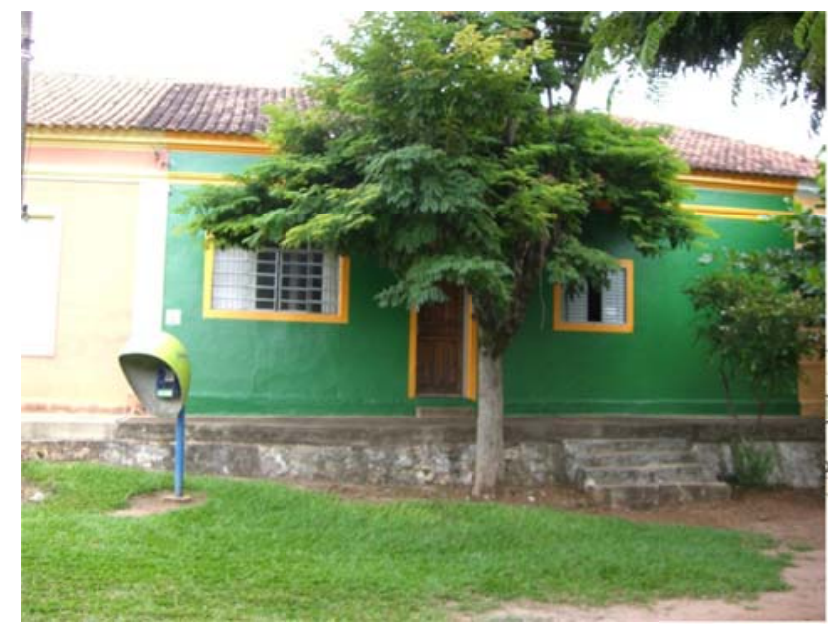

Fachada principal

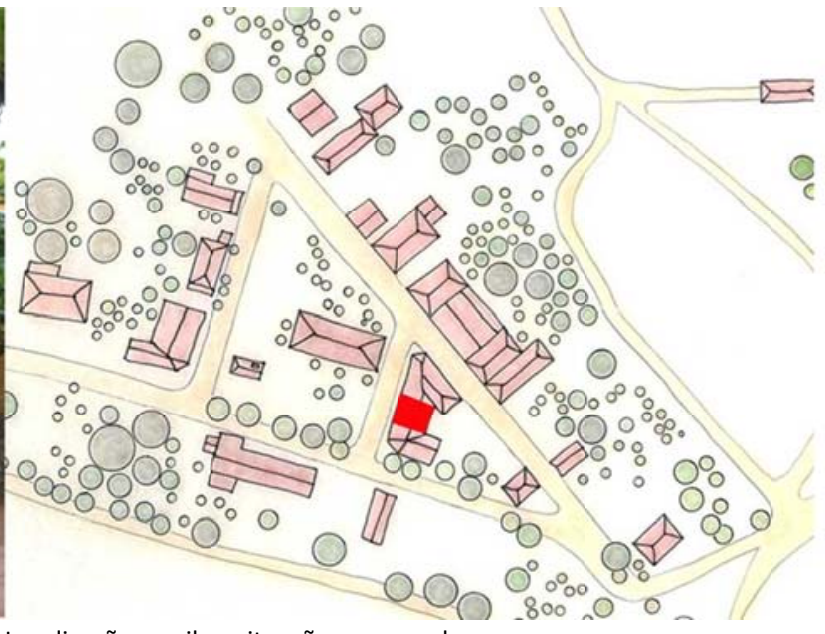

Localização na vila - situação sem escala

Fachada principal e uso atual

1. Materiais empregados na cobertura

Destruição total Canal

Francesa Fibrocimento

Vidro Metal

Plástico / fibra Laje

Outros: telha romana

3. Materiais do coroamento

Argamassa $X$

Azulejo antigo

Madeira

Outros:

\section{Cantaria}

Azulejo novo

Concreto aparente

5. Material das molduras dos vãos de portas e janelas

Não tem

Argamassa $X$

Azulejo antigo

Madeira

Outros:

7. Cores predominantes da fachada principal

Coroamento: amarelo

Molduras dos vãos: amarelo

Guarda-corpos: não tem
Destruição total

Cantaria

Azulejo novo

Concreto aparente

\section{Coroamento}

Destruição total

Frontão

Cachorros

Laje de beiral

Beiral simples

4. Materiais de acabamento da fachada principal

Argamassa $X \quad$ Chapisco

Cantaria Azulejo novo

Azulejo novo Madeira

Vidros Outros:

6. Material das esquadrias da fachada principal

Destruição total Madeira X porta

Vidro Alumínio

Ferro laminado $X$ janelas Outros:
8. Uso atual - quantificar

Residência: X 100\% Vago:

Comércio: Culto:

Serviço: Instituição:

Outros:
Dados volumétricos

\section{Gabarito}

Altura da fachada: $4,60 \mathrm{~m}$

№ pavimentos acima do nível da rua: 01

Além desses, assinalar a existência de:

Porão alto Mirante

Pav. intermediário mezanino

Outros: embasamento misto de pedra e tijolos

3. Registro de acréscimos

Não tem $X$

Acréscimo vertical

Acréscimo horizontal
Identificado a partir de:

Evidência na construção $X$

Depoimento do usuário

Outros:
2. Classificação tipológica do telhado Número de águas do corpo principal: 02

Alt. cumeeira: $1,70 \mathrm{~m}$

Cumeeira paralela à rua $X$

Com torreão

Cumeeira perpendicular à rua

Água furtada

Pav. recuado

Tipo chalé

Outros:

Sótão habitável

Descrever: 
Ficha de pré-inventário do patrimônio arquitetônico e urbanístico de Dourado - SP Vila Santa Clara: Características Arquitetônicas - Ficha 11

Identificação

Logradouro: Rua Nhonho Borges s/n - Vila Santa Clara

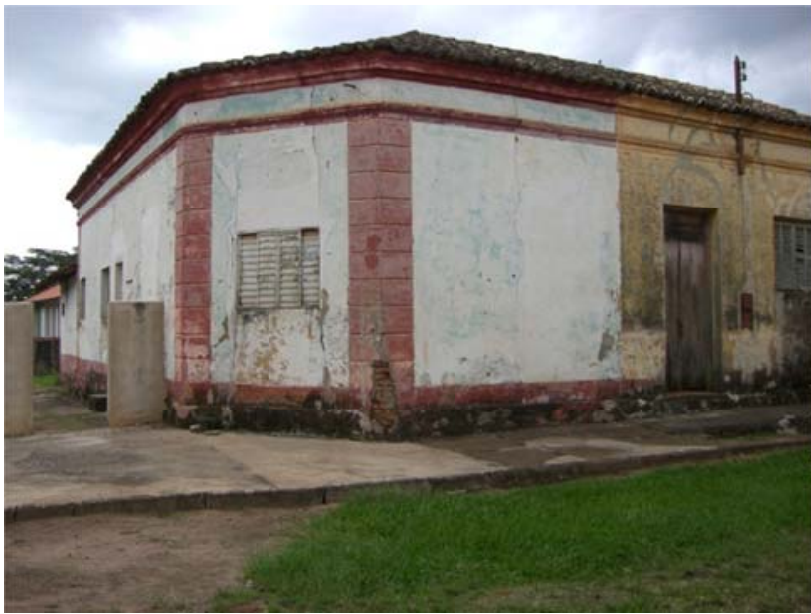

Fachada principal

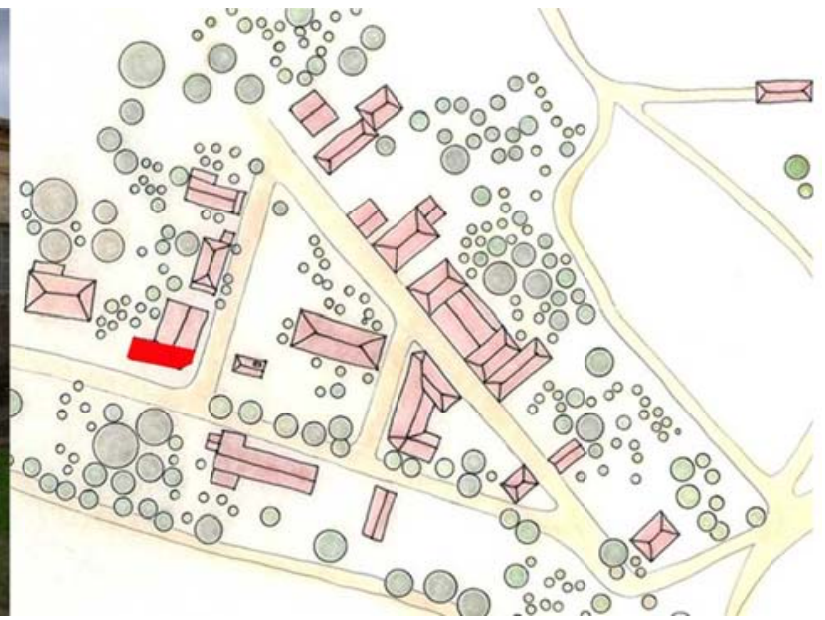

Localização na vila - situação sem escala

Fachada principal e uso atual

1. Materiais empregados na cobertura

Destruição total Canal X

Francesa

Vidro

Plástico / fibra

Fibrocimento

Metal

Laje

Outros:

3. Materiais do coroamento Argamassa $X$

Azulejo antigo

Cantaria

Azulejo novo

Madeira

Concreto aparente

Outros:

5. Material das molduras dos vãos de portas e janelas

Não tem X

Argamassa

Azulejo antigo

Destruição total

Madeira

Cantaria

Azulejo novo

Concreto aparente

Outros:

7. Cores predominantes da fachada principal

Coroamento: vermelho

Esquadrias: branco

Molduras dos vãos: não tem

Acabam. da fachada: branco

2. Coroamento

Destruição total

Frontão

Cachorros

Laje de beiral

Beiral simples

\section{Platibanda}

Cimalha $X$

Beira seveira

Guarda pó

4. Materiais de acabamento da fachada principal

Argamassa X Chapisco

Cantaria Azulejo novo

Azulejo novo Madeira

Vidros Outros:

6. Material das esquadrias da fachada principal

Destruição total Madeira

Vidro Alumínio

Ferro laminado / solda X Outros:

Guarda-corpos: não tem

Outros relevos: vermelho

8. Uso atual - quantificar

Residência: X 100\%

Comércio:

Serviço:

Outros:

\section{Vago:}

Culto:

Instituição:

Dados volumétricos

\section{Gabarito}

Altura da fachada: 4,90 m

№ pavimentos acima do nível da rua: 01

Além desses, assinalar a existência de:

Porão alto Mirante

Pav. intermediário mezanino

Outros:
2. Classificação tipológica do telhado

Alt. cumeeira: $1,80 \mathrm{~m}$

№ subsolos: não tem

Pav. recuado

Sótão habitável
Número de águas do corpo principal: 04

Cumeeira paralela à rua $X \quad$ Com torreão

Cumeeira perpendicular à rua Água furtada

Tipo chalé

3. Registro de acréscimos

Não tem

Acréscimo vertical

Acréscimo horizontal $X$
Identificado a partir de: Evidência na construção $X$

Depoimento do usuário

Outros:
Descrever: Acréscimo de um cômodoı para banheiro nos fundos. 
Ficha de pré-inventário do patrimônio arquitetônico e urbanístico de Dourado - SP Vila Santa Clara: Características Arquitetônicas - Ficha 12

Identificação

Logradouro: Rua Nhonho Borges s/n - Vila Santa Clara

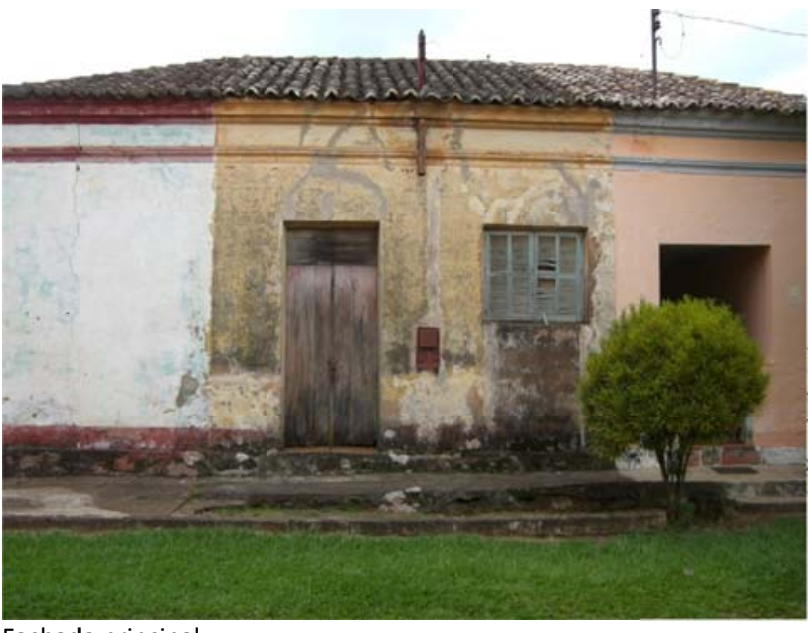

Fachada principal

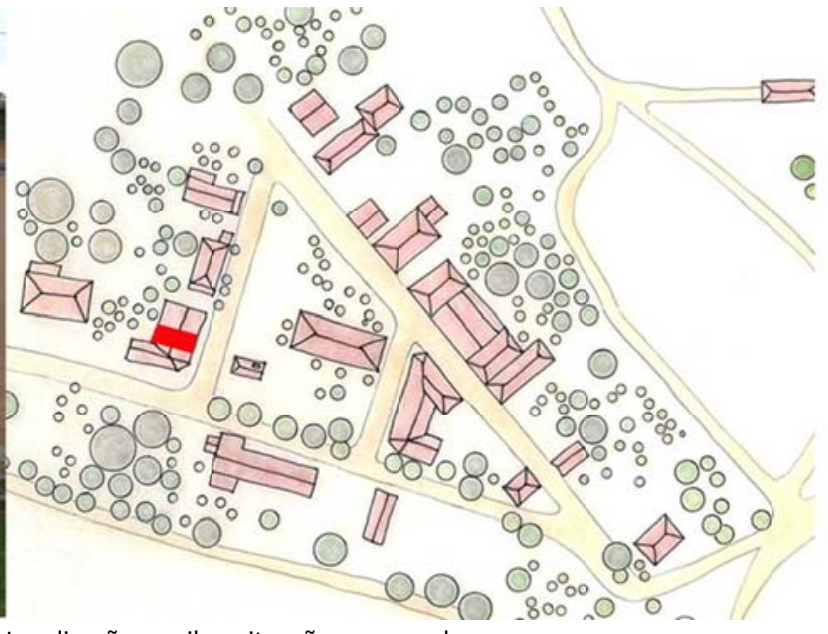

Localização na vila - situação sem escala

Fachada principal e uso atual

1. Materiais empregados na cobertura

Destruição total Canal X

Francesa Fibrocimento

Vidro Metal

Plástico / fibra Laje

Outros:

3. Materiais do coroamento

Argamassa $X$

Azulejo antigo

Madeira

Cantaria

2. Coroamento

Destruição total

Frontão

Cachorros

Laje de beiral

Beiral simples

Platibanda

Cimalha $\mathrm{X}$

Beira seveira

4. Materiais de acabamento da fachada principal

Argamassa $X \quad$ Chapisco

Cantaria Azulejo novo

Azulejo novo Madeira

Vidros

Outros:

6. Material das esquadrias da fachada principal

5. Material das molduras dos vãos de portas e janelas

Não tem X

Argamassa

Azulejo antigo

Destruição total

Cantaria

Destruição tota

Madeira X

Vidro

Alumínio

Azulejo novo

Ferro

Outros:

Madeira

Concreto aparente

Outros:

7. Cores predominantes da fachada principal

Coroamento: amarelo

Molduras dos vãos: não tem

Guarda-corpos: não tem

Esquadrias: natural / azul

Acabam. da fachada: amarelo

Outros relevos: não tem

8. Uso atual - quantificar

Residência:

Comércio:

Serviço:

Vago: X 100\%

Outros:

Culto:

Instituição:

Dados volumétricos

\section{Gabarito \\ Altura da fachada: $4,90 \mathrm{~m}$}

№ pavimentos acima do nível da rua: 01

Além desses, assinalar a existência de:

Porão alto Mirante

Pav. intermediário mezanino

Outros:
2. Classificação tipológica do telhado

Alt. cumeeira: $1,80 \mathrm{~m}$

№ subsolos: não tem

Pav. recuado

Cumeeira paralela à rua $X$

Com torreão

Cumeeira perpendicular à rua

Tipo chalé
Água furtada

Outros:
3. Registro de acréscimos

Não tem $X$

Acréscimo vertical

Acréscimo horizontal
Identificado a partir de:

Evidência na construção $X$

Depoimento do usuário

Outros:

Descrever: 
Ficha de pré-inventário do patrimônio arquitetônico e urbanístico de Dourado - SP Vila Santa Clara: Características Arquitetônicas - Ficha 13

Identificação

Logradouro: Rua Nhonho Borges s/n - Vila Santa Clara

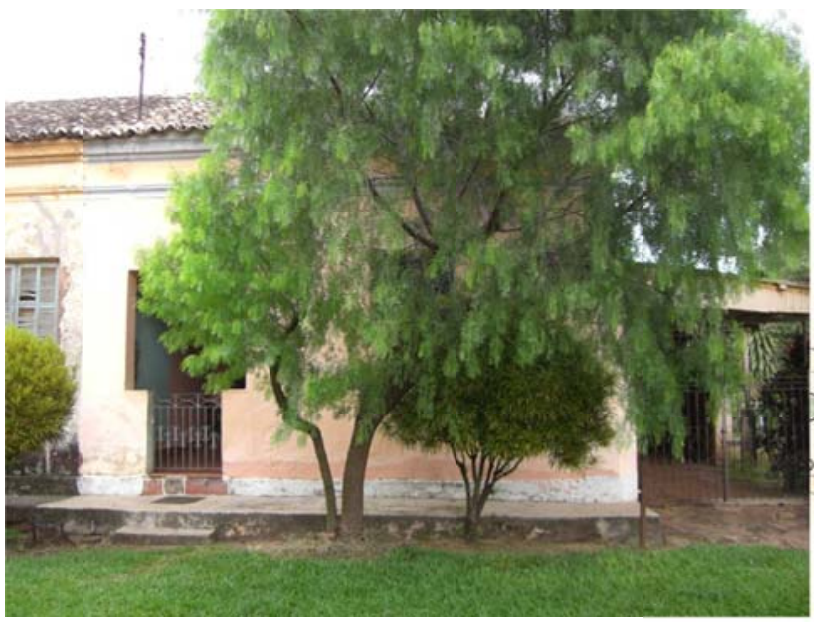

Fachada principal

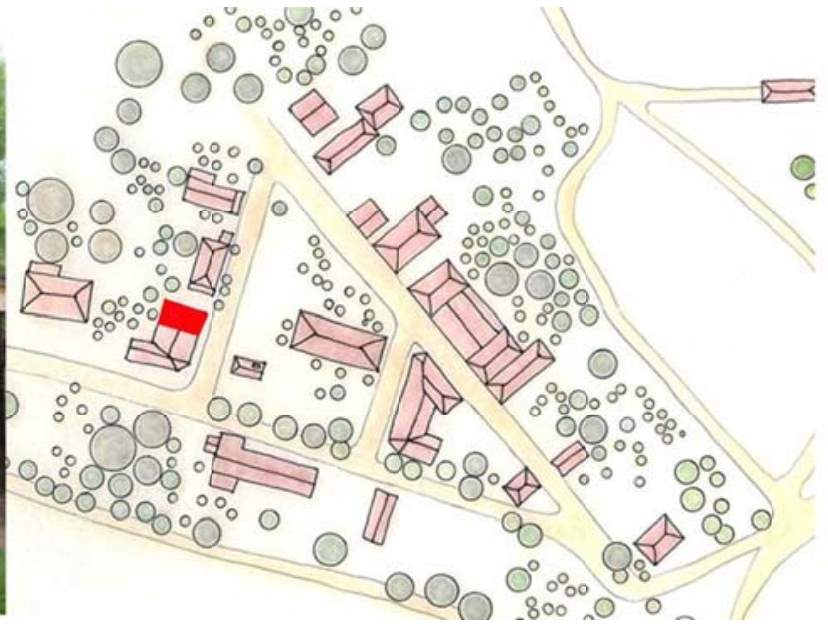

Localização na vila - situação sem escala

Fachada principal e uso atual

1. Materiais empregados na cobertura

Destruição total Canal $X$

Francesa Fibrocimento

Vidro Metal

Plástico / fibra Laje

Outros:

3. Materiais do coroamento

Argamassa $X$

Azulejo antigo

Madeira

Outros:

Cantaria

Azulejo novo

Concreto aparente

5. Material das molduras dos vãos de portas e janelas

Não tem X

Argamassa

Azulejo antigo

Madeira

Outros:

7. Cores predominantes da fachada principal

Coroamento: branco

Molduras dos vãos: não tem

Guarda-corpos: não tem

Esquadrias: branco

Acabam. da fachada: rosa

Outros relevos:

\section{Coroamento}

Destruição total

Frontão

Cachorros

Laje de beiral

Beiral simples

4. Materiais de acabamento da fachada principal

Argamassa $X \quad$ Chapisco

Cantaria Azulejo novo

Azulejo novo Madeira

Vidros Outros:

6. Material das esquadrias da fachada principal

Destruição total Madeira

Vidro Alumínio $\mathrm{X}$

Ferro Outros:

Cantaria Vidro

Azulejo novo Ferro

Concreto aparente
8 Uso atual - quantificar

Residência: $X-100 \% \quad$ Vago:

Comércio: Culto:

Serviço: Instituição:
Dados volumétricos

\section{Gabarito}

Altura da fachada: 4,90 m

№ pavimentos acima do nível da rua: 01

Além desses, assinalar a existência de:

Porão alto Mirante

Pav. intermediário mezanino

Outros:
Alt. cumeeira: $1,80 \mathrm{~m}$

№ subsolos: não tem

Pav. recuado

Sótão habitável
2. Classificação tipológica do telhado Número de águas do corpo principal: 03

Cumeeira paralela à rua $X$

Cumeeira perpendicular à rua

Tipo chalé
Com torreão

Água furtada

Outros:

3. Registro de acréscimos

Não tem

Acréscimo vertical

Acréscimo horizontal $X$
Identificado a partir de:

Evidência na construção $X$

Depoimento do usuário

Outros:
Descrever: água para garagem na lateral direita 
Ficha de pré-inventário do patrimônio arquitetônico e urbanístico de Dourado - SP Vila Santa Clara: Características Arquitetônicas - Ficha 14

Identificação

Logradouro: Rua dos Gomes s/n - Vila Santa Clara

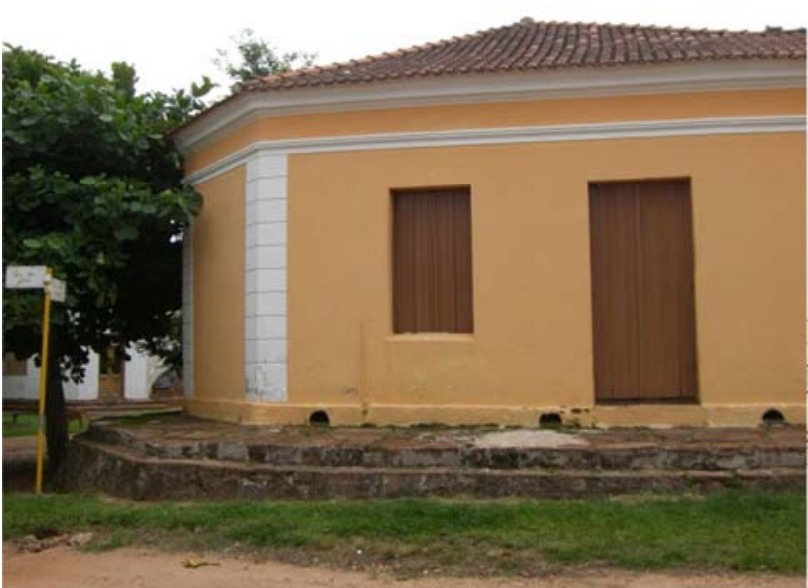

Fachada principal

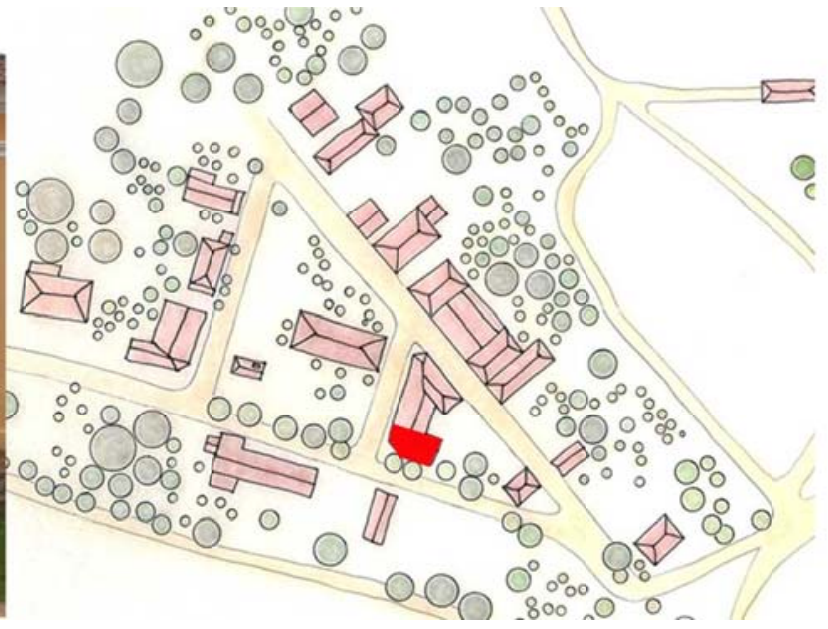

Localização na vila - situação sem escala

Fachada principal e uso atual

1. Materiais empregados na cobertura

Destruição total Canal

Francesa Fibrocimento

Vidro Metal

Plástico / fibra Laje

Outros: romana

3. Materiais do coroamento

Argamassa $X$

Azulejo antigo

Madeira

Cantaria

Azulejo novo

Concreto aparente

Outros:

5. Material das molduras dos vãos de portas e janelas

Não tem X

Argamassa

Azulejo antigo

Destruição total

Cantaria

Azulejo novo

2. Coroamento

Destruição total

Frontão

Cachorros

Laje de beiral

Beiral simples

Platibanda

Cimalha $\mathrm{X}$

Beira seveira

4. Materiais de acabamento da fachada principal

Argamassa $X \quad$ Chapisco

Cantaria Azulejo novo

Azulejo novo Madeira

Vidros

Outros:

6. Material das esquadrias da fachada principal

Destruição total Madeira $X$

Vidro Alumínio

Ferro Outros:

Madeira

Concreto aparente

Outros:

7. Cores predominantes da fachada principal

Coroamento: branco

Esquadrias: marrom

Molduras dos vãos: não tem

Acabam. da fachada: amarelo

Outros relevos: branco

Residência: $\mathrm{X}-100 \% \quad$ Vago:

Comércio:

Serviço:

Culto:

Outros:

Dados volumétricos

\section{Gabarito}

Altura da fachada: $4,60 \mathrm{~m}$

№ pavimentos acima do nível da rua: 01

Além desses, assinalar a existência de:

Porão alto Mirante

Pav. intermediário mezanino

Outros: embasamento misto de pedra e tijolos

3. Registro de acréscimos

Não tem $X$

Acréscimo vertical

Acréscimo horizontal
Identificado a partir de:

Evidência na construção $X$

Depoimento do usuário

Outros:
2. Classificação tipológica do telhado Número de águas do corpo principal: 05

Alt. cumeeira: $1,70 \mathrm{~m}$

Cumeeira paralela à rua $X$

Com torreão

Cumeeira perpendicular à rua

Água furtada

Pav. recuado

Tipo chalé

Outros:

Sótão habitável

Descrever: 
Ficha de pré-inventário do patrimônio arquitetônico e urbanístico de Dourado - SP Vila Santa Clara: Características Arquitetônicas - Ficha 15

Identificação

Logradouro: Rua 06 de fevereiro s/n - Vila Santa Clara

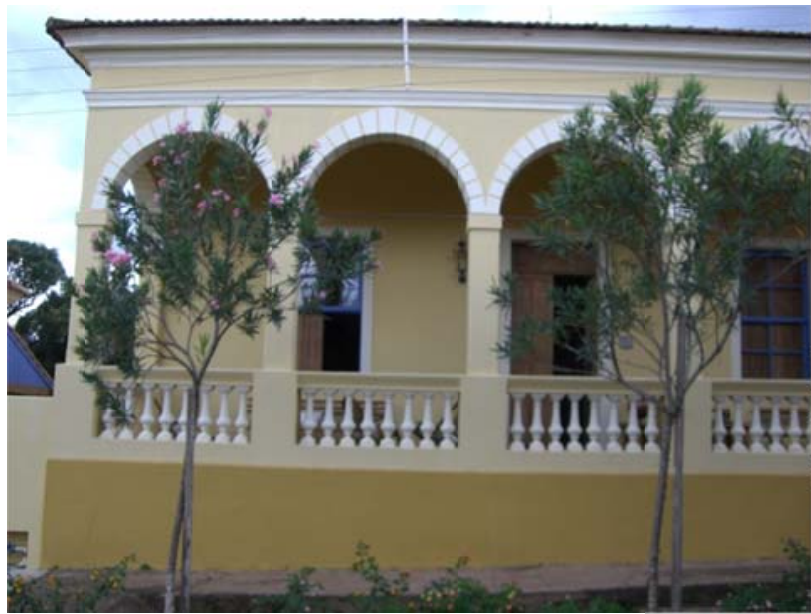

Fachada principal

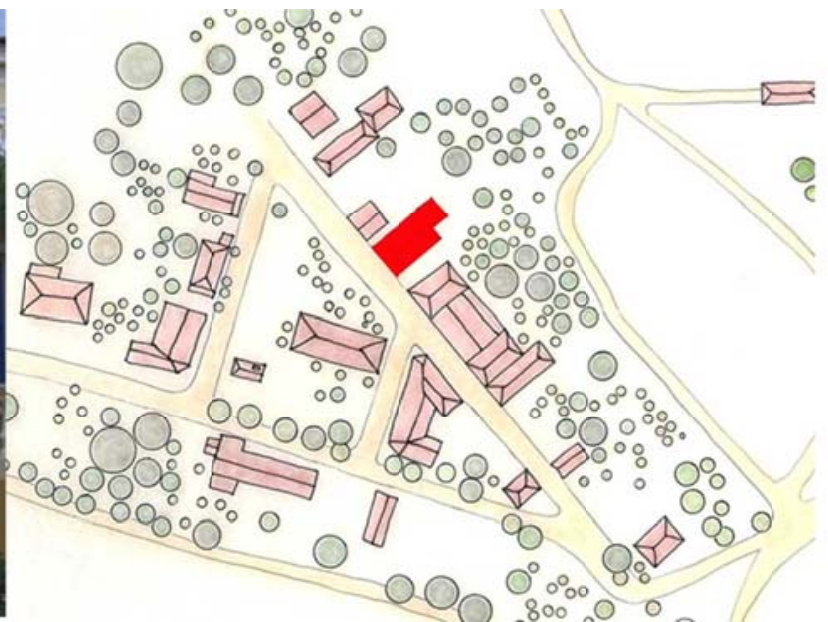

Localização na vila - situação sem escala

Fachada principal e uso atual

1. Materiais empregados na cobertura

Destruição total Canal

Francesa $X$

Vidro

Plástico / fibra

Fibrocimento

Metal

Laje

Outros:

\section{Materiais do coroamento}

Argamassa $X$

Azulejo antigo

Madeira

\section{Cantaria}

Azulejo novo

Concreto aparente

Outros:

5. Material das molduras dos vãos de portas e janelas

Não tem

Destruição total

Argamassa $X$

Azulejo antigo

Cantaria

Azulejo novo

Concreto aparente

adeira

7. Cores predominantes da fachada principal 8. Uso atual - quantificar

Coroamento: branco

Molduras dos vãos: branco

Guarda-corpos: branco

Esquadrias: azul / natural

Acabam. da fachada: amarelo

Outros relevos: branco

\section{Residência: $\mathrm{X}$}

Platibanda

Cimalha X

Beira seveira

Guarda pó

Outros:

4. Materiais de acabamento da fachada principal

Argamassa $X \quad$ Chapisco

Cantaria Azulejo novo

Azulejo novo Madeira

6. Material das esquadrias da fachada principal

Destruição total Madeira X

Vidro Alumínio

Outros:

Dados volumétricos

\section{Gabarito}

\section{Altura da fachada:}

№ pavimentos acima do nível da rua: 01

Além desses, assinalar a existência de:

Porão alto $X \quad$ Mirante

Pav. intermediário mezanino

Outros:
Alt. cumeeira:

№ subsolos: não tem

Pav. recuado

Sótão habitável

3. Registro de acréscimos

Não tem $X$

Acréscimo vertical

Acréscimo horizontal
Identificado a partir de:

Evidência na construção $X$

Depoimento do usuário

Outros:
Comércio:

Serviço:

Outros:

2. Classificação tipológica do telhado Número de águas do corpo principal: 04

Cumeeira paralela à rua

Cumeeira perpendicular à rua $\mathrm{X}$

Tipo chalé

Com torreão

Água furtada

Outros:
Descrever:

Vago:

Culto:

Instituição: 
Ficha de pré-inventário do patrimônio arquitetônico e urbanístico de Dourado - SP Vila Santa Clara: Características Arquitetônicas - Ficha 16

Identificação

Logradouro: Rua 06 de fevereiro s/n - Vila Santa Clara

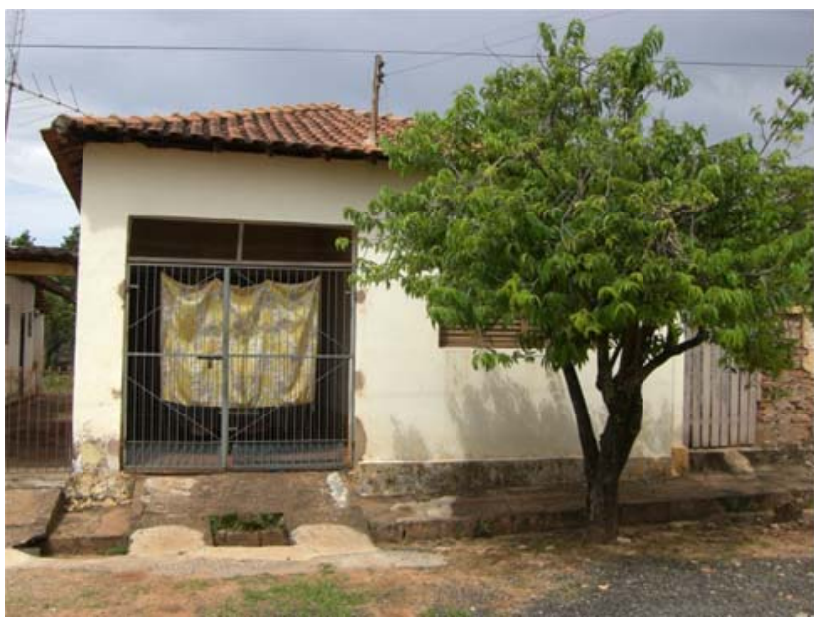

Fachada principal

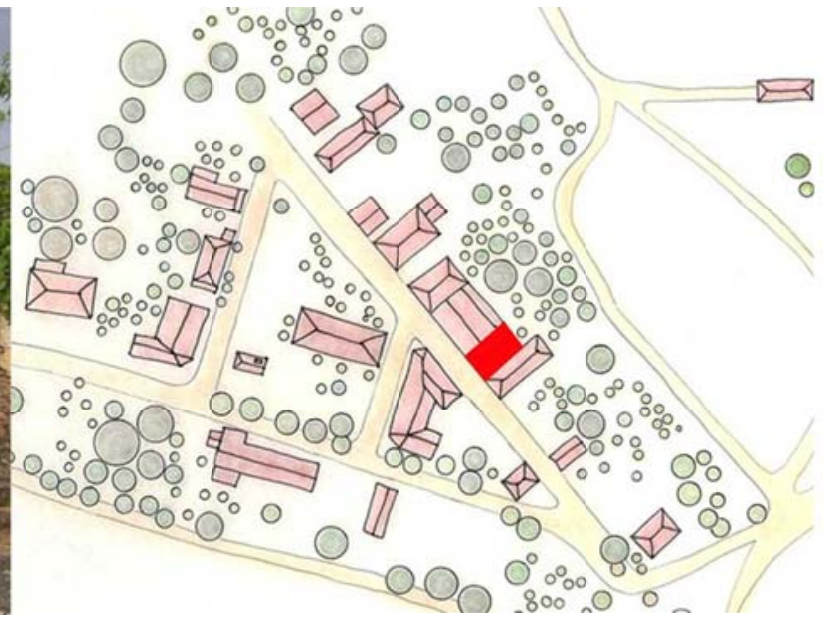

Localização na vila - situação sem escala

Fachada principal e uso atual

1. Materiais empregados na cobertura

Destruição total Canal

Francesa Fibrocimento

Vidro

Metal

Plástico / fibra

Laje

2. Coroamento

Destruição total

Frontão

Cachorros

Laje de beiral

Beiral simples $X$

Platibanda

Cimalha

Beira seveira

Guarda pó

4. Materiais de acabamento da fachada principal

3. Materiais do coroamento

Argamassa

Azulejo antigo

Cantaria

Argamassa $\mathrm{X}$

Cantaria

Azulejo novo

Azulejo novo

Vidros

Azulejo novo

Madeira

6. Material das esquadrias da fachada principal

5. Material das molduras dos vãos de portas e janelas

Não tem $X$

Destruição total

Argamassa

Azulejo antigo

Cantaria

Azulejo novo

Destruição total

Outros:

\section{Madeira}

Concreto aparente

Outros:

7. Cores predominantes da fachada principal

Coroamento: natural

Esquadrias: marrom

Molduras dos vãos: não tem

Acabam. da fachada: bege

Vidro

Madeira

Ferro X

Alumínio

Outros:

Outros relevos: não tem
8. Uso atual - quantificar

Residência: X-100\%

Comércio:

Serviço:

Outros:

\section{Vago:}

Culto:

Instituição:

Dados volumétricos

\section{Gabarito}

Altura da fachada:

№ pavimentos acima do nível da rua: 01

Além desses, assinalar a existência de:

Porão alto Mirante

Pav. intermediário mezanino

Outros:

\section{Classificação tipológica do telhado}

\section{Alt. cumeeira:}

№ subsolos: não tem

Pav. recuado

Sótão habitável Número de águas do corpo principal: 04

Cumeeira paralela à rua

Com torreão

Cumeeira perpendicular à rua $X$

Água furtada

Tipo chalé

Outros:
3. Registro de acréscimos

Não tem $X$

Acréscimo vertical

Acréscimo horizontal
Identificado a partir de:

Evidência na construção $X$

Depoimento do usuário

Outros:
Descrever: 
Ficha de pré-inventário do patrimônio arquitetônico e urbanístico de Dourado - SP Vila Santa Clara: Características Arquitetônicas - Ficha 17

Identificação

Logradouro: Rua 06 de fevereiro s/n - Vila Santa Clara
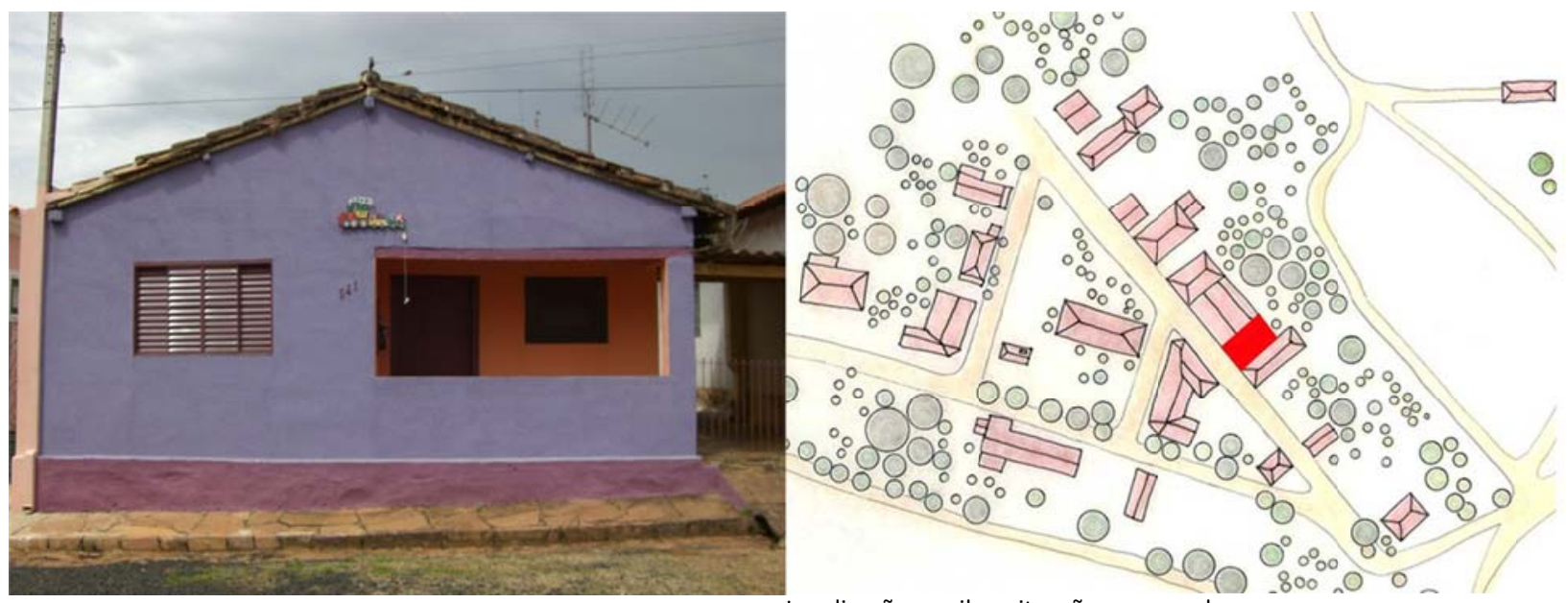

Fachada principal

Localização na vila - situação sem escala

Fachada principal e uso atual

1. Materiais empregados na cobertura

Destruição total Canal X

Francesa

Vidro

Fibrocimento

Metal

2. Coroamento

Destruição total

Frontão

Cachorros

Platibanda

Plástico / fibra

Laje

Laje de beiral

Cimalha

Outros:

Beiral simples $X$

Beira seveira

3. Materiais do coroamento

Argamassa

Azulejo antigo

Cantaria

4. Materiais de acabamento da fachada principal

Madeira X

Azulejo novo

Argamassa $\mathrm{X}$

Cantaria

Azulejo novo

Concreto aparente

Vidros

Azulejo novo

Outros:

6. Material das esquadrias da fachada principal

5. Material das molduras dos vãos de portas e janelas

Não tem $X$

Destruição total

Argamassa

Cantaria

Azulejo antigo

Azulejo novo

Destruição total

Vidro

Madeira X

Ferro $\mathrm{X}$

Alumínio

Concreto aparente

Madeira

Outros:

7. Cores predominantes da fachada principal

Coroamento: natural

Esquadrias: marrom

Molduras dos vãos: não tem

Acabam. da fachada: azu

8. Uso atual - quantificar

Guarda-corpos: não tem

Outros relevos: lilás

Residência: $\mathrm{X}-100 \%$

Vago:

Comércio:

Culto:

Serviço:

Instituição:

Outros:

Dados volumétricos

\section{Gabarito}

Altura da fachada:

№ pavimentos acima do nível da rua: 01

Além desses, assinalar a existência de:

$\begin{array}{lll}\text { Porão alto } & \text { Mirante } & \text { Pav. recuado } \\ \text { Pav. intermediário } & \text { mezanino } & \text { Sótão habitável }\end{array}$

Outros:

Alt. cumeeira:
№ subsolos: não tem

2. Classificação tipológica do telhado Número de águas do corpo principal: 04

Cumeeira paralela à rua

Cumeeira perpendicular à rua $X$

Tipo chalé
Com torreão

Água furtada

Outros:

3. Registro de acréscimos

Não tem

Acréscimo vertical

Acréscimo horizontal $X$
Identificado a partir de:

Evidência na construção $X$

Depoimento do usuário

Outros:

\section{Descrever: água lateral para garagemı}


Ficha de pré-inventário do patrimônio arquitetônico e urbanístico de Dourado - SP Vila Santa Clara: Características Arquitetônicas - Ficha 18

Identificação

Logradouro: Rua 06 de fevereiro s/n - Vila Santa Clara

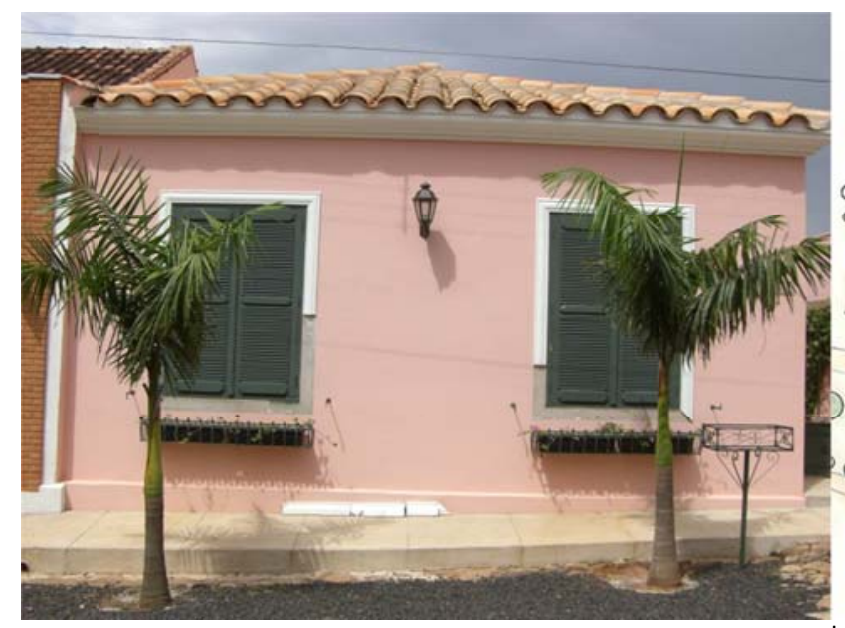

Fachada principal

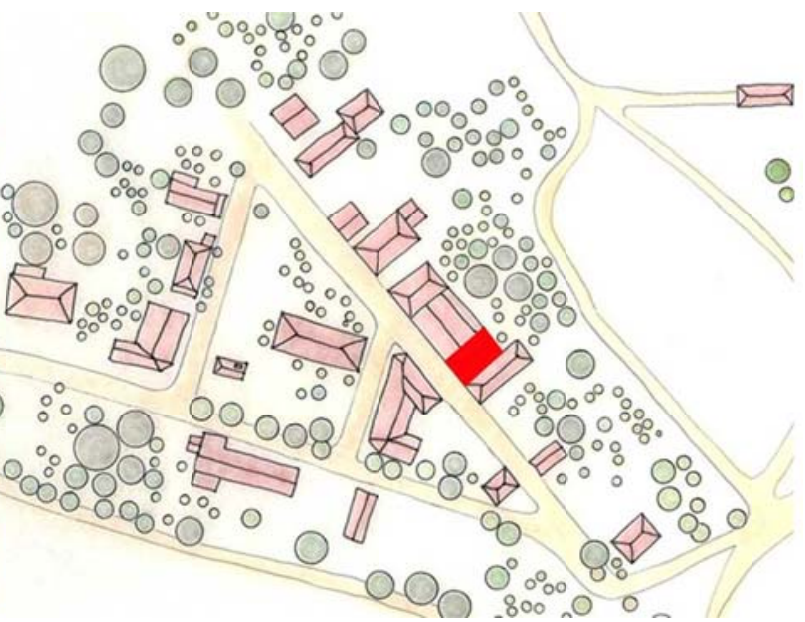

Fachada principal e uso atual

1. Materiais empregados na cobertura

Localização na vila - situação sem escala

$\begin{array}{ll}\text { Destruição total } & \text { Canal X } \\ \text { Francesa } & \text { Fibrocimento } \\ \text { Vidro } & \text { Metal } \\ \text { Plástico / fibra } & \text { Laje }\end{array}$

Outros:

3. Materiais do coroamento Argamassa $X$

Azulejo antigo

Cantaria

Azulejo novo

Madeira

Concreto aparente

Outros:

5. Material das molduras dos vãos de portas e janelas

Não tem

Destruição total

Argamassa $X$

Cantaria

Azulejo antigo

Azulejo novo

2. Coroamento

Destruição total

Platibanda

Frontão

Cimalha X

Cachorros

Laje de beiral

Beiral simples

Beira seveira

Madeira

Concreto aparente

Outros:

7. Cores predominantes da fachada principal

Coroamento: branco

Esquadrias: verde escuro

Molduras dos vãos: branco

Acabam. da fachada: rosa

4. Materiais

Outros:

Guarda-corpos: não tem

Outros relevos:

Residência: $X-100 \% \quad$ Vago:

Comércio: Culto:

Serviço: Instituição:

Outros:

Dados volumétricos

\section{Gabarito \\ Altura da fachada:}

№ pavimentos acima do nível da rua: 01

Além desses, assinalar a existência de:

Porão alto Mirante

Pav. intermediário mezanino

Outros:

Alt. cumeeira:
№ subsolos: não tem

№ subsolos: não tem

Pav. recuado

Sótão habitável
2. Classificação tipológica do telhado Número de águas do corpo principal: 04

Cumeeira paralela à rua

Cumeeira perpendicular à rua $X$

Tipo chalé

Com torreão

Água furtada

Outros:

3. Registro de acréscimos

Não tem $X$

Acréscimo vertical

Acréscimo horizontal
Identificado a partir de:

Evidência na construção $X$

Depoimento do usuário

Outros:
Descrever:
Azulejo novo

Madeira

Outros:

deira $X$

Outros: 
Ficha de pré-inventário do patrimônio arquitetônico e urbanístico de Dourado - SP Vila Santa Clara: Características Arquitetônicas - Ficha 19

Identificação

Logradouro: Rua 06 de Fevereiro s/n - Vila Santa Clara

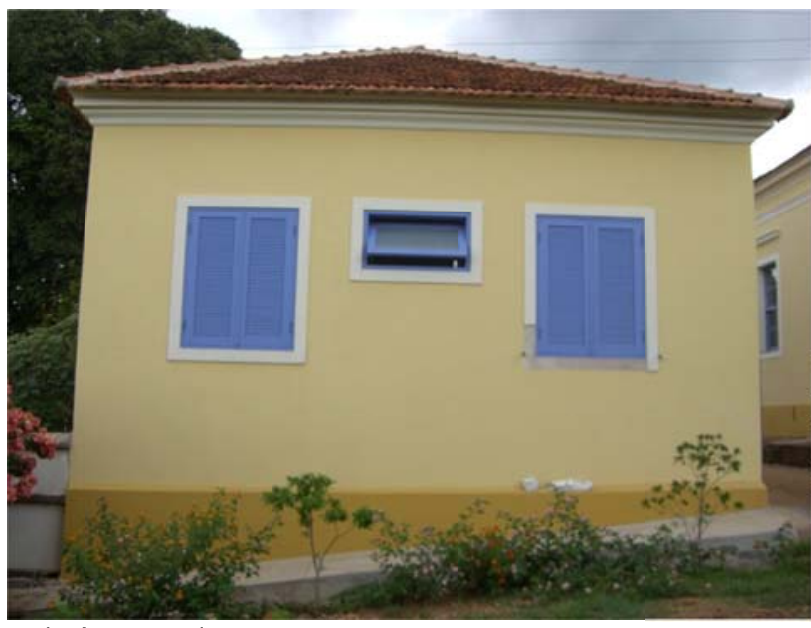

Fachada principal

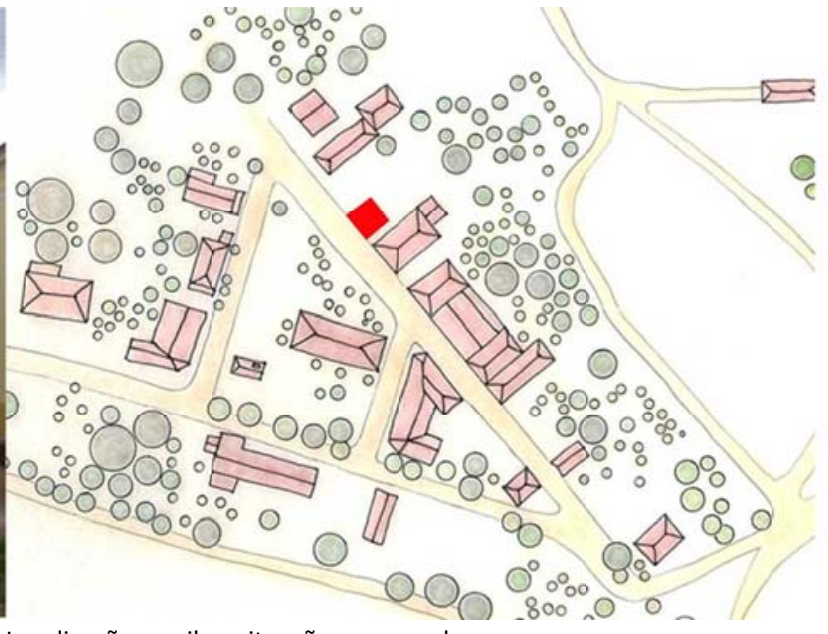

Localização na vila - situação sem escala

Fachada principal e uso atual

1. Materiais empregados na cobertura

Destruição total Cana

Francesa $X$

Vidro

Plástico / fibra

Fibrocimento

Metal

Laje

Outros:

\section{Materiais do coroamento}

Argamassa $X$

Azulejo antigo

Madeira

Cantaria

Azulejo novo

Concreto aparente

Outros:

5. Material das molduras dos vãos de portas e janelas

Não tem

Destruição total

Argamassa $X$

Azulejo antigo

Cantaria

Azulejo novo

Concreto aparente

adeira

7. Cores predominantes da fachada principal

Coroamento: branco

Acabam. da fachada: amarelo

Outros relevos: amarelo escuro

Molduras dos vãos: branco

Guarda-corpos: não tem

\section{Coroamento}

Destruição total

Frontão

Cachorros

Laje de beiral

Beiral simples

4. Materiais de acabamento da fachada principal

Argamassa $X \quad$ Chapisco

Cantaria Azulejo novo

Azulejo novo Madeira

Vidros Outros:

6. Material das esquadrias da fachada principal

Destruição total Madeira $X$

Vidro Alumínio

Ferro Outros:
Dados volumétricos

\section{Gabarito}

\section{Altura da fachada:}

№ pavimentos acima do nível da rua: 01

Além desses, assinalar a existência de:

Porão alto Mirante

Pav. intermediário mezanino

Outros:

\section{Alt. cumeeira: \\ № subsolos: não tem}

Pav. recuado

Sótão habitável
8. Uso atual - quantificar

Residência: $\mathrm{X}-100 \%$ Vago:

Comércio: Culto:

Serviço: Instituição:

Outros:
2. Classificação tipológica do telhado Número de águas do corpo principal: 04

Cumeeira paralela à rua

Com torreão

Cumeeira perpendicular à rua $\mathrm{X}$ Água furtada

Tipo chalé

3. Registro de acréscimos

Não tem $X$

Acréscimo vertical

Acréscimo horizontal
Identificado a partir de:

Evidência na construção $X$

Depoimento do usuário

Outros:
Descrever: 
Ficha de pré-inventário do patrimônio arquitetônico e urbanístico de Dourado - SP Vila Santa Clara: Características Arquitetônicas - Ficha 20

Identificação

Logradouro: Rua dos Gomes s/n - Vila Santa Clara

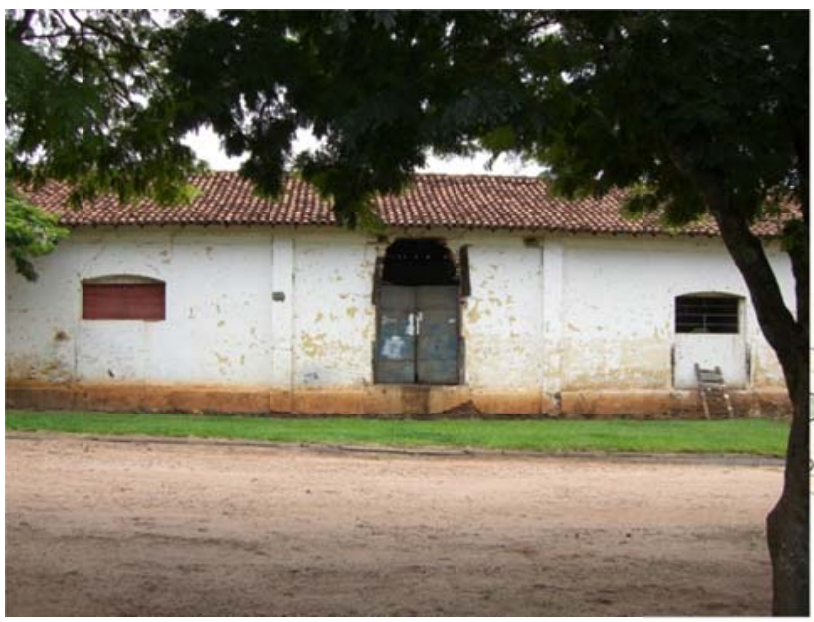

Fachada principal

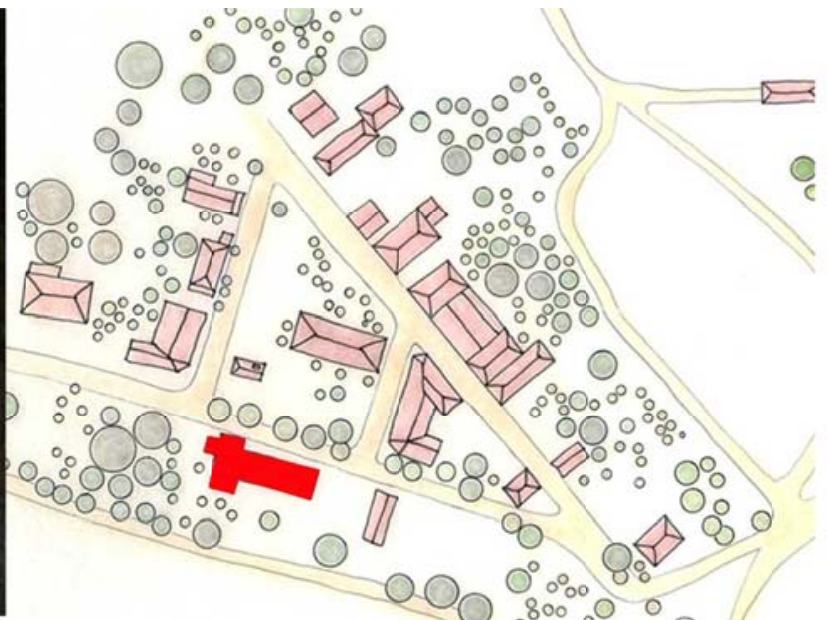

Localização na vila - situação sem escala

Fachada principal e uso atual

1. Materiais empregados na cobertura

2. Coroamento

Destruição total Canal X

Francesa Fibrocimento

Vidro Metal

Plástico / fibra Laje

Outros:

3. Materiais do coroamento

Argamassa

Azulejo antigo

Cantaria

Azulejo novo

Madeira X

Concreto aparente

Outros:

5. Material das molduras dos vãos de portas e janelas

Não tem X

Argamassa

Azulejo antigo

Destruição total

Cantaria

Azulejo novo

Destruição tota

Frontão

Cachorros

Laje de beiral

Beiral simples $X$

Platibanda

Cimalha

Beira seveira

Guarda pó

Outros:

4. Materiais de acabamento da fachada principal

Argamassa $X \quad$ Chapisco

Cantaria Azulejo novo

Azulejo novo Madeira

Vidros Outros:

6. Material das esquadrias da fachada principal

Destruição total Madeira

Vidro Alumínio

Ferro $X$ Outros:

Madeira

Concreto aparente

Outros:

7. Cores predominantes da fachada principal

Coroamento: branco

Esquadrias: não tem

Molduras dos vãos: não tem

Guarda-corpos: não tem

Acabam. da fachada: branco

Outros relevos: branco

Residência: $X-50 \%$

Vago: $X-50 \%$

Dados volumétricos

\section{Gabarito}

Altura da fachada:

Alt. cumeeira:

№ pavimentos acima do nível da rua: 01

№ subsolos: não tem

Além desses, assinalar a existência de:

Porão alto

Mirante

Pav. recuado

Pav. intermediário mezanino Sótão habitável

Outros:

3. Registro de acréscimos

Não tem

Acréscimo vertical

Acréscimo horizontal $X$
Identificado a partir de:

Evidência na construção $X$

Depoimento do usuário

Outros:
Comércio:

Serviço:

Outros:

2. Classificação tipológica do trelhado Número de águas do corpo principal: 04

Cumeeira paralela à rua $X$

Com torreão

Cumeeira perpendicular à rua

Água furtada

Tipo chalé

Outros:

Descrever:

Culto:

Instituição: 